\title{
FFLCH/USP
}

\section{FERNANDA LUCCHESI}

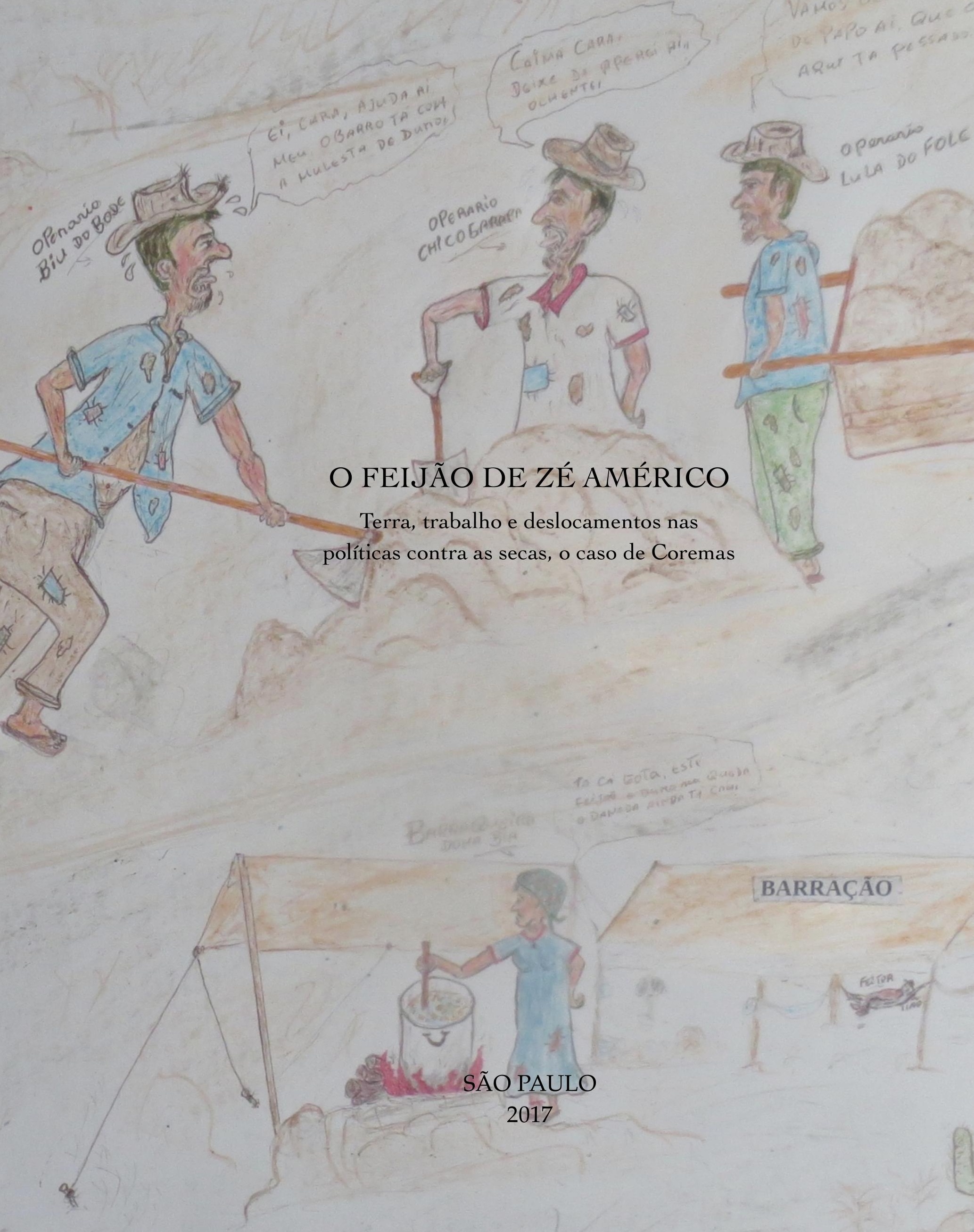


Capa: "Frente de emergência 1958 - Estrada Curemas-Aguiar". Lápis sobre cartolina, Seu Moacir 


\author{
UNIVERSIDADE DE SÃO PAULO \\ FACULDADE DE FILOSOFIA, LETRAS E CIÊNCIAS HUMANAS \\ DEPARTAMENTO DE ANTROPOLOGIA \\ PROGRAMA DE PÓS-GRADUAÇÃO EM ANTROPOLOGIA SOCIAL
}

\begin{abstract}
O feijão de Zé Américo
Terra, trabalho e deslocamentos nas políticas contra as secas, o caso de Coremas
\end{abstract}

\author{
Fernanda Lucchesi \\ Tese apresentada ao Programa de \\ Pós graduação em Antropologia \\ Social do Departamento de \\ Antropologia da Faculdade de \\ Filosofia, Letras e Ciências \\ Humanas da Universidade de São \\ Paulo, para obtenção do título de \\ Doutor em Antropologia Social \\ Orientadora: Ana Claudia Duarte Rocha \\ Marques
}

Versão corrigida

SÃO PAULO

2017 
Autorizo a reprodução e divulgação total ou parcial deste trabalho, por qualquer meio convencional ou eletrônico, para fins de estudo e pesquisa, desde que citada a fonte.

Catalogação na Publicação

Serviço de Biblioteca e Documentação

Faculdade de Filosofia, Letras e Ciências Humanas da Universidade de São Paulo

L 934f O feijão de Zé Américo: Terra, trabalho e eslocamentos nas políticas contra as secas, o caso

de Coremas / Fernanda Lucchesi ; orientadora Ana Claudia Duarte Rocha Marques. - São Paulo, 2017. $377 \mathrm{f}$.

Tese (Doutorado)- Faculdade de Filosofia, Letras e Ciências Humanas da Universidade de São Paulo. Departamento de Antropologia. Área de concentração: Antropologia Social.

1. CIÊNCIAS SOCIAIS. 2. ANTROPOLOGIA. 3. ANTROPOLOGIA POLÍTICA. I. Marques, Ana Claudia Duarte Rocha, orient. II. Título. 
Nome: Fernanda Lucchesi

Título: O feijão de Zé Américo: Terra, trabalho e deslocamentos nas políticas contra as secas, o caso de Coremas

Tese apresentada ao Programa de Pós graduação em Antropologia Social do Departamento de Antropologia da Faculdade de Filosofia, Letras e Ciências Humanas da Universidade de São Paulo, para obtenção do título de Doutor em Antropologia Social

Aprovada em: / 2017

Profa. Dra. Instituição:

Julgamento: Assinatura:

Profa. Dra. Instituição:

Julgamento: Assinatura:

Profa. Dra. Instituição:

Julgamento: Assinatura:

Profa. Dra. Instituição:

Julgamento: Assinatura:

Prof. Dr. Instituição:

Julgamento: Assinatura: 

Em memória do meu pai querido que, entre tantas coisas maravilbosas, me ensinou a gostar de estudar. 



\section{Agradecimentos}

À minha orientadora Ana Claudia Marques, pelo apoio em todos os momentos.

Ao CNPq pela bolsa que me foi concedida sem qual não seria possível realizar a pesquisa.

Ao Incra, na pessoa do ex superintendente regional do Incra na Paraíba, Cleofas Caju por ter viabilizado minha licença, sem a qual também teria sido impossível concluir esse trabalho.

Às minhas companheiras de luta do Serviço de Regularização Fundiária de Territórios Quilombolas do Incra na Paraíba, Maria Ester Fortes, Regina Marques, Sheilla Guerra e Ana Martel.

Aos servidores do Dnocs que me ajudaram na pesquisa, principalmente a Seu Moacir, do Dnocs na Paraíba, e ao maravilhoso trio da biblioteca central do Dnocs, Anésia, Margarida e Sigefredo.

Aos meus amigos e familiares, em especial à minha mãe que esteve ao meu lado em todos os momentos difíceis que passei no período de elaboração dessa tese, que não foram poucos.

A meu companheiro de todas as horas, José Henrique Artigas de Godoy.

A todos os moradores das comunidades de Mãe D'água, Barreiras e Cruz da Teresa, em Coremas, em especial a Dona Francisca Fernandes e Seu Zé Pequeno. Esse trabalho também é de vocês. 

Seu doutô os nordestino têm muita gratidão Pelo auxílio dos sulista nessa seca do sertão Mas doutô uma esmola a um bomem quié são Ou lhe mata de vergonha ou vicia o cidadão

É por isso que pidimo proteção a vosmicê Home pur nóis escuido para as rédias do pudê Pois doutô dos vinte estado temos oito sem chovê Veja bem, quase a metade do Brasil tá sem cumê

Dê serviço a nosso povo, encha os rio de barrage Dê cumida a preço bom, não esquę̧a a açudage Livre assim nóis da ismola, que no fim dessa estiage Lhe pagamo inté os juru sem gastar nossa corage

Se o doutô fizer assim salva o povo do sertão Quando um dia a chuva vim, que riqueza pra nação! Nunca mais nóis pensa em seca, vai dá tudo nesse chão Como vê nosso distino mecê tem na vossa mão

(Vozes da Seca, Luis Gonzaga e Zé Dantas, 1953) 



\section{Resumo}

O objetivo dessa tese é analisar a política de açudagem pública empreendida pelo Departamento Nacional de Obras Contra as Secas (Dnocs), a partir da reestruturação fundiária derivada dessa política e da utilização da população mais afetada pelas secas como de mão de obra nas construções de açudes. As ações de combate às secas foram acessadas através das publicações oficiais e da ação do Dnocs em Coremas. A partir do marco de 1877, as secas tornaram-se um problema nacional, mobilizando esforços e recursos para a mitigação de seus efeitos deletérios, como a alta mortalidade da população afetada e, sobretudo, as famosas retiradas que punham em marcha um exército de famintos a procura dos centros menos atingidos. A formulação de uma política contra as secas se deu em um momento de grande discussão tanto sobre o caráter nacional e a criação do Estado Nação, como sobre a constituição do Nordeste enquanto região específica. Na década de 1930, a Inspetoria Federal de Obras Contra as Secas (Ifocs), órgão que havia sido criado em 1909, foi reformulada pelo então Ministro da Viação e Obras Públicas, o paraibano José Américo de Almeida, dando início a um período de grande prestígio em termos de recursos e realizações. Entre as políticas de combate aos efeitos das secas, ganhou destaque a chamada solução hidráulica que consistia em construir grandes reservatórios públicos para acumular água, que seria utilizada nos períodos de estiagem e também em projetos de irrigação. Para José Américo de Almeida, os grandes reservatórios públicos cumpririam a dupla função de armazenar água e fornecer trabalho à população afetada, impedindo sua dizimação e fixando-a em sua região. Entre os açudes iniciados nessa época, está o Sistema Coremas-Mãe D'água, localizado no Vale do Piancó, no alto sertão paraibano. Classificada inicialmente como uma espécie de vazio demográfico, a área desapropriada para a instalação dos açudes era povoada por pequenos sítios cuja produção dependia principalmente da mão de obra de trabalhadores-moradores. Deslocados sem qualquer compensação 
por parte do Estado, muitos desses moradores tornaram-se operários nas obras do Dnocs ou rendeiros do órgão. Embora justificadas pela promessa de melhoria da vida da população do sertão, muitas das obras de combate às secas terminaram por expropriar camponeses e pequenos proprietários, tornando mais precárias as condições de trabalho a que estavam submetidos, como foi o caso em Coremas.

Palavras chave: Dnocs, Seca, Deslocamentos forçados, Frentes de Serviço, Coremas 


\section{Abstract}

The aim of this thesis is to analyze the dam building policy carried out by the National Anti Drought Department (Dnocs), from the point of view of its impacts on the distribution of land and the use of the impoverished population to build this dams. The anti drought policies were accessed by official publications and trough the actions of the Department in the city of Coremas. From the benchmark of 1877, droughts became a national problem, mobilizing efforts and resources to mitigate its effects, such as the high mortality rate and, most of all, the famous withdraws that put on march a famine army in the search of less affected centers. The formulation of an anti drought policy took place during a period of great discussion not only about the national character and the building of the National State, but also about the constitution of the Northeast as a specific region. In the 1930's, the Federal Anti Drought Institute (Ifocs), created in 1909, was reformulated by the then Minister of Transport and Public Works, José Américo de Almeida from the state of Paraíba, giving birth to a prestigious period in terms of resources and realizations. Among the anti drought policies, there was an emphasis in the so called hydraulic solution, that consisted of building big public reservoirs to store water to be used in drought periods and irrigation projects. According to José Américo de Almeida's opinion, such public reservoirs had the double function of storing water and providing jobs for the affected population, what would prevent the massive deaths and fix this population in its own region. Among the dams initiated during this period is the Coremas-Mãe D'água System, located in the Piancó Valley, in Paraíba hinterland. At first classified as if it were a demographic void, the area expropriated to install the dam were filled with small farms producing with the work of resident tenants. Uprooted without any compensation form the State, a great deal of them became workers on Dnocs enterprises or tenants of the Department. Although the anti drought policies were justified by the promise of improving the life of the population 
located in the semi-arid, many of the enterprises ended up expropriating peasants, tenants and small land owners, making the conditions of work under which they were submitted worse.

Key words: Dnocs, Drought, Uprooting, Work fronts, Coremas 


\section{Sumário}

Introdução................................................................................................................ 1

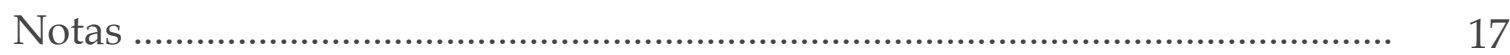

Parte I - O Dnocs e as Políticas de combate às secas $\quad 19$

1. A seca como problema nacional ........................................................................ 20

2. José Américo de Almeida Ministro das Secas e Pai da Bagaceira ................. 30

3. O ciclo revolucionário do Ministério da Viação .......................................... 45

4. Deus Não Olha Cassaco Sofrer .......................................................................... 68

5. Sob a euforia nacionalista dos 30: Os Boletins da Ifocs ............................. 75

6. Os anos 50 e as novas diretrizes do Dnocs .................................................. 85

7. O Dnocs pós golpe de 64: flagelado sai proprietário fica ............................. 106

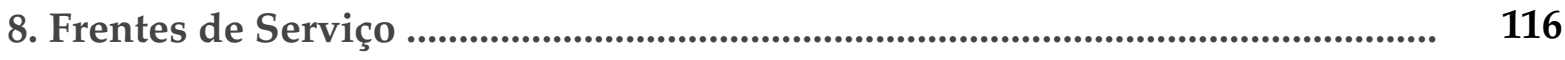

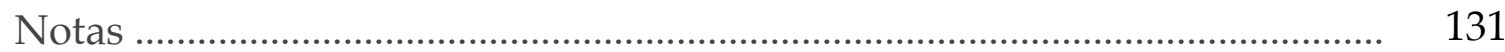

Parte II - O Dnocs em Coremas .................................................................... 135

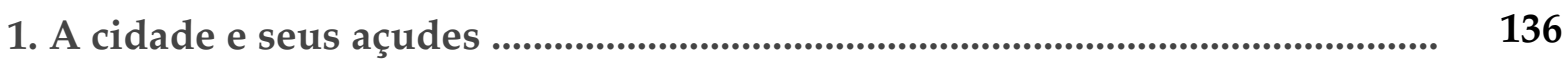

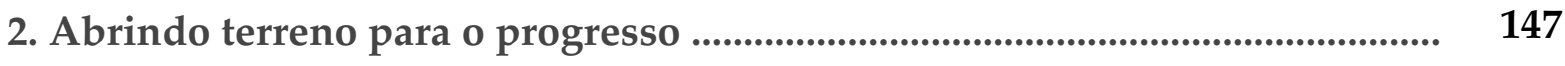

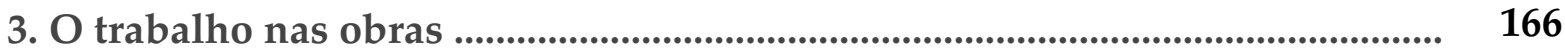

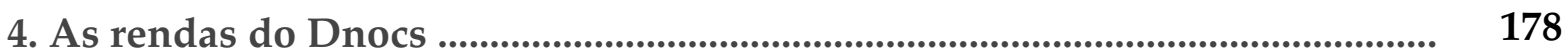

5. De moradores a rendeiros: a Comunidade Negra de Barreiras ....................... 200 
6. De moradores a rendeiros, de rendeiros a sem anuência: a Comunidade Negra de Cruz da Tereza .................................................................................... 208

7. De libertos a rendeiros: Os negros do Navio ................................................ 212

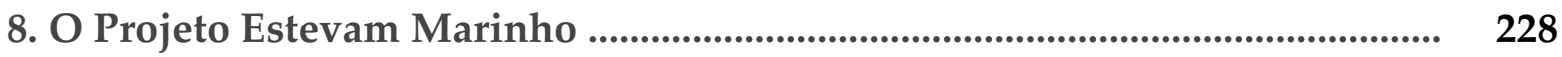

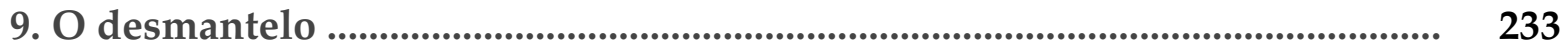

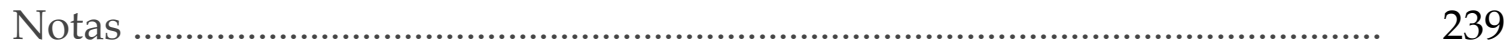

Considerações finais ..................................................................................... 245

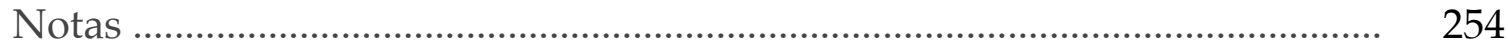

Referências Bibliográficas ............................................................................... 255

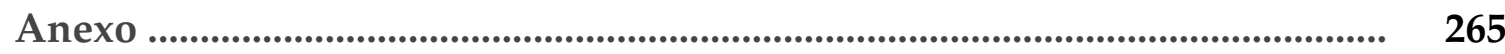




\section{Introdução}

Em meados de 1930, a pequena vila de Coremas, localizada no sertão paraibano, tornou-se palco de uma grandiosa construção. O sistema Coremas-Mãe D’água, formado pelas águas de dois açudes contíguos, foi projetado para armazenar 1.358.000.000 $\mathrm{m}^{3}$ de água e sua construção envolveu as técnicas e materiais considerados como os mais avançados da engenharia da época. Em 1957, a barragem Mãe D'água foi inaugurada com pompa pelo presidente Juscelino Kubitschek completando o sistema que forma o maior reservatório de água da Paraíba e quinto do Brasil. Além de servir como uma espécie de "caixa d'água do sertão" (Pires, 2010), os açudes tinham como objetivo a perenização dos rios Piranhas e Piancó, ação que deveria minorar ou mesmo neutralizar os efeitos das secas na região.

As obras realizadas pelo Departamento Nacional de Obras Contra as Secas (Dnocs) determinaram o afluxo de um grande número de trabalhadores de diversos graus de especialização para Coremas. Juntamente com os engenheiros, operários e as máquinas, o Dnocs levou para a cidade elementos de modernidade e urbanidade como escola, hospital, iluminação elétrica, clube recreativo e uma agência de automóvel representando a Ford, inaugurada ainda em 1937 (Silva Filho, 1996).

O presença de um corpo técnico ligado à burocracia de Estado modificou as estruturas tradicionais de poder, provocando uma reacomodação das antigas elites agrárias que, por mais que tenham conseguido migrar para o Estado, tiveram parte de seu poder diminuído (Lewin, 1993). O Dnocs também alterou completamente a estrutura fundiária do local, deslocando populações que passaram a depender diretamente do órgão, seja como arrendatários ou ocupantes de suas terras, seja trabalhando em suas obras.

Embora alicerçadas em um discurso de melhoria da vida da população do sertão, muitas das obras de combate às secas terminaram por expropriar camponeses 
e pequenos proprietários, tornando mais precárias as condições de trabalho a que estavam submetidos (Hall, 1981). Ao lado do aparecimento de uma ilha de modernidade no sertão da Paraíba, com seus carros, trens e engenheiros, milhares de flagelados foram engajados nas construções de açudes e rodovias, as chamadas emergências, trabalhando e vivendo em péssimas condições (Andrade, 1934; Mariz, [1937] 1994).

Ao se viajar pelo sertão da Paraíba, é fácil notar a proeminência que o Dnocs ainda tem, apesar de as estruturas transparecerem a decadência do órgão, como nota Silva Filho (1996) para o caso de Coremas. Os açudes com seus rendeiros são quase uma constante na paisagem. $\mathrm{O}$ discurso sobre as secas ainda mobiliza a ação política e é notável a semelhança que documentos atuais sobre o fenômeno têm com aqueles escritos desde final do século XIX1.

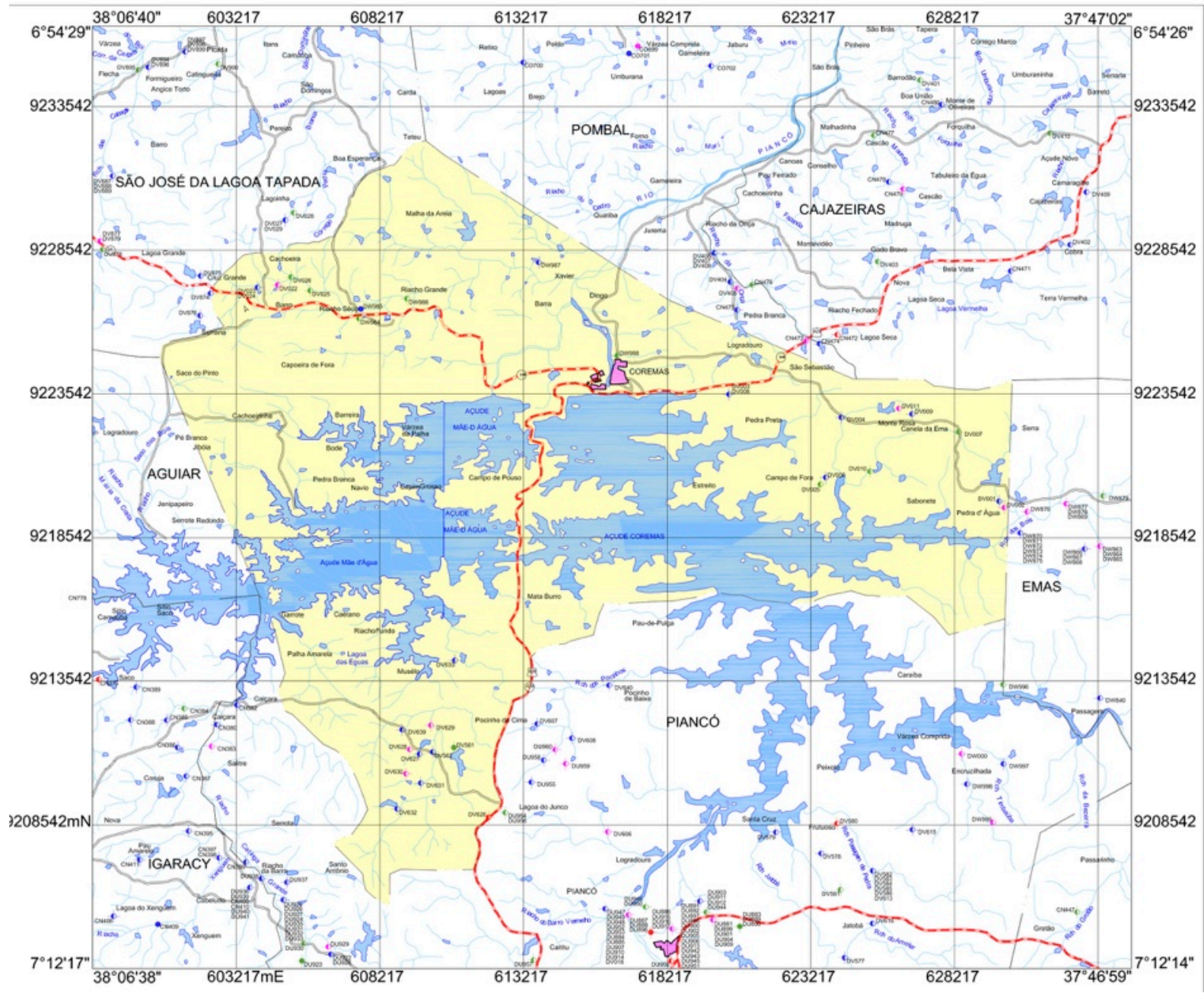


O objetivo dessa tese é analisar a política de açudagem pública empreendida pelo Dnocs, a partir da reestruturação fundiária derivada dessa política e da utilização da população mais afetada pelas secas como de mão de obra nas construções de açudes. Essas ações de combate às secas serão analisadas a partir das publicações oficiais e da ação do Dnocs em Coremas, através das dinâmicas instituídas pelo órgão a partir da década de 1930.

O estudo da ação do Dnocs em Coremas pode ajudar a compreender muitas das questões decorrentes da ação da burocracia de Estado na gestão das populações rurais. A política contra as secas criou novas realidades em grande parte da área sujeita a esse fenômeno periódico. Em Coremas, a ação do Dnocs modificou de tal maneira a paisagem e a dinâmica locais que sua própria existência como município autônomo foi condicionada pela presença do órgão.

A formulação de uma política contra as secas se deu em um momento de grande discussão sobre o caráter nacional e criação do Estado Nação. Desde a chamada geração de 1870 até pelo menos a produção intelectual década de 1930, uma das principais questões para o problema da nacionalidade era a mestiçagem (Schwarcz, 1995; Gomes, 1999). Embora as soluções divergissem conforme o autor, grande parte destes via com pessimismo o fato de o povo brasileiro ser resultado da mistura de raças tão diversas (Viana, [1923] 1938).

Essa discussão informou também a elaboração do Nordeste enquanto região particular, que começou a ganhar contornos nas duas primeiras décadas do século XX (Artigas de Godoy, 2013). Leitor atento de Euclides da Cunha, Oliveira Viana e Alberto Torres, o paraibano José Américo de Almeida enfrentou essa questão em $A$ Paraiba e seus Problemas. Nesse livro publicado em 1923, José Américo buscou, entre outras coisas, explicar a psicologia do paraibano, especialmente o sertanejo. Assim como Alberto Torres, José Américo construiu um quadro positivo da mestiçagem.

O sertanejo não seria um Hércules Quasímodo como sentenciara Euclides da Cunha, mas um Hércules perfeito, fruto da mistura dos antigos bandeirantes com 
valorosos indígenas. Em seu desenvolvimento, o sertanejo se embranquecia e era moldado pelo clima impiedoso que assolava o sertão com as secas periódicas, tornando-se cada vez mais "forte" - a "rocha viva" da nacionalidade.

Para José Américo, os principais problemas da Paraíba, e também do Nordeste, não eram derivados de seu povo, mas sim da seca e da omissão do Estado. Sete anos após A Paraiba e seus Problemas, o autor assumiu o Ministério da Viação e Obras Públicas, ao qual estava subordinado o órgão de obras contra as secas - na época, a Inspetoria Federal de Obras Contra as Secas (Ifocs). Muitos dos problemas e soluções apontados no livro de 1923 e em outras obras literárias, como A Bagaceira de 1928, podem ser encontrados nos decretos e relatórios que assinou.

O pensamento de José Américo ainda influencia a visão que os paraibanos tem de si, em especial no que concerne ao discurso da seca como problema (Albuquerque Júnior, 1988) e à idéia de um sertão embranquecido.

O discurso sobre a seca teve um impacto direto sobre as populações mais vulneráveis aos efeitos das crises climáticas, como pequenos sitiantes e moradores. Classificados genericamente de flagelados ou retirantes, essa população foi engajada na construção de açudes e rodovias, não só por estas serem importantes obras de integração regional, mas porque o trabalho nas obras era em si uma política de desenvolvimento.

$\mathrm{Na}$ primeira parte dessa tese, foram analisadas as políticas de combate às secas desenvolvidas pelo Dnocs ao longo do século passado, enfatizando os dados sobre a construção de grandes açudes públicos e o engajamento da população afetada nas obras.

Muitos foram os livros e estudos publicados sobre o tema das secas nordestinas e não foi o intuito dessa pesquisa esgotar a discussão sobre o fenômeno. A análise apresentada baseou-se principalmente na produção do órgão contras as secas - relatórios, boletins de serviço, apostilas e outros -, procurando destacar aquilo que seus dirigentes e funcionários consideraram importante produzir e 
divulgar acerca dos temas da acumulação de água e do trabalho dos retirantes e flagelados.

O recorte temporal priorizou o período compreendido entre a promulgação do Decreto 19.726, em 20 de Fevereiro de 1931, e a instalação do Projeto Piloto Estevam Marinho na bacia hidráulica do açude Coremas em 1971. O Decreto assinado por José Américo de Almeida em 1931 aprovou o novo regulamento da Ifocs e fixou quatro grandes sistemas prioritários para efeitos de realização de obras de açudagem. Entre eles, estava o Sistema do Alto Piranhas do qual os açudes de Coremas fazem parte. O Projeto de irrigação instalado na década de 1970 não teve um impacto tão relevante como a construção dos açudes iniciada em 1937, mas marcou a aplicação da nova diretriz do órgão delineada com a criação da Sudene.

Foi destacada ainda a ação do paraibano José Américo de Almeida à frente do Ministério da Integração e Obras Públicas entre os anos de 1931-1934 e 1953-1954. Além de político influente, José Américo foi romancista e ensaísta prolixo, deixando registrado em seus livros sua concepção sobre o problema das secas. Assim como no caso das produções do Dnocs, buscou-se apreender o que o próprio ministro escreveu sobre essa questão, assim como sobre sua própria atuação no ministério.

A segunda parte da tese buscou analisar a ação do Dnocs em Coremas, destacando a reestruturação fundiária empreendida pelo órgão através das desapropriações, deslocamentos populacionais e arrendamentos de terras públicas.

A primeira vez que estive em Coremas foi como servidora do Incra. Desde 2006, ocupo o cargo de Analista com habilitação em Antropologia tendo sido lotada no Serviço de Regularização de Territórios Quilombolas, primeiramente na Superintendência Regional do Maranhão (SR-12/MA) e depois na da Paraíba (SR-18/PB).

Devido aos conflitos entre o Ibama e os agricultores que plantam na vazante do açude Mãe D'Água, a Comissão Pastoral da Terra no sertão da Paraíba (CPTSertão) encaminhou um pedido de abertura de processo para regularização de três 
áreas remanescentes de quilombo no município de Coremas: "Comunidade Negra de Barreiras" (situada na beira do açude), "Comunidade Negra de Mãe D'água" e "Comunidade Negra de Cruz da Tereza".

Os pedidos de certificação das comunidades como remanescentes de quilombos haviam sido encaminhados em 2006 para a Fundação Cultural Palmares. Esse procedimento antecede a abertura do processo no Incra e equivale ao reconhecimento formal do Estado que a comunidade "é remanescente de quilombo". ${ }^{2}$

A presença de comunidades negras remanescentes de quilombo em Coremas não aparece em grande parte da produção sobre o local (Cunha, 1948; Andrade, 2008; Almeida, 2004; Pires, 2010). Apenas a versão impressa de Coremas, seu lugar na história Silva Filho (1996) menciona a existência um lugar conhecido por "Serra do Navio" como sendo um antigo "quilombo de negros".

O autor reproduziu a idéia difundida pela historiografia tradicional da Paraíba de que teria havido poucos escravos no sertão e que, os que existiam, teriam sido vendidos ainda no final do século XIX (Joffily, [1892] 1977; Almeida, [1923] 1994; Rocha, 2007), fixando a origem do povoado fora de Coremas.

Segundo Silva Filho, os membros dessa comunidade estariam plenamente integrados à sociedade local e não seriam "mais vítimas de preconceito social descarado" (Silva Filho, 1996, pp. 27, 28), revelando que essa população foi vítima de preconceito aberto e permanece sofrendo um preconceito velado.

Assim que a equipe do Incra chegou em Coremas, fomos informados sobre a localização e situação fundiária das comunidades. Duas delas, "Barreiras" e "Mãe D'água", estavam na área de influência direta do açude Mãe D'água. A primeira, situada na beira do açude, estava em questão com o Ibama devido às novas regulamentações do órgão sobre a utilização dos trechos de vazante para plantio. Sobre a segunda, distante $5 \mathrm{~km}$ do núcleo urbano, o representante da CPT-Sertão falava da falta de terra de trabalho.

Nos dias que se seguiram à nossa chegada, a presença do Dnocs foi ficando 
cada vez mais forte, a começar pela imponente barragem que divide o bairro Mãe D'Água em dois e que esconde o antigo povoado Navio, hoje submerso.

Mãe D'Água é uma espécie de bairro rural e suas casas encontram-se distribuídas em dois setores divididos pela ponte sobre o rio Aguiar, localizada no sangradouro da barragem. Do lado direito de quem olha para barragem foi construída uma vila operária para abrigar os funcionários do Dnocs que trabalharam na sua construção, existindo ainda hoje algumas das casas construídas pelo órgão. Do lado esquerdo, começou a se formar na mesma época uma vila para abrigar os trabalhadores menos qualificados e que ficou conhecida como "Vila dos Mulambos". Posteriormente, toda essa região foi desapropriada e dividida em lotes pelo Dnocs para serem arrendados. Esses lotes são conhecidos localmente por rendas.

Com o desaparecimento do Navio, seus moradores se espalharam. Conforme as águas foram subindo, as casas foram também se encostando e subindo nas serras que circundavam o povoado. Algumas famílias foram para as cidades próximas, como Piancó, Souza e Pombal, outras permaneceram em Coremas ocupando os bairros como Cabo Branco e Cruz da Tereza, na periferia da cidade, ou fixaram-se em Mãe D'Água ou Barreiras.

São do Dnocs as rendas ocupadas pelas famílias deslocadas do Navio e que se fixaram em Mãe D'água após a inauguração da barragem. São ainda do Dnocs as rendas como a de Seu Zé Pequeno e seus irmãos localizadas em Barreiras. Os terrenos ocupados pela "Comunidade Negra de Cruz da Tereza", que reune antigos moradores das fazendas da região, também são do Dnocs.

Não houve, na época da construção dos açudes, nenhuma política para o reassentamento da população deslocada dos povoados e fazendas. Grande parte desta população trabalhou na construção da barragem e demais emergências instaladas na região, que empregou de maneira parcial e transitória as famílias afetadas. 
A única política compensatória levada a cabo pelo Dnocs em Coremas diz respeito à indenização dos proprietários desapropriados. A área desapropriada incluiu não só o trecho de terras onde se formou o lago dos açudes, mas também as terras que se tornaram "irrigáveis", compreendendo grande parte do município.

Embora as normas para arrendamento editadas em 1950 estabelecessem como objetivo fixar agricultores "reconhecidamente pobres", não houve nenhuma política sistemática para o assentamento da população que afluiu para a região devido às obras nos açude nem para os moradores das propriedades desapropriadas.

A ação do Dnocs desestabilizou a organização produtiva e social e do lugar, desagregando antigas comunidades e conectando seus antigos habitantes ao órgão seja como arrendatários, ocupantes ou trabalhadores eventuais.

A demanda pela regularização fundiária encaminhada ao Incra pelas comunidades negras de "Barreiras", "Mãe D'água" e "Cruz da Tereza" está baseada na ação desagregadora do Estado e sua efetivação deve ser entendida como medida de compensação.

Essa tese não irá discutir o processo de regularização no Incra nem qualquer outra questão envolvendo o debate sobre as comunidades quilombolas, em termos identitários ou territoriais. Apesar disso, grande parte da análise da ação do Dnocs no município de Coremas foi construída a partir das conversas com os membros dessas comunidades.

Em The Architecture os Memory, Joelle Bahloul estudou o passado de uma família e seu grupo doméstico buscando explorar a semântica da memória articulada por um grupo disperso devido ao deslocamento forçado (uprooted). Um dos pontos centrais do estudo é a articulação da identidade na memória narrada (narrative memory). Essa memória constitui, para a autora, um tipo específico de elaboração memorialista cujo suporte principal é a narrativa - uma narrativa oral da memória. Embora focada no passado de um grupo de famílias, a maneira pela qual essas 
famílias escolhem expressar seu passado revela o poder da narrativa oral na construção de sua identidade presente (Bahloul, 1996, p. 9).

Bahloul ressalta a importância que os corpos, lugares e objetos ganham na produção dessas narrativas, que se concentram em um espaço doméstico (a casa coletiva Dar-Refayl), influenciando a própria percepção do tempo."Time in domestic memory is made up of odors, images, and objects. It is materialized and closely associated with the concrete use of the household's space". Esse tempo impregnado de sentidos é um tempo corporificado/materializado (embodied time) (Bahloul 1996, p. 104).

Outro aspecto que se destaca na análise é o constante contraste entre a dureza das condições materiais do passado e uma vida de maior conforto no exílio francês por um lado, e, por outro, a abundância de "boas" relações interpessoais em DarRefayil e a escassez de relações no presente, como se o passado tivesse como objetivo instruir o presente e carregar aspirações para o futuro - "as if a moral were being projected onto the past" (Bahloul, 1996, p. 134).

As recordações de um passado de privações e dificuldades são suavizadas pela afetividade dos relacionamentos de familiares e de vizinhança, principalmente na fala das mulheres. "Women excel in the narrative art of balancing happiness and pain - a strategy for moralizing the past human context and humanizing a difficult world. Laughter has the effect of distancing past hardships and humanizing their present happy results" (Bahloul, 1996, pp. 80,81).

Tomando o livro de Bahloul como inspiração metodológica, busquei apreender as narrativas apresentadas pelas famílias deslocadas sobre seu passado, levando em conta dois cortes temporais: antes e depois da construção dos açudes e antes e depois da decadência do Dnocs de Coremas, iniciada na década de 1980.

Grande parte do tempo que passei em Coremas foi tomada por conversas coletivas em passeios pelos açudes, pela barragem de Mãe D'água, entre as casas dos moradores, em visitas ao Dnocs e em atividades produtivas como o trabalho nos 
roçados ou na fabricação de louça de barro. Dessas conversas participaram sobretudo as mulheres de Mãe D'água, Barreiras e Cruz da Tereza, mas muitas delas contaram com a participação de Seu Zé Pequeno, exímio contador de histórias e importante liderança local, que animou muitas das reuniões com suas piadas e causos.

Assim como para qualquer população sertaneja, a água é um tema que perpassa grande parte das preocupações cotidianas e determina as atividades domésticas. É preciso estar perto d'água para plantar e criar ou ter dinheiro para cavar um açude ou captar a água do rio. Deve-se buscar a água para o uso da casa ou esperar que ela "chegue" pelo sistema do Dnocs.

As águas da barragem tiveram também um enorme impacto na região e transformaram não só as práticas mas também as relações sociais. Escassez e abundância de água são frequentemente relacionados com a quantidade e qualidade das relações familiares e de vizinhança, num constante jogo entre passado e presente. Essas relações nunca se dão de uma só maneira, dependendo do bem que se leva em conta e do grupo envolvido.

Para os antigos moradores do Navio, por exemplo, antes da barragem seu povoado era repleto de água, permitindo a abundância de arroz e plantas frutíferas e a possibilidade de manter uma criação. Em suas memórias, as relações sociais eram muito intensas. As águas do açude, embora abundantes, destruíram o povoado, precarizando suas atividades econômicas e relações sociais. Para os moradores da Vila dos Mulambos, o açude abriu a possibilidade da melhoria das condições de vida via trabalho, mas não significou a abundância de água. Sua escassez, entretanto, possibilitava um intenso contato entre os vizinhos em atividades como lavagem de roupa e coleta de água, relações que diminuíram quando os moradores conseguiram recursos para construir açudes em seus terrenos.

Outro tema tema constante de debates e reavaliações diz respeito às relações desses grupos com a burocracia local. O fato de as terras ocupadas serem do Dnocs 
força o estabelecimento de relações entre os servidores do órgão e a população de arrendatários e ocupantes. No caso dos rendeiros, por exemplo, a própria norma estabelece que modificações como reformas e novas construções dependem da aprovação do Dnocs.

Embora os rendeiros e ocupantes mais pobres não tivessem acesso livre à repartição até há pouco tempo, a ordem imposta pelas chefias mais antigas é tida como positiva. A maior centralização da administração é louvada principalmente com relação às áreas de domínio público, como é o caso do Rio Aguiar cujo acesso esta atualmente trancado por proprietários locais.

Conforme aponta Herzfeld, a maioria dos estudos sobre a burocracia analisam seu funcionamento e, por isso, avaliam o sucesso ou fracasso de determinadas instituições em seus próprios termos: atendimento das necessidades do cidadão, imunidade à patronagem e eficiência. Embora a burocracia ocidental esteja baseada no discurso da racionalidade e da impessoalidade, tanto as regulações formais como as práticas burocráticas estão embebidas nos valores cotidianos ("are fully embedded in everyday values") (Herzfeld, 1992, p. 18).

Nesse sentido, os burocratas não são nem insensíveis seguidores da norma nem vítimas sem escolha. Esses atores especificamente posicionados tem que trabalhar de um lado com normas oficiais conflitantes e, de outro, sob constante pressão social (Herzfeld, 1991, p. 14).

Com objetivo de acessar os efeitos da instalação dos açudes no cotidiano dos moradores de Coremas do ponto de vista da burocracia local, foram pesquisados os arquivos do Dnocs no município e nas sedes do órgão em João Pessoa, Recife e Fortaleza.

A idéia inicial era apreender a maneira pela qual os funcionários do Dnocs descreveram e organizaram os dados sobre as populações locais, instituindo uma nova ordem derivada não só das obras mas do ordenamento dado pela burocracia, a exemplo do exercício de interpretação realizado por Teresa Holmes nos arquivos 
britânicos das colônias no Kenya (Holmes, 2009). Pesquisando nesses arquivos, Holmes analisou, entre outras coisas, o desconforto dos agentes britânicos com relação à não uniformidade da região e a tentativa destes de criar uma ordem a partir dessa desordem. Nesse processo, os britânicos produziram um novo ordenamento fundiário.

Esse projeto inicial foi de certa forma frustrado pelo estado em que se encontram os arquivos do Dnocs. Apesar do imenso número de pessoas que empregou e da quantidade de terras que ainda possui, o escritório do órgão em Coremas não tem mais arquivos e os papéis, mesmo novos, amontoam-se em um canto, muitos ilegíveis pela ação da umidade e de bichos. Em nossa primeira visita a Coremas, fomos informados por funcionários do órgão que os arquivos da construção dos açudes haviam sido destruídos por um antigo diretor, que ateara fogo a todos os papéis.

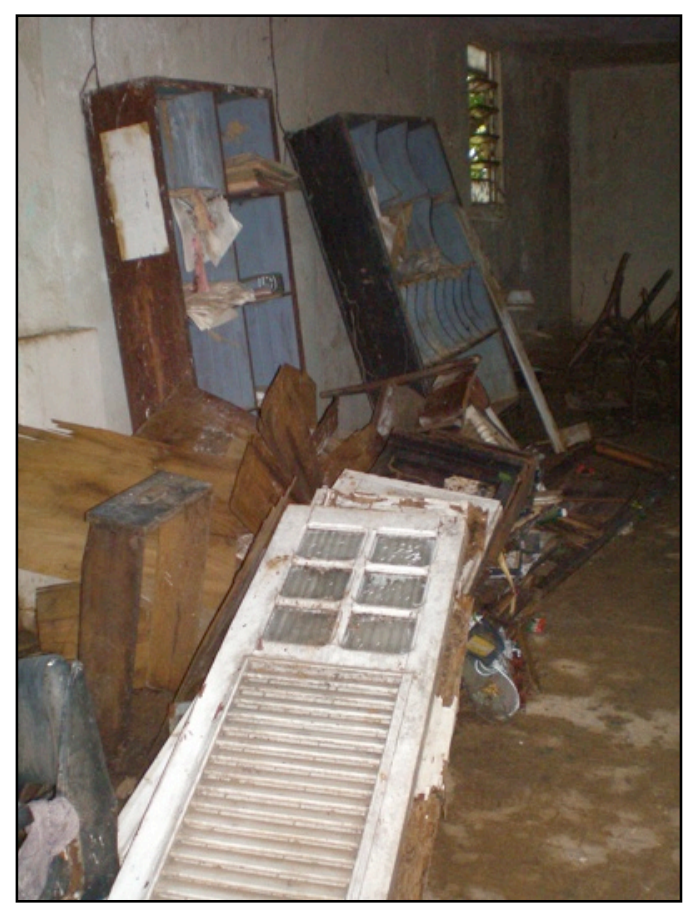

Dnocs em Coremas, mar. 2009.

A destruição dos documentos e fotos referente a Coremas, ou por que alguém tacou fogo, ou por que se perderam nas mudanças das sedes regionais, ou ainda simplesmente por que botaram no mato, perseguiu essa pesquisa como espécie de sina.

Nos arquivos de João Pessoa, Recife e Fortaleza, as várias mudanças internas levaram à destruição de grande parte do acervo do órgão. Em João Pessoa, os poucos documentos que não haviam sido transferidos para Recife no início da década de 1970 foram amontoados aleatoriamente em poucas estantes escondidas do público no andar ocupado pela Divisão Técnica.

O único arquivo organizado em João Pessoa é o do Recursos Humanos, 
mantido por Seu Moacir. Seu pai havia sido funcionário do Dnocs e, além de trabalhar na construção de muitos açudes pelo estado, também havia cuidado do arquivo do RH. Seu Moacir cuida desse arquivo como fosse um legado de seu pai, mantendo-o organizado e enfeitado de cartazes temáticos como o que foi utilizado na capa dessa tese.

Em Recife, a instalação de outros órgãos no imponente conjunto de prédios do Dnocs diminuiu seus espaços. Entre as mudanças, a biblioteca que ocupava um dos andares do prédio principal foi desalojada para dar lugar à Advocacia Geral da União. Todos os livros, e demais arquivos "sem lugar", foram guardados em grandes caixas de papelão e depositados no espaço antes ocupado pela agência do Banco do Brasil que atendia os funcionários do órgão. O conteúdo das caixas, que foram dispostas como um grande paredão e tomavam todo o espaço da antiga agência, não foi discriminado, tornando uma missão quase impossível achar alguma coisa sem contar com uma equipe de apoio.
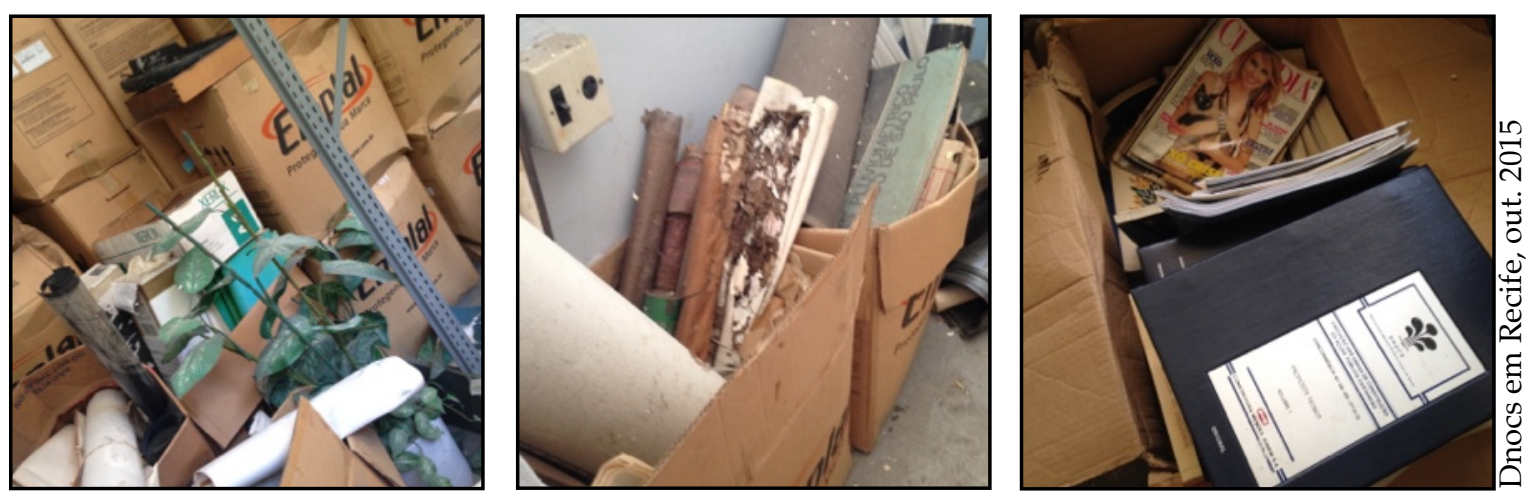

O enorme galpão do Dnocs no Pici, em Fortaleza estava praticamente inviabilizado para pesquisa, embora existisse ali um princípio de organização. Neste arquivo, estão reunidos os documentos de todas as realizações do órgão de combate às secas e foi possível encontrar documentos referentes ao início do século XX. Foi iniciado ali um projeto para organização e higienização dos documentos, mas o trabalho foi interrompido no meio porque o contrato com a empresa que estava fazendo o serviço não foi renovado. Parte da documentação referente às secas do Ceará foi também digitalizado por um núcleo de pesquisa da Universidade Federal 
do Ceará.

Atualmente, o galpão possui centenas de caixas empilhadas no centro, sem indicação do conteúdo das mesmas, circundadas de mapas, planilhas, cadernetas, revistas velhas, restos de máquinas, antigos carimbos, livros raros, etc.

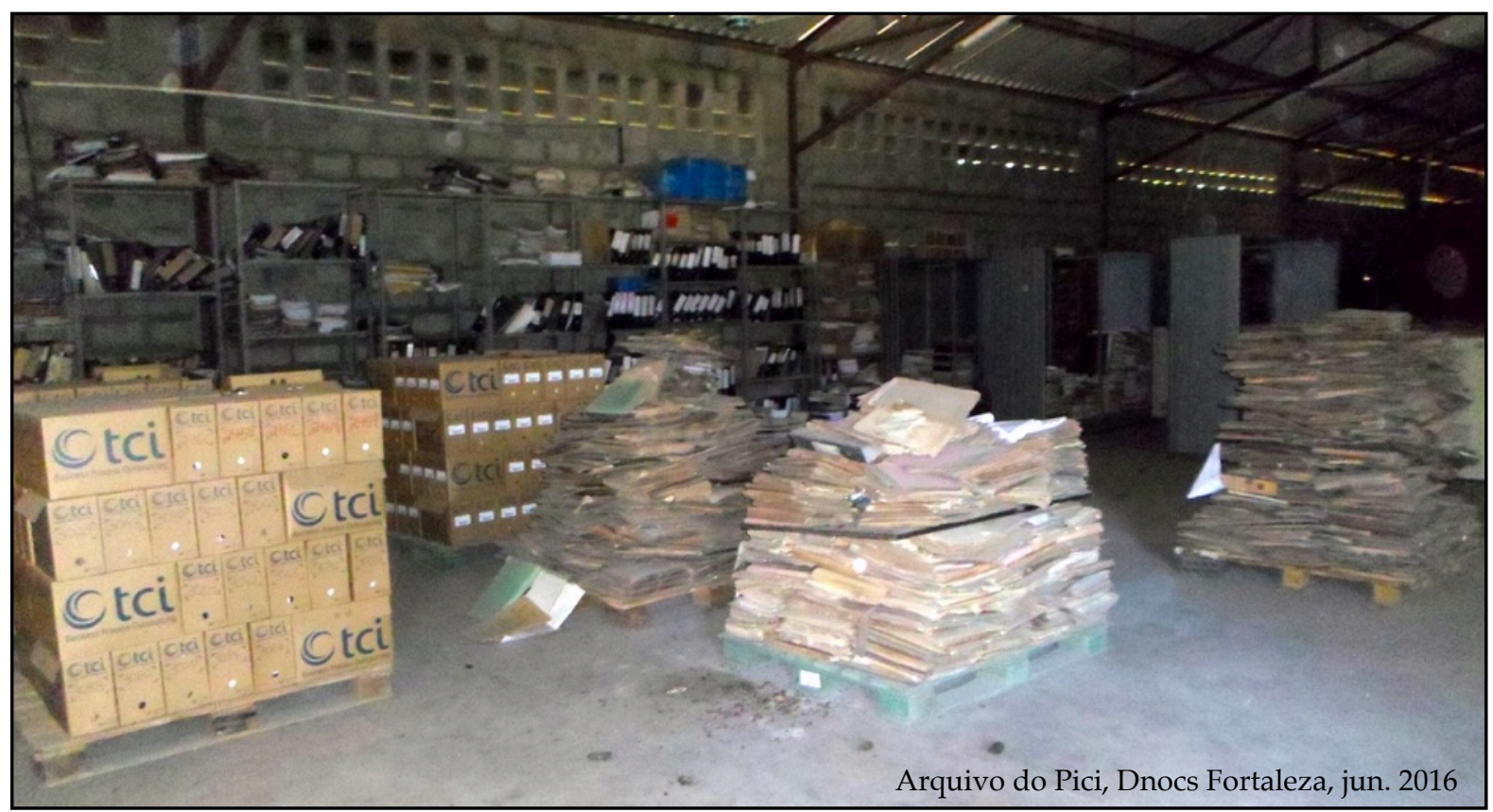

Os servidores que trabalharam nesses arquivos, como é o caso de Dona Margarida, de Fortaleza, Seu Moacir e outros, lamentam o descaso das administrações do Dnocs que fizeram com que a memória de mais de um século de atuação fosse praticamente inutilizado.

Grande parte material produzido sobre Coremas usado na tese foi localizado no Dnocs em João Pessoa. A impressão que se tem sobre a documentação arquivada na Divisão Técnica, e que compreende o período estudado, é que se trata dos papéis que não foram enviados para Recife na década de 1970, talvez por já se encontrarem desorganizados naquele momento. Em lugares diversos das estantes, encontrei pedaços de processos, mapas, desenhos de detalhes técnicos dos açudes, rascunhos de tabelas, cadernetas taquiométricas, termos de ajustes, boletins de exploração, ofícios soltos, telegramas.

Em vista dessa documentação escassa e desorganizada, foi preciso levar a 


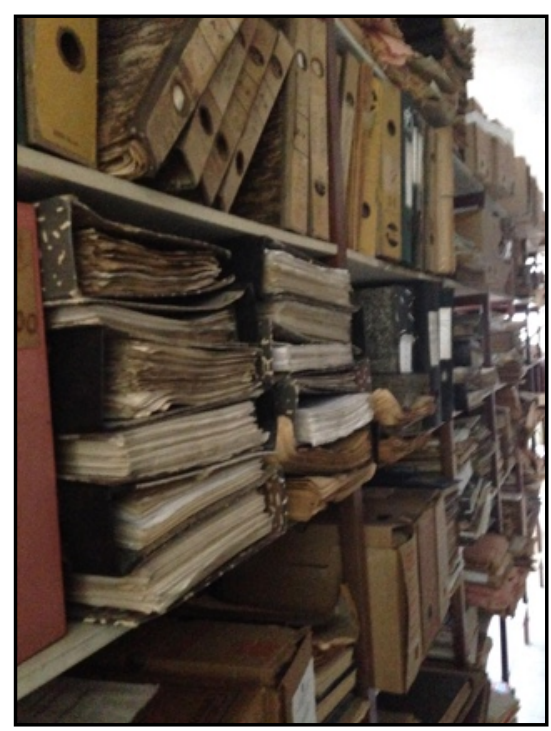

Dnocs em João Pessoa, mar. 2015

sério o método indiciário analisado por Ginzburg ([1986] 2009), procurando nos papéis as pistas sobre uma realidade complexa e não experimentada diretamente. Elementos residuais e marginais como marcações feitas à mão, observações de técnicos, e mesmo tabelas não preenchidas, foram exploradas ao máximo. Ao mesmo tempo, foi dada atenção ao que esses documentos revelavam em suas omissões, desbotamentos, incoerências e emendas suspeitas (Dawsey, 2009).

A partir dessa documentação dispersa e fragmentária foi possível seguir alguns indícios sobre a atuação do órgão em Coremas, sobretudo acerca das desapropriações e arrendamentos de terra.

Ao contrário dos arquivos, a Biblioteca Central do Dnocs em Fortaleza encontra-se organizada e bem cuidada ocupando um espaço adequado a seu tamanho. Nessa biblioteca, foi possível pesquisar muitas publicações oficiais que foram o principal material utilizado na primeira parte dessa tese.

O estado dos arquivos do Dnocs é também uma representação da decadência experimentada pelo órgão, que teria se iniciado com a criação da Sudene e se acentuado no início da década de 1990. Comentando sobre as estruturas abandonadas do órgão em São Gonçalo, incluindo o arquivo destruído pelo fogo pouco antes da minha visita em dezembro de 2016, os funcionários chamaram atenção para a progressiva diminuição do quadro funcional. A Residência de São Gonçalo, que já teve 1.500 funcionários trabalhando em seu tempo áureo, atualmente conta com apenas 16 funcionários para administrar uma infra estrutura muito maior que sua capacidade operacional.

O mesmo ocorreu em Coremas, onde cerca de três funcionários trabalham atualmente na sede local. Grande parte da antiga estrutura do Dnocs instalada no 
município nas décadas de 1930 e 1940 já foi vendida e muitas das casas do antigo e destacado bairro foram demolidas. A falta de capacidade de gerenciar as terras sob seu domínio, as acusações de vendas de lotes e a iminência da doação de terras para a prefeitura fragiliza a situação dos moradores, principalmente aqueles localizados na periferia da cidade como é

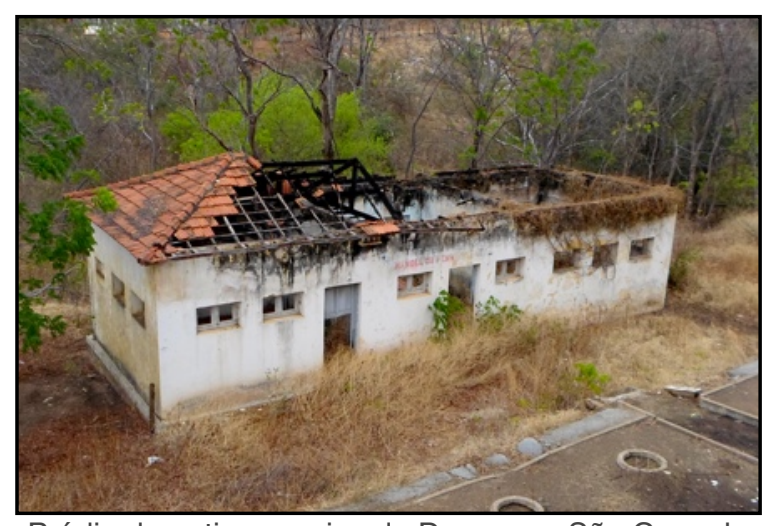
o caso dos que estão em Cruz da Tereza.

A seca declarada há cinco ano reduziu a limites mínimos a capacidade dos açudes deixando ainda mais visível tanto a decadência da infraestrutura do Dnocs, como a total ineficácia das políticas implementadas pelo órgão contras as secas do ponto de vista da população que é mais sujeita a seus efeitos. Essa população, composta sobretudo de moradores e posseiros, foi durante o período estudado alvo das políticas contras às secas, ao mesmo tempo que justificaram a própria existência destas. 


\section{NOTAS:}

${ }^{1}$ Esse é o caso do documento de 2013 intitulado "Carta da Paraíba" do movimento S.O.S Seca da Assembléia Legislativa da Paraíba. Ao lado da descrição dos infortúnios causados pela última estiagem, são solicitadas novas obras contra as secas.

${ }^{2}$ Embora o artigo que prevê a titulação das terras ocupadas por comunidades remanescentes de quilombo tenha surgido com Constituição de 1988 (Art. 68 ADCT/CF), foi apenas após sua regulamentação através do decreto 4.887, de dezembro de 2003, que as demandas por titulação começaram a ganhar maior visibilidade. A atribuição da regularização ao órgão fundiário, o Incra, contribuiu para esse processo. Grande parte dos movimentos sociais e das próprias comunidades já tinha, então, uma relação estabelecida com o Incra. Em 2005, foi lançado o "Programa Brasil Quilombola", que prevê um conjunto de políticas públicas em favor dessa população, articulando vários ministérios. Apesar de as verbas serem do Governo Federal, as ações são implementadas via municípios, o que também fez com que a temática ganhasse maior visibilidade. 


\section{Parte I}

\section{O Dnocs e as Políticas de combate às secas}

A era de [18]77 figura como um ponto de referência no passado dos paraibanos, no seu calendário de calamidades.

Toda a psicologia desse povo ficou sendo dominado pelo conceito da seca (A Paraiba e seus Problemas, Almeida, [1923] 1994, pp. 206, 207). 


\section{A seca como problema nacional}

A seca de 1877 é considerada como um marco na história das secas. Durante os anos de 1877-79, meio milhão de nordestinos deixaram suas terras e foram contabilizadas 200 mil mortes (Pomponet, 2010, p. 2). Para Cunniff (1975), mesmo descontados os exageros característicos da literatura, as evidências não deixam dúvida de que a "Grande Seca" foi uma catástrofe de grandes proporções.

Embora as secas já fossem registradas desde o século XVII com grande número de perdas (Sudene, 1981), em 1877, o fenômeno adquiriu relevância nacional. Ao analisar as razões que tornaram essa seca um marco, Durval Albuquerque Júnior chama atenção para o fato de que tanto sua abrangência como sua duração foram menores que secas anteriores, cujas taxas de mortalidade haviam sido tão grandes ou mesmo maiores. Ao contrário destas, porém, a "Grande Seca" atingiu em cheio as elites que enfrentavam um período de crise econômica, levando parte destas à falência e causando "pânico e indignação contra a falta de proteção que lhe foi negada pelo Império, o qual cobria de benesses as outras províncias". Além desse fato inédito, o autor destacou o papel da imprensa na "reelaboração" da imagem da seca (Albuquerque Júnior, 1995, p.116).

Um dos fatores que contribuiu para a divulgação e nacionalização do problema foi divulgação da catástrofe na imprensa da corte através de uma série de artigos de José do Patrocínio, que havia sido enviado para cobrir a seca no Ceará. Além dos artigos escritos, a revista O Besouro reproduziu, em 1878, algumas

Corrêa, J. A. Secca de 1887-78. A coleção completa dos retratos está disponível em "brasilianafotografica.bn.br". das fotos do cearense Joaquim Antônio Corrêa 
retratando vítimas da seca, uma iniciativa pioneira no fotojornalismo brasileiro (Andrade e Loggato, 1994). Na publicação, o desenho de Bordallo Pinheiro representa a mão de uma caveira segurando duas das fotografias de Corrêa reproduzidas por litogravura. A montagem recebeu o seguinte título: "Paginas Tristes: Scenas e aspectos do Ceará (Para S. Magestade, o Sr. Governo e os Srs. Fornecedores verem) (Copias fidelissimas de photographia que nos foram remettidas pelo nosso amigo e collega José do Patrocinio).

As notícias sobre os efeitos da seca também sensibilizaram o Imperador. $\mathrm{Na}$ Fala do Trono de 1877, o Imperador caracterizou a seca como um "flagelo" e defendeu políticas para minorar os efeitos "de tamanha calamidade" (Artigas de Godoy, 2013). A partir desse momento, a própria seca tornou-se uma questão política (Lewin, 1993).

Em seu livro composto da reunião de artigos escritos em março de 1878 e publicados no periódico Illustração do Brazil, José Américo dos Santos descreveu as ações da comissão do Instituto Politécnico nomeada para estudar a seca que assolava algumas províncias do norte do Império. O autor havia sido designado a emitir um parecer sobre as conclusões da comissão.

Na introdução ao livro, Santos também ressalta o papel da imprensa em fazer com que a seca fosse conhecida na capital do Império.

No theatro dos acontecimentos trabalham, com toda a abnegação, cidadãos conspicuos, acudindo a todo instante com os urgentes socorros á corrente immensa de retirantes, que, acossados pela fome com todo o seu hediondo cortejo, se acharam na dura necessidade de abandonar o seu sólo natal e os seus penates, para irem longe em busca da esmola de trabalho remunerado (Santos, 1883, pp. 1, 2).

Segundo sua avaliação, o governo não havia feito o necessário para evitar os problemas derivados da crise, tendo a iniciativa privada contribuído mais e de maneira mais eficaz para amenizar o sofrimento da população. ${ }^{3}$ Para embasar suas críticas às ações do governo, o autor citou um artigo do Senador Pompeu, do Ceará, 
publicado no Jornal do Commercio em 16 de dezembro de 1877 e reproduzido a seguir:

O que hoje se observa, foi com muita antecedencia por mim prevenido.

Se o governo tivesse acreditado que a secca do Ceará não era um facto transitorio; que teria longa duração e terriveis consequencias, chegaria a convencer-se da conveniencia das medidas então apresentadas.

Agora realisa-se o que ha tempo foi dito: o systema da esmola inutilisou uma população prestavel e dá em resultado a perda de um capital importante, sem a menor vantagem para a provincia; no emtanto, que, se o governo tivesse adoptado o trabalho, podia ter gasto mais algumas centenas de contos, porém teria com este dispendio dotado a provincia de obras importantissimas como a do porto, da alfandega, e sobretudo a estrada de ferro de Baturité, que, sem razão de ser, está condemnada ao esquecimento do governo (Santos, 1883, p.5, grifou-se).

Santos criticou ainda os problemas no envio de gêneros alimentícios para as áreas afetadas, apontando para o fato que, apesar de o governo alegar ser impossível o transporte dos centros de distribuição para as áreas afetas, os retirantes conseguiam fazer a pé e com fome o mesmo trajeto.

Para o autor, as causas da seca não eram apenas naturais, mas derivadas da degradação moral do povo dos estados afetados. Em sua interpretação, a "vida nômade" dos sertanejos não poderia ser "de grande vantagem", fazendo com que os mesmos se descuidassem de dar caráter de permanência às suas construções, que conferiam um aspecto de "grande atrazo ou de civilização muito primitiva, senão aspecto de completa decadencia" à região (Santos, 1883, pp. 14, 15).

Conforme relatou Santos, na sessão de 30 de outubro de 1877 do Instituto Politécnico Brasileiro, foi apresentada e aprovada a seguinte proposta:

Proponho que se nomeie uma comissão especial incumbida restrictamente de apresentar parecer ácerca das seguintes medidas, lembradas como convenientes para remediar as tristes condições das provincias assoladas pela secca: 
1. ${ }^{\circ}$ Abertura de poços artesianos

2. ${ }^{\circ}$ Abertura de vias de communicação acompanhadas de pólos instantaneos e estações de mantimentos

3. ${ }^{\circ}$ Construcção de açudes junto dos povoados ou outros pontos mais apropriados.

4. ${ }^{\circ}$ Canalisação dos rios, estabelecendo no seu curso represas ou açudes

5. ${ }^{\circ}$ Abertura de um canal que communique as aguas do rio S. Francisco com o Salgado, ou outros rios do Ceará.

O parecer deverá considerar cada uma d'estas medidas:

1. ${ }^{\circ}$ Sob o ponto de vista de sua utilidade para minorar os males que as seccas periodicas acarretam á população das duas provincias.

2. ${ }^{o}$ Sob o ponto de vista de sua maior ou menor exequibilidade, apreciandoas, tanto quanto possivel em relação ao tempo que exigiria sua realisação, e ao dispendio pecuniario em que importaria (Santos, 1883, pp. 16, 17).

O então presidente do Instituto, D. Pedro II, nomeou a comissão encarregada de apresentar o parecer a André Rebouças, Carneiro da Cunha e a José Américo dos Santos. Depois de apresentar uma longa discussão sobre a impossibilidade de ligar o rio São Francisco ao Salgado, fazendo o primeiro desembocar no rio Jaguaribe, no estado do Ceará, Santos apresentou as propostas, dividindo-as em dois grupos: "de ocasião" e preventivas.

Entre as medidas de ocasião foram citadas: a remessa de alimentos, que deveriam ser distribuídos apenas mediante trabalho - a denominada "esmola remunerada" -; construção de certas obras públicas como cadeias, escolas, casas, etc; e a emigração forçada quando houvesse impossibilidade de permanência no local de origem. Entre as a ações preventivas foram apontadas: a constituição de um serviço meteorológico, espalhando aparelhos de coleta de dados nas áreas afetadas; melhoramento dos portos; construção de estradas de ferro, que garantiriam não só trabalho mas a chegada de alimentos, prevenindo as retiradas; e a construção de grandes açudes, como havia sido feito India (Santos, 1883, pp. 30-32).

Entre as propostas apresentadas pelo autor, a utilização da mão de obra 
flagelada em obras públicas como meio tanto de garantir o sustendo das mesmas como de impedir a chegada dessa população depauperada nos centros econômicos tornou-se uma espécie de consenso entre a elite político-científica da época.

Para Albuquerque Júnior $(1988,1995)$, o principal acontecimento resultante do evento de 1877 foi a "invenção" de um "discurso da seca" que transformou o fenômeno no principal problema do Nordeste.

Uma característica que chama atenção nas mais variadas produções sobre a seca e seus efeitos é o que Cunniff denomina de "exagero retórico" (Cunniff, 1975). Tanto telegramas de presidentes de província como cordéis, romances, comunicações de políticos locais, textos jornalísticos, ensaios científicos e mesmo algumas produções técnicas, carregam as tintas ao máximo no sentido de pintar uma situação de calamidade pública.

Os impactos da seca de 1877 e a produção de obras literárias sobre o sertão e o flagelo da seca, consolidaram uma imagem do sertanejo como flagelado e fixaram no imaginário nacional a cena protagonizada pelos retirantes, populações famintas, sujas e doentes, que perambulavam pelo sertão. Essa população que vagava sem destino causava medo aos proprietários e aos habitantes das cidades, que acreditavam ser preciso ocupar os flagelados dando-lhes trabalho e civilizando-os.

A partir desse evento, começaram também a ser publicadas obras literárias que tinham como pano de fundo as secas. Como ressalta Albuquerque Júnior, essas obras, que iriam ser classificadas mais tarde como regionalistas, exploram as imagens e acontecimentos "mais chocantes e mais apelativos" buscando com isso impactar a opinião pública nacional (Albuquerque Júnior, 1988, p. 232).

Esse é o caso do romance de Domingos Olímpio intitulado Luzia Homem, publicado em 1903. A ação se passa na cidade cearense de Sobral durante o ano de 1878. As descrições oferecidas são de uma realidade chocante, tornando-se mais pungentes à medida que a narração se desenrola. A situação que se desenhava na cidade com a chegada de levas de retirantes é descrita da seguinte maneira: 
A população da cidade triplicava com a extraordinária afluência de retirantes. Casas de taipa, palhoças, latadas, ranchos e abarracamentos do subúrbio, estavam repletos a transbordarem. Mesmo sob os tamarineiros das praças se aboletavam famílias no extremo passo da miséria-resíduos da torrente humana que dia e noite atravessava a rua da Vitória, onde entroncavam os caminhos e a estrada real, traçado ao lado esquerdo do rio Acaraú, até o mar. Eram pedaços da multidão, varrida dos lares pelo flagelo, encalhando no lento percurso da tétrica viagem através do sertão tostado, como terra de maldição ferida pela ira de Deus; esquálidas criaturas de aspecto horripilante, esqueletos automáticos dentro de fantásticos trajes, rendilhados de trapos sórdidos, de uma sujidade nauseante, empapados de sangue purulento das úlceras, que lhes carcomiam a pele, até descobrirem os ossos, nas articulações deformadas. E o céu límpido, sereno, de um azul doce de líquida safra, sem uma nuvem mensageira de esperança, vasculhado pela viração aquecida, ou intermitentes redemoinhos a sublevarem bulcões de pó amarelo, envolvendo como um nimbo, a trágica procissão do êxodo (Olímpio, [1903] 1983, p. 6).

Entre essas levas, chega à cidade Luzia, a heroína do romance, trazendo com ela a mãe doente. Luzia consegue trabalho na obra da penitenciária de Sobral. Fora do ambiente da construção, a situação é de desamparo total, como ilustrado na cena que descreve um grupo de crianças que perambulava por uma feira:

Magotes de crianças nuas, de hedionda magreza de esqueleto, de grandes ventres, obesos e lustrosos como grandes cabaças, lançavam olhares, terríveis de avidez, sobre as pilhas de rapaduras, grandes medidas de quarta, desbordantes de farinha e feijão, pencas de bananas, rumas de beijus, alvíssimas tapiocas, montes de laranjas pequeninas e vermelhas, colhidas na véspera, nos pomares murchos da Meruoca.

Os míseros pequenos, estatelados ao tantálico suplício da contemplação dessas gulodices, atiravam-se às cascas de frutas lançadas ao chão e se enovelavam, na disputa desses resíduos misturados com terra, em ferozes pugilatos. Era indispensável ativa vigilância para não serem assaltadas e devoradas as provisões à venda, pela horda de meninos, que não 
falavam; não sabiam mais chorar nem sorrir, e cujos rostos, polvilhados de descamações cinzentas, sem músculos, tinham a imobilidade de couro curtido. Quando contrariados ou afastados pelos mercadores aos empuxões e pontapés, rugiam e mostravam os dentes roídos de escorbuto. Eram órfãos quase todos, ou abandonados pelos pais; não sabiam os próprios nomes, nem donde vinham. Privados de memória, bestificados pela carência de carinhos, anestesiados pelo contínuo sofrer, eram esses pequeninos mendigos gravetos de uma floresta morta, despedaçados pelos vendavais, destroços de famílias, dispersadas pela ruptura de todos os laços de interesses e afetos.

Às vezes, a morte os surpreendia durante o sono, junto de um tronco ou na soleira de uma porta. Trespassavam como pássaros, sem contorções, sem estertor, sem um gemido, silenciosos, tranquilos, num sossego de morte, num sossego de liberdade (Olímpio, [1903] 1983, p.50).

A última descrição dos retirantes que ainda chegavam na cidade é ainda mais tétrica. Uma amiga de Luzia, Tereza, que também havia se retirado para Sobral, caminhava para casa da primeira quando se deparou com um grupo que marchava para a cidade. Tereza se habituara àquelas cenas e à "vizinhanças da miséria nas formas mais lúgubre e vis", já vira de tudo.

Vira crianças, a sugarem os seios murchos das mães mortas; cadáveres desses entezinhos abandonados sobre a estrada, devorados por urubus e cães vorazes: criaturas, ainda vivas e exangues, torturadas pelas bicadas de carcarás a lhes arrancarem, aos pedaços, as carnes ulceradas e podres. Vira mães desnaturadas ocultarem em crateras de formigueiros, o fruto de amores criminosos, ou traficarem com filhas impúberes; pais desalmados, incestuosos e delinqüentes dos mais torpes crimes, como se o concurso de todas as dores e de todas as baixezas, condensando-se em enorme e fantástico suplício, os houvera transformado em monstros hediondos, rebalsando-se em lances trágicos de ferocidade inconsciente. Diante dela haviam tombado, fulminados pela fome, indivíduos de aparência sadia e robusta, estrebuchando no chão como epilépticos a tragarem terra aderente aos dedos sangrentos e blasfemares contra o Deus impassível que os desamparava, os renegava filhos pecadores, condenados, em vida, às torturas daquele inominável inferno da 
miséria (Olímpio, [1903] 1983, p. 83).

Ao contrário das descrições lúgubres da população que se retirava, as cenas das obras são positivadas e são sublinhados seus aspectos redentores. $\mathrm{O}$ autor se posiciona favoravelmente à utilização da população que vagava pelos sertões como mão de obra nas construções empreendidas pelo poder público, assim como muitos de seus contemporâneos. Domingos Olímpio deixou bem clara a sua posição logo no início do romance.

Acertara a Comissão de Socorros em substituir a esmola depressora pelo salário emulativo, pago em rações de farinha de mandioca, arroz, carne de charque, feijão e bacalhau, verdadeiras gulodices para infelizes criaturas, açoitadas pelo flagelo da seca, a calamidade estupenda e horrível que devastava o sertão combusto. Vinham de longe aqueles magotes heróicos, atravessando montanhas e planície, por estradas ásperas, quase nus, nutridos de cardos, raízes intoxicantes e palmitos amargos, devoradas as entranhas pela sede, a pele curtida pelo implacável sol incandescente.

$\mathrm{Na}$ construção da cadeia havia trabalho para todos. Os mais fracos, debilitados pela idade ou pelo sofrimento, carregavam areia e água; aqueles que não suportavam mais a fadiga de andar amoleciam cipós para amarradio de andaimes; outros menos escarvados amassavam a cal; os moços ainda robustos, homens de rija têmpera, guindando material aos pedreiros, ou conduzindo às costas, de longe, das matas do sopé da serra, grossos madeiros enfeitados de palmas virentes, de ramos de pereiro de um verde fresco e brilhante, em festivo contraste com o sítio ressequido e desolado. E davam conta da tarefa, suave ou rude, uns gemendo, outros cantando álacres, numa expansão de alívio, de esperança renascida, velhas canções, piedosas trovas inolvidáveis, ou contemplando com tristeza nostálgica, o céu impassível, sempre límpido e azul, deslumbrante de azul (Olímpio, [1903] 1983, p. 1).

Além do livro de Olímpio Domingos, outras obras literárias ajudaram a divulgar as cenas das retiradas. A publicação de Os Sertões, de Euclides da Cunha, em 1902, acabou por incluir definitivamente na pauta nacional a questão do sertão e da seca (Albuquerque Júnior, 1988). Mas, apesar de o discurso da seca mobilizar 
recursos e políticas desde o marco de 1877, a primeira instituição nacional de combate aos efeitos das secas, a Inspetoria de Obras Contra as Secas (Iocs), subordinada ao Ministério da Viação, foi criada apenas em 19094. Também pela primeira vez, recursos do tesouro nacional garantiram os meios para que os estados nordestinos construíssem estradas regionais, facilitando o escoamento da produção, principalmente do algodão (Lewin, [1987] 1993).

A Diretoria da Inspetoria foi ocupada pelo engenheiro Arrojado Lisboa, tido como grande empreendedor e "homem de visão excepcional" (Guerra, 1981). Sob sua direção, foi empreendida uma série de estudos que buscavam acabar com o problema da seca no Norte do país.

Os engenheiros tiveram papel destacado na proposição e execução de projetos contra a seca. Com o advento da República, esse grupo tornou-se politicamente influente, passando a compor um "corpo técnico" capaz de modificar a realidade da nação intervindo diretamente na mesma (Ferreira, Medeiros \& Simonini, 2009). Em discurso proferido aos "engenheirandos" de 1920, o engenheiro Francisco Ferreira Ramos afirmava que as secas, "sobretudo as do nordeste", "são problemas que a vós [engenheiros] compete resolver para a glória vossa, para orgulho da Engenharia Nacional e para o bom nome do nosso Instituto". ${ }^{5}$

Além de resolver problemas como aqueles causados pelas secas, tratava-se de integrar, desenvolver e civilizar o país por meio da ação direta e objetiva - "técnica". Contrapunham-se, assim, a um saber mais "teórico" e distante da realidade, próprio dos bacharéis de direito e medicina de então. Assim como esses, porém, atribuíam a si mesmos uma importância tal que a denominação Engenheiro vira uma espécie de título de nobreza, sendo grafado em letra maiúscula e aposto ao nome $\left(\mathrm{Eng}^{\mathrm{O}}\right)$ como Dom ou Dr.. ${ }^{6}$

O Engenheiro e deputado estadual do Rio de Janeiro Mateus Nogueira Brandão publicou, em 1908, um livro no qual analisou a seca de 1903, propondo medidas para amenizar os efeitos causados pelo fenômeno cíclico que atingia os 
estados da região que denominou de "Nórdeste". Para o engenheiro, as grandes secas que acometiam os estados dessa região só deixariam de ser "tão calamitosas" a partir do momento que os moradores do sertão pudessem se precaver destas através da irrigação do solo e aproveitamento das águas da chuvas.

Brandão criticou a política assistencialista dos socorros públicos que, além de inúteis para solucionar o problema, eram caras e motivo para a cobiça dos governantes locais, apontando para o fenômeno que seria no final da década de 1950 conceituado pelo jornalista Antônio Callado como indústria da seca: a utilização flagelo como justificativa para a captação de recursos pelos governos locais, que os utilizavam, entretanto, para outros fins.

Nestas occasiões [secas] renascem do sentimentalismo altruista as suggestões de medidas a tomar promptamente, por se verificar a hypothese do art. $5^{\circ}$ da Constituição da República [que determina que a União prestará socorros aos Estado que, em caso de calamidade pública, os solicitar], quando dos Estados flagellados reclamam com insistencia os socorros.

Preoccupam-se alguns exclusivamente com o processo da distribuição desses soccorros publicos, sempre serodios e inefficazes para salvar o capital humano, livrando o povo do martyrio e da extincção pela fome. Ainda mais atormentam-se com a ideia de que os socorros, porventura concedidos pelo Governo, hajam de ser ministrados por intervenção da comissões regionaes.

Porquanto, poderá fazel-o por meio e com auxilio dos funccionarios federaes e seus agentes de confiança.

Ainda sobrevivem muitos contemporaneos da pavorosa calamidade de 1877-1879, com a qual despendeu o Governo Imperial quantias superiores a 60 mil contos de réis, que assim saccou sobre o futuro, onerando todo o paiz com o augmento da divida publica e consequentes impostos (Brandão, 1908, p. 38).

Assim como o autor de Luzia Homem, Brandão afirmou aplaudir "com sincero entusiasmo" a política de proporcionar trabalho aos braços que superabundavam na região, utilizando-os nas barragens, açudes, reservatórios, poços artesianos e vias 
férreas. A esmola humilha e escraviza, escreveu, usando o bordão que seria repetido até pelo menos a década de 1930, quando a utilização de mão de obra retirante tornou-se a linha mestra da política de socorros.

O conhecimento técnico dos engenheiros se materializou nas grandes obras de açudagem e na construção de uma malha de transportes que visava integrar o Nordeste à economia do país. O papel desempenhado por eles no órgão de obras contra as secas foi enorme, fazendo parte de suas normativas antigas que este seria dirigido por um Engenheiro.

\section{José Américo de Almeida, Ministro das Secas e Pai da Bagaceira}

Com relação ao montante de verbas destinadas ao órgão de combates às secas, destacam-se os períodos em que o paraibano Epitácio Pessoa esteve frente à presidência da República (1919-1922) e que o também paraibano José Américo de Almeida foi Ministro da Viação e Obras Públicas (1930-1934 e 1953-1954), sendo ambos considerados redentores de seu povo.

Epitácio Pessoa foi o primeiro governante a realizar um plano de açudagem pública e de construção de rodovias na Paraíba. A soma dos investimentos feitos no Nordeste no primeiro ano de seu governo, em 1919, alcançou a cifra de 145.947 contos de reis. O valor para o ano de 1918, último ano da gestão de Venceslau Brás, havia sido de 2.326 contos de reis (Pomponet, 2010: 3).

Entre as ações de seu governo, destaca-se o contrato celebrado entre Governo Federal e as firmas inglesas $\mathrm{CH}$ Walker e C ${ }^{\circ}$ LTDA e Northon Griffin e C'LTDA e a americana Dwight P. Robinson e CoInc, em fevereiro de 1921, entregando a estas firmas a execução do "plano geral de Grande Açudagem do Nordeste Brasileiro" (Ifocs, 1925, p. IX). As obras dos açudes Piranhas e São Gonçalo, na bacia do rio Piranhas, na Paraíba, ficaram a cargo da empresa americana.

Muitas obras foram paralisadas após o fim do mandato de Epitácio Pessoa em 1922 e retomadas apenas com a entrada de José Américo no Ministério da Viação. 
Entre essas obras, estava a do açude São Gonçalo, em Souza na Paraíba. A retomada da construção de São Gonçalo foi retratada no romance da escritora local Ignez Mariz, publicado dois anos depois da inauguração do açude, em 1935.7 Em uma das passagens desse livro, o personagem principal comenta com a mulher sobre as mudanças operadas pelo Ministro, entre eles a mobilização da Cruz Vermelha para o envio de leite condensado às crianças.

- Quem mandou [o leite]?

- O nosso Ministro, mulher, quem havera de ser mais? Você não sabe que depois de Epitácio só elle se lembrou de nós? E é porque é daqui. Diz o povo, Marica, que elle escreveu um livro todinho contando a sêcca.

- Elle já foi "retirado", Zé?

- Você é besta Mariquinha. Elle é um doutor formado. Diz o povo que inventou as histórias de cabeça, como a gente faz conta... Mas eu já ouvi lêr um pedaço do livro na goiabeira de compadre Luiz Silva e foi tal qual o que nós passemo... (Mariz, [1937] 1994).

O livro escrito pelo Ministro ao qual o protagonista do romance A Barragem se refere é o ensaio A Paraiba e seus Problemas, publicado em 1923. O livro foi encomendado pelo então governador do estado, Sólon de Lucena, que pretendia homenagear Epitácio Pessoa registrando as benfeitorias por ele promovidas na região. Talvez como nenhum outro autor, José Américo foi responsável pela versão paraibana do "discurso oficial da seca" de que fala Albuquerque Júnior.

Comentando sobre A Paraiba e seus Problemas em seu discurso de posse na Academia Brasileira de Letras em 1967, José Américo destacou que o livro deveria ser um memorial do plano empreendido por Epitácio com o fim de evitar que esse fosse suspenso por seu sucessor (Almeida, 2009).

Antes de proceder à descrição das obras daquele que qualifica como "superhomem", José Américo buscou provar que as secas eram um fenômeno caracterizado pela irregularidade das chuvas e seus efeitos poderiam ser remediáveis através de medidas preventivas, como o armazenamento de água em grandes reservatórios. $\mathrm{O}$ 
autor lançou mão de vários estudos científicos sobre os aspectos físicos, climáticos e geológicos do território paraibano, no intuito de evidenciar que a Paraíba corresponderia, "vantajosamente, pelo conjunto de seus elementos físicos, ao emprego dos dinheiros públicos despendidos em seu benefício" (Almeida, [1923] 1994, p. 41).

Se o principal problema da Paraíba era a seca, não menos grave era o abandono do estado por parte do Governo Federal. O descaso se traduzia não só pela falta de recursos, mas também pela ausência de qualquer repartição pública federal em terras paraibanas.

Tal "alvitre monstruoso" só poderia se dar pela ignorância da natureza do estado "na integridade da sua formação." (Almeida, [1923] 1994, p. 41).

Haveria não só um total desconhecimento sobre os pontos positivos da natureza e história da Paraíba, mas também sobre os "infortúnios" causados pelas secas no estado.

Descontente com a centralidade ocupada pelo Ceará na política de socorros, José Américo construiu seu argumento visando demonstrar que era na Paraíba que deveriam ser concentrados grande parte dos recursos, uma vez que: 1) o estado seria tão ou mais assolado pelas secas que o Ceará, sendo atingido em quase sua totalidade; 2) a geografia local, com suas serras e seus boqueirões, favoreceria a construção de grandes reservatórios de água; e 3) o povo paraibano reuniria o que há de melhor das raças branca e indígena, sendo capaz de prosperar desde que garantidos os meios materiais.

Para José Américo, o "martírio dos paraibanos", ao contrário do sofrido pelos cearenses, ainda permanecia "inédito", dando a falsa impressão de que o estado não sofria com as secas. O autor construiu então o que denomina de "martirológio", uma cronologia das secas seguidas de seus efeitos deletérios (Almeida, [1923] 1994, pp. 161, 162). Conforme vai avançando em sua cronologia, o autor vai carregando as tintas na descrição dos "infortúnios" e "desgraças" sofridas, que teriam atingido o 
ápice durante a seca 1877. Essa teria sido tal que, em Pombal, a retirante Dyonisia dos Anjos "roubara" uma menina de 5 anos que teria decapitado e comido. Mesmo os proprietários mais abastados e os temíveis cangaceiros teriam fugido da fome.

Para ilustrar tamanha "tragédia coletiva" o autor reproduziu um poema de Nicandro Nunes do Nascimento e Bernardo Nogueira, "dois rapsodos plebeus", que tem entre as suas estrofes:

- Com razão, paes, te aflagellas

Não teres trajes decentes

Que cubram as innocentes

Carnes das filhas donzellas

Seminuas saem ellas,

Com a vista baixa no chão,

Se escondendo entre os mais vão,

Dos olhos lagrimas correndo,

A quem encontram é dizendo

Foge povo do sertão!

- A fome foi tão canina

Que, se mais saber tu queres,

No Pombal duas mulheres

Comeram uma menina.

(...)

- Marchemos a encarar

Trinta mil epidemia,

Frialdade, hydropsia,

Que ninguém póde escapar
Os que para o brejo vão

Morrem de epidemia;

Soffrem fome todo o dia

Os que ficam no sertão,

Neste pego de afflicção.

Vae o sertão ficar vago!

- Que é feito dos cangaceiros

Que dominavam Teixeira?

Deu-lhe a fome uma carreira;

Foram esbarrar no lameiro

Quedê homens de dinheiro

Que ralhavam no sertão?

Que é feito do valentão

Que cevava o guarda-costa?

Vive tudo de mão posta

Dizendo Deus dai-nos pão (Almeida, [1923] 1994: 204-206).

Para além da fome e da mortalidade, o autor sublinhou os efeitos de desagregação moral resultantes do fenômeno, que colocava em risco a honra das sertanejas. A perambulação dos retirantes do sertão para o "lameiro" (Brejo paraibano) é também repisado. Para José Américo, os problemas não estariam restritos às áreas afetadas, já que os retirantes que iam para as áreas mais úmidas 
causavam epidemias, aumentavam a prostituição e saqueavam o comércio.

O flagelo das secas, expresso na imagem do sofrimento físico e moral do retirante, surgiu como o grande argumento para justificar a necessidade de investimento em obras contra as secas. Ao sentimento de pena ligava-se o temor da invasão de "hordas" que poderiam a qualquer momento invadir as áreas mais abastadas e cometer todo tipo de crimes, desde saques até a antropofagia, ameaçando a saúde e a moral das famílias com seus corpos "nús". Esse sentimento dúbio, de compaixão e temor, despertado pelo retirante iria acompanhar as obras de José Américo e grande parte da literatura sobre as secas.

O autor descreveu como foi tocado pessoalmente pelo fenômeno durante a seca de 1898, quando presenciou a passagem dos retirantes por Areia, sua cidade natal, localizada na região do brejo paraibano. Segundo seu relato,

Foi a minha primeira impressão [1898] pessoal da calamidade. E a retentiva infantil tocada por cenas tão violentas é indelével. Nunca mais me esqueceu o espetáculo constristador que eu mal compreendia e que ainda hoje me arrepia a sensibilidade.

Era uma macabra procissão de múmias.

Passavam, aos ranchos, na solidariedade da dor comum.

Depois de terem palmilhado os sertões longínquos, mortos de sede, de fome e de fadiga, ainda marchavam, caveirosos e arquejantes, atrás de um conforto inatingível.

Se a gente se compadecia da penúria orgânica dos adultos, deformados pelas perturbações tróficas, com a pele enegrecida colada às longas ossaturas, desfibrados e fétidos, pelo efeito da autofagia, quanto mais das crianças mirradas que entravam pela vida tão desgraçadamente (Almeida, [1923] 1994, pp. 215, 216).

Em seu livro de memórias, José Américo relatou também a convivência com os filhos da seca. Ao descrever as atividades cotidianas de seu tempo de criança no engenho de seu pai, o autor anotou:

Lá pelas seis horas, vinha a moleca Francisca, cria de casa, trazendo a 
toalha ao ombro. Nas secas alguns retirantes desfaziam-se dos filhos.

Ficavam esses resíduos. A cabrita lavava e enxugava os nossos pés. Só os pés mereciam dormir limpos: o resto do corpo não andava no chão e esperava o banho de cuia, quando Deus era servido (Almeida, 1976, p. 25).

Em A Paraiba e seus Problemas, juntamente com a descrição dos efeitos desagregadores das secas, o autor citou as políticas de socorros, demonstrando sua total ineficiência e também o "abandono" sofrido pela Paraíba. Até 1877, a ação do Governo Monárquico estaria restrita ao repasse de verbas para a compra de alimentos pelas províncias e municípios afetados, a chamada "esmola pública". A partir desse momento, o governo passou a utilizar os retirantes como mão de obra na construção de açudes e estradas.

Tais obras, criticou, ficavam a cargo de "chefes políticos locais" que, além de "consumirem avultadas quantias no interesse partidário", não obedeciam a critérios técnicos, desaparecendo "aos primeiros invernos" (Almeida, [1923] 1994: 301). Esse quadro iria mudar, segundo o autor, apenas com o governo de Epitácio Pessoa e o fortalecimento da estrutura do órgão federal de combate às secas.

Assim como muitos pensadores da época, José Américo via na grande açudagem a maneira mais eficaz de armazenar água para os momentos de crise, assim como de garantir trabalho para a população flagelada. Nesse sentido, a "estrutura" do sertão paraibano era singularmente vantajosa, bastando "'restaurar a terra"' ao "fechar os boqueirões" (Almeida, [1923] 1994, p. 382). Essa tese já havia sido defendida por Irineo Joffily em suas Notas sobre a Paraiba ([1892] 1977, pp. 17, 18), livro considerado inaugural na historiografia paraibana.

Depois de demonstrar as vantagens geográficas do investimento no estado, o autor dissertou sobre os benefícios oferecidos pelo povo paraibano em geral, e pelo sertanejo, em especial. A visão negativa do mestiço expressa pela maioria dos intelectuais brasileiros até pelo menos a década de 1930 engrossava as críticas sobre os gastos com os socorros a essas populações. ${ }^{8}$ 
José Américo dedicou um capítulo inteiro de seu livro para desfazer essa visão e justificar o interesse nacional na preservação do sertanejo, espécie de ícone da nacionalidade que guardava as características mais nobres das raças originárias. Para o autor, "o que se atribui a uma desgraça hereditária é, simplesmente, um mal social", fruto de um meio "de péssima organização econômica e de analfabetismo esterilizador" (Almeida, [1923] 1994, p. 537).

O sertanejo mestiço, beneficiário direto das políticas contra as secas, não seria um "decaído" ou "desequilibrado funcional" incapaz de trabalho produtivo, como sentenciaram Euclides da Cunha e Oliveira Viana. Apoiando-se no elogio que Alberto Torres fez ao mestiço em O Problema Nacional Brasileiro, José Américo ressaltou a capacidade produtiva do sertanejo, observada mesmo sob as condições mais precárias.

Para Euclides da Cunha e Oliveira Viana, a reunião de características morfológicas e psicológicas díspares, oriundas de tipos raciais muito diferentes, resultaria inevitavelmente em um tipo instável, refratário à civilização.

Segundo Oliveira Viana, o "caos étnico" do nosso tipo "antropológico e racial" seria ainda mais acentuado no caso dos cruzamentos com negros (Viana, [1923] 1938:, p.155). Euclides da Cunha já havia chegado à mesma conclusão em Os Sertões, no qual diferenciou o mestiço "neurasthenico" do litoral, que é mulato, do mestiço do interior, resultante da mestiçagem do branco com o índio. Ao contrário da indolência do litoral, o tipo sertanejo seria vigoroso, "um forte", embora ainda deformado pelo caldeamento de raças, um "Hercules-Quasimodo", segundo definição que ficou famosa (Cunha, [1902] 1905, p. 114).

Mesmo afastando a tese que condenava a mestiçagem, José Américo replicou a diferenciação oferecida por Euclides da Cunha entre os mestiços do sertão e os da zona canavieira (litoral e brejo), reduzindo ao máximo a influência do "homo affer" no tipo sertanejo. Confrontado com um alto número de escravos em cidades sertanejas como Piancó em finais do século XIX, o autor fez desaparecer essa 
população durante a seca de 1877, quando, afirmou, muitos teriam sido vendidos para outros estados ou morrido de fome.

Segundo o autor, no sertão, a mistura racial principal teria se dado entre índios e brancos. A população seria "quase toda clara", "tão clara, até nas classes inferiores, que não pode constituir os 'curibocas puros', apresentados por Euclydes da Cunha como tipo normal desse povo" (Almeida, [1923] 1994, p. 524).

José Américo replicou a idéia expressa em Evolução do Povo Brasileiro (Viana, [1923] 1938) de que os indígenas brasileiros (e portanto os sertanejos) teriam uma "aversão" de raça com relação aos negros, e parece tornar realidade o sonho de Oliveira Viana ao afirmar que, excluído da mistura o negro, "elemento inferior", não teria havido o "desequilíbrio das influências opostas" e, talvez, se verificasse "na hipótese, a evolução do mameluco para o ariano. É, porventura, o processo de clarificação, o retorno atávico, a lei da seleção étnica" (Almeida, [1923] 1994, pp. 524, $525)$.

Fornecidas as condições mínimas de sobrevivência, como garantia de água, alimento, saneamento, instrução e trabalho, o sertanejo poderia se desenvolver plenamente. Além disso, era necessário fixar esse elemento em seu "habitat". Todas essas questões, escreveu, seriam resolvidas com as grandes barragens, intervenção que teria por si só "um alcance decisivo" (Almeida, [1923] 1994, p. 554).

A defesa da continuidade das grandes obras públicas nas regiões afetadas pelas secas, feita no ensaio de 1923, parece não ter surtido efeito junto aos presidentes Artur Bernardes e Washington Luis.

No Relatório dos trabalhos executados pela Ifocs durante o ano de 1924, o então Inspetor, Arrojado Lisboa, relatou a paralisação de grande parte das obras em curso, que foram definitivamente suspensas em 1925, através do decreto 16.769. Esse decreto suspendeu não só as obras a cargo da Ifocs, como também todas as obras públicas que estavam sendo executadas pelos diversos ministérios. ${ }^{9}$ 
Apesar das obras terem sido paralisadas pelo próprio governo brasileiro, o fato de elas estarem sob responsabilidade de empresas estrangeiras foi apontado como um dos fatores do insucesso das mesmas, como veremos mais a frente.

Em 1927, foi ainda extinta a "Caixa Especial das Obras de Irrigação de Terras Cultiváveis do Nordeste Brasileiro" que havia sido criada em 1924. No relatório dos trabalhos executados em 1927, o Inspetor Palhano de Jesus descreve as más condições das obras paralisadas, ressaltando as constantes ameaças de "bandoleiros que perambulam na região" e até mesmo dando nota da passagem do grupo de "Lampeão" nas obras paralisadas do açude Pilões, na Paraíba (Ifocs, 1928).

Quando uma nova crise já se prenunciava, José Américo retomou o tema da seca em A Bagaceira, livro que alcançou projeção nacional e é considerado um dos marcos fundadores da literatura regionalista do Nordeste. Segundo explicou em seu discurso de posse na Academia Brasileira de Letras, não havia sido possível utilizar todo o material reunido para a preparação de A Paraiba e seus Problemas: "Eu tinha mais o que dizer e essa disponibilidade procurava outro meio de expressão. Era a substância de um romance: A Bagaceira. Recuei, para ver tudo a distância, com uma aparência mais simbólica" (Almeida, 2009, p. 4).

Ambientado em uma fazenda em Areia, o romance se inicia com a chegada de um grupo de retirantes que fugia da seca de 1898 e buscava trabalho, assim como o grupo que José Américo havia testemunhado quando criança.

Era o êxodo da seca de 1898. Uma ressurreição de cemitérios antigos esqueletos redivivos, com o aspecto terroso e o fedor das covas podres.

Os fantasmas estropiados como que iam dançando, de tão trôpegos e trêmulos, num passo arrastado de quem leva as pernas, em vez de ser levados por elas.

Andavam devagar, olhando para trás, como quem quer voltar. Não tinham pressa em chegar, por que não sabiam aonde iam. Expulsos do seu paraíso por espadas de fogo, iam, ao acaso, em descaminhos, no arrastão dos maus fados. 
Fugiam do sol e o sol guiava-os nesse forçado nomadismo.

Adelgaçados na magreira cômica, cresciam, como se o vento os levantasse. E os braços afinados desciam-lhes aos joelhos, de mãos abanando.

Vinham escoteiros. Menos os hidrópicos - doentes da alimentação tóxica - com os fardos das barrigas alarmantes...

Não tinham sexo, nem idade, nem condição nenhuma. Eram os retirantes. Nada mais (Almeida, [1928] 2004, p. 8, grifou-se).

Reaparecem no romance de 1928 os temas da degeneração física e moral da população devido "a libertinagem das secas", o êxodo forçado e a exploração a que ficava sujeita essa população (Almeida, [1928] 2004, p. 38). Ao mesmo tempo, os sertanejos são definidos como movidos pelos seguintes "sentimentos fundamentais": a "dignidade da família e o apego à gleba" (Almeida, [1928] 2004, p. 98).

Em um dos trechos d'A Bagaceira, o patriarca da família retirante conta um caso no qual defendera a honra de uma moça que "não tinha ninguém por si". Entusiasmado com o desfecho da história, o herói do romance exclama acerca daquele que salvara a donzela: "Reservas da dignidade antiga! Resistência granítica, como os afloramentos do Nordeste! Solidificação da família! Tesouro das virtudes primitivas!" (Almeida, [1928] 2004, p. 42).

Outro ponto explorado no romance é a inadequação da população retirante ao Brejo e o contraste entre a "pureza" dos sertanejos e a mentalidade de engenho dos brejeiros, cujos "costumes estragados" eram "resíduos da escravaria, [d]os estigmas da senzala" (Almeida, [1928] 2004).

Em 1935, após a sua passagem pelo Ministério da Viação e Obras Públicas (1930-1934), José Américo publicou mais dois romances Coiteiros e O Boqueirão. Em seu discurso de posse na Academia Brasileira de Letras em 1967, o autor comentou sobre esses dois romances: "não consentindo" suas responsabilidades certas manifestações, só ao deixar a pasta liberei duas novelas que moravam na minha cabeça: Coiteiros e O Boqueirão.

Segundo sua interpretação, esses livros completariam de alguma maneira a 
sua análise dos problemas da Paraíba e também dos problemas do Nordeste, que vinha se configurando como região específica desde o início da República.

O Boqueirão narra os acontecimentos em uma pequena cidade do sertão da Paraíba entre o início e a paralisação das obras de construção de um açude público. Remo, o herói do romance, retorna à terra natal após ter concluído o curso de engenharia. Com ele, seguiram para o sertão um amigo americano, Frank White, e uma comitiva de engenheiros para realizar uma grandiosa obra no boqueirão da cidade.

Todo o romance é permeado pelo choque entre os costumes "atrasados" dos fazendeiros e sertanejos matutos e o progresso representado pelos engenheiros. Ao descrever a chegada da comitiva, José Américo caracterizou o assombro dos fazendeiros:

Os fazendeiros, senhores do sertão, encolhiam-se, à beira do caminho, para darem passagem a essa investida do progresso. Saltavam, humildemente, segurando os cavalos famosos, "marchadores" e "esquipadores" insignes, em toda a redondeza, que se exasperavam com as patas nos peitos dos seus donos.

Mandões que haviam interceptado as estradas empiquetando-as, com sua milícia privada, tombavam dos animais passarinheiros (Almeida, [1935] 1979 , p. 128, 129).

O choque entre os costumes é exemplificado no contraste entre as mulheres pudicas sertanejas versus as modernas americanas que, de tão livres, "mais pareciam homens". Quando os amigos Remo e White discutem sobre o assunto, o americano parece mais apaixonado pela "alma sertaneja" - "tentar mudar a alma de um povo é expô-lo a perdê-la; tudo pode ser artificial, menos a alma" -, enquanto o brasileiro acredita na modernização do sertão e do sertanejo (Almeida, [1935] 1979, p. 140).

Remo enfrentou oposições de todos os lados, mas a certeza da mudança era garantida pelas fabulosas máquinas que transformavam a realidade de cidadezinhas pelo sertão afora. 
Remo sentia que ia ser devorado pelo seu ideal. Tanto se lhe inflamara na alma em entusiasmos vãos, que se queimava a si próprio. Queimava, no sentido das decepções mais acres. Desejando a tudo e renunciando tudo. Criando um mundo de fantasias e sofrendo por que não encontrava a realidade. Os contrastes de ambiente deformavam-lhe as sensações mais simples em conflitos interiores.

O sertão já lhe queria mal pelo bem que lhe fazia.

Os acampamentos cresciam, à beira dos açudes, com ares de cidades.

Era uma improvisação de vida nova, ao lado dos burgozinhos caducos.

Tudo mais se atrofiava.

Cidades cruzadas de becos mais largos que as ruas. Ruazinhas que se acabavam onde começavam. Cidades de uma só rua. Nem se dizia cidade: "vive na rua". Casas viradas umas para as outras, como em conversa: umas, mais petulantes avançavam; outras, fora do alinhamento, que nunca existira, modestamente recuadas. Ruazinhas humildes que já eram ruínas antes de serem ruas. Ruazinhas onde quase não se havia casas e onde havia mais casas do que gente. Com uma oiticica no meio que parecia dar mais sombra do que todas as casas juntas. Ruazinhas mesquinhas que adormeciam antes do cair da noite, com lampiões indigentes que só serviam para mostrar as trevas. Passavam vaqueiros, como se andassem de costas, ainda com cores do passado. E os bodes esfregavam-se entre si, com uma distinção de citadinos.

Processava-se a assimilação violenta, uma nova concepção da luta pela vida.

Era o mundo que se chegava, por que nunca iriam conhecê-lo.

Sentados nas calçadas carcomidas, em mangas de camisa, como se aquilo fosse a sala de visitas de toda a população urbana, os mais velhos davam à trela:

- Ah meu amigo, isso acaba mal. Não se pode endireitar assim.

Eram as últimas expressões de um tempo que se diluía.

Só tiravam o cachimbo pra cuspir.

Remo ensaiava persuadir:

- Não precisamos mais de chuva; a chuva ou não vem ou vem tarde e 
às más horas. O que queremos é água.

Um aprovou com os olhos duros de pedra:

- Bom já me falaram nisso. Prouvera a Deus.

Mas outro revidava:

- Não acho vantagem. O sr. compreende. É melhor não pensar na seca. Só se pensa na seca quando ela vem. É o que lhe digo. Falo como mais velho.

Outro, com maçarocas de cabelos nos ouvidos, percebia ainda menos:

- Que é que o sr. está pensando? A seca faz mal, mas já se sabe o mal que faz. Recebe-se como se pode, como uma doença qualquer. O pior é a gente não saber o que vem.

Remo fazia-se de apóstolo:

- É a salvação de todos nós.

E, com a fala repousada, comido da ferrugem das tradições, um outro replicava:

- O quê? De que serve salvar, se o sertão vai ser outro. Eu juro! Antes a seca que vem e passa. E tudo fica como é.

Interrompiam a discussão.

- Não lhe dê corda! Foi correr o mundo e ficou assim.

Cada um desses dias devoradores do passado era um desequilíbrio de valores humanos. A recusa de adaptação exprimia, sobretudo, o temor de uma felicidade portadora de atritos morais.

E o boqueirão blaterava, com um clamor de vento estrangulado. Espedaçava-se um redemoinho na sua garganta seca (Almeida, [1935] 1979, pp. 142, 143).

A construção da barragem foi descrita como uma maneira de "domar o sertão", corrigir a terra "insubmissa", travando uma verdadeira "guerra ao sol". José Américo de Almeida discute a resistência dos sertanejos e aponta para os efeitos dessa resistência nos trabalhos da barragem. Era preciso que os operários acreditassem também naquilo que faziam e, ao passo que as máquinas ganhavam certa humanidade, era preciso também tornar os homens máquinas.

Nas descrições dos costumes atrasados, Remmo critica o "padrinho padre Cícero" e seu romeiros - "É preciso dar cabo desse fanatismo!". Acusado de "ser 
contra" o padre, atribui a acusação à "vingança dos fornecedores comilões, dos aproveitadores insaciáveis que estavam acostumados a chupar os ossos dos retirantes, nas transações da seca" (Almeida [1935] 1979, p.180).

Com o desenrolar da trama e também das obras, Remo acredita que o sertão vai, enfim, civilizando-se. O entusiasmo do qual é tomado termina com a chegada de um telegrama que mandava paralisar as obras. Transportando à sua cidadezinha imaginária a história de muitos lugarejos, como São Gonçalo e Boqueirão de Piranhas, na Paraíba, que tiveram suas obras iniciadas por firmas americanas contratadas durante o governo de Epitácio Pessoa em 1922 e paralisadas logo depois na gestão de Artur Bernardes.

O chefe da comissão recebeu um telegrama com a nota urgente. E, como se fosse uma ordem para continuar a beber, esvaziava garrafas sobre garrafas, sem dizer nada. Mas olhava, demoradamente, para cada copo cheio, antes de tomá-lo, vendo a espuma desfazer-se.

Remo apanhou, afinal, o telegrama que já voava no chão. E, depois de lê-lo, afastou a garrafa de cerveja. Achou a espuma mais amarga.

Ergueu-se, levantando um copo cheio de vinho, como se estivesse cheio de sangue.

Soltou um grito de protesto nacional, como um urro doloroso:

- Não pode!

E saiu, com o copo entornado na mão arroxeada:

- Pára a música!

Ergueu o braço, acima de todas as cabeças:

- Olhem isto!

O papel verde, todo dilacerado, mudava de cor.

Os americanos moviam as sobrancelhas em sinal de indiferença.

Estranhavam:

- O que é isso?! Você que animava tudo, cabeça de toda festa?!

E ele invectivava com mais veemência, a alegria que criara:

- Eu não sabia!...

Outros que não atinavam com essa exaltação repentina: 
- Venha animar!... Sem você não tem graça...

Em resposta, ele soletrava o telegrama, como se não soubesse mais ler.

Era a ordem de paralisação das obras. O governo não tinha mais dinheiro. O mais que podia fazer era matar um pouco da fome dos sertanejos, quando houvesse seca, que sempre havia (Almeida [1935] 1979, p. 190).

Além do drama da paralisação das obras, e do progresso no sertão, fica evidente na passagem acima a falta de compromisso dos técnicos estrangeiros com os trabalhos. Para Remo, e também José Américo, as obras tinham um verdadeiro fundo patriótico.

O romance termina em verdadeiro tom de tragédia, a barragem inacabada se desintegrando com o tempo e as moças sofrendo com a passagem fugidia da civilização. As máquinas abandonadas foram saqueadas e as estradas, tomadas pelo mato: a "natureza sertaneja triunfava sobre a civilização intrusa". Frank White fugiu em seu carro, uma moça correu atrás de seu amor. Remo desesperava-se à beira do boqueirão,

E Irma desapegou-se da serra. Não se fundiram duas almas no sacrifício final. Ela despencou, sozinha, formando uma barragem simbólica, amassada em sangue, corpo despedaçado, fechando o boqueirão, num protesto vingativo de esperanças ludibriadas (Almeida [1935] 1979, p. 203).

Esse era o espírito que animava o Ministro empossado com a revolução de 1930. Entre suas primeiras medidas, está a aprovação de um novo regulamento para a Ifocs, por meio do Decreto no 19.726, de 20 de Fevereiro de 1931. Esse decreto deu destaque à construção de açudes e canais de irrigação, obras que seriam executadas diretamente pela Ifocs utilizando a mão de obra nacional formada nos últimos anos, e inaugurando uma espécie de época de ouro do órgão.

A gestão de José Américo à frente do Ministério da Viação (1930-34) favoreceu a criação de diversas repartições federais no interior da Paraíba. O próprio Ministro, acompanhado do Presidente Getúlio Vargas e do Ministro da Agricultura, o cearense Juarez Távora, visitaram os municípios sertanejos durante a seca de 1932. A viagem 
foi acompanhada pelo jornalista pernambucano Orris Barbosa, que publicou no livro Seca de 1932: Impressões sobre a crise nordestina o relato de viagem. Barbosa escreveu entusiasmado que "as obras contra as secas, realizadas em 1931-33, salvaram a reputação da Revolução de Outubro, perante a história", deixando suas marcas indeléveis nos 22 açudes públicos concluídos durante o Governo Provisório, além de canais de irrigação e estradas (Barbosa, [1935] 1998, p. 79).

\section{O ciclo revolucionário do Ministério da Viação}

José Américo de Almeida teve uma atuação destacada na implementação do Governo Provisório de Getúlio Vargas, juntamente com outros nordestinos como Juarez Távora, contribuindo para elaboração do Nordeste enquanto região particular.

Apesar de a referência a uma região denominada Nordeste fosse comum nos trabalhos sobre as secas desde pelo menos 1903 e fazer parte da literatura oficial e mesmo de decretos, a região só seria registrada oficialmente na divisão do território brasileiro fixada em 1942 pelo recém criado Instituto Brasileiro de Geografia e Estatística (Ibge).

Segundo registrou a publicação comemorativa dos 64 anos de existência do órgão contra as secas, intitulada DNOCS - um órgão a serviço do Nordeste:

A preocupação com o Nordeste reascende durante os primeiros anos da década de 30, em consonância com as origens e inclinações do novo movimento político de então, no qual o Nordeste contou com forte poder político, ao lado da forte corrente de sentimento nacional, favorável a este rincão, expresso e estimulado nos romances sociológicos de José Lins do Rego, Jorge Amado, José Américo, Raquel de Queiroz e outros. É a época que tem a marcá-la a presença de José Américo a frente do Ministério da Viação e Obras Públicas (Araujo, 1974, p. 7).

Quando José Américo assumiu o Ministério em 1930, a seca que iria marcar a República já se esboçava. No relatório de atividades aa viagem de inspeção das 
medições das descargas de rios na Paraíba e Rio Grande do Norte, realizada em 1928, o auxiliar técnico de Raul de Freitas relatou a situação de crise causada pelo atraso nas chuvas. Caso não chovesse em breve, anotou, a safra de algodão seria perdida nos sertões do Seridó, no Rio Grande do Norte, e nos vales do Rio do Peixe, Piancó e Piranhas, na Paraíba.

Notei verdadeira miseria nas populações por onde transitei, - de fome em vista da escassez e encarecimento dos generos de primeira necessidade e ainda mais pela falta de trabalho, localidade houve que affluiram pessôas junto a mim julgando tratar-se de serviço de grande monta, pedindo trabalho afim de dar sustendo as suas familias, que não comiam já a dois dias. Creia Sr. Chefe, se não houver o proseguimento do inverno no rincão nordéstino, teremos que assistir mais um verdadeiro flagello, neste caso, para salvação de milhões de brasileiros será a encrementação das obras federaes (Freitas, 1928).

O Relatório dos Trabalhos executados no ano de 1928 também noticiou uma seca parcial nos estados do Ceará, Rio Grande do Norte e Paraíba. Mesmo na iminência de uma crise, o então Ministro da Viação, Victor Konder, determinou providências para que fossem "paralysadas e não iniciadas, até ulterior deliberação, obras e serviços novos que tenham que ser custeadas pelas verbas votadas para o exercício de 1928" (Ifocs, 1929, p. LXXVIII).

Para ilustrar a calamidade que se aproximava, agravada pela suspensão das obras, foram reproduzidos inúmeros telegramas dos municípios afetados, dando conta de perda de safras e da seca e solicitando obras públicas como meio de salvar a população, seguindo o modelo do que reproduzimos abaixo:

De Telha [CE], em 4 de julho de 1928

"Augustiosa situação classe pobreza" "Perda quasi toda safra". "Pede carroçavel Telha Tamboril" (Ifocs, 1929, p. LXXXIII).

Foram reproduzidos telegramas dos chefes de serviço da Inspetoria nos estados, que também narravam uma situação "calamitosa" e instavam o início de obras para o socorro da população. 
"Urgente. Chefe Seccas Parahyba N-41S, de 23 de maio de 1928. Prefeitos Serra Negra, Caicó, telegrapharam Presidente Republica communicando secca definitivamente declarada zona Seridó e pedindo socorros população mediante trabalho. Informae com segurança que ha positivo e propondo o que julgardes conveniente" (Ifocs, 1929, LXXXVII).

Com a mudança de governo decorrente da revolução de 1930, foi dada ênfase nas obras contra os efeitos da seca que já se pronunciava. $\mathrm{O}$ novo regulamento da Ifocs, aprovado pelo Decreto no 19.726, de 20 de Fevereiro de 1931, deu grande destaque à construção de grandes açudes e canais de irrigação. Buscando desenhar um plano racional, foi estipulado que as obras deveriam se concentrar em quatro bacias hidrográficas: I. Sistema do Acaraú; II. Sistema do Jaguaribe, ambos no Ceará; III. Sistema do Alto-Piranhas, na Paraíba; IV. Sistema do Baixo-Assú, no Rio Grande do Norte.

Além desse plano geral, foram determinadas "Medidas de emergência" a serem tomadas em caso de seca prolongada, abrindo a possibilidade de realização de trabalhos não previstos no plano e que tivessem como fim "o socorro imediato às populações atingidas pelos efeitos das secas" (Art. $5^{\circ}$ ). Foi prevista ainda a criação de hospedarias em zonas não atingidas pelas secas para abrigar os retirantes até que estes fossem encaminhados às "colônias de trabalhadores" (Art. 6 $6^{\circ}$ e ainda o fornecimento de transporte àqueles que, passada a seca, quisessem voltar aos seus lugares de origem $\left(\right.$ Art. $\left.7^{\circ}\right)$.

Outro ponto que diferencia esse decreto das demais regulamentações do órgão é a maior centralização das decisões, incluindo a nomeação para cargos técnicos e administrativos, como fica claro no Art. 50, Sessão V, que determina que: "Não será admitido para os serviços de escritório nenhum empregado, mensalista, diarista ou contratado, sem prévia autorização do ministro".

O decreto diminuiu a quantidade de distritos subordinados à administração central, que permanecia no Rio de Janeiro, de três para dois: o primeiro em Fortaleza, responsável pelas obras dos Estados do Ceará e Piauí e o segundo em João Pessoa, 
supervisionando os trabalhos dos estados da Paraíba, Pernambuco e Rio Grande do Norte. Como já havia apontado em seu ensaio de 1923, José Américo considerava a ausência de repartições federais um dos principais problemas da Paraíba, já que a verba destinada às obras e socorros ficava submetida aos caprichos da elite política local. A mudança do distrito responsável por esse estado e o Rio Grande do Norte, que se localizava até então em Natal, para João Pessoa é estratégica nesse sentido.

A partir do decreto de 1931, as obras dos grandes açudes passaram a ser executadas diretamente pela Ifocs. Até então, havia previsão de execução pelos estados com recursos da União ou mediante concorrência pública, conforme determinado no Art. 27 do Decreto 13.687 de 1919.

Na exposição de motivos feita pelo Ministro José Américo de Almeida ao Chefe do Governo Provisório Getúlio Vargas, para a aprovação do novo regulamento da Ifocs em 20 de fevereiro de 1931, o Ministro fez uma defesa da açudagem como única política realmente eficaz para anular os efeitos das secas.

(...) o que convém, precipuamente, como correção da natureza semiarida do nordeste, é armazenar a agua copiosa que, distribuida irregularmente, se escôa pelo seu sólo impermeavel e declivoso. Obstar essa perda pela açudagem em larga escala é a solução directa do problema da secca visando estabilizar a população sujeita a um desastrado nomadismo e aproveitar terras propicias a todas as culturas agrícolas (Ifocs, 1934, p. 45)

Como já havia apontado em A Paraiba e seus Problemas, a própria fisionomia da região se prestava bem a esse intento bastando restaurar a terra, fechando os boqueirões. Na nova organização da Inspetoria proposta por José Américo, o plano seria, consequentemente, a disseminação de açudes e obras de irrigação. Em sua avaliação, deveriam ser eliminados os demais serviços que dispersavam esforços e recursos, limitando a ação da Ifocs ao problema da água, "que é o problema do nordéste".

Além dos grandes sistemas de açudagem previstos no novo regulamento, 
deveriam ser facilitadas as construções de pequenos e médios açudes, feitos em cooperação com estados, municípios e particulares, através de financiamento, empréstimo de ferramentas e estudos e orçamentos.

Como, porém, o nordéste não poderá ficar, em breve trecho, a salvo das crises do seu clima incerto, porque o plano geral das obras da Inspectoria depende para uma solução integral de vultosos recursos, cumpre delinear o programma de soccorros immediatos aos flagellados, poupando-se aos descaminhos e aos desastres da "retirada" a esmo, que são as maiores causas do seu martyrio.

Uma das soluções indicadas para o problema das seccas é o deslocamento da população nordestina para São Paulo. Cumpre, entretanto, accentuar que cada um dos Estados do Ceará, Rio Grande do Norte e Parahyba, para não mencionar outros menos attingidos pelos accidentes do clima, dispõe de zonas tão vantajosamente favorecidas pela natureza, como São Paulo.

Para esses pontos é que se deve ser encaminhada systematicamente, a população faminta nos annos escassos. Desde que se organize um serviço de transporte que evite a extenuação das longas caminhadas, os flagellados chegarão em condições de poderem ser depois dos primeiros socorros localizados nas colonias de trabalhadores creadas pelo decreto n. 19.687, de 11 de fevereiro do corrente [que dispõe sobre a localização e amparo das vítimas das secas do Nordeste] ou em outros serviços publicos ou particulares. Dessa organização cogita o novo regulamento com a installação de hospedarias de retirantes durante as seccas prolongadas.

Assim, ficarão evitados o extravio das populações sertanejas e a pratica humilhante da mendicidade, como unico meio de subsistencia, na incidencia da calamidade (Ifocs, 1934, p. 48).

Pouco depois de aprovado o novo regulamento da Inspetoria, em 1932, foi declarada oficialmente a seca e uma comissão que contava com a presença do Ministro da Agricultura Juarez Távora, o Ministro da Viação e Obras Públicas José Américo e o Presidente do Governo Provisório Getúlio Vargas percorreram várias 
localidades assoladas pela seca. Como já foi comentado, a expedição foi registrada em pelo jornalista Orris Barbosa. Barbosa descreveu a seguinte situação no início da crise:

A desordem implantada pela fome parecia não ter mais fim. (...) Multidões errantes aterrorizavam as cidades que clamavam para os poderes públicos, retransidas diante de assaltos iminentes às suas reservas pelas massas nauseabundas e terríveis. Assim, não era raro o desfile pelas ruas de muitas cidades do Ceará, Paraíba, Rio Grande do Norte e Pernambuco, de andrajosos que, formando um exército silencioso de caquético, com a moral abatida pelos estômagos vazios, iam dispostos à prática de todos atos de desatino, sem terra, sem água, sem pão (Barbosa, [1935] 1999, p. 55).

O Relatório da Ifocs dos trabalhos realizados dos anos 1931 a 1933 destacou o papel de José Américo durante a crise instalada e ressaltou a importância da mudança empreendida pelo Decreto 19.726 de 1931 Ao contrário dos anos anteriores, nesse período foram iniciadas muitas obras, realizadas em caráter de emergência, assim como foram retomadas aquelas "deixadas pelos americanos". A implementação de um plano rodoviário, com a construção e reforma de muitas rodovias e ramais, foi descrita como "um grande passo na redenção no nordeste", uma vez que teria facilitado a retirada de famílias de flagelados, evitando a fuga a pé - e as mortes pelo caminho - e garantindo o rápido abastecimento das áreas afetadas.

Entre as dificuldades enfrentadas pela Inspetoria, foi destacado o problema causado pela afluência de flagelados, uma verdadeira "avalanche de humana" que se precipitava para onde iriam iniciar (ou se supunha iniciar) novas obras, e a falta de projetos, ferramentas e pessoal. Além destes fatores, serviram para encarecer as obras, segundo o relato do Inspetor, as más condições físicas dos trabalhadores, a superlotação dos acampamentos e o emprego de menores e mulheres.

Os campos de concentração, criados para encaminhar os trabalhadores para as obras haviam também se transformado "em outros tantos centros de ociosidade" 
dada a impossibilidade de absorver todos os trabalhadores. Ao lado de cada serviço da Inspetoria, se formavam rapidamente outros acampamentos improvisados de trabalhadores e pessoas que buscavam trabalho.

Cada centro de serviço tinha ao lado um outro campo de concentração, como V. Excia. poderá ver pelo telegrama abaixo, sob o $\mathrm{n}^{\mathrm{o}} 4-$ viagem, de 6 de maio de 1932, que de Orós enderecei ao Interventor do Ceará:

"Conversei com residentes de Jaguaribe e Icó sobre admissão maior numero operarios estrada. Todos que se apresentam com ferramenta têm sido admitidos muito embóra esta ferramenta não seja absolutamente eficiente. Entre Lavras e Jaguaribe temos atualmente em serviço estrada cerca oito mil quinhentos homens. Esse numero será aumentado logo recebamos material comprado Rio cuja primeira remessa chegou Campo Sales e para cuja distribuição determinei vinda um trem especial. Maior dificuldade para aproveitamento campos concentração reside fáto existirem permanentemente sédes das residencias numerosos famintos pedindo trabalho. Estamos em presença de outros tantos campos concentração quantas são sédes serviços. Isso acontece em Ouro Branco, Icó, Jaguaribe, Alto Santo. Creio mais justa admissão dos que se acham nas sédes, mantidos á custa de particulares, de preferencia aos dos campos oficiais concentração. Qualquer sugestão vocessencia queira fazer esse sentido receberei com prazer" (Ifocs, 1934, p. 62).

Sobre a admissão de mulheres e crianças, o Inspetor informou que se havia adotado como praxe alistar cerca de $15 \%$ do contingente de trabalhadores de crianças, admitidos "pelo lado humanitario", mas que o trabalho de menores havia sido suspenso em novembro de 1932 devido às reclamações recebidas. A admissão de menores passou, então, a ser feita apenas quando a família dependia de seu trabalho, "apesar do encarecimento da obra" (Ifocs, 1934, p. 63).

José Américo de Almeida registrou seus feitos frente ao Ministério da Viação e Obras Públicas no livro O ciclo revolucionário do ministério da viação, publicado em 1934, quando já havia deixado o Ministério para assumir o Governo da Paraíba. Antes de descrever suas ações, José Américo escreve sobre si mesmo em seção 
intitulada "Patrono dos humildes":

Mas é puro equívoco ou pérfida injustiça pensar que eu, com minha sensibilidade de espectador das tragédias da sêca, de testemunha atormentada das terras sofredoras do Brasil, não fizesse o bem só pelo amor de fazer o mal.

Tenho me constituído, ao contrário, o mais sensível patrono dos humildes e desherdados, dominado pelo constante sentimento da necessidade de correção das iniquidades que dependem dos homens, por não serem contingências da própria condição humana.

Tenho manifestado, talvês, demasias de zêlo público em detrimento dos poderosos, contra os que, perdendo muito, ainda sim perdem pouco, por que deixam, apenas, de juntar ao seu as somas das extorsões ilícitas. As empresas invulneráveis, que dessangravam o povo, começaram a sentir minha mão forte, não por uma mentalidade hostil contra essas organizações econômicas, mas para a libertação e desafôgo dos desprotegidos que elas não se apiedam de explorar (Almeida, [1934] 1982, pp. 33, 34).

Seus primeiros atos teriam visado justamente as classes desamparadas. Entre estes, estavam a isenção de impostos aos pequenos comerciantes, indústrias domésticas e prédios de diminuto valor e providências de caráter policial contra os fazendeiros que "costumavam refazer os rebanhos nas lavouras dos pequenos agricultores, antes de terminada a colheita" (Almeida, [1934] 1982, p. 34)

Ao arrolar as ações de assistência à crise da seca de 1932, José Américo destacou que somente elas já seriam prova do seu amor ao bem público. O exMinistro foi enfático ao descrever seus feitos dando um caráter dramático a eles:

Já tive ocasião de dizer que, se houvesse morrido algum flagelado de fome, teria tanto remorso a conturbar-me, como se me coubesse a culpa dessa morte. Logo que irrompeu a mais violenta e destruidora sêca do nordeste, assumi tôda a responsabilidade dos desastres humanos que não pudesse evitar, por uma intervenção solícita e abnegada. Há, no Rio de Janeiro, cearenses, riograndenses do norte, paraibanos, homens de todo o norte, em suma, que podem testemunhar pelo consenso em geral, como cumpri essa 
tarefa de humanidade, sertões a dentro, organizando os socorros, em pessoa, dando do meu, que era pouco, mas, para mim era muito, porque era todo meu, sem as achegas das representações e ajudas de custo, de que jamais me utilizei, em três longas inspeções.

Nunca se há de esquecer, quando nada, o socorro público, de cuja organização diligente e minuciosa não há memória em nenhuma outra sêca, bem como a assistência sanitária que constituiu verdadeira benemerência de enfermeiros e médicos de um devotamento exemplar.

O coração que fez isso, adoçando a desgraça de dois milhões de mártires, não podia ser indiferente a outros clamores. Não poderia levar a fome a nenhum lar quem chega a sacrificar a própria vida, em vôos temerários e afrontando os fócos pestilenciais das concentrações de trabalho para matar a fome de outros lares (Almeida, [1934] 1982, pp. 35, 36).

Sobre a atuação da Inspetoria, José Américo destacou as medidas moralizantes nos acampamentos, centros agrícolas e campos de concentração, como a proibição de bebida alcóolica, porte de arma, jogo e outras causas de perturbação, não tendo, por isso, sido registrados "os acidentes consecutivos às grandes aglomerações em meios mal policiados" (Almeida, [1934] 1982, p. 164).

O ex-Ministro sublinha o incentivo dado à construção de açudes particulares em regime de cooperação com o governo. Até 1930, haviam sido construídos 36 açudes, já no triênio 31-33, 51 foram iniciados. Tais açudes seriam um fator subsidiário poderoso aos grandes reservatórios, permitindo a manutenção das fazendas durante as longas estiagens. Embora não fosse comentado pelo autor, tais açudes eram também um poderoso meio de angariar votos e foi interpretado pela historiadora Lucia Ferreira (1993) como uma raiz da versão paraibana da indústria da seca.

Além dos postos de trabalho abertos nas rodovias e açudes, foram realizados serviços que não estavam no plano da Inspetoria, como a construção de linhas telegráficas e de 54 prédios para agências postais telegráficas; a fixação de dunas em Camocim e obras no canal de Santa Maria, no Ceará. 
Foram ainda organizados centros agrícolas destinados a assentar as famílias de flagelados. Da inspeção realizada a pedido do Ministro José Américo pelo engenheiro agrônomo Evaristo Leitão foi elaborado um relatório, publicado em 1937 sob o título O Problema Social e Economico das Obras Contra as Sêcas.

Segundo explicou Leitão, ele havia sido designado para fiscalizar o andamento e "regularizar" no que fosse possível "os serviços de localização e colonização de flagelados" dirigidos pelos interventores do Pará, Maranhão, Piauí, Ceará, Rio Grande do Norte, Paraíba, Alagoas e Bahia, imprimindo racionalidade aos serviços e garantindo o maior aproveitamento das verbas.

Conforme o relatório, o "Serviço de amparo ás vitimas nordestinas, no Estado do Pará", contava com: recebimento, hospedagem e alimentação dos emigrados, em hotel de Belém preparado para esse fim "pelos japonezes"; assistência médica, transporte gratuito para o interior, onde foram localizados em lotes no município de Bragança e nos vales do Xingu, Tapajós, Tocantins e Amazonas; distribuição de instrumentos agrícolas; discriminação a lotes rurais nas colônias "Augusto Montenegro", "Benjamim Constant", "João Pessoa", "Inatema" e "3 de outubro"; e localização de pessoas em casas de palha às margens de estradas enquanto estas esperavam o transporte para os lotes. "Uma vez localizados, os imigrados, por sua propria iniciativa, e sem assistencia técnica, roçam, derrubam, queimam, escoivaram, semeam e plantam incipientemente" (Leitão, 1937, p. 13).

Foram encaminhadas 7.755 pessoas para o Pará, localizadas posteriormente em 21 localidades em Bragança, 5 no Baixo Amazonas, 1 em Tocantins e outra em Guamá. O chefe da Comissão do Núcleo Agrícola Inglês de Souza, do Ministério do Trabalho, ainda transportou e assentou mais 950 pessoas no município de Monte Alegre, aonde estava localizado o núcleo. O pagamento era feito no fim de cada semana, quando era descontada a alimentação gasta durante esta.

No Maranhão, o Serviço de amparo aos imigrantes nordestinos ficou a cargo do Interventor Federal que autorizou a fundação de uma colônia agrícola 
denominada "Lima Campos" localizada entre os municípios de Coroatá e Pedreira, no km 62 da estrada de ferro "São Luis-Terezina". As verbas foram repassadas pelo Ministério da Viação ao Governo do Estado.

Foram divididos 140 lotes de 25 ha, nos quais ficavam os colonos obrigados a cultivar 3ha com feijão, milho, arroz e mandioca. Quando da inspeção, havia sido iniciada a construção de 10 casas definitivas de taipa, rebocadas, caiadas e cobertas de telhas e outras 40 casas e barracões cobertos de palha para abrigar provisoriamente as famílias "que ainda não podiam ir para os lotes". O estado sanitário dentro da colônia foi classificado como sofrível, sendo a atuação do médico e do enfermeiro elogiada pelos colonos (Leitão, 1937, p. 17).

No Piauí, foi utilizado como núcleo para abrigar os nordestinos o antigo Centro Agrícola "David Caldas", situado a 1.500m da margem esquerda do Rio Parnaíba, fundado anteriormente pelo Serviço de Proteção ao Índio e abandonado devido a um surto de impaludismo. O transporte dos flagelados foi feito através de caminhão, pela estrada "Terezina-União", e de balsas pelo Rio Parnaíba, junto com o material das obras da colônia.

A cada colono foram reservados um lote rural, com 25 ha e um urbano, com 2.500 metros quadrados. Os lotes estavam agrupados em 4 e 6, em quarteirões de 100m de lado, delimitados com arame farpado.

O esquema para pagamento não se diferenciava dos demais utilizados na época. Ao chegarem a colônia, os trabalhadores eram incluídos em uma folha designada pra a construção dos barracões provisórios onde eles iriam se abrigar, não havendo verba destinada a sua alimentação. Logo que chegavam à colônia, era aberta uma caderneta na cooperativa "que lhe supria do extritamente necessario a subsistencia, para desconto proporcional em folha de pagamento". (Leitão, 1937, p. 22)

No Ceará, como na Paraíba e no Rio Grande do Norte, os centros foram apenas provisórios. O núcleo visitado no Ceará, denominado Trairi, havia se 
formado em terras "tomadas por empréstimo" para esse fim durante um ano. Segundo anotação do agrônomo, as terras eram impróprias para o cultivo, já que localizadas próximas ao mar, e reduziu-se à assistência alimentar na forma de salários. Passaram por esse centro um total de 2.022 pessoas, sendo 997 (49\%) de crianças. Quando da chegada do engenheiro no núcleo, já cerca de metade das "vítimas" havia saído em busca de trabalho nas obras das estradas e barragens (Leitão, 1937, p. 26).

No Rio Grande do Norte, foram criados três núcleos agrícolas: "Maxaranguape", "São Miguel" e "Jundiaí", para assistência imediata aos flagelados. "Quando se estabeleceu o terror pánico no seio das populações, o Governo teve que dar de comer ao povo faminto e nú, sem quasi exigir-lhe trabalho" (Leitão, 1937, p. 28). No núcleo Jundiaí foram cadastrados, da sua fundação até 31 de dezembro de 1932, 1.375 flagelados, dos quais saíram 690 com destinos diversos. Em Maxaranguape, cadastrou-se 3.627 pessoas, das quais 927 já haviam deixado o lugar quando da inspeção.

Na Paraíba, fundaram-se 3 núcleos, nos municípios de Alagoa Grande, Guarabira e Bananeiras, no Brejo paraibano. O núcleo fundado em Alagoa Grande foi referido no relatório como sendo um "campo de concentração". Os trabalhadores que excederam o limite de capacidade da colônia foram levados de trem para a capital e para o "Patronato Vidal de Negreiros", em Bananeiras.

Chegaram em Alagoa Grande 3.500 pessoas, "sem pão e sem abrigo". Com os recursos da Inspetoria o prefeito providenciou o socorro a 200 famílias e fundou a colônia em terreno da usina "Tanques" onde foram construídas 200 casas de taipa (Leitão, 1937, p. 32). Logo depois da concentração de pessoas no centro, irromperam diversas epidemias e a maior parte dos colonos deixou o lugar nas primeiras chuvas.

Sob o título "Á margem da Inspeção", o engenheiro anotou que o serviço de colonização criado pela Ifocs era uma medida de emergência que não fazia parte do plano de obras. A esse respeito, contudo, havia sido editado em janeiro de 1931 o 
Decreto 19.687, determinando que o Governo Federal, por intermédio dos Ministérios do Trabalho, Indústria e Comércio, da Viação e Obras Públicas e da Agricultura, promoveria, de acordo com os estados interessados, a imediata localização e assistência das vítimas das secas do Nordeste (Art.1). Esse decreto, que dispunha sobre a localização e amparo das vítimas da seca no Nordeste, registrou como justificativas:

CONSIDERANDO que o flagelo da seca nos Estados nordestinos tem espalhado a miséria e a fome entre milhares de brasileiros;

CONSIDERANDO que é impressionante e assustadora a grande massa de infelizes, que, abandonando seus lares, reclama providências imediatas por parte dos poderes públicos;

CONSIDERANDO que a deserção forçada das vítimas da seca para fora dos respectivos Estados, acarretando o depauperamento das unidades nordestinas, deverá ser evitada e é, sobretudo, medida contra-producente, já condenada pela experiência;

CONSIDERANDO que a localização dos retirantes nos próprios Estados, em zonas atingidas pela seca, não constitue mero socorro público, sendo, um serviço da mais alta finalidade econômica a educativa;

CONSIDERANDO que a legislação vigente prevê o estabelecimento de "linhas coloniais" e a formação de "centros agrícolas de trabalhadores nacionais", constituindo futuros núcleos de atividade agrícola e industrial;

CONSIDERANDO que para esses centros rurais convergirão os habitantes acossados pela seca, ali encontrando verdadeiros postos de socorro;

CONSIDERANDO que os centros agrícolas, inteligentemente explorados, favorecem a comunidade, engrandecem a região do Nordeste e compensam o sacrifício do erário público, pelo reembolso, em grande parte, do que foi despendido no patrocínio na região;

CONSIDERANDO que o problema, dada a sua extensão e complexidade, exige o concurso da União e dos Estados e a adoção de providências em completa harmonia de vistas (...) (Decreto 19.687/1931).

Na avaliação de Evaristo Leitão, os núcleos agrícolas deveriam ser pensados como forma de completar os serviços de açudagem e sua criação deveria ocorrer 
também durante os anos "normais" e em áreas menos atingidas pelas secas, servindo como postos de socorro em tempos de crise.

Das colônias visitadas, o engenheiro agrônomo destacou o sucesso alcançado por aquelas localizadas no Piauí e no Maranhão e criticou o Serviço no Pará, que "senilizou-se sem haver alcançado seu objétivo de modo satisfatorio", devido à falta de organização e a predominância do sistema de povoamento que seguia avançando sobre a mata conforme as terras se desgastavam. O então chefe da Seção de Povoamento do Pará, Olavo Sidrim, já havia encaminhado carta ao Ministro da Agricultura a esse respeito. "Os fazedores do deserto" escreveu, eram dendrófobos "por atavismo", devastando e abandonando as terras, sem que o governo tomasse qualquer atitude (Leitão, 1937, p.44).

Para Leitão, a alta taxa de retorno populacional apontados nas colônias seria fruto do então modelo levado a cargo pelo Serviço de Colonização. Como parte do relatório, o agrônomo apresentou um projeto de colonização cooperativista que segundo ele seria a única maneira de libertar os trabalhadores, ajudando-os a "se desvencilharem dos grilhões que os condicionam á paradoxal situação de mendigos até agora intangivel" (Leitão, 1937, p. 90).

Apesar dos esquemas minuciosamente elaborados pelo engenheiro, essas cooperativas não foram implantadas e o esquema dos centros agrícolas, com suas variações em cada estado, ainda seria utilizado durante muito tempo.

Outra medida tomada pelo Ministro José Américo em 1932 foi a criação de uma Comissão Médica para assistir a população reunida nos acampamentos e campos de concentração a cargo da Ifocs e propor medidas de controle às epidemias que costumavam acompanhar as concentrações.

A Comissão, que durou de 23 de dezembro de 1932 a 18 de maio do ano seguinte, visitou vários acampamentos formados ao lado das obras em curso nos estados do Ceará, Rio Grande do Norte e Paraíba e também alguns campos de concentração no Ceará. Na Paraíba, a Comissão visitou os açudes de Condado, 
Pilões, Piranhas e São Gonçalo.

O Relatorio da Comissão Médica de Assistencia e Profilaxia aos Flagelados do Nordéste, Apresentado ao Snr. Diretor Geral do Departamento de Saúde Pública em 30 de Agosto de 1933, pelo Dr. J. Bonifacio P. da Costa, Chefe da Comissão, foi publicado em 1933. Esse é um dos raros documentos do órgão que descrevem de maneira sistemática as condições sanitárias e de trabalho dos acampamentos da Inspetoria.

O Relatório apontou para uma situação sanitária muito precária e que antecedia à seca, o que era especialmente claro na comparação dos dados de mortalidade infantil durante o primeiro ano de vida. A curva de mortalidade no primeiro ano de vida durante 1932 e início de 1933 era igual a dos anos anteriores no Ceará, devendo esta ocorrência merecer "maiores cuidados especiais, no que se refere á responsabilidade dos poderes publicos nas questões que dizem respeito á raça e, portanto, á nacionalidade" (Costa, 1936, p. 14).

Como parte desse Relatório, A Comissão Médica de Assistência e Profilaxia aos Flagelado do Nordéste definiu e publicou uma série de Instruções que deveriam ser observadas pela Ifocs do qual reproduzimos abaixo as "Disposições Gerais". O documento é um bom instrumento para avaliar as condições encontradas nas obras, revelando que a realidade era oposta àquela recomendada no documento.

1. Sempre que a I.F.O.C.S. tiver que instalar serviços, quer de açudagem, quer de rodovias, quer de outra finalidade, organisará ao lado de suas diretorias técnicas especiais, um planejamento de localisação de seu pessôal, obedecendo os postulados de higiene relativos á formação de cidades.

2. As exigencias referidas acima serão aplicaveis, na sua integralidade, aos trabalhos da I.F.O.C.S. sempre que houver necessidade de medicação de grande numero de operarios em serviços de duração maior de um ano.

3. Serão traçadas a direção e a largura das ruas, tanto quanto possível obedecendo os quatro pontos cardeais, isto é, ruas meridianas (N.S.) e ruas equatoriais (L.O.).

4. As ruas deverão ficar divididas em quadras 
5. Não serão admitidas habitações provisórias ou definitivas em áreas montantes às bacias dos açudes, aos leitos dos rios e dos canais.

6. As habitações serão providas de fôssas absorventes ou liquefatoras sempre que se tratar de construções definitivas.

7. No caso de habitações improvisadas ou de emergencia serão instaladas latrinas publicas ou coletivas com fossas absorventes ou liquefatoras na proporção de uma para quarenta habitantes.

8. As ruas, as casas e as palhoças serão numeradas.

9. Serão instalados banheiros publicos de emergencia ou definitivos de acordo com a densidade da população e suas condições de fixidez.

10. As aguas captadas dos rios, dos corregos, dos lagos, do lençol subterraneo, das fontes, dos poços e das cacimbas serão depuradas sempre que as analises microbiologicas indicarem sua poluição com indice de coli ou com um aumento de bacterias superior a cem por ar.

11. Serão admitidos poços e cacimbas com as bocas protegidas, em uma altura minima de meio metro, afastadas as hipoteses de contaminação por infiltração.

12. Serão admitidos de preferencia poços tubulares.

13. Sempre que a agua fôr julgada suspeita será feita a sua depuração artificial pelo aparelho de Wallace-Thiernnan (Cloração).

14. As analise das aguas potaveis poderão ser sob o ponto de vista químico bacteriologico, sendo exigidas repetidamente pelo Laboratorio Central dos serviços de assistencia médica as analises microbiologicas.

15. Em cada local de trabalho haverá turmas de limpeza, encarregadas das varreduras das vias publicas, da coleta, da remoção, do aterro ou da incineração do lixo.

16. Os habitantes das casas ou das palhoças serão obrigados a manter asseiadas as áreas destinadas ás suas habitações.

17. As turmas de limpeza serão orientadas no sentido de combater os fôcos de moscas e de mosquitos.

18. Na remoção de terras para os serviços de qualquer natureza deverão ser evitadas excavações que permitam a coléta dagua afim de impedir a existencia de fócos de mosquitos. 
19. Tambem serao praticadas drenagens em terrenos que constituam fócos permanentes ou transitorios de mosquitos.

20. Os estabulos e as cocheiras, particulares ou publicas, serão obrigados a coletar e recolher, diariamente, o esterco a depositos fechados ou a fazer o seu aterro.

21. Os fornecedores de generos alimenticios serão obrigados a ter generos de bôa qualidade e variedade, atendida esta ultima exigencia, de acôrdo com as possibilidades locais.

22. Os fornecedores de generos alimenticios serão obrigados a ter instalações indispensaveis para a proteção dos alimentos contra a sua poluição: caixas zincadas internamente para a farinha de mandioca, feijão, arroz e milho: caixas com tampa telada, para o pão, a rapadura, a carne sêca ou qualquer genero a ingerir sem prévia cocção.

23. Os açougues terão seus compartimentos de deposito de carne telados na impossibilidade de serem providos de camaras frigorificas

24. Os mercados e matadouros serão obrigados aos cuidados na remoção de lixo e dejétos.

25. Nos estabulos haverá proteção e limpeza do vasilhame utilisado, assim como todos os cuidados de higiene indispensavel na ordenha.

26. Qualquer casa de comercio de genero alimenticio, como as denominadas pensões e cafés, ficam sujeitas ás exigencias de proteção dos alimentos a serem ingeridos sem nova cocção, assim como a louça usada para serventia dos freguezes.

27. Nas casas de comercio de generos alimentícios a agua potavel deve ser fervida e filtrada, sendo admitido o uso de filtros de barro.

28. Nas casas de generos alimenticios será obrigatorio o uso de mosquiteiro de vidro.

29. O alimento adulterado ou deteriorado ficará sujeito à desnaturação ou á inutilisação.

30. Não haverá comercio de bebidas alcoolicas nas localidade de serviço da I.F.O.C.S.

31. Os fornecedores e os manipuladores de generos alimenticios terão carteiras profissionais, sendo submetidos a inspeção médica para 
obtenção das mesmas (Costa, 1936, pp. 25-26).

Além dos pontos gerais apresentados pelo chefe da Comissão, integram o relatório apresentado ao Ministro documentos elaborados pelas equipes que visitaram os locais das construções e campos de concentração. O relatório escrito pelo Dr. Alvaro Garcia Rosa descreveu a atuação da Comissão nos pontos de concentração de flagelados no Açude de Condado, na Paraíba, que empregava 3.000 pessoas em janeiro de 1932.

O acampamento contava com raras casas, algumas barracas cobertas de telhas e um número considerável de "alpendres cobertos de folhas" que abrigavam 6 ou 7 redes. As habitações eram esparsas e não seguiam qualquer orientação, cerca de um terço delas estava dentro da bacia hidrográfica do açude. As únicas habitações que contavam com fossas eram as casas da Residência da Inspetoria onde ficavam instalados os engenheiros e altos funcionários da repartição. Segundo o relatório,

Lixo, fézes humanas e de animais, detritos alimentares, disseminados em quantidade por todo o acampamento concorriam na formação de formidaveis exames de moscas.

Era por toda parte a miseria, o desconforto, a sêca (Costa, 1936, p. 41).

A situação em Condado foi classificada como anormal do ponto de vista sanitário, com uma alta mortalidade por doenças infecto contagiosas transmitidas pelas moscas que grassavam no local. Nem mesmo o hospital escapou das críticas, sendo referido como um "infecto pardieiro" (Costa, 1936, p. 44). Em Boqueirão de Piranhas a poucos $\mathrm{km}$ dali o estado dos acampamentos era ainda pior.

Além dos empregados da Inspetoria, que estavam localizados numa área de cerca de 60 ha a jusante da barragem, a Comissão atuou ainda no "Barro Vermelho", onde se tirava argila para a construção, e na "Pedreira", a oeste da vila operaria.

Com a movimentação das obras que aí se estão realisando, cresceu muito o arraial aí existente, desde a primeira fase da construção, entregue aos técnicos da Dwigt P. Robinson. Foram contadas por nós 625 habitações, figurando entre elas casas de construção regular de tijolos ou 
de taipa, recobertas de telha ou simples barracas de emergencia. Foi muito de lamentar que, ao chegarem as primeiras levas de flagelados, ao tempo do recomeço das obras da barragem do Boqueirão de Piranhas, não houvesse a preocupação de localisa-los convenientemente, dispondo as barracas que se fossem erguendo de acôrdo com um plano predeterminado de arruamento, o que, nem so daria uma impressão melhor de ordem e apreciavel arranjo, senão tambem acarretaria condições propicias ao imprescindivel saneamento local.

Dai, adveio uma fatal balburdia no preparo do acampamento, erguidas as barracas a esmo, onde e como ao operario melhor the aprouvesse, sacrificadas destarte muitas vezes questões poderosissimas de ar, luz e isolamento, comprometidas as exigencias do asseio tanto mais de rigor quanto aí iria residir uma população, cujo estado sanitario se carregava de cores sombrias... (Costa, 1936, p. 90).

A população de Piranhas, de acordo com o levantamento, chegou a 3.399 pessoas. Os dados registrados para mortalidade infantil foram tão impressionantes, comenta o relator, que a notícia chegou a repercutir no Rio de Janeiro:

(...) crescia o obituario mês a mês; era excessivo o numero de mortes de crianças por factores varios, entre os quais predominavam os disturbios nutritivos; infeccões do grupo tifo-paratifico-disenterico alastravam-se, acomentendo e dizimando os operarios e suas familias e já se registravam baixas no pessoal da administração. E, como acmê tragico da curva do drama epidemiologico que ai se desenrolava, tombou, vitimado pela infecção ebertiana, o Engenheiro Chefe da Construção - Dr. Moacir Avidos (Costa, 1936, pp. 92, 93).

O problema mais "desesperador" do acampamento era a falta de água, que não bastava nem para a construção em si. Os poços que abasteciam a obra foram cavados no leito da barragem provisória e estavam se esgotando durante o período da visita, tendo a administração imposto um rigoroso regime de economia d'água. Era tão "grave e impressionante" a situação em Boqueirão de Piranhas, com uma população a ser dizimada por sarampo e outras doenças contagiosas e crianças 
morrendo devido a uma alimentação tóxica, que havia se cogitado a suspensão dos serviços "como medida de salvação publica".

Fugia-se, sem exagero da verdade dos fatos, de PIRANHAS como desses lugares malsinados e indesejaveis de que todos se arreceiam...

Retiraram-se as familias de todos os engenheiros e funcionarios de relevo da administração. Pessôas escrupulosas, cujos interesses as obrigavam a estacionar nesta barragem, de nada se serviam e procuravam ai demorar o minimo de tempo possivel. Conta-se de uma ilustre comissão técnica que de PIRANHAS nem os copos quiz utilizar, bebendo agua de Caxambú, na propria garrafa!... Anedóta? Um conto exagerado, certamente...

Este era o ambiente e esta era a situação que nos deparavam... (Costa, 1936, p. 95).

Para melhorar o quadro sanitário do local foram sugeridas várias medidas, entre elas: a construção de fossas e retirada das que se encontravam na beira da água; afastamento do matadouro público, localizado ao lado do cemitério; a destruição das barracas de emergência, conforme estas fossem vagando, e substituição das mesmas por barracões simples, pondo fim à "tremenda babel desordenada e confusa" que havia se transformado o acampamento.

A vacinação passou também a ser compulsória e os trabalhadores só eram admitidos depois de serem vacinados. Apesar dessa medida, a enorme flutuação da população que buscava trabalho nas obras e o rumor de que as "meiazinhas" eram feitas com os "figos dos defuntos" arrancados pelo "papafigo", funcionário da Rockfeller que fazia as viscerotomias, dificultava a imunização (Costa, 1936, p. 97).

A mortalidade infantil de era de tal forma alta que os membros da Comissão escreveram uma carta ao Interventor da Paraíba pedindo providências. Junto com esta foram enviados os impressionantes dados coletados, que registravam o número de 162 crianças mortas para o mês de dezembro de 1932 e 165 em janeiro de 1933. Cifra que começou a diminuir apenas em abril de 1933, conforme o gráfico 
reproduzido abaixo.

A situação do acampamento em São Gonçalo, localizado à cerca de $30 \mathrm{~km}$ de Boqueirão de Piranhas foi descrita como sensivelmente melhor. As condições mais favoráveis do ponto de vista sanitário foram atribuídas à ação disciplinadora e moralisadora do engenheiro encarregado, Estevam Marinho, que "soube compreender a delicadeza da situação sanitária com que se ia de frontar, com o acantonamento de milhares de pessôas que aí chegavam maltrapilhas famintas e doentes...".

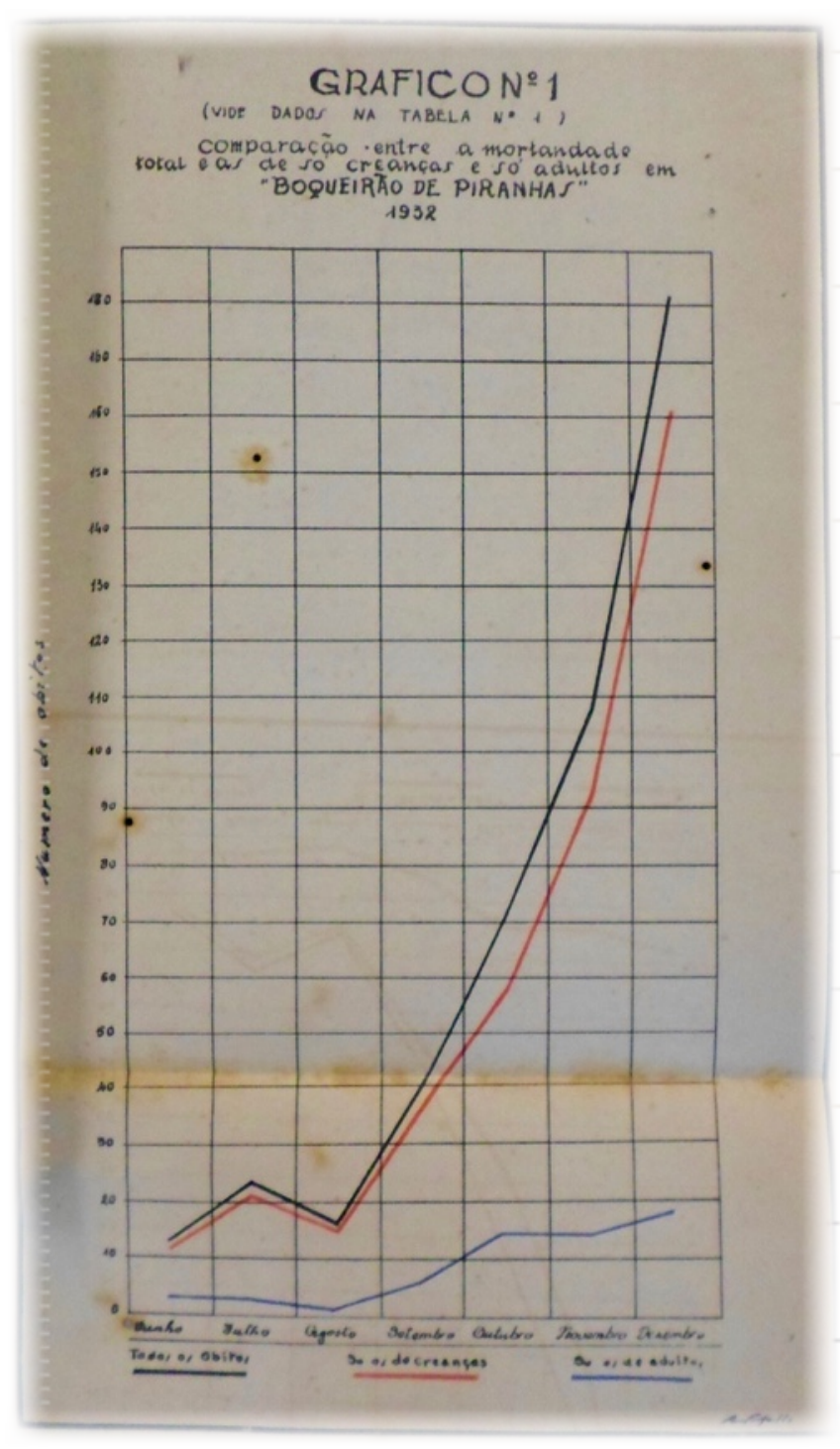

Os óbitos totais estão marcados em preto, os de crianças em vermelho e os de adultos em azul. Como o gráfico mostra, era muito expressiva a proporção de crianças no total dos óbitos
Entre as medidas tomadas por Estevam Marinho estava a escolha de um lugar adequado para $\mathrm{o}$ "abarracamento dos flagelados". As habitações dos operários foram alinhadas e a construção de novas casas dependia da permissão da administração local. As casas foram também numeradas, facilitando o trabalho de inspeção e foram organizadas turmas de pessoas idosas para fazer a limpeza regular do acampamento. $\mathrm{O}$ engenheiro combateu ainda o alcoolismo e o meretrício, sendo louvado por essas medidas moralizadoras.

Os questionários aplicados nos municípios do entorno das construções de São Gonçalo revelou um quadro endêmico na região de 
infecções do grupo tifo-entérico. Com os boatos da chegada da varíola em Souza e devido ao intenso intercâmbio entre os lugares passou-se a se exigir, além da vacinação dos operários, a imunização de suas famílias.

Embora a mortalidade infantil fosse também grave, a situação foi amenizada pelo chefe do serviço, que conseguiu usar as reservas orçamentárias para a compra de leite e farinhas para mingau para melhorar a alimentação das crianças.

As condições descritas no Ceará eram ainda piores que aquelas descritas para a Paraíba. As obras implementadas pela Ifocs não conseguiram absorver todos os que buscavam trabalho e, "na iminencia de uma verdadeira hecatombe pela fome" foram organizados os campos de concentração como medida de urgência.

A instalação de campos de concentração como medida de evitar a chegada desordenada da população faminta e doente nas capitais e grandes centros já vinha sendo utilizada desde a seca de 1877 pelo menos. Comentando a situação de um campo instalado em fortaleza durante a denominada "seca-tipo", o engenheiro do Dnocs, Luiz Carlos Martins Pinheiro, ressaltou que, em 1877, o "estado higiênico de tal abrigo era tão doloroso que foi cognominado pelo povo de 'curral'" (Pinheiro, 1960, p. 9).

Em comparação ao que havia ocorrido em 1877, as providências adotadas pelo governo teriam sido "mais enérgicas e mais prontas". O transporte se tornou mais rápido e por estradas melhores, os casos de fome diminuíram e foram registrados menos casos de morte pela ingestão de raízes tóxicas.

Apesar de terem sido distribuídos alimentos como rapadura, feijão, arroz, farinha, sal, charque, carne verde e leite para as crianças, a distribuição não foi feita de maneira homogênea e apenas no campo de concentração de Pirambu havia distribuição de alimentos já preparados.

O campo de concentração de Buriti chegou a abrigar 70.000 pessoas. Em Pirambu, 6.000 pessoas foram amontoadas em grandes galpões cobertos com folha 
de zinco em péssimas condições sanitárias. Comentando sobre a alimentação provida para esses campos, o relator chega a comparar a situação encontrada com aquela dos campos de concentração da Alemanha nazista.

Nos campos de concentração da Europa pela zona de guerra e sobretudo na area bloqueada a alimentação era o que podia ser ordinaria e pouco variada para vencer como diz Thanhauser a incipidez da alimentação cotidiana davam-se grandes quantidades de sal.

O mesmo vimos no Norte onde os flagelados usavam e abusavam das farinhas, ás quais juntávam sal. O xarque era mal lavado, quando o era agravando ainda mais a porção salina da alimentação.

Schittenhelm, que se ocupou particularmente desses fatos, chamou a atenção para as grandes analogias entre o edema de guerra e a distrofia farinacea e vendo agora essa coleção de edemaciados em todos os graus, desde a primeira infancia até á maturidade, outra idéa não podiamos deixar de ter (Costa, 1936, p. 155).

Na avaliação apresentada pelo Relatório da Comissão Médica, os campos de concentração foram apontados como tendo a pior situação sanitária, não devendo mais ser utilizado como medida oficial.

José Américo escreveria logo depois, em 1934, que não havia sido possível evitar os campos de concentração em 32, que chegaram a abrigar, no Ceará, 105 mil pessoas em apenas um dia segundo seu cômputo. Era pensamento do governo manter esses "campos improdutivos" apenas enquanto os serviços de caráter permanente não fossem organizados para absorver toda a "massa faminta", escreveu, mas, "a medida que as pessoas iam sendo alocadas para as obras afluíam em novas e numerosas levas" (Almeida, [1934] 1982, p. 163).

Entre as diferenças nas ações tomadas pela Inspetoria durante as crises geradas pelas secas de 1932 e 1942, o Inspetor Interino, Vinícios César Silva de Berredo, sublinhou a não utilização de campos de concentração, considerados, então, como um "recurso extremo" (Dnocs, 1953). 
A historiadora Luciara Frota (1985) fez a seguinte consideração sobre as aglomerações decorrentes das secas,

A seca de 32 considerada a maior desse século levou à descrença e ao desuso os campos de "concentração", talvez pelo elevado índice de mortalidade que se registrou com eventos epidêmicos. Mas as frentes de serviço, que se ligaram às estradas de rodagem, atravessaram o tempo sem modificação na sua estrutura inicial com os acampamentos coletivos imensas latadas de pau e folhas - que alojam os agricultores retirados de seu trabalho (Frota, 1985, p. 211).

\section{Deus Não Olha Cassaco Sofrer}

Cassaco era um termo utilizado para se referir aos operários - flagelados e retirantes - que trabalhavam nas obras de emergência contra às secas ou frentes de serviço. Segundo Teresa Sales, o termo era utilizado também em algumas regiões do Nordeste açucareiro para designar o trabalhador que deixara de plantar ao redor de sua moradia nas propriedades rurais como meio complementar de subsistência, "vivendo exclusivamente do salário recebido" (Sales, 1977: 18).

Cassaco é um pequeno gambá, também conhecido na Paraíba por timbu. Segundo o escritor e poeta cearense Oswaldo Lamartine de Faria,

(...) cassaco é chamado, em todo aquele mundo [nordeste brasileiro], o simples sertanejo de rêde-nas-costas que vive no ciganismo do trabalho das construções públicas. De quando remonta a sua origem, não o sabemos. É de se imaginar ter aparecido após a criação do DNOCS (Departamento Nacional de Obras Contra as Secas, antiga IFOCS), pelos idos de 1908. Distingue-se do trabalhador ocasional cuja frustração das safras nos anos secos o faz caçar ganho nas construções do governo - pela atividade permanente, de janeiro a janeiro - nas obras públicas. Indiferentes à pegada do inverno, acodem de todos cantos - isolados ou aos magotes, mais raramente com mulher e filhos, de caminhão ou a pé e quando donos de jumentos de trabalho, tangendo-os pelos caminhos - parecendo até mesmo que farejam o início da construção 
de um açude ou de uma estrada." (<www.consciencia.org/cassaconordestinos $>$ ).

Durante as obras do açude São Gonçalo em Souza, distante pouco mais de $70 \mathrm{~km}$ de Coremas, a escritora local Ignez Mariz entrevistou os trabalhadores e registrou as transformações da região no romance já citado A Barragem.

Ignez Mariz sublinhou uma característica negligenciada por Lamartine de Faria. O cassaco é um animal marsupial que carrega sempre a família consigo. Conforme a nota explicativa que a autora inseriu no texto, o cassaco era:

(*) A mais infima das categorias de trabalhadores do Govêrno. Como os serviços de Estradas e Barragens se effectuam, quasi sempre, distante de suas moradias habituaes, os trabalhadores vencem a pé leguas a fim de os alcançar. Nas macas que trazem a tiracollo elles conduzem, não só a rêde e a ração "de comer", como também os filhos pequeninos: nas nossas mattas prolifera o cassaco, animal de tamanho de um gato e semelhante ao kangurú pela bolsa que possúe no ventre para condução dos filhotes. Por isso o espirito sertanejo, irremediavelmente humoristico, fez a annos a analogia que perdura (Mariz, [1937] 1994, p. 5).

Outro ponto desconsiderado por Lamartine de Faria foi a origem de muitos desses cassacos. Como referido em inúmeros relatórios e boletins do Dnocs, a população mais vulnerável às secas, e que eram, portanto, os primeiros a se retirarem, eram os moradores das fazendas que sobreviviam de uma cultura de subsistência em terras alheias. No início de O Quinze, Rachel de Queiroz descreve as atitudes dos fazendeiros ante a seca de 1915 que se iniciava. Entre as primeiras, estava a dispensa dos moradores.

- Por falar em deixar morrer... o compadre já soube que a Dona Maroca das Aroeiras deu ordens pra, se não chover até o dia de São José, abrir as porteiras do curral? E o pessoal dela que ganhe o mundo... Não tem mais serviço pra ninguém (Queiroz, [1930] 1937, p.3).

Conforme a seca se estende, os pequenos sitiantes são também obrigados a 
se engajar nas obras. Nas palavras de José Américo, "a sêca é niveladora": os pequenos proprietários atingem "um estado de exaustão que os obriga a dispensar o pessoal e a pedir colocação" (Almeida, 1953, p. 9). Embora o ministro não os mencione, os grandes proprietários estão excluídos dessa fórmula, ocorrendo o nivelamento apenas entre os estratos mais baixos.

Em 1934, o jornalista cearense Cordeiro de Andrade (1910-1943) deu o título do seu primeiro romance de Os Cassacos. Conforme explicou no prefácio do livro dedicado a Jorge Amado, Pelegrino Jr., Amando Fontes e Graciliano Ramos, o autor tinha cerca de dez anos quando foi declarada a seca de 1919, tendo ouvido muita coisas dos retirantes e observado outras tantas. "Na ausencia, pois de outro qualquer mérito" comentou, ao menos seu livro teria a virtude de ser "sincero".

Como a dedicatória do livro permite entrever, Cordeiro de Andrade era simpático às idéias comunistas da época. Um dos protagonistas da história, o farmacêutico de uma pequena localidade próxima a Sobral, é perseguido por lutar pelas melhorias das condições dos trabalhadores e incitar a revolta popular.

O romance é pontuado de diálogos que criticam a cobiça dos bispos, da elite branca, dos chefes das comissões de obras e dos demais funcionários da Ifocs. Em um desses diálogos, os moradores começam a se agitar fazendo previsões e também a sofrer por antecipação pela seca que logo seria oficialmente declarada:

E uma crente:

- Ainda pode ser creatura [que a seca seja um fato]. Pra Deus nada é impossível. Eu sai do partido que a gente precisa resar, porque si nosso senhor não mandar chuva dá um toquisinho no coração dos governos prá se lembrarem dos inocentes que precisam de serviço e comissão.

Uma outra entrando na conversa.

- Comissão não digo, mas porém, vai ter serviço do governo e é muito. Só tenho é uma quezila por negócio onde corre vale... Embirrei e embirrei mesmo... O dotô ajudante já chegou pras obras do açude do Forquilha que vae ser um marzão sem fim. A igreja do Campo Novo vai ficar 
debaixo d'água. Isto é um descomungo.

(...)

Uma mulher apreciou:

O governo deu que mandar a comissão de trabalho prás infelizes viúvas desamparadas e direitas que não fazem ponto na feira nem no Bêco Livre. Tomara mesmo que venha é um tal de dotô comunismo que falam por aí, protetor de pobre, a ver si a gente tem trabalho sem aturar as ingrisias dos brancos relaxados (...) eu mal sei que o vigario e os brancos, são mal com ele, mas não m'anporto (Andrade, 1934, pp. 22, 23).

Um dos personagens que surgem ao longo do livro é o pernambucano Marcelino cego, cassaco que chegara ali "no quinze", "fiado nos serviços publicos que andavam ultimando, parece que na rodagem da Maruoca e da Ibiapina". Marcelino, a mulher e seus quatro filhos, sendo um "de peito", procuravam uma nova colocação. "Recorreu a um, a outro e nada de arrumar trabalho", ao que o narrador explica:

Você sabe como é serviço de governo. Quem não tem padrinho morre de fome e não consegue coisa nenhuma. Depois de o chamar o quadro está completo, só à força de um pistolão remove as dificuldades

(..)

E note-se: naquêle ano, não existia campo de concentração, e o povo que chegava ia se agasalhando debaixo dos pés de páu, nas calçadas, estiradas no chão como bichos brutos (Andrade, 1934, p.44).

Retirantes e cassacos são identificados um ao outro, de maneira que todo retirante era um cassaco em potencial. E assim como os retirantes de A Bagaceira (Almeida, [1928]), eles não tinham sexo nem idade tornando-se bicho pelo sofrimento.

Os trens despejavam, diariamente na cidade chusmas de retirantes de todas as espécies e de todas as idades. Povo sem sexo. Eram, apenas, os cassacos. Esfarrapados, os olhos compridos de fôme, engolindo o cuspo, mastigando vento, corriam os olhos súplices pelos taboleiros sortidos de brôas, que se enfileiravam em linha reta, estação em fora (Andrade, 1934, p. 53, grifou-se). 
Os abusos sofridos pelas meninas e mulheres durante as secas e as obras contra estas são tema recorrente do livro. Os crimes eram imputados aos brancos de elite e também aos "doutores" das obras. A hierarquia social era transportada para as obras e se revelava em cada aspecto, como no acesso à água por exemplo. Em um dos diálogos do livro um carregador de água fala para outro:

- Você já viu? Durma com esta: Pois não é que este mundo anda mesmo errado! Branco não pode beber agua de poço por que faz mal, uma agua limpinha chega a gente vê até as piabas no fundo. E os cassacos, coitados, que bebem lama, dando graças a Nosso Senhor, morrem? (Andrade, 1934, p. 81).

Mudando a narrativa para Sobral, onde havia sido instalado um campo de concentração para o qual afluíam os retirantes que procuravam socorros e trabalho nas obras públicas, o narrador descreve um grupo de trabalhadores que estavam carregando pedra para o calçamento das cidades: "Não tinham noção do tempo, nem das coisas. Possuiam uma personalidade zero". Ganhavam pouco, trabalhavam muito e passavam a rapadura, farinha e violão. Faltava-lhes "consciencia proletária", sentencia (Andrade, 1934, p.112, 113). Na bodega junto à obra um grupo de trabalhadores conversa e o feitor se irrita:

- Vambora, negrada malandra.

Alguém reclamou, baixo:

- O cativeiro já se acabou. Ah! Se eu podesse ir pro Amazonas...

- Péde um adjuntório ao senhor Bispo, rapaz. É pá casca.

Lá iam eles, nús da cintura para cima, caixão á cabeça, o suor escorrendo entre os peitos murchos, as têmporas latejantes, ensopados, molhados, os molambos que lhe cobriam o sexo. Homens? Não! Apenas isto: os cassacos (Andrade, 1934, p. 114, grifou-se).

Conforme o tempo vai passado e a seca se intensificando, os retirantescassacos que não paravam de chegar já não conseguiam ser absorvidos pelo campo de concentração tomando as ruas da cidade com seu estribilho rouco: "Uma esmolinha por amor de Deus! Menos uma moncheinha de farinha, pra quebrar o 
jejum doninha!" (Andrade, 1934, p.178).

As precárias condições às quais os cassacos ficavam submetidos nas obras, contadas em prosa e verso, não impediram que esses trabalhadores fossem classificados de malandros e aproveitadores, como a citação que abre essa seção deixa entrever. $\mathrm{O}$ escritor Rodolfo Teófilo ${ }^{10}$ descreveu a situação no Ceará durante a seca de 1919 da seguinte maneira:

Há no Estado uma massa flutuante, que não se fixa, andeja, que vive nos bons tempos agregada às fazendas ou aos povoados, alimentada por pequenos salários.

Essa massa de ciganos é a primeira que se desloca. Não vence a travessia a pé, como em outros tempos, quando a viagem era de cem léguas, palmilhando um solo quente como um borralho, sofrendo as agonias do mais penoso calvário, afrontando os lances mais atrozes: porque a estrada de ferro, vae ao coração do Estado [Ceará] e a onda de famintos espraia-se na vizinhança das estações da via férrea, vivendo das esmolas dos passageiros e caridade dos habitantes do lugar. A população adventícia vai avolumando-se crescendo até constituir um perigo para os naturais.

É a ocasião de enxotá-los; e os habitantes cotizam-se e pagam a passagem dêles no trem.

Os vagões enchem-se de retirantes gordos, fortes, vestidos de roupas ainda sãs mas sujas, nogentos, exalando um cheiro de porcaria que embebeda. Êste fertum especial da sujidade é tal que empesta o trem inteiro, vindo da causa dêste (Pinheiro, 1960, p. 25).

A cada seca declarada, a massa de trabalhadores expulsas das terras aonde viviam é utilizada como mão de obra nas construções de açudes públicos e particulares, rodovias e outras obras. Na seca de 1932, como já foi mencionado, essa população passou a ser organizada nas obras de maneira mais sistemática, embora precariamente alojados conforme demonstrou relatório da Comissão Médica de Assistência e Profilaxia aos Flagelados do Nordeste. Nesse relatório, foi descrita também a alimentação precária fornecida aos cassacos, que chocava pela sua pouca 
quantidade, diversidade e qualidade, principalmente em face dos trabalhos executados. A Comissão que visitou as obras do açude São Gonçalo, em Souza, registrou a alimentação costumeira fornecida.

Os generos da alimentação costumeira dos "cassacos" eram: farinha (de mandioca), feijão, arroz, sal... Numero de refeições durante o dia: - UMA (o que aqui se chamaria almoço ajantarado). Alguns "cassacos", os sem responsabilidade de familia faziam duas refeições.

De referencia á quantidade de alimento: - 1 litro de feijão, ou seja 850 gramas (...) tinha que bastar para o operario comer durante 6 dias, conseguintemente ração diaria de mais ou menos 140 gramas.

O cardapio não seria commplexo. Apenas o feijão cosido com agua e sal (unico tempero) e farinha a fartar... Quando havia arroz para o almoço, seria somente arroz. Raramente feijão e arroz se associavam...

Quando a alimentação era colletiva, para varios flagelados da mesma barraca, um litro de feijão daria para 4 pessôas se alimentarem durante 3 dias (a quota diaria neste caso se restringia a cerca de 70 gramas). Em compensação, o estomago se empanturrava de farinha, por isso que um litro correspondia em peso a (700 gs.) as 4 pessoas, comensais do litro de feijão acima, tragavam-no em um dia.

\section{(...)}

Por vezes, a vida apertava, e, nesta conformidade, não seriam mais as 140 grs. aproximadamente da ração per capita diaria, anteriormente citada, o que o "barraqueiro" teria de levar á panela. Os grãos de sua mão mal cheia não dariam para engrossar a agua com sal. A isto, chamava o flagelado, ironicamente, "chá de feijão"...

Deante de alimentação tão pobre quantitativamente e qualitativamente surpreendiam, visitando-se as turmas de trabalho, a robustez e a capacidade produtiva apresentadas pela maior parte dos operarios. É, em verdade, admiravel a resistencia daqueles titanicos "caboclos" nordestinos!... (Costa, 1936, pp. 105, 106).

A situação alimentar descrita no relatório que visitou os Centros Agrícolas instalados durante a seca de 1932 não era muito melhor que essa. Sobre centro 
agrícola Trairi, no Ceará, o engenheiro Evaristo Leitão, mostrando também surpresa em relação à execução de trabalhos tão pesados mediante tão parca ração, anotou:

Examinando uma caderneta de fornecimento pertencente ao trabalhador Manoel Augusto Ferreira, turma 3, numero 5, que sustenta a mulher e oito filhos observei que só de farinha de mandioca, arroz, rapadura, café, tudo em quantidade minima vive essa pobre gente. Só uma vez em 15 dias apareceu em sua mesa $11 / 2$ quilo de carne de bode.

Só mesmo resistencia organica do sertanejo, de que nos fala Euclides da Cunha, ao descrever esse típo genuinamente brasileiro, suporta tão angustioso e prolongado sofrimento (Leitão, 1937, p.139).

As péssimas condições a que ficavam submetidos os operários das obras do governo se replicou no tempo e no espaço. Em Coremas seu lugar na história, Edvaldo Brilhante relembra uma brincadeira de infância com a sigla DNOCS que, de Departamento Nacional de Obras Contra as Secas, virava "Deus Não Olha Cassaco Sofrer".

Como ressaltado por Frota (1985), as condições precárias dos trabalhadores alojados em acampamentos coletivos improvisado atravessaram as décadas sem muita modificação. Apesar disso, o primeiro levantamento sistemático acerca das condições de vida dessa população por parte dos órgãos de combate às secas só foi realizado em 1970, como será analisado mais a frente.

\section{Sob a euforia nacionalista dos 30: Os Boletins da Ifocs}

Aproveitando o clima positivo gerado pelo grande número de obras e verbas foi lançado, em janeiro de 1934, o primeiro número do Boletim da Inspetoria de Obras Contra as Secas. Editado mensalmente até 1936, os boletins foram diminuindo sua periodicidade até ser interrompido pela primeira vez em 1942.

O objetivo da publicação, conforme explicitado em seu "Programa", era tornar pública a atividade da Inspetoria na "dedicação em geral pela salvação do Nordeste". Grande parte dos boletins é, portanto, dedicada à descrição das obras em curso. A 
estratégia de dar publicidade aos feitos da Inspetoria se alinhava à política de propaganda empreendida durante os governos de Getúlio Vargas. Nesse sentido, os feitos do ciclo revolucionário da Ifocs seriam exaltados por ainda muito tempo.

O quarto número do Boletim, publicado em abril de 1934, reproduziu parte do relatório apresentado pelo então Inspetor das Secas, Luis Vieira, ao Ministro José Américo sob o título: "As dificuldades com que lutou a Inspetoria de Sêcas, no socôrro aos flagelados, em 1932". Neste, são relatados os esforços feitos pela Ifocs para salvar vidas e para evitar o "êxodo sempre inconveniente e prejudicial" empregando 220.000 flagelados em suas obras. O primeiro item reproduzido dizia respeito justamente à "afluencia de flagelados". Segundo o Inspetor:

A afluencia de famintos desnorteava; não havia improvização capaz de atender á avalanche humana que se precipitava para os logares onde se iniciava uma obra ou se supunha iniciar.

No açude Lima Campos, por exemplo, ao chegar ao local o pessoal encarregado da construção (abril 13-932) já lá aguardavam socorros mais de 3.000 pessoas.

Esse numero aumentou bruscamente attingindo em outrubro do mesmo ano a soma vertiginosa de 7.500 almas (Ifocs, 1934b, p. 177).

Devido à falta de ferramentas para o trabalho, eram admitidos todos aqueles que possuíssem ao menos um "arremedo" de ferramenta. Embora o problema imediato de absorção dos flagelados fosse resolvido dessa maneira, a falta de ferramentas adequadas levaria, por fim, ao encarecimento das obras. Outros problemas levantados pelo Inspetor foram a insuficiência de projetos disponíveis, a carência de pessoal e a falta de meios de transporte e materiais de construção em quantidade capaz de atender às obras que se iniciavam. Em meio a todas essas dificuldades, o Inspetor ressaltou os avanços feitos em São Gonçalo com a retomada das obras pelos funcionários da Ifocs:

(...) o milagre de trabalho, de paciencia e de dedicação realizou-se: operarios brasileiros sob a direção de engenheiros brasileiros em um supremo 
esforço, dentro de três mêses faziam movimentar as instalações deixadas pelos americanos (Ifocs, 1934b, p. 179).

No boletim de março de 1935 (vol. 3, n³), foi reproduzido o artigo do engenheiro civil Henrique Novais, com o título "Um inquerito dos 'Diarios Associados' sobre a obra da Revolução no combate ás sêccas do Nordeste". Segundo Novais,

Corrigir e attenuar esse contraste violento - quasi entre a vida e a morte - nos seus diversos aspectos - economico, social e politico - é em que consistem os problemas do Nordeste, a exigirem descortino dos grandes estadistas (Ifocs, 1935, p. 92).

Nessa luta são citados Nilo Peçanha, que organizou a Inspetoria, Epitácio Pessoa, aparelhando-a "para a vida e para o progresso" e, finalmente, Getúlio Vargas que orientou e sistematizou a ação do governo de maneira racional. $O$ primeiro governo constitucional teria, assim, que completar a "humanitaria" obra do Governo provisório. Comentando sobre as diretrizes dadas pelo regimento da Inspetoria de 1931, o engenheiro avaliou como sábia a decisão do ministro de concentrar as obras de açudagem nos quatro sistemas determinados pelo Decreto 19.726/1931, assim como foi a de descentralizar os serviços antes reunidos no Rio de Janeiro.

Entre os resultados principais da nova administração, Novais ainda apontou a manutenção da "população flagellada nos limites de seus Estados", impedindo, assim, "que se dissipasse pelo êxodo e por outros maleficios da Sêcca o grande capital humano que aquella população representa" (Ifocs, 1935, p. 96).

Obra humanitaria, enfim, que só póde ser bem comprehendida pelos que já presenciaram as scenas pungentes das retiradas; os que verificaram a resistencia daquella gente verdadeiramente estoica aos martyrios multiplos das longas estiagens e das inundações; - o desejo absorvente de retornar á terra sertaneja, ansia que devora aquelles que as calamidades dali dispersaram e que voltam, com os maiores sacrificios, apenas se normaliza o caprichoso regimem climatologico (Ifocs, 1935, p. 99). 
Outro ponto que mereceu destaque foi a construção das estradas ligando as áreas afetadas aos centros de produção da região. Para o autor, o grande progresso do Nordeste, "seu verdadeiro surto de civilização", estaria ligado à introdução do automóvel Ford durante a seca de 1915 (vol. 3, nº 4, p. 145).

A Constituição de 1934 consolidou a inclusão das secas no conjunto das normas da República ao inserir um artigo fixando uma porcentagem da receita da União para as ações e obras contra as secas. O Art. 177 determinava que a as obras e serviços de assistência contra os efeitos das secas nos estados do Norte seriam custeadas por uma quantia de pelo menos $4 \%$ da receita tributária da União. ${ }^{11}$

Esse artigo foi regulamentado pela Lei $\mathrm{n}^{\circ} 175$ de 7 de janeiro de 1936, reproduzida no primeiro número do Boletim desse mesmo ano (vol. 5, $n^{\circ} 1$ ). A Lei $n^{\circ}$ 175 estabeleceu o primeiro traçado do polígono que representa as áreas afetadas pelas secas. $\mathrm{O}$ art. 4 dessa lei aponta para uma maior centralização das ações por parte do poder executivo central, fixando que as obras de emergência só poderiam ser executadas após "autorização expressa" do Poder Executivo, através de um decreto, referendado pelos ministros da Fazenda e da Viação e Obras Públicas, que fixaria suas despesas.

O nacionalismo crescente da era Vargas pode ser acompanhado pela propaganda das ações do Ifocs feita nos Boletins e também pela participação do órgão nas grandes exposições nacionais organizadas pelo governo.

O boletim referente aos meses de outubro a dezembro de 1936 (vol. 6, n 2) traz um artigo sobre a participação da Inspetoria na "1 ${ }^{a}$ Exposição Nacional de Educação e Estatística", inaugurada no Rio de Janeiro em 20 de dezembro. O stand da Ifocs foi descrito como "uma revelação auspiciosa",

Aos descrentes, aos derrotistas, está demonstrada de um modo palpavel a utilidade e alta finalidade dos serviços já executados e em execução. Os resultados obtidos com os serviços agricolas nas bacias de irrigação constituem prova irretrucavel da vitoria do patriotico 
emprehendimento da Inspetoria (Ifocs, 1936, p. 50).

Foram expostos, além de maquetes que demonstravam o funcionamento dos esquemas de irrigação, um mostruário dos produtos agrícolas produzidos nas bacias dos açudes, estudos botânicos e de piscicultura e expostos quadros com as realizações da Inspetoria (açudes, poços, rodovias, entre outros).

No decorrer dos boletins, ao lado das obras de açudagem, vão crescendo em importância as realizações referentes aos planos de irrigação das bacias hidráulicas dos açudes já construídos. No Boletim da Ifocs, vol. 7, nº 2 de 1937, foram publicadas as "Instrucções para o estudo complementar das bacias de irrigação dos açudes publicos". Os levantamentos das bacias deveriam levar em consideração os seguintes aspectos 1) estudo da situação legal das terras; 2) levantamento e cadastro das propriedades; 3) estudo e classificação dos terrenos da bacia do ponto de vista agrícola; 4) coleta e análise de dados sobre a situação social, econômica e financeira, com dados relativos, entre outros, ao "modo de cultivo actual das terras; relações do proletario rural com os proprietarios das terras; salarios; arrendamento; arrendamento pago em espécie; quotas correspondentes em uso"; 5) avaliação das despesas por hectares para as diferentes classes de terra; 6) estudo das possibilidades e vantagens econômicas das diferentes espécies cultivadas (Ifocs, 1937a, p. 100).

Em 30 de setembro de 1937 Getúlio Vargas instalou a ditadura do Estado Novo através de um golpe de Estado. Vinte dias após o golpe, o gaúcho Mendonça de Lima assumiu a frente do Ministério da Viação e Obras Públicas, substituindo o baiano João Marques Reis (1934-1937). O Boletim da Inspetoria que se seguiu ao golpe procurou chamar a atenção de Mendonça de Lima, que não era nordestino, acerca da importância da obra do Ifocs no Nordeste.

Em seção intitulada "Depoimentos sobre a obra realizada pela Inspectoria", destinada a divulgar depoimentos sobre a zona afetada pelas secas aos que desconheciam aquelas paragens, foi reproduzida uma carta enviada pelo professor Sud Mennucci ao próprio Ministro. Após destacar os grandes feitos da Ifocs e 
sublinhar os avanços da experimentação agrícola do Instituto José Augusto Trindade, Mennucci faz um apelo para que o Ministro visite o Nordeste.

Não vou narrar-lhe o que vi, pois sei que, dentro de pouco, vae fazel-o pessoalmente. Tenho a certeza que as Obras Contra as Seccas terão muito a lucrar com essa visita. (...) O Nordeste precisa de sua visita. Vá vêl-o. Certificar-se-á de que as obras, que foram um panamá, em outro tempo (opinião local), são hoje uma iniciativa seria e efficiente. Tomará contacto com o Instituto Experimental da Região Seccas em formação em São Gonçalo, pois sua installação está dependendo do termino das obras dos edificios. Com aquella gente, São Gonçalo será uma entidade scientifica que honrará o Brasil.

Vá travar relações com o homem do nordeste, o mais forte e o mais ousado representante da raça, lutador incansavel que eu chrismei de titan, tanto elle me impressionou na sua indomavel resistencia de tres seculos pela conquista da zona aspera, trabalhando em condições de inferioridade total, em comparação com os seus irmãos camponezes do planeta, pelejando sem o menor desfallecimento, sem o menor desejo de abandonar a terra ingrata, sem o menor vislumbre de desanimo. Aquelle é o homem de que o Brasil precisa para o seu campo, com mentalidade agraria definitiva e que por isso mesmo, precisa ser amparado, protegido, mimado até, se for possível.

(...)

Vá ver o Nordeste, cel. Mendonça de Lima. Vá ver esse homem simples e estoico, revelando a sua penosa labuta nas feiras e mercados. Voltará, como eu, mais enthusiasmado ainda com a nossa terra e dedicará áquelas obras, o seu zelo, o seu carinho, o seu amor, não de Ministro mas de pae. (Ifocs, 1937b, p. 197)

Um anos após a implantação do Estado Novo, foi publicado um extenso dossiê sobre as ações da Inspetoria no vol. 10, $\mathrm{n}^{\mathrm{o}} 2$, de seu Boletim publicado em dezembro de 1938. A justificativa apresentada para estas assentava-se em um discurso de unidade nacional na busca da correção dos desequilíbrios entre os estados, "provocadores fatais de ideias separatistas".

E o Nordeste brasileiro constitue uma de nossas grandes reservas 
econômicas cujo estado potencial se rompe periodicamente com a produção exuberante dos anos de bons invernos.

Garantir a continuidade dessa produção através dos anos sêcos é o problema que o govêrno atual vem encarando, desde 1930, com a intensidade garantidora de seu completo êxito e a convicção de que resultará em benefício para todo o país, graças à integração de uma rica zona no verdadeiro rítmo de sua economia.

O govêrno procura, assim, corrigir, por meio de obras oportunas, as desigualdades provocadas por fatores naturais extranhos à vontade humana.

E o elemento humano que labuta naquelas paragens mostra-se digno do esforço empreedido pelo govêrno. O nordestino merece as obras contra as sêcas por sua tenacidade na luta contra um meio hostil, na maioria das vezes, e por sua atividade que só esmorece quando não dispõe mais de recursos a empregar contra a natureza rebelde (Ifocs, 1938, p. 157).

O dossiê listou todas as obras realizadas pela Inspetoria desde sua criação em 1909, enfatizando, entretanto, que apenas a partir de 1930 é que teria se consolidado uma política "firme e bem orientada". A inclusão de um artigo garantindo uma verba destinada aos socorros com as secas na Constituição de 1934 (Art. 177) também teria concorrido para o fins das paralisações de obras, observadas no período anterior.

A Lei $\mathrm{n}^{\mathrm{o}} 175$ de 7 de janeiro de 1936, que regulou o disposto no Art. 177 foi descrita como consubstanciando "toda essa orientação patriótica do govêrno". Entre as obras contidas no plano estipulado no regulamento da Inspetoria de 1931 e reforçado na Lei de 1936, estão o açude "Curema" e "Mãe D'água". Sobre esses açudes o documento registrou que:

Os trabalhos de instalação para a construção do "Curema" foram iniciados em 1936 tendo os trabalhos propriamente de construção da barragem começado em 1937. O aparelhamento que dispõe o "Curema" representa o que há de mais moderno na construção de barragens de seu tipo. O "S. Gonçalo" já conta com mais de 39 quilômetros de canais de irrigação. 
Os açudes Curema, Mãe D'água, São Gonçalo e Piranhas, partes integrantes do sistema do Alto Piranhas, contribuirão eficazmente para a regularização do grande rio, principalmente os dois primeiros cuja capacidade conjunta vái a quasi 1-1/ 2 bilhão de metros cúbicos (Ifocs, 1938, p. 165).

Além das obras de açudagem dos grandes sistemas, é ressaltada importância das obras rodoviárias, sobretudo como fator de absorção de mão de obra flagelada. São descritos ainda os programas de irrigação das bacias, a cargo da Comissão de Serviços Complementares e da Comissão Técnica de Piscicultura. Integram o documento numerosas tabelas ressaltando o volume de recursos e realizações decorridas da Revolução de 1930.

Essas cifras elevadas de obras realizadas e pessoas atendidas (ou redimidas) foram propagandeadas também na "Exposição do Estado Novo", inaugurada em 10

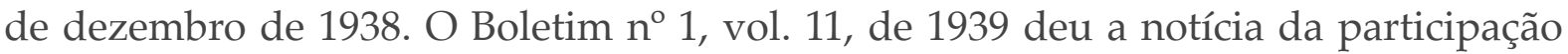
da Inspetoria na Exposição. Segundo a notícia,

A Inspetoria de Sêcas concorreu ao certamem, apresentando uma farta documentação do período de trabalho intenso de realizações fecundas iniciados depois de 1930. O seu stand mostrava informações detalhadas por meio de maquettes, gráficos, paineis artísticos, fotografias, produtos agrícolas, etc. sôbre os serviços executados em açudagem irrigação, rodovias, serviços agro-pecuários e piscicultura.

O motivo central do stand - uma região transformada pela irrigação era representado por meio de dois paineis artísticos medindo $1 \mathrm{~m}, 50 \times 1 \mathrm{~m}, 50$ cada um colocados lado a lado, representando um dêles uma cena de "retirada" de flagelados da sêca e o outro uma cena de irrigação já conhecida de grande parte dos nordestinos graças aos empreendimentos da administração atual. Havia, em baixo do quadro da sêca, a legenda: "As obras evitarão as cenas dolorosas da retirada durante uma sêca". Abaixo do quadro da irrigação lia-se: "A irrigação garantirá permanentemente a abastança, mesmo durante uma grande sêca (Ifocs, 1939a, p. 125).

De 1939 até 1942, grande parte dos artigos publicados nos Boletins foram 
trabalhos técnicos sobre maquinário, piscicultura, culturas irrigadas, estudos hidrológicos e geológicos e notícias dos serviços de perfuração de poços. No único Boletim de 1942, foi publicado o primeiro artigo do órgão a tratar das condições de vida dos trabalhadores rurais localizados nas regiões dos açudes do Ifocs. E s c r i t o pelo engenheiro agrônomo Inacio Ellery Barreira, "Observações sôbre as condições de vida e de trabalho do operário rural" descreve os núcleos formados com a construção do açude Forquilha, no município de Sobral, no Ceará. ${ }^{12}$

O autor chamou atenção para um fenômeno recorrente em torno dos açudes da Ifocs: a formação de núcleos populacionais em locais antes desabitados, não raro sendo esses em pouco tempo elevados a categoria de vila, como foi o caso daquela localizada ao sul da barragem do açude Forquilha, a $18 \mathrm{~km}$ de Sobral. Parte da população que formava o núcleo havia trabalhado nas obras como cassacos e permanecido na região tornando-se moradores das fazendas ou trabalhadores alugados.

Segundo Barreira, o trabalhador tinha ali condições de vida idênticas às encontradas em outros estados nordestinos: durante a estação seca brocava e cercava seu roçado para, com o início das chuvas, plantá-lo de "milho, feijão, mandióca, arroz, melancia, gerimum e algodão, todas as culturas consorciadas" (Ifocs, 1942, p. 12).

Nas terras não irrigadas, explicou, os proprietários as davam "gratuitamente" a seus moradores com a condição destes trabalharem três dias na semana para aquele, "com a retribuição diária de $2 \$ 00$ a $2 \$ 500 "$. Já em terrenos irrigados pelos reservatórios da Ifocs, "o proprietário o dá 'de meia'", devendo o morador repassar lhe metade de sua produção. Ao proprietário caberia

(...) a obrigação de dar terras, sementes, e a pagar a taxa d'água (\$003 por $\mathrm{m}^{3}$ ) à administração do açude, competindo àquele (colono), fazer ou custear as operações necessárias - desbravamento do terreno, plantação, capinas, irrigações, colheita, etc (Ifocs, 1942, p. 12). 
Nas observações do engenheiro, os processos produtivos utilizados seguiam os mesmos padrões tradicionais - "machado e enxada" - sem nenhuma restrição ambiental para a preservação das matas. A solução indicada foi a desapropriação de toda a área irrigada para a posterior divisão desta em lotes "e cedê-los depois de destocados, a pequenos proprietários".

Barreira descreveu as habitações construídas pelos próprios moradores como pequenas, baixas, escuras, "sem qualquer conforto e higiene de acôrdo mesmo, com a índole, a rusticidade e o grau de atrazo, de ignorância, de falta de instrução dos seus moradores". Na opinião do autor,

O homem rural - o sertanejo - é rústico por excelência, cuja qualidade lhe permite enfrentar todas as intempéries; na estação invernosa, às chuvas prolongadas no roçado, continuando no "cabo da enxada" com as vestes molhadas, até ao cair da noite, quando volta ao seu lar, muitas vezes só com a "tijéla" de café que tomou nos prelúdios do dia, ao sair da sua choupana; no verão, da manhã ao escurecer, com o machado ou a foice às mãos, nú da cintura para cima, parecendo até que a desafiar os raios causticantes do sol nordestino (Ifocs, 1942, p. 13).

Além dos moradores, havia os operários diaristas que recebiam uma quantia diária que variava conforme o combinado com o patrão. O proprietário de terras se dedicava à lavoura e criação de gado, morando via de regra na cidade onde desenvolvia outras atividades como o comércio. A criação de gado era entregue ao vaqueiro que, como pagamento, recebia um número preestabelecido de bezerros por ocasião da "ferra".

Barreira descreve ainda as atividades de coleta dos frutos da oticica e da cera de carnaúba, cuja palha era usada para a fabricação de chapéus feitos por mulheres e crianças e vendidos na cidade. Por fim, o engenheiro anota a precariedade das escolas da região e sugere a instalação de uma escola agrícola.

Segundo as descrições do artigo, pouco tinha mudado para os que já eram moradores das fazendas da região ou para aqueles que haviam abandonado suas 
moradas em fazendas de outras localidades durante a seca de 1919 e se fixado ali após a conclusão do açude de Forquilha em 1928.

Após o primeiro número do volume 17 de 1942, que contém o artigo comentado acima, a publicação dos boletins foi suspensa, apesar da seca declarada neste ano. O volume 18 só foi publicado cerca de 16 anos depois, em agosto de 1958, marcando um novo período áureo do órgão contra as secas. Entre as explicações para a suspensão do Boletim durante tanto tempo, está o "êxodo" dos servidores do Dnocs causado pelos baixos salários do órgão. Nesse intervalo, a Inspetoria foi transformada em Departamento, através do Decreto-Lei n ${ }^{\circ} 8.486$ de 28 de dezembro de 1945.

\section{Os anos 50 e as novas diretrizes do Dnocs}

Durante seca declarada em 1952, José Américo de Almeida era governador do Estado da Paraíba, tendo se licenciado do cargo para assumir novamente o Ministério da Viação e Obras Públicas no qual permaneceu até o suicídio de Getúlio Vargas em 1954.

Assim como tinha feito em 1932, o Ministro visitou várias localidades do polígono. Os feitos dessa gestão foram registrados no livro As sêcas do Nordeste, de autoria do próprio ministro e publicado ainda em 1953.

Ao assumir pela segunda vez o Ministério da Viação e Obras Públicas em 1953, José Américo afirmou ter encontrado esgotado o fundo de emergência e os pagamentos atrasados, o que fazia com que as obras se arrastassem mais que o necessário, além de abalar a credibilidade do Departamento.

As sêcas (como se diz vulgarmente) sempre foram responsáveis por tradição de impontualidade nos pagamentos. Conta-se mesmo no Ceará uma anedota que define êsse mau costume. Encontrando-se Arrojado Lisboa em inspeção ao Orós, perguntou-lhe um caipira: "Dr., e êsse açudão também vai ser fiado?". Só no $1^{\circ}$ Distrito [Ceará], no ano passado, houve um atraso de 11 
meses (Almeida, 1953, p. 7).

Entre as medidas tomadas pelo Ministro, estava a determinação que os pagamentos fossem feitos semanalmente e em dinheiro, eliminando os intermediários "que levavam, no mínimo, 10\% dos salários". Foram destacadas ainda: a suspensão de obras adiáveis; o restabelecimento dos projetos originais de Coremas e Mãe D'água, cancelando a revisão que pretendia elevar o nível de água; o aumento de barragens que dispunham de área irrigada, como Condado, na Paraíba; o desenvolvimento de uma rede de canais "como meio de reabilitar a açudagem pela utilização da água acumulada"; a desapropriação das bacias de irrigação; e a liberação das dotações orçamentárias para a média açudagem, que havia sido suspensa.

Para José Américo, o problema das secas seria sempre um problema d'água. "A condenação das grandes barragens, tão em moda, não é abonada pela técnica nem pela experiência dessas construções", sendo sua única limitação o fato de estar restrita a certas áreas geográficas. Com relação a esse aspecto, o plano de obras traçado pelo Decreto $\mathrm{n}^{\mathrm{o}}$ 19.726, de 20 de fevereiro de 1931, que delimitou quatro grandes sistemas de açudes, ainda era "perfeito e atual" (Almeida, 1953, p. 12).

O que se deve fazer, antes de tudo, é fixar prioridades para as obras já projetadas, tendo em vista o seu valor econômico e sua eficiência específica. E atacá-las sem as solução de continuidade que tanto tem desacreditado essas iniciativas. Basta lembrar que o Acarape foi feito em 15 anos; o Morcêgo em 12; o Santo Antonio das Russas em 17; o Soledade em 21; o Forquilha em 9; o Cruzeta em 10 e o Tucurutuba em 8. Mas em compensação vimos em 1932 o Lima Campos feito em 9 meses, o Joaquim Távora em 18 meses e o General Sampaio em 8 meses, além de outras improvisações estupendas da passagem de Luis Vieira por essa esfera de ação (Almeida, 1953, p. 12).

Para completar o quadro acima, pode-se citar que, após retomadas as obras dos açudes Boqueirão de Piranhas e São Gonçalo em 1932, ambos foram finalizados em 4 anos. O açude de Coremas demorou 5 anos para ficar pronto, de 1937 a 1942. Já 
a construção da barragem Mãe D'água se arrastava há onze anos quando foi escrito o livro, tendo levado ao todo 15 anos até sua inauguração em 1957.

Mas, ao contrário da defesa inconteste da grande açudagem feita por José Américo em 1932, em 1950 essa política foi alvo de críticas de sua parte, que reconhece suas falhas sob o ponto de vista do desenvolvimento econômico.

Mas aqui tenho que ser leal. Tenho que confessar que, apesar de adepto da grande açudagem, de sua função econômica, reconheço ser falho o seu papel para um fim essencial: a intervenção contra a desorganização do trabalho criada pela sêca. Por maior que seja a sua capacidade e por mais bem equipados que estejam, não poderão êsses reservatórios cumprir sua principal missão que seria absorver as massas flutuantes, a avalanche dos deslocados do campo nas épocas de desemprêgo ocasionado pela paralisação das atividades agrícolas, por falta de chuvas (Almeida, 1953, p. 13, grifou-se).

O açude deveria ser feito apenas se sua utilidade fosse economicamente vantajosa, como fator de abastecimento com ou sem seca. O que se deveria abandonar era "a rotina que eterniza sua construção". O meio sugerido para tanto foi a construção por "empreitada", contratando empresas por concorrência pública. "Ficará dessa forma, determinado prazo mínimo do seu término, além da conveniência de ser assegurada a continuidade, de govêrno a govêrno, sem paradas desastrosas" (Almeida, 1953, p. 14).

O Ministro mudou sua perspectiva também com relação a esse aspecto. $\mathrm{Na}$ regulamentação da Ifocs que aprovou através do decreto 19.726/1931, em vista do fracasso representado pela paralisação dos contratos firmados com as empresas estrangeiras durante o mandato de Epitácio Pessoa, José Américo tinha mudado o artigo anterior que previa a assinatura de contratos com firmas especializadas estipulando, em 1931, que obras seriam executadas diretamente pela Ifocs.

Com relação à nova perspectiva dada aos açudes, outro ponto destacado é que a água não deveria ser "para guardar" mas sim "para irrigar". O Ministro criticou a falta de um plano estabelecendo o regime de exploração das terras irrigáveis 
(Almeida, 1953, p. 14).

É essa outra complicação que anos de inércia e indiferença nos legaram. Ouvi pôr toda parte, na minha recente excursão, que se torna impraticável o processo das desapropriações das obras iniciadas, de acôrdo com as exigências do Domínio da União, devido, principalmente, à excessiva documentação. Os latifúndios de áreas beneficiadas permanecem invioláveis. Discute-se ainda qual o regime preferido, se arrendamento ou propriedade. Têm curso no Congresso nada menos que cinco projetos de lei sobre a colonização dessas terras, com prévio expropriamento, tendo a Comissão de Política Agrária aproveitado o do Deputado Maurício Joppert como melhor subsídio para o ante-projeto elaborado. O Executivo já encaminhou outro ante-projeto de desapropriação por interêsse social. O Conselho de Economia deve estar elaborando um trabalho sôbre a colonização dos vales úmidos. (Almeida, 1953, p. 14).

A grande açudagem deveria ser acompanhada também por obras complementares, entre elas a construção os pequenos e médios reservatórios, algo que já vinha destacando desde a década de 1930. Segundo sua interpretação, todo homem do sertão teria fé no açude particular e todos desejavam essa cooperação "como um presente do céu" (Almeida, 1953, p. 15). A disseminação dos pequenos açudes, segundo o Ministro, equivaleria às grandes barragens "com a vantagem de estar em toda parte", "evitando a invasão das obras públicas, a afluência devoradora dos que não tem nenhum refúgio". "Os grandes açudes serão núcleos humanos e os pequenos dispersão" (Almeida, 1953, p. 15). Por esse mesmo motivo os poços deveriam ser incentivados.

Como medida preventiva foi sublinhada também a importância de se fazer estoque de produção com auxílio de financiamentos do Banco do Brasil e Banco do Nordeste, o fomento da produção e o desenvolvimento da cultura irrigada, que seria a nova prioridade entre as políticas do órgão a partir de então.

Com relação às medidas de emergência, José Américo apontou a necessidade de se organizar as migrações inevitáveis, dirigindo a população para estados como o 
Maranhão, dada sua proximidades e suposta disponibilidade de terras. As obras públicas com a consequente utilização de mão de obra flagelada foram, mais uma vez, as principais medidas de emergência tomadas.

Entre as obras realizadas, estão a continuidade da barragem Mãe D'água, a construção das rodovias: Patos-Piancó, Curema-Piancó, São Gonçalo-Curema-São Bento e do ramal rodoviário Mãe D’água-Barragem de Lages, além do campo de pouso, todos na região de Coremas. Conforme os relatórios dos trabalhos executados nesse ano, foi tão expressiva a quantidade de postos abertos por essas obras que ainda hoje os moradores de Coremas denominam o feijão preto de "feijão de Zé Américo" em analogia ao feijão enviado para suprir os trabalhadores emergências (Entrevista Francisco José de Souza, dez. 2016).

Ao comparar a seca de 1932 com a que se iniciava então, José Américo anotou que, ao contrário da primeira, a crise que se instalava apresentou a seguinte particularidade: "a resistência do pessoal à transferência para os centros de trabalho de caráter permanente. Cada município, cada distrito, exigia sua obra, sob ameaça de marcha para as cidades de verdadeiras legiões" (Almeida, 1953, p. 4).

Essa particularidade potencializou, de certa forma, a estratégia utilizada há muito e que consistia em pintar um quadro de calamidade extrema na busca de recursos e obras para a sua região, a chamada indústria da seca..$^{13}$

Durante o ano de 1953, o presidente Getúlio Vargas recebeu uma série de telegramas de políticos e da elite dos municípios inseridos no polígono das secas. Pela leitura destes, somos levados a considerar que pouco havia mudado desde o final do século XIX, pelo menos no que diz respeito ao "exagero retórico" destacado por Cunniff (1975).

Praticamente todos estes telegramas descreviam um quadro aterrorizante para, em seguida, solicitarem açudes e estradas para empregar os flagelados. Os telegramas não tinham como objetivo criticar a ação do governo mas sim obter recursos. 
O telegrama enviado pelo prefeito de Catolé do Rocha, na Paraíba, avisava que a estrada do município estava "coberta de flagelados que seguem em direção a cidade pedindo trabalho e viveres" e que, se nada fosse feito, cairia sobre Catolé "uma hecatombe" (Cpdoc, 2010, fl. 225).

O prefeito de Oeiras no Piauí escreveu afirmando que a cidade estava "completamente cheia de "centenas de flagelados" e que a prefeitura estava se empenhando para o transporte destes para o Maranhão. A obra que tinha sido instalada pelo Dnocs no município só tinha vaga para 300 mas lá chegavam todos os dias "umas quatrocentas pessoas", relatou. Por fim, o prefeito pedia que fosse permitido que o Dnocs aceitasse "mais matriculas" e que fosse autorizado que os colonos da Colônia Agrícola pudessem "atacar serviços estradas não por empreitada... mas por diarias" (Cpdoc, 2010, fl. 264).

Essa série de telegramas revela também as soluções dadas pelas administrações locais, como a utilização da população no trabalho em fazendas particulares, açudes e rodovias, a migração financiada pelo Estado e a criação de núcleos para exploração agrícola.

A interrupção brusca no governo de Getúlio Vargas de certa forma paralisou as realizações do Dnocs até a entrada de Juscelino Kubitschek na Presidência da República em 1956, marcando um novo momento de valorização das políticas contra as secas e de desenvolvimento regional.

Apesar de muitos açudes terem sido construídos nesse período, a irrigação passou a ser a diretriz central do Dnocs. O novo projeto de irrigação estava subordinado ao plano de desenvolvimento do Nordeste elaborado em 1958 pelo grupo de trabalho criado especificamente para traçar esse plano, o Grupo de Trabalho de Desenvolvimento do Nordeste (Gtdn), que culminou com a criação da Sudene em 1959, através da Lei no 3.692.

Talvez a mais contundente crítica ao modelo da açudagem, ou "solução 
hidráulica", tenha sido a apresentada por Celso Furtado, coordenador do Gtdn e idealizador da Sudene, cuja criação é interpretada como golpe de morte no Dnocs por alguns servidores do órgão. Para Furtado, o simples armazenamento de água pouco contribuía para a melhora nas condições de vida das populações afetadas, sendo "mera etapa preliminar na execução de uma política de melhor aproveitamento de terras e águas na região".

No documento do Gtdn publicado em 1959, Furtado observou: "Pode-se afirmar com segurança que a seca não é hoje problema social menos grave do que quando se iniciou o combate sistemático aos seus efeitos" (Furtado, 2009, p. 88). Mais tarde, Furtado comentaria sobre esse momento que:

Por essa época, já havia no Nordeste sete bilhões de metros cúbicos represada graças às barragens construídas pelo DNOCS, sem que se soubesse exatamente para quê. Quando eu trabalhava na CEPAL, fui certa vez consultado sobre esses dados. Na ausência de aproveitamento hidrelétrico e de irrigação, os técnicos que manuseavam os dados para efeito de compilação estatística eram de opinião que devia haver erro de números, do contrário a água teria sido represada para evaporar-se, diziam. Eu sabia que a água estava ali para servir uma pecuária extensiva nas longas estiagens, mas também sabia que uma tal explicação era pouco convincente, pois a utilização da água em benefício da pecuária não impedia seu uso na irrigação. Limiteime a dizer que os projetos de irrigação deviam estar em curso de execução, se bem que carecesse de informação precisa sobre a matéria. Nessa época, o jornalista Ântonio Callado ainda não havia construído o conceito de "indústria das secas", conceito aliás esotérico para quem não penetra nos arcanos da vida política brasileira (Furtado, 1989, p. 38).

No início de 1959, após a publicação do documento elaborado pelo Gtdn, o presidente reuniu os governadores nordestinos recém-empossados no Palácio do Catete para apresentar o plano de criação da Sudene. JK abriu seu discurso salientando o início de uma nova era para o desenvolvimento dos estados nordestinos: 
Considero o dia de hoje um dos mais assinalados do meu período presidencial, pois com êle se inicia nova fase da luta pela libertação do Nordeste brasileiro. O Brasil tem derramado lágrimas sôbre o destino de milhões de patrícios nossos, obrigados a sofrer as inclemências da natureza madrasta e a participar das agruras de uma existência que encontrou sua expressão mais perfeita e terrível na denominação de "vidas sêcas", que lhe deu um dos mais exatos e implacáveis romancistas do drama nordestino. Vidas sêcas, vidas sem rumo, vidas sem qualquer espécie de confôrto... (Ibge, 1959, p. 101)

Embora o Nordeste figurasse como "um problema de consciência" para a nação, nos dizeres do presidente, as muitas medidas tomadas até então não tinham conseguido resolver de maneira eficaz o problema da região. Os investimentos feitos para "reparar os efeitos das desgraças periódicas das estiagens cruéis", repetidos a cada seca, seriam fruto da incapacidade de encontrar os "remédios drásticos a serem aplicados".

Com seu discurso, o presidente afirmava inaugurar também uma nova fase da luta contra as secas, "criadora de uma nova ordem de coisas", que levaria a região a uma "prosperidade estável". Tratava-se de enfrentar o "mal do subdesenvolvimento", "tomando de assalto" as regiões afetadas pela seca.

Depois que a nação assistiu ao encontro das turmas que abriram na floresta selvagem o primeiro caminho por onde se realizará a redenção do mundo amazônico; depois que as grandes obras prometidas passaram de projeto a execução - Furnas, Três Marias e outras -, a promessa solene de acelerarmos o progresso do Brasil de cinquenta anos em cinco deixou de provocar a ironia e os risos negativos dos descrentes. Creio que ninguém duvidará que envidaremos um esfôrço pertinaz contra os fatôres que tornam adversas a vida no chamado Polígono das Sêcas. Ao movimento de alta envergadura que hoje inicio, darei, pelo menos a mesma prioridade que dei às principais metas do meu governo (Ibge, 1959, p. 102).

O presidente destacou a importância dos estudos sobre o Nordeste que 
estavam sendo realizados e mencionou sua participação no encontro dos bispos de Campina Grande, em 1956, onde havia sido proposto um plano de ação envolvendo todos os órgãos federais de alguma forma vinculados ao assunto. Nessa ocasião, JK assinou 19 decretos executivos baseados nas conclusões do encontro e que sancionaram medidas que beneficiavam todos os estados do Nordeste. Em consequência desses decretos, foram ainda iniciados projetos relativos à fundação de núcleos coloniais, reaparelhamento de portos, irrigação, inauguração de postos de saúde, maternidades, abastecimento de água, abertura de estradas, perfuração de poços, aproveitamento energético dos açudes, educação e assistência social.

Poucos dias depois da edição desses decretos, em 6 de julho de 1956, JK sancionou a Lei $\mathrm{n}^{\mathrm{o}} 2.814$, que dispõe sobre a concessão de auxílio aos municípios situados no Polígono das Secas para a instalação de serviços públicos de abastecimento de água.

São citadas, ainda, as obras realizadas pelo Dnocs no campo da açudagem, com o represamento de cerca de "120 por cento adicionais em relação ao total de reservatórios terminados desde o Império até aquela data". Os programas de colonização efetivados em 18 açudes sob o controle do órgão também são ressaltados, destacando o número de 10.988 famílias assistidas "com 65.694 pessoas, tôdas vivendo à custa do próprio trabalho" (Ibge, 1959, p. 103).

Todas essas obras, entretanto, ainda não tinham sido capazes de diminuir o atraso da região com relação às áreas localizadas no Centro-Sul do país, situação que só poderia ser resolvida através de um plano coordenado de atividades produtivas baseados em estudos meticulosos sobre a região. A ênfase desse plano deveria ser justamente a zona sujeita às secas, cuja economia era "particularmente débil" e sua produtividade "quase primitiva", já que ocupada basicamente com lavouras de subsistência (Ibge, 1959, p. 105). Uma política econômica "realista" para a região, explica, deveria ter com principal objetivo a modificação do então sistema de produção, exigindo esforço coordenado de "reorganização econômica e social" que 
compreendia, entre outras medidas, abrir de frentes de colonização para o aproveitamento pleno das terras, deslocando a fronteira agrícola; prover a região com fontes regulares de renda, com o acréscimo da produtividade e "comercialização dos recursos disponíveis", como o algodão e o gado; incentivar a pomicultura e a industrialização de frutas em conserva e óleos vegetais.

Com relação ao desenvolvimento da faixa úmida litorânea, JK destacou o fomento às exportações e à industrialização como medida dinamizadora da economia nordestina.

De acôrdo com o programa elaborado [pelo Gtdn], impõe-se desde logo, mediante aprovação legislativa, a criação de um órgão do govêrno federal em condições de coordenar as atividades das numerosas repartições administrativas que exercem atribuições no Nordeste. A idéia que aceitei foi a de uma entidade flexível e eficiente, necessáriamente imune às solicitações do empreguismo, que possa não só impulsionar a ação administrativa em curso, dando-lhe perspectiva e continuidade, como executar projetos específicos enquadrados nos esquemas oficiais ou particulares de financiamento.

A Superintendência do Desenvolvimento do Nordeste - novo órgão, objeto de mensagem ao Congresso Nacional por mim hoje assinado, - será dotada de recursos próprios - um fundo rotativo de um bilhão de cruzeiros a serem utilizados em projetos constantes de um Plano Diretor e estará diretamente sob a supervisão e a fiscalização do Presidente da República. Sua ação promocional se exercerá por meio de um Conselho Técnico de Planejamento e Contrôle e de uma Secretaria executiva, em projetos de âmbito regional ou mediante assistência técnica aos estados. Fato realmente digno de menção, a mensagem ao Congresso, que propõe o novo órgão, não prevê a criação de cargos (lbge, 1959, p. 107).

JK terminou seu discurso conclamando os governadores a participarem ativamente do plano integrado de desenvolvimento regional e encerra com a frase: "O Brasil é um só!" (Ibge, 1959, p. 109).

Embora o presidente não mencione em seu discurso, em 1958 havia sido 
declarada seca. Os efeitos dessa crise foram tão intensos que alguns comentaristas chegaram a avaliar que ela teria sido maior que a de 1932. O montante de verbas destinadas ao Dnocs nesse período foi grande, contribuindo para isso não só a seca mas também a política de desenvolvimento inaugurada pelo governo Kubitscheck.

Nesse clima de renovado nacionalismo e centralidade dos órgãos que atuavam no Nordeste, os boletins do Dnocs, cuja publicação havia sido paralisada em 1942, voltaram a ser editados.

O artigo que abriu segundo número de 1958, intitulado "A luta contra as sêcas", reproduziu a exposição do então Ministro da Viação Lucio Meira na câmara dos deputados, feita para prestar contas dos recursos destinados aos socorros da grave crise provocada pela seca, que assumira "proporções trágicas, quase dantescas".

Logo no início de sua exposição, o Ministro pontuou a existência de um novo conceito acerca do problema das secas que levava em conta sobretudo seus efeitos de natureza econômica. Na nova conceituação, a seca apresentava-se como um "desequilíbrio entre a produção e o consumo".

A causa fundamental dos problemas não era a falta de chuvas, mas o aproveitamento ainda insuficiente das águas "e especialmente as debilidades naturais da economia nordestina". A "seca econômica" traduzia-se pela "impossibilidade transitória de garantir ao homem a subsistência".

Por tudo isso é que eu me atrevo a dizer que, nas condições brasileiras, pelo menos, a sêca ainda é incontrolável. Por que? Por motivo das debilidades da economia nacional e do ainda vigente primarismo da economia nordestina.

Muitos lembrarão, em contrapartida, o exemplo tão recente de Israel. Mas na verdade, o Estado semita não corrigiu a aridez do seu território; atenuou-lhe simplesmente os efeitos. E assim contornou, em parte a sêca, com um tipo de irrigação que ainda não está ao nosso alcance: a irrigação pelo dinheiro, pela técnica, pelo desenvolvimento econômico sobretudo industrial 
ou agro-industrial, de um país que mal se compara, em área, ao nosso Estado de Sergipe (Dnocs, 1958, p. 8).

Além da falta de recursos, o parco desenvolvimento da irrigação do Nordeste seria fruto da resistência do espírito conservador e rotineiro dos proprietários das terras irrigáveis. Lucio Meira ressaltou também a necessidade de investimentos para além do combate às secas e apontou que o governo estava se empenhando em um planejamento global para a região no sentido de "valorizar o Nordeste para integrálo" (Dnocs, 1958, p. 26).

Embora a introdução à exposição do Ministro registrasse que já estava se vendo, no Nordeste, as tristes cenas descritas nos livros, Lucio Meira destacou que: "Hoje, com o açude, com a estrada, com o caminhão, a mortalidade em decorrência das sêca, reduz-se a cifras inexpressivas" (Dnocs, 1958, p. 16).

O ano de 1959 marcou o cinquentenário do órgão de combate às secas. Além dos quatro boletins publicados nesse ano, foram lançadas duas separatas ao $\mathrm{n}^{\mathrm{o}} 3$, vol. 19, de fevereiro e uma outra ao boletim de novembro, todas organizadas pelo Engenheiro Luiz Carlos Martins Pinheiro, da "Sessão de Estudos e Projetos" do Dnocs.

Uma das separatas ao número de fevereiro foi a intitulada "Açudagem Pública". A publicação registrou o legado construído pelo Dnocs desde os tempos da Inspetoria até então, apontando para o fato de que aquele era um momento importante na história do órgão e também do Nordeste.

A segunda separada ao Boletim citado foi a intitulada Obras contra os efeitos das Sêcas (Sêca de 1958). Apesar de todos os esforços despendidos por parte do poder público, registrou Pinheiro, a região vinha sofrendo um "empobrecimento acentuado em relação à Federação" (Pinheiro, 1960b, p.1).

Sobre a seca de 1958, Pinheiro destacou a paralisação quase total das atividades agropecuárias, tendo sido verificada uma redução de 50\% no valor da produção, segundo dados do Banco do Brasil. Para minorar os efeitos do 
desemprego em massa, foram mobilizadas verbas federais e somente o Dnocs chegou a ter "396.937 flagelados distribuidos em suas diversas frentes de serviço na semana de 27 de setembro a 3 de outubro" (Pinheiro, 1960b, p. 7).

Conforme o documento, no início dessas frentes, havia sido estabelecida a diária de Cr\$ 60,00, valor que foi rapidamente reduzido para Cr\$40,00 devido ao grande número de pessoas que buscavam trabalho. Conforme os dados levantados, em abril a frequência operária iniciou com 130.818, aumentando no fim do mesmo mês para 192.010 e, um "salto brusco na semana seguinte", fez o número chegar a 278.653. Na na última semana do ano registrou-se 352.780 trabalhadores (Dnocs, 1960b, pp. 7,8).

Segundo Pinheiro, a intensidade da seca de 1958 foi muito maior que aquelas registradas nos 30 anos anteriores, tendo sido tomadas as seguintes medidas emergenciais: liberação da pesca nos açudes públicos e particulares ${ }^{14}$, permissão para o aproveitamento de todas as terras de vazante, alocando trabalhadores nas mesmas; autorização do acesso de qualquer pessoa a todos os meios de abastecimento de água para uso doméstico; abertura de frentes de trabalho em todos os locais aonde houvesse um "número razoável de necessitados locais" ou sua transferência para outro serviço; distribuição de vacinas para todas as frentes; distribuição em massa de medicamentos, leite em pó e farinhas; assistência médicoodontológica; transporte de gêneros alimentícios em grande quantidade para a região.

Sobre a rede rodoviária construída pelo Dnocs, Pinheiro ressaltou que o Nordeste possuía, então, a mais "apertada malha" do Plano Rodoviário Nacional, cujas linhas mestras foram dadas pelo Decreto $\mathrm{n}^{\circ}$. 19.726, de 20 de fevereiro de 1931. Apesar da "entrega" da rede rodoviária ao Departamento Nacional de Estradas de Rodagem (Dner), criado em 1937, o Dnocs havia concluído mais de $1.140 \mathrm{~km}$ de novas rodovias, sendo a construção da Nordeste-Brasília a maior obra de então (Dnocs, 1960b, p. 29). 


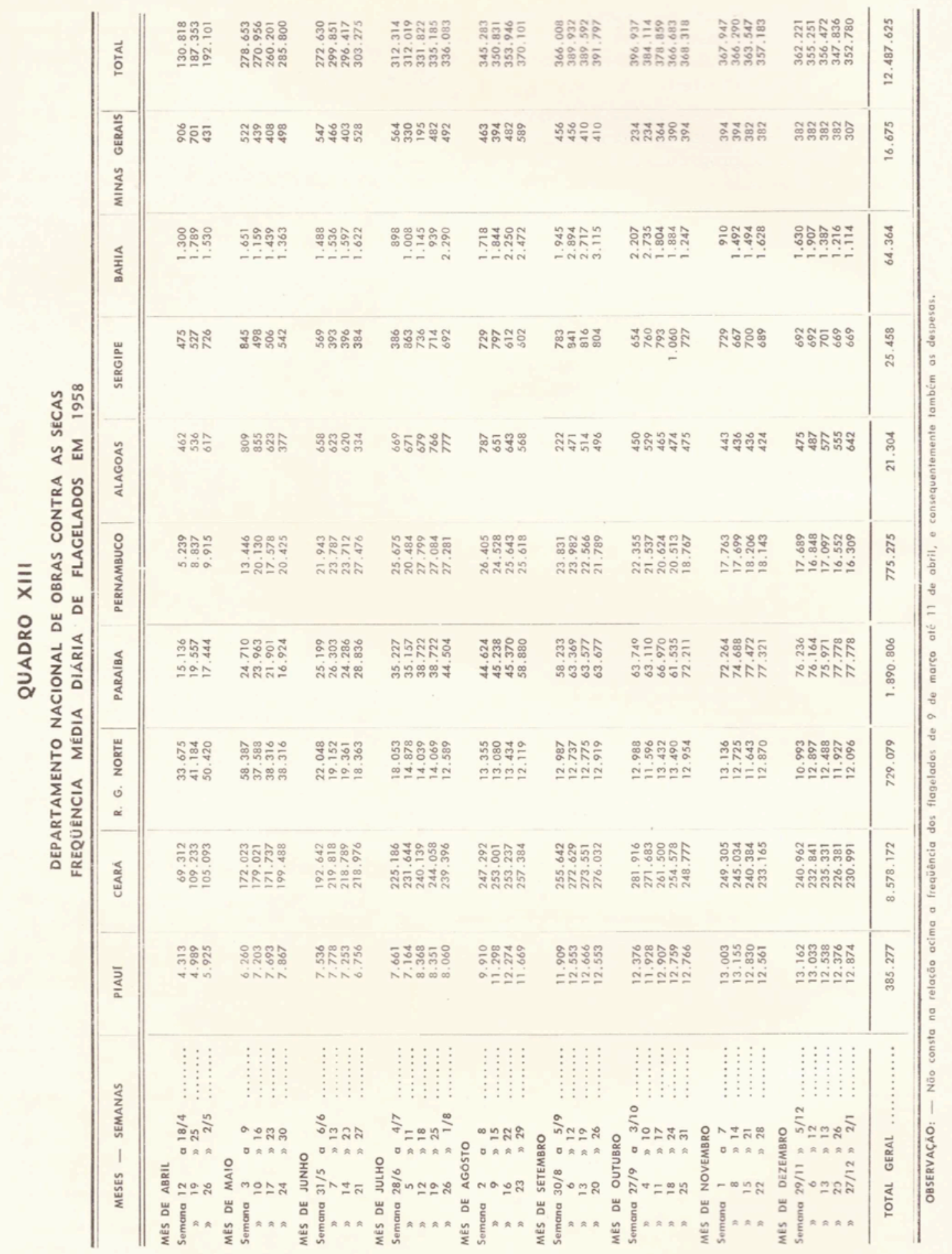

(Pinheiro, 1960b) 
A terceira separata publicada em 1959 foi Notas Sôbre as Sêcas. Nesta, o Eng Luiz Carlos Martins Pinheiro apresentou uma cronologia das secas e das ações tomadas pelo governo federal destacando aquelas que visavam solucionar problema da massa de retirantes em cada um dos períodos. Assim como ocorreu durante as outras crises, aquela enfrentada em 1958 não atingia apenas a área do Polígono das Secas, mas todo o país. Segundo Pinheiro,

O Rio de Janeiro e outros centros urbanos do Sul por exemplo sofrem de problemas sociais que têm se mostrado insolúveis com_cêrca de 800.000 pessoas que nas piores condições sanitárias e de educação vivem em suas "favelas", graças aos emigrantes que recebe principalmente dos nove Estados que constituem o Polígono. Brasília foi inegávelmente de grande importância para localização das populações desejosas de abandonar a zona sêca. Foram lá denominados de "candangos" e constituem a quase totalidade de sua população (cêrca de 60.000 pessoas em princípios de 1959). Lá a construção civil não só tem empregado todos os flagelados que normalmente demanda à Brasilia, como tem pago mesmo comissões a agentes proprietários dos afamados "paus-de-arara" para atrair maior número de homens.

Êstes "paus-de-araras" representam outro efeito das sêcas. A necessidade de escoamento dos excessos de população do Polígono em benefício da própria região, obriga aos naturais em certas ocasiões fecharem os olhos a êstes traficantes de massas humanas. Recolhem os homens através de intensa propaganda pela região, prometendo empregos certos com salários que jamais podem conseguir ou imaginar que venham a obter onde vivem. Os atraídos vendem tudo que possuem a fim de pagarem o transporte altamente lucrativo. Após dias de penosas viagens em caminhão sem o mínimo confôrto e intensa promiscuidade onde homens, mulheres, crianças, papagaios, araras micos e outros animais se acotovelam em meio a bagagem, chegam a terra prometida. Descarregados em meio às ruas sem o menor abrigo, são lançados à própria sorte. Os que já consumiram suas economias, entregam-se com a familia à caridade pública. O problema agora é dos "paus de araras", como são conhecidos no Sul os nordestinos, e das autoridades locais que nada podem para solucioná-lo (Pinheiro, 1960c, p. 75, grifou-se). 
Reforçando a nova perspectiva adotada pelo governo e também pelo órgão, o Boletim n ${ }^{\circ}$ 3, vol. 19, de fevereiro de 1959, publicou o artigo do Conselho Nacional de Economia intitulado "O problema nacional das secas". Esse artigo condensa a nova perspectiva do governo iniciado em 1956 com relação às secas e ao Nordeste.

O Conselho havia sido instado a produzir uma série de estudos e pareceres relativos ao desenvolvimento da região Nordeste, entre eles o parecer sobre o Projeto de Lei e Irrigação no Polígono das Sêcas, em 1954. Para fundamentar essa produção, foram feitas missões de campo, como a coordenada pelo Conselheiro Edgard Teixeira Leite que percorreu os estados da Paraíba, Pernambuco e Ceará. "Ao dar maior publicidade" às pesquisas com o artigo sobre o problema nacional das secas, o Conselho pretendia prestar uma "patriótica contribuição ao Govêrno da República" que vinha empregando esforços para a melhoria das condições de vida dos nordestinos.

O aspecto nacional do problema das secas é sublinhado sob o ponto de vista dos avanços para nação que derivariam da plena integração da região Nordeste, uma vez que era rica em matérias primas. Sobre o retirantes que fugiam, então, através das rodovias e "se encarapitavam nos 'paus de arara'", "oferecendo tema, por vezes trágico, para ampla literatura", o artigo ressalta que eles não representavam a realidade das regiões semi-áridas, sendo antes resultado de uma população reduzida à "extrema carência". O termo "flagelado" consistiria em uma qualificação pejorativa e preconceituosa devendo ser abolida em favor do termo "desempregado". 15

A sêca, no seu sentido econômico, deve, pois, ser definida como um fenômeno de depressão, e com sua característica de paralisação de produção e consequente desemprêgo. A sua conceituação nesses têrmos é de singular importância no encaminhamento de soluções seguras e duradouras. Deixa-se de focalizar apenas o ambiente físico, para abranger os diferentes aspectos sociológicos que o fenômeno realmente encerra (Dnocs, 1959, p. 7).

A seca de 1932 teria marcado o início da "aplicação da doutrina", que se tornara consensual, de fornecer emprego às populações afetadas em seus próprios 
municípios. A seca de 1952-53 havia atingido uma população maior que a anterior, "talvez sete milhões de habitantes" e, no entanto, "apesar do drama ter sido evidenciado em todo o realismo pelos diversos meios de publicidade produzindo intensa emoção em todo o país", esta não teve consequências tão graves como as anteriores. Não teria havido perdas humanas, os rebanhos foram menos atingidos e o deslocamento de população teria sido bem menor.

Mesmo com a relativa melhora da situação ao longo dos anos, as medidas tomadas até então não teriam sido eficazes com relação ao desemprego da população, de um lado devido à falta de "resistência econômica das regiões" e, de outro, "da ausência de adequada organização de medidas preventivas e de preparo de programas de emergência" (Dnocs, 1959, p. 9).

Sob esse ponto de vista, o artigo ressaltou a importância da abertura de vias de transporte, da realização de diversas obras nas áreas afetadas e da existência de um programa previamente elaborado. Para uma política eficiente, deveria haver "duas ordens e providências" distintas: as de emergência e as de caráter permanente. As de emergência consistiriam em fornecer empregos em obras realizadas pelo governo e também de iniciativa particular, "financiadas pelo poder público, quando necessário". As medidas de caráter permanente deveriam: 1) garantir a continuidade na produção, 2) racionalizar a produção agropecuária e industrial e 3) "conhecer e explorar novos recursos naturais".

No item intitulado "teatro da incidência" o artigo oferece uma reflexão sobre as diferentes delimitações do polígono das secas. A área reconhecida em Lei como sujeita às secas e que deveria ser objeto de políticas públicas estava circunscrita, até 1933, a parte dos territórios do Ceará, Paraíba e Rio Grande do Norte, excluídas, inclusive, as respectivas capitais. Raramente havia menção a Pernambuco ou Piauí. "O episódio calamitoso era designado vulgarmente pela expressão: sêcas do Ceará" (Dnocs, 1959, p.10).

Depois da inclusão do Art. 177 na Constituição de 1934, determinando uma 
porcentagem fixa a ser aplicada no combate aos efeitos das secas, o teatro da incidência foi progressivamente aumentando. A Lei 175, de 7 de janeiro de 1936, ampliou a área de aplicação do artigo constitucional e desenhou o primeiro "polígono das secas", com 1.150.662 quilômetros quadrados.

A Constituição de 1946 modificou a redação do artigo denominando o fenômeno de "seca do Nordeste", ampliando, assim, o escopo de aplicação dos recursos para toda a região. ${ }^{16} \mathrm{~A}$ área original do polígono foi ampliada ainda antes da promulgação da Carta Constitucional de 1946 através do Decreto-lei no 9.857 de 13 de setembro desse mesmo ano.

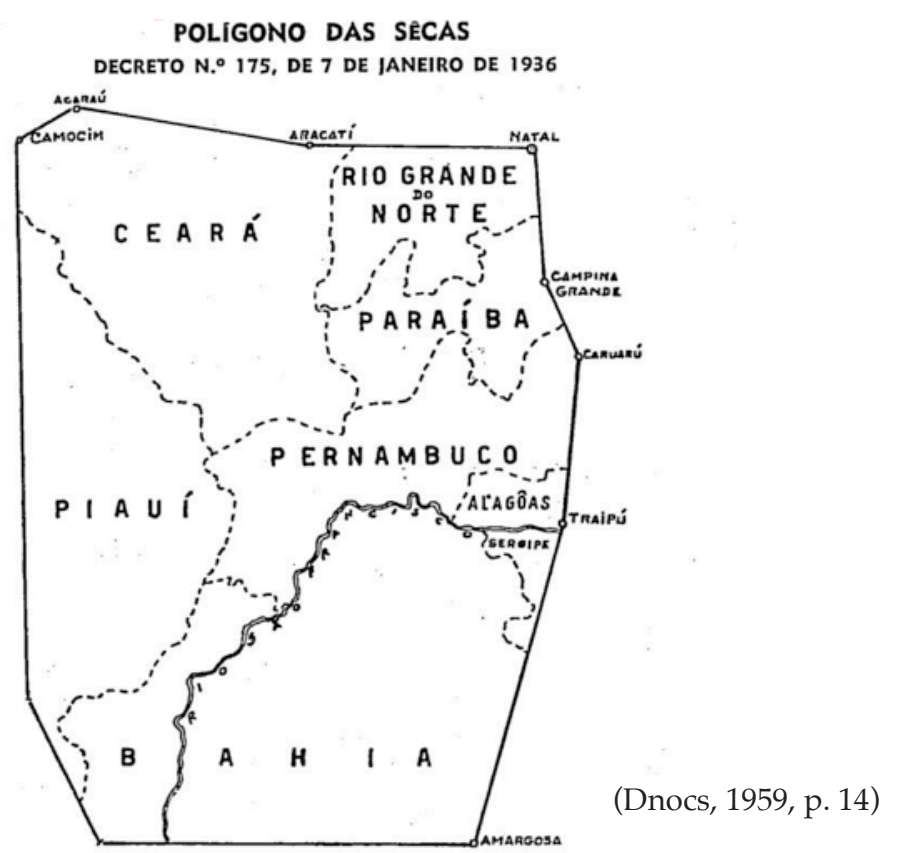

O Conselho apontou tendência dos legisladores em ampliar as áreas estendendo os benefícios "ao maior número de habitantes". Mesmo acreditando na boa intenção dos mesmos, o alargamento do polígono não seria a "expressão rigorosamente técnica do teatro do problema", representando, antes, uma delimitação de sentido político. Os critérios de inclusão e exclusão deveriam obedecer à classificação da área como pertencendo ou não ao semi-árido. $\mathrm{O}$ aumento segundo critérios não técnicos causava ainda a sobreposição com área da Comissão do Vale do São Francisco, que tinha quase metade da área incluída no polígono.

Mudando o critério de exclusão, o polígono poderia ser definido como "um 
arquipélago composto de grandes ilhas semi-áridas e de outras, também grandes, possuindo condições perfeitamente normais para a vida animal e vegetal" (Dnocs, 1959, p.15).

POLIGONO DAS SECAS

DECRETO N. 9.857 DE $13-9-1947$

DECRETO N.0 1.348 DE $10-2-1951$ (0)
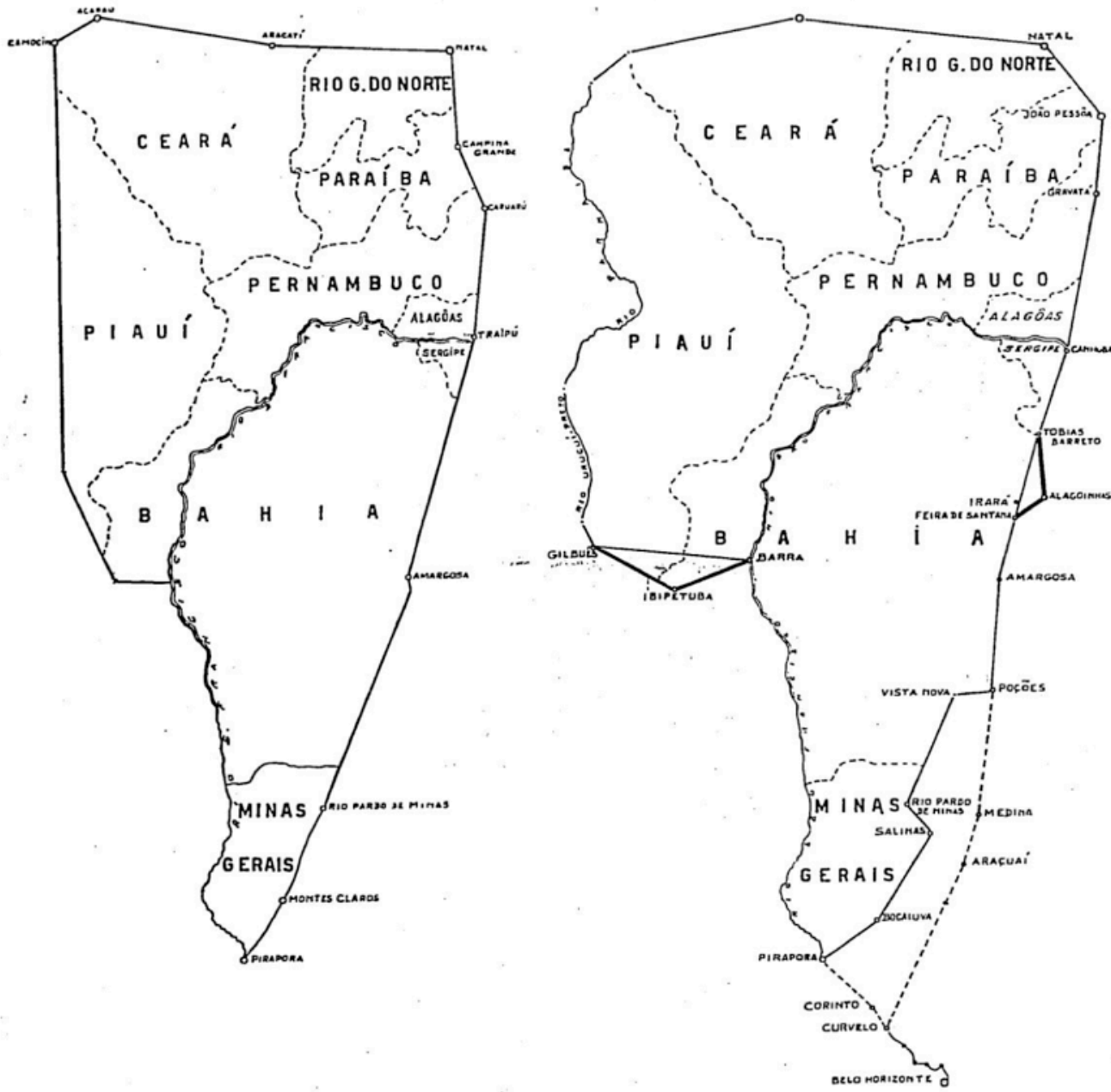

(Dnocs, 1959, p. 16)

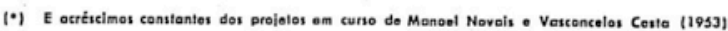

Considerando a elaboração de um plano de medidas permanentes de combate às secas, o Conselho propôs que os trabalhos de preparo da terra para agricultura, como terraplanagem, canais de irrigação e drenagem, deveriam fazer parte da legislação relativa ao tema garantindo a implantação de sistemas de exploração dos grandes açudes. Os laboratórios de estudos de solos, como o Instituto José Trindade em São Gonçalo, são vistos como de maior importância. 
Ainda sobre o período anterior, o Conselho registrou os erros administrativos no planejamento e execução dos projetos teriam levado um elevado número de açudes sem utilização nenhuma, apesar do dinheiro gasto. Dos 130 açudes públicos construídos até então, "91, com capacidade total de 232.000.000, foram entregues aos Estados e Municipalidades porque não se prestassem ao aproveitamento agrícola digno

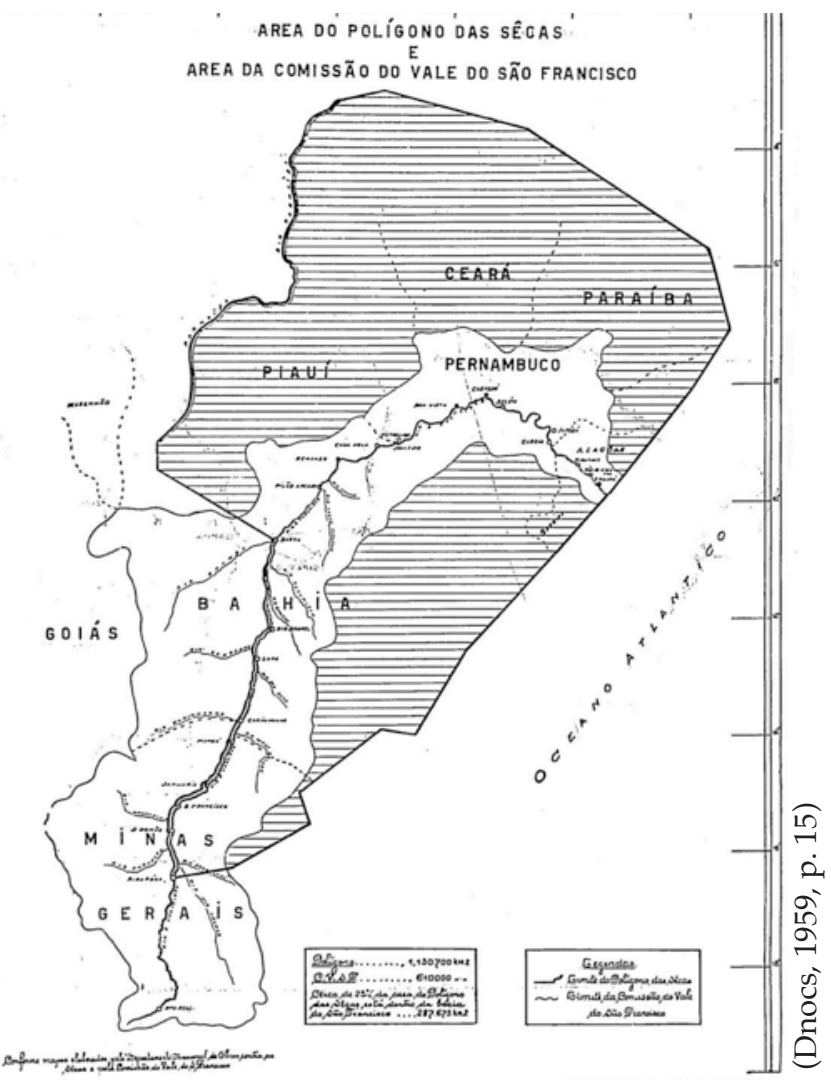
de nota". A área irrigada não seria maior que 8.000 ha, "dos quais 5.000 hectares beneficiados com as obras de represamento diretamente administrados pelo DNOCS" (Dnocs, 1959, pp. 30, 31, grifos no original). ${ }^{17}$

Os fatôres de retardamento são de três ordens:

a) carência de planos sob vários aspectos;

b) falha na execução;

c) interferência perturbadora de ordem política.

Dêles em conjunto advêm as seguintes consequências:

a) demora excessiva na execução das obras, que, além de outros prejuízos, encarece seu custo;

b) execução de obras mal projetadas;

c) interferência perturbadora de ordem política (Dnocs, 1959, p. 31).

Outra questão levantada é a centralização das obras por parte do Dnocs, que as executava por administração direta o que acabava por resultar na descontinuidade das ações, algo para o qual José Américo havia chamado atenção durante a seca de 1952 (Almeida, 1953). Ao insistir na pretensão de realizar as obras 
por meio de seus chefes de serviço, que raramente dispunham de dinheiro à disposição, ficava a administração refém dos fornecedores locais transformando as obras em um terrível sistema de exploração: "É, enfim, o sistema do 'vale', em que se paga à última hora, pelos piores processos com todos os inconvenientes daí resultantes" (Dnocs, 1959, p. 33).

O Conselho destacou ainda outras amarras administrativas como a quantidade de regras para os açudes em cooperação, problemas nas desapropriações e perda de funcionários qualificados do quadro pelos baixos salários pagos pelo órgão.

A política sugerida deveria seguir as seguintes diretrizes: 1) realização de obras de aproveitamento da água existente; 2) escalonamento dos projetos segundo a seguinte ordem de prioridade: lugares de maior densidade demográfica, açudes públicos com aproveitamento d'água, emprego de meios de captação e distribuição de água; 3) zoneamento da regiões segundo atividades; 4) continuidade dos estudos e pesquisas na região e, por fim, 5) constituição de um órgão superior "que tenha a seu cargo traçar o programa das obras, controlar a sua execução, propor medidas de emergência e permanentes, articular as atividades dos Ministérios e repartições federais, estaduais e municipais, e orientar a iniciativa particular" - ou seja, a Sudene (Dnocs, 1959, p. 41).

A criação da Sudene - e dos demais órgãos que passaram a atuar no Nordeste - foi recebida com ressalvas por alguns dirigentes e funcionários do Dnocs, uma vez que isso contribuiu para a diminuição de suas atribuições e também de sua autonomia. A história do Dnocs apresentada no site do órgão afirma que, de 1909 até por volta de 1959, o órgão foi praticamente "a única agência governamental federal executora de obras de engenharia na região".

[O Dnocs] Construiu açudes, estradas, pontes, portos, ferrovias, hospitais e campos de pouso, implantou redes de energia elétrica e telegráficas, usinas hidrelétricas e foi, até a criação da SUDENE, o responsável único pelo socorro às populações flageladas pelas cíclicas secas que assolam a 
região.

Chegou a se constituir na maior "empreiteira" da América Latina na época em que o Governo Federal construía, no Nordeste, suas obras por administração direta tendo marcado com a sua presença, praticamente, todo o solo nordestino.

Com a criação de órgãos especializados, o acervo de obras construídas pelo Departamento vinculado a ações "não hídricas", como rodovias, linhas de transmissão, ferrovias, portos, etc, foram àqueles transferidos. Posteriormente, transferiram-se aos Estados as redes de abastecimento urbano e à SUVALE, hoje CODEVASF, os Projetos públicos de Irrigação situados no vale do Rio São Francisco (<http: / / www.DNOCS.gov.br/php/ comunicacao / registros.php?f_registro=2\&>).

\section{O Dnocs pós golpe de 64: flagelado sai proprietário fica}

A publicação dos boletins do Dnocs sofreu uma nova interrupção em 1960. Os temas das publicações dos anos 1958-60 versavam sobre as potencialidades do Nordeste e sobre os estudos e projetos de desenvolvimento para a região. Essa nova interrupção do boletim do órgão iria durar até 1965. A partir de então, a publicação foi toda voltada para os projetos de irrigação, indicando a mudança de fato na orientação do órgão da acumulação de água para o beneficiamento das bacias dos açudes. Além dessa mudança, que já vinha se processando, o público alvo das políticas também se modificou. Ao invés de ações voltadas aos flagelados e retirantes, os beneficiários da nova política do Dnocs serão os "pequenos" proprietários das terras das bacias hidráulicas dos açudes públicos.

A apresentação ao relatório dos trabalhos realizados no ano de 1965 declarou que aquele havia sido o ano mais produtivo do Departamento. Entre as medidas positivas descritas, foi incluído um item sobre as novas normas e manuais de serviço que estavam sendo elaborados:

Procurando aperfeiçoar a rotina administrativa, um acôrdo foi levado a efeito com técnicos da Fundação Getúlio Vargas, a fim de que cinco Manuais 
de Serviço fossem elaborados, de modo a dar normas simplificadas e racionais ao andamento dos assuntos referentes ao Pessoal, Material, Contabilidade, Patrimônio e Tesouraria. Os manuais serão implantados em 1966. Esta medida é considerada de elevada importância para o bom andamento da rotina administrativa da Autarquia (Dnocs, 1966, p.6).

O relatório termina também eloquente e positivo, salientando que a repartição continuava a contribuir com uma "parcela ponderável" para o progresso da região Nordeste. Conforme o documento, um açude criava um núcleo de estabilidade social, um poço representava "uma mancha de vida num deserto", uma estrada, o "intercâmbio de riqueza"; a energia elétrica levava o conforto e estimulava a indústria; e o abastecimento d'água conduzia as localidades sertanejas "à civilização". As obras espalhadas pelo Dnocs nos "mais longínquos rincões" teriam até mesmo transformado os hábitos alimentares da população do interior.

Êsse nosso sentimento de dever cumprido, todavia, não deve exprimir a idéia de que para o D.N.O.C.S., uma missão terminou. Em absoluto. Consideramo-nos apenas chegados ao limiar de uma nova etapa.

Acreditamos que a região sêca do Nordeste, esta terra tão discutida, que mede uma vez e meia tôda a América Central Continental, populosa na mesma proporção, jamais, esta terra reuniu condições tão propícias ao seu soerguimento econômico (Dnocs, 1966).

Para o Dnocs essa era também uma nova era. O Departamento havia se tornado uma autarquia através da Lei no 4.229 de 01 de junho de 1963, que conferiu maior autonomia ao órgão, principalmente em relação ao uso e destinação de recursos. Essa Lei criou também o Fundo Nacional de Obras Contra as Secas (Art. 12), com o objetivo de custear as obras sob sua atribuição.

O Decreto 57.425 de 14 de dezembro de 1965 aprovou outro regimento e conferiu à autarquia um novo quadro de pessoal. Esse decreto transferiu ainda a sede do Dnocs para Fortaleza. Outra grande vitória, segundo relatório, foi a sanção da Lei 4.593, de 29 de dezembro de 1964, que disciplinava a desapropriação para as 
obras de combate às secas do Nordeste. Essa Lei definiu, entre outras coisas que:

Art. $1^{\circ}$ A União promoverá o aproveitamento intensivo das terras irrigadas e irrigáveis pelo Poder Público, nos Estados da Bahia, Sergipe, Minas Gerais, Alagoas, Pernambuco, Paraíba, Rio Grande do Norte, Ceará, Piauí e Maranhão, de acôrdo com os planos regionais de irrigação, elaborados pelos órgãos competentes.

(...)

Art. $4^{\circ}$ Para possibilitar a execução dos planos de irrigação, poderão ser efetuadas desapropriações por utilidade ou necessidade públicas, assim como por interêsse social.

$(\ldots)$

Art. $6^{\circ}$ Nas desapropriações previstas nesta lei (art. $4^{\circ}$ ), serão excluídas indenização às valorizações decorrentes de obras hidráulicas ou complementares construídas pelo Poder Público ou por êle projetadas (Lei $4.593 / 1964)$.

Depois de desapropriadas, as terras seriam divididas em lotes e posteriormente distribuídos a agricultores da região, que pagariam aluguel, além de outras taxas fixadas pelo órgão executor. A propriedade do lote agrícola pelo "regante" seria "resolúvel [revogável] e indivisível".

Em 1965, foi publicada ainda uma edição comemorativa dos 56 anos de existência do órgão nacional de combate às secas intitulado 56 anos de luta contra as sêcas: Realizações e Perspectivas. O objetivo da publicação seria tornar conhecido o "principal, senão único, órgão do governo com atuação na área do Polígono das secas", ao mesmo tempo que registrar as obras iniciadas ou concluídas no primeiro ano do "Governo Revolucionário". A publicação destacou que,

A expansão do Polígono das Sêcas, oficialmente admitida com a Lei $\mathrm{n}^{\circ}$ 1.348 , de 10.02 .51 (...) e a complexa burocracia dos órgão subordinados ao MVOP, provocaram a adoção de uma política descentralizada, para atender a evolução da atual dinâmica administrativa. A Lei $\mathrm{n}^{\circ} 4.229$, de $1^{\circ}$ de junho de 1963, satisfez a êsse imperativo, reestruturando o DNOCS e transformando-o em entidade autárquica com autonomia administrativa, financeira e técnica. 
Hoje, o DNOCS, dentro da realidade político-administrativa do país, gerada pela Revolução de 31 de março de 1964, há prosseguido a árdua tarefa de prevenir e atenuar os efeitos das irregularidades pluviais com importantes realizações em tôda a vasta região do Polígono das Sêcas, que abrange uma área de quase um milhão de quilômetros quadrados, com uma população superior a uma dezena de milhões de habitantes (Dnocs, 1965a, p. 12).

Apesar da mudança no foco das políticas da autarquia, o Dnocs continuou a preparar os planos de emergência para as secas, que, segundo determinação da Sudene deveriam ser elaborados antes de ser declarada a seca - e não depois como aconteceu até o final da década de 1950.

A apostila da Administração Central do Dnocs contendo as normas para o Plano de Emergência do ano de 1965 mostra a nova realidade do órgão instituída com a criação da Sudene. O primeiro ponto levantado pelo manual foi justamente a necessidade de se fazer "entendimentos" com os outros órgãos federais incluídos na área do Polígono das secas, a fim de dividir responsabilidades caso fosse oficialmente declarado o estado de emergência, conforme o estabelecido na lei 3.692 de 15 de dezembro de 1959, que instituiu a Sudene.

A área de cada estado deveria ser dividida em zonas de influências dos órgãos, conforme determinação do "grupo coordenador" sob responsabilidade da Sudene. Cada zona seria subdividida "em tantas residências quantas forem as obras e serviços normais ou abertos por ocasião de EMERGÊNCIA dentro de um determinado número de pessoas" (Dnocs, 1956b, p.1). A sede das Residências deveria ainda ser localizada fora das zonas urbanas, "a fim de evitar perturbações na vida normal das comunidades".

O plano previa para cada residência uma quantidade aproximada de 3.000 pessoas com, no mínimo, 6 divisões de 20 turmas de 25 pessoas. Cada turma seria composta de: 1 feitor, 25 flagelados, 1 Barraqueira, 1 Aguador (quanto necessário), além dos servidores técnico e administrativos.

O manual revela também uma maior burocratização das normas e a 
instituição de inúmeras formas de controle da mão de obra que continuava a ser denominada de flagelada. A admissão e dispensa de pessoal administrativo, "quer funcionário ou flagelado", estaria a cargo somente dos Residentes ou Chefes de Zonas, "bem como a aplicação de penalidades".

$\mathrm{O}$ alistamento deveria seguir o seguinte ritual: o alistado deveria ter "o seu dedo polegar imerso em solução indelével, para evitar duplicidade de alistamento"; uma vez alistado, o flagelado receberia uma caderneta para fornecimento de gêneros e uma chapa ou medalha de alumínio numerada. Essas chapas seriam cromadas numa corrente e presas "ao pescoço do flagelado de modo que não saiam pela cabeça e servirão de identificação permanente durante o flagelo" (Dnocs, 1965b, p. 6).

O alistado teria ainda uma ficha numerada contendo seu nome, residência, idade, zona e número da medalha, e só poderia ser identificado através, de pelo menos, dois dos três documentos: Caderneta - Ficha - Medalha

Os feitores seriam escolhidos entre "os flagelados mais inteligentes e letrados" (Dnocs, 1965b, p. 6). Uma vez de posse dos documentos de identificação, o flagelado deveria dirigir-se ao posto médico ou ambulatório para vacinação.

O trabalho de menores, assunto que causava polêmica em cada uma das secas, deveria se dar da seguinte maneira:

Tendo em vista os dispositivos legais vigentes, não será permitido o alistamento de menores de 16 anos; todavia, deve a Diretoria-Geral conseguir do Juiz de Menores a permissão, em caso excepcional de calamidade pública, de alistar menores de 15 a 18 anos. Nesse caso será exigida a certidão de idade ou batistério. Inválidos e velhos deverão submeter-se prèviamente a inspeção médica a fim de serem conduzidos ao destino competente (Dnocs, 1965b, p. 6).

As tarefas do serviço seriam distribuídas a cada dia de trabalho ou de maneira a garantir a permanência do pessoal até pelo menos o primeiro expediente de sexta feira. A folga aos domingos seria concedida apenas se o trabalhador batesse o ponto durante todos os dias da semana. Em caso de doença comum, seria concedido "meio ponto no primeiro dia de afastamento, ponto integral no dia seguinte e continuando 
doente, atestado pelo médico, receberá nos dias subsequentes 5 horas de trabalho" (Dnocs, 1965b, p. 10).

Apesar das muitas crítica recebidas, o sistema de fornecimento de alimentos continuava a ser, segundo o manual, o de "armazém reembolsável". O pagamento dos trabalhadores da emergência deveria ser feito em espécie e mediante as seguintes regras:

O fornecimento máximo em gêneros poderá ser até $80 \%$ dos vencimentos de cada empregado restando o saldo para liquidação em espécie no fim de cada mês, medida esta que inclusive permite a garantia quanto ao problema de possíveis danos praticados contra o Patrimônio da Repartição.

Os pagamentos em espécie serão de responsabilidade dos Agentes pagadores, os quais ficam sujeitos a Legislação em vigor a respeito.

Quanto ao pagamento de gêneros, a responsabilidade inside sôbre os Gerentes dos Armazéns Reembolsáveis.

Os Agentes Pagadores serão nomeados pelo Sr. Diretor Geral do DNOCS, por indicação dos chefes dos setores.

Os demais pagamentos de despesas de emergência obedecerão a rotina dêsse Departamento (Dnocs, 1965b, p.19)

Com relação ao $2^{\circ}$ Distrito de Obras com sede em João Pessoa, foi previsto pelo plano, além das obras públicas, a construção de açudes em cooperação para o "aproveitamento de mão de obra operária nos locais das próprias fazendas". Este plano "permitiria criar mão de obras para 9.600 operários, atendendo, por conseguinte 48.000 flagelados" (Dnocs, 1965b, p. 45).

Ainda em agosto de 1965, a Lei $\mathrm{n}^{\circ} 4.763$ alterou mais uma vez o polígono, aumentando a área para englobar também o município baiano de Vitória da Conquista.

A relativa proeminência gozada pela sede do órgão em João Pessoa iria mudar em 1967, quando uma reforma administrativa criou a $3^{\text {a }}$ Diretoria Regional com sede em Recife, abrangendo as áreas dos estados de Pernambuco, Paraíba, Rio Grande do Norte e Alagoas, mudança que subordinou o Dnocs da Paraíba ao de Pernambuco. 
Embora tenha significado uma perda do status do Dnocs na Paraíba, essa mudança foi apontada como positiva no relatório anual da autarquia. Na introdução deste, o Diretor Geral do Dnocs Eng ${ }^{\circ}$ Ary de Pinha enfatizou mais uma vez a mudança de perspectiva do órgão, que se afastava da chamada "solução hidráulica da açudagem" que marcara a sua "longa e operosa" existência. Iniciando, em 1967, uma nova política de "aproveitamento social e econômico de sua infraestrutura hidráulica", através na ênfase nos projetos de irrigação (Dnocs, 1968, p.1).

Embora não tenha sido elencado entre os acontecimentos do ano, deve-se registrar que a Constituição de 1967 revogou o principio da aplicação de 3\% da renda tributária da União em planos de defesa contra as secas. Ao contrário, a Constituição de 67 inseriu dispositivo contrário à fixação de receitas, em seu artigo 65, § 3, "segundo o qual, nenhum tributo terá a sua arrecadação vinculada a determinado órgão, fundo ou despesa" (Dnocs, 1971, p. 54).

Para o ano de 1968, foi destacado o início da produção de estudos para avaliar as potencialidades das bacias hidráulicas dos açudes públicos do Dnocs. Esses estudos passaram a ser realizados por equipes técnicas do órgão ou ainda por "equipes especializadas contratadas através de consórcios de firmas nacionais e internacionais". Foram elaborados, no período, 2 novos projetos: "Estreito (MG) e Sumé (PB)" e instalados escritórios nos projetos de 5 estudos feitos por consórcio. Sob a responsabilidade na $3^{\mathrm{a}}$ Diretoria Regional, estava o estudo do perímetro irrigado do açude Estevam Marinho em Coremas (Dnocs, 1969, p. 6).

O número de projetos de irrigação e consórcios citados aumentou nos relatórios subsequentes. Para o ano de 1972, foram citados o assentamento de 400 colonos em parcelas irrigadas e a instalação de 10 novas gerências locais. Ao todo, 39 projetos estavam em curso nesse ano.

No artigo "Irrigation in the Brazilian Northeast: anti-drought or anti peasant?", o antropólogo Anthony Hall discutiu os projetos de irrigação implementados pelo Dnocs na Paraíba e no Ceará, durante a década de 1970. O autor apontou que, apesar de a Sudene ter mudado a diretriz das políticas de combate aos 
efeitos das secas da açudagem para a irrigação, apenas em 1971 foi publicado o primeiro plano sistemático de irrigação, elaborado pelo Grupo Executivo de Irrigação para o Desenvolvimento (Geida) em conjunto com uma firma israelense de consultoria chamada Tahal.

The proposals were highly ambitious and envisaged the irrigation of 195,000 hectares of land in the Northeast by 1980, requiring a total investment of Cr\$ 188.7 million or US 195 million at 1971 values. Under the plan DNOCS was responsible for 36 projects covering 78.000 hectares. The Companhia do Desenvolvimento do Vale do São Francisco (CODEVASF) would irrigate 112,000 hectares in seventeen schemes in the São Francisco Valley, the largest in the Northeast. Not content with these targets, DNOCS set itself the even more ambitious goals of irrigating a total of 100,000 hectares and settling 22,000 families on its projects by the end of the 1970s (Hall, 1981, p. 158).

Segundo avaliação de Hall, tais objetivos estavam longe de serem alcançados. Na verdade, a irrigação terminou sendo tão inoperante ao combate aos efeitos das secas como haviam sido os açudes. Até 1975, apenas $4 \%$ do número de famílias assistidas previsto para 1980 tinha sido alcançado e apenas 900 famílias trabalhavam em 12 projetos.

Ao contrário de criar mais empregos no campo, ressalta Hall, os projetos de irrigação terminaram por retirar da terra um número maior de agricultores do que aquele que conseguiam assentar. Os vales selecionados para implantação para os projetos eram densamente povoados e a propriedade da terra estava fracionada em pequenas propriedades. Os custos de expropriação dessas áreas não foram planejados nos projetos o que levou a consequências desastrosas nos casos analisados por Hall.

The high social costs of irrigating heavily populated valley lands must be taken into account by any development strategy worthy the name; but in the feasibility studies used as the basis for irrigation in the Northeast they are conspicuous if only by the almost total absence of any reference to the 
problem. Whether by design or out of ignorance, dislocation is a hidden cost in the PPI plans for Brazil. Three case-studies illustrate the magnitude of the problem. On DNOCS's largest project, Morada Nova in the sate of Ceará, the final total 3.000 people to be settled represents one-sixth of the original population of the area, some 18.000. On the second largest scheme, São Gonçalo, in the state of Paraíba, 3,000 colonists will replace the former population of 7,000. Even on the smaller projects such as Sumé, Paraíba, at least 76 families were forced to move to make way for the current total of 26 irrigation farms (Hall, 1981, p. 160).

Nos casos analisados por Hall, os posseiros, que representavam grande parte das famílias deslocadas, não receberam qualquer compensação monetária pela perda das terras que ocupavam, assim como ocorrera em Coremas há mais duas décadas. Além disso, os agricultores beneficiados eram justamente os que já estavam em uma condição melhor. Apenas 5\% dos agricultores dos projetos estudados haviam sido afetados severamente por alguma seca, levando o autor a perguntar se esses projetos seriam de combate às secas ou aos camponeses (anti-drought or anti peasant?). ${ }^{18}$

A tese do Engenheiro Luis Saboya de Albuquerque, chefe do Departamento de Fomento e Produção do Dnocs, Desenvolvimento Econômico e social dos vales beneficiados por obras do DNOCS, publicada em março de 1964, revela de maneira didática quem deveriam ser os beneficiários da nova política do órgão.

Diante do desafio de beneficiar todos os vales com açudes do Dnocs, Albuquerque sugeriu que tais iniciativas deveriam ser primeiramente de ordem mista, "estabelecendo-se a cooperação entre a União e a iniciativa privada", conforme estipulado pelo Art. 2, letra s, da Lei $\mathrm{n}^{\mathrm{o}} 4.229$ de 1963, que transformou o órgão em autarquia (Dnocs, 1964, p.3). A organização dos beneficiários seria feita em sociedades de economia mista denominados centros rurais. Segundo o autor,

Os CENTROS RURAIS teriam objetivos fundamentalmente econômicos, visando lucros comerciais e industriais, dos quais participariam os associados na proporção de seus capitais e da contribuição de sua produção (Dnocs, 1964,p.4, grifou-se). 
O autor se posiciona contrariamente à organização em cooperativas, uma vez que estas eliminariam os lucros e não garantiria o controle total dos vales pelo Dnocs. No caso dos centros rurais, o controle seria garantido pela determinação de que o órgão teria $51 \%$ do capital subscrito. Além disso, a exclusividade no comando das atividades seria garantida da seguinte maneira:

Nas áreas cobertas pelos canais, o contrôle se exerce através do fornecimento da água. Entretanto, nos cursos dos rios perenizados, as águas se tornam de dominio público, de uso comum, perdendo assim, o DNOCS o contrôle que lhe caberia exercer na promoção do desenvolvimento e aproveitamento das obras.

Nêste caso, resta ao Departamento exercer medidas tendentes a manter sua exclusividade, a qual poderá ser exercida através da Eletrificação e Assistência técnica (Dnocs, 1964, p. 15).

Apesar da crítica ao modelo cooperativista apresentada pelo Diretor de Fomento e Produção, os beneficiários dos vales irrigados foram organizados em cooperativas nos projetos desenvolvidos pelo Dnocs. Como chama atenção Hall (1981), entretanto, o significado do termo cooperativa não era definido claramente nas publicações oficiais, sendo utilizado como meio de incutir um espírito geral de cooperação entre os irrigantes.

Além disso, as cooperativas deveriam guiar-se por um estatuto elaborado pelo Dnocs, garantindo a participação do órgão em cada passo destas - "Lip service is paid to-operativism by DNOCS, but the official paternalism is the order of the day", como ressaltou Hall.

Segundo o Art. 5 do estatuto da "sociedade cooperativa mista", os associados tinham que entrar com um "capital social" que não deveria ser inferior ao valor de um mil cruzeiros novos (Dnocs, 1969, p.174). Não havia muita diferença entre esse modelo e o sugerido pelo engenheiro Luis Saboya Albuquerque, sendo apenas apensada a palavra cooperativa. Além do capital inicial que configurava um impeditivo aos agricultores mais pobres, as grandes perdas registradas na produção 
dessas cooperativas também dificultavam a permanência desses agricultores.

Outros programas de fomento à agricultura, como o Programa de Redistribuição de Terras e de Estímulo à Agro-indústria do Norte e do Nordeste (Proterra), instituído pelo Decreto-Lei n 1.179 de 6 de julho de 1971, também terminaram por beneficiar os agricultores em melhor situação sócio econômica, uma vez que era necessário que se dessem garantias ao banco para obter financiamento. Apesar de mencionar em seu título a "redistribuição" de terras, os trabalhadores sem terra estavam excluídos do programa, já que não tinham como apresentar as garantias para o financiamento (Hall, 1981, p. 167).

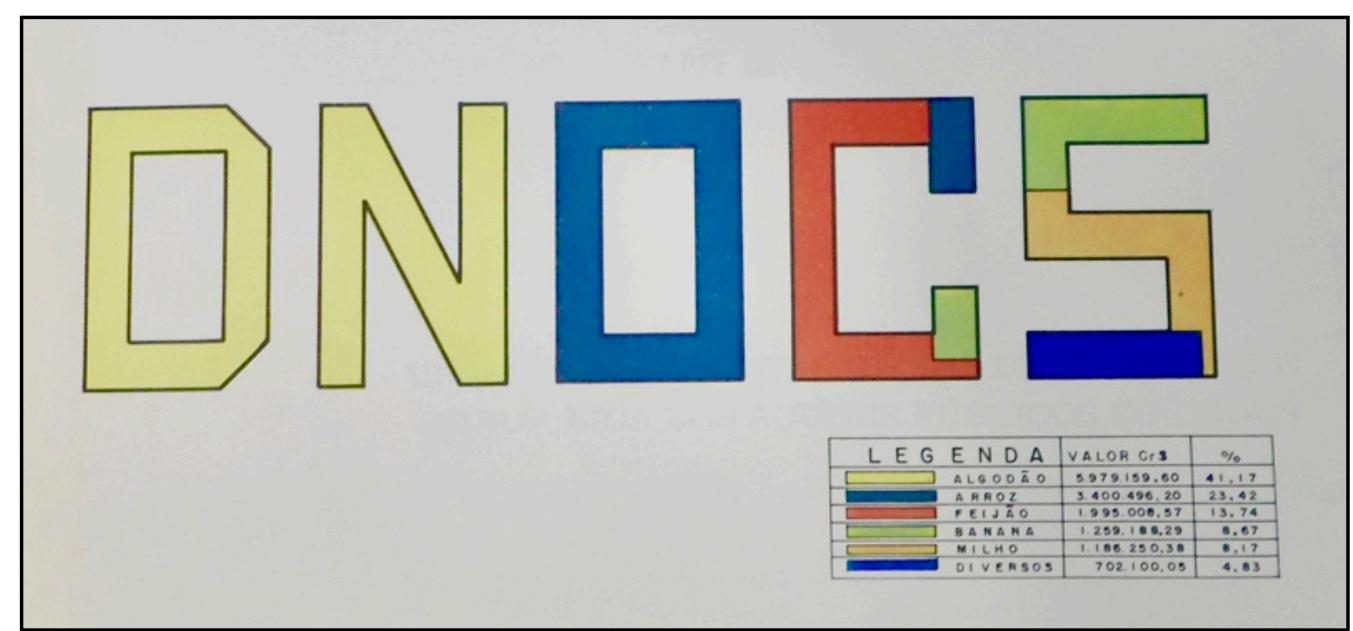

Gráfico intitulado "Valor da produção agrícola comercializada, por cultura, dos perímetros irrigados do Dnocs, $1^{\circ}$ semestre de 1976" (Dnocs, 1976, gráfico 7).

\section{Frentes de Serviço}

A utilização da mão de obra dos trabalhadores afetados pelas secas em obras públicas foi uma política instituída ainda no final do século XIX e tinha como uma de suas justificativas a substituição da esmola - que humilhava e escravizava a população segundo a elite político científica da época - pelo trabalho. Era a "esmola remunerada" segundo conceito oferecido pelo Senador Pompeu (Santos, 1878).

De acordo com dados oficiais, em 1942, o Governo empregou 35.000 trabalhadores deslocados; em 1951 cerca de 65.000, em 1952 cerca de 49.000 e, em 
1953, cerca de 119.000. Em novembro de 1958, os órgãos governamentais empregaram 536.000 trabalhadores, "que, com suas famílias, representavam 13\% da população do Nordeste" (Dnocs, s/d, p. 20).

Apesar da absorção da mão de obra deslocada ser considerado um dos problemas mais sérios a serem resolvidos durante as secas, apenas em 1970 foi realizado o primeiro estudo oficial sistemático sobre os trabalhadores das frentes de serviço, ou emergências como são mais conhecidas.

O propósito central da publicação Frentes de Serviço: Estudo sócio econômico da população atingida pela sêca de 1970 (Dnocs, 1971), segundo explicação contida na apresentação da mesma, era o de apreender de forma sumária e objetiva a situação das áreas secas através da análise da condição sócio econômica dos alistados. Tendo como unidade social atingida a família, o estudo buscava ainda uma "análise comparativa da evolução da situação do elemento humano antes da crise e do seu comportamento quando atingido pela sêca, como alistado."

O referencial inicial da pesquisa levou em consideração três grupos de aspectos: 1) o ponto de vista tradicional dos estudos sobre a seca; 2) a evolução oficial dos órgãos e 3) "a situação específica do homem e da família do alistado nas Frentes de Serviço".

No início da pesquisa, havia 83 frentes de serviço com um total de 391.088 alistados. Foi feito o sistema de amostragem por conglomerado (frente de serviço), selecionadas $10 \%$ das frentes e aplicados 1.500 questionários. Pouco depois do início da pesquisa, o número de alistados aumentou para 1.650.

Os questionários direcionados ao alistados foram compostos de 33 perguntas divididas em 3 grandes conjuntos, a saber: 1) a situação do alistados, com perguntas sobre características pessoais como o nível de politização, seu associativismo, e o grau de participação no processo produtivo; 2) a situação da famílias, focando a organização da estrutura familiar "de modo a poder-se aquilatar o nível de aspiração do homem alistado"; e 3) as condições da Frente de Serviço sob o ponto de vista do 
alistado, seus planos futuros e sugestões para amenizar sua situação em face da seca.

Esses questionários foram complementados com entrevistas feitas com os administradores e com as famílias dos alistados que se encontravam nas imediações. No inquérito das chefias das frentes, foram enviado questionários a 126 frentes em funcionamento em dezembro de 1970, dos quais 86 questionários foram preenchidos $(68,2 \%)$. Dezesseis dessas frentes eram na Paraíba, duas administradas pelo Dnocs, nove pelo Departamento de Estrada e Rodagem da Paraíba (DER) e cinco pelo Batalhão de Engenharia do Exército..

Foi elaborado ainda um roteiro para a entrevista de proprietários rurais e enviado inquérito aos prefeitos de 120 municípios em cujas cidades "foram detectados problemas", como saques, problemas de alistamento e afluência de "flagelados" em grande número. Segundo o relatório, os inquéritos com os prefeitos e proprietários rurais não teriam sido muito produtivos por tratar-se de um período de troca de mandatos. Com relação aos proprietários rurais, grande parte destes não se encontrava em suas terras durante a seca. Sobre as respostas dos trabalhadores, foi anotado uma "retração" dos alistados nas respostas que pudessem de alguma maneira encetar críticas ao "novo patrão" (no caso, a direção das frentes).

Com relação às políticas às políticas de combate às secas empreendidas até então, a publicação ofereceu o seguinte diagnóstico:

As consequências das crises climáticas são as econômicas, as sociais e as políticas, com intensidade variável no tempo e no espaço. As econômicas são o fracasso total ou parcial das colheitas, a diminuição ou secagem dos pastos, perdas de pêso, de produção e até mortandade dos gados, redução do poder aquisitivo do povo com restrição nas transações comerciais e o encarecimento dos gêneros alimentícios. As sociais se caracterizam pelo desemprêgo de mão-de-obra, movimentação e êxodo das vítimas com complicações nos transportes, disseminação de doenças nas aglomerações de flagelados, atritos pessoais, desagregação de famílias e aumento no número de menores abandonados. As consequências políticas, no passado, foram: 
interrupção dos programas anuais de trabalho dos órgãos responsáveis, intervenções dos chefes locais nos serviços, atrasos nas providências administrativas, início de serviços sem os estudos adequados e dificuldades no fornecimento de alimento (Dnocs, 1971, p. 43).

O período no qual foi aplicado o inquérito coincidiu com a frequência máxima das frentes e os estados que mais concentraram flagelados foram Ceará, Rio Grande do Norte, Paraíba e Pernambuco, representando 90,3\% do total socorrido pelo Plano da Sudene. Na análise dos dados das 126 frentes selecionadas, constatou-se que 18 delas contaram com 203.616 alistados, representando 52,1\% do total de alistados nas Frentes. Apenas três das localidades com maior concentração tinham açudes considerados de grande capacidade.

Na análise dos questionários preenchidos pelos chefes das Frentes estudadas, a migração figurava entre a maior causa de afastamento dos trabalhadores das frentes.

O deslocamento das famílias atingidas, ainda prevalece entre as mais importantes causas do afastamento do alistado, indicadas pelas chefias das Frentes de Serviço. Confirma-se mais adiante, com a análise da situação do alistado, que as migrações internas e para fora do Polígono das Sêcas, continuem, ainda, como uma das consequências marcantes da sêca no NE, não obstante a própria Política de Emergência tenha por objetivo evitar o deslocamento dos flagelados (Dnocs, 1971, p. 76, grifos no original).

Entre os problemas sociais indicados pelas chefias 32,1\% correspondia ao item "salário pequeno". Chamou atenção dos pesquisadores que 14,1\% das respostas correspondiam ao item "nenhum problema", o que poderia revelar uma omissão deliberada ou ainda uma "completa incapacidade de avaliação dos problemas humanos que, direta ou indiretamente, os envolveram nas chefias das Frentes de Serviço", indicando a falta de preparo dos chefes (Dnocs, 1971, p.80).

Os pesquisadores chamaram atenção para o fim das hierarquias encontradas antes das secas durante as frentes de serviço, que puseram em condições iguais 
diferentes estratos e gerações de trabalhadores. Assim como já havia anotado José Américo de Almeida, a seca era niveladora. Entretanto, dessa hierarquia desfeita estavam ausentes os proprietários mais remediados (médios e grandes).

Em virtude das condições de trabalho, verificou-se o nivelamento entre pais e filhos; entre agregados e pequenos proprietários; entre barraqueira e os demais alistados; entre maiores e menores; entre sadios e enfêrmos; entre velhos inválidos e jovens. A hierarquia social que porventura tenha resistido ao impacto da situação de miséria da família rural dever ter encontrado nas Frentes de Serviço o seu derradeiro estágio (Dnocs, 1971, p. $81)$.

A alimentação insuficiente, o "primitivismo" do alojamento, o abastecimento precário de água e a distância com que foram colocadas as turmas face ao desenvolvimento das estradas foram os fatores que mais contribuíram para a ocorrência de atritos entre a administração e alistados. O problema apontado como sendo "mais cruciante" para os alistados foi o da espera pelo alistamento, uma vez que a demanda era maior que a oferta em grande parte das frentes.

Um dos itens sobre os problemas encontrados nas Frentes dizia respeito à "Pressão social nas áreas atingidas". Entre os fatores de pressão no período da seca estavam a presença de um "excesso de flagelados" nas sedes das Frentes por ocasião do alistamento e os saques e os assaltos aos transportes, principalmente trens.

Mesmo com essas pressões, não foi anotada qualquer referência a ações de desordem nos 86 questionários recebidos das chefias. Também não houve nenhuma ocorrência anotada pela equipe que aplicou os questionários, mesmo quando aconteceram problemas de abastecimento. As próprias chefias se declararam surpresas com a passividade com que se aguardava o alistamento, mesmo estando os trabalhadores sem se alimentar e acampados com a família. Como ilustrou o depoimento do chefe da Frente Paulistana, no Piauí: "Quase não tenho comentários a tecer, pois o trabalho sempre se promoveu com harmonia, tendo em vista o estado premente de cada trabalhador, os quais se apresentavam famintos, pacatos e 
resignados" (Dnocs, 1971, p.88, grifos no original).

Segundo Lara Castro (Ferreira, 2009, 2011), entretanto, os trabalhadores não eram tão passivos como relatados nas publicações do Dnocs, revoltando-se através de saques, invasões às obras, desordens nas ruas e ameaças diversas. Conscientes do medo que provocavam, os cassacos conseguiram muitas vezes melhorar a situação a que estavam submetidos. A publicação sobre as Frentes deixa isso claro ao reproduzir manchetes de jornais sobre os saques e outros distúrbios.

As chefias foram também solicitadas a destacar os pontos positivos e negativos das Frentes. O chefe da Frente de São Mamede, em Pernambuco, fez a seguinte anotação:

POSITIVOS: Evitar que o homem morra devido à fome (embora não evite a fome).

NEGATIVOS: 1- Abandono das terras; 2- Expor operários à epidemia em geral; 3- Contaminação generalizada de doenças; 4- Separação entre membros de famílias; 5- Prostituição devido à ingenuidade e ao convívio no campo; 6Exploração de comerciantes e proprietários em geral; 7-Despesas excessivas da SUDENE em aquisições de carros e suas manutenções, bem como administração; 8-Falta de interêsse dos flagelados pelos serviços (não the trazem benefícios diretos), havendo pouco aproveitamento com verbas aplicada; 9 - Expor flagelados a brigas, furtos e morte entre êles próprios; 10Criação de ambiente vicioso entre pessoas de diversa formação moral, sem condições de contrôle e correção (Dnocs, 1971, p. 97, grifos no original).

Pouco havia mudado nas avaliações oferecidas pelos administradores das emergências desde a década de 1930, a maioria dos alistados ainda eram os moradores das fazendas, as condições a que ficavam submetidos nas frentes permaneciam precárias e seu trabalho pouco produtivo, apesar das grandes somas gastas nestes esquemas. Segundo o Relatório do Departamento de Estradas e Rodagem (DER) do Estado da Paraíba citado pelo estudo:

(...) o homem que deixa o seu lar e procura alistamento numa frente de emergência é, sem sombra de dúvidas, um necessitado. Pelas nossas 
observações, cêrca de 15\% dos alistados procedem da zona urbana, dos quais $9 \%$ são desempregados, sem profissão, e 6\% são pequenos comerciantes ou artesãos. Parte dêsse pequeno percentual procura alistamento numa frente de trabalho, na ilusão de que irá receber pagamento sem executar nenhum trabalho, e geralmente criam nas turmas de que fazem parte problemas sociais para dificultar a administração. Os $85 \%$ restantes procedem da zona rural e são compostos de pequenos proprietários de terra (cêrca de 15\%), e os demais moradores de favor (cêrca de 70\%). Nem os primeiros, como os segundos, têm condições de suportar a estiagem sem a ajuda do Govêrno, pois thes falta garantia de sobrevivência. São em geral cumpridores do dever e têm facilidade para executar serviços de construção de estradas. São afeitos ao sofrimento e não escondem o prazer de viver, mesmo que em um barraco coberto com palhas (Dnocs, 1971, p.100, grifou-se).

Os questionários realizados com os alistados foram analisados no quarto capítulo. Com relação ao grau de analfabetismo, $75 \%$ dos entrevistados era analfabeto, dado influenciou diretamente o gráfico sobre a participação dos trabalhadores nas últimas eleições: $61,5 \%$ dos alistados não havia votado, ou por que era analfabeto, ou por que não tinha atingido a idade suficiente. Entre aqueles que votaram, a pesquisa constatou que grande parte havia atrelado seu voto ao de seu patrão.

A tabulação dos dados referentes à participação dos trabalhadores em sindicatos, cooperativas ou associações de classe, causou estranheza aos pesquisadores devido os baixos resultados encontrados. 92,3\% dos entrevistados declarou não participar de nenhum tipo de associação e apenas 5,8\% afirmou participar de sindicato.

O comportamento do homem do campo (alistado) em relação à vida associativa é de total omissão, a julgar pelos dados obtidos. Não parece ter grande significação para a maioria a organização sindical, a cooperativa ou a associação de classe. Depara-se o analista com duas opções: ou o homem do campo encontra-se completamente afastado da vida associativa ou, sabedor da pouca aceitação dos patrões quanto às formas de organização dos 
assalariados, meeiros e agregados, procura manter-se reservado e até mesmo 'desentendido' do assunto (Dnocs 1971, p. 106).

Além da questão dos patrões, certamente o fato de o país estar sob a vigência de um governo ditatorial influenciou a resposta dos trabalhadores o que, entretanto, não foi registrado pela publicação - provavelmente pelo mesmo motivo.

A grande maioria dos alistados (90\%) estava ligado a atividades relacionadas à agricultura, justamente o setor mais afetado pela seca. Parte destes (15\%) afirmaram não ter renda alguma dedicando-se às culturas de subsistência e um elevado número de trabalhadores não tinha a menor idéia de sua renda anual. ${ }^{19}$ Apenas 10,8\% dos entrevistados declarou receber vantagens "consistindo em cereais, sementes, refeições, etc., o que transformando em cruzeiros seria, em média, um valor máximo de Cr\$ 100,00".

O gráfico da distribuição dos alistados de acordo com o tamanho da propriedade em que trabalhavam apontou que 63,0\% destes trabalhavam em propriedades com até 100ha. Nas pequenas propriedades, prevalecia a agricultura de subsistência e nas médias e grandes, o algodão.

Foi incluída na pesquisa uma pergunta sobre a atitude do patrão perante a seca, revelando que 64,05\% destes permaneceram nas fazenda depois de declarada a seca. 31,05 já não moravam na propriedade antes da seca. Grande parte das terras era explorada no regime de parceria. Embora não seja especificado em que consistia o regime de parceria, a leitura da pesquisa leva a crer que se tratam dos moradores das fazendas, ou "moradores de favor" segundo conceituação do chefe do DER-PB.

Foram também visitadas 8 fazendas cuja renda prioritária provinha do gado e algodão em consórcio. Todas as fazendas visitadas tinham açude mas nenhuma com assistência técnica. A seca havia causado perda de mão de obra em quatro das propriedades "sendo que 38 famílias de parceiros, perfazendo um total de 232 pessoas, deixaram as fazendas em busca das frentes de serviço" (Dnocs, 1971, p.119).

A segunda seção do quarto capítulo foi denominada "Da Família". Esta 
encontra-se dividida em sete itens: 1) estrutura da família; 2) renda familiar; 3) alimentação; 4) habitação; 5) educação dos filhos; 6) emigração e 7) situação da família atingida pela seca.

Além dos dados coletados através dos questionários, foram feitas "observações 'in loco'" e realizada entrevistas informais com 15 famílias localizadas nas Frentes de Valença, no Piauí; Tamboril, Iracema e Sobral, no Ceará; e Itaporanga, na Paraíba.

A composição etária das famílias dos alistados mostrou uma maior prevalência de jovens menores de 18 anos (53\%), o que, segundo os pesquisadores, influenciava na presença expressiva de menores alistados.

Dos dados obtidos resultou uma média de 6,6 pessoas, familiares ou dependentes, por alistados. Os pesquisadores ressaltaram que esse resultado havia surpreendido, uma vez que os "mais categorizados trabalhos e relatórios técnicos" utilizavam como média o número de cinco pessoas por família.

Sobre esse respeito é possível acompanhar a mudança do número médio de pessoas por família nos relatórios e demais documentos produzidos pelo Dnocs ao longo dos anos. Até fins da década de 1950, o número médio de pessoas por família considerado para avaliar a quantidade de pessoas beneficiadas por determinada obra ou emergência era seis. Como veremos no capítulo seguinte, a normativa da órgão sobre o arrendamento de seus lotes datada de 1950, estabelecia como "família média" aquela que tinha de seis a nove membros.

Com relação às atividades desempenhadas pelos membros da família antes da seca, os pesquisadores apontaram que 70\% dos homens desempenhava trabalhos agrícolas. As mulheres são referidas como auxiliando nos trabalhos da lavoura. Na perspectiva dos pesquisadores, haveria durante as secas um aumento da contribuição feminina na renda familiar, exercendo esta a função de barraqueira. Além das esposas, 70,1\% dos que contribuíam para a renda familiar do alistado eram os filhos dos mesmos, também alistados nas frentes. Destes, 55,7\% tinha entre 15 e 20 
anos de idade.

Os principais itens da alimentação eram feijão, farinha e arroz. Segundo anotação dos pesquisadores, a deficiência alimentar não era só "caracterizada pela limitada quantidade de alimentos consumidos pelos alistados e seus dependentes, como também pela falta de outros gêneros na maioria das localidades estudadas e ainda pelos altos preços dos mesmos"' (Dnocs, 1971, p.124). Pouco tinha mudado, portanto, com relação aos relatos da década de 1930 (Costa, 1936; Leitão, 1937).

As observações mais contundentes dos pesquisadores acerca das condições dos trabalhadores das Frentes de emergência foram feitas através das fotos e suas respectivas legendas, que muitas vezes transcrevem o trecho de algum livro ou estudo. No item sobre as habitações dos alistados e suas famílias, por exemplo, encontra-se descrição:

(...) os barracos onde habitam as famílias dos alistados são cobertos de fôlhas sêcas e palhas de carnaúba. O chão é de terra frouxa e nêle é feito o fôgo para cozinhar os alimentos. Em habitações dêsse tipo alojam-se famílias dos mais variados tamanhos ou turmas de serviço, com 25 homens cada uma. Ressalta-se, porém que as famílias e as turmas de trabalhadores comumente se alojam em barracos separados. Observa-se ainda, nos barracos a existência de rêdes sujas devido a poeira e a escassez de água, seja para lavar a roupa e utensílios domésticos ou para tomar banho. Os instrumentos de trabalho: carros de mão, picaretas e pás são também guardados nos barracos. Os barracos são construídos nas proximidades dos locais de trabalho e constantemente deslocam-se na medida que se desenvolvem as etapas da estrada (Dnocs, 1971, p. 128).

A foto que antecede essa descrição é de uma casa de taipa, construção ainda comum no sertão, acrescida da seguinte citação de autoria de Arrojado Lisboa: "os que veem a pobreza e selvagem rusticidade das habitações sertanejas uma manifestação de indolência nativa deveriam refletir que ninguém promove construção sólida em terras alheias" (Dnocs, 1971, p.128). 
O item "Situação da família atingida pela seca" procurou captar a percepção dos alistados e sua família sobre sua situação antes e depois da ocorrência da seca. $60,1 \%$ indicaram uma piora nas condições depois da seca, sendo as principais causas apontadas a fome, o ganho insuficiente na lavoura, as doenças e a desagregação da família. 22\% considerou que sua situação havia melhorado com a seca devido ao aparecimento de emprego e 17,9\% considerou não haver diferença entre as duas situações, uma vez que nunca haviam tido "qualquer condição mínima de bemestar" (Dnocs, 1971, p. 134). Com relação à pergunta sobre se tiveram problemas morais e sociais durante a seca, 41,5\% declarou-se sem problemas, gerando o seguinte comentário dos pesquisadores:

Quanto a êste último caso, atribuiu-se a uma propositada omissão dos entrevistados diante dos entrevistadores, considerados por êles como representantes das autoridades. A hipótese de considerar a afirmação do alistado ("não ter problemas") como sendo de completa alienação ou estado de quase inconsciência diante da realidade, é pouco provável (Dnocs, 1971, grifos no original).

Sobre a opinião dos alistados acerca do plano de emergência em execução, os pesquisadores registraram que as respostas foram reservadas e até "omissas", devido "em parte, à interpretação errônea de que suas declarações poderiam prejudicar-lhes as relações com a chefia e até ameaçar-lhes a permanência na Frente de Serviço" (Dnocs, 1971, p. 140).

O item referente ao "Conhecimento do alistado sôbre a atuação dos órgãos do govêrno" foi elaborado a partir de sondagem sobre o órgão público de maior utilidade ou mais conhecido na região. A Sudene era a conhecida de $74,6 \%$ dos entrevistados, apesar de não ter administrado nenhuma Frente. Já o Dnocs, que administrou grande parte das Frentes, foi citado por apenas 8,3\% dos entrevistados. Para os pesquisadores, a Sudene era o órgão mais conhecido porque a distribuição de gêneros alimentícios e de água era feita em caminhões da Superintendência.

O planejamento futuro dos alistados foi apreendido para dois cenários: bom 
inverno e persistência da seca. 86,0\% afirmaram que retornariam ao local de origem em caso de bom inverno. Com relação aos planos diante de uma nova seca, 68,1\% dos alistados declararam que iriam permanecer nas frentes, 7,7\% disse que iria emigrar, e 3,5\% responderam: “deus decide". Para os pesquisadores, o alto índice de pessoas que afirmaram permanecer nas frentes era uma "manifestação de que a continuidade na dependência do governo constitui uma solução permanente à situação de penúria do alistado" (Dnocs, 1971, p. 143).

No tocante ao "Nível de aspiração e sugestões dos alistados para amenizar os efeitos da seca", 26,7\% mencionou a distribuição de sementes e 38,7\% afirmou aspirar apoio financeiro. Alguns dos entrevistados afirmaram não saber o que pedir aos governos e outros disseram ainda que não adiantava pedir, já que não iam conseguir mesmo. Cruzando esses dados com aqueles sobre a forma da posse da terra de onde provinham, que apontavam que os alistados proprietários representavam apenas $19,7 \%$ do total, os pesquisadores registraram a falta da menção à distribuição de terras ou reforma agrária:

Depara-se, mais uma vez, com a dualidade de interpretação, ou o homem se omitiu de dar sua verdadeira resposta por julgar que o entrevistador era autoridade ligada à chefia das Frentes, ou é tão forte a submissão que o sistema patriarcal impôs à sua estrutura mental que o tornou alienado no tocante aos próprios desejo de bem-estar e liberdade. Haja visto que, um número bastante insignificante manifestou-se desejoso de receber do governo terras para plantar (Dnocs, 1971, p. 146).

Teria sido interessante se os pesquisadores tivessem incluído entre as perguntas alguma referente ao número de emergências em que o alistado já havia trabalhado e outra englobando os membros da família, de forma a ser possível apreciar o trabalho reiterado de diferentes gerações da mesma família nas emergências, como ocorreu em Coremas.

O Capítulo 5 foi dedicado à percepção das "autoridades" dos técnicos sobre a política de emergência, dos quais selecionamos algumas críticas e sugestões. O 
Deputado Federal Paes de Andrade do Ceará fez uma análise que publicou no Jornal de Brasília de 18 de março de 1971. O Deputado criticou a Sudene nos seguintes pontos:

1. não realizou a adequação administrativa dos órgãos públicos locais, federais, estaduais e municipais ao desenvolvimento regional;

2. não fêz, como anunciara, organização agrária no Nordeste e a sua promoção agropecuária;

3. não efetivou ou contribuiu para efetivar uma política de preços mínimos e uma comercialização em favor do desenvolvimento da agricultura;

4. anunciou e não realizou a política de abastecimento do Nordeste e suas capitais;

5. reduziu o DNOCS a um simples departamento de recursos hidráulicos, e não conseguiu a implantação das obras de irrigação;

6. nada fez quanto à distribuição das reservas florestais do NE;

7. não equipou as indústrias têxteis nem oleaginosas, cerígenas básicas (Dnocs, 1970, p.151).

Na avaliação do Eng. agrônomo Francisco Alves de Andrade e Castro, as medidas colocadas em práticas durante a seca de 1970 redundaram em prejuízos financeiros dada a baixa produtividade do trabalho e ao emprego inadequado dos trabalhos. Entre os problemas sociais causados, a Frente teria gerado "desajustamento, maus hábitos, depressões, deslocamento de trabalhadores para serviços aleatórios e improdutivos", além disso os salários haviam sido "deprimentes, deixando desesperança e fundas cicatrizes morais..." (Dnocs, 1971, p. 155)

Os técnicos do Governo do Estado da Paraíba, José Luis de Almeida e João Soares Júnior, apontaram para o fato de a estrutura agrária não ter mudado nada após 10 anos de Sudene. Ao contrário dos trabalhadores alheios caracterizados pela pesquisa, os técnicos observaram um aumento na conscientização das massas "levando-se a rápidas concentrações nas cidades pondo em risco a ordem social. Para isso, irônicamente, também concorre a facilidade de transporte e comunicações 
hoje existentes." (p. 158, grifos no original). Entre as sugestões dadas estavam o fortalecimento da propriedade rural e o financiamento de obras rurais.

Nas observações preliminares do estudo (cap. 6), os pesquisadores anotaram a não ocorrência de epidemias e demais problemas sanitários observados em outras secas. Com relação à população atingida, destacou-se que "os efeitos da sêca incidiram sobremodo nas camadas populacionais dependentes das terras alheias e sôbre pequenos proprietários de baixa produtividade", e os maiores prejuízos "se concentram nas faixas populacionais ligadas à lavoura, determinando fluxos sucessivos de flagelados em busca das Frentes de Serviço"' (Dnocs, 1971, p. 169).

$\mathrm{O}$ atraso político-administrativo do meio rural do NE (regiões atingidas pela seca) está, de certa forma, caracterizado pela letárgica submissão do homem do campo - dependente do "senhor de terras" -, e, pela manifesta repulsa dêste último a qualquer inovação de seus dependentes e auxiliares (entrevista com pessoas que comandam decisões).

(...)

Os indicadores sociais e econômicos levam a conclusão de que o atraso a que está submetido o homem do campo não é uma fatalidade imposta pela agressividade do meio que o colocou na retaguarda dos acontecimentos, mas sim a tradicional estrutura dos meios de produção a que está ligado e à ineficácia das medidas oficiais nos períodos considerados normais (Dnocs, 1970, pp. 171, 172).

De acordo com a conclusão do estudo as medidas de emergência adotadas em 1970 traziam em seu interior a antítese da doutrina do desenvolvimento regional, "ao tomar como 'emergência' uma ocorrência típica da região" (Dnocs, 1971, p. 174).

Essa conclusão poderia ser estendida para o conjunto das políticas de socorros tomado em sua longa duração. Desde 1877, a esmola remunerada passou a ser a principal forma de socorro às populações atingidas pelas secas. Ao mesmo tempo, a existência da massa de flagelados liberada pelas secas serviu, desde então, como justificativa para a realização de obras e portanto o repasse de verbas para as várias instâncias locais. O trabalho dos cassacos permaneceu altamente precarizado ao longo 
das diversas gestões e nenhuma medida foi tomada no sentido de melhorar sua situação durante as crises. Como chamou atenção Hall (1981), muitas vezes essas políticas terminaram elas mesmas por forçar o deslocamento dos trabalhadores piorando sua situação.

Como veremos na Parte II, a ação do Dnocs em Coremas deslocou muitos trabalhadores no processo de desapropriação para instalação dos açudes. Por não serem proprietários, os moradores dos sítios foram simplesmente desalojados sendo muitos deles engajados nas muitas emergências contra as secas ocorridas no lugar. 


\section{NOTAS}

${ }^{3} \mathrm{O}$ autor destaca, entre as doações, a feita pela rainha da Inglaterra, mostrando que a seca repercutiu também fora do Brasil.

4 O Iocs tornou-se Ifocs (Inspetoria Federal) em 1919, na gestão do paraibano Epitácio Pessoa na Presidência da República e Dnocs (Departamento) em 1945, sob o governo Getúlio Vargas.

5 Discurso proferido pelo Dr. Francisco Ferreira Ramos, paranympho dos engenheirandos de 1919, na sessão solene realizada em 19 de fevereiro de 1920, no salão da Congregação da Escola Polytechnica. Revista Polytechina, São Paulo, 1920, p.65 (apud Ferreira, Medeiros \& Simonini, 2009, p. 7).

6 Em Os Bruzundangas, Lima Barreto fez uma crítica ao Brasil de sua época através do relato de um país imaginário, a Bruzundanga. Comentando sobre a nobreza da Bruzundanga, Barreto aponta a grande influência da "nobreza doutoral": "O título — doutor — anteposto ao nome, tem na Bruzundanga o efeito do - dom - em terras de Espanha". Lima Barreto registrou como os mais importantes grupos os médicos, os advogados e os engenheiros. $\mathrm{O}$ autor se contrapunha totalmente à característica intervencionista e autoritária de tratamento das camadas mais pobres e foi um crítico feroz do pensamento técnico científico dos finais do século XIX e início do XX, corporificado exemplarmente por Euclides da Cunha (Sevcenko, [1983] 1999; Schwarcz, 1995).

7 Segundo a biografia da autora apresentada pelo IHGP, no qual é patrona na cadeira $\mathrm{n}^{\circ} 34$,

"Maria IGNEZ Marques MARIZ nasceu na cidade de Sousa, Paraíba, no dia 26 de dezembro de 1905. Era filha do Dr. Antônio Marques da Silva Mariz e de Da. Maria Emília Marques Mariz. Faleceu no Rio de Janeiro, em 1952.

Estudou os primeiros anos escolares na cidade natal e fez o curso de Pedagogia no Colégio Nossa Senhora das Neves, em João Pessoa. Desde cedo demonstrou que seguiria um caminho diferente das demais mulheres da sua época. Muito criança começou a ajudar Dr. Silva Mariz, como era conhecido o seu pai (chefe político, médico e rábula), na difícil missão de liderar um povo sofrido.

Aos dezoito anos começou a colaborar em jornais e revistas do alto sertão. Na década de 30 iniciou a "Campanha Pró-Bibliotecas Municipais", sentindo-se realizada com essa iniciativa. Em 1937, Ignez publicou, pela José Olympio, o romance A Barragem, que a projetou nacionalmente e foi muito bem aceito pela crítica sulista." http:/ / www.ihgp.net/ memorial7.htm

8 A discussão sobre a mestiçagem e a viabilidade do mestiço nacional ocupou grande parte do debate intelectual que se iniciou com a geração de 1870 e se seguiu até meados dos anos 1930 (Schwarcz, 1995; Gomes, 1999). Nessa seção, foram tratados apenas os autores e obras citados por José Américo de Almeida. 
${ }^{9}$ Decreto $n^{\circ} 16.769$, de 7 de Janeiro de 1925 : "Suspende, durante e exercicio de 1925, todas as obras publicas que estão sendo executadas, e dá outras providencias.

O Presidente da República dos Estados Unidos do Brasil:

Considerando que, não tendo sido votada a nova lei da receira para o exercicio de 1925, ficou a administração publica privada de recursos que ella creava e que permitiriam, sem pertubação do equilibrio do orçamento, occorrer as despesas com alguns dos melhoramentos que o progresso do paiz reclama;

Considerando que a situação do Thesouro, com cujas dificuldades vem o actual Governo lutando, desde os primeiros dias de sua existencia, o obriga a extremo rigor na politica de economia que tem adoptado e, por conseguinte, a não somente reduzir ao minimo as despezas ordinárias, mas também a adiar todas as obras e serviços extraordinários,

DECRETA:

Art. $1^{\circ}$ Ficam suspensas, durante o exercicio financeiro de 1925, todas as obras publicas que estão sendo executadas pelos diversos ministérios.

Art. $2^{\circ}$ Para aquellas que são objecto de contractos serão celebrados accôrdos que prorroguem os prazos de sua execução, de modo a evitar rescisões onerosas.

Art. $3^{\circ}$ Revogam-se as disposições em contrário.

Rio de Janeiro, 7 de janeiro de 1925, $104^{\circ}$ da Independencia e $37^{\circ}$ da Republica".

10 Rodolfo Teófilo (Salvador 1853 - Fortaleza 1932) escreveu vários livros com a temática da secas, entre eles destacamos os trabalhos de cunho historiográfico: História da Seca no Ceará (1884), Secas do Ceará - Segunda metade do século XIX (1901), Seca de 1915, Seca de 1919.

11 O Relatório dos trabalhos realizados no ano de 1935 se inicia com a nota da aplicação, pela primeira vez, do disposto no Art. 177 da Constituição de 1934, o que garantiu a continuação do plano de obras proposto em 1931. Entre as obras citadas, está o inicio da instalação do Acampamento em Coremas.

12 Esse é o local onde se passa grande parte da ação do romance Os Cassacos, analisado na seção anterior.

13 Em sua dissertação de mestrado sobre o mandato de José Américo de Almeida como governador da Paraíba, Jivago Correia Barbosa (2012) chamou atenção para o papel do governador na reprodução da indústria da seca na paraíba, assim como ressalta que apenas os municípios alinhados a ele foram favorecidos com obras. Sem dúvida a nova ênfase nos açudes particulares, dádiva a que todos os proprietários almejavam, serviu para angariar muitos votos.

${ }^{14} \mathrm{Na}$ mencionada exposição de Lucio Meira sobre as ações implementadas durante o ano de 1958, o Ministro destacou que: "O Serviço de Piscicultura, visando minorar os efeitos da sêca, efetuou a distribuição entre os flagelados, de abril a esta data [julho], de cerca de 50 mil anzóis e respectivas arpoeiras, de diferentes tipos, fornecendo aos guardas de pesca e zeladores de açudes instruções sôbre a utilização dos mencionados aparelhos (Dnocs, 1958, p. 14). 
15 Apesar dessa recomendação o termo flagelado seria utilizado nas publicações oficiais do Dnocs e da Sudene até, pelo menos, a década de 1970.

16 "Art 198 [CF 1946] - Na execução do plano de defesa contra os efeitos da denominada seca do Nordeste, a União despenderá, anualmente, com as obras e os serviços de assistência econômica e social, quantia nunca inferior a três por cento da sua renda tributária.

$\S 1^{\circ}$ - Um terço dessa quantia será depositado em caixa especial, destinada ao socorro das populações atingidas pela calamidade, podendo essa reserva, ou parte dela, ser aplicada a juro módico, consoante as determinações legais, empréstimos a agricultores e industriais estabelecidos na área abrangida pela seca.

$\S 2^{\circ}$ - Os Estados compreendidos na área da seca deverão aplicar três por cento da sua renda tributária na construção de açudes, pelo regime de cooperação, e noutros serviços necessários à assistência das suas populações" (grifou-se).

17 Ilustrando essa seção, há uma foto das comportas do Açude Estevam Marinho, em Coremas, com a legenda: "Açude Estevam Marinho (ex-Curema), vazão de 40.000m3 por segundo. Concluído desde 1943 e não utilizado por falta de turbinas" (Dnocs, 1959, p.31).

18 Hall atribui esse fato à legislação brasileira, que prevê que os primeiros lotes deveriam ser destinados aos proprietários desapropriados.

19 Os dados referente à renda das famílias no interior do Maranhão nos cadastros de famílias quilombolas do Incra também apresentavam essa mesma tendência quando comecei a trabalhar na autarquia em 2006. Grande parte dos entrevistados, que sobreviviam de uma agricultura de subsistência não tinha idéia de sua renda ou declaravam não ter renda anual nenhuma. O cenário foi se modificando sensivelmente com a ampliação dos programas de distribuição de renda do governo federal, em especial do programa "Bolsa Família" que, junto com o "Luz para Todos" transformou a realidade do interior do Maranhão. 


\section{Parte II}

\section{O Dnocs em Coremas}

Eu nasci no milênio que ficou atrás

E falar de Coremas eu sei demais (bis)

I

Com orgulho eu falo fatos daqui

Da nossa origem que foi nação Kariri

Coremas símbolo de água e peixe

Que uniu-se aos Panatis

1938 na divisão do Brasil

Surge um distrito com a clareza do Sol

E essa vila a partir daquela data

Pertencia a Piancó eu vi

Eu nasci no milênio que ficou atrás

E falar de Coremas eu sei demais (bis)

II

Fundaram Coremas comerciantes e fazendeiros

Gratos a Deus ergueram uma capela

Fogos de artifícios comidas e bebidas
Fizeram parte da festa

Nunca esquecemos João Soares Evangelista

Manoel Gonçalves Piranhas e Antônio Moreira

E o ilustre Antônio Luca de Lacerda

Autores desta proeza eu vi

nasci no milênio que ficou atrás

E falar de Coremas eu sei demais (bis)

III

Getúlio Vargas quando ditador

Aqui lançou a pedra fundamental

Estevam Marinho foi o grande engenheiro

Desse mar colossal

Foi audácia do Estado Novo

Muitos cassacos em Coremas trabalharam

A cafuringa as pás e as enxadas

Esse açude edificaram eu vi

(Coremas passado e presente, Almeida, 2004) 


\section{A cidade e seus açudes}

Apesar de pouco conhecido nacionalmente, é fácil achar o município de Coremas no mapa do estado da Paraíba. Nele está grande parte do maior açude do estado e quinto maior reservatório de água do Brasil.

O município de Coremas localiza-se no Vale do rio Piancó, na mesorregião do Sertão Paraibano e dista 397 km da capital. O povoado "Boqueirão de Curema" era um distrito de Piancó, tendo sido elevado à categoria de vila pelo decreto $\mathrm{n}^{\circ} 39$ de 17 de Maio de 1938 e à categoria de município, com a denominação de Coremas, pela lei estadual $n^{\circ} 1005$, de 30 de dezembro de 1953. Segundo informação do site "Cidades" do Ibge, Coremas teve seu maior incremento populacional em meados da década de 1930, com o início da construção do açude de mesmo nome. ${ }^{20}$

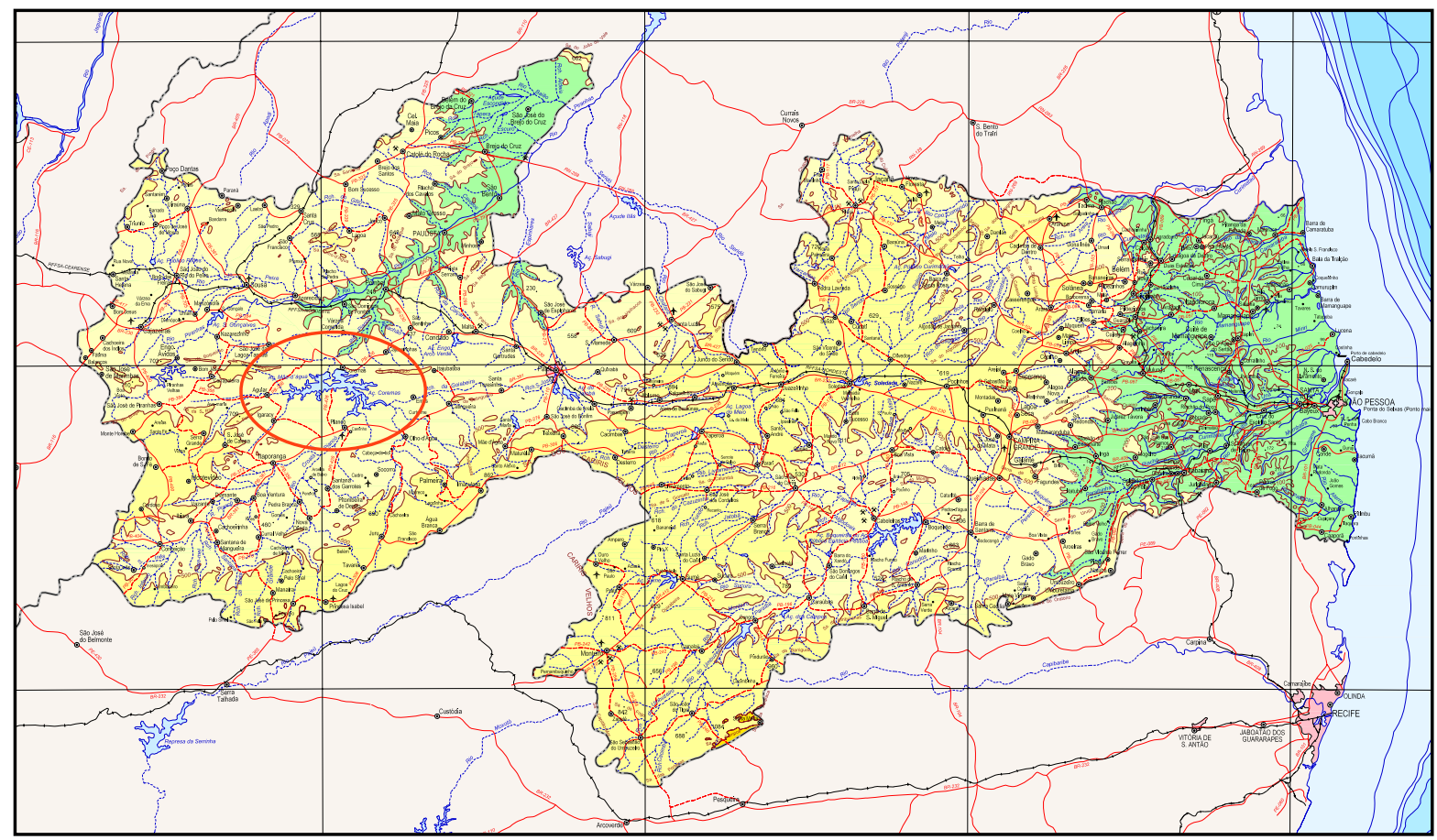

De acordo com página do Dnocs na internet, foram necessárias três barragens para fechar o boqueirão "Curema", garganta aberta pelo rio Piancó na serra de Santa Catarina, e formar o lago do açude que foi inaugurado por Getúlio Vargas em 1940. Ainda no ano seguinte, foram iniciadas as locações para uma nova barragem no boqueirão "Mãe D'Água", formado pela passagem do rio Aguiar na serra de Santa 
Catarina, a $5 \mathrm{~km}$ da vila.

O povoado de "Boqueirão do Curema" surgiu em meados do século XIX com a construção de uma capela devotada a Santa Rita de Cássia em terras doadas pelo fazendeiro Gonçalves Piranhas, à margem direita do rio Piancó, e permaneceu como um amontoado de casas até 1919, quando surgiu uma feira livre dinamizando a economia até então baseada na subsistência (Andrade, 2008).

O grande impulso para o desenvolvimento local ocorreu apenas na década de 1930, com a chegada de trabalhadores para a construção dos açudes e outras obras conexas, como as rodovias Curema-Piancó, São Gonçalo-Curema-São Bento, o ramal rodoviário Mãe D’Água-Barragem de Lages e o campo de pouso de Curema, entre outras.

Segundo relato da memorialista coremense Chiquinha Guedes, a zona rural do município era povoada de sítios que plantavam gêneros de subsistência, cana de açúcar para o fabrico de rapadura e algodão. A coleta dos frutos da oiticica, árvore nativa da região e abundante nos sítios, também era uma importante fonte de renda. Dona Chiquinha recorda que seus pais contavam que, quando o bisavô se estabeleceu com a família no local, os sítios eram localizados em terras apossadas (Entrevista Chiquinha Guedes, 2009).

Relatos de antigos habitantes de Coremas, recolhidos na pesquisa de mestrado de Andrade (2008, p. 71), afirmam que havia uma grande quantidade de pequenos sítios com muitos moradores na área que foi inundada pelos açudes.

Com o início das obras do açude, a área do povoado antigo, na margem direita do rio Piancó, foi ocupada pelos trabalhadores de baixa especialização (Entrevista Chiquinha Guedes, 2009). Na outra margem do rio, foi construído o Acampamento da Inspetoria para alojar os servidores do órgão.

Segundo o historiador local Edvaldo Brilhante Silva Filho (1996), o Acampamento erigido pela Inspetoria tinha 113 casas contando com uma infraestrutura "bastante moderna", com 
(...) casas bem ventiladas, arborizadas com árvores frutíferas, jardinagens exuberantes, água encanada e energia elétrica. Foi idealizado para possuir conforto, comodidade, simplicidade e no lazer de seus moradores (algo revolucionário naqueles tempos) (Silva Filho, 1996, p. 110).

As casas dos funcionários foram distribuídas em 3 ruas de acordo com suas ocupações. Na rua "U" ou "rua dos doutores", ficava a casa do engenheiro chefe e dos servidores de alto escalão. Na rua "R" ou rua "Dezesseis", havia dezesseis casas destinadas aos funcionários com cargos administrativos hierarquicamente inferiores. Na rua "S" ou rua "Mecânica", moravam os técnicos. Segundo Silva Filho (1996), os nomes das ruas foram dados pelo topógrafo Sabino Guimarães Coelho, entusiasta da União Soviética, de forma que o conjunto dos arruamentos formavam a sigla URS.

Juntamente com as casas dos funcionários, que contavam com iluminação e água encanada, foram construídos no Acampamento: a primeira escola do município, o primeiro hospital, a primeira cooperativa, maternidade, hotel, apiário, agência de correios e telégrafos, cadeia, capela, horta, pomar, club recreativo, praça de esportes (poliesportiva), campo de futebol, a primeira piscina do estado, cinema para 180 pessoas e mesmo uma agência de automóvel representando a Ford, inaugurada ainda em 1937.

Segundo Dona Chiquinha Guedes, toda a elite coremense queria morar no Acampamento. A vida social da cidade passou a girar em torno do Dnocs, com seus bailes de carnaval, sessões de cinema e club recreativo. Silva Filho lembra que mesmo os apitos que marcavam os horários de trabalho dos funcionários do órgão passaram a ser algo "bastante tradicional na vida diária da cidade" (Silva Filho, 1996).

Ao contrário do ambiente "limpo", moderno e bem organizado do Acampamento (Andrade, 2008), do outro lado do rio o antigo povoado crescia desordenadamente para abrigar os trabalhadores que não eram servidores do órgão - os cassacos. Escrevendo sobre a vila de Curema no ano de 1941, o Padre Pedro Luz Cunha anotou no Livro de Tombo: 
(...) era um ambiente pobre, depravado e desoluto em que vivia a mocidade operária (pois aqui é quase todo mundo: ou pequeno comerciante, ou pequeno proprietário ou simplesmente operário) (Andrade, 2008, p. 73).

Tanto os cassacos, como os técnicos especializados do órgão e parte dos funcionários de categoria também se mudavam para acompanhar os empreendimentos do Dnocs. A instalação de uma infra estrutura moderna para abrigar os servidores do órgão ocorreu durante a construção dos demais açudes públicos do estado, como foi o caso de São Gonçalo, pequeno povoado de Souza, a $71 \mathrm{~km}$ de Coremas. Como já foi mencionado, as obras desse açude foram iniciadas no governo de Epitácio Pessoa (1919-1922), paralisadas por Artur Bernardes e retomadas na década de 1930, durante o Governo Provisório de Getúlio Vargas. Segundo Soares (2013), autor de São Gonçalo: Fragmentos da História,

O acampamento federal de São Gonçalo principiou com ares de modernidade, podendo ser considerado uma anomalia urbana positivomoderna, para as décadas de 1920 e 1930, pois já nasceu grandioso, ocasionando sentimentos antagônicos de ciúme e orgulho à cidade de Sousa.

Na metrópole rural federal, falavam-se inglês e alemão nas calçadas e esquinas, enquanto "doutores" e altas autoridades oficiais discutiam assuntos relevantes para o destino dos sertanejos, nos escritórios e canteiros de obras da Inspetoria, espalhados por toda a extensão da localidade (Soares, 2013).

Ao lado da "metrópole rural federal" surgiram também as moradias improvisadas dos cassacos. Em seu romance sobre a construção do açude São Gonçalo, Ignez Mariz descreveu o acampamento da seguinte forma:

Na "Rua das 16", plana, de casas pertencentes á Inspectoria Federal de Obras Contra as Sêccas, moram os feitores, apontadores, fiscaes e demais empregados de categoria.

Em collinas ao redor se trepam as moradias risonhas do Engenheiroresidente e pessoal do Escriptorio. Esses bangalôs são a unica nota de conforto civilizado no meio agreste de São Gonçalo.

E distantes, como se tivessem mêdo de se approximar, as casas de 
cassacos. Baixinhas e disseminadas negligentemente, assim de longe mais parecem caixa de phosphoro, espalhadas sem nenhuma intenção artistica, para brinquedo de menino pobre (Mariz, [1937] 1994, p. 7).

De São Gonçalo partiram as máquinas, engenheiros e cassacos para Coremas, esvaziando grande parte da estrutura estabelecida de uma hora para outra. O último capítulo de A Barragem inicia em tom melancólico descrevendo esse momento:

Sobre todas as cousas, no próprio ar, já se experimentava em São Gonçalo essa tristeza indefinida de fim de festa.

A Barragem está prompta. Em meio o revestimento de cimento da parêde, do lado da bacia hydraulica.

Os caminhões afundam a estrada de Souza a Pombal, pejados do machinismo do São Gonçalo, que se vae mudando para o acampamento do "Corema". Este terá inicio em fevereiro.

O povo tambem já vae arrumando a trouxa pra dar o fóra.

Ficarão aqui apenas reduzido numero de operarios para o trabalho do Sangradouro e aquelles que, cansados de vida incerta, vão se dedicar de vez á agricultura (Mariz, [1937] 1994, p. 321).

O clima de "fim de festa" iria demorar mais algumas décadas para chegar a Coremas. Antes mesmo do término das obras do primeiro açude, começou a ser construída a nova estrutura para abrigar os trabalhadores que iriam executar as obras da barragem Mãe D'água.

Segundo relato de Dona Chiquinha Guedes, antes da chegada do Dnocs na cidade, Mãe d'Água era a denominação do poço formado pelas águas do rio Aguiar após a passagem deste pela serra de Santa Catarina. Seu avô lhe contou que o nome do poço havia sido dado pelos índios que moravam nas locas da serra, que acreditavam que o lugar era habitado por uma moça encantada "muito linda e muito loira".

A nova vila do Dnocs foi instalada na margem esquerda do rio Aguiar. Os moradores da região lembram que o espaço foi dividido em quatro setores para abrigar os trabalhadores da nova barragem: vila operária, vila mecânica, fundação e 
pedreira ou britador. Aqueles com baixa qualificação, os cassacos, ocuparam a outra margem do rio Aguiar, ficando o local conhecido como "vila dos mulambos".

De acordo com Dona Francisca Rita Silva Martins, que se mudou com a família na época das obras da barragem e se estabeleceu na "vila dos mulambos" onde mora até hoje, o nome foi dado por que lá residiam as pessoas mais pobres "umas pessoas muito briguentas, eram muito zoadentas, brigavam por nada" (Entrevista Francisca Rita, 2009). Outros atribuem a alcunha ao fato de o local não ter água, fazendo com que as pessoas ficassem com o aspecto de molambo.

Os engenheiros e pessoal da administração do Dnocs, permaneceram no Acampamento próximo ao núcleo urbano de Coremas. No sopé da serra de Santa Catarina, com vista para o açude Mãe D'água, foi construída uma "imponente casarepouso" para o Engenheiro Chefe Estevam Marinho. Toda construída em pedra e com uma cascata artificial, a casa virou atração turística da cidade (Silva Filho, 1996, p. 113).

Na região de Mãe D'Água foram instalados bares com piscinas que utilizam a água do açude. Os piqueniques ao lado da barragem tornaram-se o passeio dominical predileto da região. Segundo relato de uma antiga moradora da cidade, registrado por Andrade (2008),

É como se fosse assim, Coremas não cresceu como essas cidades vizinhas, tipo o que, cresceu em volta de uma igreja, aquela coisinha pequena. Coremas começou a crescer depois da construção do DNOCS, uma obra grandiosa, o maior açude do Brasil, a maior obra de engenharia daquele tempo, que se tinha no Brasil. Aí vieram pessoas estudiosas, intelectuais, médicos, pessoas que tinham sofisticação, uma diferenciação, uma classe mais urbanizada. Aí isso favorecia o crescimento mais avançado em relação a outras cidades vizinhas. Você pode perceber que Coremas tem essa diferença das outras cidades. As outras é só aquela coisinha de nada. Em 1950, naquele tempo, é como se Coremas aqui fosse um local onde o pessoal vinha do sítio, era aquela coisa mais voltada ao rural, entende? Lá no DNOCS não, era restrita, aquela coisa mais urbanizada (Andrade, 2008, p.80). 
A história dos açudes e do Dnocs se mesclam de tal maneira à história de Coremas que o historiador local, o médico Edvaldo Brilhante da Silva Filho, ao fixar o significado de Coremas como "uma espécie de peixe saboroso" em seu livro Coremas o seu lugar na história, concluiu que,

Coincidentemente, muitos anos depois, foi magistralmente erguido no antigo território dos índios, um enorme açude (maior reservatório d'água da Paraíba), que hoje tornou-se um grande "centro produtor e exportador de peixes", dentre eles, tilápias, curimatãs, camarões, tucunarés, sardinhas, piranhas, etc., sendo vendido em várias cidades da Paraíba e de outros estados do Brasil. Ontem, a cidade de Coremas-PB incorporava os peixes ao seu nome de origem indígena; hoje, tem incorporado os peixes à sua economia (como a maior fonte de arrecadação de tributos dentro do município) (Silva Filho,1996, p. 15).

Comentando com os moradores de Mãe D'água a história de Dona Chiquinha Guedes sobre a presença de uma moça encantada que habitava o poço que deu nome ao lugar, uma das moradoras afirmou que, na verdade, a mãe d'água era a filha do engenheiro Estevam Marinho, que se encantava e atraía os homens para o poço.

Estevam Marinho é tido em alta estima até os dias de hoje. Receberam seu nome a barragem que forma o açude Coremas, o primeiro hospital do município e a rua que limita o Dnocs com a cidade. O clube recreativo foi denominado "Clube 6 de setembro" em alusão à data de nascimento do engenheiro e a capela "Santa Terezinha" foi assim homenageada em louvor da santa de devoção de sua esposa (Silva Filho, 1996).

A casa que o engenheiro construiu na beira da barragem também se misturou às histórias locais e acredita-se que nela há uma botija com moedas de ouro, escondida por um dos cangaceiros que, antigamente, transitavam pelo local.

Em 2004, Severino Lopes de Almeida, conhecido por Preto de Chico Jacó, escreveu um cordel intitulado Coremas, Passado e Presente. Deste cordel foram retiradas as estrofes que servem de epígrafe a esse capítulo. A história de Coremas 
foi contada por Preto de Chico Jacó através da seguinte sucessão: primeiro vieram os índios, depois os fazendeiros (brancos desbravadores), a capela e, então, o açude do Dnocs, com suas figuras ilustres, engenheiros máquinas modernas e cassacos.

O brasão de Coremas também ilustra a centralidade tida pelo açude na representação do município. Conforme explica Silva Filho,

Coube aqui ao gênio criativo da professora Maria Lourdete Bezerra da Silva (coremense, porém nascida em Mossoró-RN), que concebeu um lindo brasão, onde contemplou todas as raízes da cidade, além das riquezas existentes. Na parte superior, foi colocado um cocar indígena (significando nosso passado junto aos índios da tribo Coremas, os primeiros moradores da

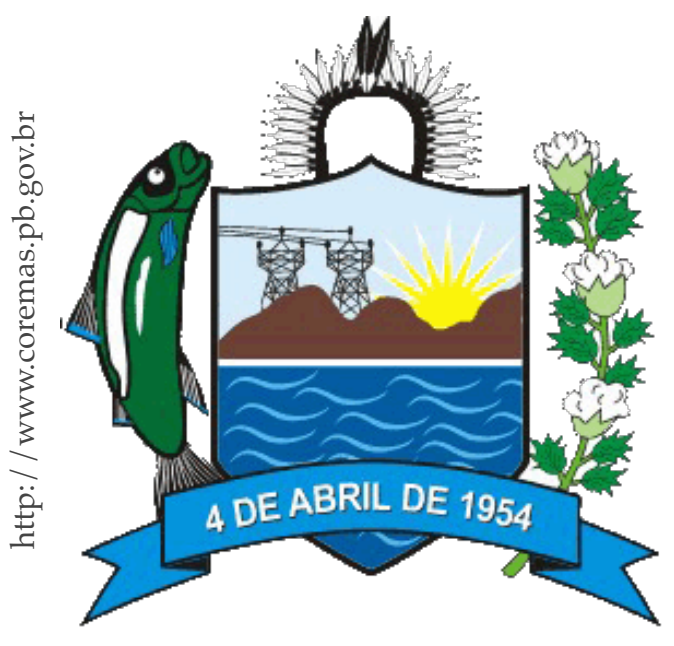
região), na lateral esquerda temos um peixe (significando nossa relação ao rio Piancó, hoje produto agrícola), ao centro o sol poente (significando que a região fica no longínquo sertão nordestino), as serras em número de três (significando nosso relevo, com elevações da Serra de Santa Catarina e do Doidos), os postes de transmissão de energia elétrica num total de três também, ao cume das serras (significando nossa energia elétrica das turbinas [do Dnocs], levando energia elétrica para várias cidades sertanejas), e as águas azuis ondulantes (significando nosso maior orgulho, a barragem Estevam Marinho - o açude maior do estado da Paraíba), finalmente na parte inferior, um laço estilizado com a data de "04 de abril de 1954", uma alusão à histórica data da emancipação política da cidade (Silva Filho, 1996, p.186).

Buscando compreender o significado da expressão born and bred (nascido e criado) na cidade inglesa de Bacup, a antropóloga Janet Edwards percebe a importância que seus moradores atribuem ao passado como maneira de definir a sua identidade presente. Pertencer a Bacup significaria conhecer o lugar, suas casas e pessoas - "expertise is a corollary of belonging" (2000, p.8). No segundo capítulo de Born and Bred, "Naming and Placing", a autora analisou os eventos selecionados 
pelos moradores de Bacup na construção da história do lugar, partindo da idéia de que o passado, assim como o parentesco, apresenta às pessoas um problema ao levantar questões sobre o que lembrar e o que ignorar, o que revelar e o que esconder.

Um dos focos de análise desse capítulo é o trabalho de reconstrução histórica empreendido por historiadores locais. A preocupação da autora não é sobre a veracidade ou não dos fatos narrados mas como estes são selecionados e arranjados de maneira a formar uma bela história ("a nice history") tanto para cidade como para aqueles que a contam, fortalecendo dessa maneira a identidade local.

Em Coremas, seu lugar na história, publicado em 1996, o historiador coremense Edvaldo Brilhante Silva Filho elaborou a primeira história local com o intuito de preservar a memória da cidade de Coremas para as futuras gerações. Conforme explicou na apresentação de seu livro,

Uma das maiores preocupações que tive desde o início do projeto é proporcionar um novo despertar na juventude coremense atual, pois como não sabem de certos fatos históricos que ocorreram em nossa cidade, tem feito com que gerações inteiras e sucessivas percam os seus referenciais de cidadania. Tenho sonhado com o dia em que as crianças de Coremas, sentadas nos bancos escolares estudarão, além da história do Brasil e da Paraíba, a história de Coremas.

E finalizando, reafirmo minha grande satisfação pessoal, e a alegria incontida pela conclusão desta humilde e singela obra. Digo-vos ainda, em nome de minha geração, o quanto é maravilhoso e motivo de orgulho ser COREMENSE.

Coremas, eu te amo, e não é de hoje! (Silva Filho, 1996, p. 9).

Embora o autor afirme ter encontrado através de criteriosa pesquisa muitos significados para a palavra Coremas ou Curema, todos estes estavam relacionados à cultura indígena e à grande nação Cariri, sendo Coremas o nome de uma das tribos que integravam essa nação. Essa tribo teria tido grande destaque no processo de povoamento do Vale do Piancó uma vez que seus componentes eram "pessoas 
valentes, hostis, aguerridas e resistentes ao contato do homem branco" (Silva Filho, 1996, p. 13).

Além de uma abordagem preliminar a Coremas, a primeira parte do livro já aponta a idéia que norteia todo texto: construir uma bela narrativa para a cidade, destacando os aspectos que caracterizam o local como uma terra de pessoas valentes, aguerridas e resistentes e apontando para sua grande singularidade: a presença do maior açude da Paraíba.

Os fazendeiros que foram para a região do Piancó após a "pacificação" dos índios eram, assim como estes, corajosos e destemidos, já que fixaram suas moradas "nos longínquos sertões da Paraíba". A caracterização de Coremas como local longínquo e sertanejo é uma constante no livro, na medida que a dificuldade climática e de acesso acrescentam um distintivo a mais à bravura de seus habitantes.

Após a caracterização inicial da cidade, passando por seu nome, fundadores e principais aspectos geo econômicos, há uma seção dedicada à primeira conexão da cidade com um evento destacado da história nacional: a passagem da Coluna Prestes. Embora a Coluna tenha apenas passado pela cidade, o autor considera a "data histórica para a cidade de Coremas".

Se a passagem da Coluna merece destaque, as visitas presidenciais à pequena cidade "encravada no sertão da Paraíba" são exaltadas como grande motivo de orgulho. "As capitais dos estados têm seus orgulhos exaltados, quando nossos presidentes lhes visitam, então, Coremas, tem que perpetuar na memória (História) esses fatos".

Coremas foi visitada por três presidentes, Getúlio Vargas (16/10/1940), Eurico Gaspar Dutra (01/10/1949) e Juscelino Kubitscheck (15/01/1957). Todas as visitas estiveram relacionadas ao sistema Coremas-Mãe D'água.

Nessa seção, aparece pela primeira vez outro mote que orienta todo o livro: a contraposição de um passado glorioso à atual situação de abandono tanto dos açudes como da cidade e do próprio Dnocs. "O que ontem foi orgulho de governos 
federais, e tratado como menina-dos-olhos por políticos de várias esferas (Federal, Estadual)", lamentou, "hoje só parece um espectro, vítima implacável de um esquecimento danoso, estamos dentro de declínio que só faz aumentar paulatinamente" (Silva Filho, 1996).

Os capítulos 9 e 10 são dedicados mais especificamente ao papel do Dnocs e da construção do açude na constituição da cidade de Coremas. Segundo o autor, haviam apenas poucas casas (cerca de 26) antes do início da obra que marcaria, efetivamente, o início da cidade.

Ao mesmo tempo que são enfatizados os signos de modernidade que tornaram singular e motivo de orgulho a pequenina cidade encravada no sertão, $\mathrm{O}$ autor inseriu um subitem denominado "A decadência do DNOCS". Nesse, Brilhante anotou que "nas primeiras décadas depois da construção do açude, a vila do DNOCS era disputada por excelentes engenheiros, que sonhavam em dirigir todo aquele complexo (Coremas - Mãe Dágua), morando confortávelmente na residência-oficial", ao contrário da situação atual do bairro que está completamente descaracterizado e "vivendo somente de boas e distantes lembranças" (Silva Filho, 1996, p.114).

A seção dedicada a "O açude Mãe d'Água", é repleta de informações técnicas de maneira a sublinhar "gigantismo da barragem", que empregou máquinas e materiais dos "mais modernos" disponíveis à época, "algumas estranhas para o homem da região, chegando a causar tremendo espanto e admiração".

Mereceram destaque também as atuações do "grande paraibano" José Américo de Almeida e dos "jovens engenheiros idealistas", sobretudo o engenheiro chefe, Dr. Estevam Marinho, responsável por este que foi até 1960 "o maior açude do Brasil". Assim como a seção anterior, esta se encerra lamentando o abandono de Mãe D'água.

Observação (6): Que o abandono ao qual está relegado o açude de Coremas / Mãe d'Água é um ato desrespeitoso e impatriótico com o Brasil que o fez nos anos 40. É triste constatar o descaso governamental das últimas 
décadas, quando o sistema hídrico, passou pelas mãos de vários ministérios, contribuindo ainda mais com o desmantelamento do DNOCS. Observação (7): Que o açude Coremas/Mãe d'Água precisa, urgentemente, encontrar um novo direcionamento nas suas diretrizes, ou seja, achar uma identidade própria; e esperamos que ocorra como em outros açudes, a de exemplos: Açude Boqueirão de Cabaceiras (com o turismo efervescente capitaneado por Campina Grande-PB), Açude Itãns (polo de turismo aquático em Caicó-RN), além de outras potencialidades existente como: o aproveitamento pesqueiro, hidrelétrico, perenizador de rios. A população da cidade nunca entendeu porque o maior açude da Paraíba, jamais teve um projeto sério, viável economicamente no setor da irrigação, tendo em vista, que outros reservatórios insignificantes foram contemplados, a exemplo de São Gonçalo (Souza-PB), Sumé e Condado. As autoridades federais ligadas à autarquia (DNOCS) tem historicamente negado uma explicação plausível ao povo coremense, e é por isto que o marasmo continua aos dias atuais (Silva Filho, 1996, p. 124, grifou-se).

Assim como na analise feita por Edwards para a cidade de Bacup, falar do passado, e de um determinado passado, é uma maneira de mobilizar projetos de futuro. Aqui, como em outras partes do livro, Edvaldo Brilhante sublinhou a grandiosidade do passado de uma longínqua cidade do sertão da Paraíba que abrigou o maior açude do Brasil e chegou a ser "a capital noturna do país"21 por três vezes, contrastando-o com a decadência em que se encontra a cidade, numa tentativa declarada de mobilizar coremenses e "autoridades" a reaver a identidade local e o merecido destaque.

\section{Abrindo terreno para o progresso}

Os estudos nos boqueirões de Curema e Mãe D'água começaram a ser realizados logo após a criação do Inspetoria de Obras Contra as Secas (Iocs) em 1909. Na publicação que resultou das observações coletadas em expedição chefiada pelo o engenheiro Miguel Arrojado Lisboa (então responsável pela Inspetoria) e o geólogo 
Roderic Crandall em 1910, os autores destacaram as vantagens da curiosa geografia da região, com dois rios, o Piancó e o Aguiar, cortando a Serra de Santa Catarina em dois pontos distantes apenas cerca de $4 \mathrm{~km}$ um do outro (Crandall, [1910] 1977).

A descrição do local, acentuando as vantagens da construção de dois açudes contíguos leva o leitor a acreditar que a área a ser inundada seria uma espécie de vazio populacional. Há uma vaga menção à ocupação do local, através do registro de perdas agrícolas em anos anteriores devido à enchente dos rios. Crandall apontou ainda o baixo custo da desapropriação, devido à pequena área que o açude iria inundar.

Em 1912, foi formalizado o processo do açude público "Mãe D'água". Entre os poucos documentos que integram esse processo encontra-se a descrição do Boqueirão Mãe d'Água feita pelo Engenheiro Louis Phillipes e um desenho do mesmo, encaminhados à administração central em novembro de 1912.

Boqueirão do Rio Aguiar

Visitei este boqueirão mas faltando instrucções não fiz qualquer exploração. O boqueirão proprio é muito estreito. Ao nivel da agua não tem mais de $20 \mathrm{~m}$ de largura, e debaixo deste nivel aperta-se mais. Para uma altura consideravel todos os dois lados são quasi perpendiculares.

Tem de 7 a 8 metros dagua; e no fundo, em alguns logares encontra-se pedra limpa enquanto em outros tem areia. É pouco provável que tem muita areia porque na parte mais estreita a violencia da corrente carregaria este material leve fora do boqueirão, deixando a pedra limpa. Esta areia é depositada 50 metros por baixo numa praia como mostra o desenho.

Acima do boqueirão ha uma linha de pedra deserta de um lado do rio ao outro; e esta pedra impede perfeitamente a entrada no boqueirão da água e da areia dos poços e praias no leito do rio por cima da garganta.

Devido a esta linha de pedra, e a ausencia de areia no boqueirão, a construção duma barragem neste logar seria muito facil.

A pedra é a mesma que se encontra no Boqueirão de Curema. É quartzito de boa qualidade.

O Boqueirão do Rio Aguiar esta mais ou menos distante 4 kilometros 
do de Curema; e o rio entra a mesma serra, e as mesmas formações geológicas (Proc. $n^{\circ}$ 215/912, fl.4).

Apesar dos estudos terem sido realizados ainda em 1912, a instalação do açude Coremas foi iniciada apenas em 1935, conforme as notas fiscais encontradas no arquivo da seção de Desenvolvimento Humano do Dnocs em João Pessoa. As máquinas e parte dos operários foram transferidos do recém inaugurado açude de São Gonçalo, pela estrada que liga as duas localidades. Esta estrada também recebeu melhoramentos, conforme registram as notas encontradas.

O levantamento das propriedades inseridas no perímetro das bacias dos açudes de Coremas e Mãe D'água já havia sido concluído ainda em 1924. No processo referente ao açude público "Mãe d'Água", autuado em 9 de maio de 1927 na $4^{\mathrm{a}}$ secção do Ifocs (Rio de Janeiro), foram apensados três telegramas trocados entre o então Inspetor da Ifocs, Engenheiro Arrojado Lisboa, e o Engenheiro Ernesto Pyles, localizado em São João do Rio do Peixe, a pouco mais de $60 \mathrm{~km}$ de distância de Coremas. No primeiro deles, com data de 12 de março de 1923, Arrojado Lisboa pedia informações urgentes sobre o estado em que se achava o levantamento de "Mãe D'água" e perguntava quanto tempo demoraria para concluí-lo.

Dois dias depois, Ernesto Pyles respondeu que o levantamento estava pela metade, "com uns tres mil hectares levantados" e com vinte cadernetas taquiométricas prontas, sendo ainda necessários mais três meses para a conclusão dos trabalhos (Proc. sn/927, fls. 3-7). Em 6 de fevereiro de 1924, o engenheiro encaminhou à administração central do Ifocs, a planta topográfica da bacia hidráulica do açude "Mãi D'agua", a planta topográfica do boqueirão de mesmo nome, 43 cadernetas taquiométricas do levantamento topogáfico da bacia e do boqueirão e 4 cadernetas de nivelamento. Foi também remetida nessa ocasião a planta incompleta da bacia hidráulica de "Curema" (off. nº 5, Proc. sn/927, fl. 8).

A desapropriação por utilidade pública das áreas necessárias às obras dos açudes estava prevista pelo decreto n 19.726 de 20 de fevereiro de 1931. O Art. 17 
deste decreto dispõe que:

As obras cuja realização compete à Inspetoria, serão executadas em terras patrimoniais, ou previamente doadas, ou indenizadas, salvo caso de seca prolongada, - com o caráter de calamidade pública, - em que, depois de desapropriadas, a ocupação poderá anteceder à indenização, independente das formalidades (depósito do preço ou expedição do mandato judicial), exigidas pelo artigo 41, § $1^{\circ}$ do decreto n. 4.956, de 9 de setembro de 1903 (Decreto 19.726/1931, grifou-se). ${ }^{22}$

O artigo seguinte determina as terras consideradas de utilidade pública. São elas:

Art. 18. Para o fim de desapropriação serão considerados de utilidade pública;

a) as terras necessárias à construção das barragens e obras preparatória e complementares; a abertura de estradas de acesso, conservação e vigilância das bacias hidráulicas barragens e obras de irrigação, inclusive faixas circundantes às bacias, com 200m de largura, a partir da cota da crista das barragens, e seguindo a inclinação do terreno, e faixas à jusante, da mesma largura (200m) e comprimento que for julgado necessário;

b) as terras inundadas, consideradas como tais as áreas compreendidas entre as cotas do sangradouros e cristas das barragens;

c) as terras que ficarem ilhadas no perímetro inundado dos açudes;

d) as matas cuja conservação for julgada necessária (Decreto 19.726/1931, grifou-se).

As terras irrigáveis também seriam passíveis de desapropriação quando essas fossem julgadas necessárias ao estabelecimento de núcleos agrícolas ou fiscalização de serviços, caso essas não fossem cultivadas por seus proprietários (Art. 19).

Embora os trabalhos tivessem sido iniciados ainda em 1935 e os levantamentos fundiários estivem concluídos desde 1924, os primeiros pagamentos de indenização de terras ocorreram apenas em 1937.

No livro despesas referente a esse ano, foi possível localizar quatro escrituras 
públicas de "desapropriação amigável por utilidade pública" registradas no Cartório do Escrivão de Paz João Figueiredo Filho. Foram anexadas às escrituras as notas com os valores pagos e a assinatura dos donos declarados, de duas testemunhas e do chefe da Comissão do Alto Piranhas, Estevam Marinho, representando a Ifocs nesse ato. Além das notas referentes às escrituras apensadas no livro, havia mais duas notas de pagamento referentes às desapropriações realizadas pela Inspetoria. Analisando as descrições das escrituras, é possível afirmar que, até dezembro de 1937, tinham sido pagos, pelo menos, os lotes de 1 a 7, o lote 9 e o de número 14.

Em umas das listas de lotes pagos pelo Dnocs em Coremas, há o registro do pagamento dos 10 lotes de terra não contíguos pertencentes a Francisca Pereira de Carvalho e Maria Silva de Lacerda (6.310ha ao todo) ainda em 1939. Os demais pagamentos foram feitos a partir da década de 1940, mas ainda existiam lotes a pagar em 1975, quando os documentos referentes às desapropriações na Paraíba foram enviados para a sede do Dnocs em Recife.

Os pagamentos feitos em 1937, cujas escrituras estão no livro de despesas referente a esse ano, aparecem na tabela mais antiga encontrada no arquivo da Divisão Técnica do Dnocs em João Pessoa. Essa tabela está sem assinatura ou indicação de data. Pelo estilo do papel e da impressão, é provável que a mesma tenha sido feita entre as décadas de 1940 e 1950. Nessa tabela, estão relacionados 558 lotes com a numeração de 1 até 520 (quarenta e um desses apresenta uma letra ao lado de numeração repetida). Um deles (lote 177) não possui indicação de área e outros 3 estavam "fora da faixa' (lotes 417, 352, 353).

Consta dessa tabela o nome do proprietário, o "lugar" onde estava a propriedade, a área da mesma, quem assinou a notificação, ou levantamento feito pelo Dnocs, e o "número das folhas". Não há indicação sobre o que se refere o número de folhas, que são poucas e repetidas, podendo se referir ao número das folhas do livro em que foram coletadas as assinaturas.

A indicação da assinatura não aparece nas listas subsequentes e o lugar de 
localização dos lotes só aparece novamente nas fichas de "cadastro das desapropriações do açude E. Marinho-Mãe D'água" anotadas a lápis e com muitas anotações com datas diversas. Essas duas relações são as únicas a indicar as áreas pagas em 1937.

Analisando as áreas dos lotes anotadas na primeira tabela, tem-se que $82 \%$ dos mesmos tinha área inferior a 60 ha (27\% entre 0-10ha, 35\% entre 10,1-30 ha e 20\% entre 30,1-60 ha) e apenas 8\% possuía área superior a 100 ha, conforme gráfico. ${ }^{23}$

Os dados representam graficamente o relato de Dona Chiquinha Guedes e aqueles coletados por Andrade (2008), mostrando a existência de inúmeras pequenas propriedades, ou sítios como são denominadas localmente. ${ }^{24}$

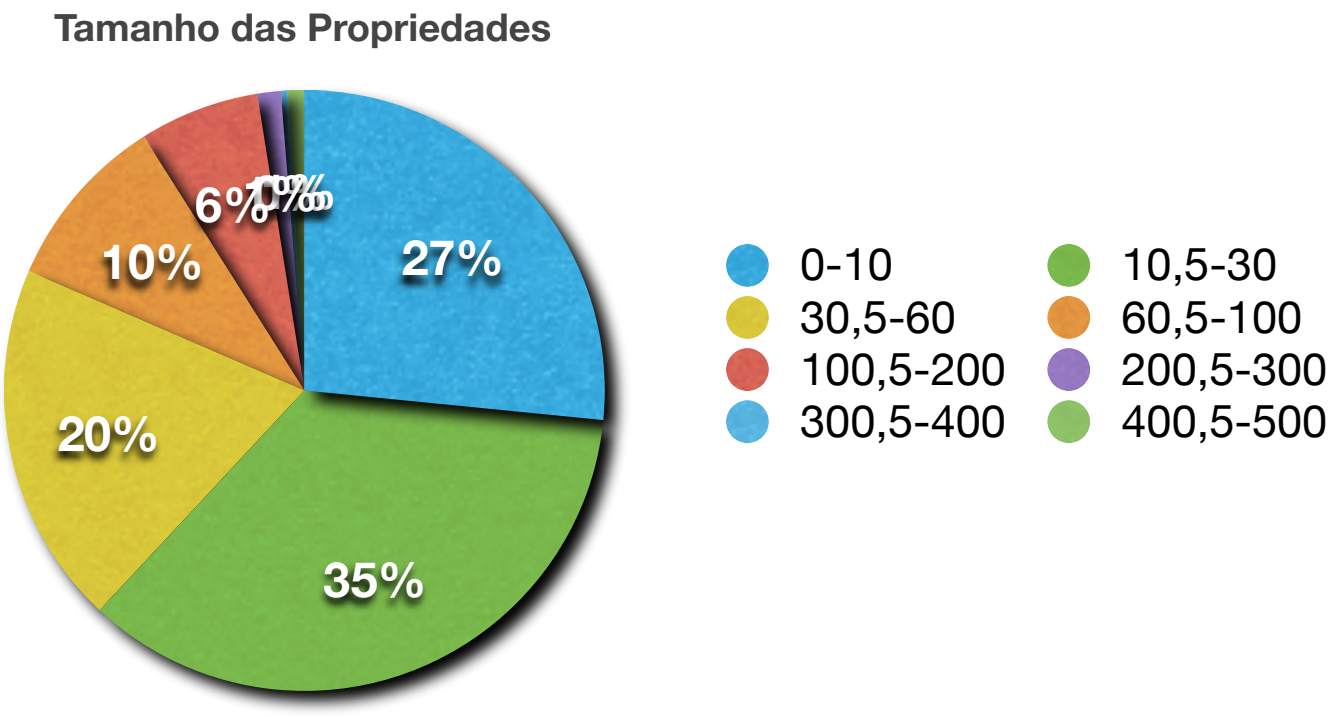

Em meados de 1950, quase uma década depois de iniciadas as obras de fundação do açude Mãe D'água, novos lotes foram cadastrados para serem desapropriados. Os novos levantamentos foram iniciados em 27 de julho de 1954, de acordo com telegrama enviado pela $3^{\text {a }}$ Residência no dia 29 do mesmo mês.

Poucos tempo depois, em setembro de 1954, foi encaminhado ao Chefe do Dnocs em João Pessoa um pedido de providências que Assembléia Legislativa do Estado da Paraíba havia feito junto ao Presidente da República. Neste, a Assembléia solicitava que a construção do açude Mãe D'água fosse paralisada, uma vez que os 
serviços para a desapropriação dos lotes inseridos na bacia hidráulica deste açude não tinham sido concluídos, o que deveria ser feito antes do fechamento da barragem. Atendendo à solicitação da Assembléia, foram enviadas duas turmas para finalizar o serviço.

Mesmo não tendo sido finalizado o cadastramento, em 7 de dezembro de 1954 o decreto 36.570 declarou de utilidade pública para efeito de desapropriação pelo Dnocs a área de terreno com 159.937.000m² (cento e cinquenta e nove milhões novecentos e trinta e sete mil metros quadrados [15.993,7ha]) necessária à construção dos açudes Curema e Mãe D'água ${ }^{25}$. Esse decreto foi renovado em 1961, através do Decreto $n^{\circ}$ 50.436, de 11 de abril, e, novamente, pelo Decreto $n^{\circ} 63.278$, de 25 de setembro de $1968 .{ }^{26}$

A fundamentação legal do primeiro decreto declaratório é o art. 87, inciso I, da constituição e o Decreto-Lei $n^{0}$ 3.365, 21 de junho de 1941, que dispõe sobre as desapropriações por utilidade pública. ${ }^{27}$

O primeiro decreto declarando de utilidade pública uma área como sendo necessária à construção de um açude público por parte do Dnocs foi expedido em 21 de setembro de 1948 (Decreto $n^{\circ}$. 25.532)28. Além da legislação citada acima, fundamentam estes decretos desapropriatórios os Arts. 17 e 18 do regimento do Dnocs aprovado em 1931 (Decreto 19.726/1931).

Em 26 de janeiro de 1949, foi editada a primeira normativa interna dando instruções sobre o processamento de desapropriações e pagamento de indenizações, substituída pela de $n^{\circ} 1$-T de 5 de novembro de 1950. Entre os anos de 1949 e 1958 foram publicados 92 decretos declarando de utilidade pública áreas necessárias às obras do Dnocs (Dnocs, 1958 1).

O levantamento dos novos lotes da bacia hidráulica do açude Mãe D'água foi concluído em 28 de fevereiro de 1955 (telegrama 30.03.1955, Proc. 108/55) e, em 24 de maio de 1956, o Engenheiro Residente Ivanildo Marinho Cordeiro de Campos encaminhou para a sede em João Pessoa os cadastros dos lotes 553 a 561 e suas 
respectivas plantas.

O lote de número 553, primeiro desse novo levantamento, englobava parte da Fazenda Cachoeirinha, uma das maiores da região. O proprietário desta, Antônio Lopes Filho, foi prefeito de Coremas nos períodos 1955 a 1959, 1963 a 1969 e 1973 a 1977.29

Carta SB 24 Z-C-II (Sudene, 1982)

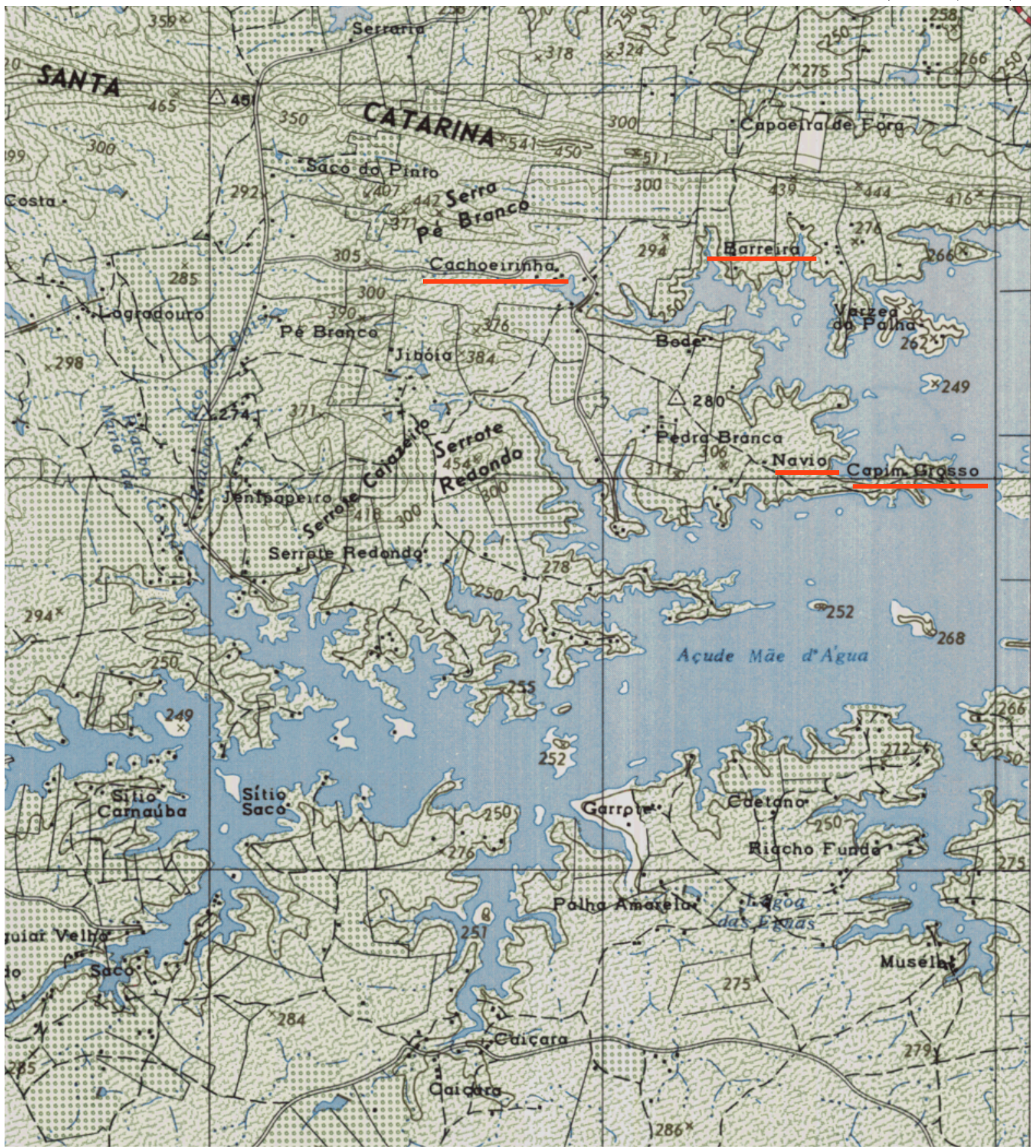


A relação das benfeitorias desse lote, que é parte do processo de desapropriação, mostra uma realidade bem distinta daquela descrita por Roderic Crandall em 1910 e que caracterizava a área dos futuros açudes como uma espécie de vazio demográfico (Crandall, [1910] 1923).

De acordo com o levantamento feito pelo Dnocs, a parte da Fazenda Cachoeirinha a ser desapropriada, com 22,1500 ha de terra de aluvião de encosta e 144,8500 ha de terra de tabuleiro aluvial, continha as seguintes benfeitorias: um algodoal mocó, em franca produção com a área de 26,6250 ha; 27 oiticicas grandes; 38 oiticicas de porte médio; 30 oiticicas pequenas (2 a 5 anos); 170 covas de bananeiras grandes; 50 jucazeiros grandes; 3 mangueiras grandes; 7 mangueiras pequenas; 3 ateiras grandes; 4 coqueiros grandes; 2 coqueiros pequenos; 110 mandacarus grandes; um açudinho de terra (construção tosca) com 102,700 m³; 7 casas de taipa, cobertas de telhas, sem reboco e caiação com o piso de barro batido, em bom estado de conservação com a área de 426,00 m²; 5.453 metros de cerca de madeira trançada.

O lote de número 558, pertencente a João Soares de Souza, era vizinho à área desapropriada da fazenda de Antônio Lopes. A área do lote de João Soares era de 253,75ha e também continha entre suas benfeitorias um algodoal em produção, muitas oiticicas, canafístulas, mandacarus e carnaúbas e dez casas de taipa, cobertas de telhas, sem reboco e caiação, piso de barro batido, em bom estado de conservação, com 543,10m². Também vizinho, estava o lote de João Pereira de Oliveira (lote 598) com 310 hectares que tinha, entre outras benfeitorias, 325 pés de oiticicas grandes, 515 carnaubeiras grandes, 4.352 palmas e, 12 casas de taipa (cobertas de telhas com piso de barro batido, em bom estado de conservação, totalizando 1.006,10 m2 de área coberta).

Outra área vizinha era Barreiras, lote 554, de propriedade do Senhor Gonçalo André de Lacerda. Como o proprietário discordou da avaliação feita pelos engenheiros do Dnocs, uma segunda avaliação foi feita no local. Após essa nova avaliação, foi assinado o termo de ajuste em maio de 1957, transcrito abaixo: 
Aos vinte e quatro (24) dias do mês de maio do ano de 1957 no escritório da $3^{\text {a }}$ Residência do Segundo Distrito do Departamento Nacional de Obras Contra as Sêcas, sitio no acampamento do açude público ESTEVAM MARINHO (ex-Curema) Município de Coremas, Estado da Paraiba, compareceu, a convite do Snr. Eng ${ }^{\circ}$ Vitoriano Gonzales y Gonzales, autorizado pela Portaria 16-S de 25-6-956 do sr. Chefe do Distrito, o cidadão GONÇALO ANDRÉ DE LACERDA, brasileiro, casado, agricultor e sua esposa, Maria Salomé da Silva, brasileira, casada, domestica, ambos residentes no Municipio de Campos Sales, Estado do Ceará, aqui representados por seu procurador o cidadão José Ferreira Cavalcanti, brasileiro, solteiro, comerciante, residente na cidade de Coremas, conforme procuração que apresentou, que, sendo proprietário do lote de terra assinalada na planta cadastral do açude público MÃE D'ÁGUA no municícpio de Coremas do Estado da Paraíba, sob o numero 554, ajustou com o Departamento Nacional de Obras Contra as Sêcas, a desapropriação amigavel por utilidade pública, do mencionado lote de terra e das benfeitorias nele existentes, conforme adiante se descreve, por ficarem na área necessária ao referido açude, mediante a indenização de TREZENTOS E DEZOITO MIL DUZENTOS E QUARENTA E OITO CRUZEIROS (Cr\$ 318.248,00), o lote de terra numero 554 aludido é situado no lugar denominado Barreiras extremado, ao norte e partes de leste e de oeste, com terrenos restantes da mesma propriedade, que ficam fora da área sujeita a desapropriação, delimitados pela linha de demarcação do contôrno da bacia hidraulica do açude Mãe D'água, a parte restante de leste, limita-se com os lotes de terra ns 226 e 555, o primeiro já pertencente a União Federal [lote denominado como Navio, cujo proprietário Cândido Rufino de Souza foi pago em 1942] e o segundo de propriedade de Antônio Matias da Silva; ao Sul, ainda com o mesmo lote n. 555 e com o de n. 558 de propriedade de João Soares de Souza, a parte restante de oeste limita-se também com o lote n. 558 mencionado. O lote de terra n. 554, mede a área total de 1.028,500 metros quadrados, de terra de aluvião fluvial de aluvião de encosta e de taboleiro aluvial, tem no mesmo encravadas as seguintes benfeitorias: um algodoal mocó em franca produção, com a área de 365.250 m²; 56 oiticicas grandes; 225 
jucazeiros grandes; 5 carnaubeiras grandes; 97 juazeiros grandes; 2 barragens de alvenaria de pedra argamassada de cal, revestida com argamassa de cimento, com o volume de alvenaria de 181, $540 \mathrm{~m}^{3}$; um açudinho de terra (construção tôsca) com o volume de terra de 36 metros cúbicos; uma casa de tijolos coberta de telhas, tendo a frente rebocada e caiada, com o piso ladrilhado a tijolo proprio, em bom estado de conservação, com área coberta de $84,60 \mathrm{~m}^{2} ; 10$ casas de taipa cobertas de telhas, com os pisos de barro batido em bom estado de conservação, com a área total de 291,10m² e 6.853 metros lineares de cêrcas de madeira trançada. A propriedade foi adquirida por compra feita a Antonio Leopoldo Urtiga e sua mulher dona Rita Eufrasina Urtiga, conforme escritura de compra e venda, devidamente transcrita no Registro de Imóveis desta comarca de Coremas sob o numero 109, às fls. 34 do livro n. 3, em data de 28 de junho de 1956. Os proprietários que estão pleno acôrdo com as medições e avaliação procedidas, declaram que no lote de terra assim discriminado, não existe outra qualquer benfeitoria ou proprietario, além do que foi acima declarado, comprometendo-se a apresentarem oportunamente a documentação necessaria e a transferencia da posse do Imovel mediante escritura de desapropriação quando lhes for solicitada.

Gonçalo André e sua esposa tiveram ainda mais um lote desapropriado, o de número 646, também em Barreiras. Essa propriedade foi adquirida dos mesmos vendedores que o lote descrito acima e a data do registro da escritura de compra e venda também é a mesma. O termo de ajuste, assim como do lote descrito anteriormente, só foi assinado após uma segunda avaliação.

Outros proprietários também discordaram da avaliação feita pelos engenheiros do Dnocs, como foi o caso de Maria Amélia de Souza que, em 15 de setembro de 1956, solicitou revisão na avaliação de sua terra (lote 559), recebida através do ofício $\mathrm{n}^{\mathrm{o}} 116-\mathrm{T}$ do Dnocs datado de 6 de junho do mesmo ano. De acordo com a solicitação "os preços aludidos" eram muito baixos "tanto na parte de baixo (terrenos) como nas benfeitorias". O pedido foi atendido e uma nova avaliação foi feita em 31 de outubro do mesmo ano.

Ainda nessa mesma data, foi encaminhada uma nova avaliação das terras de 
João Soares de Souza e o preço anteriormente estipulado em 473.340,10 subiu para $545.414,20$ na segunda avaliação, representando um aumento de cerca de $15 \%$ no valor inicial.

O proprietário Paulo Andrade de Souza também considerou muito baixos os valores atribuídos a algumas de suas benfeitorias, como a palma e duas casas de taipa. A área de seu lote era bem menor que as citadas anteriormente totalizando 19,5ha. Na breve descrição deste, vê-se que esse proprietário era bem mais modesto que os que foram citados até aqui.

Quero adiantar a V.S. que o preço da minha palma grande e media num total de 64.999 covas que posso provar que existe a qualquer momento que mandar verificar, saiu a 4,50 e 2,00 respectivamente e a casa a 100,00, sendo a mesma coberta de telhas, com madeiramento de primeira, caiada e rebocada por dentro, com piso atijolado.

Por isso é que venho pedir encarecidamente a V.S. se digne de mandar o engenheiro da Residência, a mandar fazer na casa, de 6,00, 400 e uns 140,00 que só assim é que pode compensar alguma coisa, por que tenho que dividir o dinheiro de minha propriedadezinha com os meus filhos herdeiros de minha falecida mulher e ficar com alguma coisa para procurar outro meio de vida, já que a a agua vai destruir a minha propriedade que se a agua não cobrisse eu não queria indenizar por preço nenhum.

Faço essa reclamação porque já reclamei em primeiro lugar ao engenheiro e ele me disse que só tinha ordem do senhor de botar os preços médios (Of. 6 de dezembro, 1956).

O lote de Paulo Andrade foi pago em 1957, mas não foi possível verificar se foi feita uma nova avaliação. Os herdeiros de Izidoro Matias também enviaram solicitação para revisão da avaliação recebida em 5 de junho de 1956 através do ofício 111 "T". Os herdeiros consideraram muito baixa a indenização "em face do valor das cousas elevado nível de padrão de vida" e apelaram ao "elevado espirito de justiça" do Diretor para que concedesse um aumento de cem mil cruzeiros no terreno a ser desapropriado (Of. 17 de dezembro, 1956). 
Um dos proprietários descontentes contou ainda com a interveniência do deputado Plinio Lemos, que enviou requerimento ao Dnocs solicitando providências (Req. 3008/1958). Em 16 de dezembro de 1959, foi enviado rádio pedindo informações para responder ao deputado. As informações requeridas foram:

a) Desde quando procedidas avaliações lotes 681 e 768 propriedade Francisco Luiz França encravados açude Mae Dágua pt b) qual montante de avaliações pt c) se convidado pelo engenheiro encarregado obras vg compareceu sede residencias vg devidamente munido escritura domínio vg devidamente registrado pt d) se dnocs por seu delegado vg oficiou expropriado dando valores avaliação feitas e se o mesmo concordou com recebimento importância oferecida pt e) se citados lotes estão cobertas águas bacia hidrográfica mãe d'água e desde quando pt f) motivos que levam (ilegível).

Embora não tenha sido possível localizar o processo de Francisco Luiz França, encontramos seu nome em uma das relações de proprietários não pagos elaborados pelo Dnocs em João Pessoa.

Depois de feitas as avaliações, alguns proprietários construíram benfeitorias em seus terrenos esperando ser ressarcidos também pelas novas construções. Em 4 de dezembro o proprietário do lote n. ${ }^{\circ}$ 595, João Maria da Silva, dá a saber que construiu uma casa de taipa e telhas com 80 palmos de fundo por 36 de frente e 200 metros de cercas de madeira e pede para que seja medida a referida benfeitoria para que seja indenizado

Esse não deve ter sido o único caso, o que fez com que o Engenheiro Residente enviasse ofício à administração central no dia seguinte ao pedido de João Maria da Silva, notificando que alguns proprietários de terras "localizadas na área necessária ao açude público "Mãe D'água"' estavam construindo casas apesar de já possuírem "propostas para desapropriação amigável por utilidade pública" e solicitando providências (of. n 59 "D").

Como espécie de compensação aos baixos valores pagos nas desapropriações, em 16 de fevereiro de 1962, o Vigário de Piancó enviou uma carta ao Ministro da 
Viação solicitando máquinas para o transporte e preparo de material para a reconstrução da Igreja Matriz.

O povo piancoense recebeu os benefícios da barragem de Coremas, como seja a energia elétrica, mas êste benefício lhe custou pesada soma de sacrifícios, entre os quais, perdeu sua antiga matriz, hoje na faixa atingida pelas águas da grande reprêsa.

A indenização já foi feita, entretanto, não correspondeu ao valor do secular templo, condenado a ser reduzido a escombros, seu material seria destinado a construção da nova Matriz.

Uma Igreja que foi o bêrço da civilização de todo o Vale do Piancó deverá ser conservada como uma relíquia histórica da região.

(...)

Essa cooperação [empréstimo de maquinário] se justifica pela razão de Piancó ter perdido sua antiga Igreja, ora causa de uma obra do Govêrno Federal, o açude de Coremas,

Trata-se de uma obra que virá beneficiar tôda uma coletividade. Será um amparo à classe operária necessitada de trabalho, em certas fases do ano, principalmente naqueles de longo estiagem.

A área desapropriada foi ampliada ainda mais uma vez através do decreto $\mathrm{n}^{\circ}$ 61.173 de 18 de agosto de 1967, que declarou de utilidade pública a área de terreno com 20.902.000m2 (vinte milhões, novecentos e dois mil metros quadrados [2.090,2ha]) necessária à implantação do Projeto de Irrigação do Açude Público Estevam Marinho. ${ }^{30}$ Essa nova declaração ocorreu antes de terem sido pagas todas as indenizações dos imóveis abrangidos pela declaração de utilidade pública de 1956.

Os processos de desapropriação se arrastaram por mais de duas décadas, tornando ainda mais defasado o valor das indenizações. Buscando corrigir a distorção, o proprietário Manoel Bezerra de Souza enviou carta ao Diretor Regional em março de 1970 (processo 210/70).

Com a presente venho expôr a V. Excia, uma situação e solicitar a vossa boa vontade no sentido de resove-lo: Sou proprietario de varios lotes de 
terra, situados na bacia hidráulica do açude público Mãe D'agua no municipio de Coremas, correntes de serem desapropriados há varios anos, haja visto que as terras se acham cobertas pelas águas sem nenhuma produtividade e consequentemente me acho prejudicado juntamente com outros na mesma situação.

Sr. Diretor, existe outro fato que considero com a minha ignorancia peculiar de matuto, que trago tambem a baila, é que a tabela de preços unitários continua a mesma de 10/02/66, publicado no boletim oficial $\mathrm{n}^{\mathrm{o}} 4$, depois que já tivemos mais de três salários mínimos e o custo de vida subiu mais de $200 \%$, principalmente em terras pois enquanto o D.N.O.C.S., paga Cr\$ 30,00 por hectáre de de terra de $1^{a}$, o particular não vende um hectáre de carrasco por menos de $\mathrm{Cr} \$ 200,00$.

O proprietário afirmou ainda que havia tido notícias sobre uma nova tabela que estava sendo elaborada exclusivamente para Sumé e já que "o custo de vida não subiu só em Sumé" pediu que fosse elaborada uma nova tabela também para Coremas.

Muitas listas referentes às desapropriações foram elaboradas. Em uma pasta contendo os termos de ajuste de 1959, localizei uma lista feita parte à lápis e parte a caneta com o título "Relação de Propriedades ajustadas em Mãe D'água", datada de 1957, com 110 propriedades. Nessa mesma pasta, sem data, anotada a caneta, encontrei ainda a lista com 174 "proprietários com respectivos lotes e áreas não pagas do açude Estevam Marinho".

Em uma lista datilografada organizada pelo Auxiliar Administrativo Raimundo Moraes em 24 de abril de 1961, foram relacionados 225 lotes (527 a 856). No final desta consta uma nota explicando que as avaliações foram elaboradas de acordo com os preços médios da tabela expedida pelo Dnocs em 1956. Para o lote 553 de Antônio Lopes Filho foi feita a observação de que este "não quiz proposta". O mesmo foi anotado para o lote 558 de José Soares de Souza. Na folha inicial dessa lista foram feitas duas anotações a caneta: "Ver se coincide com os lotes a pagar pela ficha" e "Até 1961, não foram pagos os lotes constantes desta relação", assinado (ilegível) em 
31 de janeiro de 1969.

Outra das muitas listas que foi possível localizar na confusão dos documentos da Divisão Técnica da sede em João Pessoa foi a intitulada "Quadro dos processos pagos no açude público 'Mãe D'água' até o presente", assinada por Josilino Jorge dos Santos com data de 13 de março de 1962. O quadro, datilografado, contém duas anotações a caneta uma no topo direito do documento "conferir pelas fichas" com flechas indicando as entradas da tabela referente a área, quantia, o número do lote e pagamento e, ao lado do título do quadro a indicação "em 1959". São listados 36 proprietários e 53 lotes. Um dos proprietários foi pago em outubro de 1955, 3 em 1957 e o restante em 1958.

Como foi apontado na Parte I, em 1967 uma reestruturação do Dnocs mudou a hierarquia entre as sedes regionais e o Dnocs de João Pessoa passou a ser subordinado à $3^{\text {a }}$ Diretoria Regional (DR) com sede em Recife. Grande parte dos documentos referente aos açudes foi transferida de João Pessoa para Recife a partir dessa data, inclusive os processos, tabelas e outros documentos referentes às desapropriações das bacias dos açudes públicos na Paraíba. Grande parte das listas que permaneceram entre os documentos aleatoriamente guardados no setor técnico são listas preliminares, com anotações a caneta ou lápis como se estivessem sendo corrigidas para serem enviadas para a $3^{\mathrm{a}} \mathrm{DR}$.

Entre estas, foi possível localizar a "Relação de propriedade dos Bens Imóveis pertencentes ao D.N.O.C.S., referente a indenizações de terras e benfeitorias no açude público Sistema 'CUREMA - MÃE D'AGUA'" com data de 16 de outubro de 1967. A lista, assinada pelo Chefe da SA/ST - $2^{\circ}$ D.O., contem a seguinte observação: "Trata-se de uma via da relação remetida a $3^{\mathrm{a}}$ DR c/ o Ofício n ${ }^{\circ}$ 1853/SA/ST, de 17 de outubro de 1967". São elencados 74 proprietários. Uma das entradas da tabela diz respeito à escritura do imóvel em nome do Dnocs e ao registro da mesma. Grande parte das escrituras (73\% do total) foram lavradas durante os anos de 1957 e 1959. Entre 1950 e 1956 apenas 3 escrituras foram lavradas e entre 1963 e 1966, outras 17. 
Nessa lista não foram registradas as desapropriações feitas nas décadas de 1930 e 1940.

Em 25 de setembro de 1968, foi elaborada nova tabela indicando a situação de 652 proprietários e 866 lotes com o título "Quadro demonstrativo das indenizações do açude público 'Estevam Marinho', construído no município de Coremas, Estado da Paraíba". Apesar de o título fazer referência apenas ao açude Estevam Marinho, as desapropriações da bacia hidráulica do açude Mãe D'água também constam da relação. Segundo informação no final da tabela, os dados foram "extraídos à luz das escrituras". Apesar do decreto de 1967 mencionado acima, as desapropriações são todas anteriores a essa data. Como já foi mencionado, poucos foram os pagamentos feitos na década de 1960.

Nessa tabela, além do nome dos proprietários, número dos lotes, valor e área dos mesmos, há uma coluna com a situação do pagamento dos lotes, divididas em quatro situações: lotes pagos sem processo (PGSP), lotes pagos arquivo distrital (PGAD), lotes a pagar sem processo (APSP) e lotes a pagar com processo (APCP).

Comparando as informações dessa tabela com a lista dos processos remetidos da sede em João Pessoa para Recife em 1973, vê-se que os lotes denominados como "pagos arquivo distrital" são aqueles que possuem processo. Embora não seja especificado como foram pagos os lotes sem processo, é possível que estes tenham sido pagos mediante termo de ajuste assinado pelos proprietários na sede do Dnocs em Coremas, como foi o caso de Mariano Lucio da Silva e sua esposa, que receberam pagamento através de assinatura de termo de ajuste em 16 de outubro de 1958 e aparecem na tabela como lote pago sem processo.

Na relação dos documentos enviados da sede do Dnocs em João Pessoa para a sede do órgão em Recife em 1973 (caixas 1 a 14), há 335 proprietários e 494 lotes desapropriados nas bacias hidráulicas dos açudes Coremas e Mãe D'água. Esses processos foram concluídos, ou seja, os proprietários receberam indenização por seus lotes. Muitos outros, entretanto, não foram pagos e permanecem encaixotados 
na sede de João Pessoa. Essas caixas foram organizadas em 1969.

Os problemas gerados pelas avaliações e demoras nos pagamentos resultou em um processo de investigação. Em 15 de fevereiro de 1971, um ofício remeteu o processo $n^{\circ} 01393 / \mathrm{MI} / \mathrm{GAB} / \mathrm{GB} / 70$ para que se procedesse uma sindicância a fim de apurar as irregularidades que estariam ocorrendo nas desapropriações de terras abrangidas pelo Açude Público Estevam Marinho (Of. 13DR3/SRDCT). Não foi possível, entretanto, verificar as providências tomadas para sanar as irregularidades nas desapropriações.

Analisando os termos de ajuste e processos não pagos, chama atenção as datas de algumas aquisições de terra. O registro das escrituras de compra e venda de Gonçalo André e sua esposa, por exemplo, datam de 1956, ano em que o processo de cadastramento dos lotes já havia sido concluído, apontando pra um processo de intensa especulação imobiliária.

Antônio Lopes também adquiriu a fazenda Cachoeirinha quando o açude de Coremas já havia sido construído e os levantamentos para desapropriação da bacia hidráulica do açude Mãe D'água já haviam sido iniciados. Embora não tenha sido possível definir a data correta da aquisição, o Sr. Severino Jorge de Amorim, nascido em 1937 na fazenda Cachoeirinha, afirmou que seu primeiro patrão havia sido João Félix de quem Antônio Lopes comprou a propriedade. Segundo relato de um antigo morador, Antônio Lopes adquiriu a fazenda ao quitar as dívidas de João Félix no banco. Este tornou-se morador em sua antiga família e desgostou-se morrendo logo depois. 31

Esse não foi o único episódio dramático causado pela especulação de terras derivada das obras públicas no local. Dona Francisca Silva Guedes, 80, moradora de Mãe D’água há mais de 60 anos, contou que seu marido era filho de um fazendeiro local e tinha grande apego à terra. Mesmo quando tornou-se funcionário do Dnocs durante a construção da barragem, mantinha um roçado no qual trabalhava durante as tardes. Após a venda da propriedade do pai para Amâncio Faustino, ele "varreu a 
cabeça" e "pegou uma crise de nervos". Foi à João Pessoa tentar um empréstimo para comprar a propriedade de volta mas "quando voltou já estava louco". Dona Francisca ainda mora na casa do Dnocs que o marido "ganhou" quando era funcionário do órgão.

No recenseamento dos estabelecimentos rurais da Paraíba realizado pela Diretoria Geral de Estatística em 1920, foram recenseados 1.175 estabelecimentos no município de Piancó. ${ }^{32}$ Rita de Cássia de Andrade apontou em sua dissertação a existência de 661 escrituras de terra registradas no Cartório Lucas de Lacerda em Coremas referentes à zona rural do distrito entre os anos de 1922 e 1939 (Andrade, 2008, p.71). O verbete "Coremas" do Dicionário Corográfico do Estado da Paraiba registrou ainda que o recenseamento de 1940 contou 939 propriedades rurais 4.449 pessoas morando na zona rural (Medeiros, 1959, p.87).

Comparando o recenseamento de 1920 com a mais antiga lista de lotes cadastrados para desapropriação pelo Dnocs, percebe-se a progressiva divisão dos sítios em propriedades menores, tendência que Andrade também detectou em sua dissertação. As propriedades com denominação Mãe D'água, por exemplo, eram apenas 3 em 1920. Já no levantamento do Dnocs iniciado na década seguinte, apareceram 15 propriedades com esse nome. O estabelecimento rural Estreito estava dividido em duas propriedades em 1920, registradas em nome de José de Carvalho Silva Sobrinho e Izidora Ursolina de Maria e outros. Em 1942, quatro lotes com essa denominação foram pagos a Firmino Lucas de Lacerda.

O levantamento realizado pela Ifocs durante os anos de 1923 e 1924, a construção de açudes públicos em municípios próximos como os de Condado, Boqueirão de Piranhas e São Gonçalo e a iminente realização de obras federais em Coremas dinamizaram a estrutura agrária do local acentuando o processo de divisão de antigas propriedades e aquecendo o mercado de terras.

Ao mesmo tempo que as descrições dos lotes feitas nos processos e termos de ajuste demonstram que a área era bastante produtiva, ao contrário da realidade 
descrita por Crandall em 1910, elas escondem os dados sobre a quantidade real de pessoas que vivia nesses lotes. Como veremos mais a frente, os moradores dessas fazendas não aparecem nessas relações e apenas podemos supor sua presença expressiva pela indicação das casas de taipa constante das propriedades.

\section{O trabalho nas obras}

A construção dos açudes e estradas na região de Coremas mobilizou grande número de trabalhadores organizados de maneira precária nas "obras de emergência contra as secas", ou simplesmente emergências segundo denominação regional.

A "fôlha de pagamento dos operarios empregados nos serviços de construção do açude publico 'Curema'" referente ao mês de dezembro de 1937, registrou 1.610 operários. No mesmo período, um resumo dos trabalhadores da estrada de rodagem São Gonçalo-Curema registrou mais 257 pessoas. Em fevereiro do ano seguinte, a obra no açude de Coremas registrou 1.717 pessoas para o mês de fevereiro e, em dezembro, o órgão ainda mantinha em sua folha 1.539 operários, além dos mensalistas do órgão.

O açude "Curema" foi inaugurado por Getúlio Vargas em 1940, mas a obra só terminou de fato em 1942. Em 1941, a folha do mês de março registrou 1.083 operários. Ainda em 1939, antes de terminada a construção do primeiro açude, foi estabelecida a locação definitiva para a barragem do açude Mãe D'água. Segundo o Engenheiro Estevam Marinho,

(...) a bacia hidrográfica do "Mãe D'água" não podendo, por si só, atender à capacidade do reservatório, receberá o concurso das águas do "Curema" que, pela sua extensão e altura média de chuvas, está apta a abastecer com folga, o conjunto dos dois reservatórios. Pode-se dizer mesmo, que se trata dum reservatório único, reprodução, em menores proporções, do grande lago que existiu antes de ter sido cortada a Serra de Santa Catarina nos três boqueirões do "Piranhas, "Curema" e "Mãe D'água". Procura assim a Inspetoria de Sêcas reconstituindo, dentro das finalidades em vista, um pouco 
das condições naturais do passado, preparar num futuro, que já se divisa próximo, a felicidade duma extensa região graças à formação de reservas dágua que lançadas nos canais irão garantir a agricultura, ou então, correndo pelos leitos dos rios contribuirão para regularizar os seus regimens (Dnocs, 1939b, p. 82).

O objetivo do conjunto Coremas-Mãe D'água, conforme exposto acima, era a regularização do Rio Piancó, principal formador do rio Assú. A obra tinha importância no aproveitamento intensivo das terras do baixo vale tornando possível a existência de um rio perene "cortando os sertões da Paraíba e do Rio Grande do Norte". Com a perenização dos rios, as margens seriam ocupadas pela pecuária e os lotes irrigados poderiam ser usados pelos particulares "em substituição ao precário sistema de vazantes nos leitos sêcos das torrentes".

E a água do Nordeste é tão preciosa que seria um crime construir reservatórios de simples regularização; êles devem, sempre que possível, ser principalmente de retenção, isto é, amplos, capazes de recolher, de armazenar toda a água que a êles afluir, para que essa mesma água, domada convenientemente, transforme o leito sêco do rio antigo em um filete perene e contínuo, portador de umidade e de vida aos moradores ribeirinhos, aos rebanhos, à pequena agricultura ou então vá cumprir nos campos, atravez dos canais adutores, sua missão suprema que é a irrigação (Dnocs, 1939b, p. $82)$.

As obras no boqueirão de Mãe D'água só foram de fato iniciadas em 1942, ano em que foi declarada outra grave seca. O decreto-lei 4.228 de 2 de abril de 1942, liberou um "crédito especial" para o Ministério da Viação e Obras Públicas (Mvop) de "7.970:000\$0 para as despesas em obras rodoviárias", como a finalização do ramal do Cariri e a construção do trecho Jardim do Seridó-Caicó, no sertão paraibano.

Em maio de 1942, um telegrama do Chefe da Comissão do Alto Piranhas, localizada em Coremas, dava conhecimento da chegada de "caravanas emigrantes" a procura de emprego,

Desde o dia 12 de fevereiro suspenderam chuvas há 8 dias chegando 
Curema caravanas emigrantes procura emprego face perspectiva sêca cerca 800 homens reduzidos extrema situação sem trabalho consternados... (Dnocs, 1953, p. 25).

Além das obras em curso, o Inspetor propunha que fossem tomadas as seguintes medidas:

d) A distribuição de famílias de retirantes pelas vazantes das bacias hidráulicas dos açudes públicos construidos; as vazantes que normalmente são arrendadas, poderão ser cedidas, a título gratuito, enquanto perdurar a crise, a critério do Chefe do Distrito ou Comissão;

e) a localização de famílias retirantes nas áreas irrigadas dos Postos Agrícolas, distribuidos pequenos lotes para cultura, nas condições anteriores;

f) a localização, ainda em pequenos lotes, de famílias retirantes nas áreas das bacias de irrigação já dominadas pelos canais e ainda não cultivadas pelos respectivos proprietários

A última das providências indicadas implica o preparo prévio das terras a serem cultivadas (destocamento e terraplanagem) e a ocupação, mediante arrendamento, que teria de ser compulsório, da propriedade particular, durante o momento de crise. É providência que exige assim exame mais detido e meticuloso para que possa ser proposta definitivamente (Dnocs, 1953, p. 27).

Entre as providências que já tinham sido tomadas estava o alistamento "imediato" nas obras dos açudes "Curema" e "Mãe D'água", "de cerca de 900 retirantes, pela substituição, sem prejuizo da economia, da execução manual à mecânica em determinados trabalhos" (Dnocs, 1953, p.27).

Para "diminuir a pressão avassaladora de necessitados" sobre as obras da barragem de Coremas, foram autorizados ainda os trabalhos de retificação e drenagem da bacia de irrigação das Várzeas de Sousa (Dnocs, 1953, p.30). Segundo o Inspetor,

A gravidade real da situação que se esboçava para as populações 
rurais de grande parte do Nordeste, e cujo desenvolvimento as chuvas recentemente caídas tendiam a atenuar, era, entretanto, claramente evidenciada pelas aglomerações adventicias existentes nos principais nucleos de população das zonas atingidas, ou alistadas rapidamente nas obras atacadas ou apenas intensificadas para atender à emergência: Em Iguatú, no Ceará, em cinco dias, haviam sido alistados, para os trabalhos da construção da rodovia Central do Piauí cerca de 10.000 homens, reduzidos a 7.000, por ocasião da minha primeira visita (17 de abril [de 1942]) em consequência das chuvas recentemente caídas, e que já eram cerca de 8.000, na minha segunda passagem (dia 23), com o retorno de alguns desiludidos ou menos corajosos; em Olho Dágua do Melão, residência de construção da rodovia Transnordestina, instalada a 12 de Abril, havia alistado a 17, pela minha passagem alí, 4.000 homens; fechado o alistamento, por falta de ferramentas, havia ainda grande número de necessitados aguardando admissão ao trabalho; em Patos, Paraíba, encontrei, a 11 de abril, mais de 2.000 flagelados, cujo encaminhamento para as obras das barragens de Curema e Mãe D'água, canais das Varzeas de Souza e trabalhos de construção do ramal do Carirí foi desde logo assentado; em Caicó, Jardim do Seridó, Currais Novos, no Rio Grande do Norte, era grande a pressão dos necessitados adventícios sobre as populações locais: - a instalação a 16 de abril, dos trabalhos de construção do trecho Jardim do Seridó-Caicó, do ramal do Catolé do Rocha, autorizada por V. Excia., constituiu um desafôgo para as três cidades indicadas.

A afluência tumultuária de trabalhadores às obras cresce de valor como indice de desequilíbrio da vida na região quando se considera o fato iniludível de lutarmos, em regra, com dificuldade de braços para o andamento normal os trabalhos da Inspetoria, o que tem condicionado a mecanização progressiva dos nossos serviços. Carateriza perfeitamente a situação de carência, quasi se pode dizer miserabilidade, de um proletariado rural, que acorre em massa, de grandes distancia por vezes, para disputar um salário infimo de Cr\$3,00 a Cr\$ 4,00 diários (Dnocs, 1953, p. 34).

Em 14 de julho de 1942, foi publicado o Decreto-Lei nº 4.475 cujo parágrafo único destinava ao Mvop o "crédito especial de 12.000:000\$0 (doze mil contos de 
réis)", para as despesas com as obras já aprovadas, "tendo em vista a atual situação do Nordeste assolado pela seca".

A folha de pagamento da Ifocs/Comissão do Alto Piranhas de dezembro de 1942, referende ao pessoal empregado nos serviços de construção do açude publico "Mãi D'Água", estava baseada no decreto citado acima e tinha como título "crédito especial". Nela, estão listados cerca de 360 trabalhadores.

Em uma tabela apresentada no relatório dos trabalhos realizados em 1942 contendo o número de operários alistados e de "pessoas amparadas", foi anotado o seguinte contingente nas obras dos açudes "Curema" e "Mãe D'água", respectivamente: 1.600 operários e 8.000 pessoas amparadas, e 1.400 operários e 7.000 pessoas amparadas. O número de pessoas amparadas foi obtido multiplicando o número de operários por cinco, assumindo, portanto, que essa era a quantidade média de membros das famílias assistidas. É citada ainda a mineração de ouro no vale do Piancó, onde haveria mais de 4.000 trabalhadores (Dnocs, 1953, pp. 36, 37).

Entre os anos que separaram a seca de 1942 e aquela do início da década seguinte, em 1952, as obras seguiram um ritmo lento e utilizaram uma quantidade bem menor de mão de obra que nessas duas crises. No Relatório referente aos trabalhos realizados em 1953, a Barragem Mãe D'água é referida como sendo o mais importante empreendimento do Departamento em execução. A publicação registrou que a construção tinha, porém, um serviço lento devido a fatores diversos como o estado precário da maquinaria desgastada pelo tempo, problemas no transporte de materiais, principalmente de cimento e dificuldades em se operar com muitas máquinas ao mesmo tempo (Dnocs, 1953, p. 92, 94).

Com a seca de 1951-53, a verba do Dnocs, que era de Cr\$219.244.762,10, "foi reforçada com recursos da emergência" que totalizaram Cr\$ 218.750.000,00, dobrando praticamente a sua verba (Sudene, 1981). Em 1952, a folha de pagamento do açude Mãe D'Água chegou a contar com 778 trabalhadores. Em abril de 1954, havia 584 pessoas na folha. No mesmo período, a folha de pessoal para as obras de 
Mãe D'Água marcada com a anotação "serviços extraordinários" contava com mais 383 trabalhadores. A folha de maio registrou 707 trabalhadores e mais 417 de serviços especiais.

Em de 24 de setembro de 1956, o Diretor Geral do Dnocs solicitou ao Ministro da Viação e Obras Públicas um "crédito de emergência" para a conclusão das obras do açude público Mãe D'água, que deveria ter sido finalizada neste mesmo ano. A justificativa do porquê da dotação prevista não ser suficiente foi o "aumento de nivel salarial, recentemente autorizado pelo Excelentissimo Senhor Presidente da República". De acordo com o Diretor,

Releva notar as vantagens economicas e sociais decorrentes da contrução do referido açude para a sua região, sendo certo que a sua ultimação no corrente exercício evidenciará, de modo conclusivo, o interesse do atual Governo em amparar a zona do chamado polígono das secas.

Poucos dias depois do apelo do Diretor, foi editado o Decreto $n^{\circ} 40.044$, autorizando a execução de obras de emergência no Estado da Paraíba:

Art. $1^{\circ}$ Fica o Ministério da Viação e Obras Públicas autorizado a executar, pelo Departamento Nacional de Obras Contra as Sêcas, as obras de emergência necessárias à ultimação do Açude Público de Mãe d'Água no Estado da Paraíba.

Art. $2^{\circ}$ As obras referidas no artigo $1^{\circ}$ correrão à conta da reserva especial de que trata o art. $2^{\circ}$ da Lei $\mathrm{n}^{\circ}$ 1.004, de 24 de dezembro de 1949, fixando, assim, o limite das respectivas despesas em Cr\$ 5.000.000,00 (cinco milhões de cruzeiros) (Decreto 40.044/1956). ${ }^{33}$

Ainda em 1956, em 1 de junho, foi editado o decreto $n^{\circ} 39.288$ dispondo sobre as medidas necessárias ao máximo aproveitamento do Açude de Curema e sua área de influência, reproduzido a seguir:

O PRESIDENTE DA REPÚBLICA, usando da atribuição que lhe confere o art. 87, item I, da Constituição, e

CONSIDERANDO_as conclusões a que chegou o recente "Encontro dos Bispos do Nordeste", realizado em Campina Grande; 
CONSIDERANDO as sugestões dos órgãos governamentais vinculados ao desenvolvimento social e econômico daquela região;

CONSIDERANDO a necessidade da fixação do homem nordestino ao seu meio, mediante a realização dos projetos propiciadores da riqueza e bemestar;

\section{DECRETA:}

Art. $1^{\circ}$ Os órgãos federais mencionados neste Decreto, diretamente ou em cooperação, promoverão as medidas necessárias ao máximo aproveitamento do Açude Curema de sua área de influência, inclusive mediante instalação de equipamento para produção de energia elétrica, linhas de transmissão, serviços de abastecimento de água no Vale do Piancó e estabelecimento ou melhoria de vias de acesso.

Art. $2^{\circ}$ O Departamento Nacional de Obras Contra as Sêcas (D.N.O.C.S.), do Ministério da Viação e Obras Públicas, além de sua parte executiva, coordenará os trabalhos de planejamento e execução a cargo de quaisquer entidade investidas de atribuições na realização do presente projeto.

Art. $3^{\circ}$ Cooperarão com o D.N.O.C.S., no empreendimento, o $1^{\circ}$ Grupamento de Engenharia, o Instituto Nacional de Imigração e Colonização, o Departamento Nacional de Estradas de Rodagem, o Departamento Nacional de Estradas de Ferro, o Departamento Nacional de Endemias Rurais, o Serviço Especial de Saúde Pública, o Instituto Nacional de Estudos Pedagógicos, o Serviço Social Rural, o Ministério da Agricultura e outras entidades federais, estabelecendo-se mediante entendimento mútuo, a missão ou tarefa de cada entidade em um plano de conjunto, a ser submetido à aprovação do Presidente da República dentro de 60 (sessenta) dias, a partir da data dêste Decreto.

Parágrafo único. O D.N.O.C.S. articular-se-á, ainda, com outras entidades públicas ou privadas nos têrmos do plano que fôr estabelecido.

Art. $4^{\circ} \mathrm{O}$ plano a que alude o artigo anterior deverá especificar as providências cabíveis e os fins a atingir, êstes referidos em têrmos numéricos com a indicação dos prazos previstos para cada etapa do empreendimento.

Art. $5^{\circ}$ Dentro de 120 (cento e vinte) dias, a partir da data dêste Decreto, o D.N.O.C.S., por intermédio do Ministério da Viação e Obras Públicas 
apresentará à Presidência da República relatório sucinto e objetivo sôbre o andamento dos trabalhos, dificuldades encontradas bem como as medidas que se façam mister para a realização do projeto.

Art. $6^{\circ}$ Êste decreto entrará em vigor na data de sua publicação.

Art. $7^{\circ}$ Revogam-se as disposições em contrário (Decreto 39.288/1956, grifou-se).

Como foi apontado na Parte I-6, esse não foi o único decreto editado nesse mesmo dia e que teve justificativa as conclusões do "Encontro dos Bispos do Nordeste" realizado em Campina Grande em 1955 e a necessidade de fixar os nordestinos em sua terra através da geração de riqueza e bem estar. Entre os decretos registrados na compilação Legislação do D.N.O.C.S estão os de número 39.284, 39.285, $39.286,39.287,39.288,39.290,39.294,39.295,39.296,39.297,39.298,39.299$ e 39.230 . Todos os 13 decretos dispõem sobre obras e medidas visando o melhoramento da região, marcando uma nova etapa nas políticas de desenvolvimento empreendidas por Juscelino Kubitschek (1956-1961).

A barragem Mãe D'Água foi inaugurada em 1957 por JK. No ano seguinte, segundo publicação da Sudene, "a seca surgiu com intensidade bem superior às registradas após 1919". Entre as medidas adotadas, "abriu-se frentes de trabalho em todos os locais que se fizesse necessário atender a um número razoável de necessitados locais, ou transferi-los em veículos do Dnocs, quando este número não justificasse uma frente de serviço" (Sudene, 1981, p. 34).

O decreto $n^{\circ} .43 .686$, publicado 7 de maio de 1958, considerando, entre outros, "a calamidade que assola o Nordeste e a necessidade de proporcionar aos órgãos do Govêrno os meios necessários para dar assistência às vítimas da sêca" e "a necessidade de serem atacadas obras e serviços de emergência, assim como a impossibilidade de atender ao crescente número de flagelados com os recursos normais do Orçamento da União", concedeu ao Ministério da Viação e Obras Públicas o crédito extraordinário de Cr\$2.000.000.000,00 destinado à realização de obras e serviços de assistência às vítimas da seca, através do Dnocs, do 
Departamento Nacional de Estradas de Rodagem, do Departamento Nacional de Obras de Saneamento, do Primeiro Grupamento de Engenharia e do Instituto Nacional de Imigração e Colonização. Metade dessa verba foi destinada ao Dnocs. O segundo distrito do órgão, com sede em João pessoa, ficou com 50 milhões de cruzeiros da verba extraordinária para o exercício de 1958 (Ofício Dnocs 1150C de $30 / 08 / 1958)$.

Entre as folhas de pagamento do Dnocs para esse ano, estão as do pessoal que havia trabalhado nas obras de "irrigação e exportação d'água dos açudes Curema e Mãe D'água". No item "Classificação da despesa", há a anotação "Defesa c/as Sêcas do Nordeste ( $\operatorname{art}^{\mathrm{o}} 198$ da Constituição Federal)". No mês de fevereiro, a folha de pagamento tinha apenas duas páginas, em março já eram 6, mais uma outra folha com duas páginas com a anotação "(extraordinário)". Em outubro de 1958, a folha dos operários que trabalharam na rodovia Curema-Aguiar, tinha 12 páginas e 684 trabalhadores. A de dezembro contava com 28 páginas e 1.627 trabalhadores listados. O pagamento dessas folhas ocorreu apenas no ano seguinte, com base no decreto $\mathrm{n}^{\circ}$. 46.432, de 15 de julho de 1959 que destinou ao Ministério da Viação e Obras Públicas, "o crédito especial de Cr\$3.750.000.000,00".

O "Relatório dos serviços realizados durante o primeiro trimestre de 1958" elaborado pela $3^{\text {a }}$ Residência do Dnocs, localizada em Coremas, também enfatizou o grande número de trabalhadores engajados nas obras de emergência.

No mês de março foram atacados, nesta Residência, diversos servicos de caráter de emergência, afim de amparar o pessoal flagelado desta região assolada pela sêca. A frequencia dos operários nos serviço da barragem (que já havia sido inaugurada) foi de 96 operários. Os serviços de emergência citados foram:

1- Alargamento da rodovia Coremas-São Gonçalo - trecho São José- São Gonçalo, a frequência média do mês de março foi de 1.772 operários;

2 - Rodovia Coremas-Aguiar frequência média de 1.561 operários;

3 - Rodovia Destêrro-Serra Negra, via Ipueira, 762 operários. 
A média total de operários registrada para o mês de março de 1958 foi de 4.095 pessoas. O relatório dos serviços médicos apontou ainda o atendimento de 1.055 adultos e 375 crianças

O "Relatório dos trabalhos realizados pela Residência do Alto Piranhas, durante o $2^{\circ}$ trimestre do ano de 1961, apresentado ao Sr. Chefe do $2^{\circ}$ Distrito" demonstra ainda um grande número de obras e trabalhadores na região, apesar de mudanças internas e diminuição das verbas terem afetado os serviços, na avaliação da administração local. ${ }^{34}$

Após relatar a dificuldade de conservação dos $220 \mathrm{~km}$ de rodovias a cargo da Residência, devido a falta de recursos e pessoal, o Engenheiro Residente Admilson Matheus de Lima ponderou:

O que nos tranquiliza é a certeza de havermos disciplinado nossos esforços ao máximo em busca do cumprimento de nossas obrigações, e procurando corresponder a confiança que nos foi depositada pela Chefia do Distrito, tão acertadamente entregue a uma das cabeças brancas veneráveis do DNOCS.

Como ocorrência de maior transcendência à cambaleante Residência do Alto Piranhas, tivemos no mês de junho a fusão da Quarta Residência e da extinta Comissão Hidrelétrica a êste Setor. Medida esta recebida com agrado pelo seu alto acerto, desde que o Alto Piranhas sempre foi um marco avançado de eficiência e trabalho do DNOCS. Aventuramos a prognosticar, desde logo, nova éra para a Região a partir do segundo semestre, face os recursos oriundos dessa junção e também da unidade e centralização de mando.

Em 1962, uma nova seca mobilizou frentes de trabalho na região, embora em menor intensidade que em 1958. O relatório dos "trabalhos levados a efeito pela $3^{\circ}$ Residência durante o ano de 1962", destacou as seguintes realizações:

Terminamos os estudos topográficos da linha Cajaseiras-JatobáBonito. Prosseguimos com assentamento de postes da linha Pombal-Catolé. Concluimos e inauguramos os serviços de energia elétrica da cidade de 
Itaporanga.

Instalamos a fábrica de postes de Mãe D'água, recuperamos parcialmente o britador.

Concluimos o assentamento de postes e iniciamos o cruzamento da linha Cajazeiras-Jatobá.

Prosseguimos com a construção de reservatórios da estação de tratamento dos serviços de abastecimento d'água da cidade de Ibiara.

Prosseguimos com os serviços de abastecimento d'água de Princesa Isabel.

Continuamos, com incremento, a fabricação de postes de 14 a 16 metros para a Chesf (Proc. 113/62).

De 1935 até os primeiros anos da década de 1960, um grande número de trabalhadores de baixa especialização foi ocupado nas obras em Coremas. O moderno conforto do Acampamento em nada lembrava as condições dos cassacos, que além de trabalharem com ferramentas inadequadas, ficavam "reféns do barracão", devido ao atraso dos salários (Mariz, 1994; Andrade, 1934).

Além dos denominados flagelados ou retirantes que afluíam dos municípios vizinhos, parte da legião de cassacos foi formada pelos trabalhadores rurais da região que haviam sido deslocados. As irmãs Francisca, 71, e Tereza, 74, moradoras do bairro rural Mãe D'água, se lembram vivamente da infância em meio às obras do Dnocs, onde trabalharam muitos de seus parentes. Nas palavras de Dona Francisca: “mas vale! Essa barragem eu vi o começo do alicerce dela, meu pai trabalhava lá, meu pai, meus avôs, meus tios... eu é que ia deixar a merenda pra eles" (Entrevista, jun. 2009).

Um de seus tios, João Vicente de Souza, 95, lembra-se que, quando começou a trabalhar no açude, saiu do Navio e foi morar em uma das casas construídas pelo Dnocs em Mãe D'água para abrigar os operários da obra. Durante os trabalhos no Dnocs, João Vicente recebeu o apelido de Lampião, em referência ao chapéu de aba quebrada que usava para trabalhar. Seu Lampião, como é conhecido na região, contou ainda que seu pai também trabalhou nas obras, "no açude grande [Curema/ 
Estevam Marinho] e na barragem [Mãe D'água]", assim como seus cunhados que se mudaram para Mãe D'água através de sua interveniência junto aos funcionários do Dnocs.

Apesar de tantos moradores do Navio, antigo povoado de Tereza, Francisca e Lampião, terem trabalhado nas obras do Dnocs, apenas este último tornou-se servidor do órgão. A casa construída pelo Dnocs que ele ocupava, conhecida por "casa grande" - sede dos famosos forrós dos pretos - é hoje ocupada por um de seus filhos.

A finalização da barragem Mãe D'água, em 1957, liberou um grande número de trabalhadores. Os que não quiseram, ou não conseguiram, empregar-se nas obras de outros açudes em construção viram-se de repente seu emprego. Muitos deles ficaram também sem suas casas e roças, inundadas com o represamento das águas. A intensa seca de 1958 tornou ainda mais aguda a situação dos agricultores recém deslocados.

Esse foi o caso de Manoel Fernandes, pai de Francisca e Tereza. Por achar-se doente na ocasião, Manoel não quis acompanhar a turma que estava sendo deslocada para as obras em outro município e mudou-se com a esposa e seus 11 filhos para o "Mufumbo", na aba da serra de Santa Catarina. A seca de 58, entretanto, tornou escassa a água disponível e o trabalho na agricultura impraticável no "Mufumbo".

Por intermédio do chefe do Dnocs, José Maria de Aguiar, a família foi morar em uma renda em Mãe D'água na vilinha conhecida por "Britador". Um dos trabalhos que absorveu a população local foi o trabalho nessa localidade, onde homens, mulheres e crianças quebravam e juntavam as pedras utilizadas na construção das estradas e açudes do Dnocs. A esposa e as filhas de Manoel, assim como algumas de suas netas, passaram a trabalhar ali.

Maria do Desterro Fernandes da Silva, 52, filha de Dona Francisca, contou ter trabalhado quebrando pedra no britador junto com a avó, trabalho que garantia o sustento de muitas pessoas quando era criança. Desterro recordou ainda que em 
determinada época pessoas de Coremas e de outras cidades da região compravam delas a brita, cuja medida de venda era uma lata. Uma das senhoras que participava da entrevista observou: "aqui não tem ganho não, tem que se virar com essas coisas" (Entrevista, jun. 2009).

O trabalho nas emergências estabelecidas ainda em 1957 absorveu também muitos trabalhadores. Conforme inúmeros relatos, nem todos os membros ativos da família podiam se alistar nas emergências, ficando o número de admitidos reduzido a um ou dois. Assim, ao mesmo tempo que geraram emprego para um grande número de pessoas, as emergências não garantiam o sustento pleno das famílias. Além de insuficiente, o trabalho temporário em obras do governo é relembrado como extremamente extenuante, fazendo jus ao trocadilho citado por Silva Filho no qual Dnocs virava sigla para Deus Não Olha Cassaco Sofrer.

\section{As rendas do Dnocs}

Os terrenos das bacias hidráulicas dos açudes que não ficaram cobertos pelas águas foram arrendados desde pelo menos 1948. A primeira norma referente às "Instruções relativas ao regime administrativo do serviço de irrigação e arrendamento dos terrenos de vazantes e outros, nos açudes a cargo da Inspetoria de Obras Contra as Secas" foi aprovada pela Portaria Ministerial de 26 de abril de 1919 e regulou o disposto no Art. 24 do Regulamento da Inspetoria de 1916 (Decreto $12.330 / 1916) .35$

Essa Portaria foi substituída pela de no 118 de 6 de fevereiro de 1950, da qual reproduzimos alguns dos artigos:

\section{I - TERRAS DE MONTANTE}

Art. $1^{\circ}$. As terras situadas nas bacias hidráulicas dos açudes públicos denominam-se "vazantes" e "terrenos secos", ficando êstes acima e aquêles abaixo na soleira do sangradouro.

Art. $2^{\circ}$. O DNOCS providenciará a divisão em lotes com sinais e numerações 
visiveis, das terras pertencentes à União, localizadas nas referidas bacias.

Art. $3^{\circ}$. Os chamados terrenos "secos" são separados dos de "vazantes", cabendo, porém, a preferência no seu arrendamento aos arrendatários das "vazantes" que lhe ficarem contíguas.

Art. $4^{\circ}$. As vazantes terão de trinta (30) a cinquenta (50) metros de frente e fundo variável de acôrdo com o nível dágua, tendo-se em vista a fertilidade e umidade do terreno.

Art. $5^{\circ}$. Os lotes da faixa sêca terão de 2 (dois) a 4 (quatro) hectares.

Art. $6^{\circ}$. Os lotes de vazante e faixa sêca serão arrendados com o fim de localizar e fixar as famílias de agricultores reconhecidamente pobres.

(...)

Art. $14^{\circ}$. O arrendamento vigorará, no caso de falecimento do arrendatário, se com o mesmo, estiverem de acôrdo os seus herdeiros, ficando, porém, obrigados a respeitar o contrato, assinado por seu antecessor, em tôdas as cláusulas e condições.

(...)

Art. $16^{\circ}$. Nos casos de sêca e mediante autorização do Ministro da Viação e Obras Públicas, poderá ser feita a redistribuição das vazantes, a critério da Administração, de maneira a permitir a localização, nas margens do açude, do maior número possível de retirantes; serão, entretanto, respeitadas, até a colheita, as culturas existentes ao ser autorizadas a administração.

\section{Direitos e Deveres dos Arrendatários}

Art. $17^{\circ}$. A preferência de arrendamento deve ser dada na seguinte ordem:

7. aos que houverem doado terras para a construção do açude, desde que conste cláusula de preferência na respectiva escritura;

8. aos responsáveis por famílias numerosas, compreendendo-se como tais, as compostas por mais de nove pessoas;

9. aos responsáveis por famílias médias, isto é, compostas por mais de cinco pessoas;

10. aos responsáveis por famílias de menos de cinco pessoas.

Art. $18^{\circ}$. Aos candidatos nas condições dos itens 1 e 2 do art. $17^{\circ}$ poderão ser concedidos até no máximo de 4 lotes na faixa úmida e 10 hectares na faixa sêca e para os demais casos, será feita a distribuição equitativa de modo a 
ficar aproximadamente 1 ha para cada pessoa da família.

Art. 19․ É aconselhável, sempre que for possível, a residência, no lote, do arrendatário e da sua família.

Art. $20^{\circ}$. Não é permitido ao arrendatário:

a. o sistema de parceria agrícola sob qualquer modalidade;

b. a criação à sôlta de animais de qualquer espécie;

c. pescar fora da época determinada por lei;

d. caçar com armas de fogo ou armadilha em qualquer época do ano, salvo quando se tratar de aves e animais prejudiciais à agricultura, a juízo da Administração;

e. fazer barragens nos cursos dágua;

f. fabricar telhas, tijolos, louças de barro e carvão sem a indispensável autorização da Administração do açude;

g. explorar carnaúba e frutos de oiticica e de árvores localizadas nos terrenos da União, o que é privativo da União;

h. utilizar-se e ramas de canafístula e juázeiro existentes nos lotes arrendados, sem prévia licença da Administração do açude.

Art. 21. Os lotes não poderão ser sublocados nem responderão por compromissos estranhos às prescrições destas Instruções.

Art. 22. Os arrendatários ficam obrigados a cultivar a faixa úmida (vazantes), integralmente e plantar na faixa sêca o algodão mocó, culturas alimentares e essências florestais para proteção das terras contra erosão.

Art. 23. As culturas nas bacias hidráulicas serão, de preferência, cereais e gêneros alimentícios.

Art. 24. Os arrendatários poderão aproveitar, para criação de animais, os restos de culturas, desde que construam, na faixa sêca, currais próprios onde os animais possam receber as rações de restôlhos ou de forragens.

Art. 25. O desmatamento de capoeira só poderá ser executado com a permissão da Administração do açude e ùnicamente para ser o terreno ocupado por lavouras.

Art. 26. Será facultado ao usuário, com permissão da Administração, cortar madeira para construção ou conservação de casa ou morada, cêrcas, tapumes, desde que a utilização se faça exclusivamente dentro dos terrenos da União. 
Art. 27. Os arrendatários são obrigados a fornecer dados e informações necessários à confecção das estatísticas organizadas pelo Departamento Nacional de Obras Contra as Sêcas.

Art. 28. As residências deverão ser edificadas acima do nível do coroamento da barragem.

Art. 29. Cada família é obrigada a construir uma fossa, embora rústica, que impeça o escoamento de dejeções para o açude.

(...)

Art. 31. É permitido tirar água do açude para lavagem de roupa, de animais e outros fins, desde que as mesmas, depois de utilizadas, não voltem ao açude.

Art. 32. Os lotes da faixa sêca, que não se prestarem para o plantio, poderão ser arrendados para pastagens até o máximo de 10 (dez) hectares a cada arrendatário; o prazo de arrendamento inicial máximo será de 1 (um) ano e o preço o estipulado no art. 56 destas instruções.

Art. 33. Os arrendatários de lotes nas condições do artigo anterior obrigar-seão a cercar os respectivos lotes, a fim de que os animais não prejudiquem as culturas dos outros usuários, sob pena de responderem pelos prejuízos causados.

\section{Disposições Especiais}

Art. 34. É proibido o arrendamento às pessoas abastadas não incluídas no item 1. do Art. 17 e aos servidores públicos.

Art. 35. O arrendatário poderá ser afastado do lote, com rescisão do respectivo contrato;

a. por infração às cláusulas regulamentares;

b. por vício de jogo ou embriaguez;

c. por patentear qualidades negativas de moralidade, disciplina e operosidade.

Art. 36. A exclusão do arrendatário e caducidade do contrato de arrendamento competem à autoridade administrativa imediatamente superior à Administração do açude cabendo a esta propor tais medidas, comprovando os motivos alegados.

Art. 37. Competirá, ainda, à autoridade imediatamente superior à Administração do açude, determinar a caducidade do contrato de 
arrendamento, quando o terreno fôr necessário a obras, instalações ou outros fins.

Art. 38. Terminado o prazo de arrendamento, cabe à Administração julgar a conveniência ou não de sua renovação.

Art. 39. As ordens da administração serão dadas por escrito. (Dnocs, 1958 1, pp. 121-125).

O objetivo dessa norma, como explicitado nos artigos citados acima, era fixar famílias reconhecidamente pobres sujeitas aos efeitos da secas em lotes destinados ao plantio de culturas de subsistência (principalmente milho, feijão, arroz) e de algodão, produto de maior valor comercial da região.

Os terrenos (lotes) eram arrendados sem qualquer tipo de benfeitoria, como casas ou fossas, e os arrendatários não recebiam nenhum tipo de crédito de fomento para sua instalação ou produção, situação que iria mudar somente na década de 1990 como veremos a seguir.

Apesar de instituir um regime de quase propriedade plena, ao prever, por exemplo, que o arrendamento seria passado de pai para filho em caso de morte (Art. 14), o contrato poderia ser revogado a qualquer tempo à critério da Administração do açude (Art. 37). Ficava também a critério da Administração local renovar ou não os contratos, atribuindo um grande poder às chefias locais, a quem caberia também aprovar atividades cotidianas como a abertura de roças e o corte de madeira (Arts. 25 e 26$)$.

Essa espécie dúbia de propriedade iria mais tarde ser fixada pela Lei 4.593, de 29 de dezembro de 1964, para os lotes irrigados, determinando que "propriedade" do lote agrícola pelo "regante" seria "resolúvel [revogável] e indivisível" (Art. 15).

Além de ficarem obrigados a plantar determinados produtos, como o algodão, aos rendeiros foi vedada a exploração de produtos de alto valor comercial, destacando-se a proibição da exploração das palmeiras de carnaúba e dos frutos de oiticica, mesmo quando as árvores estivessem dentro do lote arrendado. 
Como se pode perceber pelas descrições dos lotes desapropriados apresentadas anteriormente, as carnaúbas e principalmente as oiticicas estavam presentes em grande parte destes, assim como as canafístulas e juazeiros, cujo uso passou a depender da autorização da Administração. Apenas nos lotes vizinhos de Antônio Lopes (553), João Soares (558), Gonçalo André (554) e João Pereira de Oliveira (598), havia 449 oiticicas grandes, 353 médias e 287 oiticicas pequenas.

A proibição sobre a oiticica teve maior impacto local. Em 17 de outubro de 1957, a Assembléia Legislativa do Estado da Paraíba aprovou o requerimento de autoria do deputado Bivar Olinto e outros, no qual os deputados pediam ao Diretor do Dnocs que fosse permitido a os arrendatário do açude de Coremas pudessem explorar as oiticicas inseridas dentro de suas rendas em benefício próprio, conforme justificativa transcrita abaixo:

No corrente ano a safra de algodão está reduzida na área do açude Curemas, em mais de 50\%, o que vem criando uma situação dolorosa para os agricultores daquela região.

Propicia-se animadora, por outro lado, a safra de oiticica, que somente terá início em fins de dezembro, observando-se, todavia magnifica floração do oiticical em referência. Acontece que, apesar de arrendados os terrenos da bacia hidráulica - daquele açude do Governo, os arrendatários não têm direito a desfrutar as oiticicas compreendidas dentro dos terrenos arrendados ao poder público.

A Administração do açude Curemas é quem todos os anos vem fazendo a colheita, sem contudo o produto da venda constar de leis ou ôrçamentos da República, não trazendo por isso mesmo, qualquer prejuizos as rendas públicas, a liberalidade ora solicitada, que vem beneficiar um crescente número de pequenos lavradores daquela zona, deveras prejudicados, êste ano, com a redução da safra de algodão.

Não deve o Governo exigir mais de pequenos lavradores, - quando não lhes assiste com a técnica e não lhes oferece crédito para a fundação de novas safras, nem lhes garante o preço do nosso principal produto que é o algodão, haja visto o esforço dos nossos deputados Pedro Gondim, Jacob 
Frantz e Jader Medeiros, que há cerca de dois mezes se encontram no Rio de Janeiro e quasi nada de positivo conseguiram em benefício do algodão nordestino, enquanto S. Paulo tem bons financiamentos e prêço garantido pelo Govêrno para as suas safras presente e futuras. Êsse tratamento desigual entre o Norte e o Sul tem acarretado sérios prejuizos aos nossos plantadores de algodão e do melhor algodão que se produz no País (Assembleia Legislativa do Estado da Paraíba - OF/No 788/GS/ZMV).

O ofício da Assembléia foi transcrito e encaminhado ao "Sr. Diretor Geral de Secas" em 4 de novembro de 1957. Serafim Rodriguez Martinez, chefe do $2^{\circ}$ Distrito com sede em João Pessoa que subscreve o ofício, fez questão de esclarecer porém que:

(...) o oiticical, como também o carnaubal, dos açudes "Estevam Marinho" e "Mãe D'água", todos os anos é posto em concorrência pública, sendo sua renda recolhida à Delegacia Fiscal do Tesouro Nacional nesta cidade.

Os frutos da oiticica beneficiados produzem um óleo de efeito secativo utilizado na indústria de tintas e sua coleta se inicia após a safra de algodão. Os frutos coletados na região dos açudes era vendida para a Brasil Oiticica S.A, instalada em Pombal, a cerca de 30km de Coremas, na década de 1930.

Uma monografia sobre a árvore da oiticica fez parte do Relatório Geral sobre $O$ Brasil na Feira Mundial de Nova York de 1940. Nessa monografia, consta a informação de que a Comissão dos Serviços Agrícolas e Complementares das Obras Contra as Secas estava "estudando o cultivo de oiticica em experiências ecológicas e botânicas" sendo os terrenos nas adjacências de riachos e açudes os mais propícios à sua adaptação. Ainda de acordo com o relatório, o Nordeste era o principal centro de produção, crescendo a árvore de maneira abundante nos vales dos rios Açu e Apodi, no Rio Grande do Norte, em quase todo estado do Ceará e nos municípios paraibanos de Piancó, Misericórdia (Itaporanga) e Catolé do Rocha. O relatório cita a Brasil Oiticica S.A. que atuava tanto no Ceará como em Pombal na Paraíba (Vidal, 
1942, pp.737, 738). Em Piancó, a extração de oiticica atingiu 600 toneladas, no valor de 1,2 milhao de cruzeiros, no ano de 1959 (Ibge, 1962).

Em 1938, o governo brasileiro proibiu a exportação das sementes de oiticica, incentivando, por outro lado, a exportação de seu óleo. Em 1939, o Ceará abrangia $80 \%$ das exportações, sendo seguido pela Paraíba. O governo brasileiro regulamentou a classificação e padronização da oiticica através do decreto 6.226 de 4 de setembro de 1940.

Entre as contribuições feitas para a "Golden Gate Exhibition" estava um folheto sobre a oiticica (foram 11 folhetos ao todo: oiticica, mandioca, caroá, carnaúba, mate, cacau, cromo, manganês, níquel, ferro e ouro). A oiticica fazia parte de um "'stand' precioso para mostrar o que nos deu a natureza" na Feira Mundial de Nova York (Vidal, 1942, p. 799).

O relatório sobre O Brasil na Feira Mundial de Nova York de 1940 menciona ainda a carnaúba entre os produtos relevantes economicamente enviados para a exposição:

O nordeste das secas mandou para aquí a "árvore da vida", a carnauba, palmeira cuja aplicação toma vulto de dia para dia pelo valor de seus produtos e sub-produtos e cuja cera importada pelos Estados Unidos atingiu, em 1938, ao montante de 9.157.753 quilos (Vidal, 1942, p.800). ${ }^{36}$

O contrato padrão assinado pelo arrendatário Izaiais Laurentino em 1970, elaborado com base nas normas aprovadas pela Portaria do Dnocs $n^{\circ} 7 /$ DFP de 30 de março de 1964, ainda mantinha a proibição da exploração da carnaúba e da oiticica (Art. 8, item i, Contrato 892/1970). Já aquele assinado em 1979 pelo arrendatário Antonio Martins de Souza estabelecia não ser permitido a exploração destas árvores "salvo se devidamente autorizado pelo Dnocs" (Cláusula 7ª item e, Contrato 848/79).

Atualmente, não há menção a essas árvores nos contratos de Concessão de Uso assinados pelo Dnocs, o que parece ter se tornado desnecessário com a decadência da exploração dos frutos da oiticica e o fechamento da Brasil Oiticica, maior empresa 
exploradora no país.

Sobre a proibição da utilização dessas árvores que tinham grande valor comercial, é no mínimo intrigante o fato de que ficava vedada assim uma fonte potencial de desenvolvimento dos agricultores locais, apesar desse desenvolvimento servir como justificativa mesma da política de loteamento e arrendamento dos terrenos sob influência dos açudes.

A previsão de redistribuição das áreas de vazante em caso de seca, visando assentar o "maior número possível de retirantes", estabelecida no Art. 16 da Portaria de 1950, teve o texto ligeiramente modificado nos contratos de 1970 para enfatizar que essas áreas poderiam ter o tamanho reduzido conforme cada caso analisado pela administração. A partir dos contratos firmados em 1979, a menção aos retirantes desapareceu, apesar das secas que ainda estavam por vir.

Os contratos firmados em meados da década de 1990, passaram a ser denominados contratos de concessão de uso e não mais de arrendamento. Mesmo os contratos já existentes foram renovados nesse modelo. Neste novo instrumento, foram incluídas também as obrigações do Dnocs (concedente).

\section{CLÁUSULA SEXTA: - DAS OBRIGAÇÕES DO CONCEDENTE:}

Dentro das possibilidades locais, o CONCEDENTE oferecerá ao CONCESSIONÁRIO a assistência técnica para o desenvolvimento de suas atividades agro-pastoris, e apreciará os requerimentos que forem propostos para fornecimento de água para uso doméstico e atividade agro-pastoris (Contrato $n^{\circ} 72$ / DERUR/2D/1997).

Os contratos de Concessão de uso assinados a partir de 2005 ampliaram as obrigações do concedente como exposto a seguir:

\section{CLÁUSULA TERCEIRA - DAS OBRIGAÇÕES DAS PARTES}

\section{I - O DNOCS obriga-se a:}

d) Entrega da área devidamente loteada para exploração, por parte do CONCESSIONÁRIO, conforme planta e memorial descritivo dos mesmos;

e) assessorar o CONCESSIONÁRIO, durante a vigência deste Contrato o 
uso da área concedida, para fins exclusivos de atividades agropecuárias;

f) orientar, tecnicamente, ao CONCESSIONÁRIO quanto à manutenção e conservação racional dos recursos naturais preexistentes, em uso, e, principalmente, no que se refere a prática da agricultura;

g) acompanhar e fiscalizar a execução do objeto deste contrato pelo CONCESSIONÁRIO, orientando-o para seu fiel cumprimento;

h) promover, sem alteração do valor hectare da terra, a troca da área, desde que haja disponibilidade quando esta, a vista de laudo, emitido pelo setor competente do DNOCS, e configurada a inexistência de culpa do CONCESSIONÁRIO, for considerada economicamente inviável;

i) fiscalizar a ocupação da área concedida a fim de impedir o uso indiscriminado do solo;

j) assistir, tecnicamente, ao CONCESSIONÁRIO, quando solicitado por este.

Entre as restrições inseridas aos contratos ao longo dos anos, destaca-se a incorporação da legislação ambiental nos contratos mais recentes. Os contratos assinados em 2005, incorporaram em sua cláusula primeira, "Do Objeto", a Resolução 302 do CONAMA de 29 de março de 2002, que determina a manutenção de área de preservação permanente (faixa de terra com largura marginal de 100m a partir do nível de sangria do açude).

O concessionário passou a ser proibido de utilizar qualquer tipo de agrotóxico ou adubo químico e "preservar $20 \%$ da área concedida para reflorestamento natural ou planejado, de acordo com o art. 16, da Lei $\mathrm{n}^{\mathrm{o}} 4.771$, de 15/09/1965, e a nova redação dada pela medida provisória n ${ }^{\circ}$ 2.166-67, de 24.08.2001".

Embora já existissem regras para o arrendamento dos lotes do Dnocs quando da implementação dos açudes em Coremas, os processos mais antigos das pastas individuais dos rendeiros existentes na sede do Dnocs em Coremas são datados de 1966. A maior ênfase dada às normas de execução do Dnocs a partir de 1965, conforme exposto na Parte I-7, provavelmente determinou que fossem refeitos os contratos de arrendamento de acordo com um novo padrão.

Algumas das carteiras individuais de recolhimento de taxas, expedida pelo 
órgão, e que estão arquivadas nessas pastas, contém a informação de que a pessoa em questão é rendeira desde data anterior, sendo 1947 a referência mais antiga. Foram encontradas também referências a contratos feitos em 1948 mas, infelizmente, essa documentação não pode ser localizada.

No arquivo da Divisão Técnica do Dnocs em João Pessoa, há uma série boletins mensais de "fiscalização, reparos e exploração do Açude Público Curema", compreendendo os anos de 1955 e 1957 (Proc. $n^{\circ}$ 222/55 e n 143/57). Os boletins foram preenchidos em formulário pré formatado pelo zelador do açude e enviados para o Serviço de conservação, exploração e patrimônio da sede do órgão no Rio de Janeiro.

O item III do boletim dizia respeito à "Exploração e rendas diversas" e continha os seguintes itens: 1) "Terrenos de vasantes ou humidos"; 2) "Terrenos sêcos ou superiores"; 3) "Terrenos de irrigação"; 4) "Pesca no açude, sangradouro e bacia de irrigação"; 5) "Canôas, botes, e outras embarcações"; 6) "Casas, depositos, cercados, etc e seus alugueis". Na série encontrada, apenas os itens 1, 2 e 6 estavam preenchidos. Os de número 1 e 2, referentes aos arrendamentos rurais, continham os seguintes sub itens:

1. Terrenos de vasantes ou humidos:

a. Frente aproximada dos terrenos arrendaveis ........... metros, pertencentes a ..........

b. Lotes arrendados ..... frente ..... metros. Lotes sem contrato frente ...... metros

c. Taxas recebidas Cr\$ .... Entrega ao Fiscal em ... de.... de 19..... Taxas a cobrar $\mathrm{Cr} \$ \ldots . .$.

d. Culturas dos terrenos

e. Pessôas beneficiadas ........ Bemfeitorias......

f. Numeros e especie de animaes

2) Terrenos sêcos ou superiores:

a. Area aproximada arrendavel ...... hectares, pertencente .... a.........

b. Lotes arrendados .... area ..... hectares. Lotes sem contrato ... area .... 
hectares

c. Taxas recebidas Cr\$ .... Entrega ao Fiscal em .... de ..... de 19.... Taxas a cobrar...

d. Cultura dos terrenos ....

e. Pessôas beneficiadas ... Bemfeitorias .....

f. Numero e especie de animaes

Apesar de grande parte dos itens não ter sido preenchida pelo zelador responsável, eles dão idéia do que deveria ser levado em conta para avaliar o desempenho local da política de desenvolvimento agropecuário das bacias dos açudes, que se buscava implementar através do arrendamento dos lotes. Em termos gerais, importava quantificar a produção e número de pessoas atendidas por essa política.

Com a mudança das diretrizes do Dnocs, da construção de reservatórios para o beneficiamento dos vales irrigados pelos açudes, esses dados passam a ser os mais valorizados e divulgados como medida do sucesso das políticas do Dnocs.

As informações regularmente preenchidas dizem respeito aos lotes de vazante e de terreno seco com indicação da metragem ou área correspondente, as culturas plantadas e o número de pessoas beneficiadas. Uma vez que os números oscilam muito entre os meses (um mês há referência a 7 lotes em um e no seguinte 30, tornando a diminuir no mês seguinte), a anotação provavelmente se refere aos arrendamentos iniciados no mês.

Apesar de muitos arrendamentos combinarem uma faixa de área de vazante e uma área seca, os números anotados nos boletins mostram que essa não era uma regra. No boletim referente a junho de 1957, foram registrados 49 lotes de vazante e apenas 7 lotes secos. O item pessoas beneficiadas em todos os boletins consultados foi obtido multiplicando o número de lotes por 6, assumindo que esse fosse o número médio de indivíduos por família.

O item "Lotes sem contrato" não foi preenchido em nenhum boletim para nenhum dos itens, o que deveria significar que para cada terreno arrendado 
correspondia um contrato, mas os nomes dos contratados ou mesmo o números destes não aparecem anotados no boletins.

As áreas médias dos lotes arrendados variam discretamente conforme os meses. Para o ano de 1955, pode-se ver essa variação analisando os resultados dos boletins dos meses de junho e novembro, que tiveram o maior número de pessoas beneficiadas registrado. O boletim de junho apontou o arrendamento de 77 lotes em faixa úmida com 2.310 metros (26,36m cada) e 4.235 pessoas beneficiadas. 30 lotes de terrenos secos foram arrendados com área média de 6ha cada (212ha totais) e 180 pessoas beneficiadas. O boletim de novembro anotou o arrendamento de 7 lotes de frente com 210m ao todo (30m por lote) e 96 lotes secos com 693ha (10,03ha por lote), contabilizando 576 pessoas beneficiadas.

Os meses que registraram o maior número de arrendamentos de terrenos em faixa úmida foram junho e julho, com 49 lotes com área total de 1.560m e 98 lotes com área total de $2.000 \mathrm{~m}$ respectivamente. Com relação à medida média dos lotes, nota-se a diminuição de aproximadamente de 11 hectares de um mês para outro. Com relação aos lotes secos, o mês de janeiro teve o maior número de arrendamentos com 74 lotes abrangendo a área de 560,5ha.

Conforme os contratos feitos a partir de 1966 demonstram, a área dos lotes não era a mesma para cada uma das famílias, não importando para a determinação da mesma o número de pessoas que compunham a família, apesar da regra estipulada pelo Art. 17 das Instruções para o Arrendamento de 1950. Este artigo determinava que às famílias grandes (com mais de 9 pessoas) deveriam ser arrendados lotes com 9ha. A família de Manoel Fernandes, citada anteriormente, contava com 13 membros mas foi alocada em uma renda com 1,5ha de área. Como veremos mais a frente, esse não foi o único caso em que a área arrendada não condizia com o tamanho da família.

Apesar da todas as versões do contrato de arrendamento do Dnocs conterem cláusulas impedindo a venda, a divisão e o apossamento dos lotes arrendados, essas 
formas de apropriação eram correntes desde pelo menos a década de 1960. As vendas levaram muitas vezes à fusão de áreas e recomposição de propriedades maiores, pressionando os rendeiros de áreas menores a abandonarem suas terras. Uma das localidades em que esse processo ocorreu foi a conhecida pela denominação "Riacho de Boi". Essa área está situada na beira do açude Coremas (Estevam Marinho) sendo por isso muito valorizada por sua extensa faixa de vazante.

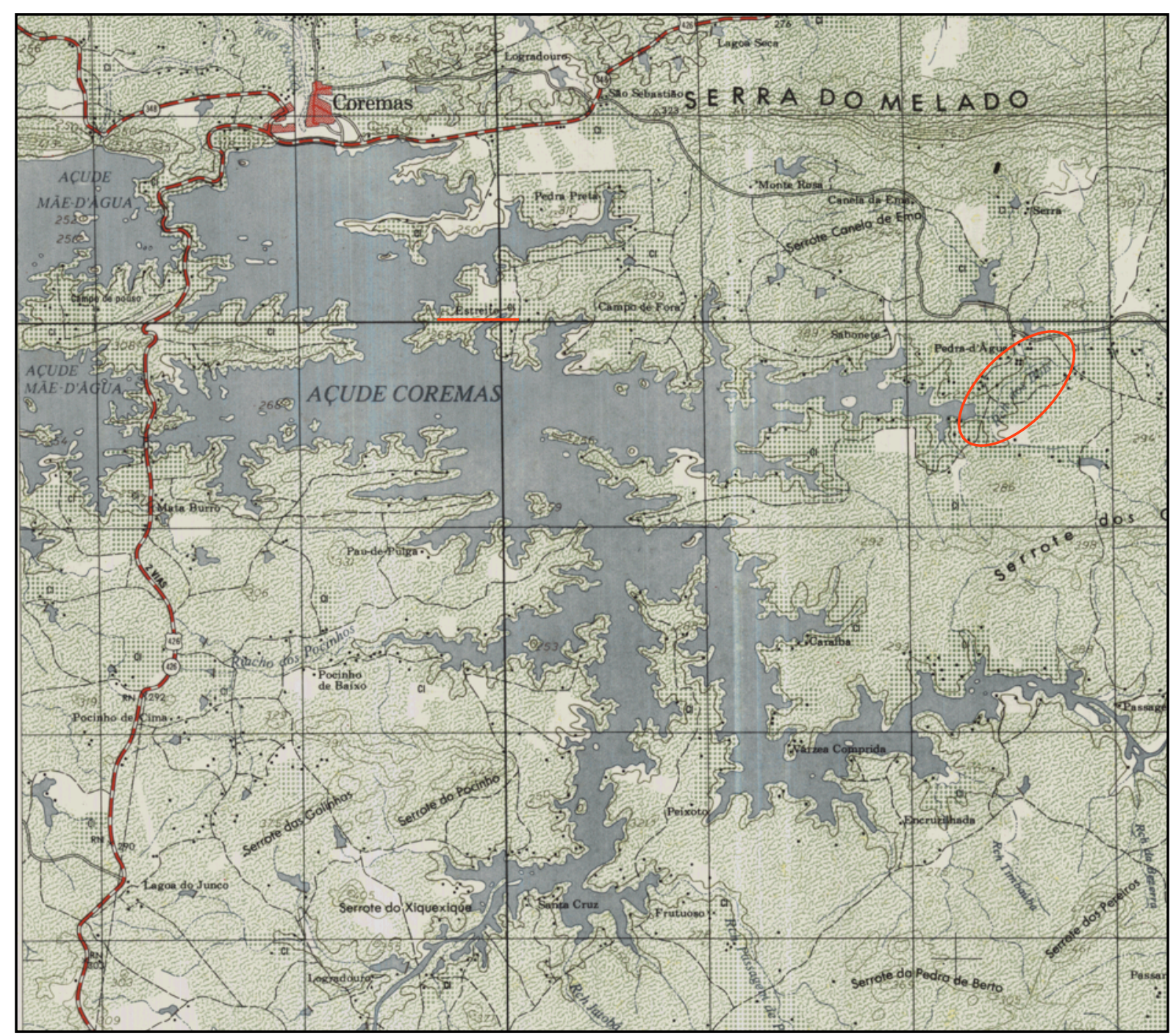

Carta Sudene, 1982, Riacho de Bois foi circundada.

Durante o cadastramento da Ifocs para a instalação do Açude Coremas (Estevam Marinho) foram levantados 48 lotes a serem desapropriados em Riacho de Boi. A área já vinha sofrendo intensa divisão desde pelo menos 1920, quando foram 
recenseadas 29 propriedades nessa localidade (Diretoria Geral de Estatística, 1926). Os lotes desapropriados que não ficaram cobertos pelas águas foram valorizados pela faixa localizada na beira do açude.

O processo de arrendamento de Antônio Silva Martins em Riacho de Boi é um exemplo da movimentação de terras na área. Os documentos apensados a esse processo serão analisados em seguida na tentativa de acompanhar esse movimento ${ }^{37}$. O pai de Antônio Silva Martins tinha o mesmo nome que o filho e já havia morrido em 1942, quando a Ifocs indenizou seu lote de 32,5ha na mesma localidade (Lote 235/ Proc. 190).

O documento legível mais antigo da pasta referente a Antônio Silva Martins (filho) é o pedido de arrendamento feito ao Dnocs de um lote de 9ha de terreno seco e 4 vazantes no Açude Público Estevam Marinho para a cultura de algodão, milho, feijão, batata, etc, feito em formulário pré formatado do órgão e assinado em 16 de outubro de 1966, quando Martins tinha 32 anos. Foi anotado com lápis vermelho em cima do formulário o número $998 .{ }^{38}$

A esse pedido segue a carteira de identificação em cartolina azul. Na parte interna à esquerda consta a identificação do arrendatário e do lado direito dados sobre a renda. Um dos campos da identificação se refere ao tempo que o mesmo é rendeiro em determinado açude ("É rendeiro desde 19 no açude "). Na ficha de Antônio Martins foi anotado que o mesmo era rendeiro desde 1947. Reproduzo abaixo algumas informações preenchidas para os anos de 1965 a 1969

\begin{tabular}{|c|c|c|c|}
\hline ANO & No DE PESSOAS $^{\circ}$ & $\begin{array}{c}\text { TERRENOS SECOS } \\
(\mathrm{ha})\end{array}$ & $\begin{array}{c}\text { VAZANTES } \\
\left(\mathrm{n}^{\circ} \text { de lotes }\right)\end{array}$ \\
\hline 1965 & 6 & 9 & 4 \\
\hline 1966 & 7 & 9 & 4 \\
\hline 1967 & 7 & 9 & 4 \\
\hline 1968 & 7 & 9 & 4 \\
\hline 1969 & 7 & 9 & 4 \\
\hline
\end{tabular}


Após a ficha que engloba os anos de 65-69, está o instrumento de renovação do "contrato de arrendamento n. 998 de 1948, firmado a 26 de 10 de 1966" por mais 4 anos, referente a 9 ha na faixa seca, 4 lotes de vazante e um terreno para edificação com 63m² (Contrato $\left.n^{\circ} 998 / 1971\right)$. Depois desse, foram apensadas mais duas ficha contendo o sumário das afirmações do contrato de renovação, também com data de 1971. Em um pedaço de papel que cobre cerca de $1 / 4$ da última ficha foi datilografada a relação da família do rendeiro e anotado as idades de seus quatro filhos $(8,5,2$ e 1$)$.

O documento seguinte, datado de 3 de maio de 1972, revela a interferência do Dnocs na relação tensa entre os vizinhos. Trata-se de um termo de acordo para o reparo de uma cerca separando as rendas de Antonio Martins e Rafael Viana da Silva, assinado pelos mesmos e pelo zelador Epitácio Carneiro de Oliveira, que estabelece:

Os rendeiros ANTONIO MARTINS DE SOUZA, e RAFAEL VIANA DA SILVA, se comprometem perante a Chefia, juntos, sem interferência de terceiros, de fazer a restauração da cêrca que o separa.

À guisa de cabeçalho vai o carimbo do "Chefe do Açude Público Estevam Marinho", José Maria de Aguiar, confirmando seu status de autoridade maior do local. Os cabeçalhos dos documentos oficiais demonstram a hierarquia de poderes envolvida até se chegar ao cargo de quem se pronuncia. No caso, o cabeçalho deveria constar o Brasão da República, menção ao Ministério da Viação, ao Dnocs, ao $3^{\circ}$ Distrito de Obras e à $4^{\circ}$ Residência em Coremas. O documento revela, porém, que o topo da hierarquia, sob o ponto de vista da gestão dos conflitos e resoluções locais, era exercido pelo chefe do Dnocs.

Em 1975, o Dnocs forneceu a declaração feita em formulário próprio com dados referentes ao arrendamento de Antonio Martins "para fins de prova junto ao Banco do Brasil S/A". Essa declaração foi feita em formulário pré formatado, denotando a ocorrência de financiamento especial para os proprietários da região. 
Todos os documentos até esse último possuem o número 998 grafado em vermelho. Essa anotação desaparece a partir das folhas da $4^{\mathrm{a}}$ via do Contrato de Arrendamento 840/79. O objeto desse contrato era o "arrendamento, pelo DNOCS, de quatorze (14) hectares de terras na faixa seca (lote $n^{\circ} 998$ ) e uma área de vazantes, com 100 metros de frente, situados no Açude Público Estevam Marinho. Como fica claro pela análise do conjunto dos documentos, trata-se de um acréscimo de 5ha no contrato anterior e não de um novo contrato.

A cláusula terceira desse contrato estipulava a duração de 3 anos, após os quais deveria ser assinado um termo aditivo. Esse termo não foi apensado ao processo, mas uma referência a ele foi feita no requerimento de Antônio Martins ao Chefe da Divisão de Pesca e Piscicultura - 3DR/DNOCS/RECIFE-PE, que reproduzimos abaixo:

ANTONIO MARTINS DE SOUSA, brasileiro, casado, agricultor, residente e domiciliado no município de Coremas, estado da Paraíba, arrendatário de 14 (catorze) hectares de terras de faixa seca e uma área de vasantes, com 100 (cem) metros de frente, localizados no Açude Público Estevam Marinho, no município de Coremas, estado da Paraíba, conforme contrato de Arrendamento $n^{\circ} 840 / 79$, celebrado em 10/01/1979, e seu Termo Aditivo $n^{\circ} 541 / 82$, firmado em $11 / 01 / 82$, vem solicitar a $S . S^{a}$., autorização para construção no lote arrendado de uma casa de alvenaria de tijolos, coberta de telha de barro comum, com $84,00 \mathrm{~m}^{2}$ de área construída, destinada a residência do requerente e de sua família, comprometendo-se a construir junto ao citado imóvel uma fossa rústica para coleta de dejetos.

Declara ainda o requerente que, depois de construído, o referido imóvel passará a fazer parte integrante do Patrimônio do DNOCS, não lhe assistindo nenhum direito de indenização na hipótese de, por qualquer motivo, vir a ser rescindido o instrumento contratual firmado com esse Departamento.

Nestes Termos

Pede Deferimento

O pedido transcrito está de acordo com o que determinava a legislação do 
órgão com relação às construções dentro dos terrenos arrendados e a sua destinação em caso de rescisão contratual.

Conforme estipulado na Portaria n 118 de 1950, todos os tipos de construções ou reforma realizados dentro das rendas do Dnocs deveriam ser comunicados à Administração (Art. 17, i). Fazia parte das determinações dessa portaria, ainda, que as benfeitorias erigidas dentro das rendas seriam revertidas para a União no caso de encerramento dos contratos independente de indenização (Art. 64).

Tanto a autorização prévia para reformas e construções como o fato das benfeitorias reverterem para o patrimônio público foram mantidas nas cláusulas dos contratos mais recentes, incluindo os feitos a partir de 2005. Como o Dnocs foi transformado em autarquia em 1963, as benfeitorias passaram a ser revertidas ao Patrimônio do Dnocs.

Duas carteiras de identificação, referente aos anos de 1970 a 1983 foram apensada após o ofício do Chefe local encaminhando o pedido reproduzido acima. Anotado a caneta na parte superior de ambas está: "contrato n 998". Para os anos de 1970 a 1977 foram registrados 9 hectares de terreno seco. A partir de 1978, foram anotados 14 hectares. O processo de 1979 formalizou, como já foi mencionado, a um aumento da mesma área já ocupada anteriormente. Não há referência à forma pela qual esse aumento se realizou - se foi uma compra de terreno vizinho feita entre pares ou se houve alguma requisição/pagamento ao próprio Dnocs -, contrariando o disposto no Art. 39 da Portaria n¹18/50 que determinava: "As ordens da Administração serão dadas por escrito".

Os terrenos de vazante são anotados pelo número de lotes desse tipo até 1974. Depois desse ano, passou-se a indicar apenas o tamanho deste. As medidas dos lotes de vazante que variavam conforme os meses, como vimos na análise dos boletins dos anos de 1955-57, passaram nessa época a equivaler a 25 metros.

Também sem qualquer tipo de justificativa, foram apensados ao processo de Antônio Martins a documentação relativa aos contratos 436/612 e 614, registrados em nome de Manoel Arruda de Souza e Sebastião Arruda Clementino, 
respectivamente. Este último era filho de Manoel Arruda e Honorina Ferreira da Conceição.

O pedido de arrendamento de um lote de 10ha e 4 vazantes em nome de Manoel Arruda foi formalizado em 9 de setembro de 1966 através do contrato de número 436. Como anexo deste pedido foi apensada uma declaração dada pelo Comissário de Polícia de Coremas atestando que Manoel Arruda era seu conhecido e que o mesmo era portador de boa conduta moral e "comprovadamente pobre na forma da lei". A declaração do Comissário foi feita na requisição padrão que reproduzimos a seguir:

\section{ILMO. SR. COMISSÁRIO DE POLÍCIA DO MUNICÍPIO DE COREMAS-PB}

MANOEL ARRUDA DE SOUZA, NATURAL DÊSTE ESTADO, DE PAIS FALECIDOS, RESIDENTE DO SÍTIO RIACHO DE BOI, SITUADO NO AÇUDE PÚBLICO ESTEVAM MARINHO, ENCRAVADO NÊSTE MUNICÍPIO, PRECISANDO PARA FINS DE DIREITO, VEM MUI RESPEITOSAMENTE PEDIR A V.S. QUE SE DIGNE ATESTAR SE O REQUERENTE É PORTADOR DE BOA CONDUTA CIVIL E MORAL BEM COMO SE O MESMO É COMPROVADAMENTE POBRE NA FORMA DA LEI.

\section{NÊSTES TÊRMOS}

P. DEFERIMENTO

COREMAS, 09 DE SETEMBRO DE 1966.

Ao contrário de Antônio Martins, cujo espólio do pai havia sido desapropriado, foi preciso que Manoel Arruda, assim como depois seu filho Sebastião, comprovasse ser pobre na forma da lei para que tivesse direito de tornarse arrendatário do Dnocs, de acordo com o objetivo expresso no Art. 5 da Portaria $\mathrm{n}^{\circ}$ 118/50 de fixar "famílias reconhecidamente pobres".

A primeira carteira de identificação do arrendatário Manoel Arruda foi anotada com os pagamentos referentes aos anos de 1965 e 1970, com 8 pessoas dependentes. O número anotado a caneta na parte superior direita da carteira também é 436. A renovação do contrato, feita em 10 de abril de 1970 indicou um novo número para o mesmo, que passou a ser 612. Esse é também o número anotado 
nas carteiras referentes aos anos de 1970 a 1974 e 1975 a 1978. A área de terreno seco e dos lotes de vazante permaneceu a mesma por todo o período. ${ }^{39}$

Na ficha de renovação do contrato de 1970 consta a informação, anotada a caneta, que o Manoel havia morrido em 1976, ficando sua renda sob responsabilidade de sua esposa Honorina Maria da Conceição. A mudança das fichas ocorreu apenas em 1978. Nesse ano, a quantidade de hectares de terreno seco anotados foi 12, 2 a mais que a medida anterior. A anotação das vazantes passou de 4 lotes para $100 \mathrm{~m}$.

Em abril de 1970, Sebastião Arruda Clementino, filho de Manoel e Honorina, firmou contrato com o Dnocs para o arrendamento de 2 ha na faixa seca (Contrato 614/1970). Não foi concedido arrendamento de terrenos de vazante, e a área parece diminuta para comportar os 10 dependentes de Manoel, segundo anotação em suas carteiras referente aos anos de 1970 a 1974 e 1975 a 1977. Segundo anotação feita a lápis no canto esquerdo da carteira de sua mãe Honorina Maria da Conceição, os dois hectares de Sebastião foram incorporados à renda de Honorina, assim como seus dependentes passaram a ser dependentes desta.

O documento que se segue aos processos de Manoel e Sebastião Arruda é uma declaração em formulário padrão com data de 13 de setembro de 2003, fornecida pelo Chefe do Dnocs em Coremas Clodovil de Souza Rêgo, atestando que a Sra. Erivanzilda Dantas Evangelista, solteira, agricultora, residente e domiciliada no Sítio Riacho de Boi trabalhava em Regime de Economia Familiar no lote $\mathrm{n}^{\mathrm{o}} 342$, medindo aproximadamente 26 hectares. A declaração afirma ainda que a mesma reside na comunidade supra desde 03 de março de 2001, no lote pertencente ao rendeiro Antônio Martins de Souza.

Na sequência dessa declaração há outra com data de 1997, assinada pelo mesmo chefe, atestando que o Sr. Antonio Martins de Souza era rendeiro em um lote de 14ha na Bacia Hidráulica do Açude Público Estevam Marinho, administrado pelo Dnocs, na localidade "Riacho de Boi" e que o mesmo trabalhava em Regime de Economia Familiar desde 26 de outubro de 1966 até aquela data. Embora não esteja 
expresso no processo, estas declarações foram dadas para fins de aposentadoria. ${ }^{40}$

Entre os documentos há um intervalo de 5 anos e 12 hectares, indicando que nesse período houve a incorporação das terras de Honorina Maria da Conceição às de Antônio Martins.

A essas declarações seguem dois contratos de arrendamento, o primeiro de 1995 e o segundo de 1982, relativos aos 14 ha de terreno seco e 100m de vazante de Antônio Martins. A carteira do arrendatário referente aos pagamentos dos anos 1984 a 2002, apensada ao processo após os contratos mencionados demonstra uma grande variação na quantidade de terras conforme tabela abaixo. Os dados referentes aos anos de 1990-1994 não foram preenchidos:

\begin{tabular}{|l|l|l|}
\hline \multicolumn{1}{|c|}{ ANO } & \multicolumn{1}{|c|}{$\begin{array}{c}\text { FAIXA SECA } \\
\text { (ha) }\end{array}$} & \multicolumn{1}{|c|}{ VAZANTES } \\
\hline 1984 & 14 & $100 \mathrm{~m}$ \\
\hline $1985 / 86$ & 28 & $200 \mathrm{~m}$ \\
\hline 1987 & 14 & $100 \mathrm{~m}$ \\
\hline $1988 / 89$ & 28 & $200 \mathrm{~m}$ \\
\hline 1995 & 14 & $100 \mathrm{~m}$ \\
\hline 1996 & 14 & $100 \mathrm{~m}$ \\
\hline 1997 & 14 & $100 \mathrm{~m}$ \\
\hline 1998 & 14 & $100 \mathrm{~m}$ \\
\hline 1999 & 14 & $100 \mathrm{~m}$ \\
\hline 2000 & 24 [riscado em caneta] & $\begin{array}{l}200 \mathrm{~m} \text { [corrigidos para } \\
100 \text { com caneta] }\end{array}$ \\
\hline 2001 & 14 & $100 \mathrm{~m}$ \\
\hline 2002 & 26 & $200 \mathrm{~m}$ \\
\hline
\end{tabular}

As variações poderiam ser explicadas pela incorporação das terras da família de Manoel Arruda em 1984, com pagamento feito em 1985, mas cuja formalização 
teria ocorrido apenas em 2002.

Após os registros de pagamento, foi apensada uma declaração com data de 23 de fevereiro de 2015 e assinada pelo atual chefe do posto de Coremas, Luis Paulo, dando conhecimento que João Mamede Alves estava "passando 02ha de terra no sítio Riacho de Boi" para Antonio Martins de Souza e que,

(...) as 02ha já é dentro [sic] da renda de Antonio Martins de Souza e que o mesmo já é Concessionário de área pertencente ao Departamento Nacional de Obras Contra as Secas (DNOCS), e quando for feito o Contrato será com 34ha de terra pertencente ao mesmo.

Finalizando o processo de Antonio Martins de Souza estão o contrato assinado pelo mesmo datado de 28 de setembro de 2005 e a carteira do arrendatário referente aos pagamentos realizados nos anos 2003 a 2016. O processo de 2005 tem como objeto o lote de $\mathrm{n}^{\mathrm{O}} 342$ com 31 hectares na faixa seca e um lote de $250 \mathrm{~m}$ de frente na faixa úmida. Desde o primeiro contrato, firmado em 1966, a área do lote na faixa seca aumentou em 22 hectares e sua área na faixa úmida mais que dobrou, passando de $100 \mathrm{~m}$ a $250 \mathrm{~m}$. A área de faixa seca passou de 9 para $14 \mathrm{ha}$, sem explicação constante do processo, em 1970. A partir da década de 1990, houve a incorporação de 12 ha de terreno seco e 100m de terreno úmido dos lotes antes arrendados à família de Manoel Arruda. De 26ha e 200m, o objeto do contrato passou por fim, e sem explicação constante do processo, para 31 ha e 250m de faixa úmida em 2005. E, segundo declaração que atestou a "passagem" das terras de João Mamede a área total do lote seria 36ha a partir de 2015.

Como acompanhamos no processo, durante os anos de 1947 e 2015, Antonio Martins recompôs, pelo menos em quantidade, a área desapropriada do espólio do seu pai e paga pela Ifocs em dezembro de 1942.

O processo de composição de áreas maiores a partir da reunião de lotes contíguos, ou pedaços destes, ocorreu não só na área conhecida por Riacho de Boi, mas em toda a faixa localizada na beira dos açudes. Como foi apontado na Parte I-7, 
tanto os projetos de beneficiamento das áreas sob influência dos açudes do Dnocs, como os programas de concessão de crédito para fomento da produção agropecuária favoreceram os agricultores de mais elevado nível sócio econômico. Tal situação favoreceu a ampliação de algumas áreas a partir da incorporação de rendas menores, como o lote de 2ha de João Mamede citado acima.

\section{De moradores a rendeiros: a Comunidade Negra de Barreiras}

A figura do morador, como elemento da estrutura produtiva paraibana, surgiu nos canaviais e engenhos já em finais do século XVII, como resposta ao empobrecimento da província. Com as crises no comércio açucareiro, os senhores de engenho retraíram a produção e transformaram parte da mão de obra escrava em moradores. Dentro de cada engenho, a força de trabalho agrícola era representada, sobretudo, por estes trabalhadores-moradores. Tinham eles o direito de explorar pequenos sítios com lavouras de subsistência e eram obrigados a trabalhar a serviço do proprietário um certo número de dias por semana. Aos proprietários, desobrigados da manutenção de seus trabalhadores, tornou-se conveniente situar seus ex-escravos como agregados e cabras do eito. Era o chamado trabalho sob sujeição (Fortes e Lucchesi, 2013).

Na Paraíba usa-se sujeito, assujeitado ou sujeição para qualificar o regime de trabalho a que ficam submetidos os trabalhadores rurais e moradores das fazendas que, em troca de morada e terra para trabalhar, têm que pagar parte (muitas vezes a metade) da produção, além de obedecer as restrições impostas dos patrões, como exclusividade na comercialização do excedente e restrição do plantio de culturas que durassem mais de um ano, entre outros.

No artigo “Libertos e Sujeitos: sobre a transição para trabalhadores livres do nordeste", o antropólogo Afrânio Garcia Jr. analisou as transformações na produção e nas relações trabalhistas na região de Areia, no Brejo paraibano, ao longo do século XX. Esse autor caracterizou a relação estabelecida entre senhores de engenho e 
moradores da seguinte maneira:

Até 1888, os senhores de engenho possuíram escravos negros de origem africana. A diferença de outras regiões açucareiras do Nordeste, o brejo parece não ter tido mais de $20 \%$ da força de trabalho constituída por escravos (Almeida, 1937, p. 208). Os senhores de engenho se apoiavam sobretudo sobre o trabalho de todos aqueles que estavam submetidos a eles pelo simples fato de residirem em seus domínios, os moradores. Depois da abolição da escravatura a parte essencial do trabalho nos engenhos era efetuada por moradores. Nos períodos de pico do ciclo agrícola faziam apelo ao trabalho sazonal de pequenos proprietários das vizinhanças, que não ficavam submetidos à mesma dependência que os moradores.

Ser morador ou tornar-se morador significava se ligar ao senhor do domínio de uma maneira muito específica, numa relação que supunha residência e trabalho simultaneamente. A ênfase na residência, que o termo morar revela, tem um forte significado simbólico. Quem se apresentava ao senhor de engenho não pedia trabalho, pedia uma morada. Entre as obrigações que a morada acarretava, havia forçosamente o trabalho para o dono do domínio, mas esta não era a questão básica: é o que distinguia o morador de um pequeno proprietário das vizinhanças que podia vir pedir apenas se havia trabalho no engenho. Ao pedir morada, quem o fazia já demonstrava não ter outra escolha melhor, que não tinha para onde ir: não tendo meios de organizar sua existência social, vinha pedir ao senhor que os fornecesse, ou mesmo que a organizasse para si. Caíam assim sob a estrita dependência do senhor, à diferença dos pequenos proprietários que, mesmo mostrando que não tinham meios suficientes para viverem sem trabalhar para outrem, podiam discutir sobre a remuneração do trabalho e dispunham de habitação própria (mesmo se dormissem no domínio durante o desenrolar dos trabalhos).

Quem dava a morada dispunha de um patrimônio fundiário suficientemente grande para the permitir recrutar famílias de trabalhadores para viverem em seus domínios. Os senhores utilizavam assim seus patrimônios fundiários para constituírem uma clientela de indivíduos submetidos a laços de dependência, rede que assegurava um poder social tanto maior quanto mais elevado fosse o número de indivíduos que a 
compunha. Em outros termos, procuravam acumular, graças ao patrimônio fundiário, uma força social específica, tanto material, pelo número de "braços" à disposição, quanto simbólica, pelo número dos que os reconheciam como senhores. Por sinal o recrutamento de moradores era feito sobretudo em bases familiares: o solicitante era em geral um chefe de família, que tinha tanto mais chance de ser aceito quanto mais numerosa fosse sua família (maior o "número de braços") (Garcia Jr., 1988, p. 4, grifos no original).

O regime de moradia é uma relação de dependência por parte dos trabalhadores em relação aos proprietários, sendo a disponibilidade permanente do morador a seu patrão o ponto central dessa forma de dominação específica. Embora fossem relatados castigos físicos, o trabalho de dominação garantia outros meios de coerção, “os 'dons generosos do proprietário' criavam para o eventual beneficiário uma dívida que não poderia ser saldada", não tendo outra alternativa que não assumir como seu o interesse de seu protetor (Garcia Jr, 1988). Esse sistema de dominação tradicional através da morada que se contrapõe ao mercado de trabalho organizado em bases capitalistas.

Conforme apontou Linda Lewin ([1987] 1993), a partir de 1870 a valorização da cultura do algodão determinou um deslocamento da elite para o interior do estado, transformando os antigos padrões de uso da terra no sertão. Nesse processo, as terras devolutas praticamente desapareceram, assim como novas relações de trabalho surgiram.

O mais forte impacto do algodão nas zonas interioranas resultou na reorganização da população rural num novo sistema de trabalho. Embora legalmente livres, os moradores agrícolas do Nordeste foram incorporados num arranjo subordinado a que eles próprios se referiam como sujeição literalmente, submissão ou subjugação.

(...)

Seja através da partilha da colheita ou de arranjos de quase arrendamento, o sistema de sujeição predominou por todo o interior do Nordeste depois do auge do algodão na década de 1860. Um meio de 
exploração que assegurava o trabalho barato e submisso para os proprietários, o sistema de sujeição divergia em dois aspectos das relações anteriores entre proprietário e morador. Em primeiro lugar, extorquia o trabalho em termos muito mais onerosos e empobrecedores. Em segundo lugar, sua existência dependia do desaparecimento ou da obliteração deliberada do campesinato médio e da conversão daquele estrato de proprietários livres em moradores agrícolas sem terra (Lewin, [1987] 1993, pp. $63,64)$.

Lewin chamou atenção para uma nova transformação após a década de 1920, com a baixa do algodão e a ocorrência da revolta conhecida por Quebra-Quilo, dividindo foreiros, meeiros, posseiros e moradores. Segundo Lewin,

Os mais favorecidos entre esses homens do campo pertenciam à categoria de morador, na qual se incluíam desde o pequeno proprietário independente até o posseiro que gozava de direitos quase permanentes de residência numa grande propriedade. Os moradores constituíam um estrato indispensável para o controle exercido pela oligarquia fundiária, pois era de suas fileiras que se recrutavam os servidores pessoais e os capangas. Estes anunciavam seu status elevado através do cobiçado privilégio de portar armas de fogo (Lewin, [1987] 1993, p. 64).

Ao mesmo tempo que é descrita como condição provisória colocando as famílias em eterno movimento em busca de melhores condições de moradia ou patrões menos perversos, também é usada para caracterizar uma condição quase fixa, dado o tempo de permanência e alargamento do círculo familiar em uma mesma propriedade.

Uma parte expressiva dos pedidos de desapropriação para fins de reforma agrária abertos nas superintendências regionais do Incra no Maranhão e na Paraíba foram feitos com o objetivo regularizar a situação das famílias que já eram moradoras de longa data das terras demandadas e que se encontravam ameaçadas de expulsão no momento do pedido. O mesmo ocorre com os processos regularização fundiária de territórios quilombolas, sendo possível em muitos casos acompanhar a 
transformação das famílias da condição de escravas a moradoras. ${ }^{41}$

Embora ainda existam muitos trabalhadores vivendo sob o arranjo trabalhomorada, o sistema ampliado da moradia começou a decair a partir da década de 1980 com fortalecimento dos sindicados, como mostrou Afrânio Garcia Jr. para o caso de Areia. Muitos proprietários foram condenados a pagar indenizações trabalhistas ou ceder parte de suas terras em favor de seus antigos moradores. Os processos de regularização fundiária são ao mesmo tempo causa e efeito da desestruturação desse sistema.

Além da busca por melhores condições de moradia, na região semi-árida, a seca é um importante fator de deslocamento dessa população. Como vimos ao longo da Parte I, os moradores eram os primeiros a ser postos em movimento com as secas, formando o exército de flagelados-retirantes do qual parte era absorvido nas obras públicas como operários cassacos.

O censo populacional de 1950 (Ibge, 1955) registrou um total de 1.845 pessoas na cidade de Piancó e 2.982 pessoas na vila de Coremas. A população vivendo na zona rural em todo município de Piancó era de 39.289 pessoas e havia, então, 16.767 pessoas com 10 anos ou mais vivendo da agricultura.

O único recenseamento que indica o número de pessoas vivendo na área rural de Coremas é o citado por Medeiros no verbete "Coremas" do Dicionário Corográfico do Estado da Paraiba de 1940. Esse é um dado valioso porque, se por um lado a descrição das benfeitorias explicita a realidade produtiva da área em que foram construídos os açudes, esta deixa apenas implícita a quantidade efetiva de pessoas que morava na região e sobrevivia da agricultura.

A simples menção ao número de casas de taipa existentes nos lotes não permite saber ao certo o número de moradores das propriedades. Só podemos supor a presença de moradores pela quantidades de casas e plantios comerciais. O algodão, principal produto da região durante a primeira metade do século $X X$, mobilizou grande número de mão de obra em determinados momentos do seu ciclo, número 
que fica encoberto nas descrições das benfeitorias nos processos de desapropriação e termos de ajuste. O mesmo ocorre na coleta de oiticica ou cera de carnaúba.

As famílias de moradores não foram cadastradas ou mesmo enumeradas, assim como não foram contabilizadas suas roças. Tomando como base uma família por casa e a quantidade média de pessoas na família o mesmo utilizado pelo Dnocs para a contagem de ocupação das rendas nos boletins mensais de fiscalização e exploração do açude Curema (1954-57) que era de 6 pessoas, uma população de pelo menos 210 pessoas foi desalojadas com as desapropriações de apenas em 5 lotes vizinhos (Barreiras, Cachoeirinha, o lote 558 de José Soares e o lote 598 de João Pereira de Oliveira).

No Boletim do Dnocs de agosto de 1958, vol. 18, $\mathrm{n}^{\circ} 1$, foi publicado o artigo "Instruções sôbre desapropriação para uso do D.N.O.C.S., escrito por José Andréa dos Santos. Assim como as normas citadas anteriormente, o texto é omisso em relação ao levantamento dos trabalhadores-moradores das áreas declaradas para desapropriação. Nas instruções sobre o levantamento cadastral da área decretada, foi citada a seção IV, cap. II, do tít. I, do Decreto-Lei n ${ }^{\circ} 9.760$ de 5 de setembro de 1946, que dispõe sobre as terras da União.

O Art. 22 da seção citada, que versa sobre a discriminação de terras da União, menciona apenas de passagem que o estudo prévio da área discriminada deveria conter um relatório, entre outros, "das criações, benfeitorias e culturas encontradas, assim como de qualquer manifestação evidente de posse de terras". As casas dos moradores e suas roças poderiam ser incluídos nesse item, mas tanto as instruções dadas no artigo, como os cadastros a que tivemos acesso demonstram que essas construções foram consideradas benfeitorias pertencentes apenas aos proprietários dos lotes.

Entre os lotes citados na Parte II-2, estava a fazenda Cachoeirinha. Ao mesmo tempo que experimentou vários fluxos de moradores, a Cachoeirinha foi o local aonde se formou o extenso núcleo familiar de José Jorge, conhecido por Zé Pequeno, 
importante liderança comunitária de Coremas. Seu bisavô, Joaquim Jorge de Amorim nasceu e se criou em Cachoeirinha, onde faleceu por volta de 1947. Um de seus filhos, Francisco Jorge de Amorim, criou ali seus 10 filhos, um deles Pedro Jorge de Amorim nascido em 1916, pai de Seu Zé Pequeno.

Outro filho de Francisco Jorge, Severino Antônio da Silva (Severino Jorge de Amorim) nascido em 1937, contou que sua família "nasceu e se criou e morreu toda na Cachoeirinha"42. Seu Severino vive atualmente em uma casa nas terras de José Hilton Lopes, um dos filhos de Antônio Lopes que também foi prefeito de Coremas (1989-1992).

O pai de Seu Severino e avô de Zé Pequeno, Francisco Jorge, morreu na fazenda Cachoeirinha em 1972 com 88 anos. Supondo que o pai de Francisco Jorge tivesse pelo menos 15 anos quando o teve, em 1884, Joaquim Jorge teria nascido em 1869, ainda sob vigência da escravidão e anteriormente à chamada Lei do Ventre Livre (1871).

Piancó teve um grande número de escravos no final do século XIX devido às plantações de algodão, é muito provável que Joaquim Jorge fosse escravo da fazenda Cachoeirinha tendo permanecido ali como morador após o fim da escravidão, exemplificando a transformação de escravos a moradores mencionada no início dessa seção.

Um dos netos de Joaquim Jorge, Pedro Jorge Amorim, pai de seu Zé Pequeno, era vaqueiro de Antônio Lopes e arrendou um lote do Dnocs em 1965. Por gozar de um status privilegiado que a função de vaqueiro lhe dava, é possível que Antônio Lopes tenha intercedido junto ao Dnocs para que Pedro Jorge se tornasse arrendatário do órgão.

Pouco depois da assinatura do contrato de arrendamento com o Dnocs em 1966, Pedro Jorge mudou-se para o Rio de Janeiro. Como seu filho Zé Pequeno era menor de 21 anos no momento de sua partida, Pedro Jorge deixou uma carta na qual transferiu seu arrendamento para seu filho. Esse documento faz parte de sua pasta 
no Dnocs de Coremas. A renda é localizada no local conhecido por Barreiras, na beira do açude e vizinho à Cachoeirinha.

Com a decadência da Fazenda Cachoeirinha, hoje completamente abandonada, muitos de seus antigos moradores também mudaram-se para Barreiras, onde, assim como Seu Zé Pequeno, são rendeiros do Dnocs.

No levantamento cadastral realizado em 2008 pela Comissão Pastoral da Terra (CPT/Sertão-PB), foram cadastrados 30 bisnetos de Joaquim Jorge morando em Barreiras nas rendas do Dnocs. ${ }^{43}$

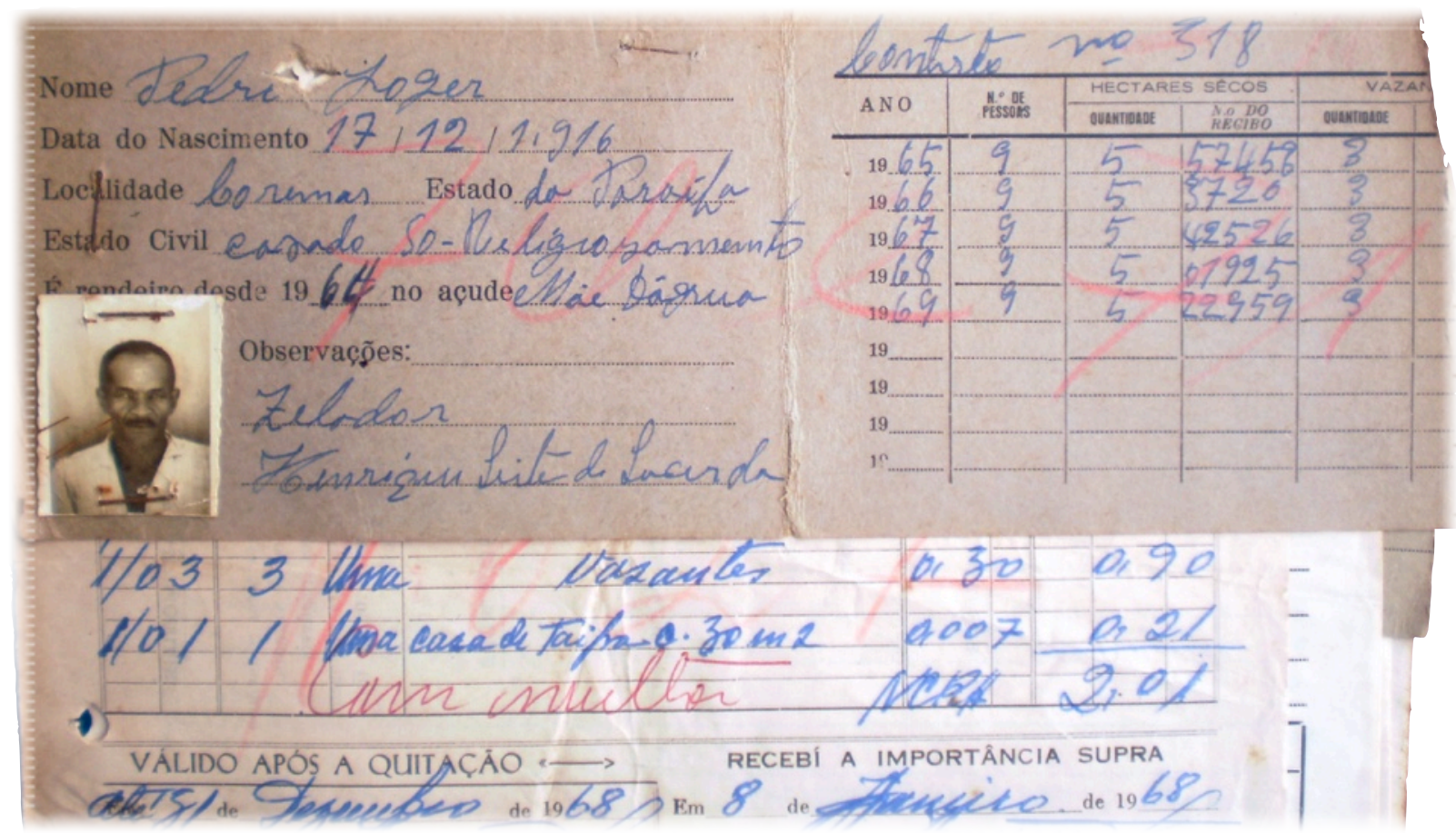

Segundo relato de alguns dos antigos moradores da Fazenda Cachoeirinha, a propriedade inteira chegou a abrigar 35 famílias de moradores. A parte que não foi desapropriada pelo Dnocs continuou a abrigar muitos moradores e manteve uma produção expressiva para a região até a morte de Antônio Lopes.

Em certidão fornecida ao Incra/PB pelo Cartório de Notas de Coremas em outubro de 2008, consta a seguinte descrição da Fazenda Cachoeirinha datada de dezembro de 1976:

Uma Propriedade Rural denominada CACHOEIRINHA, encravada 
no Distrito sede deste Município e Comarca, de baixios e carrascos, medindo (1.200), mil e duzentos hectares. Limitando-se: Ao Nascente com os herdeiros de João Soares de Souza, Ao Poente, com Tertulino Pereira de Souza, Germano Gualberto da Silva e José Joaquim de Souza, Ao Norte com João Maria da Silva, terras do DNOCS e de José Mariano de Araújo, e ao Sul com terras de José Leite da Silva, e os herdeiros de Dona Leonila Leite Ferreira, com dois (02) açudes de parede de terras apiloado, duas (02) casas de tijolos e telhas (18) dezoito casas de taipas e telhas, raizal de algodão, área total 1.200 ha.

Em entrevista realizada em 2009, Seu Lampião recordou que as famílias do Navio também plantavam na fazenda, que era vizinha deste, e que "na Cachoeirinha era tudo preto". O plantio era feito como uma espécie de camaradagem e quando se pagava renda essa era bem pouca, "era um tempo de fartura". Seu Lampião apontou também a mudança no sistema de trabalho-moradia, que passou a ser descartado pelos novos proprietários dado o avanço na garantia dos direitos dos moradores, como foi comentado anteriormente. "Hoje ninguém quer mais morador", explica, "quem tá sustentando é Deus e o Governo".

\section{De moradores a rendeiros, de rendeiros a sem anuência: a Comunidade Negra de Cruz da Tereza}

O pai de Fabiano Tomás Rodrigues dos Santos, Cícero Tomás Rodrigues dos Santos, nasceu na região de Coremas e era morador de Ciço Parente. Quando o patrão se mudou, Cícero Tomás tornou-se morador de Firmino Lucas, ainda antes da construção dos açudes pelo Dnocs. Firmino Lucas teve quatro lotes no lugar Estreito desapropriados por estar dentro da bacia hidráulica do açude Coremas.

Segundo contou um dos filhos de Cícero, Tomás Rodrigues, o pai teve ajuda do próprio Firmino Lucas para "conseguir uma renda" do Dnocs em Estreito.

Cícero Tomás vendeu essa renda pouco tempo depois. De acordo com uma de suas netas, Desterro, correu um boato de que o governo iria tomar as rendas que 
estivessem no beiço da água do açude Dnocs, "aí ele já com uns oitenta e tantos anos se impressionou e deu por pouco mais ou nada" (Entrevista, dez. 2016).

Após a venda da renda de seu pai em Estreito, Fabiano mudou-se com a família para o lugar conhecido por Cruz da Tereza, também localizado em terras desapropriadas pelo Dnocs e registradas em nome do órgão. Para construir uma casa para sua família, Fabiano pediu um pedaço chão para um dos guardas do Dnocs conhecido como Sartori. A condição para a permanência da família era a de que não construíssem uma casa de tijolos, pois a qualquer momento o Dnocs poderia requisitar o local para outro fim.

Fabiano conheceu sua esposa, Maria Salete, ainda em Estreito, onde a mãe desta também tinha uma renda do Dnocs. Dona Salete foi registrada pelos avós, Manoel José Ferreira e Maria José da Conceição em Piancó, aonde morou até os sete anos de idade. Em Coremas, foi moradora em "Campo de Fora" e em "Tabuleiro do Meio", cujo proprietário era Lucrenato Ramalho Leite, sobrinho neto do Capitão Antônio Leite que dá nome a uma das primeiras ruas da cidade.

As primeiras casas do local se estabeleceram da mesma maneira que a da família de Seu Fabiano e Dona Salete, através da permissão dada pelo guarda do Dnocs. Esse foi o caso de Dona Gorete Viera cujo pai, Ostiliano Lourenço da Silva, já havia se mudado do Navio para Mãe D'água, daí para as rendas de Riacho do Boi e, então, para Cruz da Tereza.

As rendas do Dnocs localizadas em Riacho do Boi foram sofrendo uma progressiva concentração, forçando os agricultores mais pobres a novos deslocamentos. Esse fenômeno ocorreu também em outros lugares da bacia hidráulica dos açudes. Segundo Tomás Rodrigues, antigamente Estreito era cheio de gente. Já em 2009, apenas um rendeiro concentrava nove rendas.

Riacho de Boi é uma das localidades citadas como origem de muitos moradores na Comunidade Negra Cruz da Tereza, conforme relato que instrui o pedido de certificação da comunidade como quilombola pela Fundação Cultural 
Palmares (Proc. nº 01420.001196/2006-75).

Damiana Ferreira Tomás, atual presidente da associação quilombola de Cruz da Tereza, contou que muitas famílias saíram de lá pela pressão dos novos donos dos lotes do Dnocs. Perante meu espanto acerca do termo "donos", Damiana explicou: "eu tenho um lote, mas sendo do dnocs, mas comprou diz: é meu".

Como já foi comentado, os períodos de seca também marcaram os deslocamentos pela região. Francisco Ferreira Tomás saiu de Riacho do Boi para Cruz da Tereza em 1987 por causa da seca. A falta de um projeto de irrigação abrangente faz necessário que os agricultores estejam localizados perto da água até os dias hoje.

Na época em que chegou em Cruz da Tereza, entretanto, o Dnocs já havia perdido muito da influência nas transações comerciais dos terrenos matriculados em nome do órgão. Seu Francisco comprou seu chão de "um filho de Brás Abelha". Atualmente, ele trabalha em uma renda do Dnocs e tem com o "dono" desta o seguinte acerto: ele planta na área e o resto de sua colheita serve para alimentar o gado do patrão.

A transitoriedade da posse marcada, por exemplo, pela condição de que a casa construída em terras do Dnocs fosse de taipa fez com que as famílias vivessem em um estado de insegurança, apesar da posse continuada. Quando Seu Fabiano morreu, uma pessoa tentou aplicar um golpe na família dizendo que ele havia vendido parte de sua casa. Foi preciso que suas filhas fossem à delegacia e finalmente ao Dnocs para resolver a questão.

A instabilidade das posses foi e ainda é vivenciada também pelos arrendatários e mesmo entre os funcionários do órgão, como pode-se ver no requerimento enviado ao Diretor Geral do Dnocs por Valdevino de Souza na década de 1960.

Em 16 de julho de 1962, o Assessor de Finanças do Diretor Geral, enviou ao Chefe do $2^{\circ}$ Distrito do Dnocs, o ofício 286SA encaminhando o requerimento do Sr. 
Valdevino e solicitando esclarecimentos sobre o assunto (particularmente sobre itens $5,6$ e 7$)$.

Ilmo. Sr. Diretor Geral do Dnocs,

José Valdevino de Souza, escrevente datilógrado, nivel 7, lotado nesta Administração Central, vem com a devida vênia expôr e solicitar o beneplácito dessa Diretoria para o que abaixo passo a expôr:

1 - O pai do requerente, é funcionário do Dnocs, em Coremas - $2^{\circ}$ Distrito, desde 1.932.

2 - Como funcionário daquele setor, alí viveu 30 anos em casa pertencente aquele serviço com sua esposa e 7 filhos;

3 - Agora, com o processo de sua aposentadoria foi surpreendido com aordem do Chefe daquele setor para deixar a casa que ocupa.

4 - Sr. Diretor, meu pai trabalhou pelo DNOCS, todos êsses anos, ganha presentemente $\mathrm{Cr} \$ 13.000,00$, e luta com dificuldades para manter com dignidade nossa familia; daqui ajudo no que posso, com a vantagem de estar estudando; se pedir transferencia para Coremas para conseguir que minha familia permaneça na casa, vou prejudicar-me, suspendendo meus estudos faço o $3^{\circ}$ ano Ginasial.

5 - Acrescente-se a isso o fato de meu pai já idoso, nascido e criado alí, não mais se aclimatará em outro lugar, tanto pelo seu estado de saude como pelas condições financeiras; o requerente mesmo, não poderá arcar com as consequencias de uma nova vida em Fortaleza;

6 - Assim, Sr. Diretor, apelamos para o alto senso humano de que V. Sa é portador, a fim que essa Diretoria encontre um meio de conservar minha familia na residencia que lhe foi destinada em Coremas.

7 - Sendo impossível, então apelo para que êle permaneça na casa até o fim do ano, quando então solicitarei a minha transferência para aquela Residencia, pois no momento me traria grandes prejuizos.

Embora experimentado por rendeiros, posseiros e funcionários, o processo de transformação do espaço e consequente perda de áreas de plantio é sentido de maneira mais intensa pelos moradores de Cruz da Tereza. Localizado na periferia da cidade, o bairro vem sofrendo um processo de urbanização rápido e desordenado. 
Em 2016, conforme determinação do Ministério Público Federal em Patos, servidores do Dnocs em São Gonçalo realizaram o levantamento dos moradores quilombolas nas localidades Barreiras e Cruz da Tereza. Um dos itens do cadastro é: "Imóvel foi construído com anuência do Dnocs （ ） sim （）não". No caso de a pessoa ser rendeira do órgão deveriam ser preenchidas também as seguintes opções:

ACASO FOR RENDEIRO: （）Concessionário （） contrato vencido （） contrato virgente [sic] （）Adquiriu lote com o DNOCS （）Adquiriu com terceiro ( ) Nunca foi concessionário ( ) Nome do ocupante anterior: ( ) Era rendeiro

O documento considera a existência habitações irregulares, feitas "sem a anuência do Dnocs", assim como prevê os casos em que as rendas teriam sido adquiridas de terceiros. No caso de Cruz da Tereza, que é uma área adensada localizada na periferia da cidade, a totalidade dos cadastros apontou que as habitações haviam sido construídas sem a anuência do órgão.

Como foi registrado no início dessa seção, entretanto, os moradores mais velhos do lugar declaram, entretanto, que obtiveram permissão para construírem suas casas de um funcionário do Dnocs, como foi o caso da família de Fabiano e Ostiliano há mais de trinta anos atrás. Mesmo assim, as casas de seus descendentes foram consideradas como existindo "sem anuência do Dnocs".

Outras construções grandes, como os dois postos de gasolina, uma fábrica de peixes e mesmo um motel, foram denunciadas ao Dnocs ainda no início de sua construção. Mesmo sob pressão de outros órgão como o Incra, o Ibama e o MPF, as construções irregulares continuaram, isentando-se o Dnocs de responsabilidade ao anotar elas foram feitas sem a sua anuência.

\section{De libertos a rendeiros: Os negros do Navio}

Ao lado da Fazenda Cachoeirinha existia um importante povoado negro conhecido por Navio que ficou totalmente encoberto pelas águas do açude Mãe 
D'Água. Entre os lotes cadastrados pelo Dnocs nas décadas de 1920-40, encontrei quinze registrados no local "Navio", totalizando 1.418,5 ha. Treze deles foram indenizados ainda nos primeiros anos de 1940, conforme tabela abaixo, construída a partir das muitas tabelas e listas de desapropriação disponíveis no Dnocs em João Pessoa:

\begin{tabular}{|c|c|c|c|c|c|}
\hline $\begin{array}{l}\text { Processo } \\
\text { (número) }\end{array}$ & $\begin{array}{c}\text { Lote } \\
\text { (número) }\end{array}$ & Proprietários & Lugar & $\begin{array}{l}\text { Área } \\
\text { (ha) }\end{array}$ & $\begin{array}{l}\text { Indenização } \\
\quad(\text { ano) }\end{array}$ \\
\hline 146 & 225 & $\begin{array}{l}\text { Herd. de José } \\
\text { Soares de Souza }\end{array}$ & Navio & 180 & 1941 \\
\hline 169 & 226 & $\begin{array}{l}\text { Candido Rufino } \\
\text { de Souza }\end{array}$ & Navio & 408 & 1942 \\
\hline 144 & 227 & $\begin{array}{l}\text { Herd. de D. Rita } \\
\text { Francisca de } \\
\text { Jesus }\end{array}$ & Navio & 132 & 1942 \\
\hline 173 & 228 & $\begin{array}{l}\text { Herd. de Félix } \\
\text { Rodrigues dos } \\
\text { Santos }\end{array}$ & Navio & 22 & 1942 \\
\hline 165 & 229 & $\begin{array}{l}\text { Francisco Felix da } \\
\text { Silva }\end{array}$ & Navio & 47,5 & 1942 \\
\hline 207 & 246 & $\begin{array}{l}\text { Herds. de Manoel } \\
\text { Lourenço da Silva }\end{array}$ & Navio & 34 & 1942 \\
\hline 164 & 247 & $\begin{array}{l}\text { Julio Inocêncio da } \\
\text { Silva }\end{array}$ & Navio & 77,5 & 1942 \\
\hline 209 & 248 & $\begin{array}{l}\text { Da. Maria Antonia } \\
\text { de Jesus }\end{array}$ & Navio & 64 & 1943 \\
\hline 165 & 249 & $\begin{array}{l}\text { Francisco Felix da } \\
\text { Silva }\end{array}$ & Navio & 58 & 1942 \\
\hline- & 251 & $\begin{array}{l}\text { Herds. de Da. } \\
\text { Ermínia de Lima e } \\
\text { Souza }\end{array}$ & Navio & 24,5 & - \\
\hline 172 & 252 & $\begin{array}{l}\text { João Pereira da } \\
\text { Fonseca }\end{array}$ & Navio & 51 & 1942 \\
\hline 168 & 253 & $\begin{array}{l}\text { Antonio Virginio } \\
\text { de Araujo }\end{array}$ & Navio & 10,5 & 1942 \\
\hline
\end{tabular}




\begin{tabular}{|c|c|l|c|c|c|}
\hline $\begin{array}{c}\text { Processo } \\
\text { (número) }\end{array}$ & $\begin{array}{c}\text { Lote } \\
\text { (número) }\end{array}$ & Proprietários & Lugar & $\begin{array}{c}\text { Área } \\
\text { (ha) }\end{array}$ & $\begin{array}{c}\text { Indenização } \\
\text { (ano) }\end{array}$ \\
\hline 181 & 256 & $\begin{array}{l}\text { Jose Belarmino } \\
\text { de Souza }\end{array}$ & Navio & 71,5 & 1942 \\
\hline s/n & 257 & $\begin{array}{l}\text { João Pereira de } \\
\text { Oliveira }\end{array}$ & Navio & 219,5 & não pago \\
\hline 177 & 259 & $\begin{array}{l}\text { Manoel Pereira } \\
\text { Sobrinho }\end{array}$ & Navio & 18,5 & 1942 \\
\hline
\end{tabular}

Ao ler os nomes dos proprietários cadastrados para antigos moradores do povoado, eles se lembraram que grande parte eram proprietários das fazendas vizinhas ao local que eles denominam como Navio. Assim como muitas das propriedades da região, Navio devia ser o nome de uma propriedade maior que foi sendo dividida ao longo dos anos.

Infelizmente, não foi possível localizar os processos das áreas pagas, contendo as escrituras das mesmas e o número de edificações e demais benfeitorias dos terrenos. Encontrei apenas uma listagem encaminhando esses processos, em 1975, da sede do Dnocs em João Pessoa para a de Recife.

Um dos lotes levantado foi o dos "Herdeiros de Dona Hermínia de Lima e Souza". Esse lote foi relacionado em apenas um dos levantamentos e não chegou a virar um processo. Embora ninguém conseguisse lembrar de Dona Hermínia, os sobrenomes Lima e Souza são comuns entre os negros do Navio. Uma das hipóteses para o lote não ter sido avaliado pode ter sido a falta de documentação da área.

Segundo contam seus antigos moradores, o Navio era um povoado localizado em um grande baixio nas margens do rio conhecido por "Rio do Navio" (rio Aguiar), propício para a cultura de arroz e outros plantios de vazante. Os chefes do lugar eram os irmãos Antônio Tobias Ananias e Manoel Ananias de Lima. Embora o domínio dos irmãos fosse reconhecido não apenas no povoado, mas na cidade e demais sítios da região, seus nomes não apareceram em nenhum dos levantamentos feitos pelo Dnocs. 
Além dos baixios, havia muitas criações, casa de farinha e um engenho, sendo o Navio lembrado como local da abundância, das festas e da vida em família. Dona Francisca Fernandes da Silva, neta Manoel Ananias, recordou que o povoado "era só de negro, era um povoado de negro, só de negro, não tinha branco não", "era afastado, num sabe, misturava não", e que "os terrenos da família todinha não tinham pedra não, era tudo baixio, terra boa, era tudo terra boa, oiticica, cada uma oiticica, tinha pé, tanto pé de fruta".

Sua irmã Tereza lembra também que "tinha bananeira, mangueira, cana, vazante de arroz, de batata, feijão... tinha de tudo, era fartura". E Dona Francisca arremata "era tudo de plantio, lá era um mundo sem fim, do outro lado dessa serra, plano que nem isso aqui, aí tem muita terra boa debaixo d'água...., é governo tomou de conta". As irmãs lembram também que o povoado era muito populoso, "era uma rua de casa", "tudo família", "tudo nascido e criado".

Seu Lampião, tio de Francisca e Tereza, contou ainda que "cada qual tinha o seu roçadinho" e que "ninguém passava necessidade". As roças eram destinadas à subsistência e o dinheiro que circulava vinha do algodão que era vendido "na broca". "No navio tinha broca de algodão! Por todo canto tinha algodão", relembra.

A origem do povoado não é bem certa. Uns dizem que os negros que ali habitavam teriam fugido de um Navio, ou da África ou ainda das fazendas da região do vale do Piancó. Todos, entretanto, conhecem a história dos chefes do lugar Antônio Tobias e Manoel Ananias. Segundo Dona Francisca, "essa família ainda foi escravo, e meu avô contava, meu avô era um dos escravos, o avô morreu numa base duns 90, ele morreu em [19]74". Junto com os irmãos, teriam fugido para o Navio mais uns quatro ou cinco negros, "mas ele num dizia o nome, diz, meu irmão, meu irmão, fulano, fulano...", contou Dona Francisca.

Para o historiador coremense Edvaldo Brilhante, os negros do local que ele denominou "Serra do Navio" teriam vindo de Pombal, "onde historicamente existe uma comunidade negra influente - Igreja do Rosário dos Pretos, até hoje". Ainda 
segundo Brilhante, a "Serra do Navio" seria assim denominada por um "saudosismo" dos negros que haviam chegado no Brasil de Navio e ali seria "certamente o lugar de onde se originaram todos os negros e mulatos que tenham raízes na cidade de Coremas-PB (as várias gerações)" (Silva Filho, 1996, p. 28).

Essas hipóteses, entretanto, não se confirmam. O relatório do presidente da província para o ano de 1880 registrou 1.399 escravos vivendo no município de Piancó, chegando José Américo de Almeida a apontar uma "mancha melânica" ali (Almeida [1923] 1994). Além disso, Navio era nome de uma propriedade rural que, em 1920, já havia estava dividido em 6 outras fazendas. Como vimos nas seções anteriores, um importante núcleo de famílias negras nasceu e se criou na fazenda Cachoeirinha e outro em Estreito.

O estabelecimento da origem dos descendentes de escravos em outro município que não Coremas parece, na verdade, atender ao requisito de uma bela história para cidade. Entre as coisas a esquecer na elaboração dessa história, a escravidão - e a herança africana - era certamente uma delas, assim como ocorreu na história do Brasil ensinada nos livros didáticos destinados ao público primário até pelo menos a década de 1930 (Lucchesi, 2004). ${ }^{44}$

As mulheres da geração de Antônio Tobias e Mané Ananias, incluindo suas esposas, tinham como sobrenome "Maria da Conceição" ou simplesmente "da Conceição". A geração de suas filhas também levam esse sobrenome. Em seu estudo sobre os arranjos familiares de escravos e libertos em três freguesias do litoral da Paraíba no século XIX, a historiadora Solange Pereira Rocha (2007) chama atenção para o fato de que os indivíduos negros livres elaboraram maneiras de afirmar sua autonomia adotando "nomes de família" referentes a celebrações do catolicismo "ou de nomes de santos e santas como 'Encarnação', 'Conceição', Paixão', 'Espírito Santo', 'do Rosário', 'Maria da Conceição', 'Jesus', 'das Mercês', 'das Neves' e outros" (Rocha, 2007, p. 355).

As mulheres da família da mãe de Dona Francisca, Rita Eugenia da 
Conceição, também carregam o sobrenome "Conceição". Os pais de Rita Eugenia, nascida em 1915, fugiram de Piancó para o Navio em 1932, "correndo com as vasilhas na cabeça", por causa de uma "revolução" na qual mataram "até um padre". Trata-se da passagem da Coluna Prestes por Piancó durante a qual o padre Aristides foi morto.

A Coluna passou também por Coremas, como registrado por Silva Filho, e faz parte da lembrança dos mais velhos. Dona Olaia, filha de Mané Ananias, recordou que o pessoal foi se esconder no Mufumbo e Dona Salete de Cruz da Tereza, lembrou que, quando ainda morava em Estreito, a família se escondeu achando que era um bando de cangaceiros que passava por ali.

Ainda sobre a chefia exercida pelos irmãos Tobias e Ananias, Dona Tereza lembrou que Antônio Tobias mandava em tudo: "era o chefe, o chefe, a justiça era ele, não entrava outra pessoa pra dizer, ele amarrava, quando tava brigando mandava amarrar, é ele era o chefe, só entrava quem ele queria na festa, ele era o dono da festa". A autoridade de Antônio Tobias e Mané Ananias extrapolava os limites do Navio e os irmãos eram temidos em Coremas. Um dos motivos do temor causado por eles e pelos negros do Navio era a ligação destes com o Coronel Antônio Leite, dono da Fazenda Riacho do Barro. Segundo relatos, muitos destes eram cabras do poderoso coronel que dá nome a primeira rua da cidade.

Segundo Dona Olaia (Eulália Maria da Conceição), nascida em 1911 e uma entre os 10 filhos de Mané Ananias e Maria Madalena da Conceição, sua mãe era uma cabocla brava - "nem parecia gente nossa" - que havia sido pega correndo na mata pela família do Capitão, tornando-se "cria da casa". A própria Dona Olaia relata ter sido criada na casa de Antônio Leite, na fazenda Riacho do Barro e também em sua propriedade na região do Brejo Paraibano. Dona Olaia recordou e que ela e seus irmãos eram chamados de netos pelo Capitão.

Antônio Leite foi registrado como proprietário da fazenda Riacho do Barro no recenseamento realizado pela Diretoria Geral de Estatística ligada ao Ministério da 
Agricultura, Indústria e Comércio em 1 de setembro de 1920 (Diretoria Geral de Estatística, 1926) e, de acordo com registro no Almanack Laemmert, já era Capitão em 1925.

Dona Olaia contou ainda que o Capitão falava sobre os negros do Navio que: “isso aqui eu fiquei na responsabilidade de Deus primeiramente e os, se eu morrer, vão ficar tudo nos seus cantos, tudo com suas terras, com seu gado e morando pra ninguém se reclamar de ninguém". Em sua avaliação, ele era perverso de um lado mas bom de outro, por que se não fosse sua proteção "não tinha ficado ninguém". 45

Segundo comentário de Seu Tomás Rodrigues, ex- morador do sítio Estreito, "nesse tempo não tinha polícia, era o tempo dos coronéis, quem pudesse mais mandava". O Capitão Antônio Leite não era o único proprietário de terras que mantinha relações com o povo do Navio, Dona Olaia era também afilhada de José Félix, dono de um engenho em Riacho de Bois.

As lembranças sobre cabras, cangaceiros e coronéis correspondem às descrições feitas nos jornais e na literatura especializada sobre a violência no sertão, em geral, e, a região de Piancó, em particular. Em 15 de janeiro de 1924, O Jornal publicou a seguinte trovinha na seção "Risos e frisos":

O termo de Piancó

Quasi sempre estava em armas.

Do cangaço nos alarmas,

Entre nós, estava só... (O Jornal, 15 de janeiro de 1924, p.1).

A edição de 26 de setembro de 1924, publicou a seguinte carta como parte da matéria cujo título é "O cangaceirismo no interior do Estado:

No municipio de Piancó Estado da Parahyba, 25 cangaceiros chefiados por um tal Febroneo, assaltaram a casa de fazenda do abastado proprietario, sr. João Clementino, roubando-lhe 50 contos de reis, 6 rifles e outros objectos. Como a victima não tinha mais dinheiro em casa e elles quizessem mais, rasgaram as orelhas e meteram as pontas dos punhaes debaixo das unhas do mesmo. Isto é horrivel, porém o mais horrivel é dizerem que há chefes locaes que aplaudem senão mandam taes grandezas. Por isto não tem a victima a 
quem apelar.

Apelamos para Deus (O Jornal, 26 de setembro de 1924, p. 3).

No repertório das histórias dos antigos do Navio, surgem figuras como a tia de Dona Olaia, conhecida por Luzia Miúda, uma moça velha que andava de pés pelas serras acompanhada apenas de uma pequena faca. Luzia teria matado um cabra em uma das vezes que percorreu $400 \mathrm{~km}$ para ir à procissão de Canindé, no Ceará. Como recordou Seu Zé Pequeno,

Ela tinha tanta cobertura em Curema que aquele chefe do Dnocs que trabalhava aí no Dnocs, eu esqueço o nome do cabra, deu um 38 zerado a ela. Ela tinha uma cobertura aí com esses donos, aquele pessoal rico, era uma cobertura medonha (Entrevista, dez. 2016).

A grande quantidade de armas que circulava pelas fazendas não cessou com a chegada da "civilização" trazida pelo Dnocs e as histórias de quartos que guardavam armas ainda faziam parte do repertório do tempo do neto do coronel Antônio Leite. Em uma reunião realizada pelo Incra em Barreiras em 2009, Seu Zé Pequeno comentou que num tempo desse para cada uma pessoa presente teria uma arma, situação tinha mudado apenas há pouco tempo devido a ação de uma juíza que mandou recolher as armas.

Como foi comentado na Parte II-3, durante a construção dos açudes de Coremas e Mãe D'água, muitos moradores do Navio trabalharam nas obras, como foi o caso do pai das irmãs Francisca e Tereza e filho de Mané Ananias, Severino Ananias de Lima. Conforme contou Dona Francisca "meu pai trabalhava lá, meu pai, meus avôs, meus tios..."

Com o fim das obras em Mãe D'água, os operários foram transferidos para as obras do açude Gargalheira (Barragem Marechal Dutra), no município de Acari no Rio Grande do Norte, inaugurado em 1959. Severino não quis se mudar e foi dispensado, "não ficou ganhando nada, foi grosso, era pra ter indenizado ao menos o que fosse" comenta sua filha. 
Os trabalhos eram temporários e os operários eram pagos na medida em que trabalhavam nas obras. Como já foi comentado, o único antigo morador do Navio que se tornou funcionário do órgão foi João Vicente de Souza, atualmente com 95 anos e aposentado pelo Dnocs.

A inauguração da barragem Mãe D'água, em 1957, coincidiu com a inundação do antigo povoado e Severino mudou com sua família para a aba da serra no local conhecido por Mufumbo. Dona Francisca contou que, junto com a casa dos pais, havia ainda mais três, incluindo a de seus avós. No levantamento dos lotes inseridos na bacia hidráulica do açude localizamos dois lotes nesse local. ${ }^{46}$

Assim como a família de Severino Ananias, as demais famílias do Navio tiveram que sair do local com a chegada das águas. "Foram uns pra o lado de Cachoeirinha, tem outros na Barreira, aí na Cruz da Tereza, Cabo Branco [na periferia da cidade de Coremas], é tudo família", relatou Dona Tereza. Dona Francisca ainda lembrou que "ficou um bocado lá pro canto do Campo de Aviação, espalhou um bocado pro lado de São Gonçalo, Cajazeiras, Souza, Barro, Condado, espalhou bastante (...) tem gente por todo o canto, tem uns dele que foram embora pra Rondônia... " (Entrevista, mar. 2009).

Nenhum dos moradores do Navio foi indenizado. Assim como ocorreu com os demais moradores das fazendas da região, não houve qualquer tipo de compensação pelo deslocamento forçado e perda das terras de trabalho e outras benfeitorias.

Em 1958, um ano após a inauguração da barragem, a seca intensa que assolou a região tornou ainda mais precária a situação dos moradores desalojados pelas águas. A água tornou-se de difícil obtenção no Mufumbo e as terras para trabalhar escassas. Severino Ananias levou, então, seus 11 filhos para morar em um dos galpões do Dnocs que funcionava como almoxarifado. Como estava improvisado em um galpão e já havia trabalhado nas obras da barragem, o chefe do Dnocs arrumou uma renda para a família em Mãe D'Água, no local conhecido como britador. Dona 
Francisca relatou esse processo:

Aí fizeram a barraginha, aí a água foi subindo, subindo, subindo, aí subiu a casa mais pra cima, de taipa, a casa, aí eu sei que quando fizeram a barragem grande, a barragem grande foi terminada em cinquenta e oito, foi que teve a inauguração, eu era pequena, mas foi, tem a placa lá (..), a pois sim, só sei que papai fez essa casa nessa estrada, na aba da serra, assim em cima, aí a água subiu demais ficou em cima, aí nós saímos de lá, viemos aqui pro Dnocs mesmo, daí de dentro, isso foi depois que encheu, que ela pegou a enchente grande, foi por aí em cinqüenta..., por que pra mim a festa da inauguração, foi de 57 pra 58, aí encheu aí nós saímos de lá

Mas foi enchendo num sabe, pegando, ficou casa com água dentro das casas, foi, aí foi saindo o povo, papai tirou logo nós que era tudo pequeno, tinha um menino novo que hoje em dia mora em São Paulo, aí viemos aí pro Dnocs, aí tinha umas garagens desocupadas, aí o administrador lá da Mãe D'Água que era, falou com a gente, aí falou com o engenheiro, disse, "ói tem lá um pai de família, tem que organizar", aí botaram nós lá pra vilinha da Mãe D’Água, que chamava vila do Britador, que era bem pertinho do britador que quebrava as... brita, num sabe, as pedras, aí nós ficamos morando nessa vila de casa, tinha uma casa desocupada de quatro moradores, aí nós ficamos nessa casinha, ainda hoje como de fato o terreno é meu, e é um hectare e meio, é o mesmo, que quando nós saímos aqui do Dnocs (Entrevista, mar. 2009).

Após a morte de Severino Ananias, em 1962, sua viúva, Rita Eugênia da Conceição, mudou-se pra Boqueirão de Piranhas e vendeu a renda a um senhor que era funcionário do Dnocs, o finado Mané Galdino. Dona Francisca se casou com José Lourenço da Silva, também de família do Navio, e mudou-se para Pombal. Depois de algum tempo, o marido, "que trabalhava muito nas emergências", sugeriu que eles voltassem para Coremas e comprassem a antiga renda do sogro. Em 1966, Dona Francisca arrendou as terras através de contrato firmado com o Dnocs e fixou-se ali com a família.

Muitos de seus irmãos se estabeleceram em Mãe D'Água, tornando-se 
também rendeiros do Dnocs, como foi o caso das irmãs Margarida e Tereza e do irmão José Calado. Grande parte de seus filhos também ocupa ainda as rendas do Dnocs em Mãe D'Água. No levantamento feito pela CPT/Sertão-PB em 2009 havia 31 fichas de domicílio dos descendentes diretos dos irmãos Antônio Tobias e Mané Ananias morando em Mãe D'Água .

A família de Dona Tereza e Seu Neco (Manoel Vicente da Silva), seu marido e primo, tiveram suas casas removidas ainda mais uma vez para a construção do Canal da Redenção, que leva água da barragem Mãe D'Água para Souza e abastece o açude Açu no Rio Grande do Norte. Sua sobrinha Desterro contou que eles desmancharam as casas antigas, que eram grandes, e não indenizaram nada, e que as casas construídas para substituir as anteriores não eram boas já que "emendadas uma na outra".

Nos 58 anos que as famílias provenientes do Navio ocupam as rendas do Dnocs, as únicas políticas do órgão para melhoria das mesmas foi a instalação de luz elétrica. Nenhuma medida para o saneamento das áreas ocupadas, melhoria das casas nem qualquer forma de fomento à produção agropecuária (sementes, fertilizantes, acesso a empréstimo, projeto de irrigação, etc.) foi oferecida pelo órgão.

Em uma das buscas de documentos no desorganizado arquivo da sede do Dnocs em Coremas, encontrei um levantamento feito pela Emater e pelo Dnocs na década de 1980, das famílias que ocupavam as rendas localizadas em Mãe D'Água. As famílias foram acompanhadas pelos técnicos desses órgãos e receberam instruções para coleta de lixo e tratamento de água e rejeitos em reuniões realizadas ao longo dos anos. A ação não foi além de reuniões e nas anotações pode-se perceber que a melhoria das condições sanitárias, por exemplo, era imputada unicamente às famílias, isentando o Dnocs de qualquer obrigação.

A análise das fichas mostra também a discrepância nas condições de vida entre rendeiros vizinhos. As fichas das famílias foram agrupadas de acordo com o local de moradia e o sexo da pessoa entrevistada do casal. Nas fichas, escritas a mão, 
foram feitas anotações compreendendo os anos de 1984 a 1990. As das mulheres foram preenchidas com as seguintes informações: situação atual, descrevendo se a casa era de alvenaria ou de taipa e as condições de higiene da casa e pessoal; pretensões, habilidades especiais; e sugestões para desenvolvimento futuro e constatações.

Reproduzimos a seguir dois conjuntos de fichas referentes ao casal Raimunda Cristina e Avelino Guedes e a de Dona Francisca e seu marido Manoel Fernandes. Avelino Guedes era de uma família proprietária na região de Mãe D'Àgua e parte das propriedades da família foram desapropriadas. "Hoje é tudo Dnocs", contou sua irmã Dona Chiquinha Guedes. Avelino doou o terreno aonde está localizada a escola de Mãe D'água para que o Dnocs efetivasse a construção. Na ficha de Raimunda Cristina, foi anotado:

Situação atual:

Mora numa boa casa de alvenaria muito ampla, com piso de cimento com boas condições de higiene, se trata de uma pessoa bem desenvolvida, é professora ou melhor foi professora primaria, sabe receber bem quem chega a sua casa, tem uma boa alimentação, apesar de ter pouca verdura devido a escassez, a mesma tem um poder aquisitivo um pouco elevado. No momento não tem nenhuma pretensão, possui filtro, privada, seu esposo é proprietário. Habilidades especiais = Pintar, fazer flores, costura para casa e borda a maquina

Sugestão $=$ Que dê cursos de pintura, ensine a fazer flores as pessoas de sua comunidade

Constatações $=$ controle de lixo

A ficha de Avelino Guedes aponta já de saída uma diferença grande entre os tamanhos encontrados para as áreas do Dnocs e também dos recursos disponíveis para cada um dos arrendatários.

[anotações a lápis] Realidade atual - dispõe de uma área de 18 ha própria e uma área de 30 ha do Dnocs, não tem pulverizador, tem cultivados mas não tem --, está plantando arroz, não planta hortaliças, não faz adubação orgânica. 
Existe no imóvel as seguintes fruteiras: limão, manga, mamão, banana, não faz combate as pragas, a semente de milho, feijão e arroz, são selecionadas pelo próprio produtor, existe um açude porém precisa de uma reconstrução para que o mesmo venha a acumular água, a cultura de arroz é plantada no espaçamento de $0,5 \times 0,5$

[anotação a caneta] $\mathrm{O}$ arroz não houve quase produção pois o verão de janeiro matou quase toda cultura e o produtor não plantou mais. Possui um plantio de limão de $\approx 50$ pés e vai plantar um ha de limão. O produtor possui uma área de 1,0 ha próprio para irrigação por gravidade, no entanto não dispõe de recursos.

Pretensões do produtor:

aq. de canos para tirar da barragem por gravidade, construção de um açude, construção de uma barragem de alvenaria

Sugestões Técnicas

construção de uma barragem subterrânea, construção de 01 poço Amazonas, aq. de 01 conjunto irrigação, adubação orgânica, instalação de hortas, aq. de 01 boi tração, aq. de um pulverizador

[a caneta] mudar a instalação da rede d'água, que é de ferro e já bastante estragada para uma tubulação de plástico c/ 03 pl, prática que só será possível com ajuda financeira já que a extensão é de $=1.200 \mathrm{~m}$

Após essa anotação inicial seguem os dados coletados da produção de gêneros alimentícios e algodão e do rebanho bovino de Avelino Guedes, compreendendo os anos de 1984 a 1990 e um total de 17 visitas:

Nas anotações referentes ao casal Francisca Fernandes e José Lourenço chama atenção o fato de não ter sido citada a área ocupada nem a classificação da mesma como sendo renda do Dnocs. Ao compararmos a descrição da situação de Dona Francisca com aquela de Raimunda Cristina pode-se entrever o preconceito do(a) pesquisador(a) com relação ao baixo nível sócio econômico da primeira.

Francisca Fernandes

Situação atual

Mora em casa de taipa com piso de barro batido, faz controle de lixo, as 
condições de higiene são regulares, a higiene pessoal não é muito boa, não usa água tratada, não tem filtro e nem privada, em sua alimentação tem um pouco de verdura e pouca fruta; porem desconhece o valor nutritivo das hortaliças, não sabem aproveitar bem os alimentos disponíveis na comunidade. Existe também para melhorar sua dieta bastante peixe.

Pretenções: Uma escola municipal para atender a demanda das crianças, possuir um filtro, construir privada e melhorar as condições físicas da casa Sugestão da Extensionista: Que as famílias procurem os órgãos competentes para pedir um grupo escolar.

Na ficha de José Lourenço não foi descrita a sua realidade atual, apesar de, como dissemos, ele e a mulher serem arrendatários de lote do Dnocs com 1,5ha. Consta da sua ficha apenas as anotações de sua produção feitas nas visitas dos pesquisadores entre os anos de 1985 e 1989. Os dados anotados para José Lourenço foram.

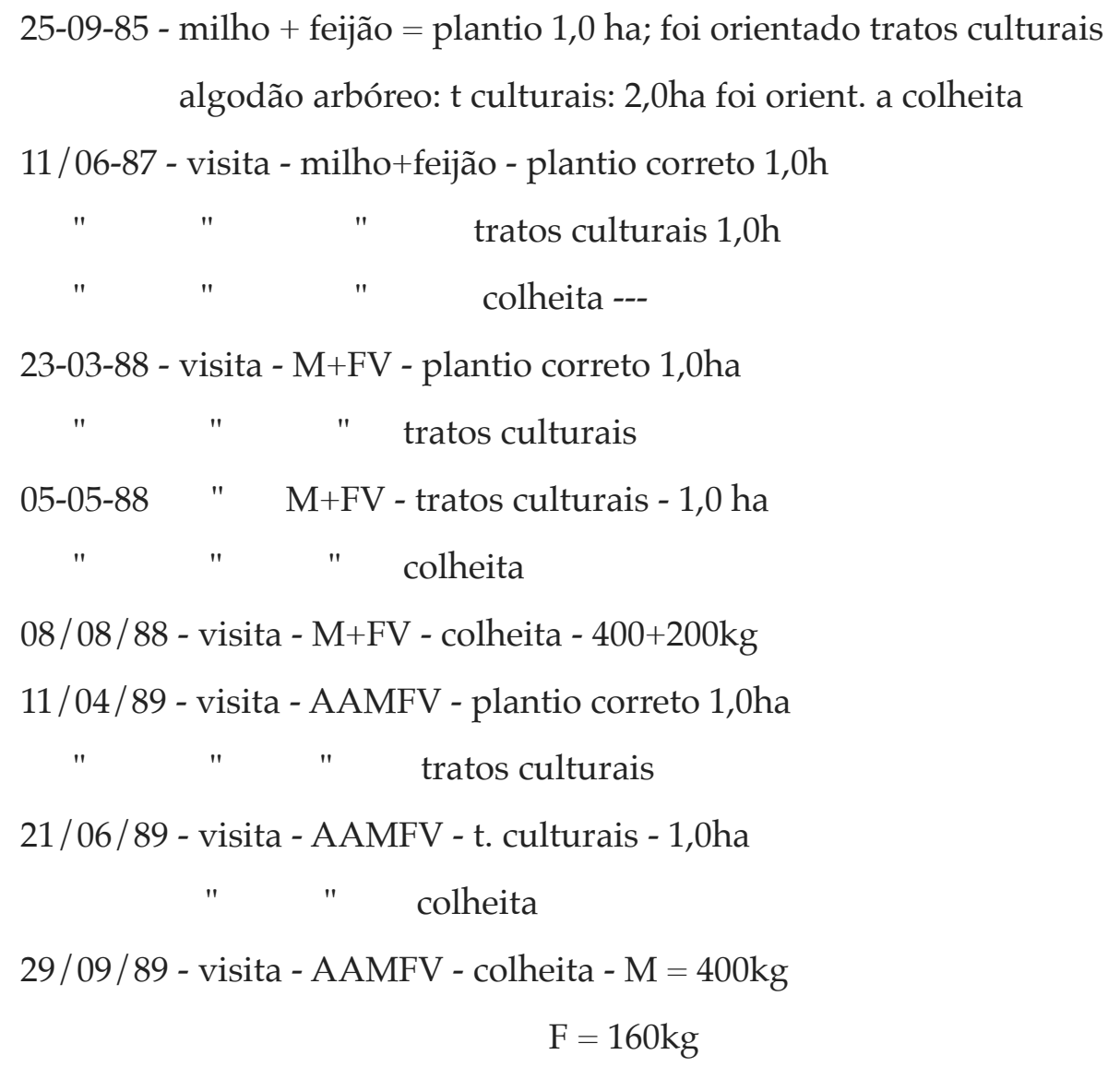

Não foram feitas sugestões para a melhoria do lote de Francisca e Manoel 
Fernandes, como a aquisição de material para irrigação ou acesso a programas de a crédito rural, deixando claro que esses benefícios estavam fora do alcance do casal dada sua condição sócio econômica, como apontado por Hall (1981) para o caso de Sumé e discutido na Parte I-7.

Segundo relato de Dona Francisca, as visitas e reuniões eram só para orientação dos moradores e nenhuma atitude concreta foi tomada para o melhoramento das rendas ocupadas pelas famílias mais pobres. As casas de taipa começaram a ser substituídas por casas de alvenaria apenas no final dos anos 2.000, um processo ainda não concluído. Dona Francisca realizou seu sonho de ter uma casa de tijolos apenas em 2009. A casa está localizada na periferia da cidade de Coremas em terras do Dnocs e o terreno foi comprado a uma atravessadora.

Mesmo constando como dever do Dnocs a garantia de infra estrutura em seus novos contratos de arrendamento, a substituição das casas de taipa por casas de tijolos está sendo feita através de convênios com outros órgãos. Os moradores relataram ainda a dificuldade em conseguir que o Dnocs doasse os terrenos para permitir as construções.

Uma parceria entre a Companhia Estadual de Habitação Popular (Cehap) e a Caixa Econômica Federal viabilizou a construção de casas populares destinadas à população quilombola. As casas só poderiam ser construídas em terreno próprio ou da prefeitura. O Dnocs, entretanto, não queria doar as áreas para a prefeitura para que a construção fosse feita. Em uma reunião com a presença da Cehap, Dnocs e Ministério Público, entre outros, um servidor do Dnocs teria dito, segundo relato de Seu Zé Pequeno, que ele não conhecia nenhum rendeiro dentro de Coremas e que lá só havia posseiros.

Seu Zé Pequeno se apresentou como rendeiro e reclamou que para o povo quilombola "construírem uma casa de Joana de barro" sempre é a "maior dificuldade do mundo" mas que "pro povo construir casas com piscina e coisa e tal" nunca tinha problema. "Não tem nenhuma democracia" avaliou. 
O representante do Dnocs teria dito ainda que eles não iriam doar as terras e sim vender, ao que foi prontamente repreendido pelo procurador federal presente, que teria dito: "você vem dizer na minha cara que vai vender as terras da união?!".

Assim como em Cruz da Tereza, houve uma grande movimentação fundiária em Mãe D'água. Além da reconcentração de áreas menores envolvendo transações de terras públicas, alguns lotes foram subdivididos e vendidos para "acomodar" mais gente.

Em entrevista realizada 2009 com Geraldo Martins de Souza, rendeiro de um lote com 20ha na localidade Mãe D'água, este comentou que "quem foi esperto comprou" lotes do Dnocs enquanto era barato, por que, então, o preço já havia subido. Seu Geraldo se disse satisfeito por ter conseguido regularizar a situação de seu lote junto ao Dnocs, incorporando inclusive o tempo total de sua ocupação. A pasta referente aos documentos de seu arrendamento estavam em sua posse e não na sede local do órgão como os demais. Apensado ao contrato com o Dnocs de um lote de 20ha está a seguinte declaração, datada de 1998:

Declaro para os devidos fins de direito que o senhor, GERALDO MARTINS DE SOUZA é rendeiro em um lote de 20ha, na juzante do Açude Público Estevam Marinho, administrado pelo DNOCS, na localidade MÃE D'ÁGUA, município de Coremas-Pb.

O mesmo trabalha em Regime de Economia Familiar desde o ano de 1977. No período de 1977 até o dia 04 de Setembro de 1995, o mesmo trabalhou como posseiro, só a partir do dia 04 de Setembro de 1995, o mesmo foi contratado como rendeiro onde permanece até a presente data.

Comentando sobre a mudança no repasse de dinheiro do governo federal diretamente para o Dnocs ${ }^{47}$, e não mais para os governos estaduais, um dos filhos de Dona Francisca, Roberto, que vive atualmente na renda da mãe em Mãe D'água, ponderou que se essa verba fosse usada para cuidados com os açudes e para desapropriação de terrenos invadidos (vendidos e ocupados irregularmente) a mudança seria positiva. 
Eu vejo que há 25 anos atrás, pode se falar a 25 anos atrás, não tinha tanta irregularidade como tem hoje, de você percorrer esses leitos de rio aqui você andar livre, com cerca em extrema aonde era, tá entendendo? De você ter, por exemplo, tem pessoas ali na Mãe D'água que tinha uma renda de Dnocs que hoje é dividida por quatro partes, que chegou e entrou e cercou com aqueles dono da renda lá, tá entendendo? Então eu acho assim que se fosse uma reativação, um mapeamento do que era, pra que voltasse o que era antigamente voltar hoje, tinha coisa que é como se dizia tirar o chapéu da cabeça de qualquer um. Tem pessoas que chegou e que falou assim, aqui é Dnocs cumpadre, eu vou passar uma cerca aqui, um pedaço fica pra tu e outro fica pra mim. Mas a documentação tá la no Dnocs tá no nome do cumpadre, esse tal que falou que ia cercar não tem nada e até hoje vive como si fosse dono, por que já tem casa própria ali, já tem benfeitoria feita ali, então, apropriou por vontade, por si próprio.

(...) então vem assim de uma compra por camaradagem, eu quero te vender aqui, é mas não tem documento, ah é Dnocs aqui tu vive a vida de urubu e não vem ninguém aqui te tirar e tu não paga e apropria dali, muitos terrenos ali na Mãe D'água tem isso, não paga direito de morar anualmente, aquela quantia que seja de baixo valor, mas se apropria do bem de valor alto... e aí fica (Entrevista, dez. 2016).

\section{O Projeto Estevam Marinho}

Com a mudança das diretrizes do Dnocs e a ênfase dada à irrigação, foram elaborados vários projetos a serem desenvolvidos nas bacias hidráulicas dos açudes construídos pelo Dnocs, como foi discutido na Parte I-7.

No Relatório dos trabalhos realizados pelo Dnocs em 1964, foi anotado o seguinte aproveitamento do açude Estevam Marinho (Ex-Curema), mostrando que a área aproveitada era muito menor que aquela que havia sido desapropriada.

\section{8 - APROVEITAMENTO}

\subsection{1 - AREA CULTIVADA}

a) Bacia hidraulica 
b) Bacia de irrigação ………………………………..... 1,5 ha

c) Total das duas bacias ............................................ 1.538,5 ha [sic]

\subsection{2 - PRODUÇÃO}

a) Bacia hidraulica ……………………………......

b) Bacia de irrigação ..............................................

c) Total das duas bacias .........................................

1.8.3 - VALOR DA PRODUÇÃO

a) Bacia hidraulica ………………………………....... Cr 120.904.330,0

b) Bacia de irrigação ................................................. Cr $356.215,8$

c) Total das duas bacias ......................................... Cr 121.260.545,8

(Dnocs, 1964, p. 138)

O Projeto Estevam Marinho, visando a implantação de um sistema de irrigação na bacia do açude de mesmo nome, foi elaborado em 1969. Conforme explicado na apresentação do mesmo:

Com mais êste projeto, procura a $3^{\text {a }}$ DR situar-se na atual política do DNOCS, de criar no Nordeste uma estrutura agrícola sólida e bem alicerçada, apoiada na irrigação, aproveitando o volume d'água já armazenado nos vários açudes construído (Dnocs, 1969b, p. 2).

Entre os objetivos do projeto estava irrigar 356ha à margem direita do Piancó "sem alterar a estrutura agrária existente", melhorar o nível social dos agricultores da bacia, "fazendo-os participar diretamente do processo de desenvolvimento regional" e criar uma nova mentalidade, organizando os irrigantes em cooperativa. Apesar de o projeto afirmar que não iria alterar a estrutura agrária, deve-se lembrar que em 1967 o Decreto n 61.173 declarou de utilidade pública o terreno com área de 2.090,2ha necessárias "à implantação do Projeto de irrigação Estevam Marinho"

Segundo os dados coletados para a elaboração do projeto, havia 759 habitantes na bacia de irrigação sobrevivendo de uma agricultura "praticada extensivamente, obedecendo às técnicas tradicionalista e superadas" e, portanto, com baixa produtividade. Com relação ao gado, o nível de criação, segundo o diagnóstico, era também antieconômico. 
Entre os fatores previstos para o aumento da produtividade agrícola, é mencionada introdução de cultivo produtivo com "ênfase especial" em capim. As áreas de agricultura de gêneros alimentícios foram distribuídas da seguinte forma: da área total de 34ha, de propriedade do Dnocs, 16ha seriam destinados à "experimentação agrícola" e 18ha seriam divididos em lotes de 4, 6 e 8ha para serem distribuídos "entre 3 famílias selecionadas entre os moradores da bacia". Quem deveria fundar a cooperativa era o próprio Dnocs e o estatuto deveria seguir o modelo elaborado pela autarquia, como já foi comentado.

Um ano depois dessa publicação, foi elaborado o Projeto Piloto Estevam Marinho (Dnocs, 1970). Entre os objetivos desse novo projeto estava o de colonizar aproximadamente 20ha com quatro famílias selecionadas "que tenham o propósito de se promover e elevar o nível econômico, logrando a participação ativa no desenvolvimento agrícola da região" (Dnocs, 1970, p. 14).

Esses lotes de aproximadamente 5ha cada serviriam como "lotes de demonstração" aos moradores da bacia de irrigação que, com o tempo, seriam integrados ao Projeto.

No Relatório dos trabalhos realizados pelo Dnocs em 1971, o Projeto é referido como algo a ser implantado e que pretendia "utilizar a água represada na irrigação de 4.500ha". A justificativa apresentada para a instalação de um projeto piloto, em uma área de 10ha, foi a de que ainda não havia um "centro de investigação e experimentação agrícola para dar suporte ao projeto" a ser desenvolvido pelo próprio órgão (Dnocs, 1972, p. 137).

Os dois volumes citados são a única documentação na pasta referente ao Projeto Estevam Marinho arquivada na Biblioteca do Dnocs em Fortaleza. Nem a minuciosa historia de Coremas escrita por Silva Filho nem o livro de Emmanoel Rocha Carvalho, Barragens de Curema e Mãe D'água, nos bastidores da construção, mencionam esse projeto.

Os dados do Projeto são registrados nos boletins de produção dos lotes 
irrigados do Dnocs durante as décadas de 1970 e 1980, mas esses não são expressivos, levando o historiador local a anotar que era uma injustiça que o maior açude da Paraíba nunca tivesse implementado um projeto efetivo de irrigação (Silva Filho, 1996).

O Projeto Estevam Marinho existiu até pelo menos o final da década de 1980, conforme pode-se depreender da referência feita ao mesmo no "Exame Tomada de Contas Especial instaurada pelo Ministério do Meio Ambiente, tendo em vista irregularidades verificadas na execução do Convênio nos $193 / 87$, celebrado entre a Secretaria de Recursos Hídricos do Estado da Paraíba e o Programa Nacional de Irrigação-PRONI", que tinha como objeto o "apoio à execução de obras nos Projetos de Irrigação de Estevam Marinho, Lagoa do Arroz e Pilões". Segundo o documento,

Na Sessão de 30/04/2002, esta Câmara rejeitou as alegações de defesa apresentadas pelos Sres Joaquim Osterne Carneiro ${ }^{48}$ e Marcos Leme Baracuhy, ex-Secretários de Agricultura, Irrigação e Abastecimento do Estado da Paraíba, e fixou novo e improrrogável prazo para o recolhimento ao Tesouro Nacional das importâncias de Cz\$ 34.541.908,80, Cz\$ 567.200,00 e Cz\$ 1.706.206,96, a contar de 02/12/1987, tendo em vista os seguintes fatos havidos irregulares (Decisão no 214/2002 - Segunda Câmara, Ata 15/2002 fl. 47 do vol. 2 dos autos):

a) alteração do objeto do convênio, no tocante ao número de conjuntos para irrigação (de 1000 para 325);

b) inexecução total ou parcial das etapas avançadas no convênio (Projetos Lagoa do Arroz, Pilões e Estevam Marinho); e

c) não-apresentação de relatório circunstanciado das ações empreendidas, e do termo definitivo de aceitação da obra.

Mais a frente, é citado ainda o "pagamento indevido de reajustamento do Contrato nos 14/88, celebrado com a empresa CONEG, relativo ao Projeto Estêvam Marinho".

Ainda com relação aos projetos de irrigação, deve-se salientar que a irrigação das várzeas de Souza através do Canal da Redenção prevista no projeto original da 
barragem Mãe D'água só se efetivou há poucos anos.

Silva Filho mencionou ainda a promessa anunciada da instalação do Projeto Sertanejo em Coremas. Esse era o nome do Programa Especial de Apoio ao Desenvolvimento da Região Semi-Árida do Nordeste, criado através do Decreto $\mathrm{n}^{\circ}$ 78.299, de 23 de Agosto de 1976, com a finalidade de:

(...) fortalecer a economia das unidades de produção agropecuária, sobretudo pequenas e médias, do semi-árido nordestino, tornando-as mais resistentes aos efeitos das secas, a partir de núcleos de prestação de serviços e de assistência técnica, previamente selecionados (Decreto 78.299/1976).

O projeto previa condições especiais de crédito a pequenos agricultores e deveria ser implementado pelo Dnocs e pelos Governos dos Estados sob supervisão da Sudene. Como verificou Hall (1981), esse projeto também favorecia aqueles proprietários que já detinham melhores condições econômicas. Além disso, nenhuma medida visando a redistribuição de terras de maneira a garantir uma melhor produtividade dos pequenos agricultores fazia parte do projeto. O Projeto terminou por não ser implementado em Coremas.

Sob o título, "As Repartições que abandonaram a cidade", Edvaldo Brilhante menciona o "Projeto Sertanejo" da seguinte maneira:

\section{Projeto Sertanejo}

Foi instalado em nossa cidade em agosto de 1978, com objetivo de prestar serviços de apoio ao homem-morador de áreas vítimas de longas estiagens, conhecido por homem forte do sertão - os sertanejos. Objetivava ainda alcançar financiamentos e apoios técnicos para pequenos e médios proprietários rurais da região. Porém, por ingerência política foi transferido para a cidade de Piancó-PB, deixando perplexo e frustrado todo o corpo de funcionários, além da população em geral.

\section{Resumo:}

Com a saída destas instituições públicas e privadas acima mencionadas [Bradesco, Paraiban, Projeto Sertanejo], além de outras, somente quem saiu perdendo foi Coremas e sua população, pois teve que regredir aos 
antigos níveis de subdesenvolvimento e empobrecimento (Silva Filho, 1996, p. 145).

Os objetivos descritos do Projeto Estevam Marinho estavam alinhados com a proposta que previa o desenvolvimento das famílias e aumento de sua renda através da produção de frutas e legumes de alto valor. Como todos os projetos elaborados após o golpe militar de 1964, a população que realmente era afetada pelas secas, os moradores e pequeníssimos proprietários, foi alijada desses projetos devido, entre outros fatores, à obrigatoriedade de custear parte destes sem condições inclusivas de obtenção de crédito.

Como relação à alegada manutenção da estrutura fundiária, não é possível avaliar até que ponto a valorização das vazantes e das terras irrigáveis pressionou a saída dos pequenos arrendatários e posseiros, como comentado anteriormente para os casos de Riacho de Boi, Estreito e Mãe D'água.

\section{Desmantelo}

O comentário sobre o processo desmantelo do Dnocs nos últimos 25 anos é geral em Coremas. Entre os motivos citados para comprovar tal processo, estão o loteamento progressivo das terras da União e a falta de ordem nos terrenos sob domínio do órgão.

Em notícia publicada pela Procuradoria da República na Paraíba na internet em 23 de abril de 2007, foram apontadas construções na área de preservação do açude de Coremas. Na ocasião, "representantes do Dnocs informaram que o problema das construções irregulares na área de domínio do órgão, mas fora da área de preservação, será resolvido entre eles".

Dois anos depois, em 2009, o Ministério Público Federal em Souza celebrou um Termo de Ajustamento de Conduta (TAC) visando a preservação do açude Estevam Marinho. Assinaram o termo, além do MPF, o Ibama, o Dnocs e a Prefeitura Municipal de Coremas. Segundo notícia publicada na página da Procuradoria da 
República na Paraíba na internet, o Ibama e o Dnocs se comprometeram a "não conceder licença, autorização ou permissão para qualquer atividade, obras ou serviços na área de preservação permanente". O Dnocs ainda assumiu o compromisso de "evitar, embargar, retirar e demolir eventuais edificações e os cultivos agrícolas realizados ao longo da margem do açude".

Segundo a matéria, "consta em procedimento administrativo do MPF que há diversas construções e ocupações irregulares na área de preservação permanente do açude. São cerca de 2 mil famílias que moram em imóveis localizados a menos de cem metros do reservatório". Foi estipulado que o grupo de trabalho criado com o TAC teria 30 dias a partir da assinatura do termo para demarcar a Área de Proteção Permanente (APP) do açude Estevam Marinho e cadastrar os moradores da área. Após o cadastro das famílias, o Dnocs teria ainda 60 dias para ajuizar ações de reintegração de posse para reaver a área ocupada irregularmente. Ação similar ocorreu também nas imediações do açude de São Gonçalo em 2008.

A atuação do Ibama fez com que parte dos agricultores recuassem suas construções e roças respeitando a determinação que ampliava a área de preservação do açude. Muitas construções permaneceram, entretanto.

A falta de ordem sentida pelos moradores é derivada em parte pela redução drástica do quadro de funcionários do Dnocs como um todo e, em especial, nas sedes locais como Coremas e também São Gonçalo. Uma funcionária do Dnocs em São Gonçalo afirmou que há 50 anos atrás, chegaram a trabalhar ali 1.500 funcionários. Em dezembro de 2016, 16 funcionários tinham que dar conta de uma estrutura muitas vezes maior que sua capacidade de atuação. Em Coremas há apenas 3 funcionários para cuidar de uma área que equivale a quase metade do total do município.

A entrada em cena de atravessadores vendendo e loteando as terras do Dnocs também contribuiu para esse sentimento.

O município de coremas possui atualmente 304 imóveis rurais cadastrados no 
Serviço Nacional de Cadastro Rural (Sncr), com uma área total de 20.418,6338ha. Desses, 290 imóveis possuem menos de 4 módulos fiscais (que equivale a 55 ha para o município), configurando pequenas propriedades e ocupam a área total de 13.170,0338; 18 imóveis tem entre 4 e 15 módulos fiscais, sendo classificadas como médias propriedades e apenas 1 imóvel é classificado como grande propriedade, a fazenda Cachoeirinha, de 1.200 ha, cujo inventário ainda não foi concluído.

As propriedades registradas em cartório em nome do Dnocs não foram declaradas no sistema cadastral do Incra, impedindo uma análise acurada da situação fundiária atual

Os dados registrados pelo Ibge no censo agropecuário de 2006 também nos faz pensar na transformação ocorrida nos últimos 25 anos, em especial na perda de centralidade do Dnocs. ${ }^{49}$

\begin{tabular}{|l|c|c|}
\hline \multicolumn{1}{|c|}{ categoria censitária } & $\mathrm{n}^{\circ}$ de unidades & área ocupada (ha) \\
\hline Arrendatário & 23 & 191 \\
\hline Assentado sem titulação definitiva & 332 & 2.848 \\
\hline Assentado com titulação definitiva & - & - \\
\hline ocupante & 138 & 742 \\
\hline parceiro & 39 & 86 \\
\hline produtores sem área & 71 & - \\
\hline estabelecimentos & 433 & 20.687 \\
\hline
\end{tabular}

De acordo com informação obtida no Serviço de Cartografia do Incra na Paraíba, não existe nenhum assentamento federal ou estadual no município de Coremas. Entretanto 332 unidades utilizaram a categoria de assentado sem título para representar sua situação fundiária.

Muitas das unidades qualificadas como assentadas muito provalmente estão situadas em terrenos do Dnocs, que detém grande parte das terras do município. A denominação assentado é contudo estranha às práticas desse órgão, conhecido pelos 
seus rendeiros. Talvez a condição "sem titulação definitiva" tenha pesado mais na escolha da categoria censitária e, nesse caso, pode-se interpretar que "sem titulação" equivalha a algo como "sem contrato", demonstrando o processo apontado para Mãe D'água. Nesse mesmo sentido, chama atenção a pequena quantidade de unidades de arrendatários.

A realidade expressa no censo de 2006 é muito diversa daquela cartografada por Emília Moreira (1997) na década para a década de 198050. O mapa intitulado "Produtores arrendatários 1980" identifica os municípios paraibanos de acordo com o percentual de arrendatários no total dos produtores rurais existentes de acordo com de 5 intervalos percentuais $(0,0-10,0 ; 10-20 ; 20-30 ; 30-40 ; 40-80)$. Ao contrário dos demais municípios da mesorregião do sertão paraibano, Coremas estava inserida no último intervalo.

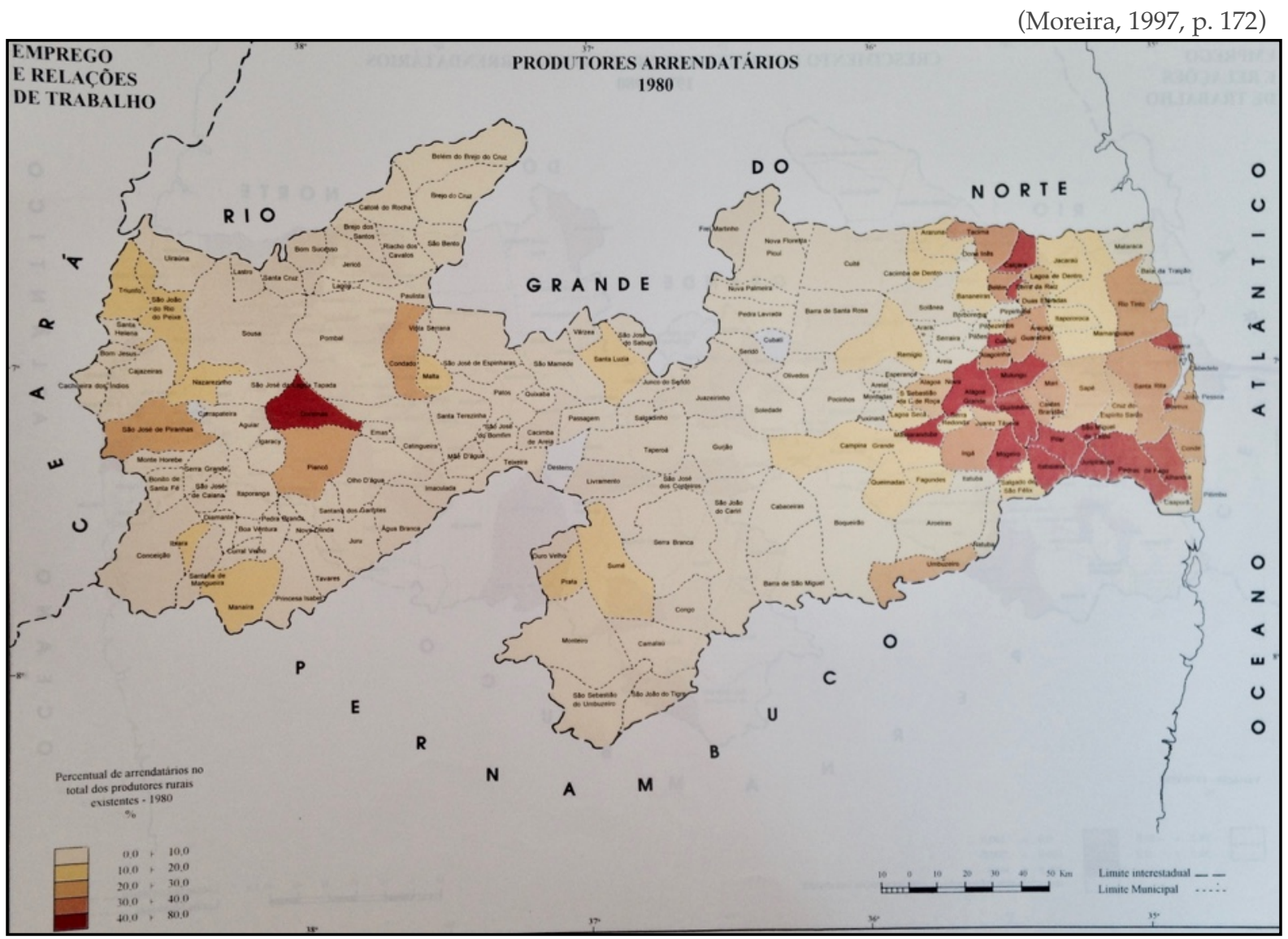

O intervalo 30-40 é apontado para apenas 3 município dessa mesorregião, um deles Piancó. Todos os três contam com açudes do Dnocs (São José das Piranhas - 
Açude Engenheiro Ávidos) Condado com um açude de mesmo nome e Piancó que abriga parte do açude de Coremas (Moreira, 1997, p. 173).

No mapa "Produtores rurais não proprietários em relação ao total de produtores 1980", Coremas também destoa dos demais municípios da mesorregião, ficando situado no intervalo "50\% e mais" (Moreira, 1997, p. 172). Com relação aos "Produtores parceiros 1980", o município foi identificado como "sem informação ou com informação incompleta" (Moreira, 1997, p. 175). No censo agropecuário do Ibge de 2006 registrado na tabela acima vemos que o número dos declarados parceiro não é irrelevante.

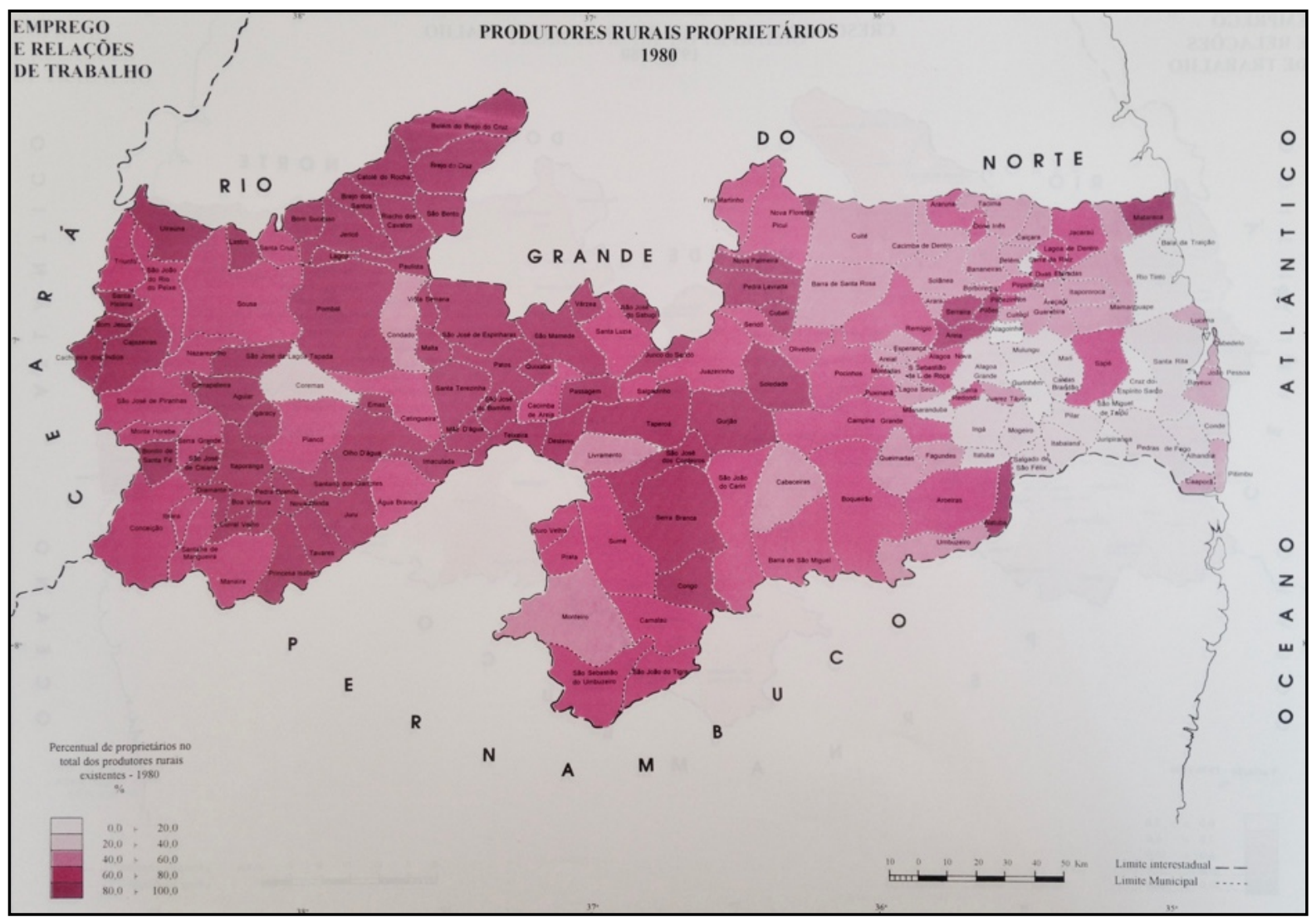

Devido a esse estado de desmantelo atribuído ao Dnocs é comum que as pessoas em Coremas desdobrem seu passado e o da região em três momentos: antes do Dnocs, o Dnocs até a década de 1990, e a realidade atual.

A seca declarada na região em 2012 fez com que os açudes atingissem níveis mínimos causando problemas de abastecimento de água, com a distribuição desigual desta, e tornando ainda mais agudo o sentimento de desmonte do Dnocs. Ao mesmo 
tempo, a perda contínua de controle do órgão sobre suas terras coloca mais uma vez em situação de vulnerabilidade a população que foi deslocada para a efetivação das obras contra as secas em Coremas. 


\section{NOTAS}

20 http: / / www.cidades.ibge.gov.br / painel / historico.php?codmun=250480

${ }^{21}$ Brilhante dá a seguinte explicação por que Coremas teria sido a "capital noturna do Brasil": "Por mera coincidência, os três presidentes que nos visitaram tiveram que pernoitar em terras coremenses e assim o fizeram, quando dormiram em comitiva no DNOCS, ficando os presidentes instalados na Casa-Grande do Chefe (residência oficial). E como manda a tradição republicana, que diz, onde encontra-se o presidente e comitiva, aí está instalado o Governo (Regime Presidencialista), então enfatizo, que Coremas-PB foi a capital do Brasil, durante três noites, para orgulho de todas as futuras gerações de coremenses."

22 O decreto n. 4.956, de 9 de setembro de 1903 aprovou o regulamento de consolidação e modificação do processo sobre as desapropriações por necessidade ou utilidade pública $\mathrm{O}$ artigo 40 desse decreto estabelece que "Nos casos de perigo imminete, como guerra, ou commoção, cessarão todas as formalidade e poder-se-ha tomar posse de uso, quando baste, reservados os direitos dos proprietarios e interessados para serem deduzidos em tempo opportuno.

23 Atualmente, o módulo fiscal em Coremas é 55 ha, segundo tabela disponível em www.incra.gov.br/tabela-modulo-fiscal, consultada em 02/02/2017.

${ }^{24}$ Em sua tese sobre o desenvolvimento econômico dos vales beneficiados pelas obras do Dnocs, o engenheiro Luis Saboya de Albuquerque oferece a seguinte análise sobre a ocupação desses vales:

“A civilização na área sêca do nordeste, se desenvolveu primordialmente às margens dos grandes rios, que proporcionavam condições mais propícias ao sedentarismo dos colonizadores.

Daí, através subdivisões sucessivas, por descendência ou tranferência, chegou-se ao retalhamento tal das primitivas sesmarias, que a maioria dos estabelecimentos atuais, se pode classificar mais pròpriamente como microfundio de que como minifundios.

Daí, também a baixa situação econômica dos estabelecimentos agrícolas"(Albuquerque, 1964, p.16).

25 Não foi possível verificar se o decreto que declarou de utilidade pública as áreas necessárias à construção dos açudes em Coremas englobava apenas os novos lotes levantados em 1955, ou se esta inclui as áreas pagas a partir de 1937 até esta data.

${ }^{26}$ Esses três decretos foram revogados em 1991, o primeiro através do decreto 99.999 de 11 de janeiro e os dois últimos pelo decreto sem número de 10 de maio. 
$27 \mathrm{O}$ decreto anterior que regulava essa modalidade de desapropriação determinava que a verificação dos casos de necessidade pública deveria ser feita por requerimento do Procurador da República (Decreto 4.956/1903). A verificação da utilidade pública era feita por ato do Congresso ou do Presidente da República, no caso de obras de competência da União ou por ela executada ou por empresários ou companhia, a quem for incumbida a execução, e por ato do Conselho ou do Prefeito do Distrito Federal, no caso das obras serem executadas direta ou indiretamente pelos municípios. Após elaborado plano de obras, era editado decreto presidencial aprovando o mesmo e declarando a desapropriação das terras contidas nesse plano.

O decreto editado em 1941, estipulava que a declaração de utilidade pública seria feita por decreto do Presidente da República, Governador, Interventor ou Prefeito. De acordo com o art. $7^{\circ}$, após a declaração de utilidade pública, as autoridades administrativas estariam autorizadas entrar nas áreas compreendidas na declaração, podendo recorrer à força policial "em caso de oposição". Ao contrário da norma de 1903, que previa a determinação da utilidade pública pelo procurador da República o novo decreto veda ao poder judiciário a verificação ou não dos casos de utilidade pública nos processos de desapropriação (Art. 8). O prazo previsto para a desapropriação era de cinco anos, período depois do qual o decreto desapropriatório caducaria. Um ano após sua extinção poderia o mesmo bem ser objeto de nova desapropriação.

28 Declara de utilidade pública para desapropriação, terrenos necessários à construção do açude público "Jacurici", nos municípios de Itiúba e Monte Santo, na Bahia.

29 Segundo Edvaldo Brilhante, Antônio Lopes Filho (1914-1990) "como político tinha um magnetismo impressionante, porém resvalava no populismo (carisma político), e daí, sua postura social ser montada no paternalismo e puro assistencialismo, com o que mantinha seu esquema político eternamente vitorioso" (Silva Filho, 1996, p. 84).

30 Este decreto também foi revogado pelo de 10 de maio de 1991.

${ }^{31}$ Segundo relato de antigos moradores de Cachoeirinha, Antônio Lopes conseguiu adquirir a fazenda ao quitar as dívidas que João Félix tinha no banco. Ainda segundo esses relatos, a esposa de João Félix teria sido enganada para que assinasse a venda da terra. Pouco depois da venda João Félix morreu em um incêndio em sua casa na cidade que ele mesmo teria provocado.

${ }^{32}$ No momento que foi feito esse levantamento, Piancó possuía 8 distritos: Piancó, Água Branca, Boqueirão dos Cochos, Jucá, São Francisco do Aguiar, Curema, Santana dos Garrotes e Olho d`Água (lbge, 1962). 
${ }^{33}$ A lei no 1.004, assinada por Eurico Gaspar Dutra em 1949, regulamentou o § $1^{\circ}$ do art. 198 da Constituição Federal, que dispunha sobre o amparo às populações atingidas pela seca do nordeste. O Art. $1^{\circ}$ dessa lei dispunha que: "A lei orçamentária consignará anualmente uma dotação global correspondente a um por cento da renda tributária da União, arrecadada no exercício anterior, para constituir o depósito especial previsto no $\S 1^{\circ}$ do art. 198 da Constituição Federal. $\S 1^{\circ}$ Vinte por cento, no máximo, da referida dotação constituirão reserva especial destinada ao socorro das populações atingidas pela sêca. Art. $2^{\circ} \mathrm{A}$ reserva de que trata o $\S 1^{\circ}$ do artigo anterior, será aplicada, total ou parcialmente, em obras de emergência e serviços de assistência às populações de zona sêca, quando ocorrerem crises climáticas que, pela sua intensidade e pela extensão da área flagelada, imponham o socorro imediato da União".

${ }^{34}$ No processo 100/61 há comunicação interna transferindo trabalhadores para Sumé, PB, o açude público deste município foi concluído em 1962.

35 O Art. 24 do Decreto 12.330/ 2016 determinava que: "Concluida a construcção, o Governo da União estabelecerá o regimen que lhe parecer mais conveniente para utilização das aguas, dos canaes e dos terrenos beneficiados, ou entregará o açude ao governo do Estado, mediante condições que, exonerando a União de onus futuros, assegurem a conservação da barragem e das obras complementares, bem como o uso publico dos beneficios do açude".

${ }^{36}$ Nessa ocasião ainda foram exibidos filmes sobre as "Obras rodoviárias do Nordeste" e os "Açudes do Nordeste" do Serviço de Obras Contra as Secas.

$37 \mathrm{O}$ intuito de acompanhar esse processo não é questionar a legalidade das transações mas exemplificar a movimentação das terras na região. A escolha desse processo, além do local, foi devido à quantidade de documentos, que era maior que a das demais pastas de arrendamento que atualmente encontram-se depositadas no chão de uma sala no Dnocs de Coremas.

38 Não foi possível verificar se havia no processo algum tipo de preferência registrada na escritura para o arrendamento do lote que havia sido desapropriado, conforme estipulado pelo Art $17^{\circ}$, inciso 1, da Portaria n 118/1950, transcrita nas páginas 28-31.

39 A mudança dos números dos processos e lotes ao longo dos anos, informação que por vezes é omitida de todo, complica sobremaneira a avaliação real sobre a quantidade dos lotes arrendados, sua localização e domínio.

40 Como as folhas do processo não foram numeradas, contrariando a norma que rege a organização dos processos, a documentação do lote pode ter sido retirada para servir de base a essa declaração e recolocada no processo sem manter a ordem cronológica dos documentos constantes do mesmo. 
41 Entre os processos abertos no Serviço de Regularização Quilombola do Incra Sr-18 / PB que se encaixam nesse padrão, estão, entre outros, os processos das comunidades: Caiana dos Crioulos, em Alagoa Grande; Sítio Engenho Bonfim e Sítio Mundo, em Areia; Sítio Matão em Gurinhém; e Sítio Pitombeira em Várzea.

42 Tanto Severino como Zé Pequeno trocaram de nome por que existiam muitas pessoas na família com o mesmo nome. Seu Severino contou ainda que a necessidade de mudança surgiu em um dos alistamentos de serviços do Dnocs.

${ }^{43} \mathrm{O}$ levantamento cadastral foi realizado em formulário do Incra elaborado pela antropóloga Maria Ester Pereira Fortes e aplicado pela equipe da CPT/Sertão-PB.

${ }^{44}$ Para provar seu argumento de que haveria pouca população negra em Coremas, Edvaldo Brilhante cita como prova os recenseamentos da população. É sabido que o preconceito a que foram e são vítimas os indivíduos negros é responsável pela sub representação dessa população no censo. Sobre o racismo em Coremas impressionou ainda o fato de Seu Zé Pequeno ser considerado "pardo" em um de seus documentos (ver anexo de fotos).

45 No levantamento feito pelo Dnocs dos lotes pagos na bacia hidráulica de Mãe D'água, encontramos o lote no lugar Barra registrado em nome de Maria Madalena da Conceição, que foi desapropriado e pago em 1941. Embora não tenha sido possível confirmar se se trata da mãe de Dona Olaia, essa propriedade pode ter sido deixada pelo Capitão à Maria Madalena.

${ }^{46}$ No recenseamento realizado pela Diretoria Geral de Estatística ligada ao Ministério da Agricultura, Indústria e Comércio em 1 de setembro de 1920, encontramos uma propriedade com o nome Mufumbo cuja proprietária era Rita Maria da Conceição, mesmo nome da cunhada de Severino Ananias. Uma das filhas de Dona Francisca contou que a bisavó morava ali também.

47 Trata-se da Medida Provisória 743 de 2016. 
48 O currículo de Joaquim Osterne Carneiro disponível na página do Instituto Histórico e Geográfico Paraibano (IHGP), informa que: "Em 1962 ingressou no DNOCS - Departamento Nacional de Obras Contra as Secas, onde ocupou dentre outras as seguintes funções: Chefe do Instituto Agronômico José Augusto Trindade, Chefe do $2^{\circ}$ Distrito de Fomento e Produção, Diretor da Diretoria de Agronomia, Diretor da Diretoria de Irrigação, Assessor do Diretor Geral, Diretor Geral Adjunto de Operações, Representante do DNOCS no Comitê de Acompanhamento da Pesquisa Sobre Industrialização de Áreas Rurais no Nordeste (Convênio DNOCS/BNB), Coordenador do Convênio firmado entre o DNOCS e o IRYDA Instituto Nacional de Desarrolo Agrário (Acordo Complementar de Cooperação Técnica no Campo da Irrigação e da Luta Contra a Seca, firmado entre o Brasil e a Espanha). Exerceu também os cargos de Coordenador de Recursos Naturais do PRODIAT - Projeto de Desenvolvimento Integrado da Bacia do Araguaia -Tocantins (Convênio firmado pelo Governo do Brasil e a OEA - Organização dos Estados Americanos), Secretário de Recursos Hídricos do Governo do Estado da Paraíba, Secretário Executivo da CEPA/PB - Comissão Estadual de Planejamento Agrícola, Assessor de Gabinete do Governador do Estado da Paraíba Dr. Antonio Mariz, com exercício no Grupo Gestor de Recursos Hídricos, da Secretaria do Planejamento e Superintendente do SENAR/AR/PB - Serviço Nacional de Aprendizagem Rural, Administração Regional da Paraíba." (http://www.ihgp.net/ curriculo_osterne.htm)

49 O censo está disponível em http://www.cidades.ibge.gov.br/xtras/temas.php? lang=\&codmun=250480\&idtema=3\&search=paraiba $\mid$ coremas $\mid$ censo-agropecuario-2006 .

${ }^{50}$ Entre as fontes estatísticas básicas utilizados para elaboração dos mapas que compõem o Atlas de Geografia Agrária da Paraiba (Moreira, 1997) estão os Censos Agropecuários de 1970, 1975, 1980 e 1985 da Fundação Instituto Brasileiro de Geografia e Estatística (FIBGE), Censos Demográficos de 1970, 1980, e 1991. 


\section{Considerações Finais}

A seca que atinge a região Nordeste desde 2011 transformou completamente o cenário da pesquisa, iniciada em março de 2009, recolocando em pauta questões referentes às políticas de combate às secas.
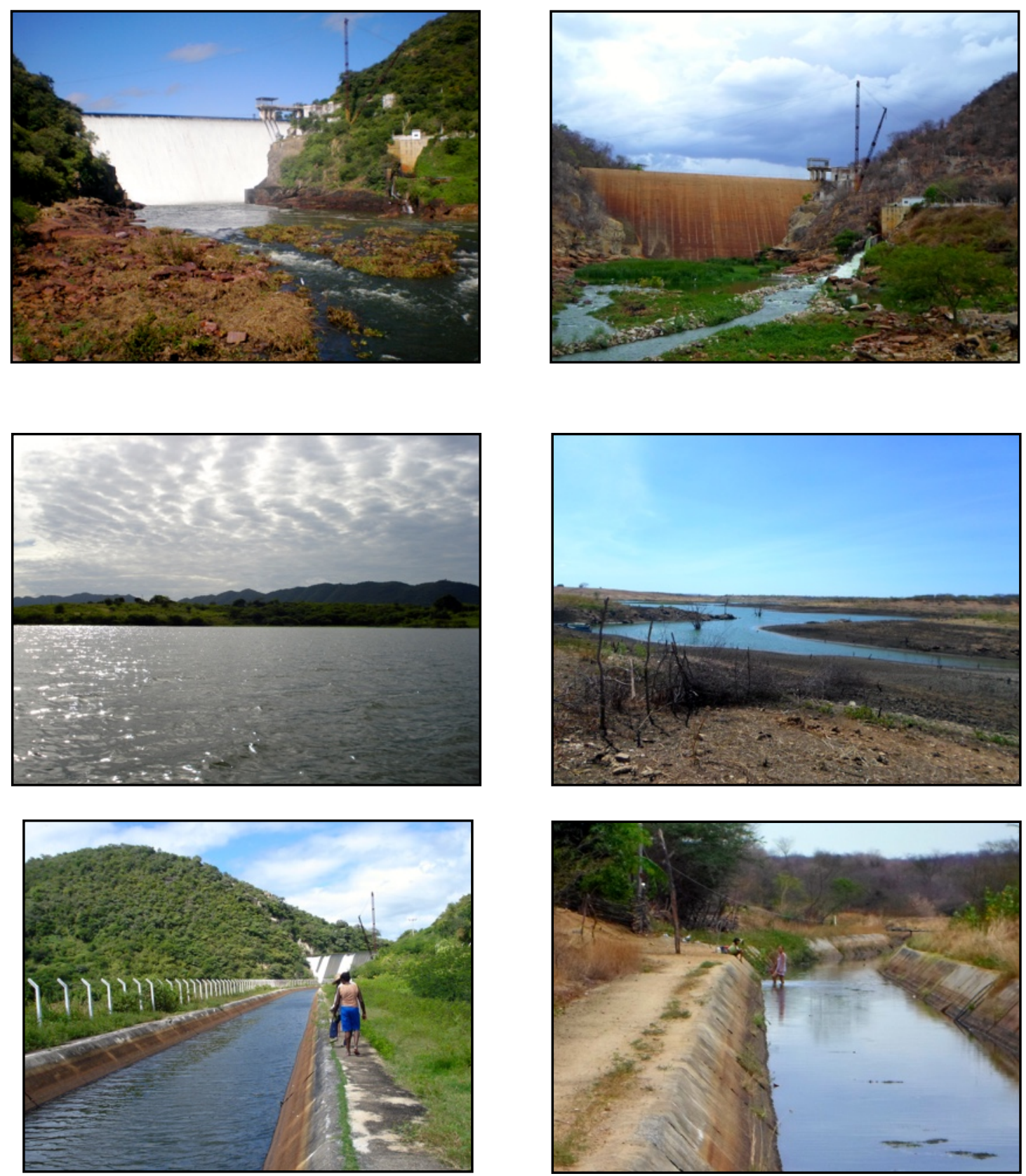
A sequência de fotos da página anterior mostra as diferenças entre a situação da Barragem Mãe D'água e do canal da Redenção em junho de 2009 (coluna da esquerda) e dezembro de 2016 (coluna da direita). As fotos que ocupam o centro da seleção mostram o açude Mãe D'água em Barreiras, tiradas de um ponto aproximado. Ao contrário da situação em 2009, quando as águas chegavam próximo às casas de Barreiras, em 2016 foi preciso andar um pouco mais de um quilômetro para chegar até a beira d'água.

Os níveis dos açudes Mãe D'água e Estevam Marinho (ex-Curema) atingiram valores nunca antes encontrados chegando, em fevereiro de 2017, a 2,4\% e 4,6\% de suas capacidades respectivamente. Devido à continuidade da seca e o baixo nível dos açudes, a Agência Nacional de Águas (ANA) vem impondo uma série de restrições à utilização da água desde meados de 2015.

Apesar da grave crise de abastecimento e de quase 5 anos consecutivos de seca, o cenário atual difere daquele relatado para outras secas, sobretudo com relação às retiradas e frentes de serviço.

Na viagem realizada de Coremas a São Gonçalo na companhia de Seu Zé Pequeno, Dona Francisca e duas de suas filhas, Neidinha e Bia, durante minha última visita a Coremas em dezembro de 2016, passamos em uma fazenda famosa da região. Ao ver que o açude da propriedade estava praticamente vazio, Seu Zé Pequeno comentou:

Seu Zé Pequeno: Eu nunca vi esse açude seco.

Dona Francisca: Sim, eu também não.

Seu Zé Pequeno: De 70 pra cá, eu nunca vi esse açude seco, que nós trabalhamos em 70 na emergencia aqui, nós entrava aí...

Dona Francisca: Quando eu vim de São Paulo ele tinha água, esse açude.

Eu: Era emergência aqui nessa estrada aqui?

Seu Zé Pequeno: Isso era emergência! Aqui só era cassaco! Você passava aqui isso era tudo estrada de rodagem, eu trabalhei aí nessa estrada o tempo todinho, a gente entrava aí e morava aí dentro, abriu uma estrada daqui pra 
Souza, a entrada era aí, e olha acabou-se a estrada...

Eu: Era Dnocs ou Governo do Estado?

Zé Pequeno: Emergência do Dnocs nada, era emergência da época da seca, era seca.

Eu: Mas o dinheiro vinha por quem pelo Governo do Estado ou pelo Dnocs?

Zé Pequeno: Era governo do Estado, não tinha nada com Dnocs, nada com Dnocs, era época de seca, de invalidez. Essa seca que tá aí, você tá vendo essa seca? Quem acabou essa seca pra ninguém tá em beiço de rodagem - homem, mulher e menino - se chama o presidente Lula. Viu?! Que hoje o dinheiro que nós ganhava no beiço da estrada fazendo rodagem, hoje nós estamos segurando o seguro safra. Quando foi seca ganha por seis meses, ele paga. Existe o seguro safra, é esse que esse presidente quer tirar todas as coisas. Se não fosse o presidente Lula o que será de nós numa época dessa, a gente tava morto. Era nu e cru passando nesses tabuleiros com a tira no pescoço. Depois que Lula entrou deu a mão a pobreza geral. Ele gritou antes de entrar na presidência que ia deixar a mesa do pobre igualmente a mesa do rico e deixou. Ele disse que na presidência ia eletrificar o mundo rural e eletrificou. Tá ouvindo? É por isso que eu, pobre, que ele deu... que não deu, eu dou valor a ele. Ele pode se candidatar mil vezes se eu for vivo eu voto nele. Que foi quem deu a liberdade para o pobre, nós não tinha liberdade nem de estudo, hoje nós tem tudo em mão. Você tá pensando, olha aqui a professora [Bia, filha de Dona Francisca], mas ela se ajoelha meio dia em ponto e toma benção a Lula, que nego não tinha direito a estudo [risos].

A reflexão de Seu Zé Pequeno toca em um dos pontos que conduz essa tese e que é a utilização de mão de obra cassaca nas obras públicas, as emergências. Durante mais de um século, a cada seca declarada, homens, mulheres e crianças foram engajadas nas obras de açudes e rodovias. Ao mesmo tempo que fixava a população durante a crise por meio do trabalho, evitando a perambulação e os possíveis saques e superpopulação dos centros, essa política também garantiu o afluxo de obras e recursos federais para as regiões afetadas - sempre sob acusação de desvios e mal uso.

Do ponto de vista dos trabalhadores, essa esmola remunerada representava uma 
solução parcial e transitória para as famílias, submetendo todos - homens, mulheres e crianças - a condições precárias de trabalho e moradia. Cíclicas como a seca, que colocava em movimento a população depauperada, essas emergências não construíram nada que beneficiou esses trabalhadores de forma permanente.

Segundo interpretação de Seu Zé Pequeno, apenas as políticas de garantia de renda, como o Garantia Safra ${ }^{51}$, foram capazes de mudar de fato a situação a que os trabalhadores mais pobres ficavam submetidos durante as secas.

A fala de Seu Zé Pequeno revela também a mudança das diretrizes do Dnocs ocorrida na década de 1970 e a multiplicação dos órgãos envolvidos nas políticas de socorros, conforme analisado nas últimas seções da Parte I.

Como chamou atenção a publicação Frentes de Serviço (Dnocs, 1971), poucos dos alistados nas frentes durante a seca de 1970 identificaram o Dnocs como órgão responsável pelos auxílios. Na Paraíba, ainda segundo dados desse estudo, apenas três frentes eram administradas pelo Dnocs, sendo a maioria implementada pelo governo do estado através do DER.

A introdução ao relatório dos trabalhos realizados em 1970 deixa clara essa mudança. Ao contrário daqueles de outras secas outras secas, em que as medidas de emergência eram sempre as primeiras a ser relatadas, é apenas depois de relacionar todos os projetos de irrigação em curso que ações do Departamento contra os efeitos da seca são brevemente anotadas no último parágrafo da introdução.

Durante a seca de 1970, Seu Zé Pequeno já era arrendatário do Dnocs. Mesmo assim, foi preciso que ele se alistasse na frente de serviço durante a crise. Talvez por isso, o Dnocs apareça em seu relato como uma espécie de a antítese dos socorros das secas - "Emergência do Dnocs nada, era emergência da época da seca, era seca (...) não tinha nada com Dnocs, nada com Dnocs, era época de seca".

A mudança de ênfase nas políticas do Dnocs da acumulação de água para a irrigação dos vales beneficiados pelos açudes não se traduziu, porém, na implementação de um plano de irrigação eficaz e abrangente para a região de Coremas (Silva Filho, 1996; Carvalho, 2013). 
Em sua tese sobre o desenvolvimento econômico e social dos vales beneficiados pelas Obras do Dnocs, publicada em março de 1964, o Engo. Luis Saboya de Albuquerque, diretor da Diretoria de Fomento e Produção, chamou atenção para o fato de que, embora o Dnocs já tivesse alcançado muitos de seus objetivos, o Departamento realizara quase meio século de obras sem atender às condições de aproveitamento dos vales beneficiados "porque as leis, então vigorantes, não lhe concediam os meios adequados e necessários". Como resultado dessa lacuna na legislação, estavam quilômetros de terras inadequadamente aproveitados. Saboya de Albuquerque mencionou como uma excessão a esse estado de coisas a iniciativa particular dos agricultores da bacia do rio Piranhas, na Paraíba. Em suas palavras,

Cita-se, como excessão, o vale do Piranhas onde, aproveitando a perenização consequente do funcionamento das turbinas do Estevão Marinho do DNOCS, os agricultores, sem a menor assistência ou ajuda, empregando moto-bombas em geral inadequadas, conseguiram transformar o vale num imenso jardim, perlustrando-se numa extensão que se situa acima de duas centenas de quilômetros. Ali se encontra o exemplo mais edificante do valor da iniciativa privada, do trabalho eficaz e econômico sem necessidade dos vultosos investimentos em grandes canais adutores para a irrigação. O rio é o seu canal. As valetas de irrigação, singelas em sua estrutura, individuais ou coletiva, constituem, em si, o resultado de longa experiência dos agricultores e poderão servir de padrão para iniciativas similares em outros vales.

Pode-se apenas conjecturar até que alto nível de aproveitamento teria ascendido os agricultores do vale do Piranhas se se lhes tivesse proporcionado a assistência devida e a energia elétrica a preço razoável, mas não inflacionários, para as suas atividades (Albuquerque, 1964, pp. 3, 4).

Mesmo com a aprovação de legislação específica para o aproveitamento dos lotes irrigados e os incentivos para o desenvolvimento de projetos de irrigação nos vales beneficiados pelas obras do Dnocs, o cenário apontado pelo engenheiro permaneceu sem muita alteração na área imediatamente beneficiada pelos açudes Coremas e Mãe D'água. A água utilizada para agricultura, criação de animais e 
também criatórios de peixes ainda é captada por iniciativa particular dos ocupantes dos vales.

Como foi apontado anteriormente, os projetos oficiais de irrigação implementados na década de 1970, assim como as modalidades de obtenção de crédito, não contemplavam os agricultores mais pobres, e portanto mais suscetíveis aos efeitos das estiagens. A ampliação do Programa de Fortalecimento da Agricultura Familiar (Pronaf) ${ }^{52}$ em meados dos anos 2.000 e de outros programas como o Bolsa Família e a Garantia Safra, permitiram que os moradores mais pobres localizados em Mãe D'água, entre outros, beneficiassem seus lotes principalmente com pequenos açudes e criatórios de peixes através da instalação de canos e bombas para captar água do açude. ${ }^{53}$

A seca iniciada ainda em 2011, e agravada desde então, interrompeu esse processo. Os açudes Estevam Marinho (ex-Curema) e Mãe D'água foram sofrendo consideráveis perdas e, já em 2013, o reservatório de Coremas contava com apenas 33.2\% de sua capacidade segundo dados da Agência Nacional de Águas (ANA) 54 .

A Resolução Conjunta ANA, Instituto de Gestão das Águas do Estado do Rio Grande do Norte (Igarn) e Agência Executiva de Gestão das Águas do Estado da Paraíba (Aesa) no 640 de 18 de junho de 2015, considerando a seca, os baixos níveis dos açudes da bacia hidrográfica dos rios Piancó-Piranhas-Açu e a necessidade de priorizar o consumo humano e dessedentação de animais, determinou a interrupção da captação de águas superficiais para fins de irrigação e aquicultura (criação de peixes, carcinicultura e outros) em todo trecho compreendido entre o açude de Coremas e o açude Armando Ribeiro Gonçalves, marcado em vermelho no mapa anexo a essa resolução e reproduzido na página seguinte.

O Art. $2^{\circ}$ dessa resolução determinou ainda a interrupção da captação de águas subterrâneas localizadas na faixa de 100 metros das margens do traçado estabelecido pelo artigo anterior, com excessão das outorgas e captações licenciadas pela Aesa e Igarn. 


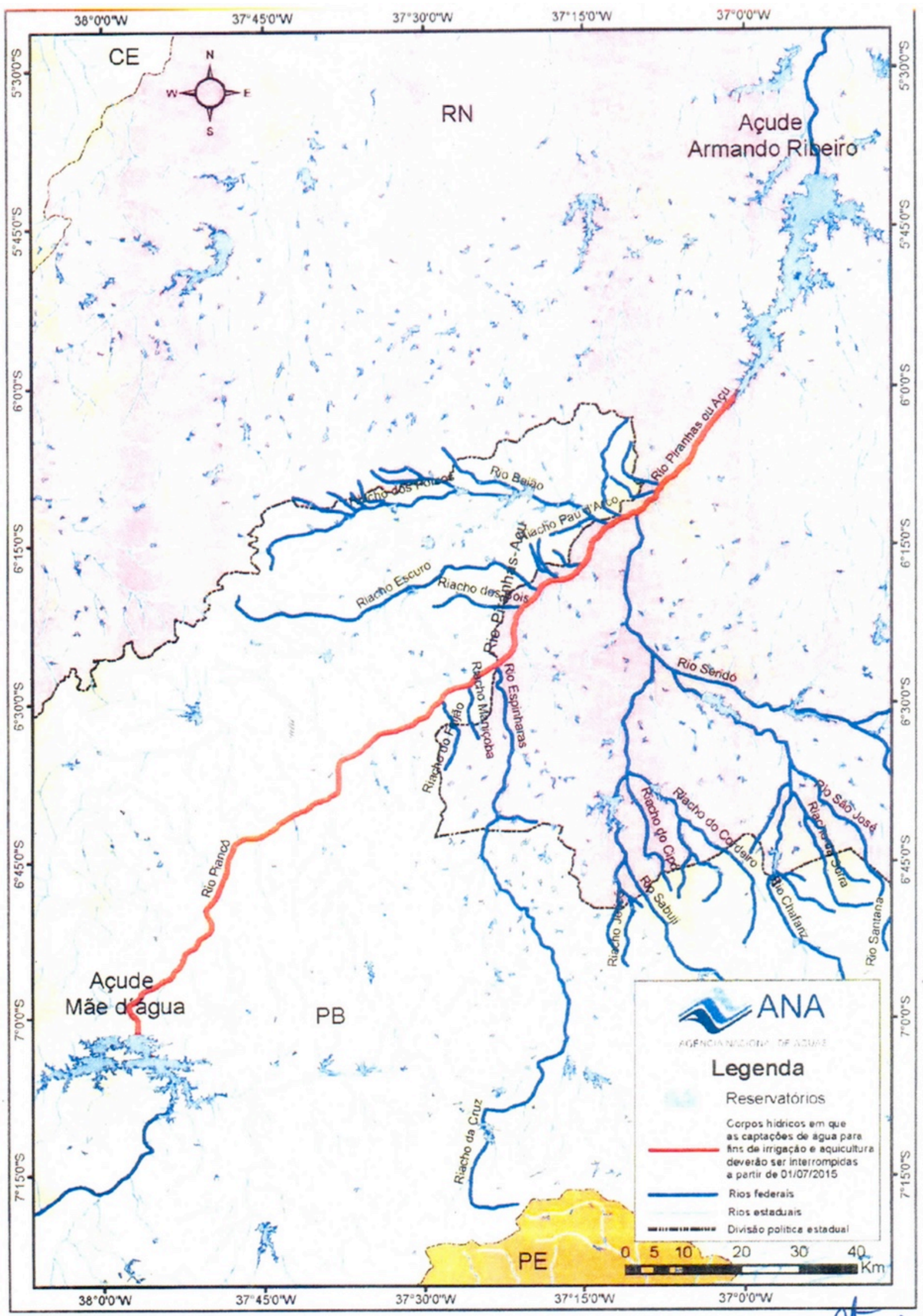


A continuidade da seca e as progressivas perdas dos açudes Coremas e Mãe D'água, determinaram a ampliação da área sujeita à interrupção de captação de água para agricultura e aquicultura.

Em novembro de 2016, uma nova resolução conjunta da ANA, Aesa e Igarn, citou, além da área mencionada anteriormente, a interrupção da captação no Rio Aguiar a jusante da Barragem Mãe D'água para quaisquer finalidades exceto consumo humano e dessedentação animal. As captações de águas subterrâneas também foram interrompidas, mesmo para as exceções previstas na resolução anterior (casos autorizados pelo Igarn e Aesa), e as outorgas foram suspensas.

Ao longo de 2016 foi feita a retirada dos canos de captação de água em Coremas, causando indignação local. Os moradores que haviam conseguido comprar canos e montar tanques de peixes durante a última década perderam seu investimento sem que fosse oferecido nenhum tipo de compensação. Embora feito de maneira privada, a captação de água para beneficiamento dos lotes era permitido e até louvado pelo Departamento, como vimos acima.

A retirada dos canos por parte do Dnocs fez com que a população residente de

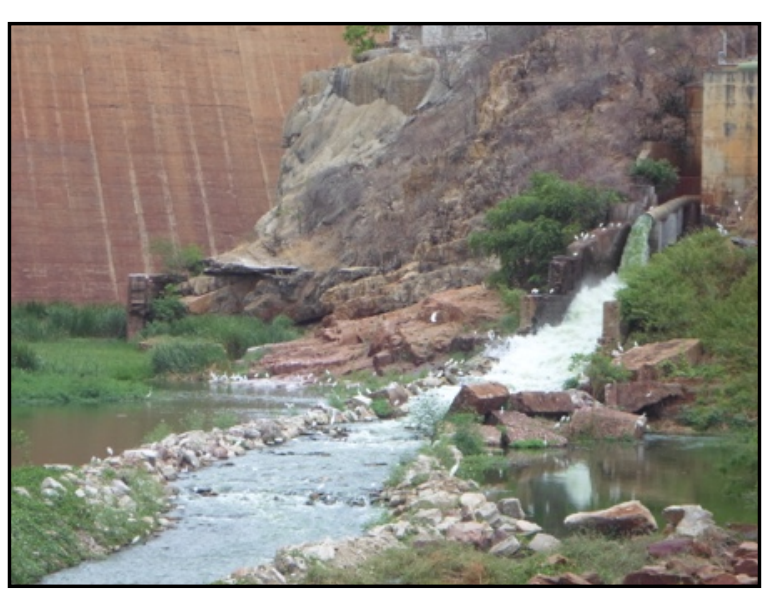

Mãe D'água se tornasse uma das mais afetada pela seca, apesar de estar localizada ao lado da Barragem. O fornecimento de água para consumo humano em Mãe D'água passou a ser feito através de uma bomba instalada pela prefeitura, mas os constantes problemas de funcionamento desse esquema de abastecimento tinham deixado a região sem água por diversos períodos.

A revolta dos moradores dessa região gerada com a retirada dos canos é aumentada pela existência de um cano jorrando água da Barragem Mãe D'água (canto direito da foto) para garantir o abastecimento de outras cidades na Paraíba e 
no Rio Grande do Norte. Esse sistema foi implementado como substituição ao canal da Redenção, que também atingiu níveis mínimos.

A constatação de que nem todos os irrigantes tiveram suas ligações interrompidas, assim como as denúncias de furto de água, revelou também a incapacidade dos órgãos envolvidos na gestão das águas, como ANA, Aesa, e a Companhia de Água e Esgotos da Paraíba (Cagepa) - além do Dnocs -, para apresentar uma solução de longo prazo, assim como para fiscalizar os empreendimentos localizados na região de influência dos açudes. Indignado pela cobrança em reunião realizada na faculdade local em dezembro de 2016, o representante da Cagepa chegou a sugerir que os próprios moradores cuidassem desse assunto entre eles.

A situação de crise no abastecimento de água criada pela atual seca põe em cheque a validade das políticas contra as secas implementadas ao longo de mais de um século. Por outro lado, a inutilização da estrutura de captação de água implantada

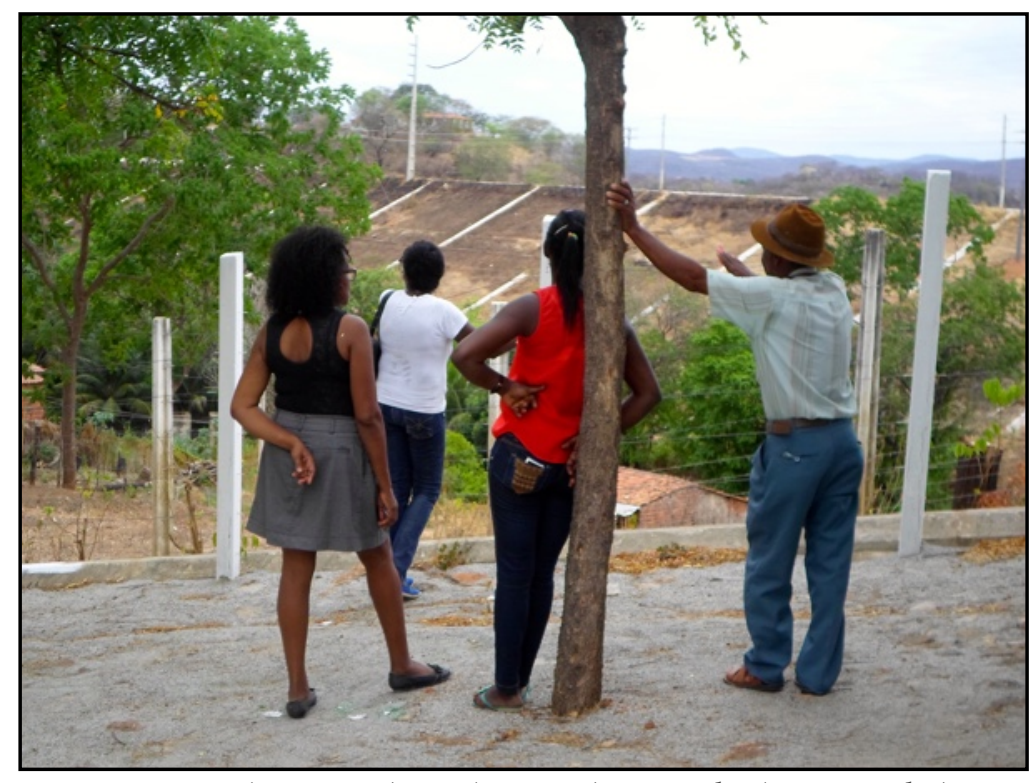

Dona Francisca (de branco), Bia (de preto), Neidinha (de vermelho) e seu individualmente pelos Zé Pequeno no mirante para a parede do açude São Gonçalo, dez. 2016 rendeiros e ocupantes das terras do Dnocs leva a pensar não só sobre a ineficácia dessas políticas mas também que essas parecem estar colocadas contra os interesses das populações mais pobres. Parafraseando a pergunta que fez Antony Hall (1981), essas políticas são, no final das contas, anti seca ou anti pobres (flagelados, retirantes, cassacos, moradores, beradeiros, quilombolas, camponeses)? 
NOTAS:

51 O benefício Garantia-Safra é uma ação do Programa Nacional de Fortalecimento da Agricultura Familiar (Pronaf) e foi criado pela Lei 10.420 de 10 de abril de 2002 e regulamentado pelo Decreto $\mathrm{n}^{\mathrm{o}} 4.962$, de 22 de janeiro de 2004. Esse benefício destina-se a garantir renda mínima para agricultores familiares de municípios sujeitos a perda de safra em razão de estiagem ou excesso hídrico situados na área de atuação da Sudene e municípios do estado do Espírito Santo referidos na Lei nº 9.690/1998.

52 O Pronaf foi criado criado em 1996 através do Decreto 1.946, com o objetivo de fomentar o desenvolvimento dos agricultores familiares. Esse decreto foi modificado pela Lei 11.326, de 24 de julho de 2006, que estabeleceu as diretrizes para a formulação da Política Nacional da Agricultura Familiar e Empreendimentos Familiares Rurais, fixou um limite para o tamanho da propriedade, que não deveria ser maior que quatro módulos fiscais, e ampliou os beneficiários da seguinte maneira no Art. $3^{\circ}$, inciso IV, $\S 2^{\circ}$ :

"São também beneficiários desta Lei:

I - silvicultores que atendam simultaneamente a todos os requisitos de que trata o caput deste artigo, cultivem florestas nativas ou exóticas e que promovam o manejo sustentável daqueles ambientes;

II - aqüicultores que atendam simultaneamente a todos os requisitos de que trata o caput deste artigo e explorem reservatórios hídricos com superfície total de ate' 2 ha (dois hectares) ou ocupem até $500 \mathrm{~m} 3$ (quinhentos metros cubicos) de água, quando a exploração se efetivar em tanques-rede;

III - extrativistas que atendam simultaneamente aos requisitos previstos nos incisos II, III e IV do caput deste artigo e exerçam essa atividade artesanalmente no meio rural, excluídos os garimpeiros e faiscadores;

IV - pescadores que atendam simultaneamente aos requisitos previstos nos incisos I, II, III e IV do caput deste artigo e exerçam a atividade pesqueira artesanalmente."

53 http: / / g1.globo.com / pb / paraiba/ bom-dia-pb / videos / v / moradores-improvisamdistribuicao-de-agua-em-coremas / 5149997

54 http: / / g1.globo.com / pb / paraiba / noticia / 2013/10/ pb-so-pode-retirar-agua-de-acudetres-vezes-por-semana-diz-ana.html 


\section{Referências Bibliográficas}

ALBUQUERQUE, Luis Saboya de. Desenvolvimento Econômico e social dos vales beneficiados por obras do DNOCS. Fortaleza: Dnocs, 1964.

ALBUQUERQUE JÚNIOR, Durval Muniz. Falas de astúcia e de angústia: A seca no imaginário nordestino - de problema à solução. Campinas: Dissertação apresentada ao Programa de Pós Graduação em História do Brasil/Unicamp, 1988.

- Palavras que calcinam, palavras que dominam: a invenção da seca do Nordeste. Revista Brasileira de História, São Paulo, v. 28, p. 111-120, 1995.

ALMEIDA, José Américo de. A Paraỉba e seus Problemas. Brasília: Senado Federal/ Fundação Casa de José Américo, [1923] 1994.

. A Bagaceira. Rio de Janeiro: José Olímpio, [1928] 2004.

. O ciclo revolucionário do Ministério da Viação. Mossoró:

Fundação Guimarães Duque, [1934] 1982.

. O Boqueirão. In: Novelas de José Américo de Almeida. Rio de Janeiro: Civilização Brasileira, [1935] 1979.

. Memórias: antes que eu me esqueça. Rio de Janeiro:

Francisco Alves, 1976.

- As sêcas do Nordeste. Rio de Janeiro: Ministério da

Viação e Obras Públicas, 1953.

. "Discurso do Sr. José Américo de Almeida". In:

Discursos Acadêmicos Tomo V, 1966-1980. Rio de Janeiro: ABL, 2009.

ALMEIDA, Severino Lopes de. Coremas passado e presente. Coremas: mimeo, 2004.

ALVES, André. Os Argonautas do Mangue. Campinas: Editora da Unicamp, 2004. 
ANDRADE, Cordeiro de. Os cassacos. Rio de Janeiro: Andersen Editores, 1934.

ANDRADE, Joaquim Marçal Ferreira de e LOGATTO, Rosângela. "Imagens da seca de 1877-78 no Ceará: uma contribuição para o conhecimento das origens do fotojornalismo na imprensa brasileira. Anais da Biblioteca Nacional, Rio de Janeiro, vol. 114, 1994.

ANDRADE, Rita de Cássia Gregório. A cidade de Coremas-PB: Geografia histórica de uma cidade pequena. João Pessoa: Dissertação apresentada ao Programa de PósGraduação em Geografia/UFPB, 2008.

ARAUJO, Genésio Martins de. DNOCS - Um órgão a Serviço do Nordeste. Fortaleza: Dnocs, 1974.

ARTIGAS DE GODOY, José Henrique. “Os Nordestes de Freyre e Furtado”. Política e Sociedade, v. 12, n 24, pp. 61-88, 2013.

BAHLOUL, Joëlle. The Architecture of Memory: A Jewish-Muslim Household in Colonial Algeria, 1937-1962. Cambridge: Cambridge University Press, 1996.

BARBOSA. Jivago Correia. Politica e Assistencialismo na Paraiba: o Governo de José Américo de Almeida (1951-1956). João Pessoa: Dissertação apresentada ao Programa de Pós-Graduação em História/UFPB, 2012.

BARBOSA, Orris. Seca de 1932: Impressões sobre a crise nordestina. Mossoró: ETFRNUNED, [1935] 1998.

BARRETO, Lima. Os Bruzundangas. Fundação Biblioteca Nacional, extraído de <http:/ / objdigital.bn.br/Acervo_Digital/livros_eletronicos / bruzundangas.pdf $>$ em outubro de [1917] 2010.

BRANDÃO, Matheus Nogueira. Estados do Nordéste - A secca de 1903. Rio de Janeiro: Léon de Rennes \& C., 1908.

CARVALHO, Emmanoel Rocha. Barragens de Curema e Mãe D'água: Nos bastidores da construção. João Pessoa: Edição do autor, 2013.

COSTA, J. Bonifacio P. da (org.). Relatorio da Comissão Médica de Assistencia e Profilaxia 
aos Flagelados do Nordéste. Rio de Janeiro, 1936.

CPDOC. Documentos sobre a secas no nordeste. Extraído de <http://www.fgv.br/ CPDOC>, em agosto de 2010.

CRANDALL, Roderic. Geografia, Geologia, Supprimento d'Agua, Transportes e Açudagem. nos Estados Orientaes do Norte do Brasil: Ceara, Rio Grande do Norte, Parahyba. Brasil:DNOCS, [1910] 1977.

CUNHA, Euclides da. Os Sertões. Rio de Janeiro-São Paulo: Laemmert \& Co, [1902] 1905.

CUNHA, Olivina Carneiro da. "Curemas". Revista do IHGP. João Pessoa: Departamento de Publicidade - Paraíba, v. 11, 1948.

CUNNIFF, Roger. "The birth of the drought industry- imperial and provincial responses to the great drought in northeast Brazil (1877-1880)". Revista de Ciências Sociais, Fortaleza, vol. VI, nº 1 e 2, 1975.

DAWSEY, John C.. "Por uma antropologia benjaminiana: repensando paradigmas do teatro dramático". Mana, Rio de Janeiro, v. 15, n. 2, p. 349-376, Oct. 2009.

DIRETORIA GERAL DE ESTATÍSTICA. Recenseamento do Brazil, realizado em 1 de setembro de 1920 - relação dos proprietarios dos estabelecimentos ruraes recenseados no Estado da Parahyba. Rio de Janeiro: Typ. da Estatística, 1926.

DNOCS. Relatório dos trabalhos realizados no ano de 1942. São Paulo: OIAL, 1953. - Legislação do D.N.O.C.S.: $2^{a}$ edição cuidadosamente revista e muito aumentada. Recife: Gráfica Editora do Recife, 19581.

. Boletim vol. 18, $n^{\circ} 1$. Rio de Janeiro, Dnocs, 1958a.

Boletim vol. 18, $n^{\circ}$ 2. Rio de Janeiro, Dnocs, $\mathbf{1 9 5 8 b .}$

. Boletim vol. 19, nº 3. Rio de Janeiro, Dnocs, 1959.

. Relatório anual de 1964. Fortaleza: Dnocs, 1964. 
. 56 anos de luta contra as sêcas. Realizações e perspectivas. Fortaleza: Dnocs, 1965a.

. Plano de emergência - sêca de 1965. Fortaleza: Dnocs, 1965b.

. Relatório anual de 1965 . Fortaleza: Dnocs, 1966.

- Plano para combater os efeitos de uma possível sêca no Nordeste em 1967.

Fortaleza: Dnocs, mimeo, s/d

. Relatório anual de 1967 . Fortaleza: Dnocs, 1968.

. Relatório anual de 1968 . Fortaleza: Dnocs, 1969a.

. Projeto Estevam Marinho, vol I. Fortaleza: Dnocs, 1969b.

- Frentes de Serviço: Estudo sócio econômico da população atingida pela sêca de 1970. Fortaleza: Dnocs, 1971.

. Relatório - 1972. Fortaleza: Dnocs, 1972.

. Dnocs em números, vol. 1, no 3-4 jul/dez 1976. Fortaleza: Dnocs, 1976.

EDWARDS, Jeanette. Born and bred: idioms of kinship and new reproductive technologies in England. Oxford: Oxford University Press, 2000.

FERREIRA, Lara de Castro. Enxadas e Compassos: seca, ciência e trabalho no sertão cearense (1915-1919). Salvador: Dissertação apresentada ao Programa de PósGraduação em História/UFBA, 2009.

. "Cassacos": trabalho, cotidiano e conflitos nas frentes de serviços na Bahia e no Ceará (1945-1962). Anais do XXVI Simpósio Nacional de História - Anpuh, São Paulo, jul. 2011.

FERREIRA, Lúcia. Raízes da Indústria da seca: O caso da Paraiba. João Pessoa: Editora Universitária, 1993.

FERREIRA, Angela Lúcia; MEDEIROS, Gabriel Leopoldino Paulo; SIMONINI, Yuri. “Obras contra a seca: a contribuição dos engenheiros para os estudos e a 
construção do território no Nordeste brasileiro (1877-1930)". Montevideo: EGAL, 2009. Extraído de <egal2009.easyplanners.info/.../ 5805_Angela_Lucia_Ferreira.doc $>$, em agosto de 2010.

FORTES, Maria Ester Pereira e LUCCHESI, Fernanda. "Comunidades Quilombolas da Paraíba".In: BANAL, Alberto e FORTES, Maria Ester Pereira. Quilombos da Paraíba: a realidade de hoje e os desafios para o futuro. João Pessoa:, 2013.

FREITAS, Raul de. Relatório apresentado ao Chefe da Sessão Técnica da Ifocs na Paraiba. João Pessoa, mimeo, 1928.

FROTAFrota, Luciara Silveira de Aragão. Documentação oral e a temática da seca. Brasília: Centro Gráfico do Senado Federal, 1985.

FURTADO, Celso. A fantasia desfeita. São Paulo: Paz e Terra, 1989.

- "Uma política de desenvolvimento econômico para o Nordeste (GTDN) (1959)". In: O Nordeste e a saga da Sudene. Rio de Janeiro: Contraponto/ Centro Internacional Celso Furtado de Políticas para o Desenvolvimento, 2009.

GARCIA JR., Afrânio. "Libertos e Sujeitos: Sobre a transição para trabalhadores livres do nordeste". Revista Brasileira de Ciências Sociais, n 7, vol.3, junho de 1988.

GINZBURG, Carlo. "Sinais: Raízes de um paradigma indiciário". In: Mitos, Emblemas, Sinais: morfologia e história. São Paulo: Companhia das Letras, [1986] 2009.

GOMES, Angela de Castro. Essa gente do Rio...: Os intelectuais cariocas e o modernismo. Rio de Janeiro: FGV, 1999.

GUERRA, Paulo de Brito. A civilização da seca: o Nordeste é uma história mal contada. Fortaleza: DNOCS, 1981.

HERZFELD, Michael. A Place in History: Social and Monumental Time in a Cretan Town. New Jersey: Princeton University Press, 1991. . The Social Production of Indifference: Exploring the Symbolic Roots of Western Bureaucracy. Chicago and London: The University of Chicago Press, 1992. 
IBGE. Estado da Paraiba - Censo Demográfico. Rio de Janeiro: Ibge, 1955.

- "Operação Nordeste". Revista Brasileira de Geografia, do Instituto Brasileiro de Geografia e Estatística, ano XXI, n 2, de abril a junho de 1959.

. Piancó - Paraíba. Rio de Janeiro: Ibge, 1962.

IFOCS. Relatorio dos trabalhos executados durante o anno de 1924. Rio de Janeiro: Ministério da Viação e Obras Públicas, 1925. Relatorio dos trabalhos executados durante o anno de 1927. Rio de Janeiro: Ministério da Viação e Obras Públicas, 1928. Introdução ao Relatorio dos trabalhos executados no anno de 1928. Rio de Janeiro: Ministério da Viação e Obras Públicas, 1929. . Relatorio dos trabalhos realizados no trienio 1931-1933. Ceará: Tipografia Minerva, 1934r.

. Boletim, volume 1, nº 1. Rio de Janeiro: Tipografia Minerva, 1934a.

. Boletim, volume 2, $n^{\circ} 4$. Rio de Janeiro: Tipografia Minerva, 1934b.

. Boletim, volume 3, nº3. Rio de Janeiro: Tipografia Minerva, 1935. . Relatorio dos trabalhos realizados no anno de 1935. Rio de Janeiro: Ifocs, 1936r. . Boletim, volume $5, n^{\circ} 1$. Rio de Janeiro: Ifocs, 1936a. . Boletim, volume $6, n^{\circ} 2$. Rio de Janeiro: Ifocs, $\mathbf{1 9 3 6}$. Boletim, volume $7, n^{\circ} 2$. Rio de Janeiro: Ifocs, 1937a. Boletim, volume $8, n^{\circ} 2$. Rio de Janeiro: Ifocs, $\mathbf{1 9 3 7 b}$. . Boletim, volume 10, $n^{\circ} 2$. Rio de Janeiro: Ifocs, 1938. . Boletim, volume 11, $n^{\circ} 1$. Rio de Janeiro: Ifocs, 1939a. . Boletim, volume 12, $n^{\circ} 2$. Rio de Janeiro: Ifocs, $\mathbf{1 9 3 9 b}$. 
. Boletim, volume 17, $n^{\circ} 1$. Rio de Janeiro: Ifocs, 1942.

HALL, Anthony. "Irrigation in the Brazilian Northeast: anti-drought or antipeasant?". In: SIMON, Mitchell (org.). The logic of poverty: the case os the Brazilian Northeast. London: Routledge, 1981.

HOLMES, J. Teresa. "When blood matters: making kinship in colonial Kenya". In: S. Bamford \& J. Leach (Eds.), Kinship and beyond: the genealogical model reconsidered. New York/Oxford: Berghahn Books, 2009.

JOFFILY, Irinêo. Notas sobre a Paraiba. Brasília: Thesaurus, [1892] 1977.

LEITÃO, Evaristo. O Problema Social e Economico das Obras Contra as Sêcas. Rio de Janeiro: Ifocs, 1937.

LEWIN, Linda. Politica e parentela na Paraiba: Um estudo de caso da oligarquia de base familiar. Rio de Janeiro: Record, [1987] 1993.

LUCCHESI, Fernanda. A História como Ideal: Reflexões sobre a obra de José Francisco da Rocha Pombo. Dissertação apresentada ao Programa de Pós Graduação em Antropologia Social/USP. São Paulo: USP, 2004.

MARIZ, Inez. A Barragem. João Pessoa: A União, [1937] 1994.

MARQUES, Ana Cláudia Rocha \& VILLELA, Jorge Luiz. “O poder e o território do bandido: Reflexões sobre Lampião, o Rei do Cangaço". Ilha, no.0, 1999, p. 119-138.

MEDEIROS, Coriolano de. Dicionário Corográfico do Estado da Paraiba. Rio de Janeiro: Departamento de Imprensa Nacional, 1959.

MONTEIRO, Manoel. José Américo - ministro das secas e pai da bagaceira. Campina Grande: folheto de cordel, 2008.

OLÍMPIO, Domingos. Luzia-Homem. São Paulo: Ática, [1903] 1983.

PINHEIRO, Luiz Carlos Martins. Açudagem Pública - Separata do Boletim no 3, vol. 19. Rio de Janeiro: Dnocs, 1960a. 
Obras contra os efeitos das Sêcas (Sêca de 1958) - Separata do Boletim n 3, vol. 19. Rio de Janeiro: Dnocs, 1960b.

Notas Sôbre as Sêcas - Separata do Boletim nº, vol. 20.

Rio de Janeiro: Dnocs, 1960c.

PIRES, Diassis. A caixa d'água do sertão. Caucáia: Governo do Estado da Paraíba/ Funarte, 2010.

QUEIROZ, Rachel de. O Quinze. Edição integral. Copyright [1930] 1937. disponível em http:/ / ola.coop.br/articles / oceb / 0042 / 9952 / o_quize_obra__rachel_de_queiroz.pdf.

ROCHA, Solange Pereira da. Gente negra na Paraíba oitocentista: População, Familia e Parentesco Espiritual. Recife: Tese de doutorado apresentada ao Programa de PósGraduação em História/UFPE, 2007.

SALES, Teresa. Cassacos e Corumbas. São Paulo: Editora Ática, 1977.

SANTOS, José Américo dos. Secca no Norte do Brasil: Março de 1878. Rio de Janeiro: Machado \& Co, 1883.

SCHWARCZ, Lilia Katri Moritz. O espetáculo das raças: Cientistas, instituições e questão racial no Brasil 1870-1930. São Paulo: Companhia das Letras, 1995.

SEVCENKO, Nicolau. Literatura como Missão: Tensões Sociais e Criação Cultural na Primeira República. São Paulo: Brasiliense, [1983] 1999.

SILVA FILHO, Edvaldo Brilhante. Coremas, seu lugar na história. João Pessoa: Geografic, 1996.

SOARES, Josemar Alves. São Gonçalo: Fragmentos da História. Souza: Ed. do Autor, 2013.

SUDENE. As secas do Nordeste (Uma abordagem histórica de causas e efeitos). Recife: Sudene-Dner, 1981

POMPONET, André. "100 anos de DNOCS: marchas e contramarchas da 
convivência com as secas". Apresentação oral-Instituições e Desenvolvimento Social na Agricultura e Agroindústria, da Bahia, Feira de Santana. Extraído de <http: / / www.sober.org.br/ palestra/13/253.pdf>, em agosto de 2010.

VIANA, José Francisco Oliveira. Evolução do Povo Brasileiro. São Paulo-Rio de JaneiroRecife-Porto Alegre: Companhia Editora Nacional, [1923] 1938.

VIDAL, Armando. O Brasil na Feira Mundial de Nova York de 1940: Relatório Geral, $2^{a}$ Parte. Rio de Janeiro: Imprensa Nacional, 1942. 


\section{Anexo}

\section{Cadernos de Imagem}

Esse anexo é composto de dois cadernos de imagens que se referem, respectivamente, às duas partes da tese. Um dos objetivos desses cadernos é apresentar ao leitor a forma como a população mais afetada pelas secas foi retratada pelas publicações oficiais e a ênfase dada por essas publicações às grandes obras de infraestrutura. No segundo caderno foram também incluídas fotos da região de Coremas feitas por mim durante a pesquisa de campo, buscando retratar a região e os principais pontos levantados acerca da ação do Dnocs em Coremas.

Os cadernos procuram, ainda, cumprir o objetivo de oferecer uma narrativa alternativa aos temas tratados na tese que possa ser apropriada por um público não letrado. A preocupação em oferecer tal narrativa relaciona-se com o trabalho que venho desenvolvendo no Incra desde 2006 e que consiste, entre outros, em elaborar relatórios de identificação de comunidades quilombolas para fins de titulação das mesmas. Grande parte dos membros dessas comunidades, tanto no Maranhão como na Paraíba, não tiveram nenhuma educação formal, dificultando a apreensão do conteúdo dos relatórios que tem como objetivo principal expressar suas próprias concepções acerca de sua história e território.

Inspirada no trabalho de André Alves intitulado Os Argonautas do Mangue (2004), comecei a elaborar cadernos de imagens, com fotos e documentos, que seguiam os conteúdos apresentados em cada um dos capítulos do relatório. Além de 
fazer com que os moradores se engajassem na elaboração desses cadernos, sugerindo assuntos, corrigindo ênfases e representações e refazendo cronologias, seu resultado tornou-se apreensível a toda comunidade. Como efeito não esperado, a inclusão dessa narrativa imagética tornou o relatório mais acessível e apreciado por outros setores da administração pública que avaliam esses relatórios e que são compostos por não antropólogos, sobretudo as procuradorias do Incra.

A disposição das fotos e legendas seguem também a sugestão de Alves (2004), deixando as imagens sem texto num primeiro plano, para a reflexão do leitor sem qualquer interferência e na página seguinte uma legenda procurando sublinhar a importância atribuída a elas por mim. 
CADERNO DE IMAGENS

PARTE I 
Capa: trecho de "Barragem da Serrinha", lápis sobre cartolina. Desenho de 
Ao longo do século XX, as secas nordestinas foram descritas e analisadas em obras literárias, pesquisas científicas, reportagens, quadros, filmes e muitas fotos. Grande parte do material iconográfico retratou o sofrimento das mortes e retiradas causadas pelas calamidades que de maneira cíclica acometiam os moradores empobrecidos do polígono das secas. Ao contrário desse material, que se tornou conhecido do grande público, as publicações oficiais do órgão de combate às secas procuraram demonstrar as obras e trabalhos nos quais foi engajada a população afetada pelas crises climáticas, denominados genericamente de retirantes e flagelados. Nas fotos de trabalhadores, principalmente aquelas publicadas até os anos 1970, os trabalhadores aparecem quase que uniformizados, trabalhando vigorosamente ou pelo menos sem expressar sofrimento.

As imagens reproduzidas nesse caderno foram selecionadas a partir de publicações oficiais, sobretudo dos relatórios e boletins da Ifocs / Dnocs. 

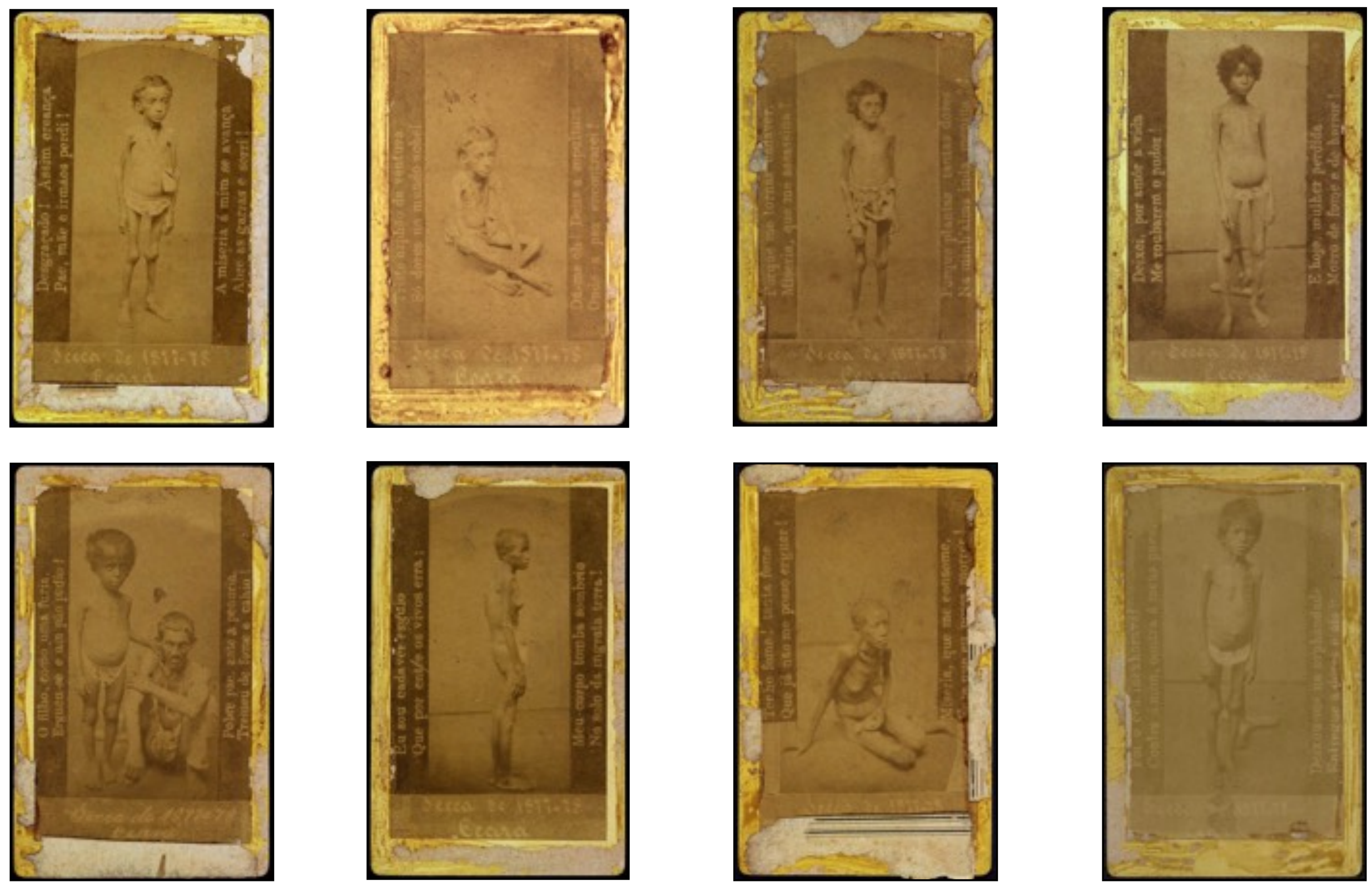
O conjunto dos cartões foi produzido por Corrêa, J.A., a partir das fotos que tirou durante a seca de 1877, no Ceará, e receberam o título de "Seccas de 1877-78". Os cartões foram dados a Dom Pedro II, que ficou bastante impressionado com as notícias que chegavam sobre a seca, referindo-se ao fenômeno como flagelo. As imagens são de fato chocantes e o conjunto das imagens com os textos cumprem seu objetivo de causar comoção.

1. "Desgraçado! Assim creança/ Pae, mãe e irmaos perdi!/ A miseria a mim se avança/ Abres as asas e sorri!"

2. "Triste orphão da ventura/ Só dores no mundo achei/ Dá-me oh! Deus a sepultura/ Onde a paz encontrarei!"

3. "Por que me tornas cadaver, / Miseria, que me assassina? / Por que plantas tantas dores / Na minh'alma inda menina?!"

4. "Deixei, por amôr a vida/ Me roubarem o pudor! / E hoje, mulher perdida/ Morro de fome e de horror!"

5. "O filho, como uma furia/ Ergueu-se e um pão pedio!/ Pobre pae, ante á penuria/ Tremeu de fome e cahio!"

6. "Eu sou cadaver esguio/ Que por entre os vivos erra; / Meu corpo tomba sombrio/ No solo da ingrata terra"

7. 'Tenho fome! tanta fome/ Que já não me posso erguer!/ Mizeria que me consome/ Faze com que possa morrer"

8. "Foi o ceu inexhoravel/ Contra á mim, contra á meus paes,/ Deixou-me na orphandade/ Entregue a dores e ais!"

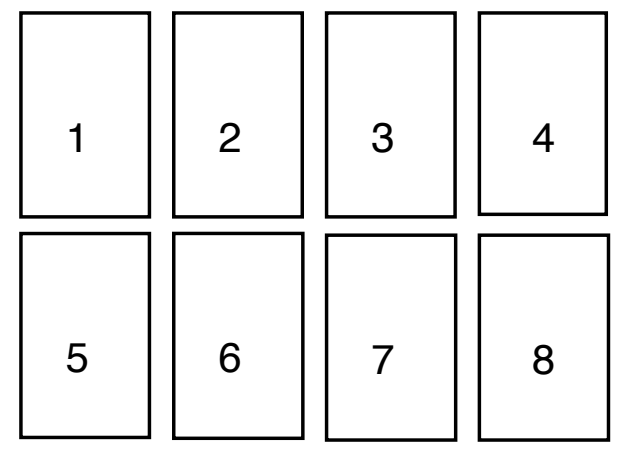




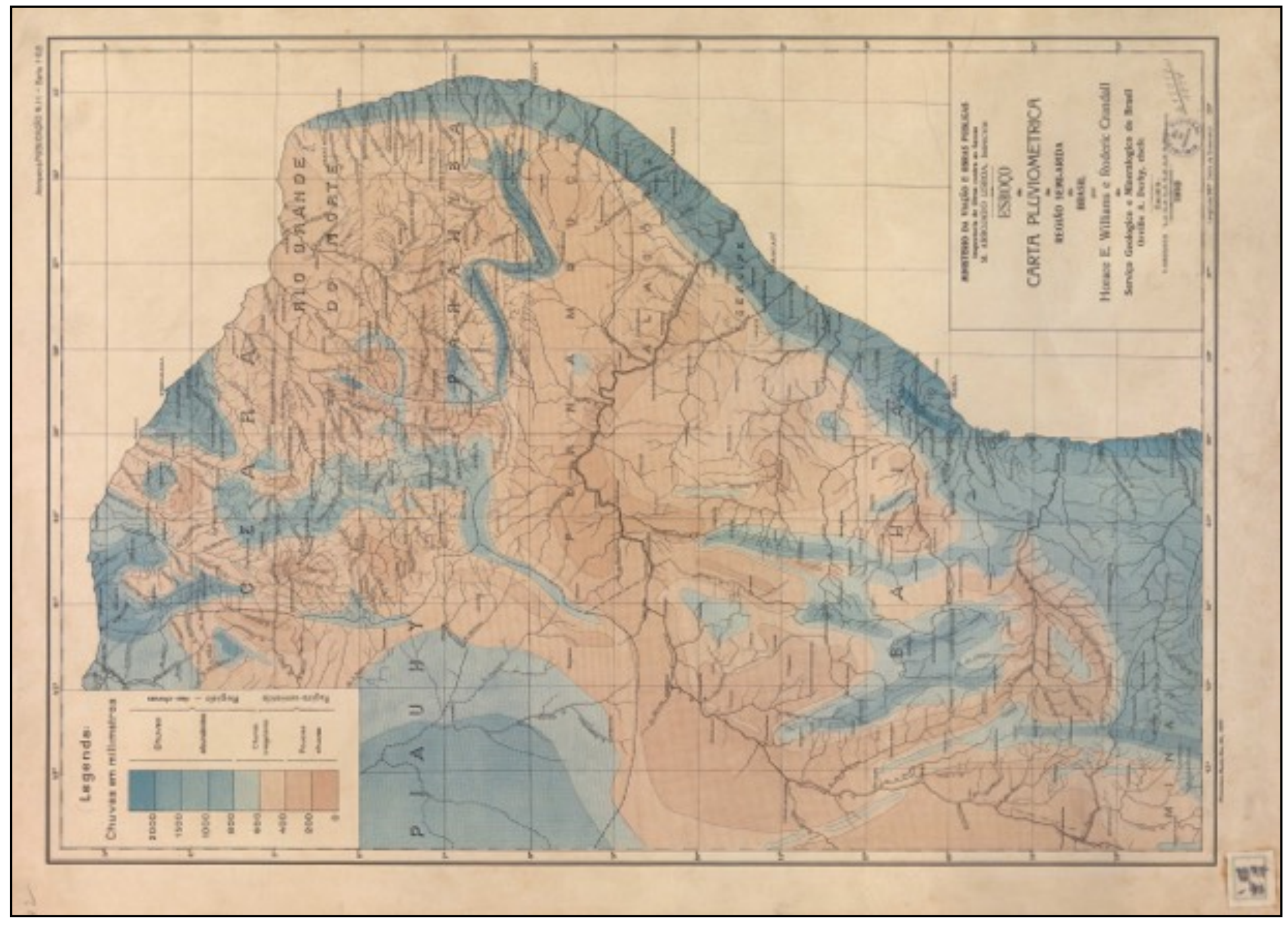


Um dos primeiros serviços da Inspetoria de Obras Contra as Secas foi a instalação de aparelhos para medir precipitação de chuvas na área semiárida. Sob o comando do Inspetor Arrojado Lisboa, muitos foram os estudos sobre a região afetados pelas secas produzindo um rico material sobre a região, como a carta reproduzida acima e os demais estudos geológicos empreendidos também sob o comando de Roderic Crandall.

1. "Esboço da Carta Pluviometrica da Região Semi-Arida do Brasil por Horace E. Williams e Roderic Crandall". Ifocs, 1910.

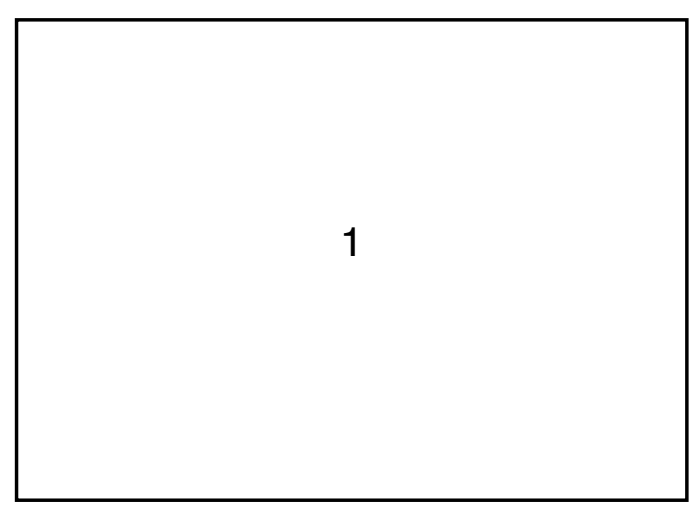



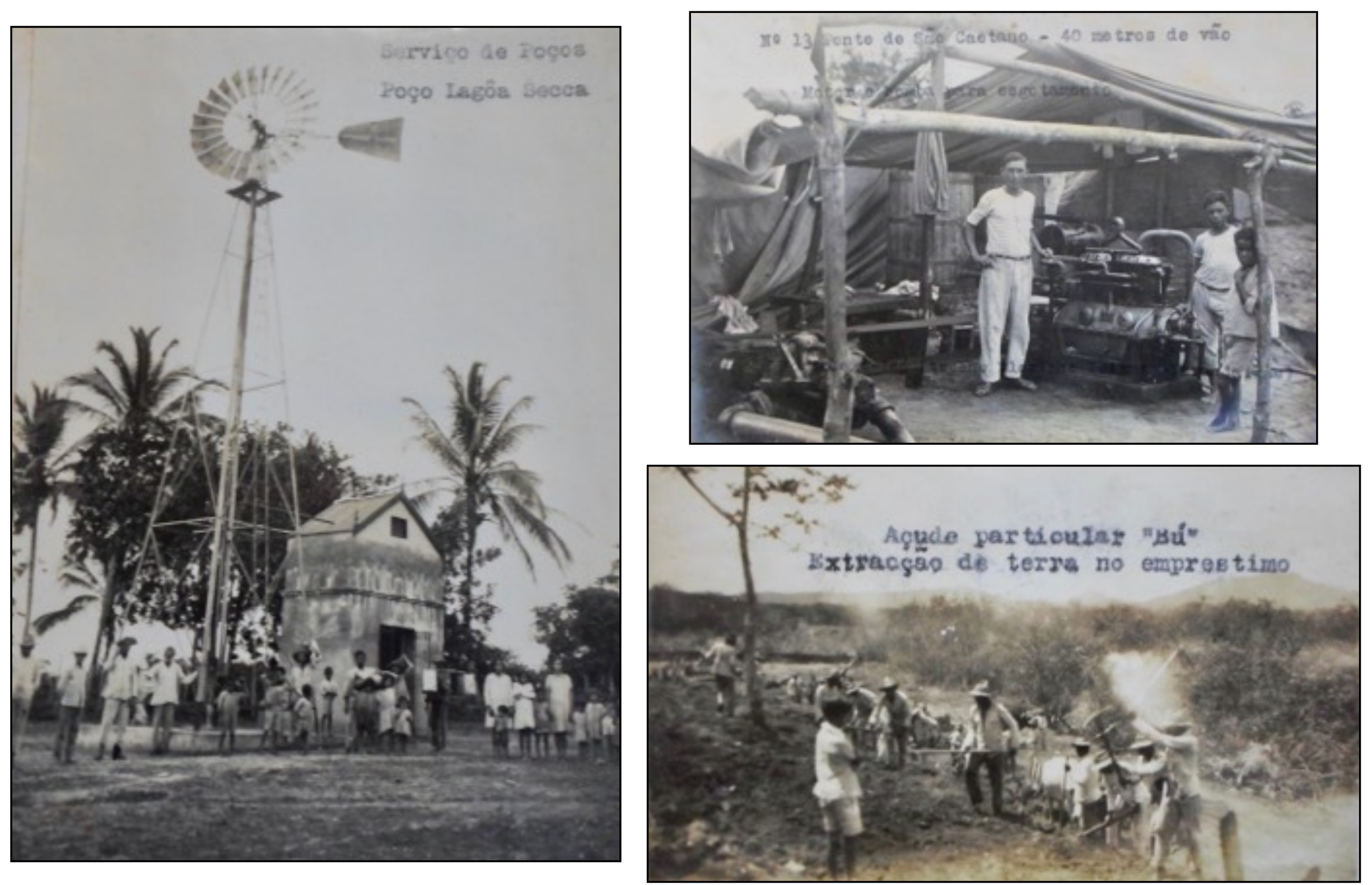
Embora essa tese tenha focado a construção de grandes açudes públicos, outros serviços tiveram grande relevância para o órgão de obras contra as secas como foi o caso da construção de estradas e de poços. O Serviço de Poços ganhou uma maior proeminência no mesmo período em que os grandes açudes perderam sua centralidade. A construção de açudes em terras particulares foi outro serviço de destaque da Inspetoria, sendo interpretados por alguns pesquisadores como a prova mais exata da chamada "indústria das secas". Nas primeiras entrevistas que realizei em Coremas, estranhei o fato de as pessoas relatarem ter trabalhado em "emergências" do Dnocs ou do Governo do Estado nas terras de tal ou qual pessoa, até descobrir que o investimento público em terras privadas para construção de açudes era prática corrente desde o século XIX. Em As sêcas do Nordeste, José Américo de Almeida afirmava ser esse benefício uma dádiva almejada por todo fazendeiro.

1. Poço de Lagoa Seca, Ceará. Relatório dos Serviços Realizados pela Ifocs no ano de 1929.

2. Maquinaria utilizada para a construção das muitas pontes da Estrada de Rodagem Fortaleza-Icó. Relatório dos Serviços Realizados pela Ifocs no ano de 1929.

3. Retirada de terra para a construção de um açude particular. Relatório dos Serviços Realizados pela Ifocs no ano de 1929.

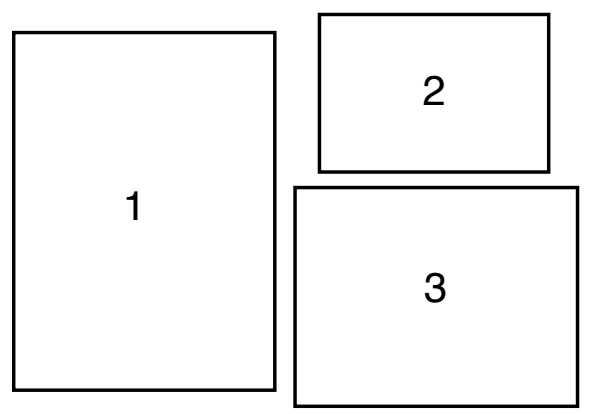




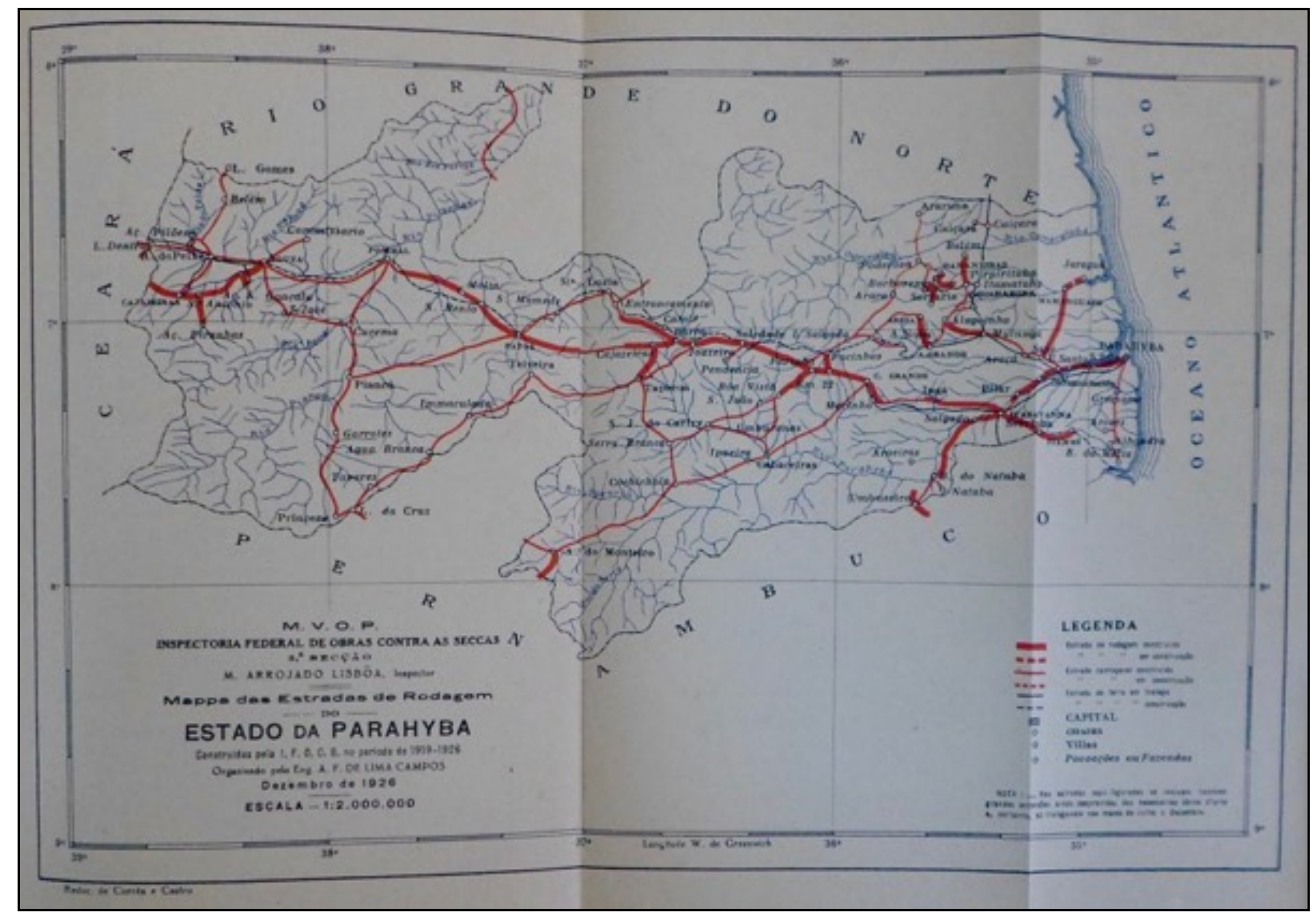


A construção de estradas teve um papel destacado entre as políticas contra as secas, sobretudo nos anos anteriores à criação do Departamento Nacional de Estradas de Rodagem (Dner) em 1937. A publicação em que se encontra o mapa acima compreende o mandato de Epitácio Pessoa como Presidente da República. Esse é tido como um dos períodos áureos do desenvolvimento regional - e também da Ifocs - com grande investimento em estradas e açudes públicos.

1. "Mappa das Estradas de Rodagem do Estado da Parahyba, Constuidas pela I.F.O.C.S, no período de 1919-1926". In: Estradas de Rodagem e Carroçaveis Construidas no Nordéste Brasileiro pela Inspectoria de Obras Contra as Seccas nos annos de 1919 a 1925. Rio de Janeiro: Ifocs, 1927.

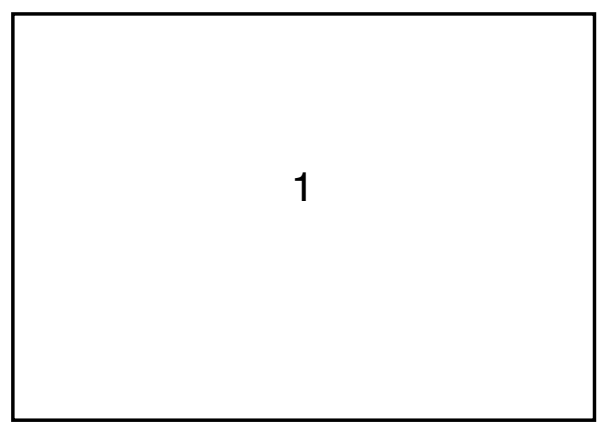



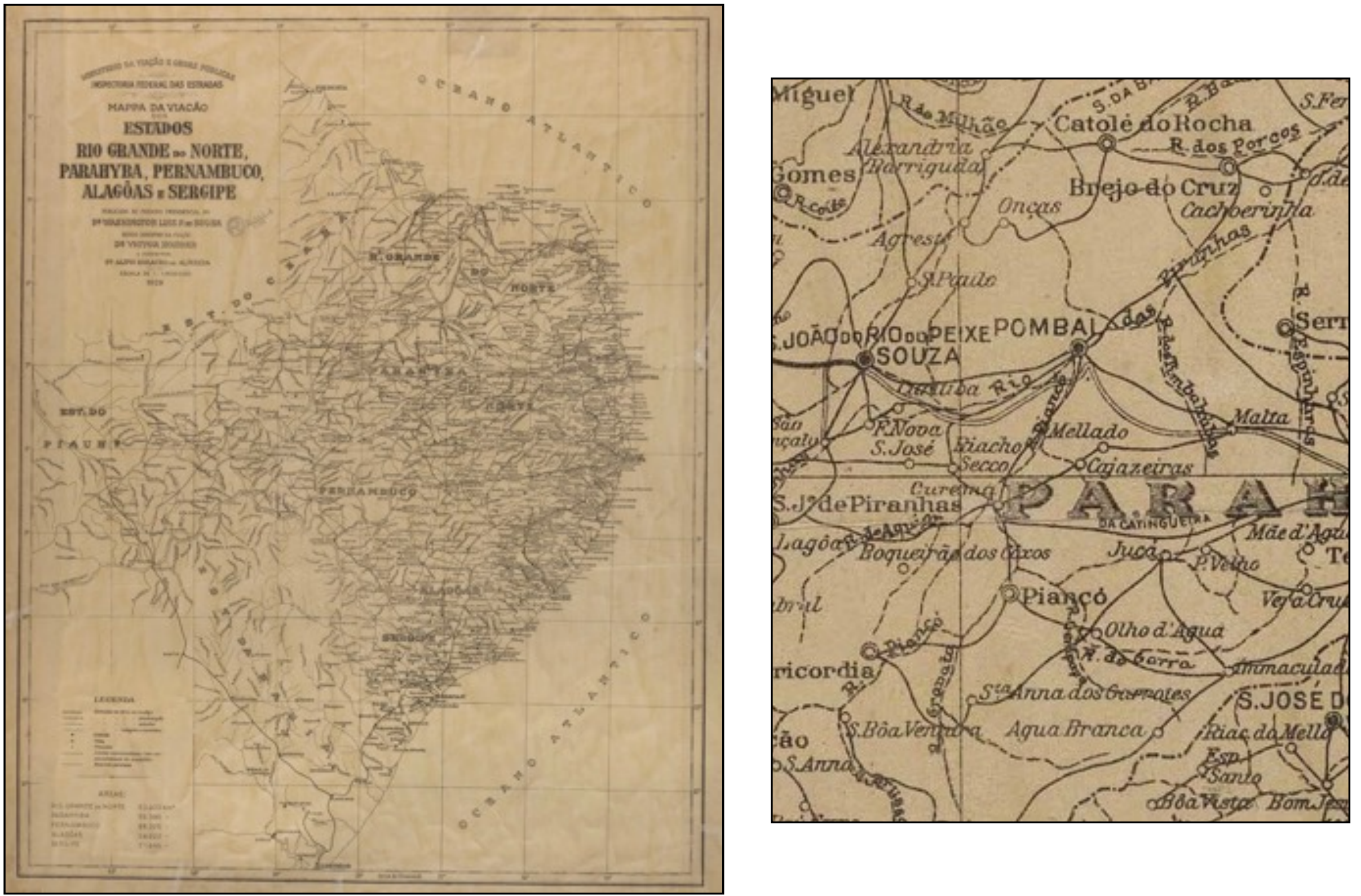
Embora já existisse um órgão responsável pelas estradas ligada ao Ministério de Viação e Obras Públicas - a Inspectoria Federal das Estradas - desde pelo menos o início da década de 1920, grande parte das estradas de rodagem do Nordeste ficaram a cargo da Ifocs até meados da década de 1940. Mesmo depois da criação do Dner, muitas estradas continuaram a ser feitas pelo Dnocs. A construção de estradas foi uma das principais ações contra as secas, sobretudo em esquemas de obras de emergência.

No detalhe do mapa vemos as ramificações que interligavam Coremas, antes da construção dos açudes públicos na localidade.

1. "Mappa da Viação dos Estados Rio Grande do Norte, Parahyba, Pernambuco, Alagôas e Sergipe". Inspectoria Federal das Estradas, 1929.

2. Detalhe do "Mappa da Viação dos Estados Rio Grande do Norte, Parahyba, Pernambuco, Alagôas e Sergipe".

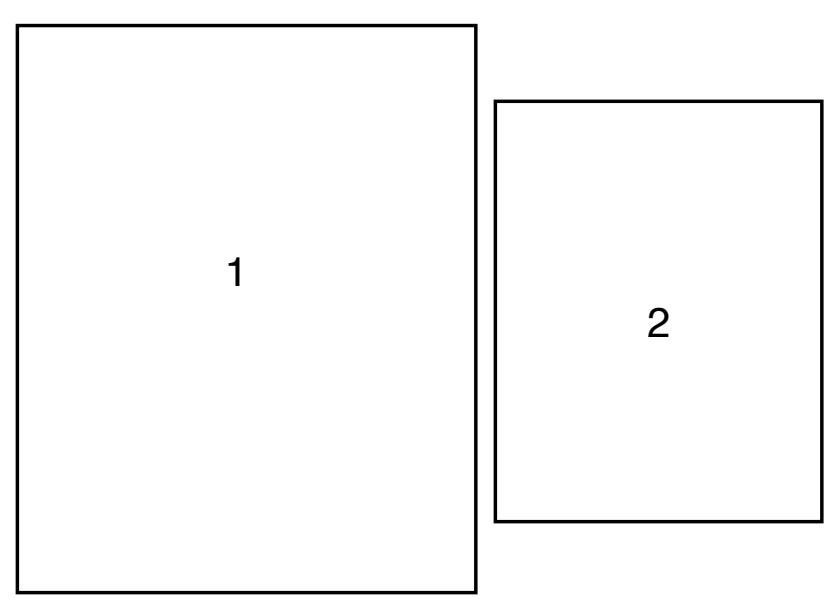



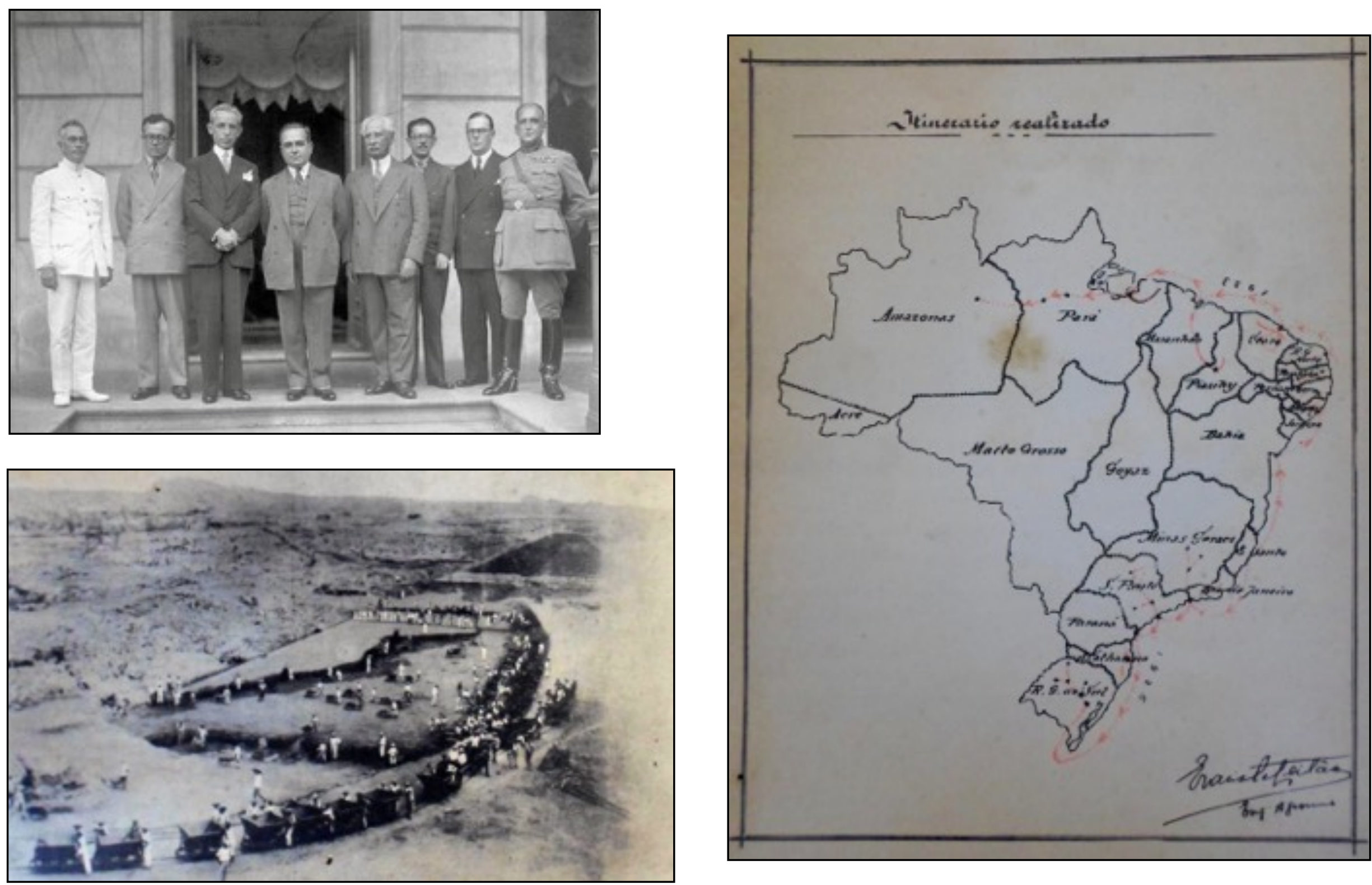

hauthavas 
O período que compreendeu o Governo Provisório de Getúlio Vargas foi tido como um segundo ápice das obras contra as secas, depois daquele experimentado durante o Governo de Epitácio Pessoa. Muitas foram os açudes e estradas construídas nesse período, que teve o paraibano José Américo de Almeida como Ministro da Viação e Obras Públicas. Além das obras de emergência, destaca-se a atuação de comissões para avaliar as políticas implementadas e propor melhorias. Entre estas estava a Comissão Médica de Assistencia e Profilaxia aos Flagelados do Nordeste.

1. Getúlio Vargas e membros de seu ministério. Da esquerda para a direita: Isaías de Noronha, José Américo de Almeida, Afranio de Melo Franco, Getúlio Vargas, Joaquim Francisco de Assis Brasil, Francisco Campos, Lindolfo Collor, José Fernandes de Castro. Novembro de 1930. Acervo Cpdoc/FGV.

2. Construção do Açude de Santa Luzia, médio sertão paraibano. In: COSTA, J. Bonifacio P. da (org.). Relatorio da Comissão Médica de Assistencia e Profilaxia aos Flagelados do Nordéste. Rio de Janeiro, 1936.

3. Itinerário realizado pela Comissão Médica de Assistencia e Profilaxia aos Flagelados do Nordéste. In: COSTA, J. Bonifacio P. da (org.). Relatorio da Comissão Médica de Assistencia e Profilaxia aos Flagelados do Nordéste. Rio de Janeiro, 1936.

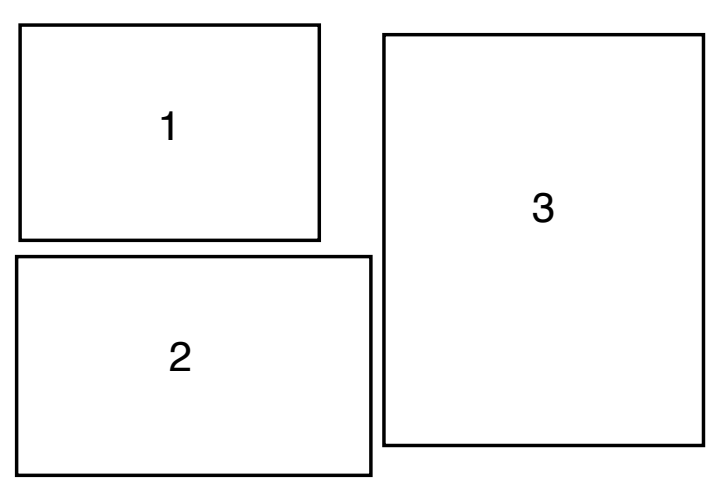



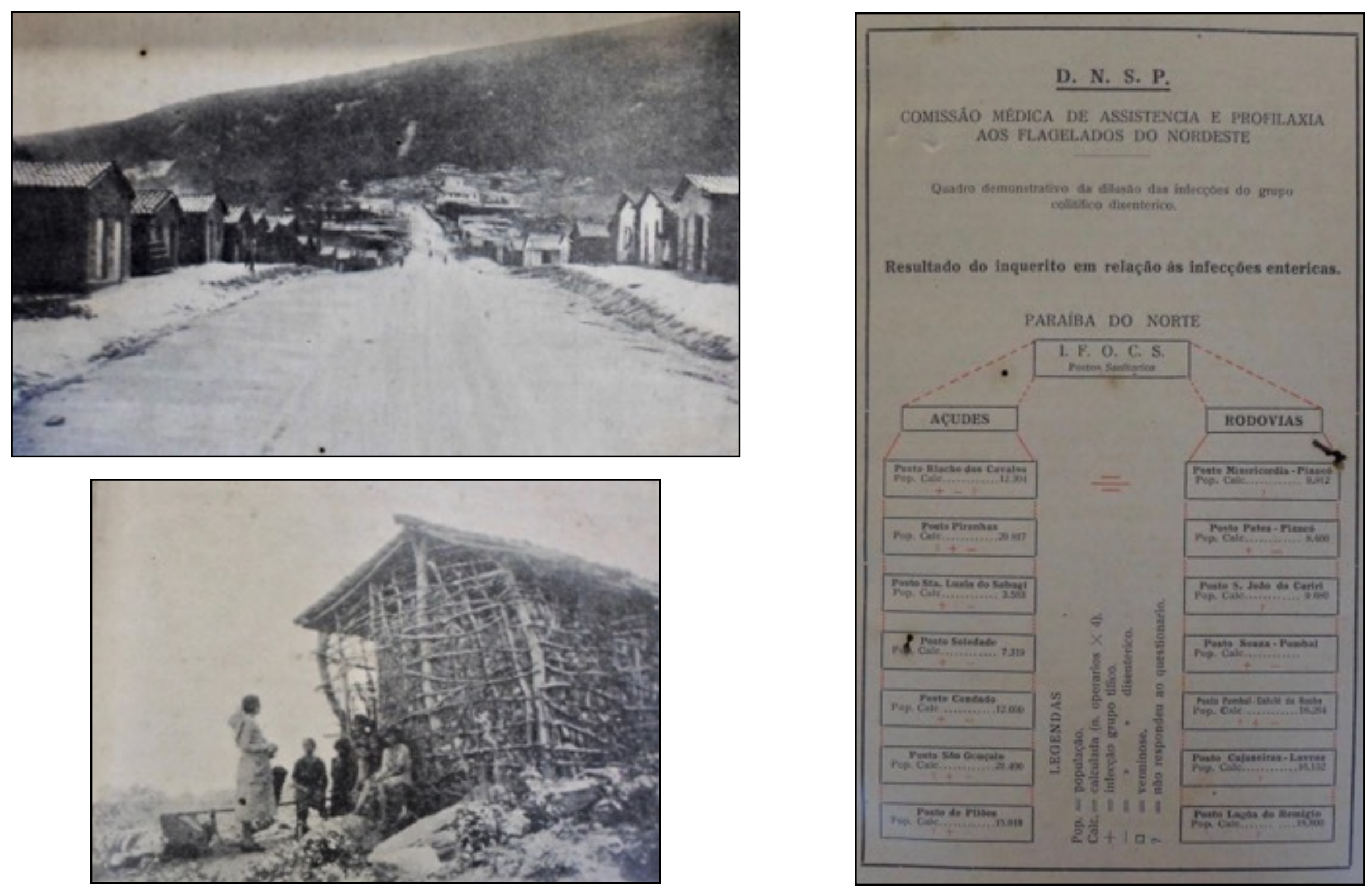
O Relatório da Comissão Médica, que percorreu os acampamentos formados ao lado das obras de grandes açudes e estradas e campos de concentração em 1933, demonstrou uma situação de extrema precariedade da população aglomerada em torno das obras e campos do Dnocs. Além da eclosão de epidemias, que se espalharam rapidamente entre uma população já desnutrida mesmo antes do início da secas, o relatório aponta para as péssimas condições sanitárias desses abrigos improvisados, que terminavam por agravar a situação. Em alguns desses acampamentos, como foi o caso daquele instalado ao lado das obras do açude São Gonçalo em Souza (PB), a chefia conseguiu contornar alguns dos problemas sanitários com o controle das edificações destinadas aos operários e a criação de turmas de limpeza pública. Já em Piranhas, há poucos quilômetros dali, o médico responsável pela elaboração do relatório escreveu que nenhum empregado de categoria queria demorar ali e, quando eram obrigados a visitar o local, levavam sua própria água com medo de infecção. O engenheiro responsável inicialmente pela obra, e que dá nome ao açude, o Engenheiro Moacir Ávidos, morreu devido a uma moléstia infecciosa contraída no local.

As fotos acima foram retiradas de COSTA, J. Bonifacio P. da (org.). Relatorio da Comissão Médica de Assistencia e Profilaxia aos Flagelados do Nordéste. Rio de Janeiro, 1936.

1. "Acampamento Açude General Sampaio". Barra do Rio Curu, CE.

2. "Quadro demonstrativo infecções entéricas".

3. "Palestra de uma enfermeira em Piranhas, PB".

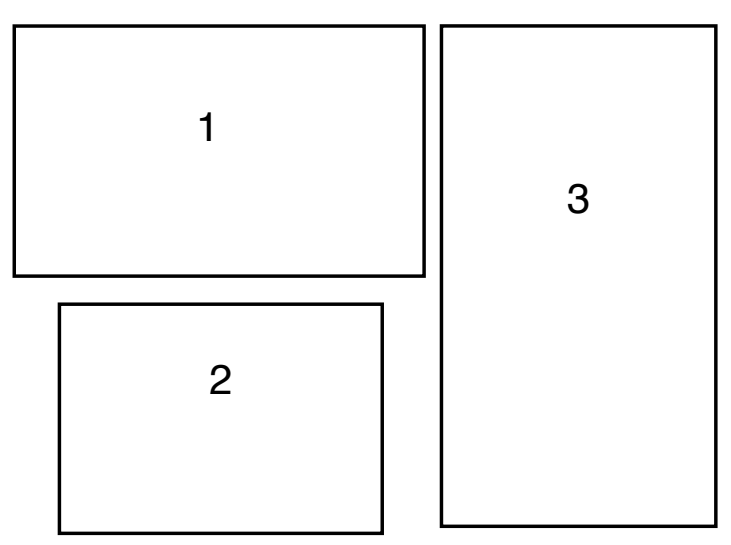




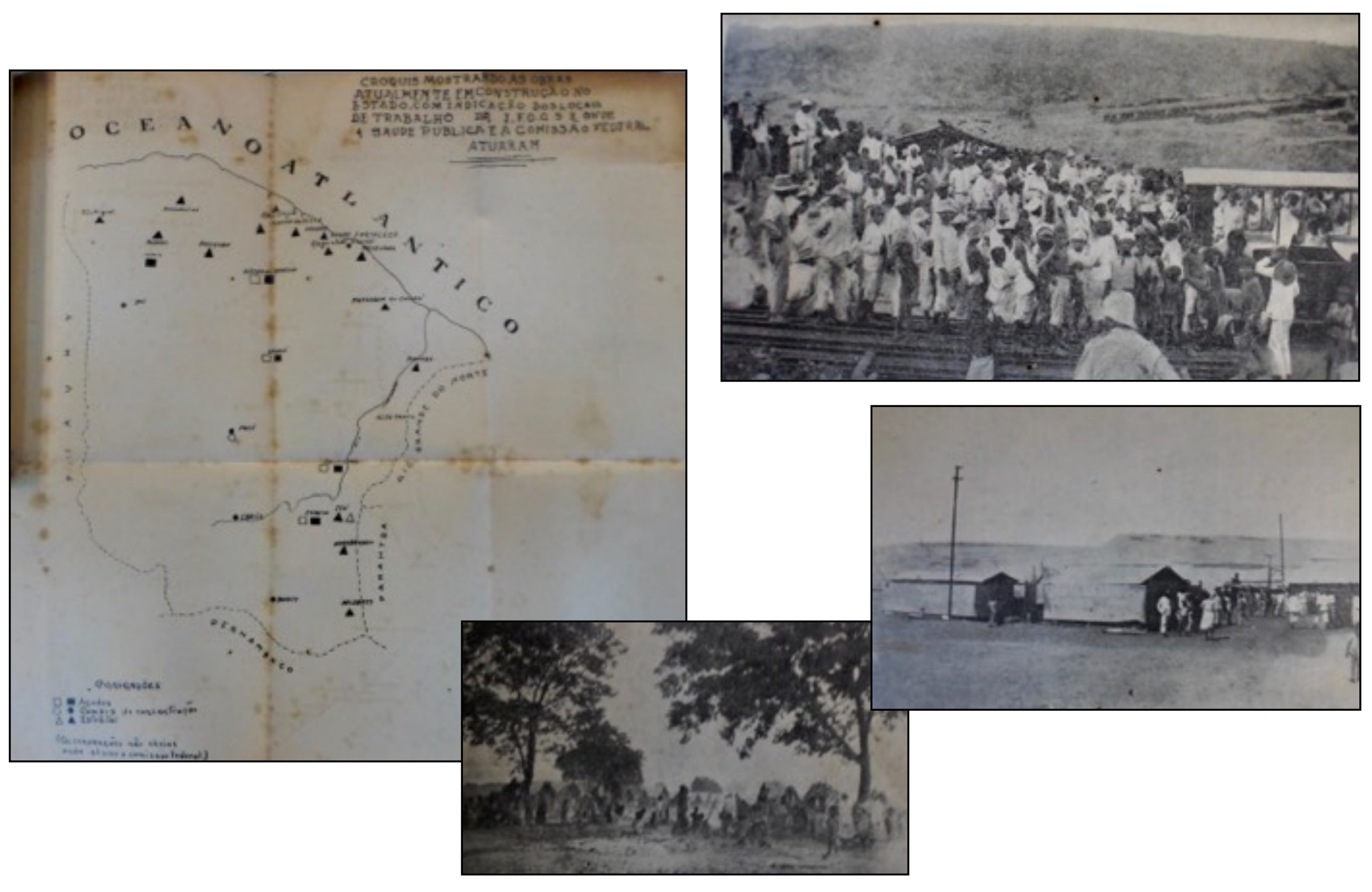


As condições dos acampamentos improvisados em torno das obras da Ifocs alarmaram os membros da Comissão Médica. A realidade encontrada nos campos de concentração espalhados sobretudo no Ceará, porém, foi muito pior. No relatório apresentado, os membros da Comissão se posicionaram contrariamente à essa política afirmando que esse tipo de medida não deveria ser mais utilizada nas crises subsequentes. O objetivo de tais campos, tal como declarado oficialmente, era dar assistência imediata aos flagelados e direcioná-los para as frentes de emergência. Entre seus críticos, essa política era vista como uma forma de impedir que a população faminta chegasse aos centros econômicos do estado, formado espécies de currais de pessoas que se aglomeravam para esperar a morte. Após a seca de 1932, os campos de concentração não foram mais mantidos pelo poder público.

As fotos acima foram retiradas de COSTA, J. Bonifacio P. da (org.). Relatorio da Comissão Médica de Assistencia e Profilaxia aos Flagelados do Nordéste. Rio de Janeiro, 1936.

1. Mapa com a localização dos campos de concentração no Ceará na seca de 1932.

2. 'Campo de Buriti, sul do Ceará

3. Campo de Patu, Senador Pompeu, Ceará.

4. Campo de Pirambu, próximo à capital Fortaleza, Ceará

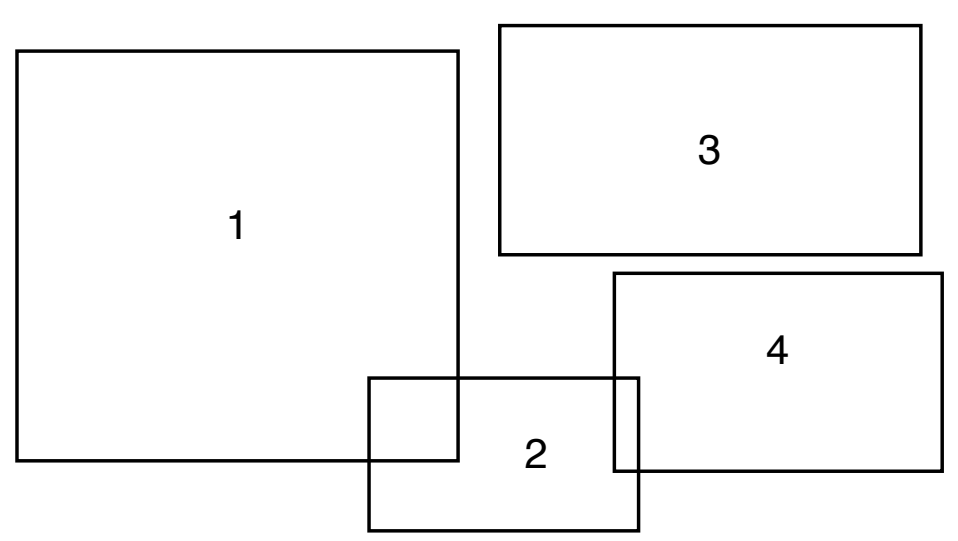



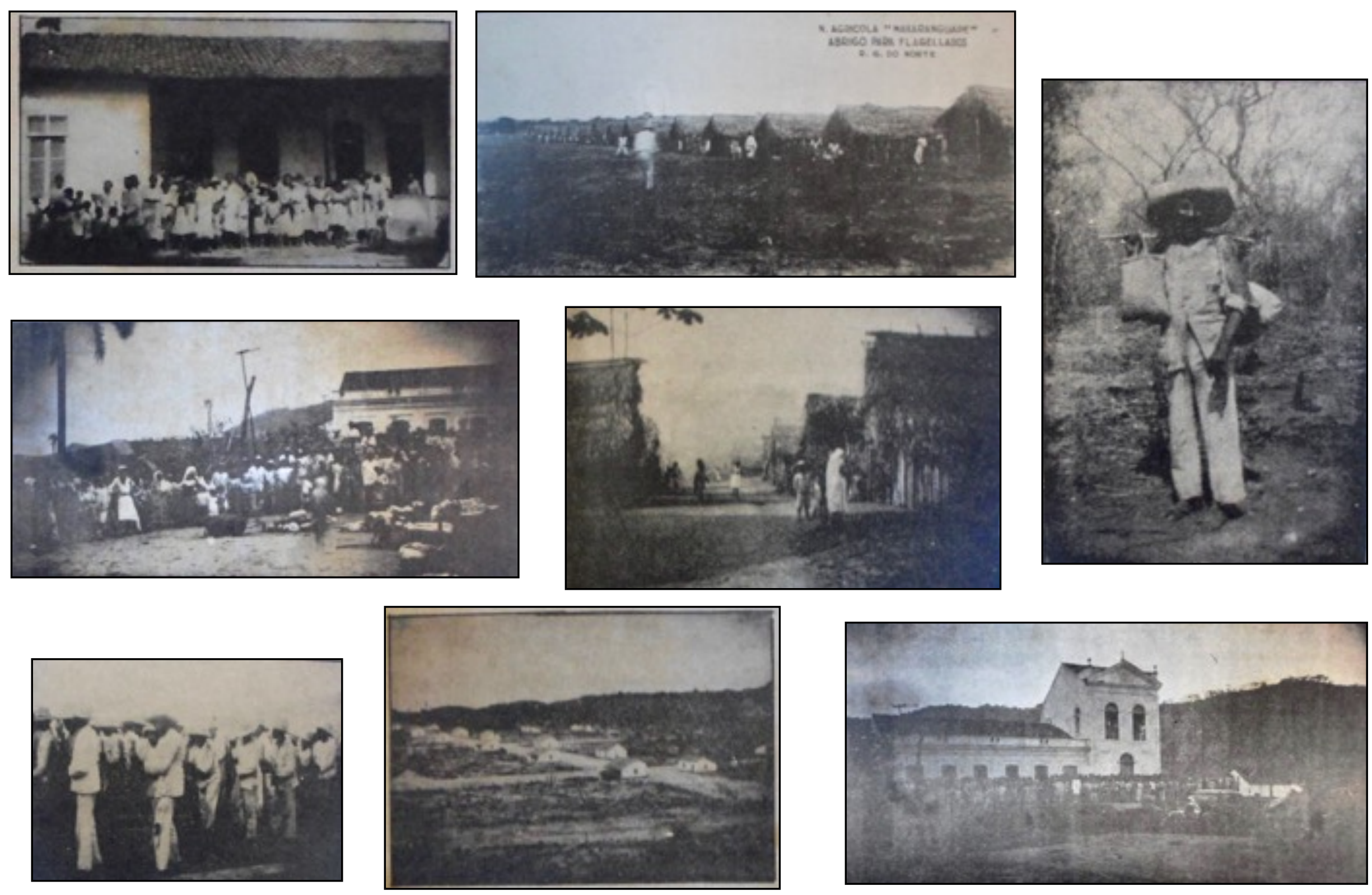
Além dos campos de concentração e das obras de combate aos efeitos das secas, os trabalhadores das áreas assoladas foram também deslocados para outras regiões do Brasil, em especial para a região amazônica e áreas de transição, como o estado do Maranhão. Durante a seca de 1932, o Serviço de Localização de Flagelados foi responsável pelo envio de levas de famílias para núcleos agrícolas mantidos pelos estados. Grande parte dos locais visitados pelo engenheiro Francisco Leitão, a pedido do Ministro José Américo de Almeida, funcionavam de maneira precária, dependendo seu maior ou menor sucesso dos estados responsáveis. $\mathrm{Na}$ avaliação do engenheiro, o serviço de colonização deveria ser encarado como uma política autônoma e sujeita a normas gerais e não como um apêndice dos serviços de socorros. As fotos acima foram retiradas de LEITÃO, Evaristo. O Problema Social e Economico das Obras Contra as Sêcas. Rio de Janeiro: Ifocs, 1937.

1. "Grupo de flagellados Colonia Davi Caldas (PI)"

2. "Alagoa Grande (PB) com vista das barracas da Colônia Tanques"

3. "Flagellados em Choró (CE)"

4. "Colonia agricola Maxaranguape (RN) abrigo para flagellados"

5. "Casas de espera a beira do caminho Pará"

6. "Colônia Davi Caldas (PI)"

7. "O retirante - Ceará"

8. "Distribuição de roupas em Areia" (PB)

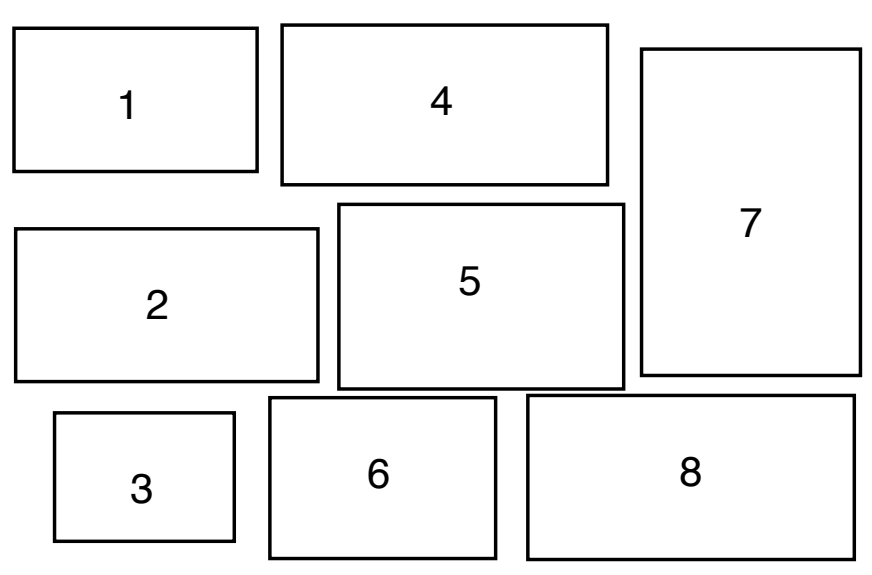



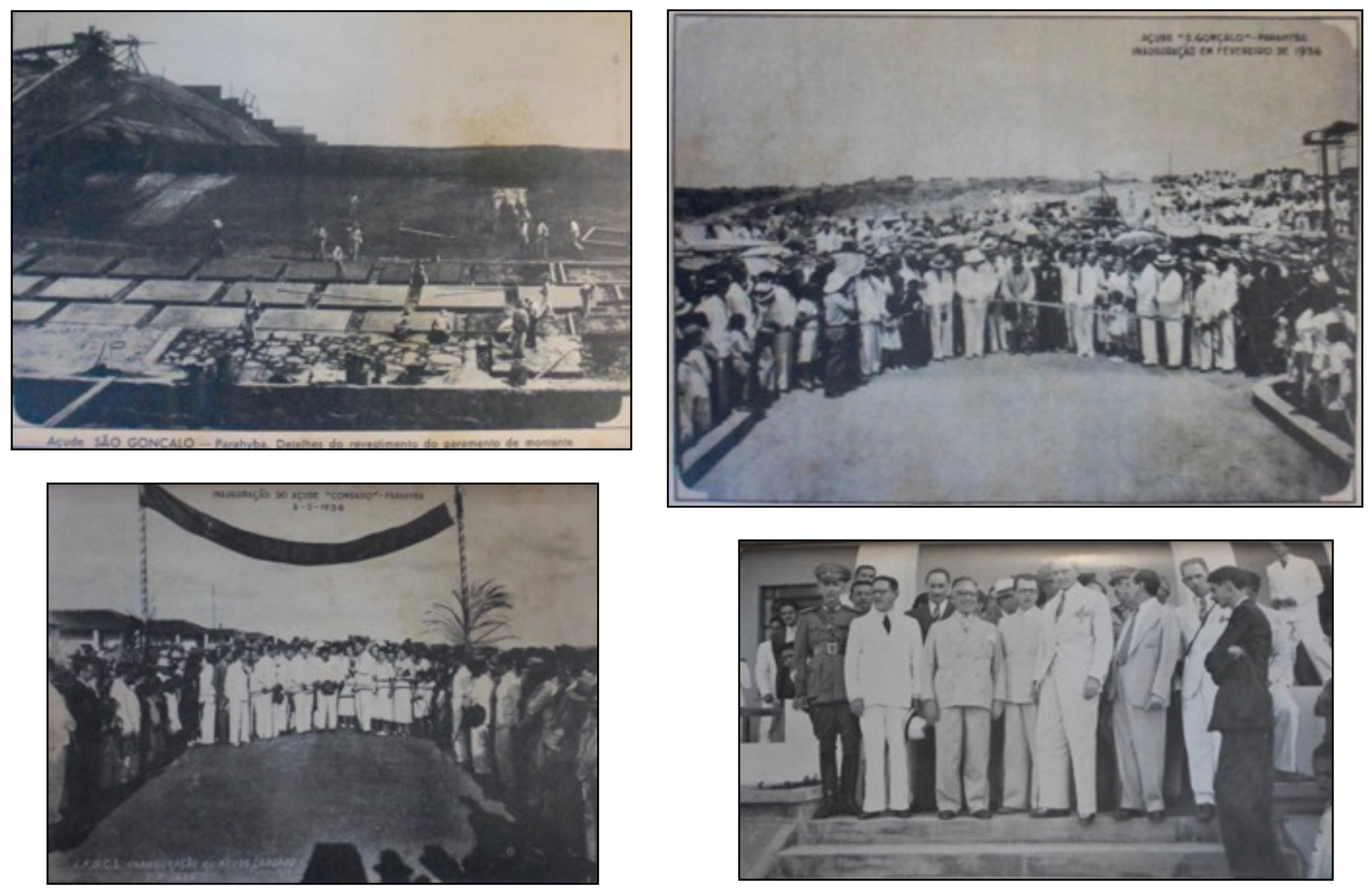
Grande parte dos açudes públicos cujas obras haviam sido paralisadas no Governo de Artur Bernardes foram retomadas durante o Governo Provisório de Getúlio Vargas. Durante muitos anos os feitos do período que teve o paraibano José Américo de Almeida a frente do Ministério da Viação e Obras Públicas foram propagandeados nas publicações do órgão de obras contra as secas.

1. Obras na parede do açude São Gonçalo, Souza, PB. Relatório dos Serviços Realizados pela Ifocs em 1934.

2. Inauguração do açude Condado (Engenheiro Arcoverde), Condado, PB. Relatório dos Serviços Realizados pela Ifocs em 1936.

3. Inauguração do açude São Gonçalo, Souza, PB. Relatório dos Serviços Realizados pela Ifocs em 1936.

4. Visita do presidente Getúlio Vargas ao posto Agrícola de São Gonçalo, Souza, PB. Relatório dos Serviços Realizados pela Ifocs em 1940.

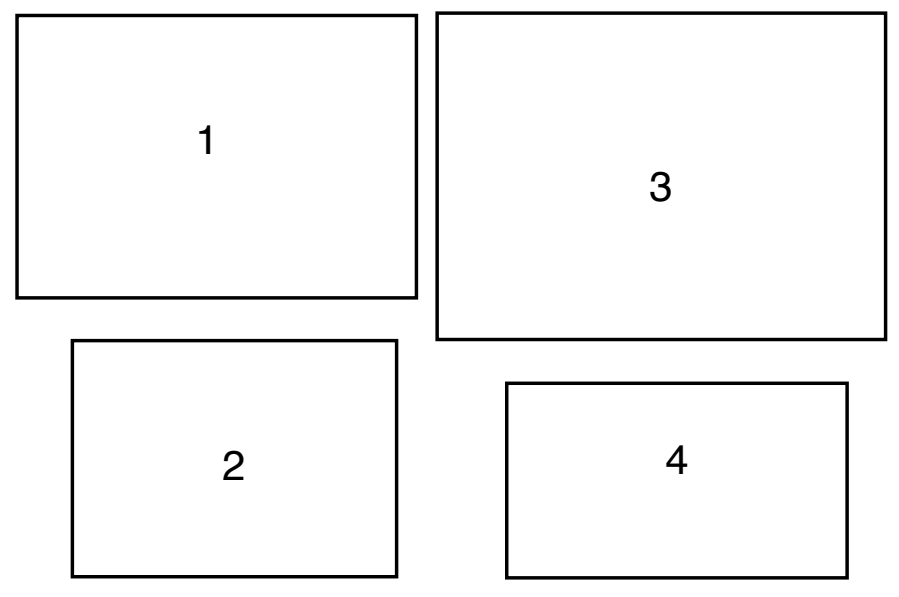



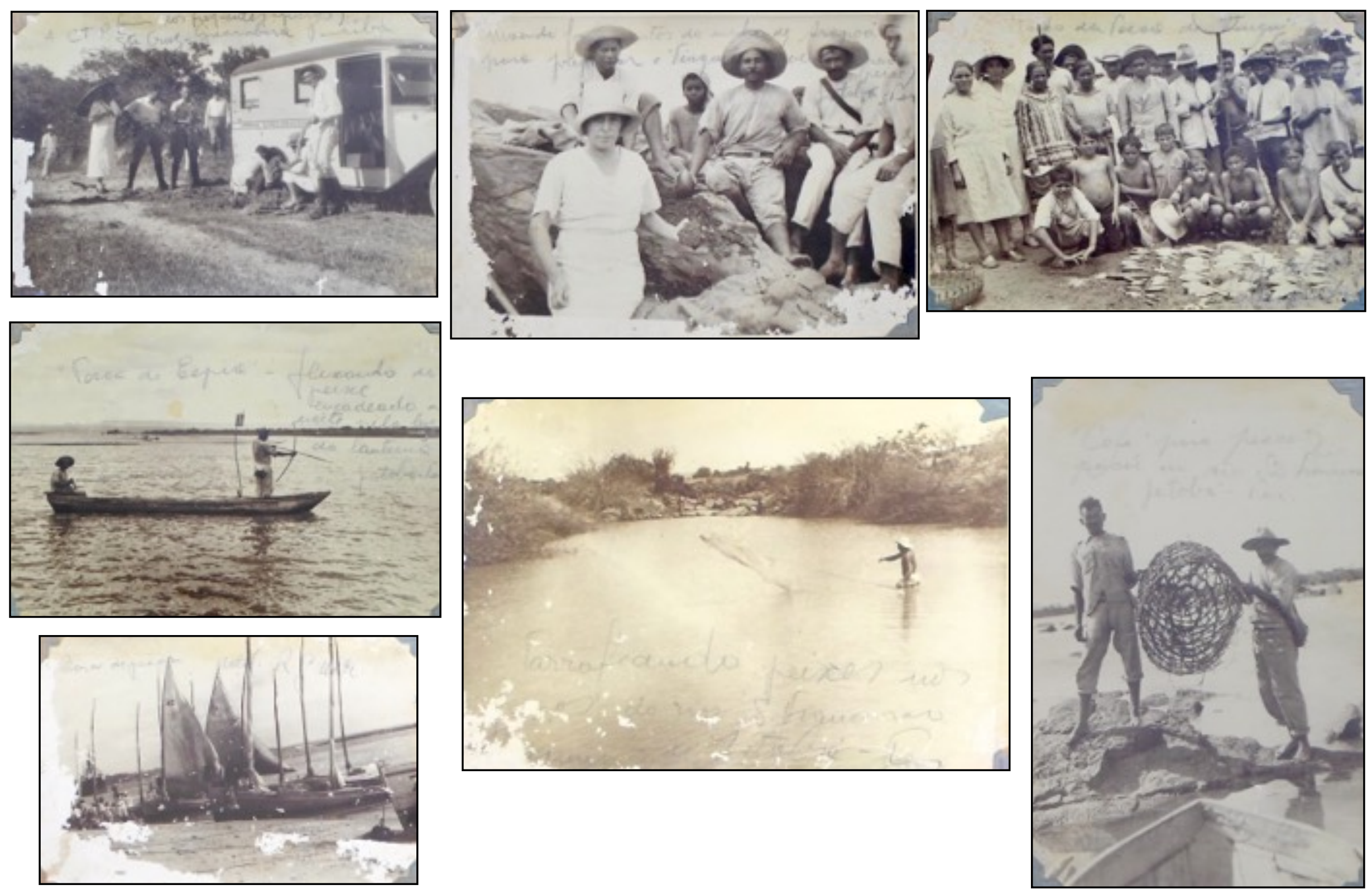
Durante seu primeiro mandato como Ministro da Viação e Obras Públicas, José Américo de Almeida criou a comissão de Piscicultura, diretamente ligada ao Ministério, com sede em Fortaleza e sob o comando de Rodolpho Von Ihering. Essa comissão foi extinta com a Constituição de 1934 mas incorporada à Ifocs com a criação dos Serviços Complementares da Inspetoria. O Serviço de Piscicultura foi criado com a transformação da Inspetoria em Departamento em 1945. No arquivo localizado na "Casa Amarela", prédio anexo à sede do Dnocs em Fortaleza, existem muitos álbuns de fotos retratando a atuação da Comissão de Piscicultura e as pesquisas e expedições realizadas. Infelizmente, o material riquíssimo encontra-se mal acondicionado e com sinais de deterioração pelo mofo. O álbum do qual as fotos da página anterior foram retirados documenta as expedições com a participação da "Senhora Iheing" com fotos de diversas técnicas de pesca utilizadas pelos moradores de áreas com açudes públicos.

1. "A CTP [Comissão Técnica de Piscicultura] (num dos frequentes apuros) em Sta Cruz- Guarabira Paraíba."

2. "'Pesca de Espia' - flexando ao peixe encadeado a noite pela luz da lanterna - Jatobá - Per".

3. "Barco de pesca. Natal - R. G. Norte".

4. "Movendo fragmentos do ninho de Arapoá para peparar o "Tinguí" (? para peixe) Jatobá - Per".

5. "Tarrafando peixes nos poços do rio S. Francisco ? de Jatobá - Per".

6. "? da Pesca de Tingui, Jatobá - Pernambuco"

7. '"Cofo para pescar pacú em rio São Francisco - Jatobá - Per."

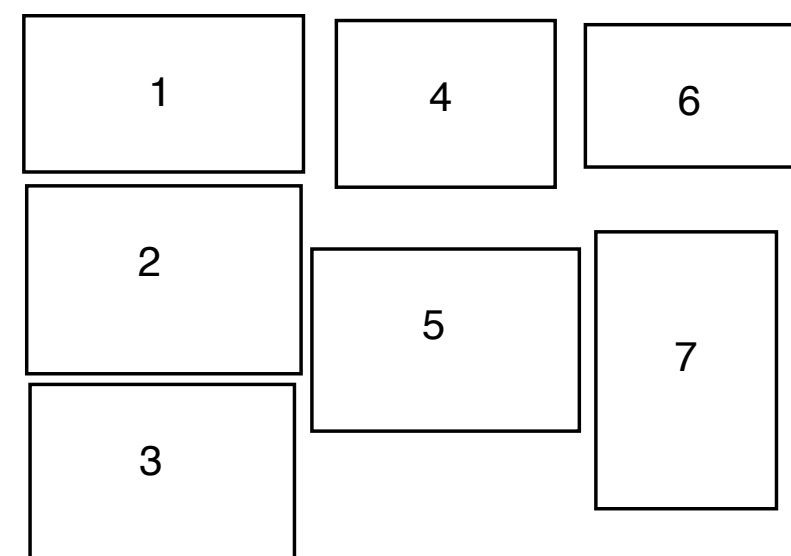



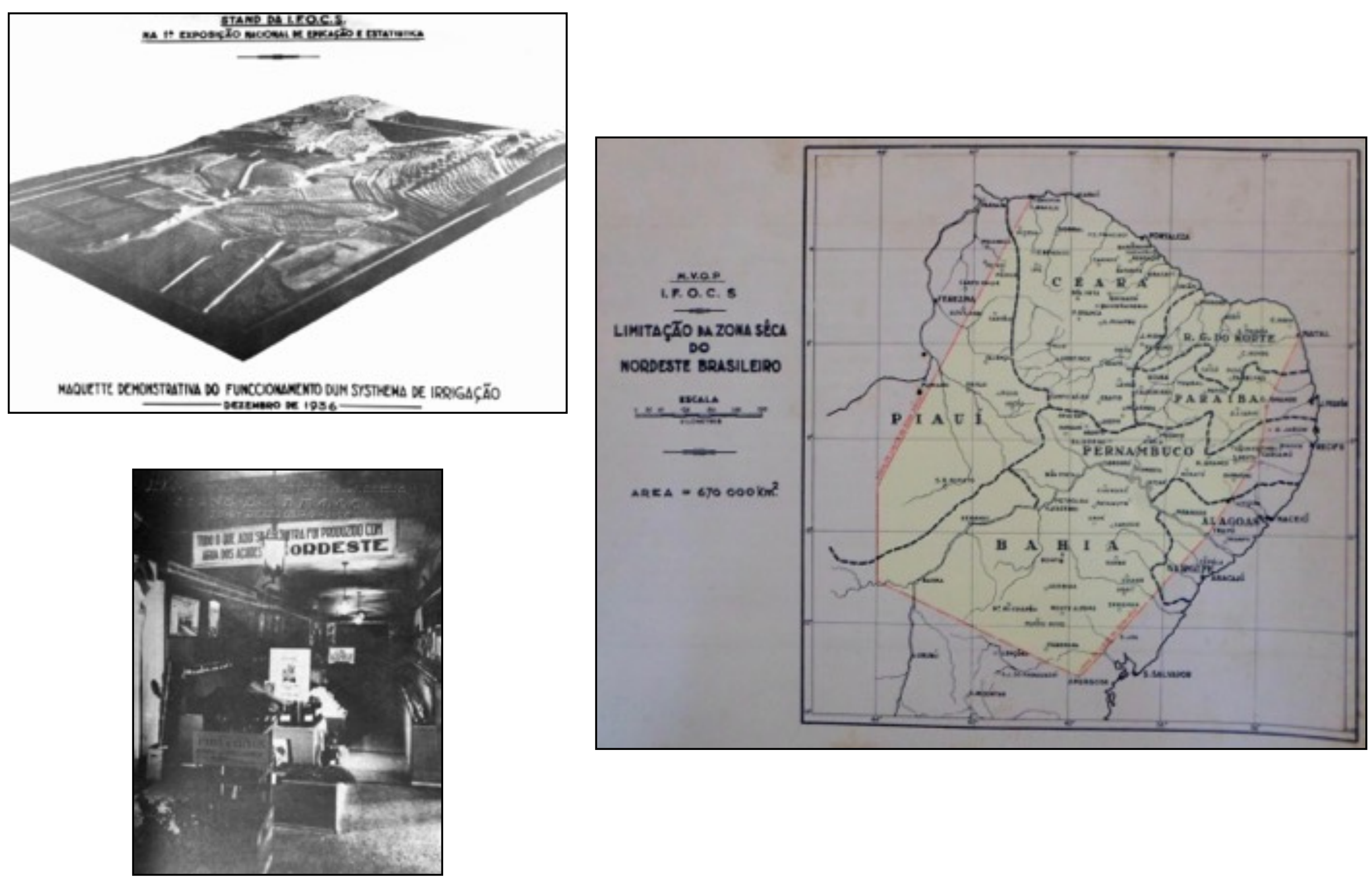
Além do otimismo gerado pela quantidade de obras e recursos destinados aos socorros e obras contra as secas, a propaganda dos feitos da Inspetoria serviu para alimentar a onda nacionalista que marcou os governos de Getúlio Vargas e da qual também era um reflexo. Dentre as ações implementadas no período, destaca-se ainda a delimitação de uma área como sujeita às secas, e portanto prioritária em termos de investimento, e a fixação de uma porcentagem a ser investida nas políticas contra as secas em artigo constitucional.

1. Stand da Ifocs na $1^{\text {a }}$ Exposição Nacional de Educação e Estatística - "Maquette Demonstrativa do Funccionamento de um Systema de Irrigação". Boletim da Ifocs, vol. 6, nº 2, 1936.

2. Stand da Ifocs na $1^{a}$ Exposição Nacional de Educação e Estatística - "Tudo o que aqui se encontra foi produzido com água dos açudes do Nordeste". Boletim da Ifocs, vol. 6, $n^{\circ} 2,1936$.

3. "Limitação da Zona Seca do Nordeste Brasileiro". Tipos de Barragem, Ifocs, 1935.

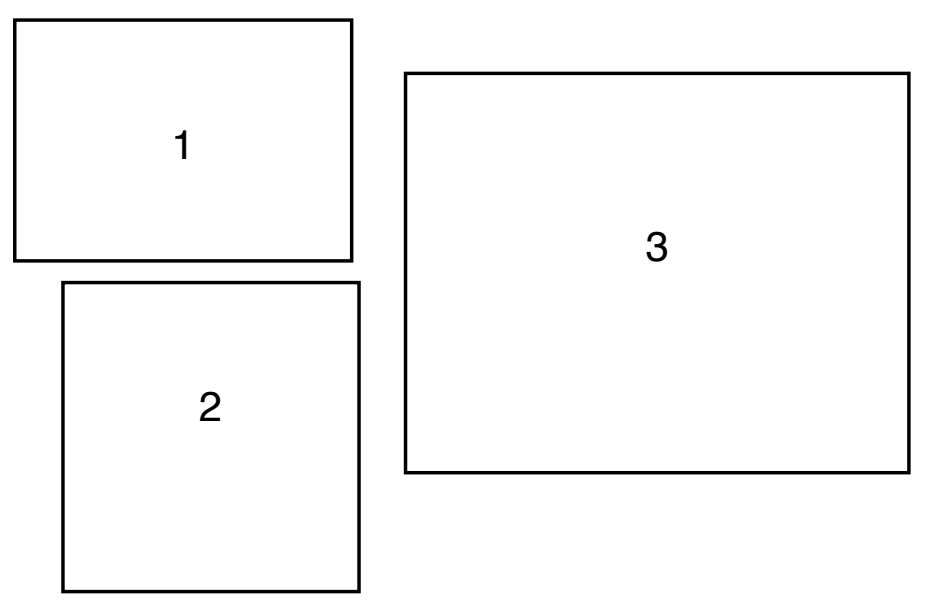



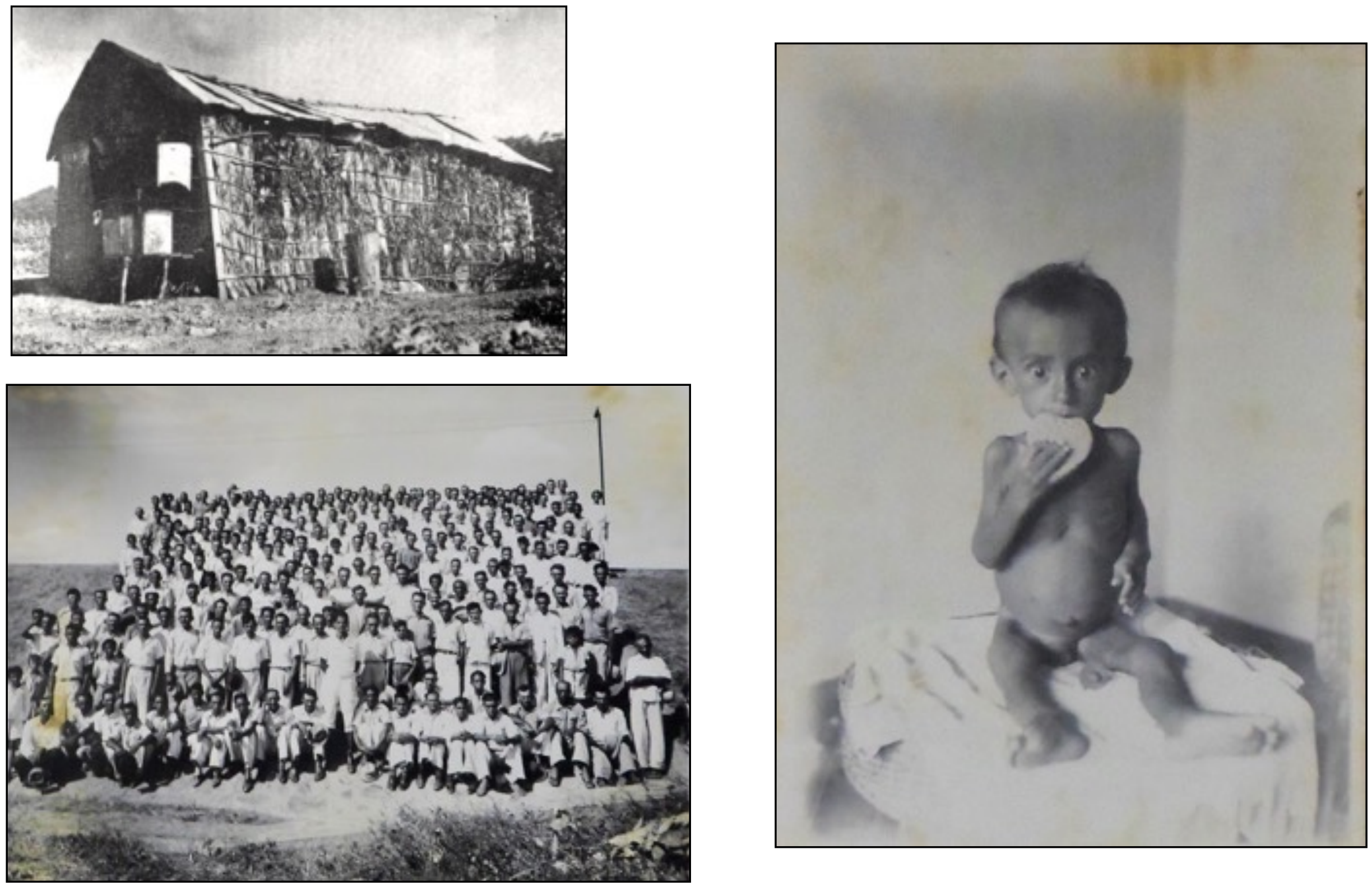
A Ifocs mantinha ligada a sua diretoria a Comissão de Serviços Complementares. Na Paraíba, essa Comissão atuou sobretudo através do Instituto José Augusto Trindade, localizado em São Gonçalo, em Souza, PB. Esse Instituto mantinha um campo experimental agrícola usando a água captada do açude e manteve também uma escola agrícola. Apesar do sucesso e novidade do Instituto, o mesmo foi abandonado pelo Dnocs e encontra-se atualmente desativado.

1. "Tipo de casa feita por operário do posto agricola de S. Gonçalo mostrando a diversidade do material de construção e pouca durabilidade de acôrdo com o espírito nômade do flagelado". Boletim da Ifocs, vol. 11, nº 2, 1939.

2. "Conjunto de pessôas (operarios, flagelados e pequenos proprietarios) que tiveram culturas irrigadas nas terras do Instituto [José Trindade, São Gonçalo, Souza, PB], no 1ºmestre de 1942". Relatório de Serviços Complementares, 1942.

3. Foto que ilustra o pedido de restabelecimento do fornecimento de leite para as crianças atendidas pelo serviço de puericultura do Instituto José Augusto Trindade. Esse tipo de fotografia, embora muito comum nas reportagens que denunciavam os horrores das secas não fazia parte dos relatórios e boletins da Inspetoria. O relatório da Comissão de Serviços Complementares que incluiu essa foto não foi publicado. Relatório de Serviços Complementares, 1942.
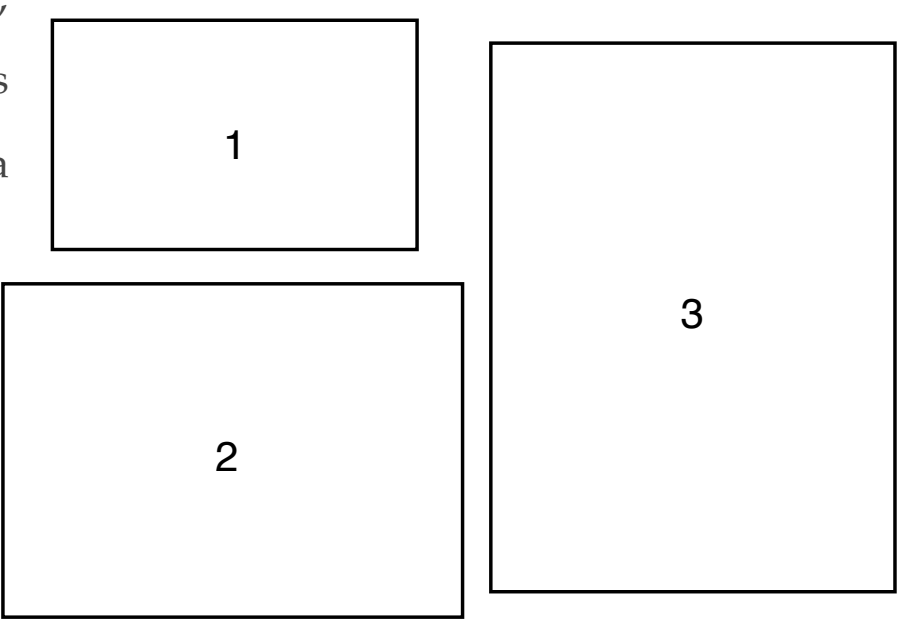


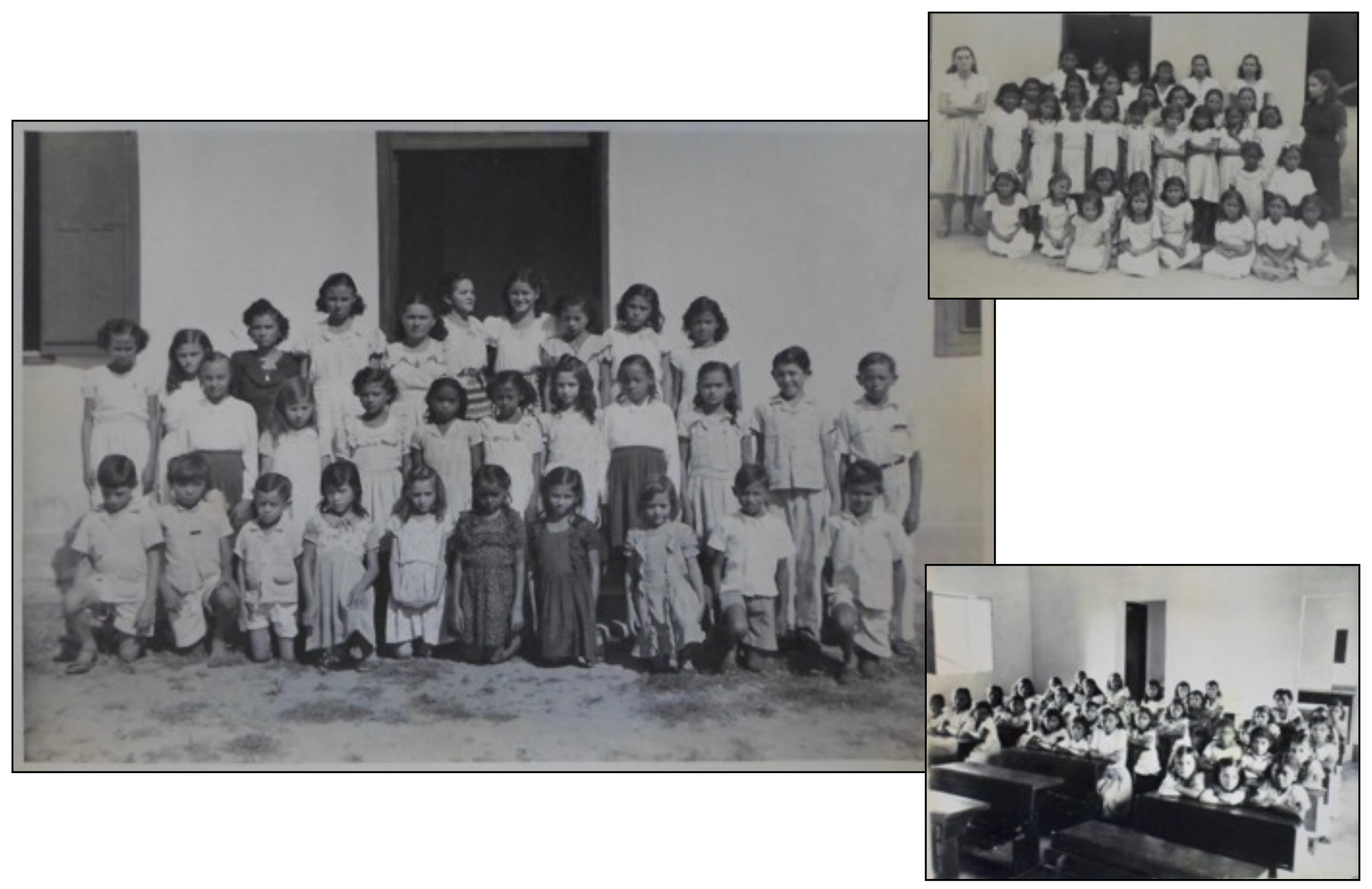


Além do Posto Agrícola Experimental José Augusto Trindade, outros postos agrícolas foram implementados durante a década de 1940. Além de pesquisas sobre espécies a serem cultivadas nos perímetros irrigados, os postos mantinham também grupos escolares. Os grupos escolares foram instalados ainda nos acampamentos da Ifocs/Dnocs, como foi o caso de Coremas.

1. "Posto Agrícola 'Lima Campos' - Alunos e professores do Grupo Escolar Rural". Icó, CE. Relatório dos Serviços Realizados pelo Dnocs em 1947.

2. "Escola Rudimentar de Condado, Grupo de alunas e professora". Relatório dos Serviços Realizados pelo Dnocs em 1948.

3. Escola Rudimentar de Condado; meninas na classe". Relatório dos Serviços Realizados pelo Dnocs em 1948.

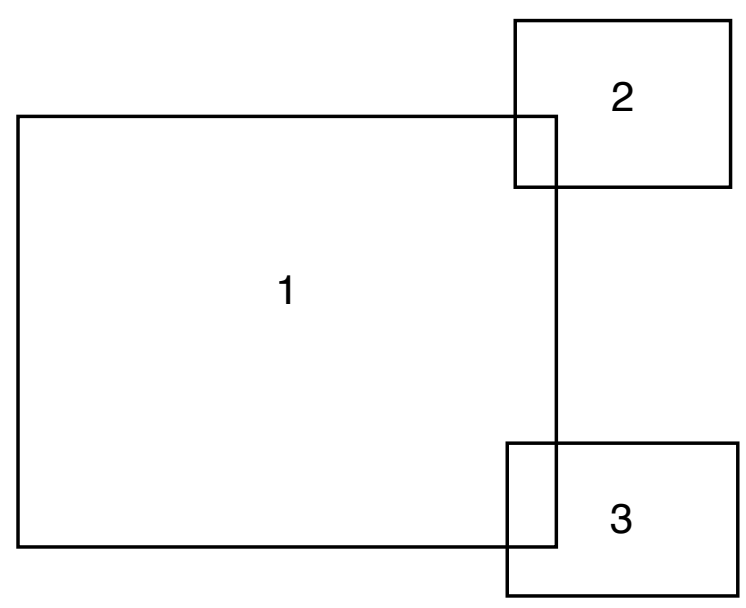



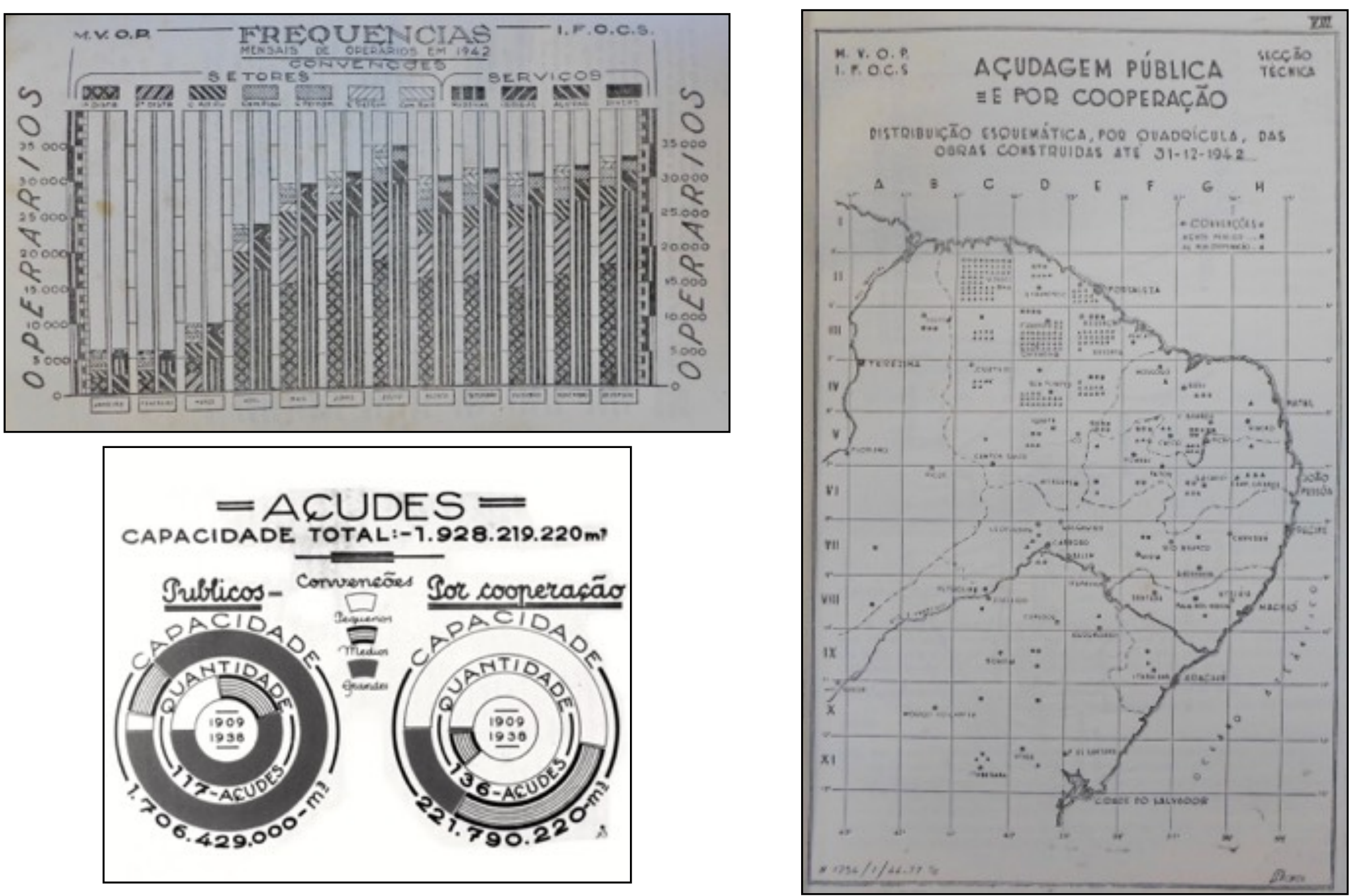
Tanto os relatório de serviços executados, como os Boletins do órgão de obras contra as secas contém muitas tabelas e gráficos dos mais variados formatos mostrando a quantidade de recursos investidos, flagelados atendidos (utilizados como mão de obra nas construções de açudes e estradas) e obras realizadas.

1. Gráfico de frequência mensais de operários durante o ano de 1942 segundo os setores alocados $\left(1^{\circ}\right.$ e $2^{\circ}$ Distrito, Comissão do Alto Piranhas, Comissão Piauí, Comissão Pernambuco, Comissão Sergipe, Comissão Bahia) e serviços realizados (rodovias, irrigação, açudagem, diversos). Relatório dos Serviços Realizados pela Ifocs em 1942.

2. Gráfico da capacidade crescente dos açudes públicos e por cooperação (feitos em terras particulares ou em cooperação com estados e municípios) entre 1909 e 1938. Boletim da Ifocs, vol. 12, nº 1, 1939.

3. Mapa açudagem publica e por cooperação. Relatório dos Serviços Realizados pela Ifocs em 1942.

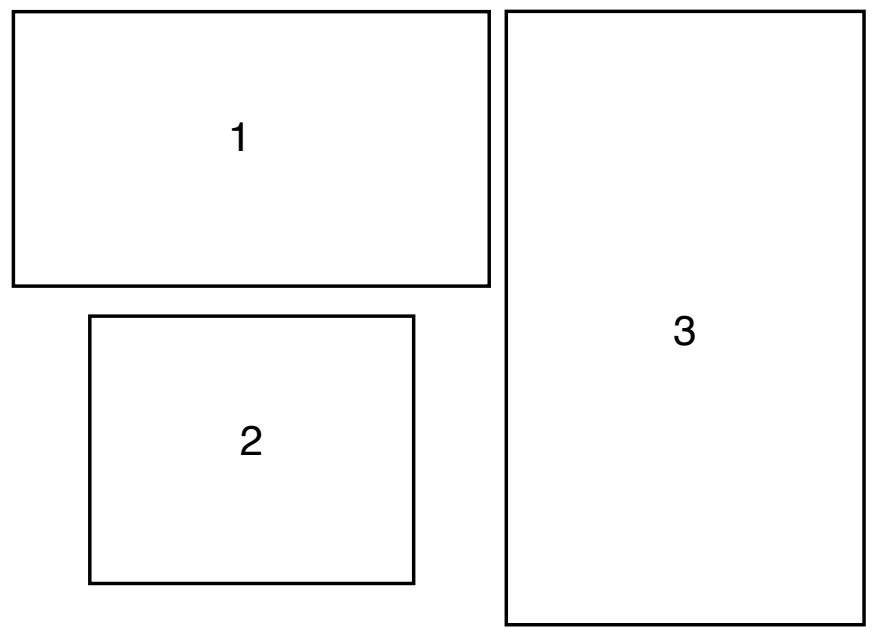



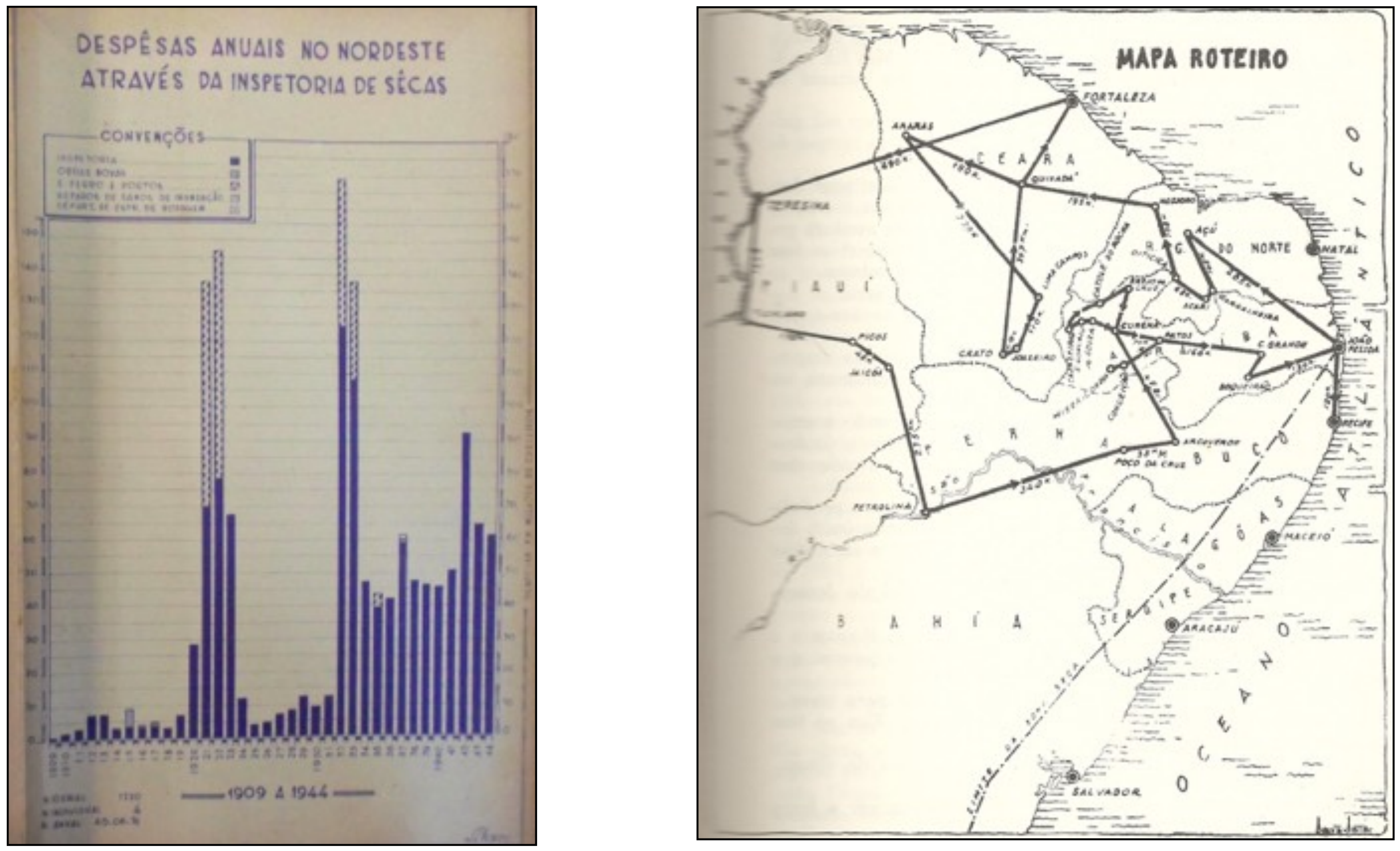
Os gráficos de despesas realizadas para obras contra as secas e demais políticas de socorros até a década de 1950 demonstram claramente dois picos de investimentos. O primeiro grande salto de investimentos ocorreu durante o governo de Epitácio Pessoa e outro durante os primeiros anos do Governo Provisório de Getúlio Vargas. Após esse segundo momento, os investimentos decaem mas mantém uma média bem mais expressiva que os anos diretamente posteriores ao governo de Epitácio. A ocorrência de secas mais graves, como é o caso da de 1942 também pressionaram o aumento dos investimentos. O mesmo ocorreu no início dos anos 1950, quando José Américo de Almeida foi novamente convidado a ocupar a direção do Ministério da Viação e Obras Públicas. Assim como na crise de 1932, José Américo realizou uma expedição para visitar os locais mais afetados e as obras do Dnocs em execução. Ao contrário da defesa incondicional da grande açudagem, entretanto, o ministro irá defender a necessidade de obras menores e facilmente disseminadas como é o caso dos açudes em terras particulares.

1. "Despêsas anuais no Nordeste através da Ispetoria das Sêcas". Relatório dos Trabalhos Realizados pela Inspetoria em 1944.

2. Mapa do roteiro percorrido por José Américo de Almeida durante a seca de 1952. As sêcas do Nordeste. Rio de Janeiro: Ministério da Viação e Obras Públicas, 1953.

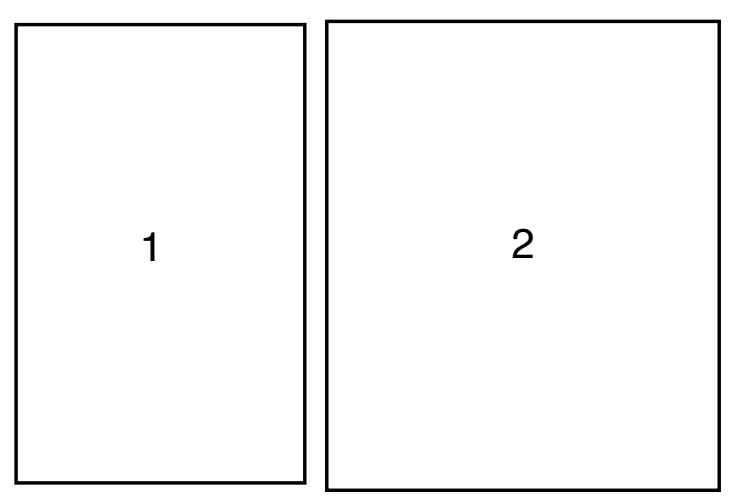



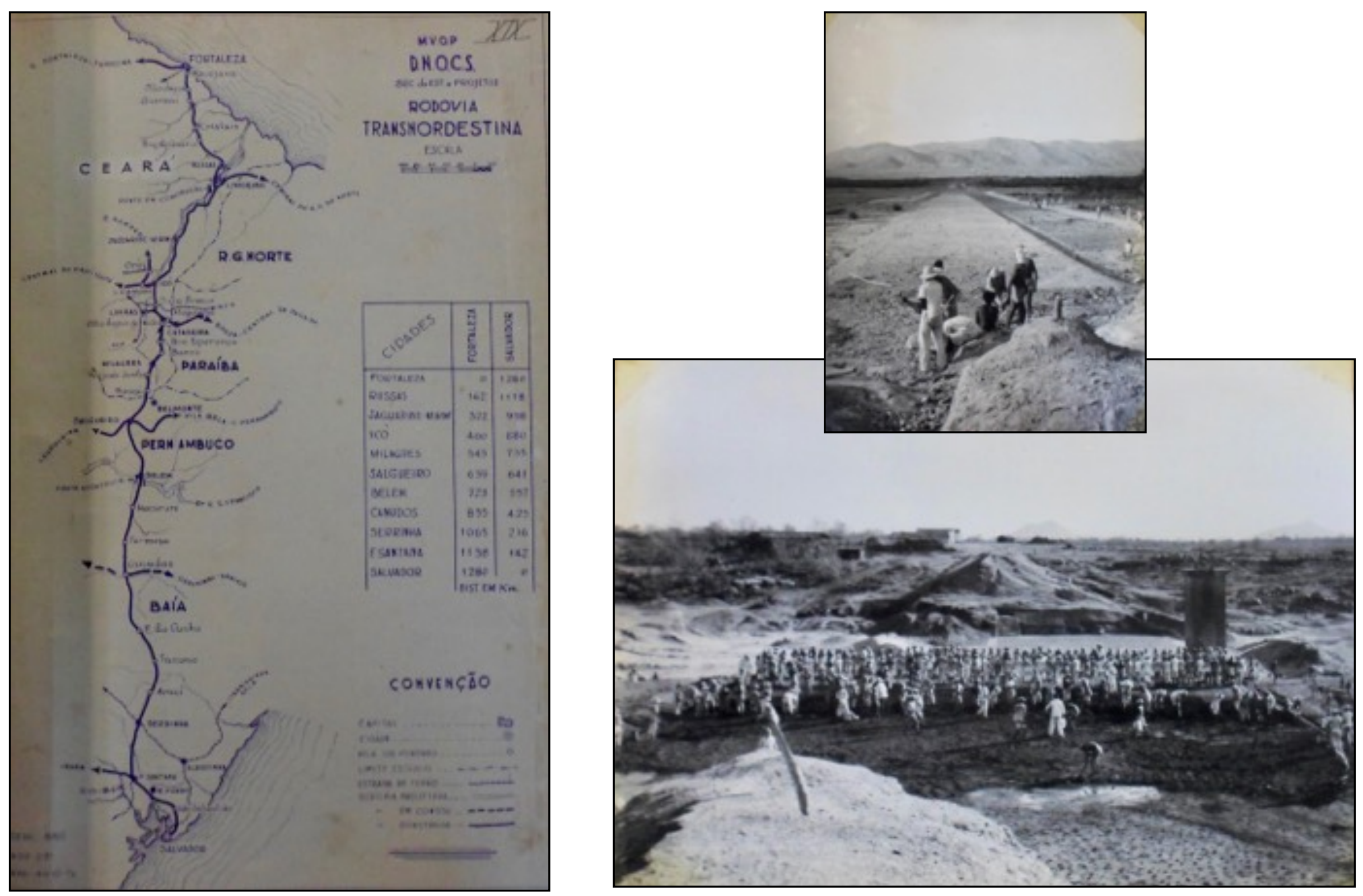
Mesmo relativizando a eficácia de grandes obras de açudagem, o Ministro deu continuidade a elas durante seu segundo mandato. As críticas apresentadas à grande açudagem pelo Grupo de Trabalho de Desenvolvimento do Nordeste (GTDN) também não fizeram com que as obras cessassem e o final da década de 1950 teria ainda um novo pico de construções durante o governo de Juscelino Kubistchek. A construção de estradas de integração regional também não saíram da pauta e continuaram a ser construídas e reparadas em esquemas de frentes de emergência a cada seca. A rodovia transnordestina, ligando os estados da região, foi uma espécie de novidade pela extensão de seu traçado (Pomponet, 2010). Posteriormente, essa rodovia foi integrada à BR-116.

1. Traçado da Rodovia Transnordestina. Relatório dos Trabalhos Realizados pelo Dnocs em 1945.

2. Vista geral da estrada de acesso ao açude Araras (Açude Paulo Sarasate), localizado entre os municípios de Varjota, Pires Ferreira, Hidrolândia e Santa Quitéria, CE. Relatório dos Trabalhos Realizados pelo Dnocs em 1951.

3. "Reconstrução do açude Patos, vista geral tomada pela margem esquerda". Sobral, CE. Relatório dos Trabalhos Realizados pelo Dnocs em 1953.

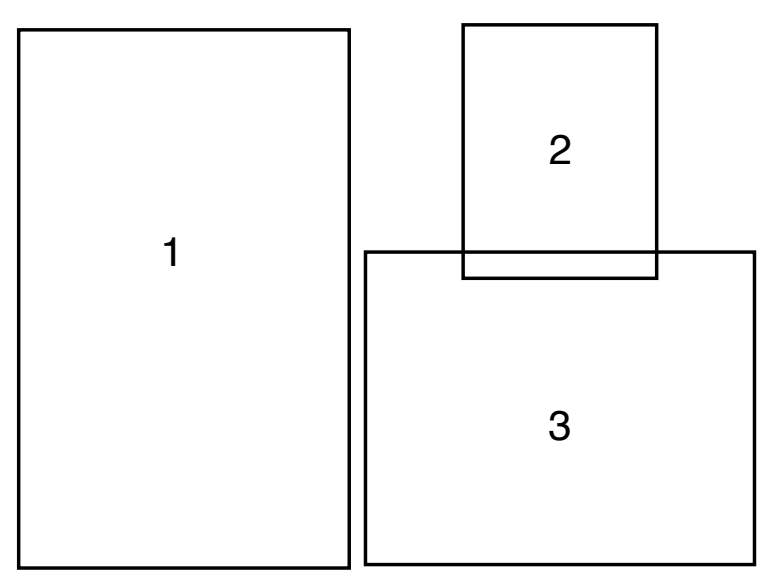



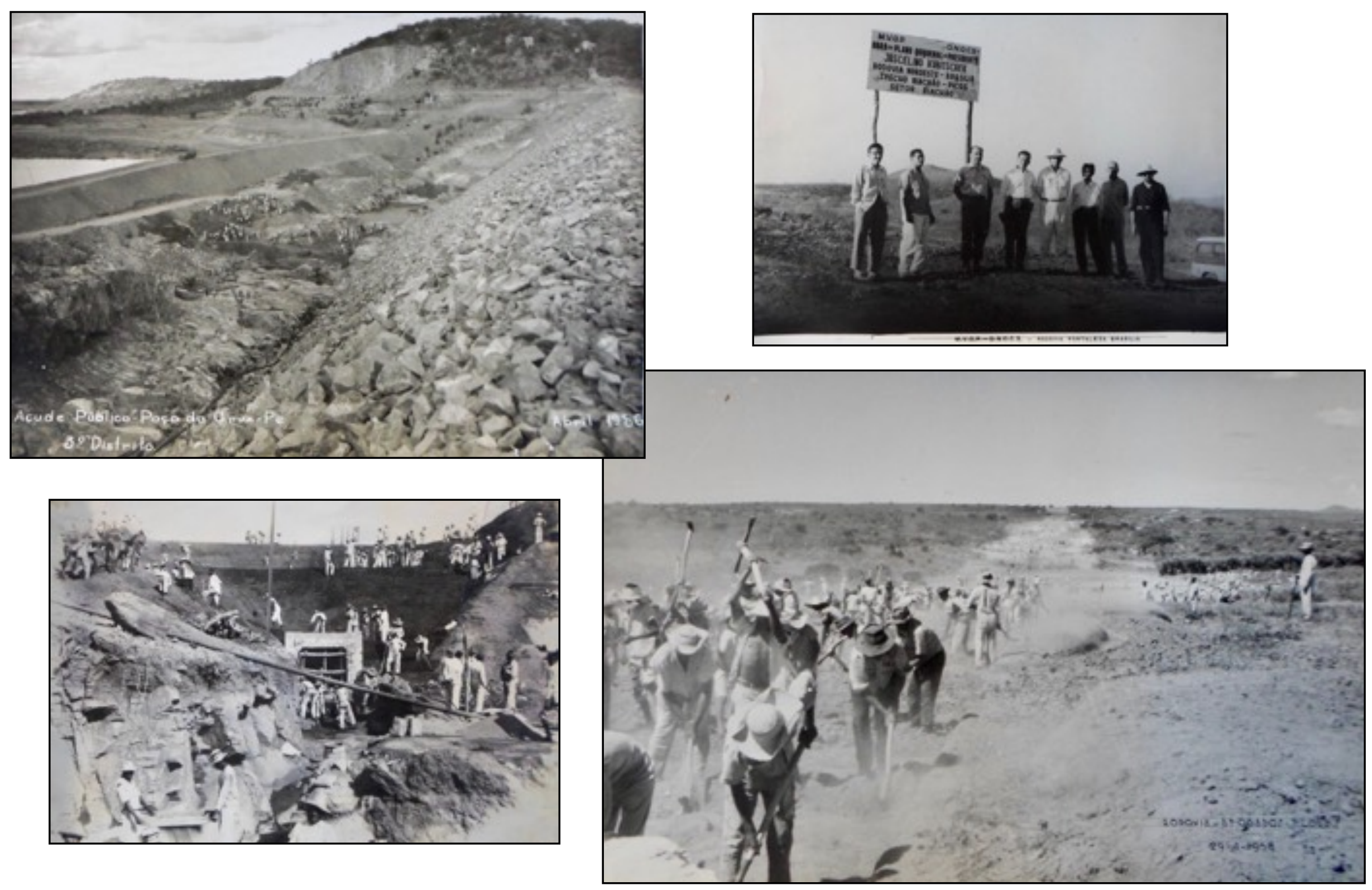
O Governo de Juscelino Kubistchek representou um novo impulso de desenvolvimento para os estados Nordestinos. Nesse período, foram desenvolvidos vários estudos na região e muitas grandes obras iniciadas e concluídas. As imagens da página anterior compõe um álbum com fotos de diversas obras empreendidas entre 1956 e 1958. Assim como no caso dos álbuns da Comissão de Piscicultura, esse álbum está sem catalogação e foi resgatado por uma das bibliotecárias da Biblioteca Central.

1. "Açude Público - Poço da Cruz -Pe - $3^{\circ}$ Distrito - Abril 1956".

2. "Obras em açude".

3. "Obra do Plano Quinquenal do Presidente Juscelino Kubitschek - Rodovia Nordeste-Brasilia - Trecho Riachão-Picos - Setor Riachão"

4. "Rodovia Afogados Flores, 29-4-1958"

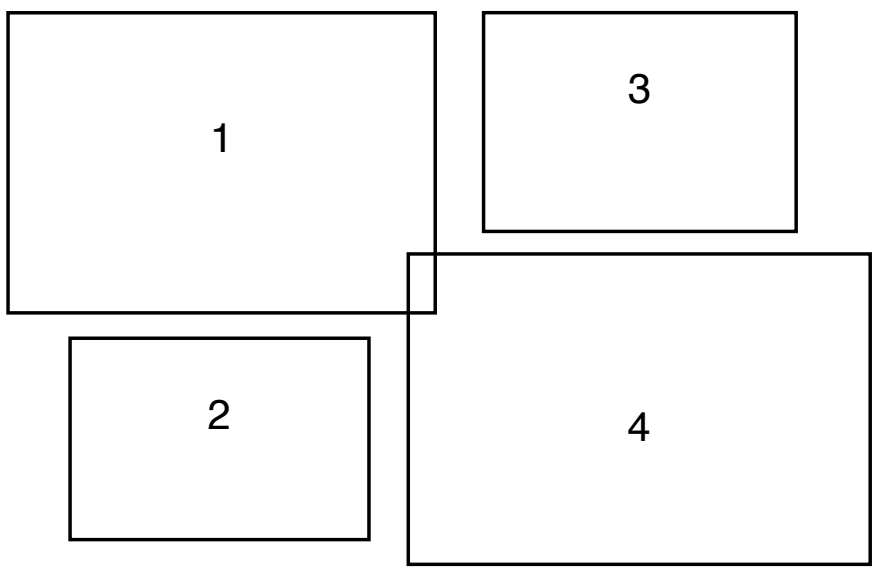




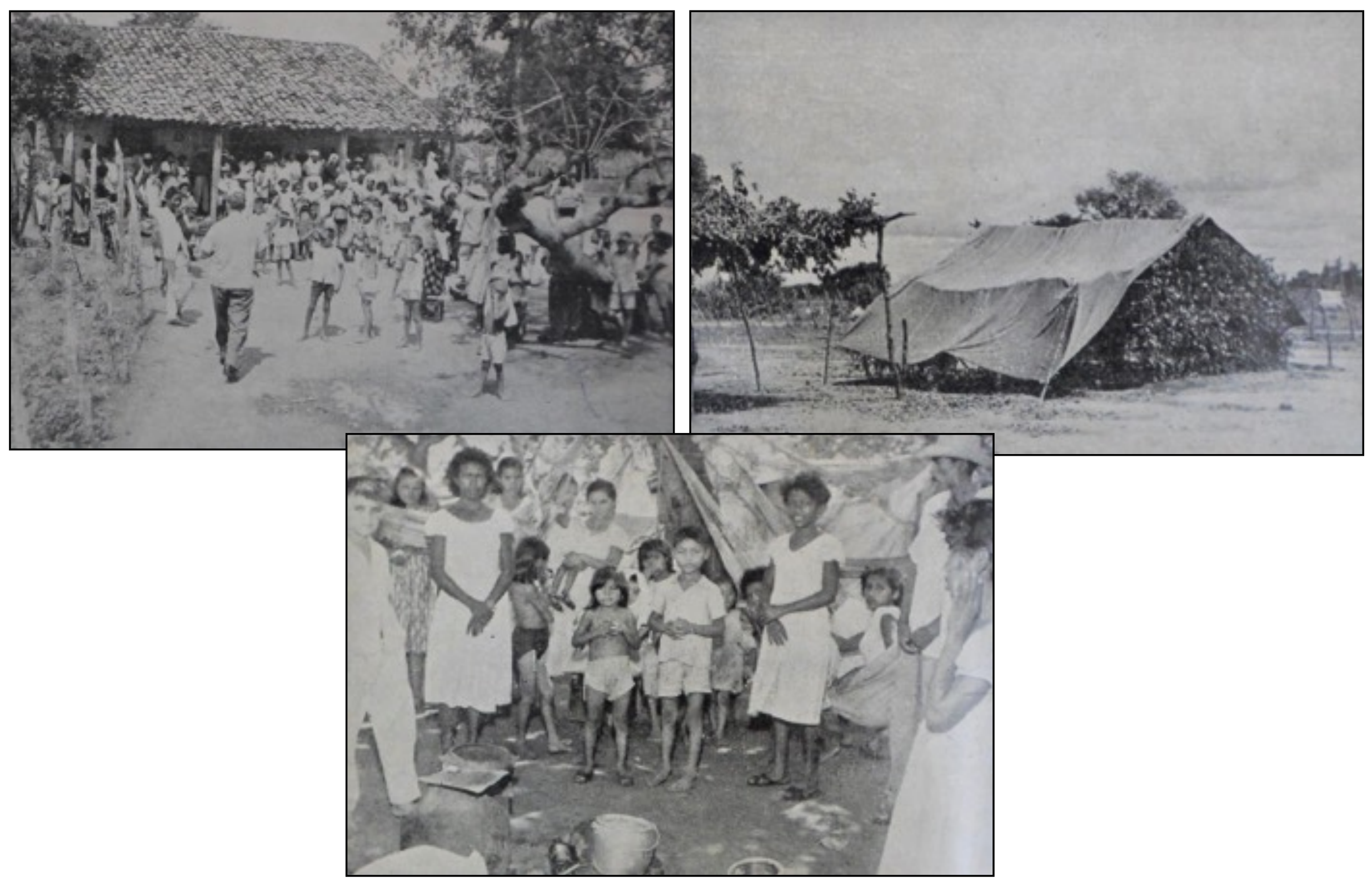


Com o novo impulso aos trabalhos contra as secas durante a presidência de JK e a eclosão de uma grave seca no ano de 1958, aumentou também o número de publicações do órgão. Os 50 anos de existência do órgão contra as secas em 1959 também favoreceu as publicações. Entre estas, estava a separata do Boletim do Dnocs intitulada Notas sobre a seca. As fotos da página anterior, retiradas dessa publicação, mostram os acampamentos formados em torno das obras em curso durante a crise de 1958. Apesar de não terem sido formados campos de concentração, esses acampamentos improvisados não se afastavam muito da realidade que havia sido descrita para os antigos campos no Relatório da Comissão Médica de 1932.

1. "Familias atingidas pela sêca em 1958, abrigadas no interior cearense".

2. "Barraca de flagelados em plena sêca"

3. "Latas: utensilios improvisados para preparação de ração alimentar na sêca".

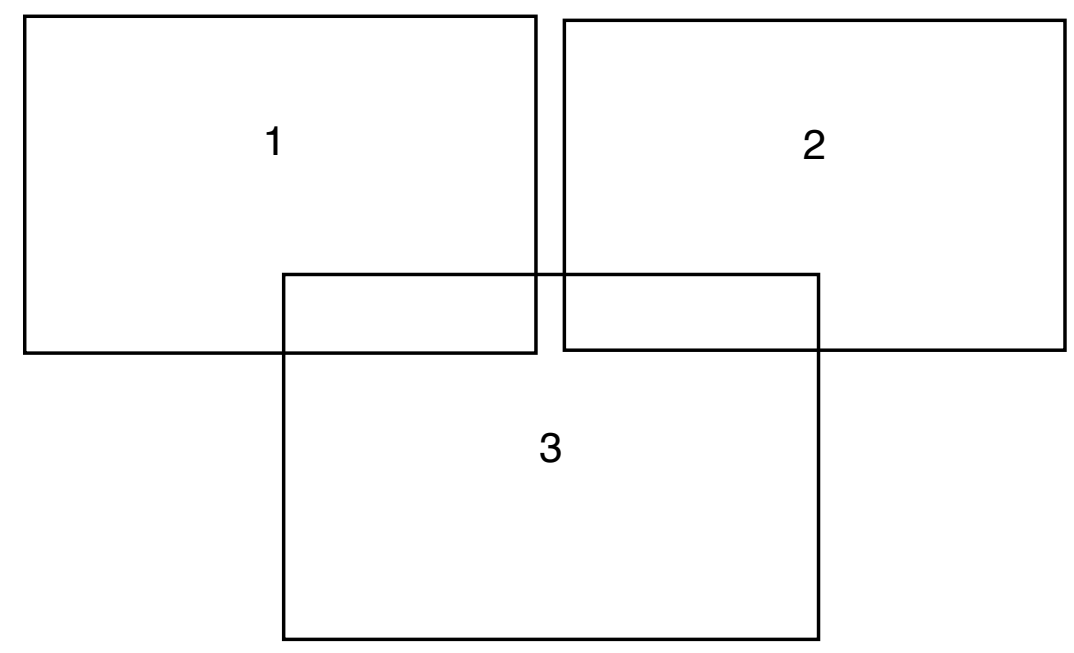




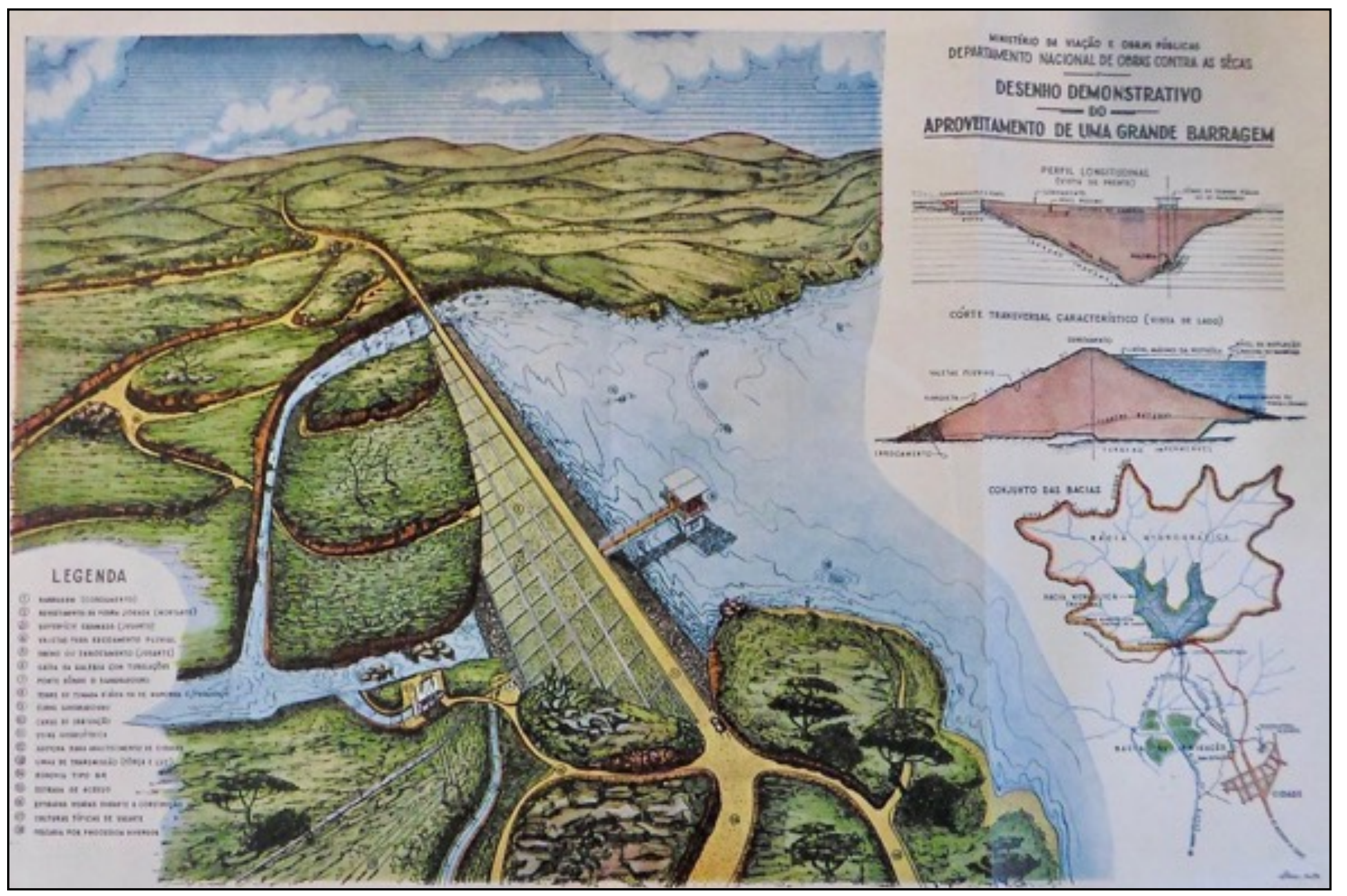


Desde as políticas conhecidas como "solução hidráulica", que focaram os recursos na construção de grandes açudes públicos, as estruturas eram pensadas não apenas para acumular água mas também para irrigar as terras no entorno dos açudes, permitindo a prática da agricultura irrigada. A ênfase nos projetos de irrigação, entretanto, só iria ocorrer em finais da década de 1950 e transformou-se na principal política implementada pelo Dnocs nas décadas seguintes. O esquema reproduzido na página anterior, elaborado pelo Dnocs, foi publicado na Revista do Clube de Engenharia em 1960. As benfeitorias conexas à barragem listadas no esquema do Dnocs são: canal de irrigação (10); usina hidrelétrica (11); adutora para abastecimento de cidades (12); linha de transmissão (força e luz) (13); rodovia tipo BR (14); estrada de acesso (15); estradas usadas durante a construção (16); culturas típicas de vazantes (17); Pescaria por processos diversos (18)

1. "Desenho Demonstrativo do Aproveitamento de uma Grande Barragem".

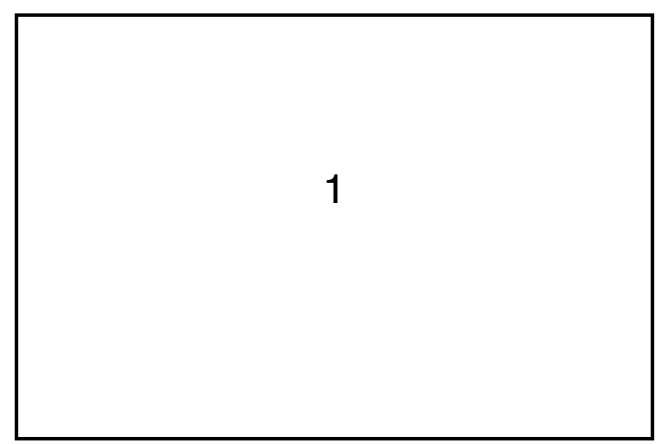



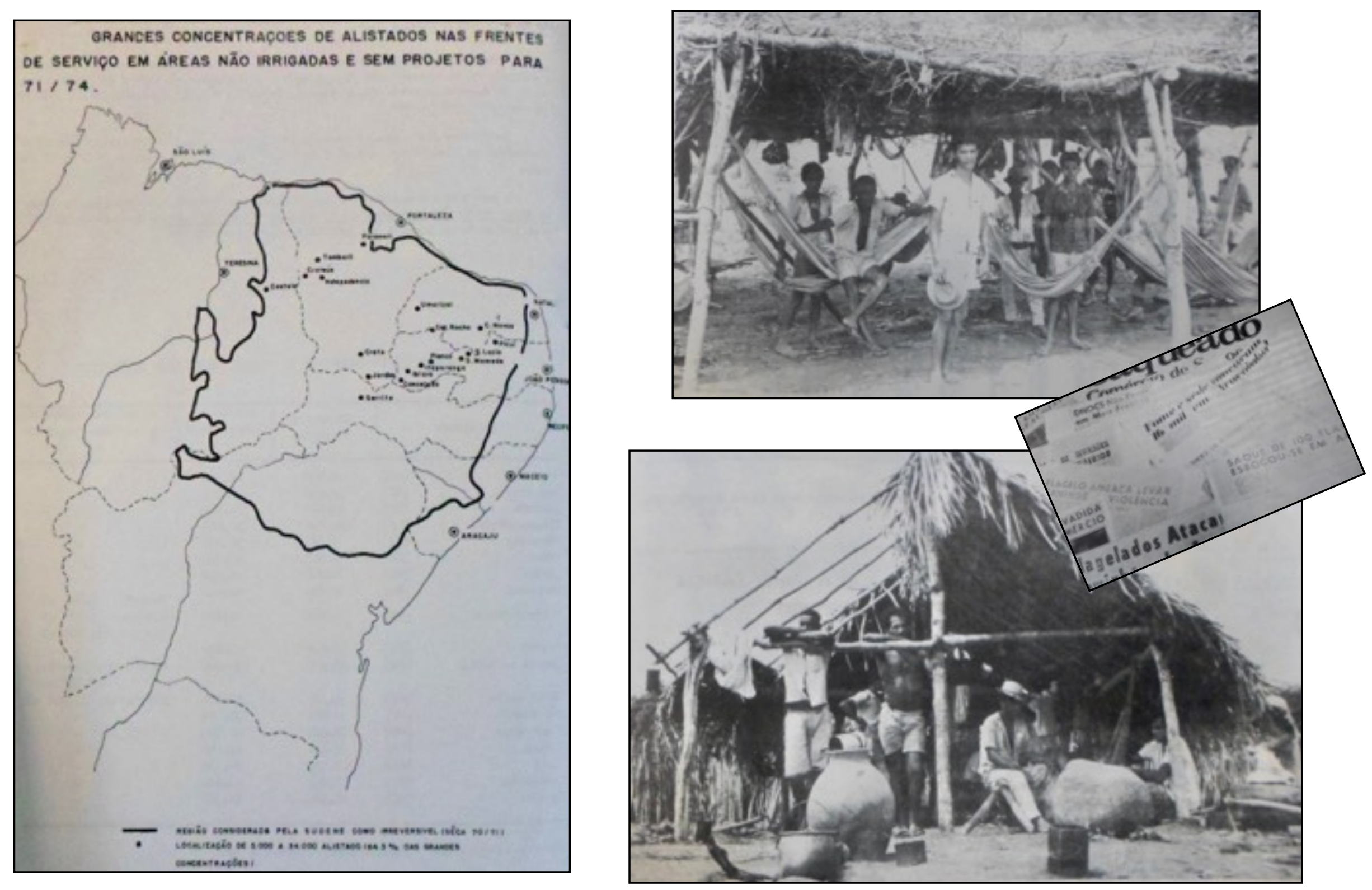
Apesar de a utilização da população atingida pela secas como mão de obra nas obras de açudagem (pública e privada), estradas e outros, ser uma das principais políticas públicas implementadas pelo órgão de combate às secas, poucos foram os estudos sobre essa população. O Relatório da Comissão Médica publicado em 1936 foi um dos primeiros a tratar mais detidamente das condições experimentadas pela população afetada, mesmo assim, concentrou seu olhar nas condições sanitárias dessa população. Apenas em 1970, foi realizada a primeira pesquisa mais abrangente sobre essa população feita pelo Dnocs. A publicação Frentes de Serviço: Estudo sócio econômico da população atingida pela sêca de 1970, buscou apreender a situação das áreas secas através da análise da condição sócio econômica dos alistados tendo como unidade social atingida a família. Os dados revelaram uma realidade que pouco havia se modificado ao longo de quase 70 anos de políticas oficiais de combate às secas. Abrigos improvisados, alimentação escassa e pouco variada, falta de água, falta de emprego para as famílias e trabalho infantil foram alguns dos problemas que persistiram ao longo do tempo.

1. Mapa com áreas de maior concentração de flagelados e sem projetos de irrigação.

2. "Barraca" na Frente de Itaporanga, PB.

3. Colagem das manchetes de jornal dando notícia de saques.

4. "Barraca" em Picos.

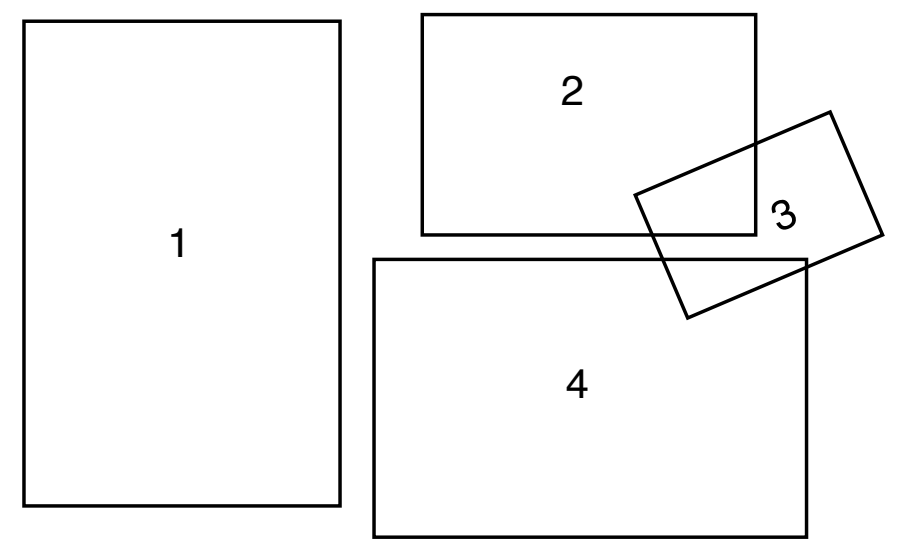



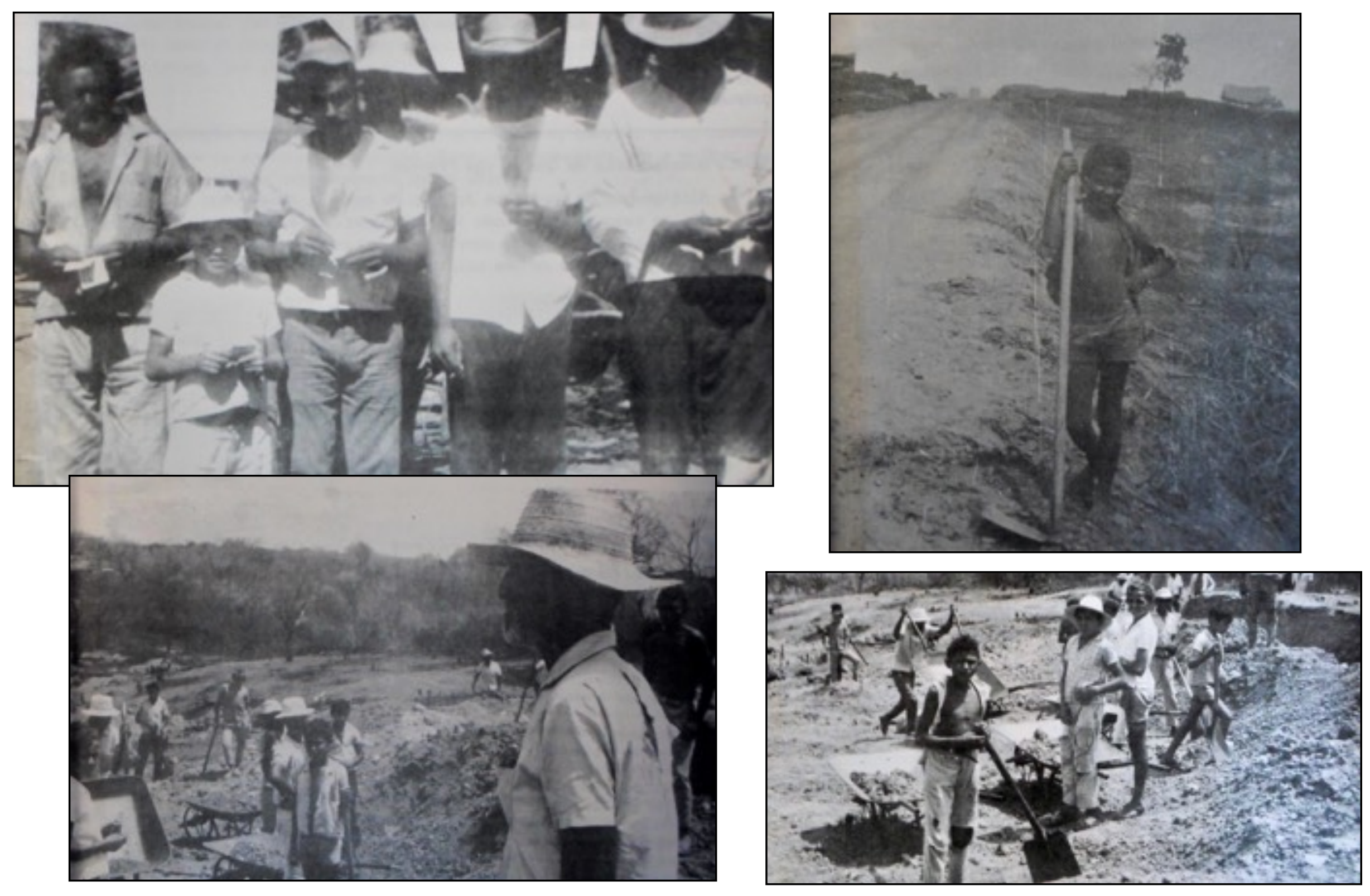
A utilização de crianças nas Frentes de Serviço foi uma constante ao longo dos anos. Em alguns períodos, como foi o caso na seca de 1932, os Juizados especiais tentaram impedir que as crianças fossem aceitas. Refletindo sobre o trabalho infantil com os dados coletados durante a pesquisa das Frentes de Serviço, os pesquisadores constataram que, muitas vezes, a criança ou o jovem era a única fonte de renda para as famílias ou compunham grande parte destas. Esse fato, segundo os pesquisadores, acabavam com a hierarquia dentro das famílias, colocando lado a lado várias gerações, como expresso na legenda da primeira foto, reproduzida abaixo.

1. '"... dia de pagamento na frente, último estágio da hierarquia social...' (Frente de Tamboril, CE)"

2. "Turma exclusivamente de menores - Custódia, PE"

3. Menino da turma de trabalho de crianças posa com a enxada, Custódia, PE

4. Turma exclusiva de menores, foto tem como legenda: "'... o inverno chega ao nordeste mas não muda a situação social...' (jornal do Brasil - Recife - Sucursal - 10/05/71)".

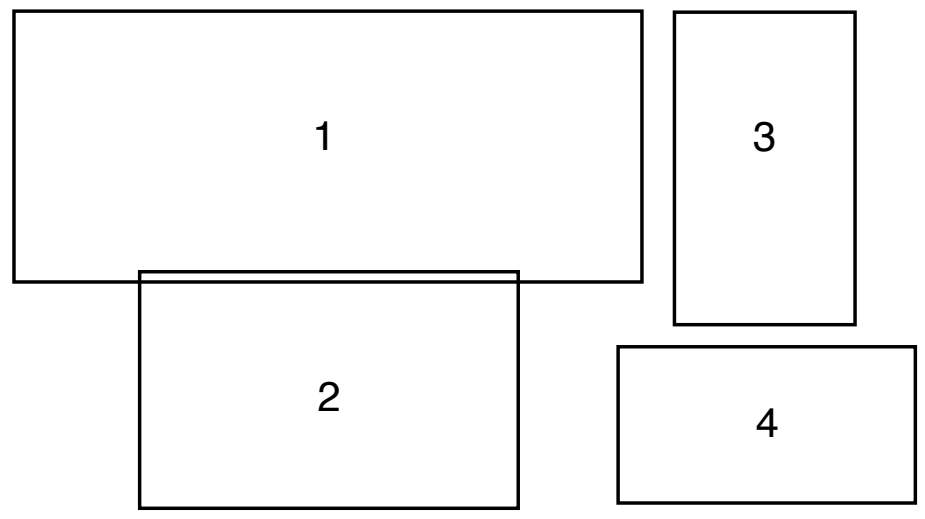



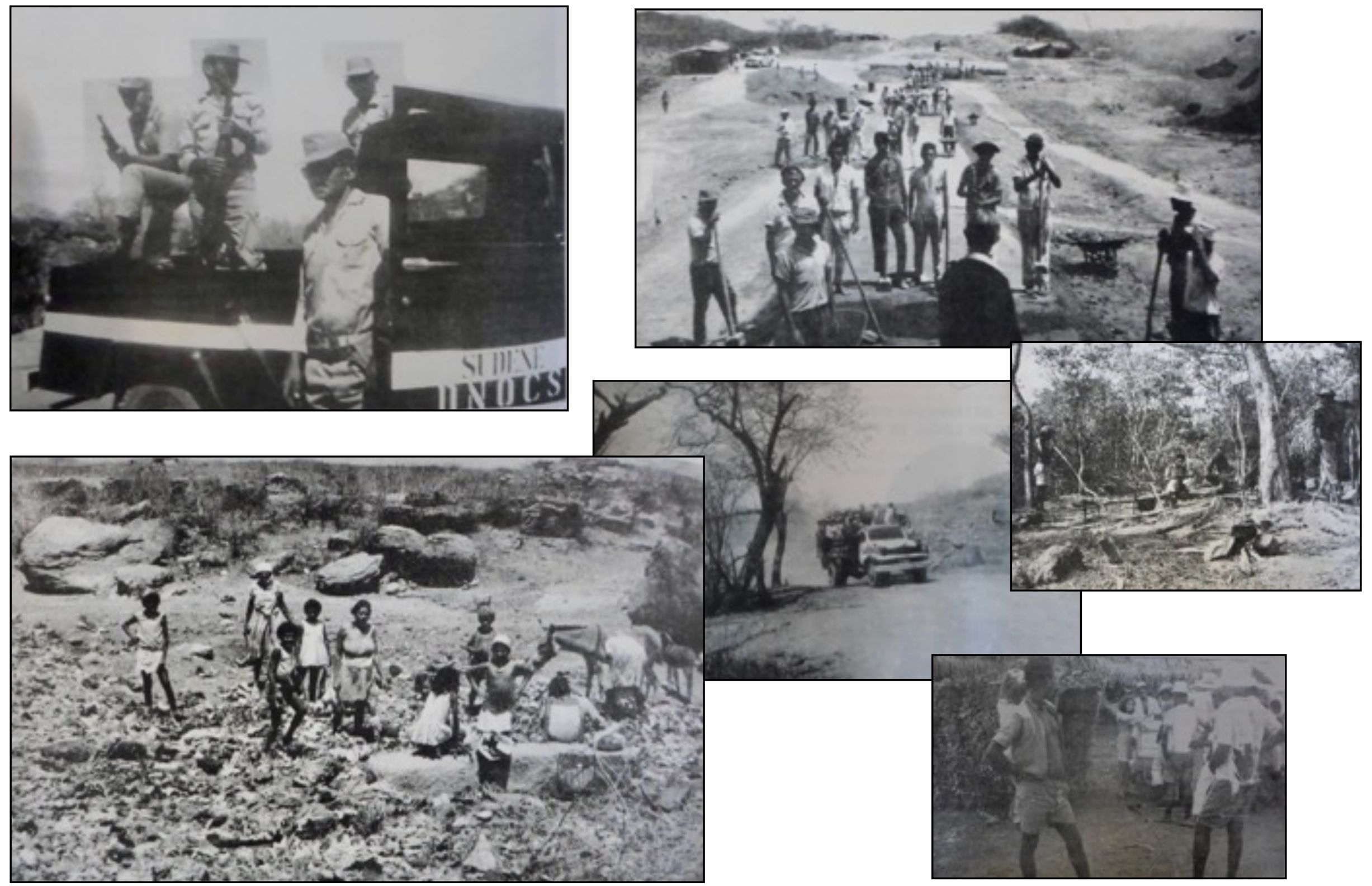
1. "Batalhão de engenharia e construção em atividade na frente de tamboril no dia do pagamento". É curioso que, mesmo os chefes de grandes partes das frentes de serviço relatarem a passividade dos trabalhadores, o pagamento se fizesse com homens armados.

2. "Cajàzeiras, PB - família revisando o lixo da cidade". O Açude Grande de Cajazeiras (Açude Epitácio Pessoa) foi terminado em 1916, mesmo assim, a obra não foi capaz de evitar a miséria de sua população.

3. Frente de Serviço em Picos, Piauí, à guisa de legenda, a seguinte citação: "'a frente de serviço é um campo de concentração cujos muros são a própria terra devastada pela sêca...' (Revista Visão - Reportagem)"

4. "Entrevista com os alistados na Frente (Picos - Oeiras - PI)"

5. Caminhão transportando trabalhadores. À guisa de legenda, a seguinte citação: "'a maioria dos flagelados, são empregados distantes de suas residências, trazendo dificuldade de transporte para os mesmos visitar e levar gêneros para sua família' (administração da frente de castelo,PI)". Na página anterior, outra foto do transporte de trabalhadores em caminhão é apresentada com a seguinte citação servindo de legenda: "... dia de recesso... preço cr\$ 1,00 por cabeça... condições do caminhão: precária... (frente de pau dos ferros, RN)".

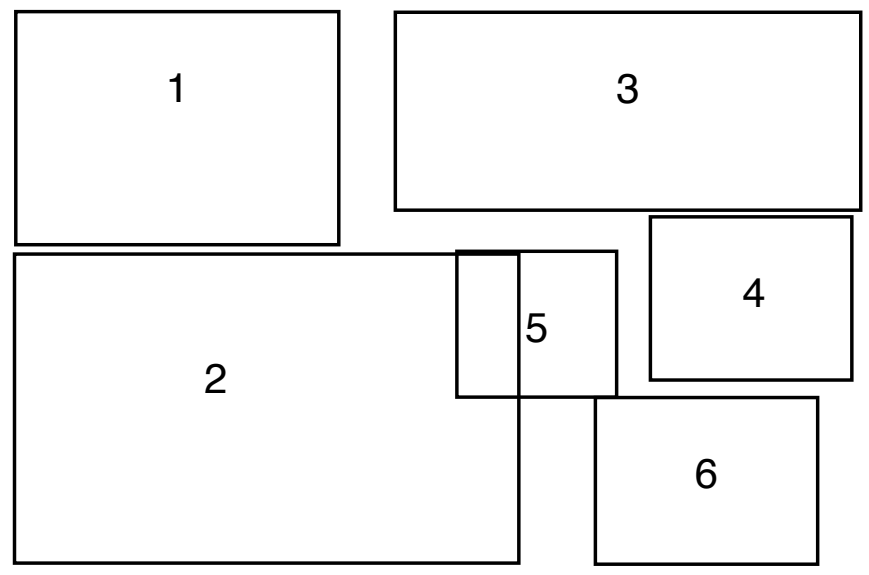



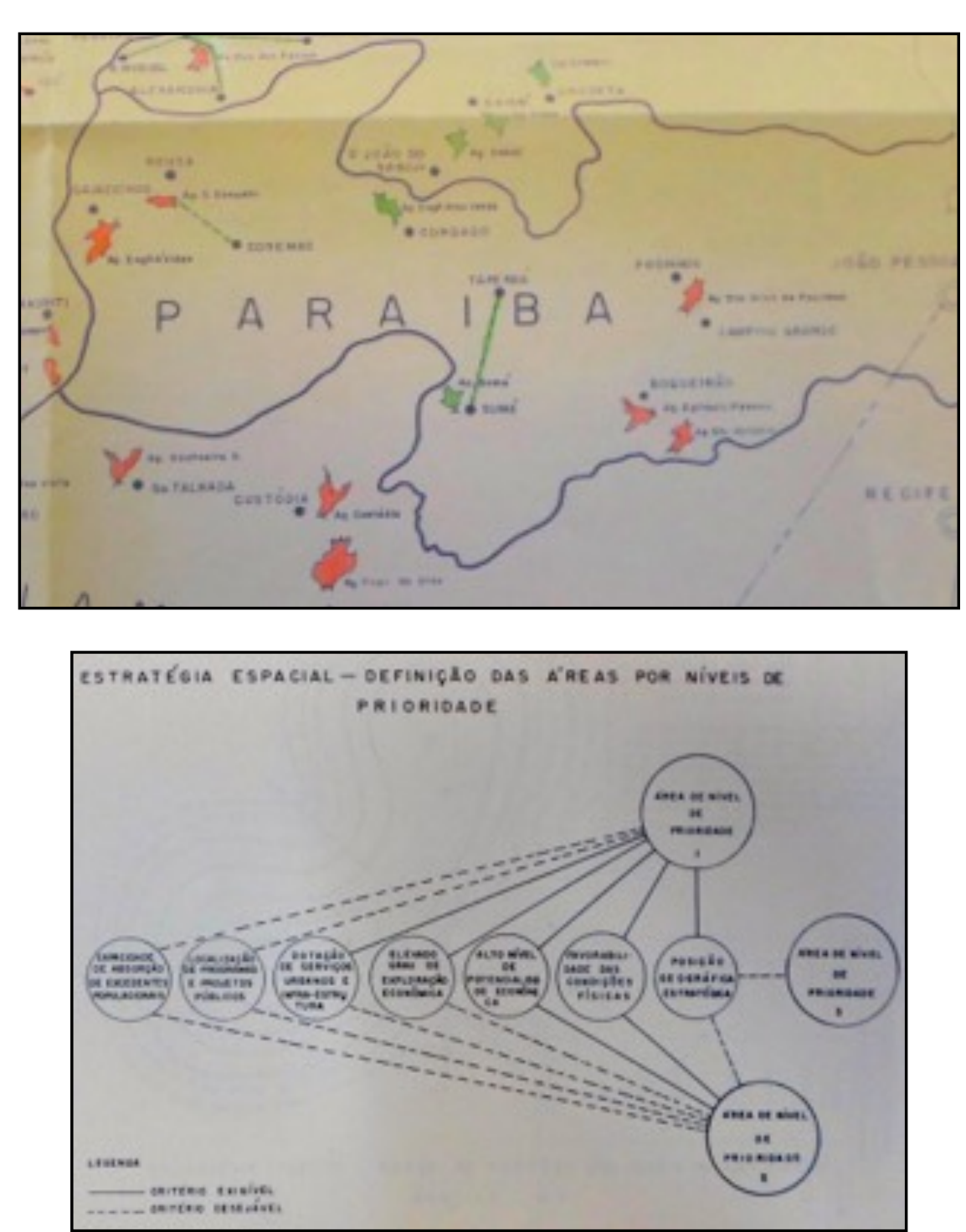

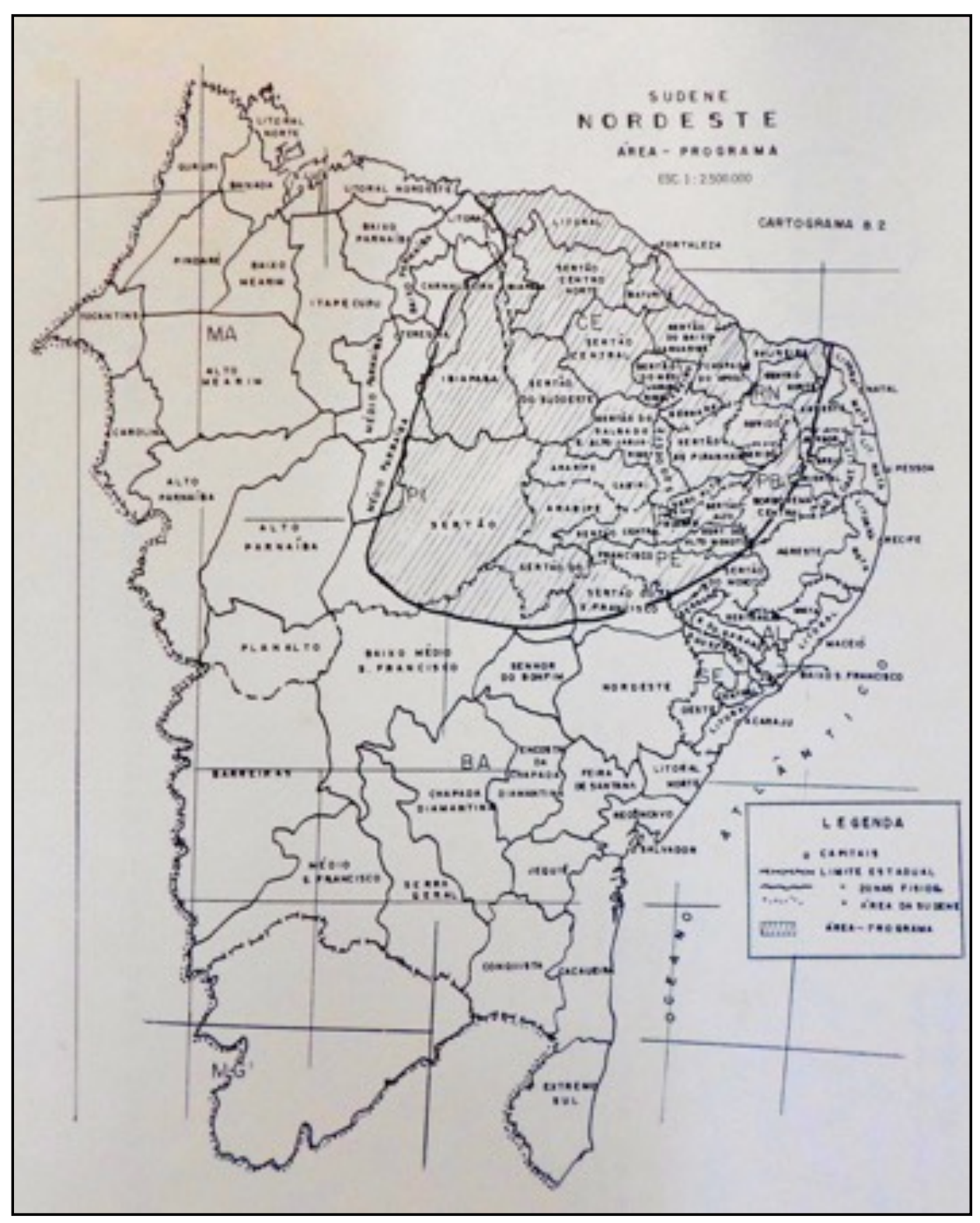


Os planos de combate às secas continuaram a ser elaborados durante toda a década de 1970, sem que muitas modificações fossem feitas nas ações dos órgãos responsáveis (Sudene/Dnocs).

1. Recorte no mapa dos serviços a serem atacados segundo plano de ação de 1971 mostrando o estado da Paraíba.

2. Organograma com a definição das áreas nas quais deveriam ser implementadas políticas (obras e frentes de serviço) segundo níveis de prioridade. Nessa publicação de 1973, Plano Integrado para o combate preventivo aos efeitos das secas no Nordeste (Minter, 1973), as soluções não inovam em nada, a não ser nos gráficos e organogramas com diferentes desenhos.

3. Mapa da área sujeita à atuação da Sudene. Plano Integrado para o combate preventivo aos efeitos das secas no Nordeste (Minter, 1973)
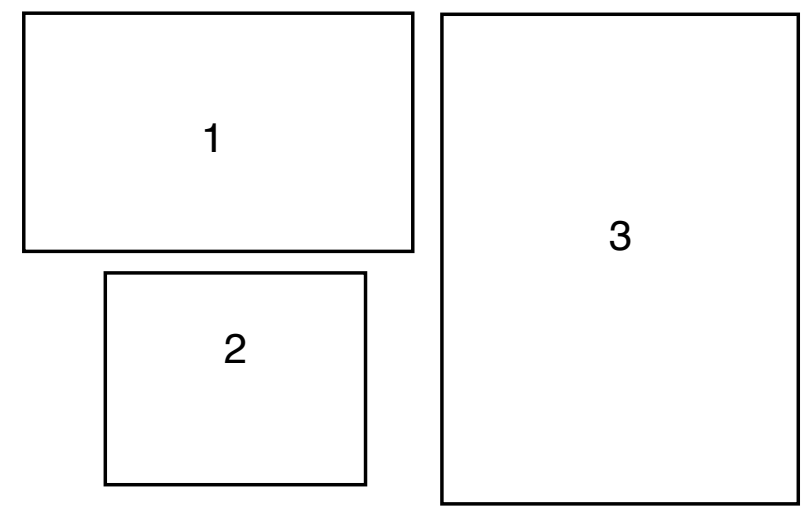


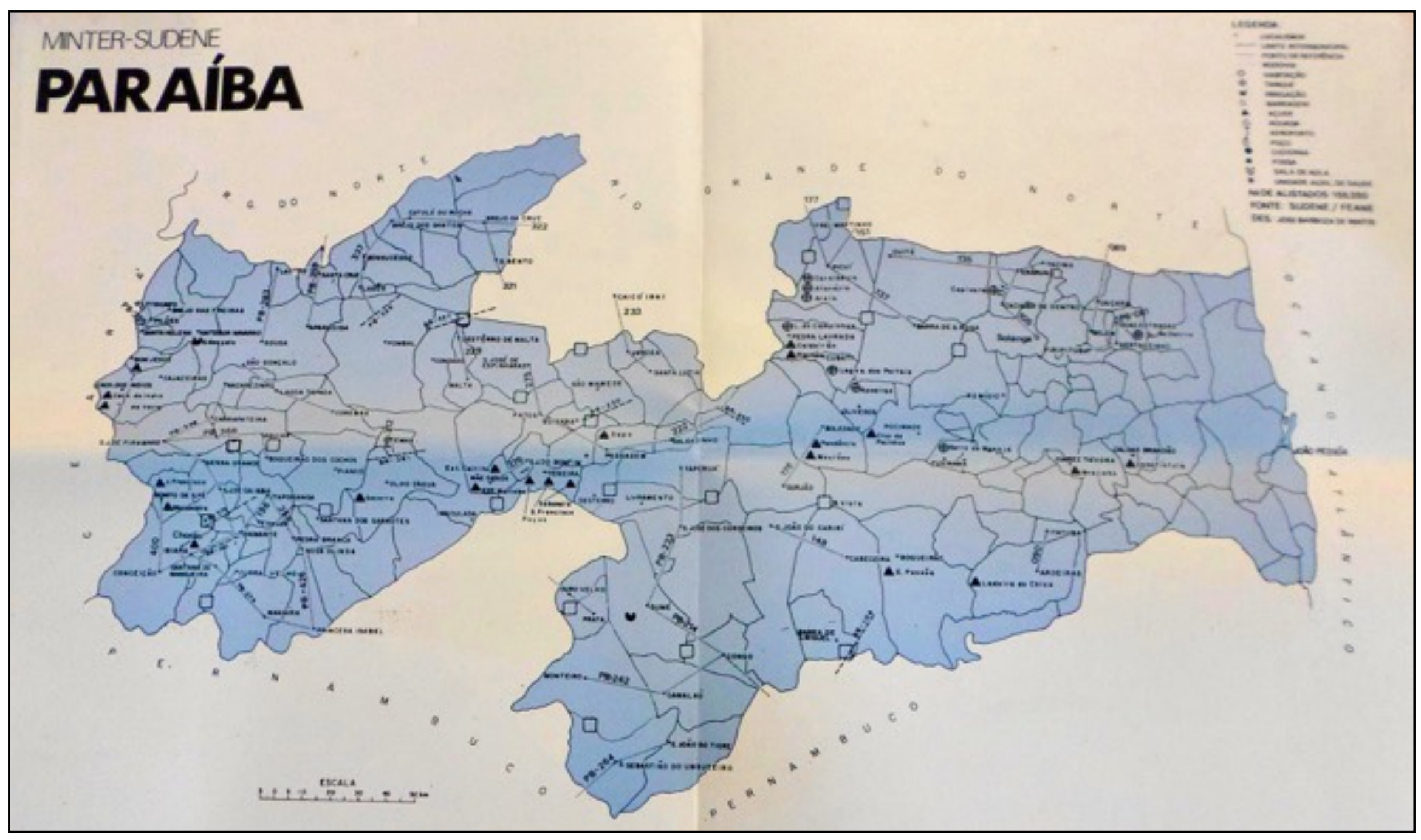


1. Mapa da Paraíba contendo as seguintes informações: rodovias; habitações; irrigação; barragem; açude; aguada, aeroporto, poço, cisterna, fossa, sala de aula, unidade de saúde. Abaixo da legenda, tem-se a seguinte informação: $\mathrm{n}^{\circ}$ de alistados 155.250. Apesar disso, não há indicação dos pontos de ocorrência de frentes de serviço. Plano de Emergência contra as Calamidades Públicas - 1979 


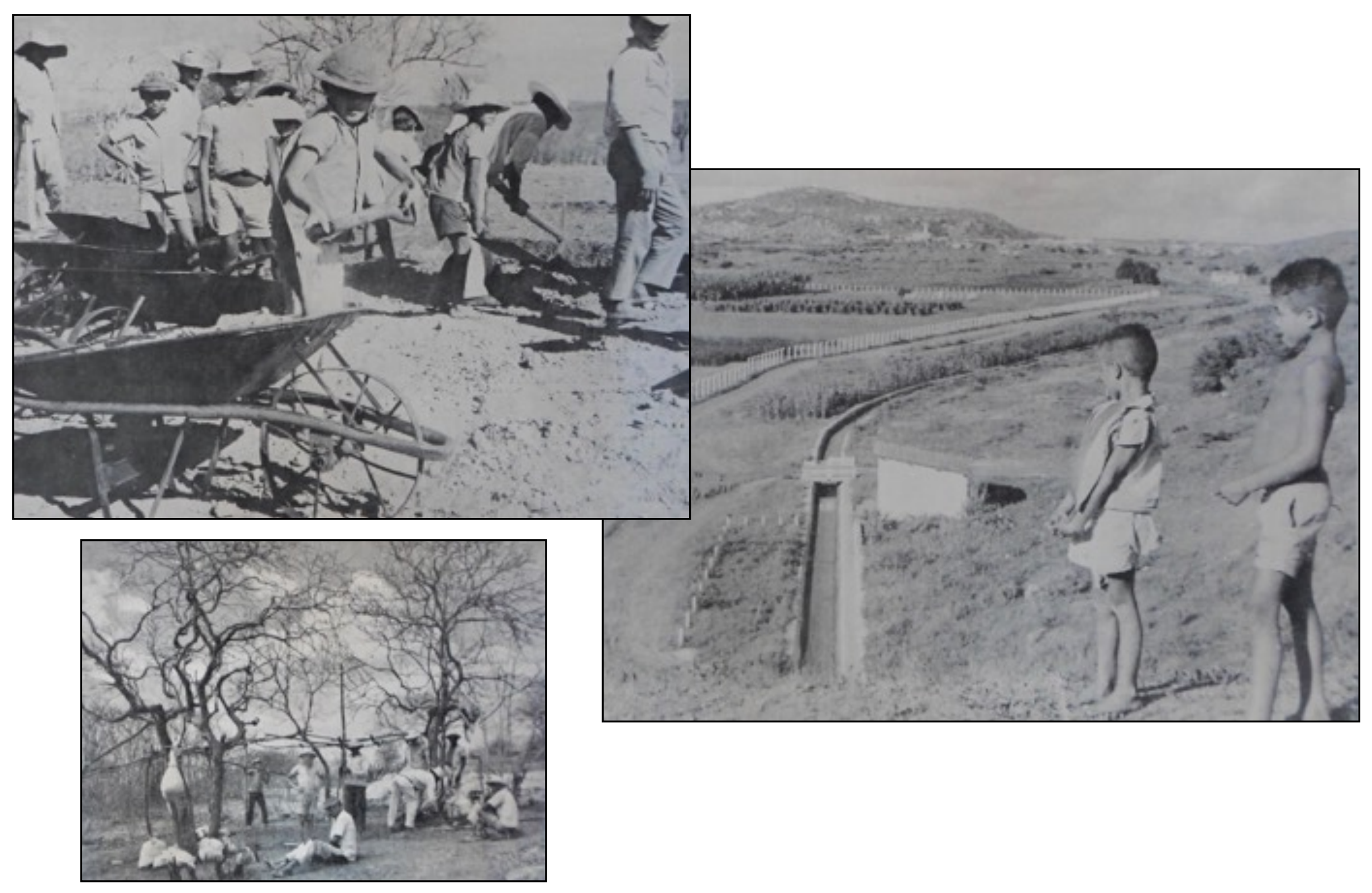


Apesar de pouca mudança nas condições de vida das famílias periodicamente alistadas nas frentes de serviço, sob a ditadura militar as mesmas tristes fotos de crianças trabalhando e abrigos improvisados recebem legendas positivas ao gosto do lema pra frente Brasil!

1. Turma exclusiva de menores publicada com a seguinte legenda: "Nas grandes secas o Governo valoriza o homem da Região oferecendo trabalho, inclusive aos jovens". Plano Integrado para o combate preventivo aos efeitos das secas no Nordeste (Minter, 1973)

2. "O sertanejo constrói seu rancho". Plano Integrado para o combate preventivo aos efeitos das secas no Nordeste (Minter, 1973).

3. "Estes terão um nordeste melhor". Plano Integrado para o combate preventivo aos efeitos das secas no Nordeste (Minter, 1973)

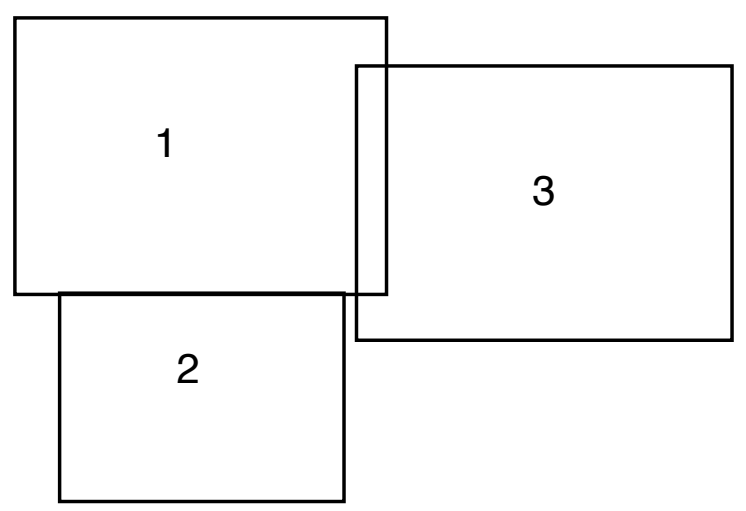




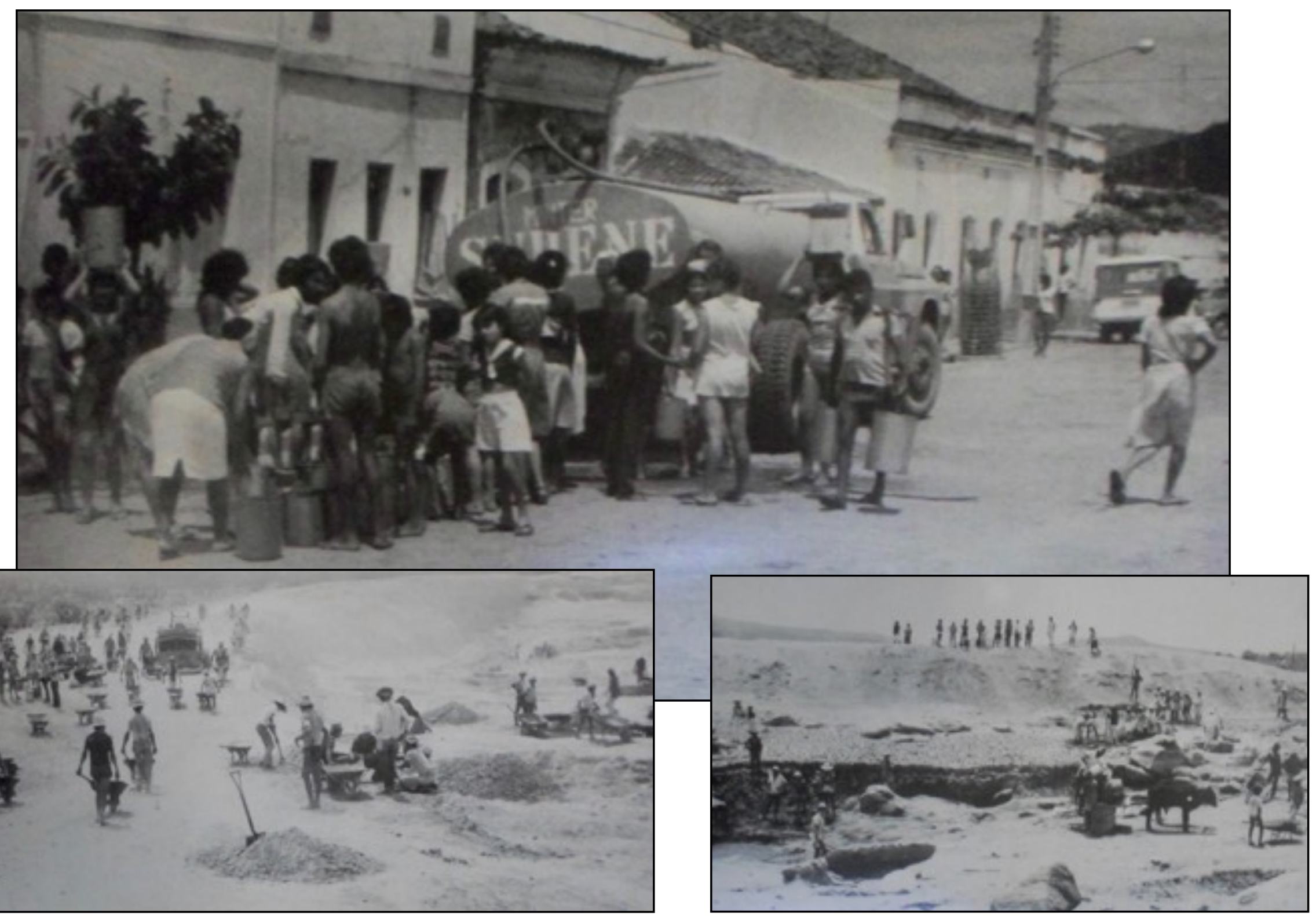


As imagens das secas nordestinas fazem parte do imaginário de grande parte da população brasileira que, a cada seca, tomava conhecimento da situação da população através de imagens de crianças mal nutridas, aglomerações em torno de carros pipa e frentes de serviços de estradas, entre outros. A seca de 1982-83 marcou a minha infância e com algumas fotos dessa seca encerro essa parte do caderno de imagens.

1. Caminhão pipa da Sudene. Carli, Gileno Dé. Séculos de Secas. Recife: s/e, 1984.

2. "Frente de trabalho em Saboeiro, no Ceará, preparando um pequeno açude". Carli, Gileno Dé. Séculos de Secas. Recife: s/e, 1984.

3. "Trabalho braçal para garantir empregos no Nordeste, enquanto a chuva não chega". Carli, Gileno Dé. Séculos de Secas. Recife: s/e, 1984.

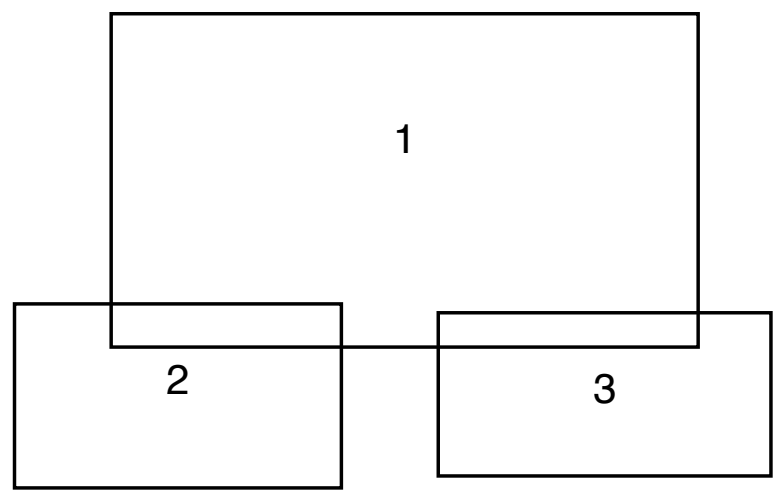


Capa: "Canal de irrigação da Várzea de Sousa", lápis sobre cartolina. Desenho de Seu Moacir. 
Entre os documentos que não encontrei nos arquivos do Dnocs, estão as fotos do período da construção dos açudes de Coremas. Talvez essa tenha sido a falta mais sentida durante a pesquisa e, a cada referência a elas minha esperança aumentava. Mas, de todo esse material, restaram algumas poucas fotos - publicadas em boletins e relatórios e reproduzidas nesse caderno - e a menção a elas nos ofícios perdidos na seção técnica. Menciono-os a seguir para registro daquilo que não vi.

Em uma pasta reunindo documentos referentes ao ano de 1952, localizei quatro ofícios encaminhando fotografias das obras em andamento, num total de 81 fotos. Em 15 de maio de 1953, foram remetidas 3 cópias de cada uma das fotos de numeração 213 a 227 referentes aos trabalhos da residência até abril daquele ano. O Ofício de 12 de abril (Of. n. 12 "T") remeteu 68 fotografias "como complementação das que foram enviadas anteriormente sobre os serviços desta e da $2^{\circ}$ residência". No mesmo dia, o Ofício. $N^{\circ} 13$ "T" enviou fotografias do "avançamento dos serviços". O Ofício de 18 de setembro de 1957 (Of. Nº 39 "T"), enviou 70 fotografias do Açude Mãe D'água e 21 da usina hidrelétrica. Em 28 de setembro de 1957 (Of. No 44"T"), remeteu, a pedido, fotografias da usina hidrelétrica, da linha de transmissão Curema-Piancó e praça de esportes do açude Estevam Marinho. Por fim, um ofício de 18 de outubro de 1957 remeteu as cópias das fotografias da inauguração da energia elétrica do município de Piancó, fornecida pelo açude público "Estevam Marinho", "com a presença do Sr. Diretor Geral do Dnocs e outras autoridades".

Além das poucas fotos de Coremas publicadas nos Boletins, ou encontradas durante a pesquisa, compõem esse caderno as fotos tiradas por mim durante as visitas a Coremas em 2009 e 2016. 


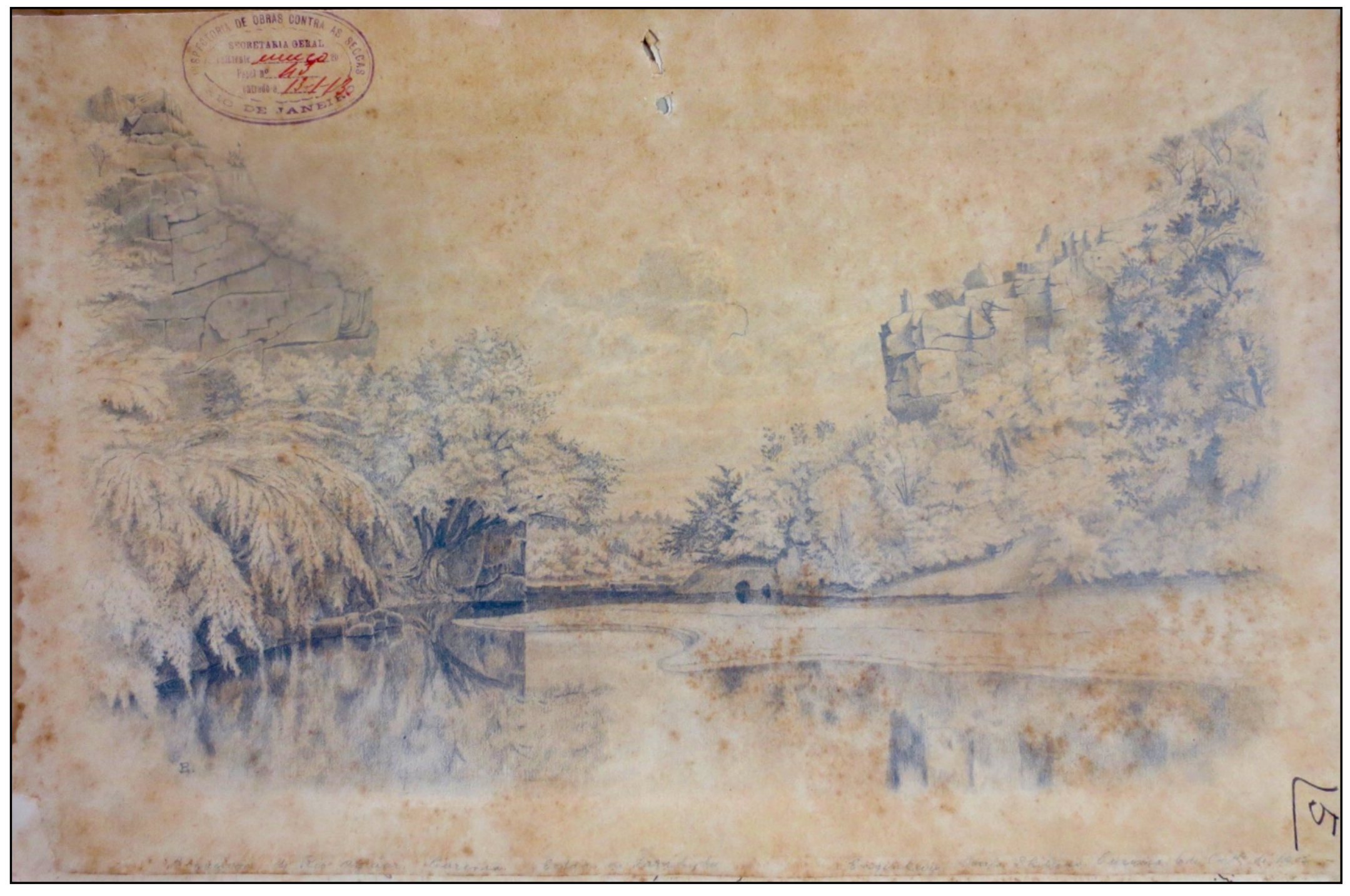


Na bagunça dos papéis depositados sem qualquer ordem ou catalogação nos fundos da sala da seção técnica do Dnocs em João Pessoa é possível encontrar muitos documentos interessantes como mapas, esquemas de barragens, desenhos das peças utilizadas nas construções, cadernetas com os dados pluviométricos, entre outros. Entre os achados da seção técnica está o desenho feito a lápis pelo Engenheiro Louis Phillips do boqueirão formado pela passagem do rio Aguiar na Serra de Santa Catarina, no local conhecido como Mãe D'água, em 1912. Segundo o engenheiro:

"Acima do boqueirão ha uma linha de pedra descoberta de um lado do rio ao outro; e esta pedra impede perfeitamente a entrada no boqueirão da agua e da areia dos poços e praias no leito do rio por cima da garganta.

Devido a esta linha de pedra, e a ausencia de areia no boqueirão, a construção duma barragem nesse logar seria muito facil". 


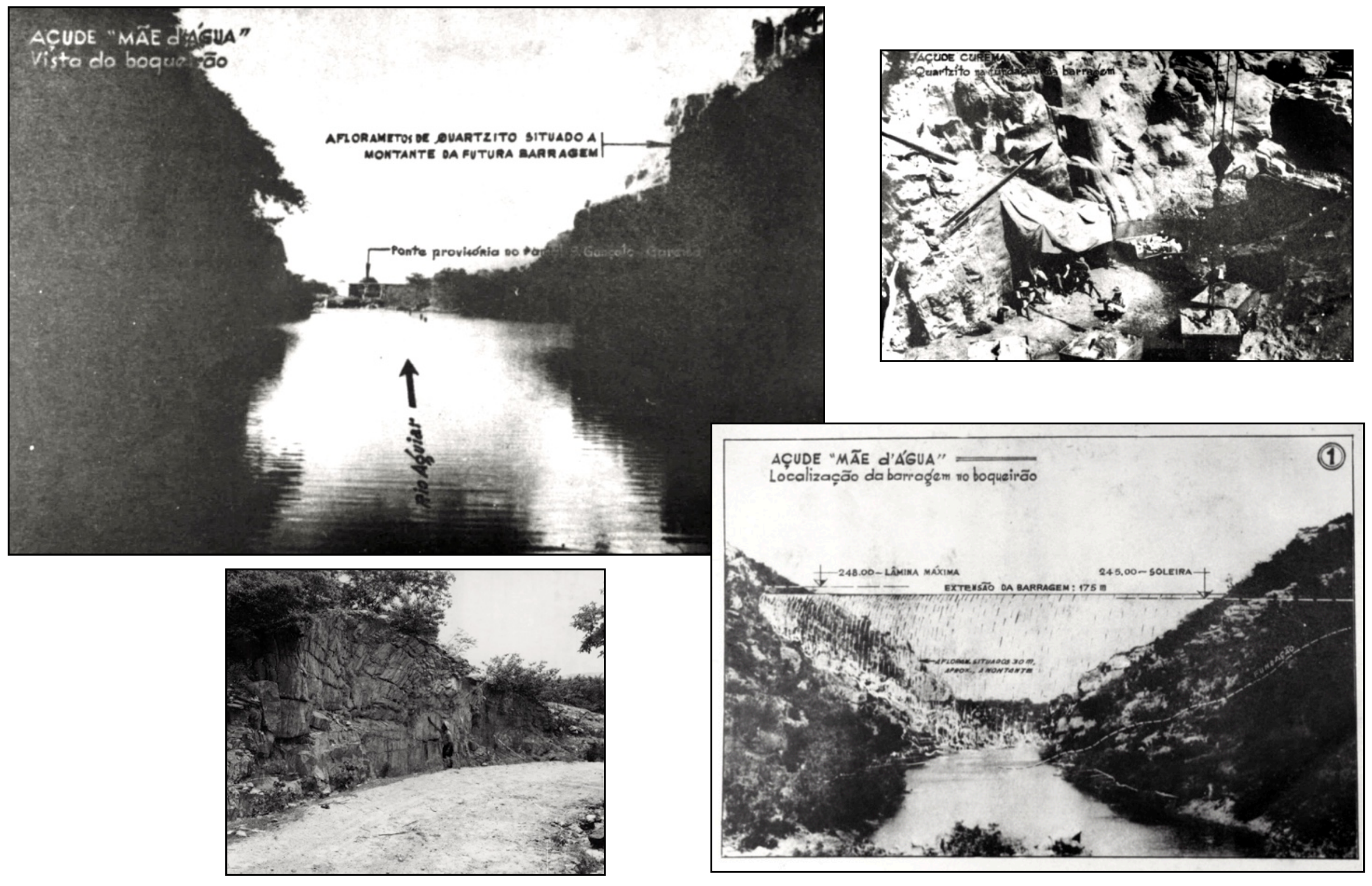


Algumas poucas fotos das muitas tomadas do início da construção dos açudes em Coremas foram publicadas nos Boletins da Ifocs, como é o caso de três das quatro fotos reproduzidas na página anterior. Essas fotos mostram detalhes do Boqueirão de Mãe D'água, apontando a qualidade das rochas que compõe a Serra de Santa Catarina.

1. Vista do Boqueirão Mãe D'água já com a ponte provisória construída. A foto, de 1939, mostra o início da construção do açude. Foram sendo feitas pequenas barragens, num total de quatro, até que o boqueirão fosse fechado completamente. Boletim da Ifocs vol.12, $n^{\circ} .2,1939$.

2. Serra de Santa Catarina próximo ao boqueirão de Mae D'água. Ibge, 1940

3. Vista das obras da fundação do açude Curema mostrando o detalhe do material do paredão composto de quartzito. Boletim da Ifocs vol.12, $n^{\circ} .2,1939$.

4. Foto do boqueirão de Mãe D'água com marcações mostrando o local da fundação e a futura barragem. Boletim da Ifocs vol.12, $n^{\circ} .2,1939$.

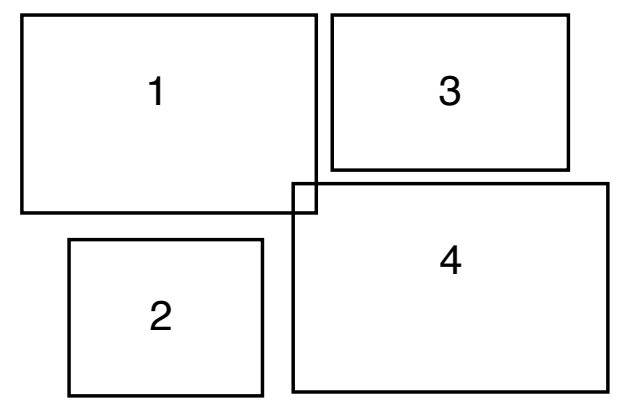



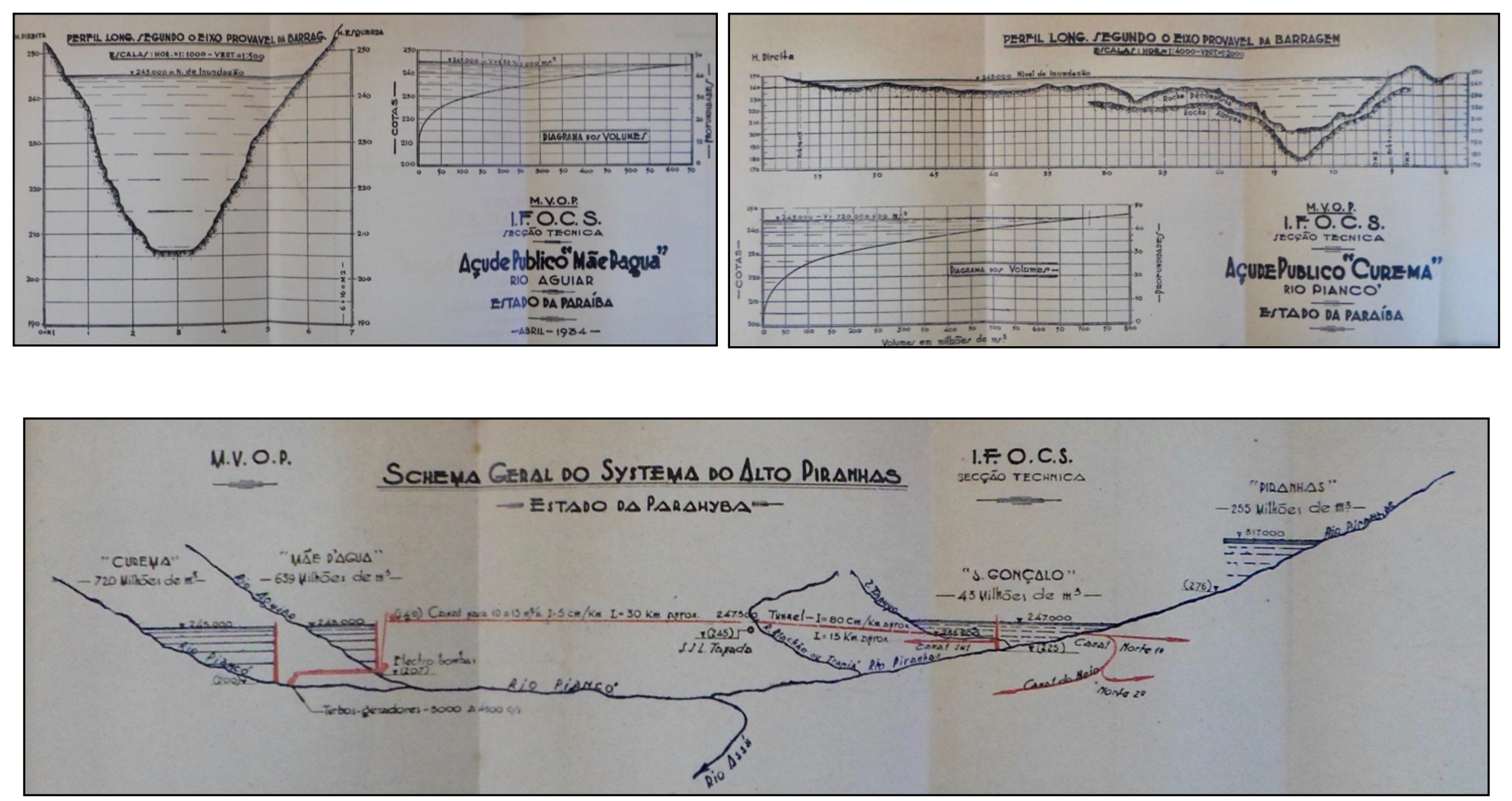
Segundo relatos dos Engenheiros do Dnocs e aqueles que acompanharam a construção dos açudes em Coremas, tratou-se de uma obra muito avançada em termos da engenharia da época. O aspecto monumental das barragens é acentuado utilizando-se inclusive o adjetivo "ciclópico", que correspondia também ao tipo de cimento utilizado na época (cimento ciclópico) conforme anotado nos manuais técnicos.

1. Perfil longitudinal segundo o eixo provável da barragem e diagrama dos volumes das cotas do açude público Mãe D'água, esquema de abril de 1934. Relatório dos Trabalhos Realizados pela Ifocs em 1931-33.

2. Perfil longitudinal segundo o eixo provável da barragem e diagrama dos volumes das cotas do açude público Coremas. Relatório dos Trabalhos Realizados pela Ifocs em 1931-33.

3. Esquema geral do sistema do Alto Piranhas, mostrando a interligação dos açudes Curema, Mãe D'água, São Gonçalo e Piranhas. Relatório dos Trabalhos Realizados pela Ifocs em 1931-33.

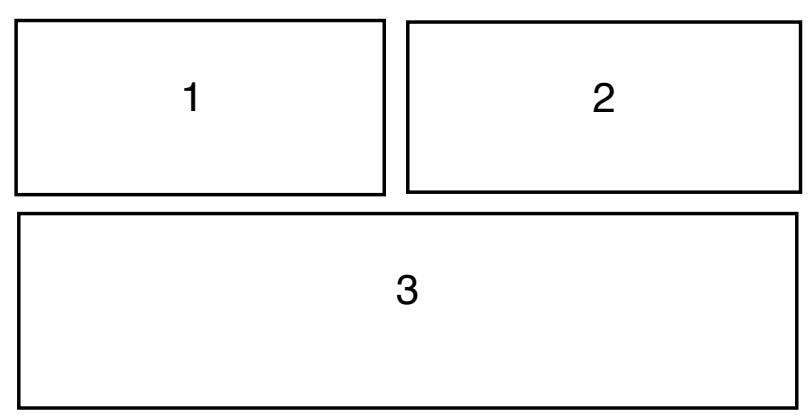




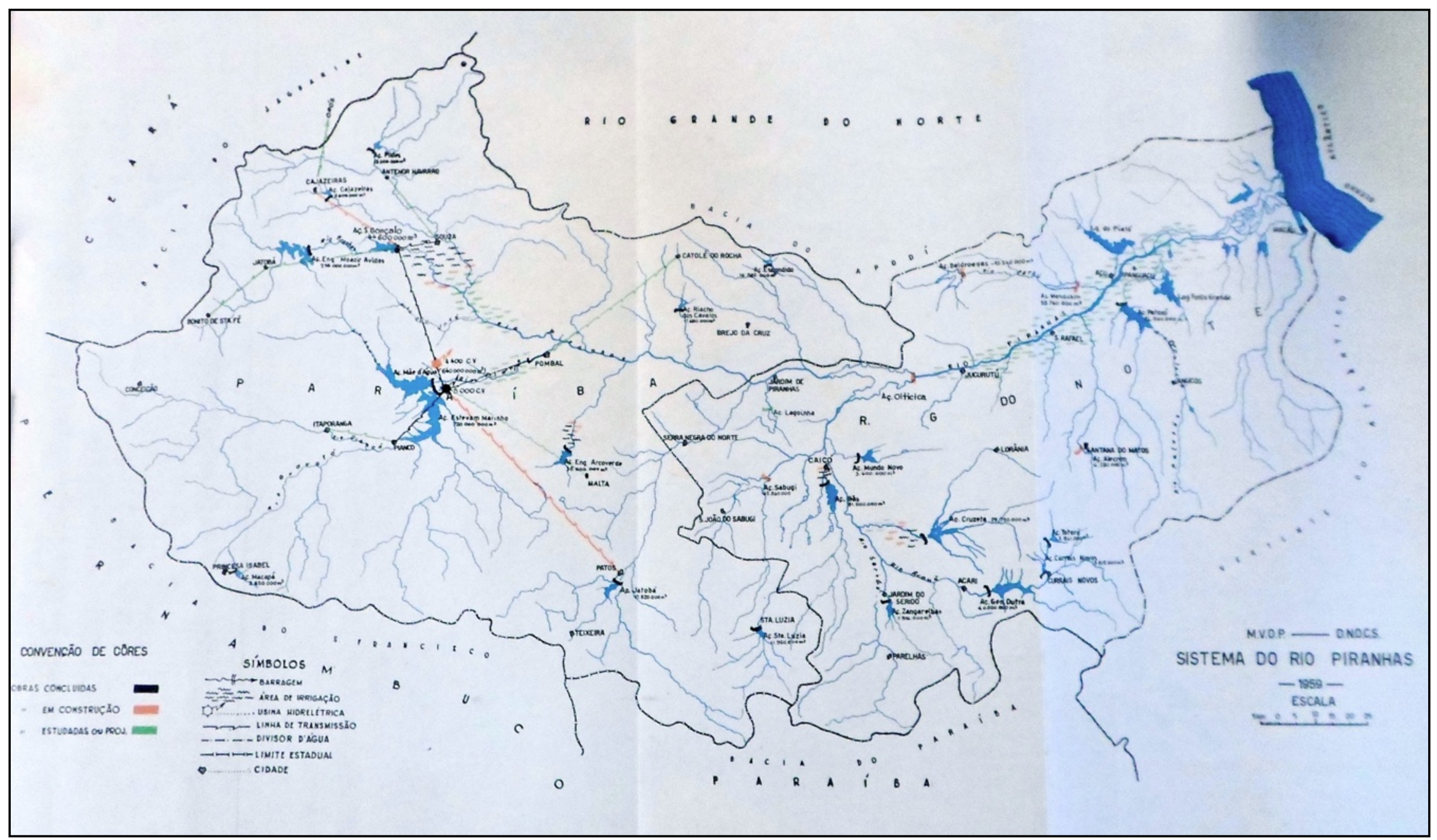


A Paraíba é marcada pela ação dos órgãos contra as secas, que espalhou açudes em toda a extensão do estado, como mostra o mapa elaborado pela Ifocs em 1959 e reproduzido na edição especial da Revista do Clube de Engenharia em 1960.

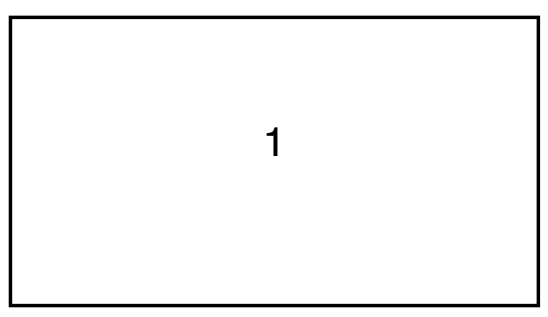




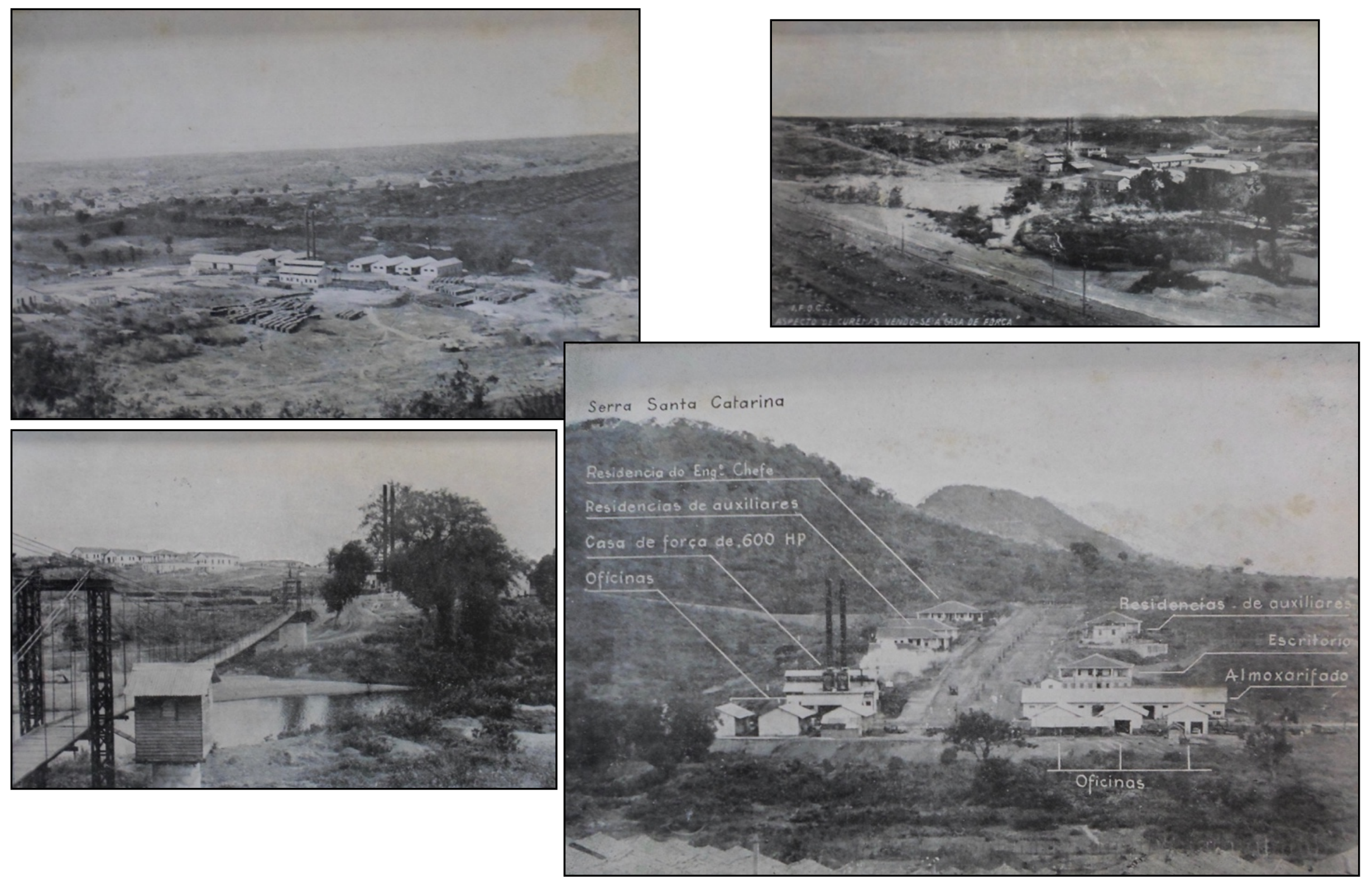


Apesar da baixa qualidade das imagens é possível ver que não havia nenhuma construção no local em que foi construído o acampamento da Ifocs e que visava abrigar os funcionários que trabalharam na construção. As poucas casas que compunham o núcleo urbano do distrito de Coremas ficavam do outro lado do rio.

1. Vista das oficina e almoxarifado, instalados para o início da construção do açude Coremas. Relatório dos Trabalhos Realizados pela Ifocs, 1937.

2. Ponte sobre o rio Piancó dividindo o acampamento da Ifocs do núcleo de Coremas. A foto foi tirada do lado do núcleo urbano, mostrando as edificações da Inspetoria ao fundo. Relatório dos Trabalhos Realizados pela Ifocs, 1937.

3. Vista do acampamento da Ifocs. Relatório dos Trabalhos Realizados pela Ifocs, 1940.

4. Acampamento da Ifocs com indicação da finalidade de cada um dos prédios. A parede do futuro açude será construída próximo à residência do Engenheiro Chefe. $\mathrm{O}$ acampamento iria aumentar consideravelmente de tamanho ao longo dos anos com a inclusão de equipamentos de lazer como um cinema, que atualmente abriga a casa maçônica local, um clube recreativo e uma escola. Relatório dos Trabalhos Realizados pela Ifocs, 1937.

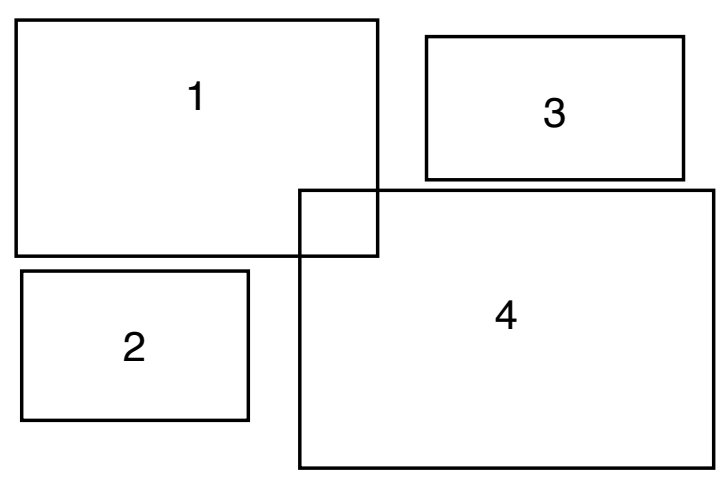



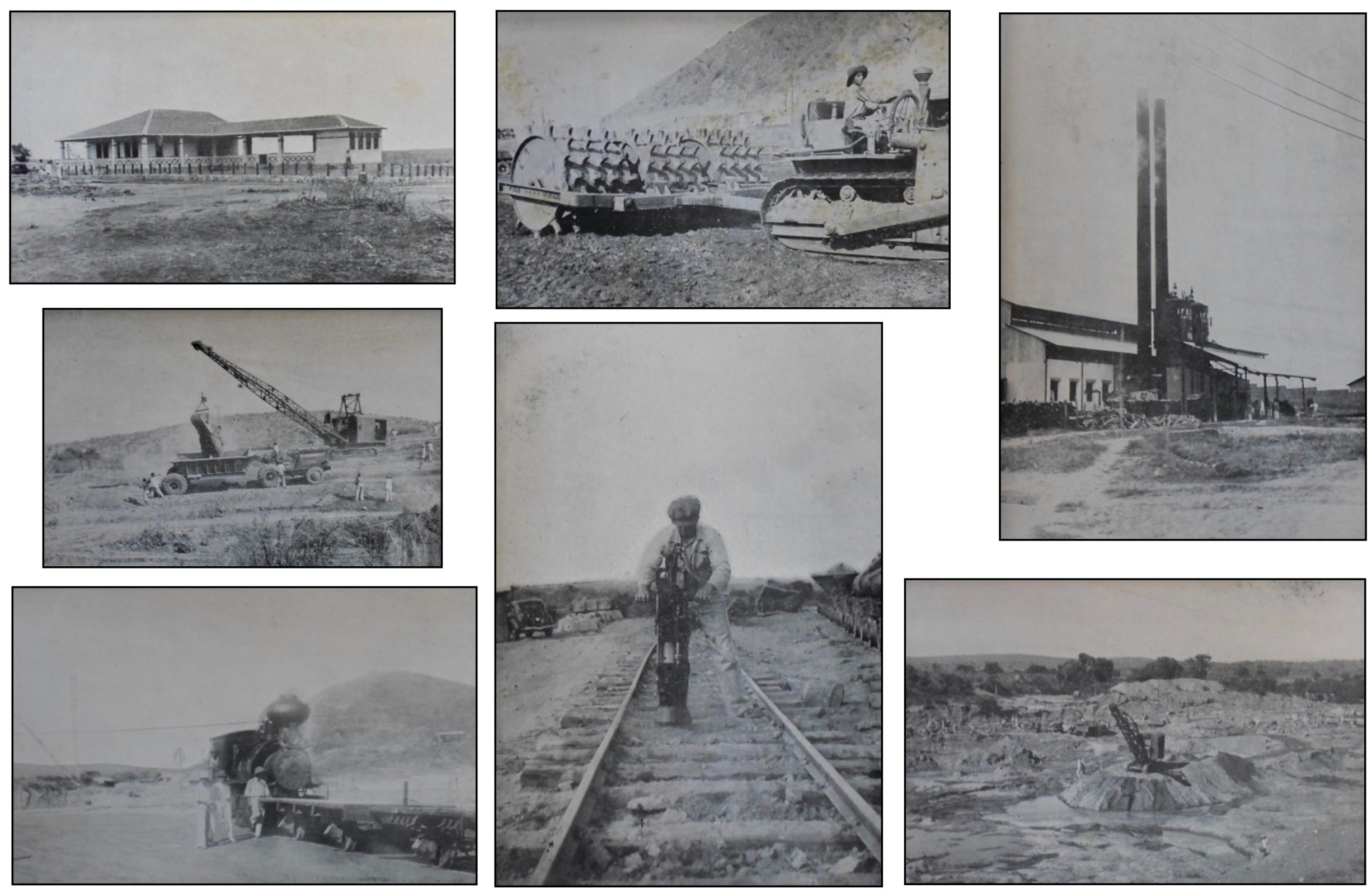
1. Grupo escolar de Coremas. Relatório dos Trabalhos Realizados pela Ifocs, 1937.

2. "Track truck". Relatório dos Trabalhos Realizados pela Ifocs, 1937.

3. Locomotiva utilizada nas obras. Relatório dos Trabalhos Realizados pela Ifocs, 1937.

4. Trator utilizado nas obras. Relatório dos Trabalhos Realizados pela Ifocs, 1937.

5. "Cafuringa". Relatório dos Trabalhos Realizados pela Ifocs, 1937.

6. Casa de força. Relatório dos Trabalhos Realizados pela Ifocs, 1937.

7. Fundação do açude Coremas. Relatório dos Trabalhos Realizados pela Ifocs, 1937.
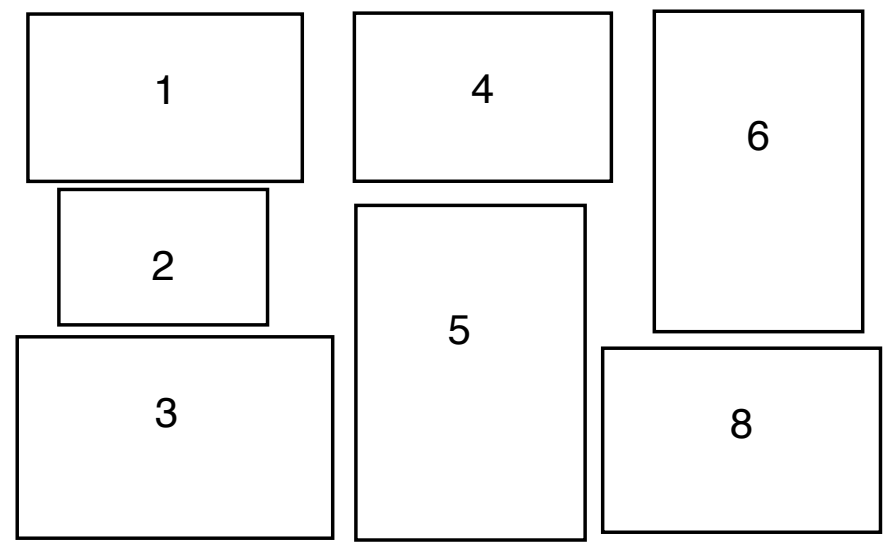

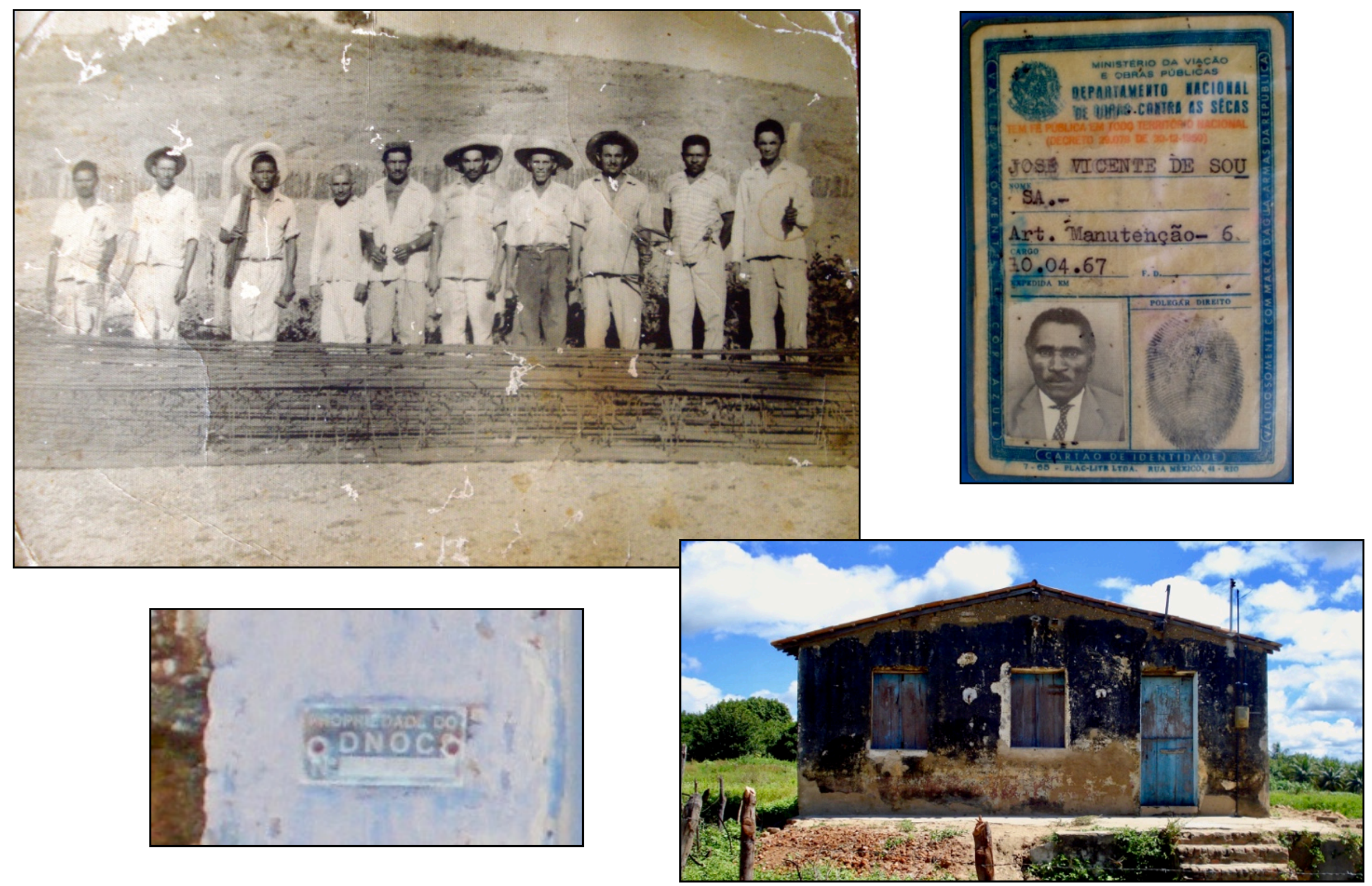
Além dos trabalhadores que foram para Coremas em busca de trabalho nas obras da Ifocs/Dnocs, grande parte dos trabalhadores rurais deslocados das terras nas quais trabalhavam, devido a implantação dos açudes de Coremas e Mãe D'água, também foram engajados nas frentes de trabalho. Poucos foram aqueles, entretanto, que conseguiram um emprego estável nos quadros da sede do órgão instalada em Coremas. Um desses poucos trabalhadores foi José Vicente de Souza, conhecido por Lampião, ex morador do povoado Navio e que ficou submerso pelas águas do açude Mãe D'água. Os trabalhadores que tornaramse funcionários tinham direito de ocupar as casas construídas pela Inspetoria na vila operária de Mãe D'água.

1. Grupo de trabalhadores nas obras do açude Coremas. Foto pertencente a um antigo mecânico do Dnocs.

2. Placa de patrimônio do Dnocs instalada na janela das casas da vila operária construída pelo órgão em Mãe D'água.

3. Carteira funcional de Seu Lampião, atualmente aposentado pelo Dnocs.

4. Casa do Dnocs de Seu Lampião. Conhecida na região como casa grande, foi por muito tempo a sede dos famosos forrós comandados por Lampião. Atualmente, a casa foi reformada e um de seus filhos mora ali com a família.

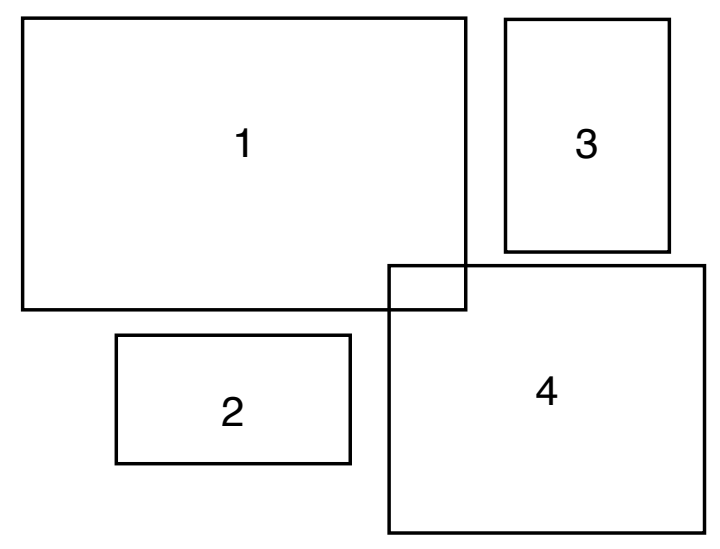




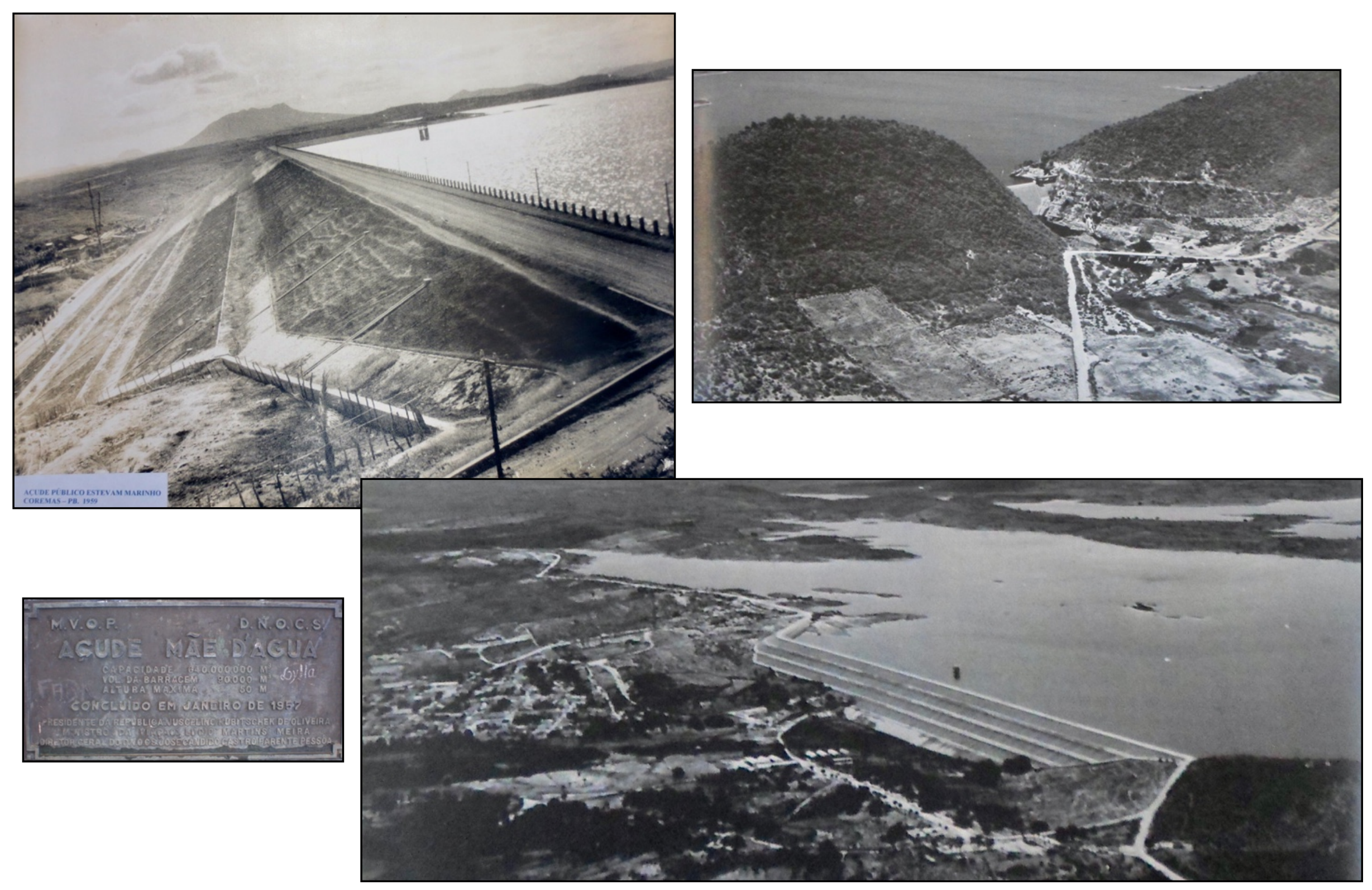


O grande impulso populacional da cidade de Coremas ocorreu durante os anos de construção dos açudes Coremas e Mãe D'água e, mesmo depois de terminada as construções, a região continuou a ser progressivamente ocupada, de maneira desordenada, sobretudo nas áreas periféricas.

1. Foto da parede do açude grande (Coremas/Estevam Marinho) ampliada e colada em cartolina encontrada no arquivo da seção técnica do Dnocs em João Pessoa, com data de 1959. Praticamente não há construções próximas a parede do açude, situação que se modificou bastante principalmente nos últimos anos.

2. Placa do açude Mãe D'água, já com sinais de deterioração pelo tempo, assim como o restante das estruturas. Março de 2009.

3. Foto do açude Mãe D'água, parte da publicação do Dnocs intitulada Barragens do Nordeste do Brasil, de 1982. A parte esquerda da foto mostra a antiga "Vila dos Mulambos". Atualmente, essa área encontra-se adensada de construções. Em 2012, ao longo de toda sua extensão, encontravam-se tanques de peixes, o que foi possível com o aumento dos financiamentos aos pequenos produtores familiares através de uma linha para irrigação e piscicultura dentro do Pronaf.

4. Foto mostrando o açude de Coremas, a cidade e o acampamento do Dnocs, também parte da publicação Barragens do Nordeste do Brasil.

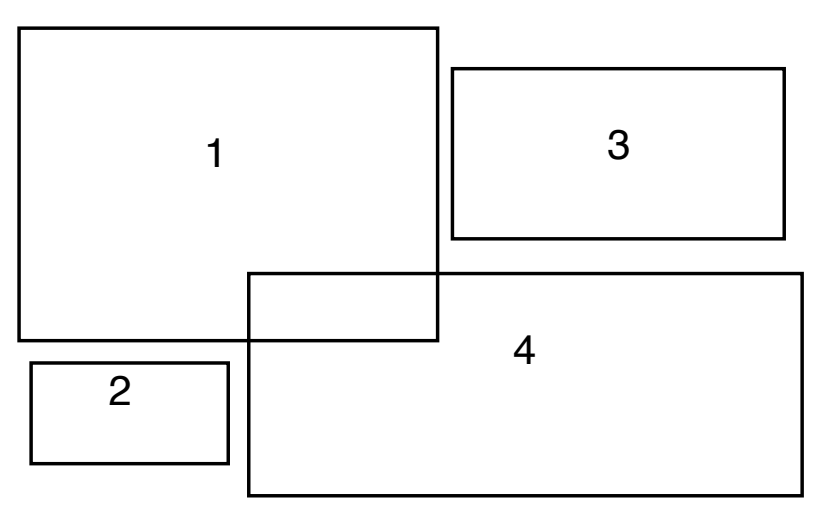




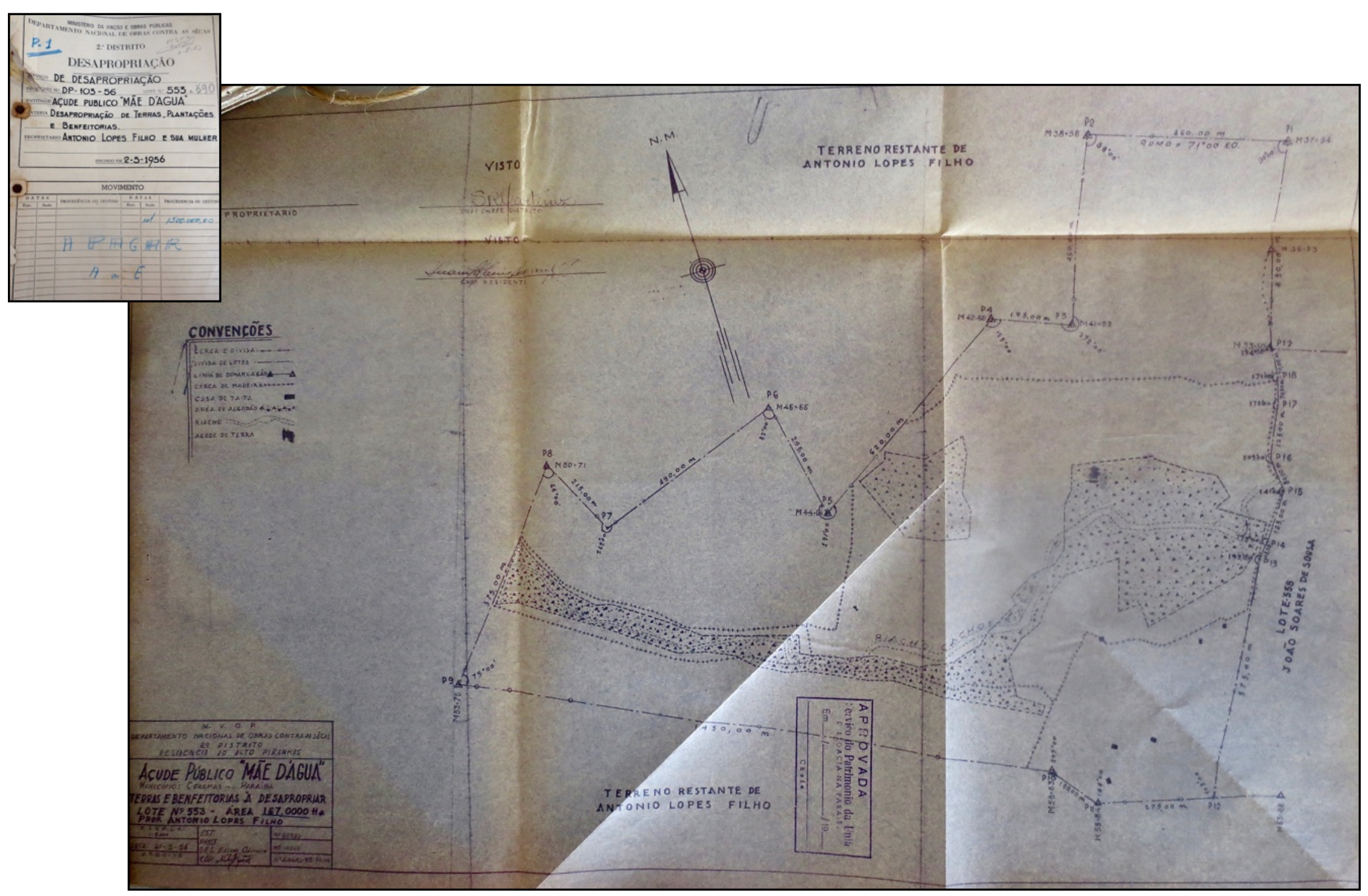


O processo de desapropriação dos lotes que foram alagados pelos açudes em Coremas e mais aqueles que compõem a bacia hidráulica do Sistema Coremas-Mãe D'água se iniciaram no final da década de 1930 e muitos lotes não foram pagos até a revogação do decreto que declarava como de utilidade pública as áreas durante o governo de Fernando Collor de Mello. Um dos lotes que não foram pagos, cujos processos encontram-se arquivados no arquivo da seção técnica do Dnocs em João Pessoa, foi o de Antônio Lopes, ex prefeito de Coremas e dono da maior fazenda da região, a fazenda Cachoeirinha. Os documentos para instrução processual dos procedimentos de desapropriação continham uma planta, como a reproduzida acima, e uma lista de suas benfeitorias, que incluíam as edificações e plantios comerciais. As roças dos moradores e o número de famílias que viviam e produziam nas terras não era especificado, podendo-se entrever sua quantidade apenas pela indicação de casas de taipa na lista de benfeitorias.

1. Capa do processo de desapropriação dos lotes de propriedade declarada de Antônio Lopes com a indicação "a pagar".

2. Planta do lote desapropriado de Antônio Lopes.

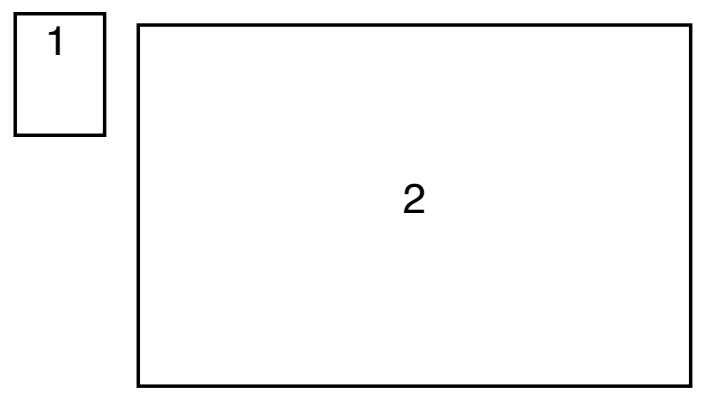



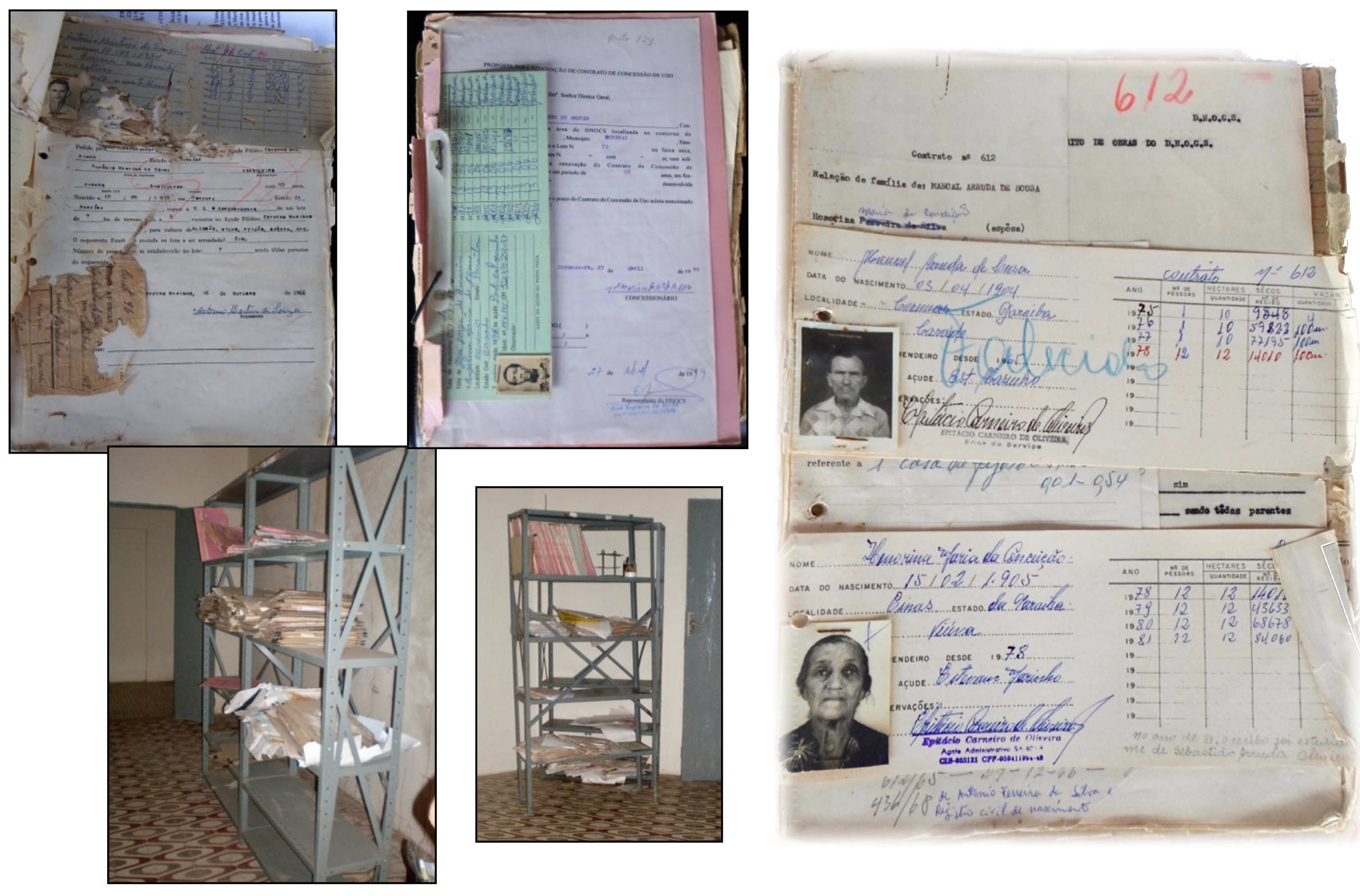
Os lotes pertencentes a bacia hidráulica dos açudes Coremas e Mãe D'água começaram a ser arrendados ainda na década de 1940, mas foi possível localizar apenas os processos formalizados a partir de 1966. Muitos dos rendeiros dessa época continuam a ocupar os mesmos lotes até hoje. A documentação referente a esses arrendamentos encontra-se em péssimas condições e os contratos mais recentes não contemplam todas as informações que os contratos iniciais. Em março de 2009, os processos dos rendeiros estavam desordenadamente dispostos em prateleiras de ferro. Em dezembro de 2016, esses processos estavam jogados no chão de uma das salas da sede do Dnocs em Coremas. A situação era tão terrível que me senti constrangida de tirar fotos em simpatia aos funcionários do órgão que, atualmente, são apenas três, um deles motorista. Seria impossível que eles pudessem organizar e recuperar toda a documentação. Entre os anos de pesquisa, muitos documentos que estavam deteriorados pela ação de umidade e bichos foram descartados. Com a previsão da chegada das águas da transposição do Rio São Francisco em Coremas e o acirramento do processo de especulação imobiliária, a falta de documentos que comprovem o tempo de permanência dos rendeiros pode deixar muitos moradores numa situação delicada. É provável que nos próximos anos novos deslocamentos sejam forçados pelo beneficiamentos das áreas próximas aos açudes.

1. e 5. Folhas da pasta de Antônio Martins.

2. e 4. Estantes contendo as pastas dos rendeiros. Março de 2009.

3. Processo de José Jorge de Amorim, homônimo e tio de Zé Pequeno.

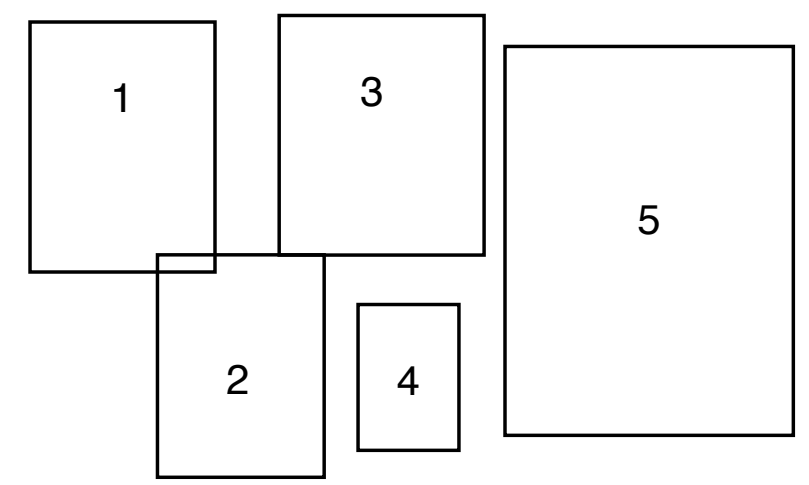




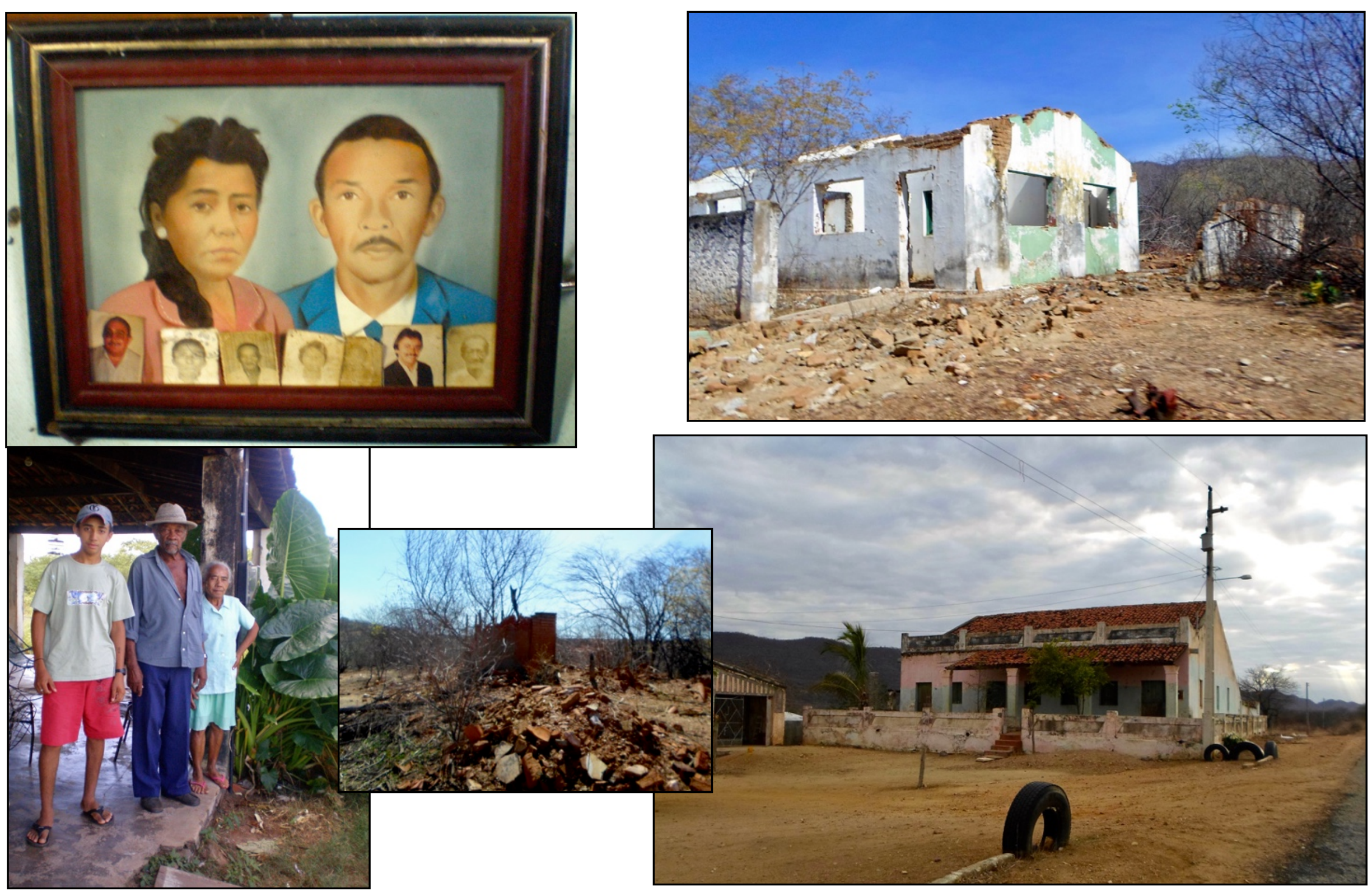


A fazenda Cachoeirinha é a única grande propriedade de Coremas de acordo com os dados do Sistema Nacional de Cadastro Rural e foi durante muito tempo a fazenda com maior número de moradores da região. Muitos desses já moravam há alguma gerações na Cachoeirinha quando Antônio Lopes a comprou, na época do levantamento das propriedades inseridas na bacia hidráulica do açude Mãe D'água. Esse é o caso do núcleo familiar de José Jorge, conhecido por Zé Pequeno. Seu tio, Severino Antônio da Silva, foi um dos últimos a deixar a fazenda e atualmente é morador nas terras de um dos filhos de Antônio Lopes, José Hilton Lopes.

1. Retrato de Severino Antônio da Silva e sua esposa. As fotos 3x4 de membros da família são tradicionalmente colocadas na parte inferior do quadro. Nesse retrato em especial, além dos familiares de Seu Severino como seu pai (primeira foto à direita) e seu irmão Pedro Jorge (terceiro da esquerda para direita), estão Antônio Lopes (primeiro da esquerda para direita) e Hilton Lopes (segundo da direita para a esquerda).

2. Seu Severino, sua esposa e um de seus netos no alpendre de sua casa na propriedade de Hilton Lopes.

3. Restos da parede de uma antiga casa de morador da Fazenda Cachoeirinha. Dez. 2016.

4. Antigo grupo escolar na entrada do núcleo de casas dos moradores da Fazenda Cachoeirinha. Dez. 2016.

5. Fazenda Barro do Coronel Antônio Leite, influente proprietário da época do início da construção dos açudes em Coremas. Dez. 2016.

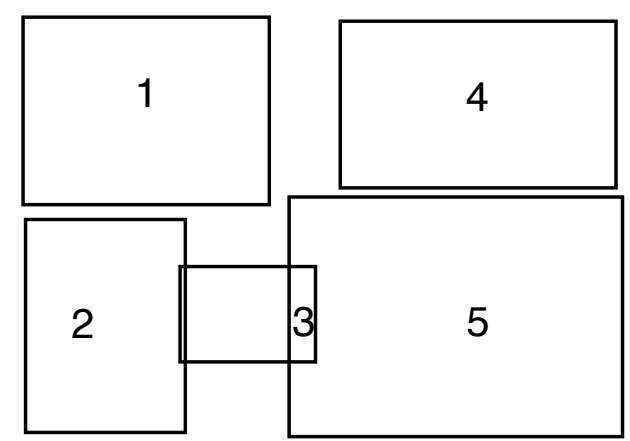




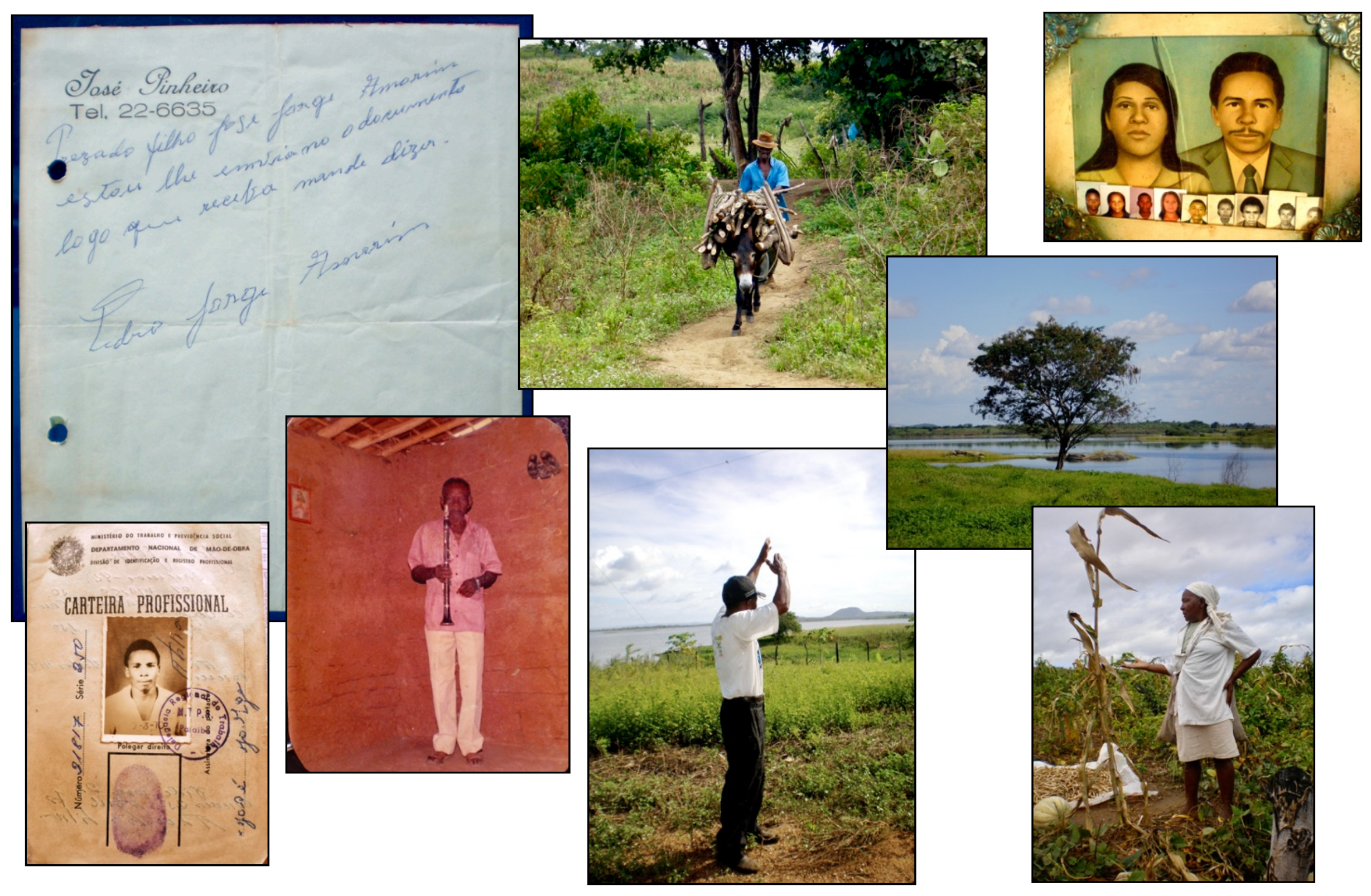


Segundo a legislação do Dnocs referente ao arrendamento das áreas desapropriadas e loteadas pelo órgão, os lotes deveriam ser destinados prioritariamente aos proprietários desapropriados e às famílias "reconhecidamente pobres". Apesar dessa determinação, não havia nenhuma norma sobre o reassentamento de antigos moradores das fazendas desapropriadas. Embora grande parte fosse, de fato, reconhecidamente pobre, nem sempre as famílias conseguiram arrendar áreas e, muitas vezes, quando conseguiram, as áreas eram pequenas. Em alguns casos, os antigos proprietários interviram a favor de seus moradores para que os mesmos conseguissem firmar os contratos com o Dnocs.

O pai de Zé Pequeno, Pedro Jorge Amorim, que era vaqueiro de Antônio Lopes e tinha uma relação privilegiada com este, conseguiu arrendar um lote no local conhecido por Barreiras. Uma vez que as rendas são passadas dos pais para seus filhos, Pedro Jorge repassou sua renda para seu filho quando foi para o Rio de Janeiro, deixando seu legado registrado em carta que compõe a documentação da renda de Zé Pequeno arquivada no Dnocs.

1. Carta de Pedro Jorge Amorim a seu filho José Jorge.

2. Uma das muitas carteira profissionais de Zé Pequeno na qual ele é curiosamente classificado como pardo.

3. Pedro Jorge e seu clarinete.

4. Seu Otacílio levando lenha no terreno que arrenda com sua família.

5. Zé Pequeno mostrando um dos rumos de Cachoeirinha.

6. Retrato de Zé Pequeno e Raimunda e as fotos de seus filhos.

7. Barreiras com o açude cheio.

8. Terreno arrendado pela família em área beneficiada por canais.

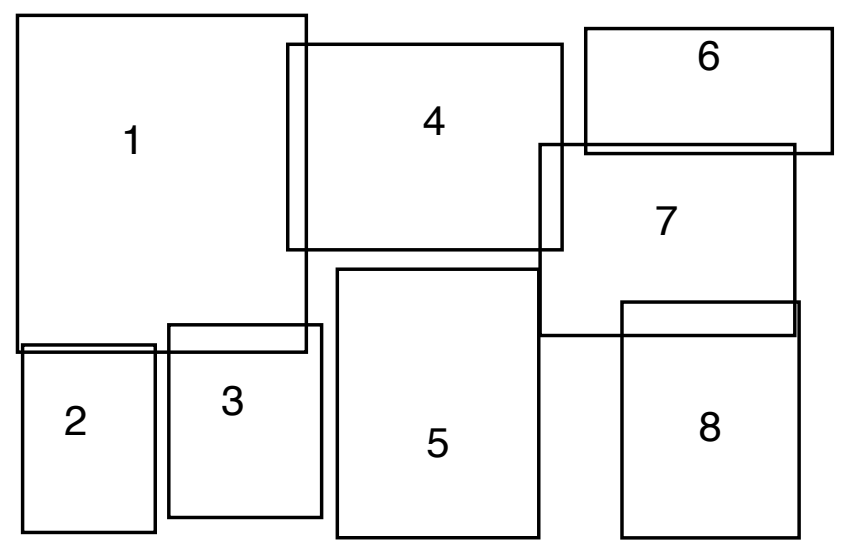



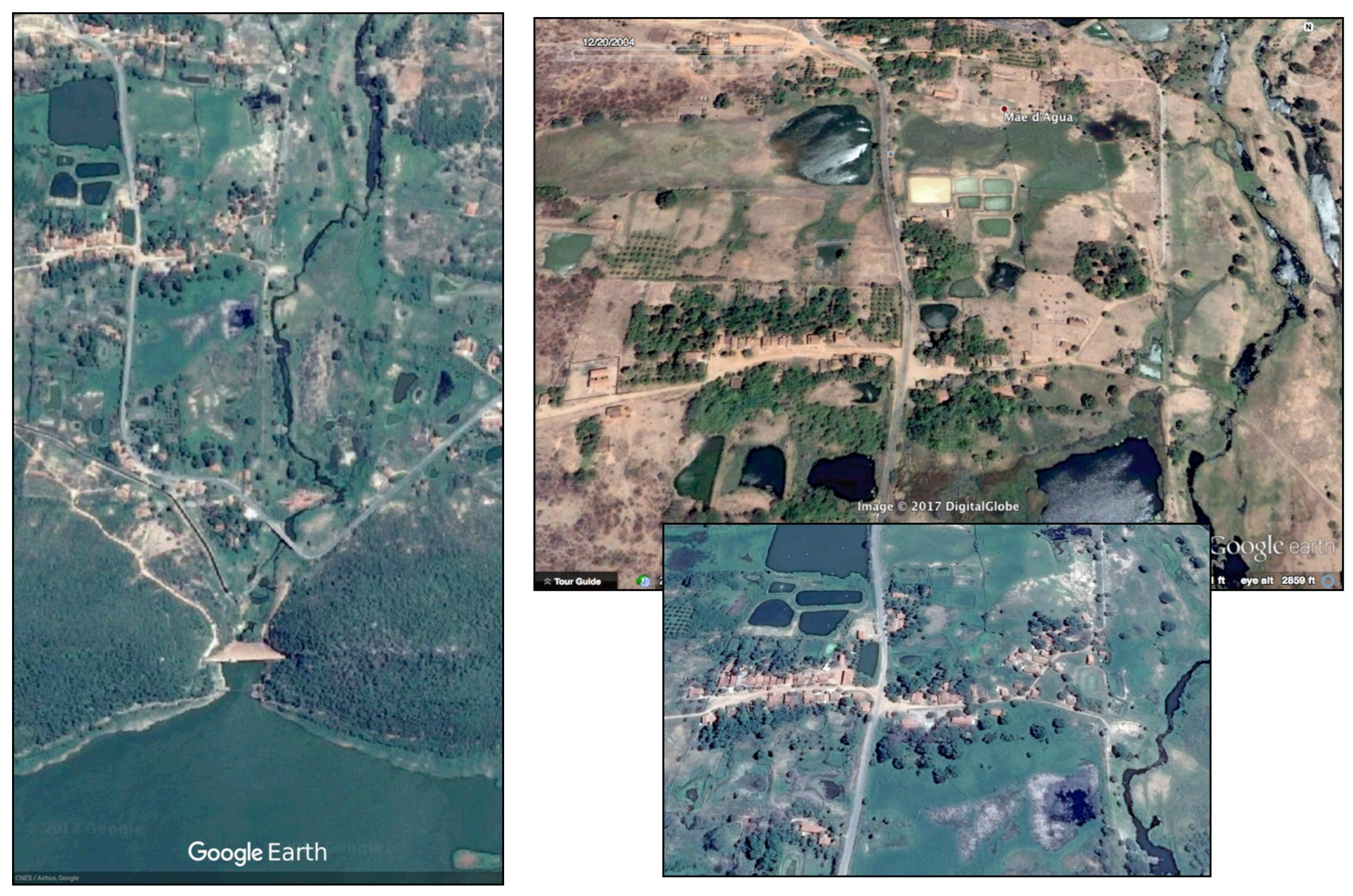
As casas construídas pelo Dnocs para abrigar seus funcionários durante a construção da barragem Mãe D'água foram construídas do lado esquerdo da mesma (posicionando-se de costas para a barragem) e estavam distribuídas segundo a atividade realizada, como por exemplo o local conhecido como "britador" onde se quebravam as pedras para as construções. Algumas casas construídas pelo órgão ainda existem atualmente. Ao contrário do padrão tradicional das casas da região, as casas do Dnocs têm o pé direito bem mais alto e janelas em casa um dos cômodos.

1. Vista geral da região de Mãe D'água, mostrando a barragem, o rio Aguiar (no centro), todas as terras pertencem ao Dnocs e são arrendadas pelo órgão. A imagem do Google Earth é de fevereiro de 2017.

2. Detalhe da antiga vila do Dnocs, em imagem de 2004. Apesar do terreno estar seco, uma vez que a foto foi tirada em dezembro no final da estação seca, pode-se ver tanques de peixes em ambos os lados das linhas de casas. Alguns rendeiros estão no mesmo lugar desde a década de 1960, como é o caso da família de dona Francisca, no conjunto de casas do lado direito da pista que liga Coremas a São José da Lagoa Tapada.

3. Outra imagem do mesmo local de casas em imagem de fevereiro de 2017. Apesar da vegetação estar verde devido às chuvas da estação chuvosa (inverno) os tanques desapareceram quase completamente devido à proibição de captação de água do Rio e do açude, permanecendo apenas os de um proprietários mais abastado.

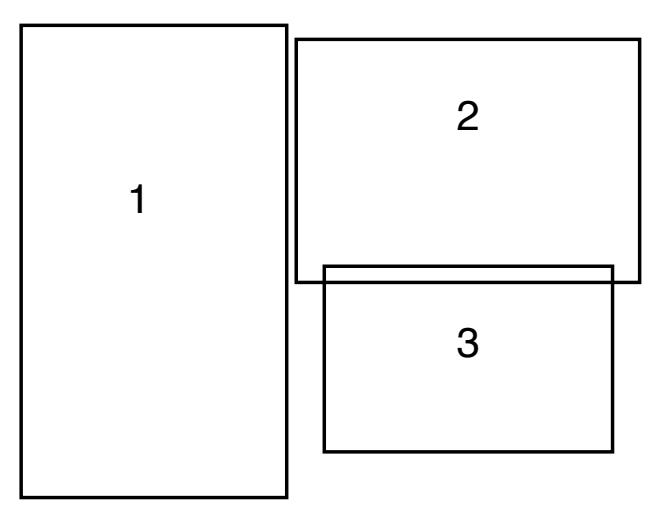




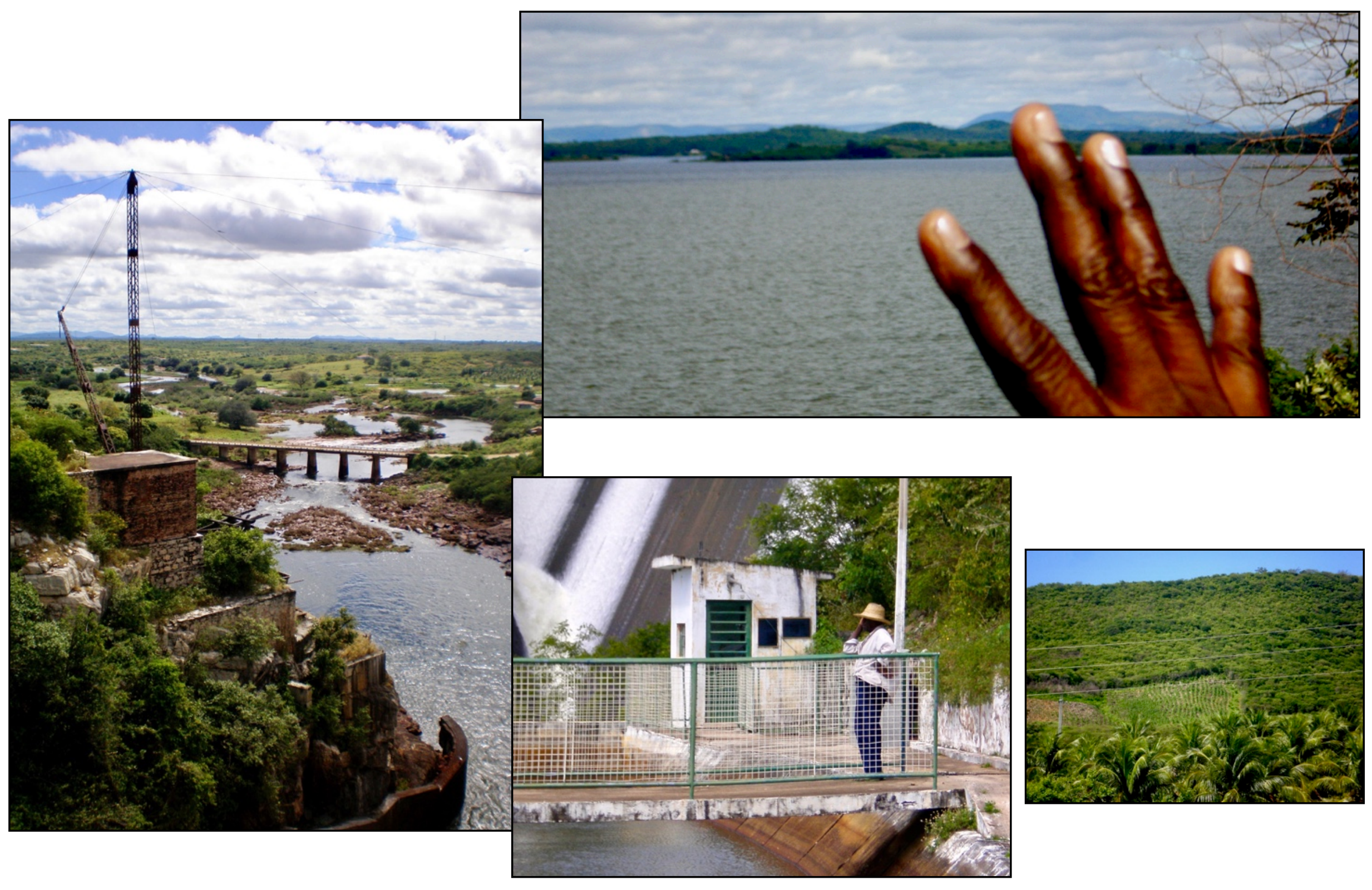


Com a construção do açude em Mãe D'água, muitos sítios ficaram submersos. Entre estes, estava o sítio Navio, povoado habitado exclusivamente por negros, conforme contam seus antigos moradores. Com o término da barragem, as famílias tiveram que deixar suas casas e roças sem que nenhuma compensação ou reassentamento tenha sido realizado pelo Dnocs.

1. Vista da casa de pedra construída pelo Engenheiro-Chefe Estevam Marinho na Serra de Santa Catarina na época da construção da barragem. Mar. 2009.

2. Dona Francisca mostra o antigo local aonde ficava o povoado Navio. Jun. 2009.

3. Seu Neco no início do canal que leva água do açude Mãe D'água para Souza. Na época da foto, a barragem estava "sangrando" e o canal cheio.

4. Roça na Serra de Santa Catarina.

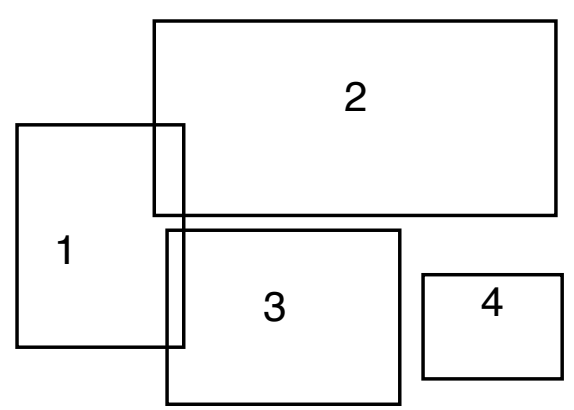




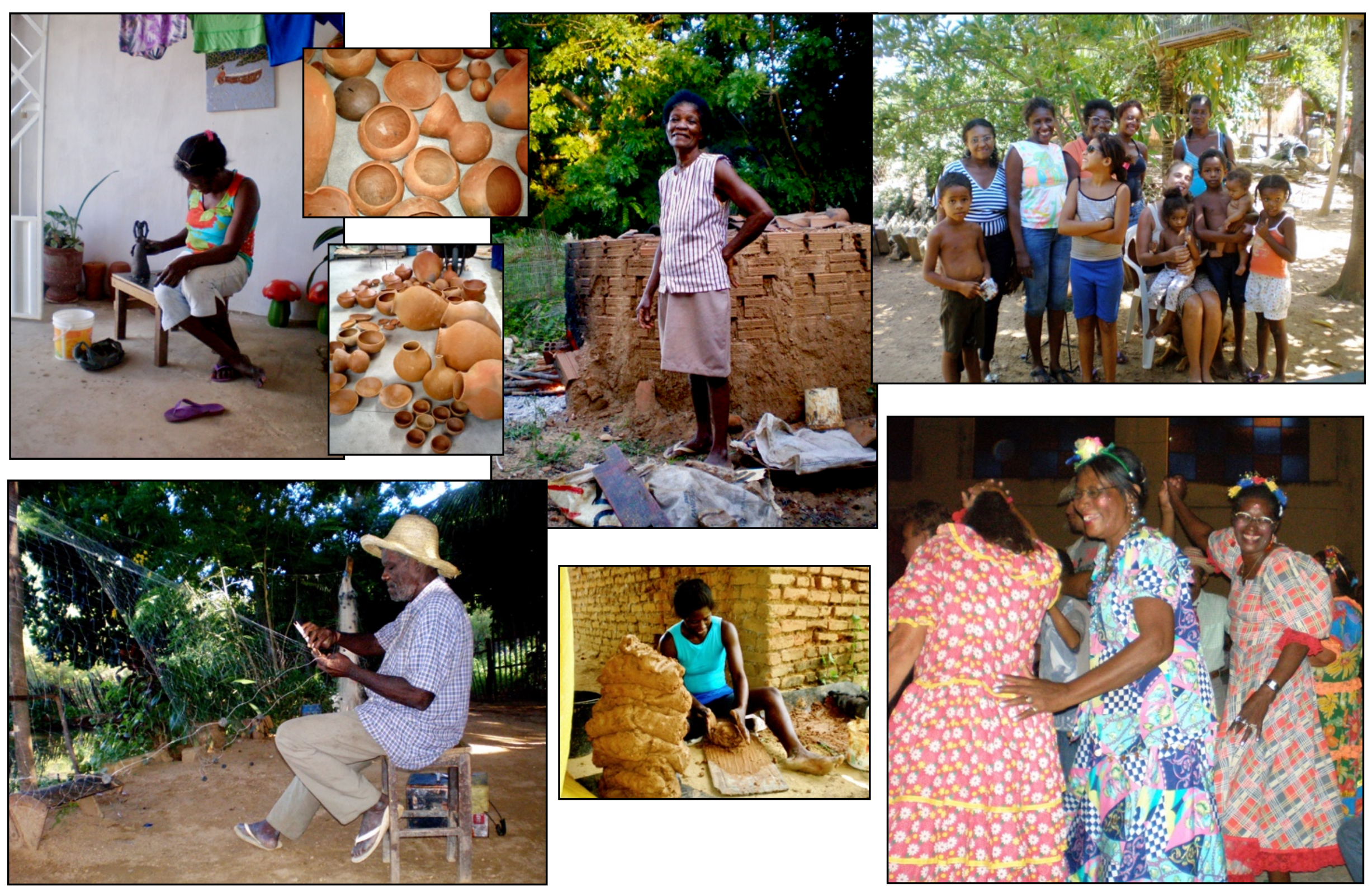


O núcleo familiar de Dona Francisca instalou-se em Mãe D'água no final da década de 1950. Com a finalização da barragem, o pai de Dona Francisca retirou-se com sua numerosa família para a aba da serra, no lugar conhecido por Mufumbo. A intensa seca de 1958, entretanto, tornou inviável a permanência da família devido à escassez de água e a família se mudou para um dos galpões construídos pelo Dnocs em Coremas, o Chefe da repartição local "arrumou" uma renda de 1,5 hectare para a família morar. Após casar-se e sair de Coremas, Dona Francisca voltou para Mãe D'água com o esposo e comprou a antiga renda do pai, assinando o contrato de arrendamento com o Dnocs em 1966.

1. Dona Francisca com uma de suas bonecas de barro. Tradicionalmente, a louça, ou loiça, de barro produzida na Paraíba compreende produtos de uso doméstico como potes, panelas, fogareiros, pratos, cuscuzeiras, etc. O Sebrae local desenvolve o incentivo do artesanato de barro diversificando a produção, incluindo peças decorativas. Jun. 2009.

2. Seu Neco costurando uma rede de pesca. A foto foi tirada da frente de sua casa, entre esta e o tanque de peixes da família, que aproveitava água do canal de Souza e mantinha verde toda sua área. Jun. 2009.

3. e 4. Utensílios de barro produzidos em Mãe D'água sendo vendidos na feira da cidade. Mar. 2009

5. Dona Tereza em frente ao forno comunitário de queimar loiça. Mar. 2009.

6. Neidinha, filha de Dona Francisca, fabricando um pote de barro. Mar. 2009.

7. Parte da família de Dona Francisca, no terreiro de Desterro, uma de suas filhas. Mar. 2009.

8. São João dos idosos, Dona Francisca e uma de suas primas. Jun. 2009.

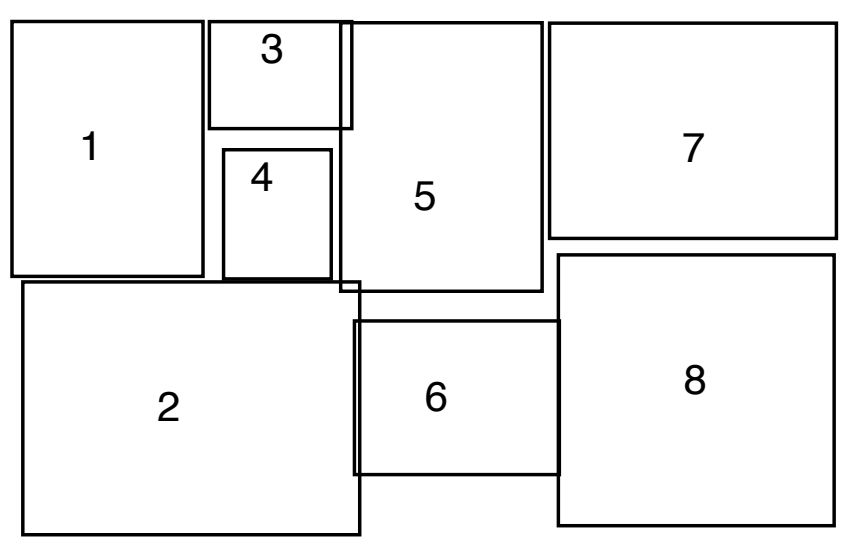



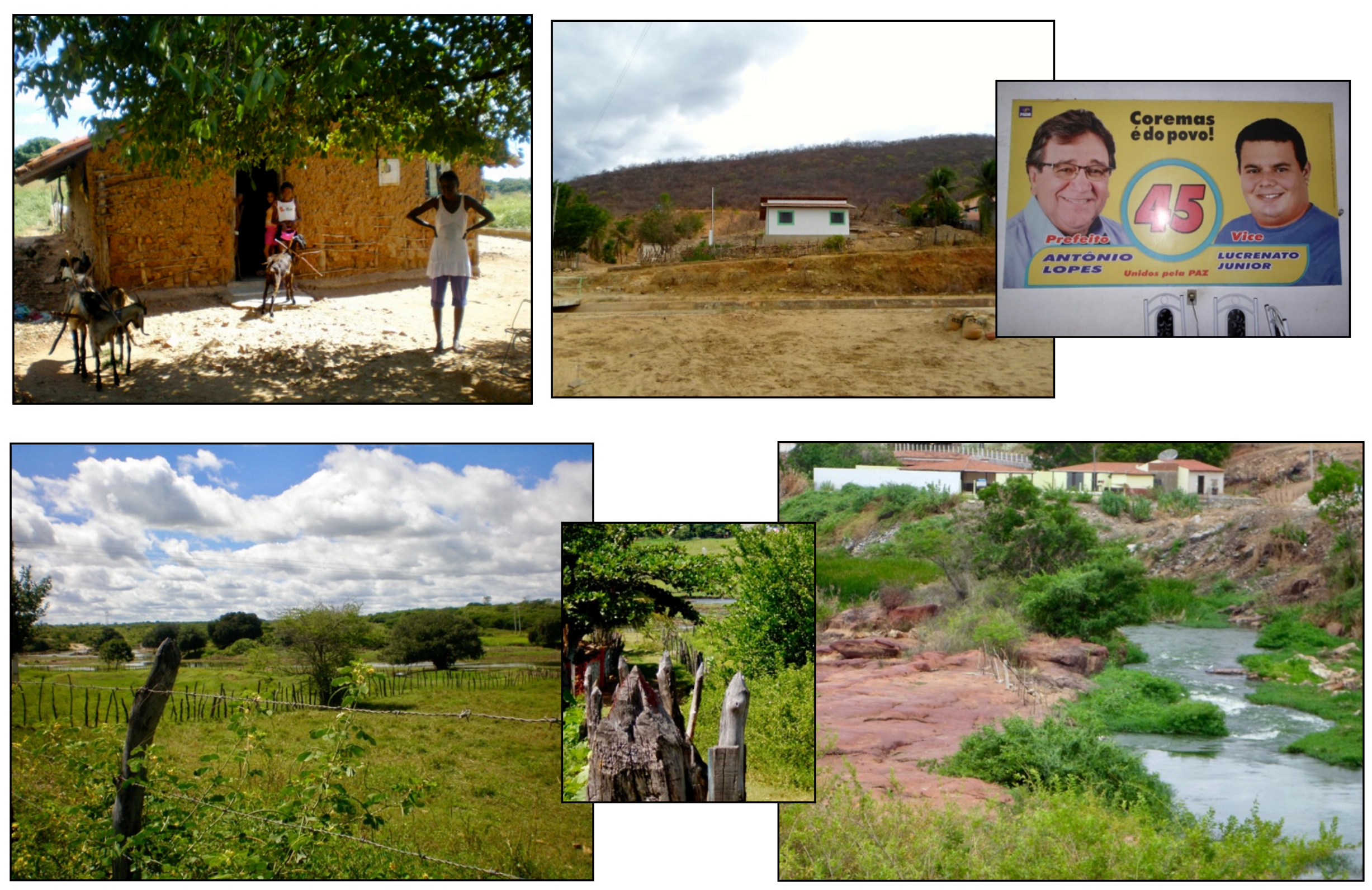
Na primeira visita a Mãe D'água, em março de 2009, ainda existiam muitas casas de taipa no local. Durante os últimos anos, as casas foram sendo substituídas devido a melhora do nível de vida da população local e a programas de distribuição de renda (Bolsa Família) e de crédito para pequenos agricultores familiares (Pronaf). Além da substituição individual das casas, a Companhia Estadual de Habitação Popular também construiu novas casas. A distribuição destas é feita de maneira problemática, envolvendo a designação de casas pela prefeitura conforme seus apoios políticos. Nos últimos anos também, as antigas rendas do Dnocs foram sendo repartidas e vendidas, aumentando a quantidade de pessoas no local. Entre os problemas derivados desse processo, está o trancamento de áreas antes de uso comum com cercas, sobretudo o acesso ao rio Aguiar.

1. Casa de taipa em Mãe D'água. Mar. 2009.

2. , 4. e 6. Cercas trancando o acesso ao rio Aguiar.

5. Além de influenciarem a distribuição de casas, mesmo as construídas por projetos federais e estaduais, os políticos locais utilizam-se das fachadas das casas de pessoas influentes na comunidade como outdoor para sua propaganda políticopartidária, como ocorre em muitos locais do interior do Nordeste. O outdoor da foto foi dado a Dona Francisca para que ela o afixasse na fachada de sua casa. O cartaz foi afixado dentro de sua residência, para não comprometer sua fachada e ao mesmo tempo não desgostar ninguém.

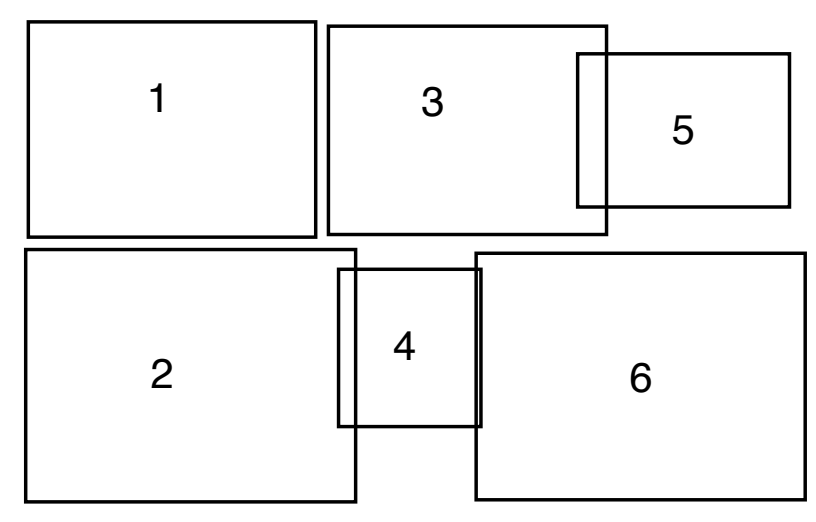




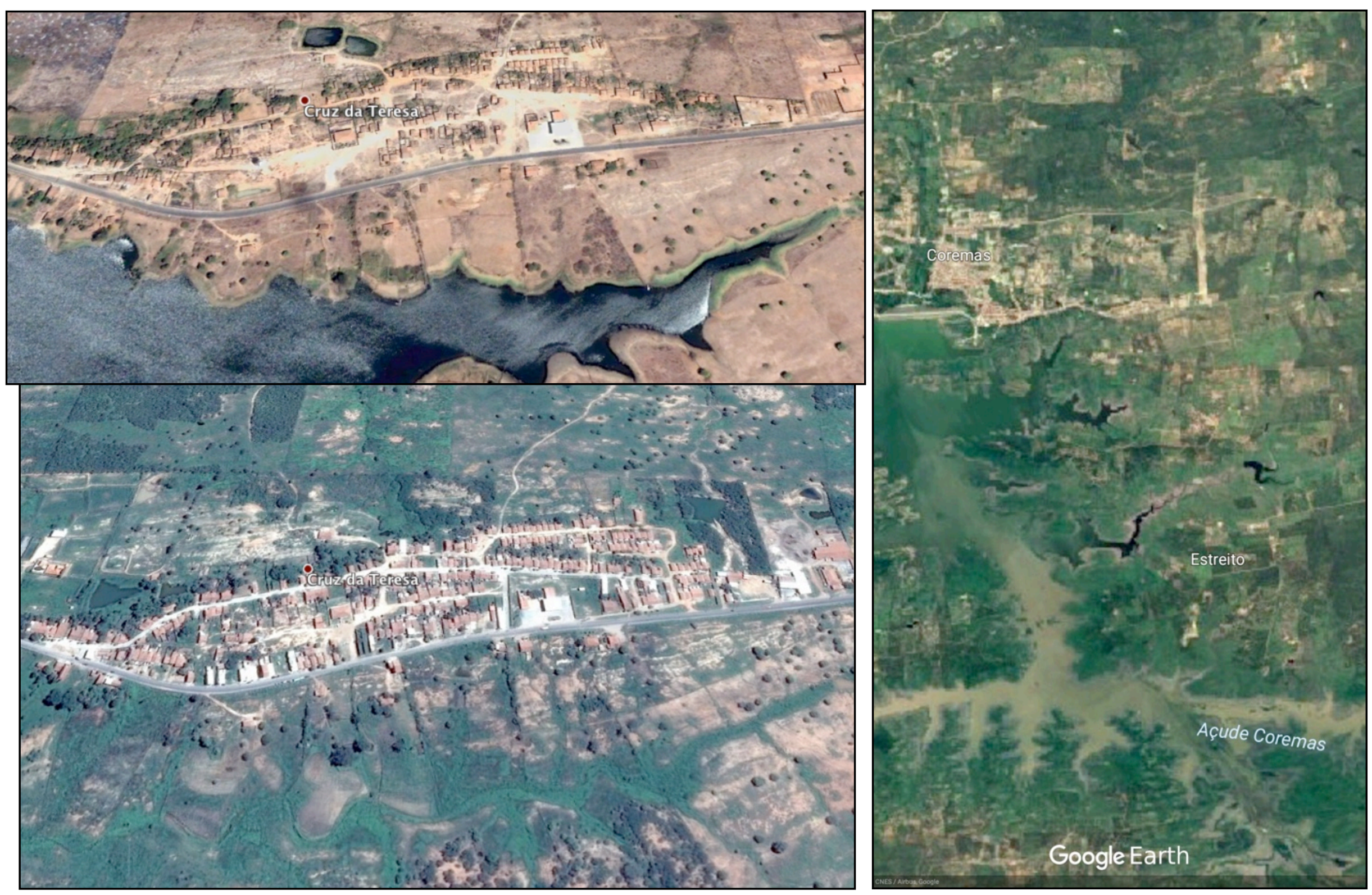


Com a retirada de antigos moradores dos sítios que ficaram submersos ou que foram desapropriados por estarem inseridos na bacia hidráulica dos açudes Coremas e Mãe D'água, muitas famílias ocuparam as terras do Dnocs na periferia da cidade, principalmente nos locais conhecidos como Cabo Branco e Cruz da Tereza. Um dos núcleos familiares que se estabeleceu em Cruz da Tereza foi o de Dona Salete e seu falecido esposo, Fabiano. Os dois se conheceram em Estreito, onde seus pais tinham rendas do Dnocs. Fabiano deixou sua renda em Estreito depois de um boato segundo o qual o Dnocs iria retomar as rendas localizadas na beira do açude para projetos de irrigação. Depois de vender por pouco ou nada sua renda, a família mudou-se para Cruz da Tereza, onde obtiveram permissão de um funcionário do Dnocs para construírem uma casa de taipa no local.

1. Imagem de Cruz da Tereza em 2004.

2. Imagem de Cruz da Tereza em 2017. Comparando as duas imagens vê-se o aumento das construções. As construções seguem em ritmo acelerado apesar de a Comunidade Negra de Cruz da Tereza demandar, desde 2006, a área para regularização fundiária.

3. Vista de Coremas mostrando o açude e o lugar Estreito.

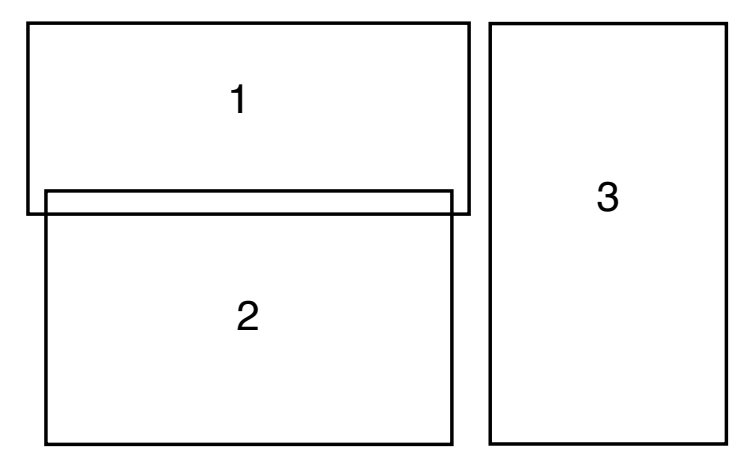




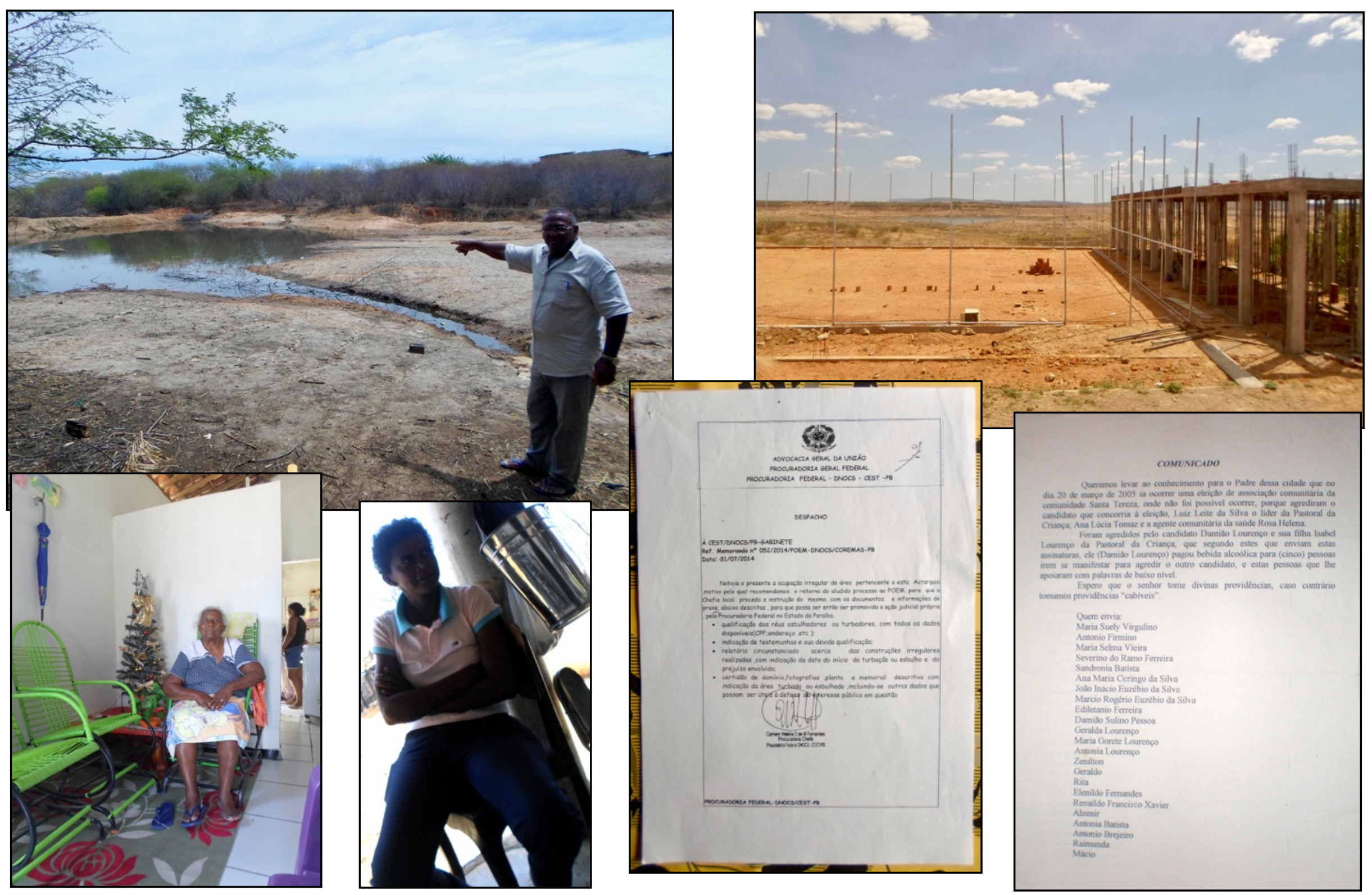


As construções que seguem em ritmo acelerado em Cruz da Tereza não são apenas de casas de moradias. Nos últimos ano, instalaram-se ali uma fábrica de peixes (apesar da proximidade das residências), dois postos de gasolina (apesar da proximidade com o açude) e um motel, entre outros. Além de ocuparem uma área que já estava sendo demandada para regularização da comunidade quilombola do local, esses estabelecimentos colocam em risco a saúde e bem estar de todos os moradores que vivem ali.

1. Francisco Ferreira Tomás mostra o local onde são despejados os dejetos da fábrica de peixes localizada em Cruz da Tereza. Feito sem qualquer cuidado sanitário, os dejetos espalham moscas e uma insuportável catinga de peixe podre. O Dnocs, assim como a prefeitura, já foi cobrado sobre a situação, uma vez que a fábrica está em terreno pertencente à autarquia, mas ninguém tomou qualquer atitude.

2. Dona Salete, em sua nova casa, construída pela Cehap.

3. Damiana (Gerinha), principal liderança quilombola local.

4. Em uma das muitas reuniões sobre a regularização fundiária da comunidade Cruz da Tereza, o Dnocs recuou na regularização da área próxima ao açude, alegando que não poderia localizar ninguém na bacia hidráulica do açude. Ao mesmo tempo, liberou a construção de uma quadra praticamente dentro do açude Coremas.

5. O Dnocs está há muito tempo ciente das ocupações irregulares sem ter tomado nenhuma atitude concreta, mesmo com pressão do MPF.

6. A ação da prefeitura dentro das associações comunitárias acirra e complica a ocupação de Cruz da Tereza.

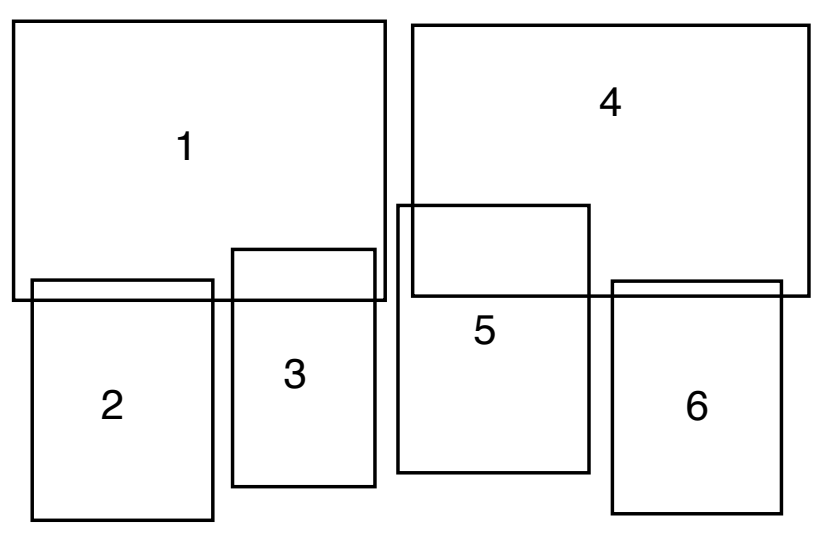



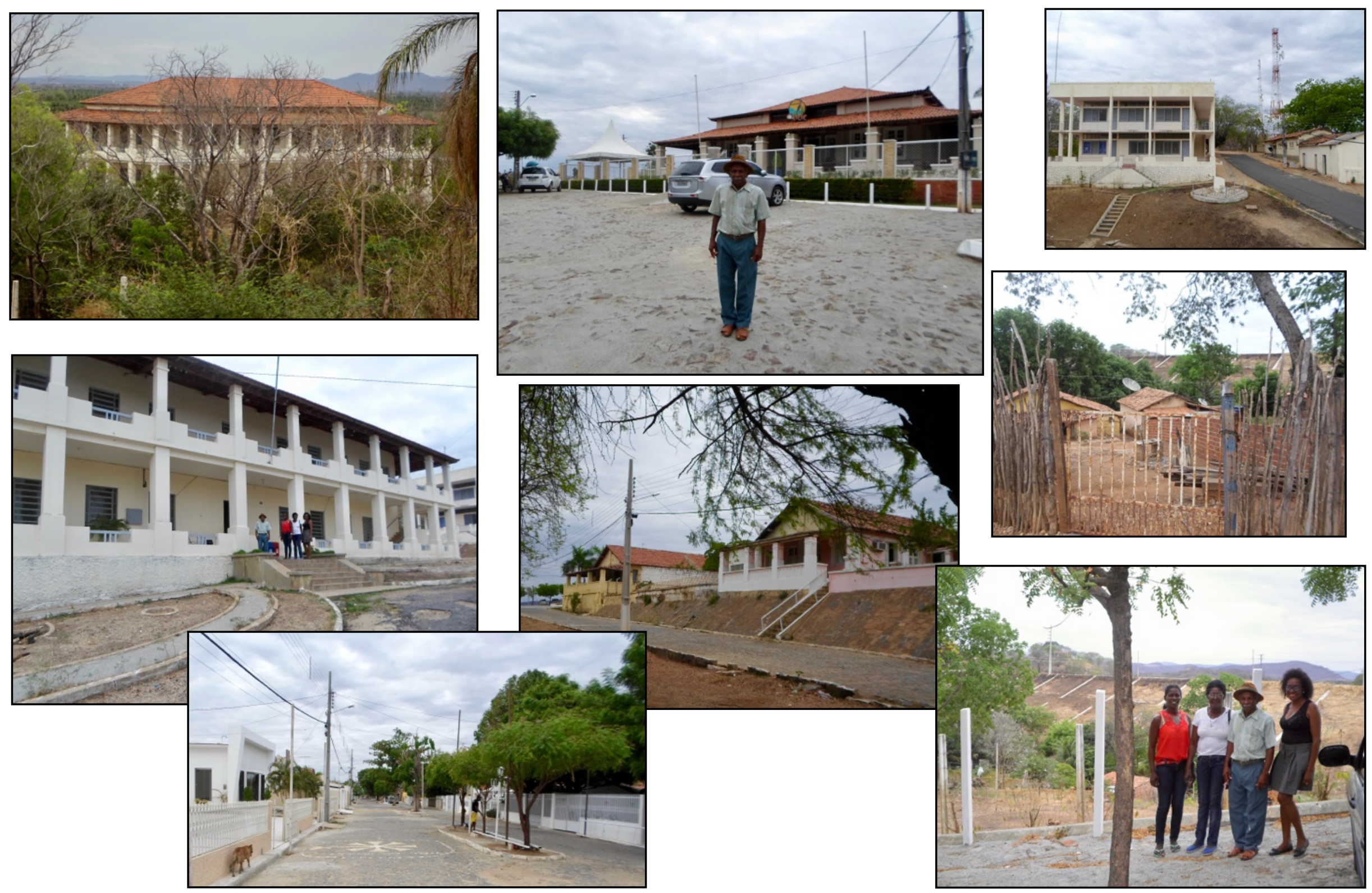
A atual decadência das estruturas do Dnocs contrasta com a grandiosidade das construções de meados do século passado. Em São Gonçalo, o conjunto inicial do acampamento do órgão permanece quase todo intacto apesar do desgaste do tempo.

1. O imponte prédio do Dnocs em São Gonçalo já contou com mais de mil funcionários. Atualmente, 16 servidores ocupam algumas salas do andar inferior. Dez. 2016.

2. Zé Pequeno, Neidinha, Bia (filhas de Dona Francisca) e Dona Francisca na escadaria da sede do Dnocs em São Gonçalo. Dez. 2016.

3. Vista do conjunto de casas dos funcionários do Dnocs, separado da parte principal do Acampamento por uma ponte.

4. Zé Pequeno em frente ao restaurante do Dnocs, no prédio que funcionava também um hotel para os visitantes ilustres do órgão.

5. Conjunto de casas dos funcionários que ocupavam o topo da hierarquia.

6. Prédio que abrigava o antigo Instituto José Augusto Trindade.

7. Casas improvisadas dos trabalhadores mais pobres no vale que termina com a parede do açude.

8. Neidinha, Dona Francisca, Zé Pequeno e Bia no mirante de São Gonçalo.

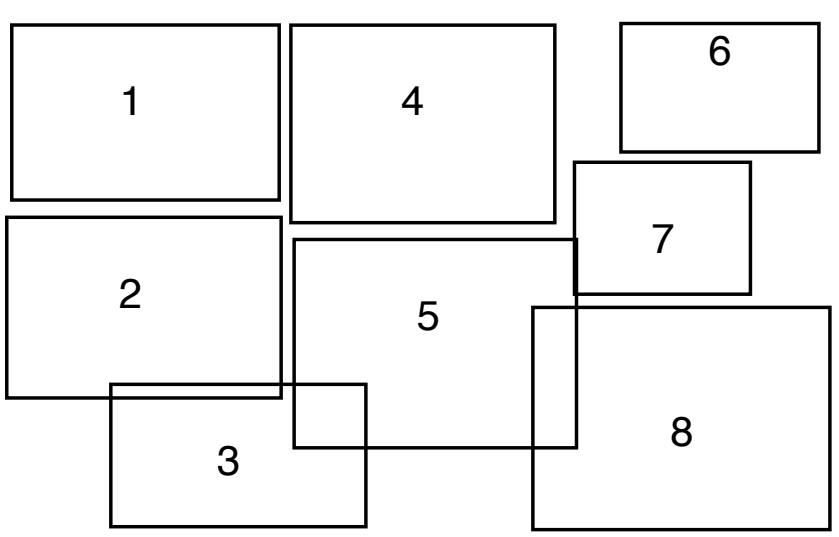




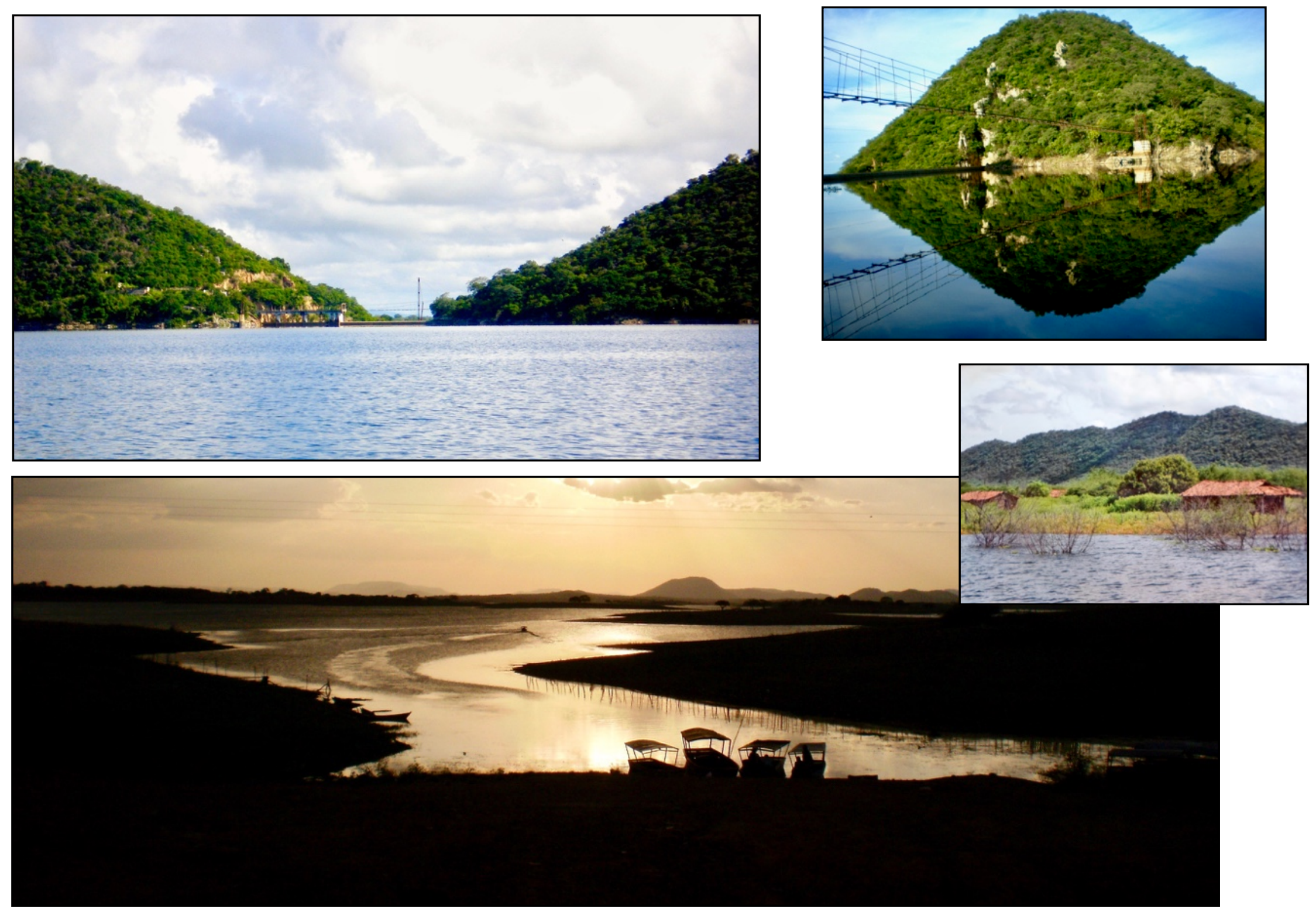


Uma das potencialidades apontadas pelo historiador local, Edvaldo Brilhante, para tirar a cidade da decadência em que se encontra seria o incentivo ao turismo, explorando a beleza do lago formado na beira da Serra de Santa Catarina.

1. Vista do Boqueirão de Mãe D'água e da ponte provisória sobre o Rio Aguiar. Jun. 2009.

2. Pôr do sol no porto do Pacatonho. Jun. 2009.

3. Trecho da Serra de Santa Catarina refletido no açude Mãe D'água. Jun.2009.

4. Cheia do açude, com as águas perto das casas, em Barreiras. Acervo de Zé Pequeno.

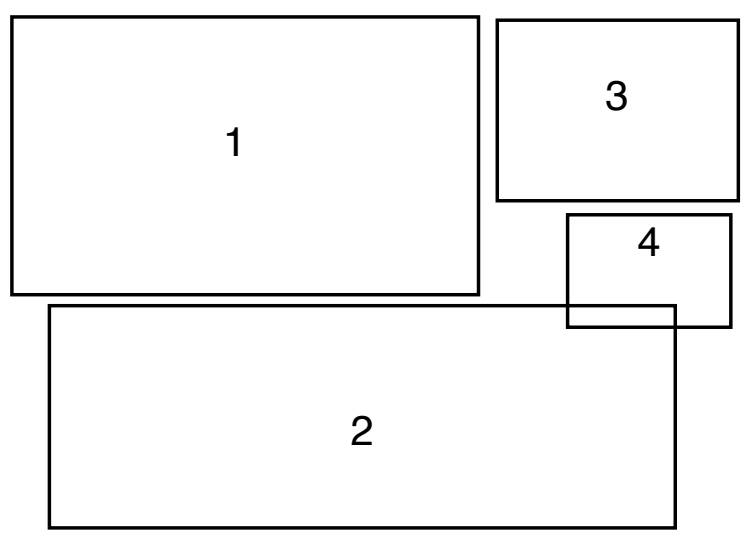



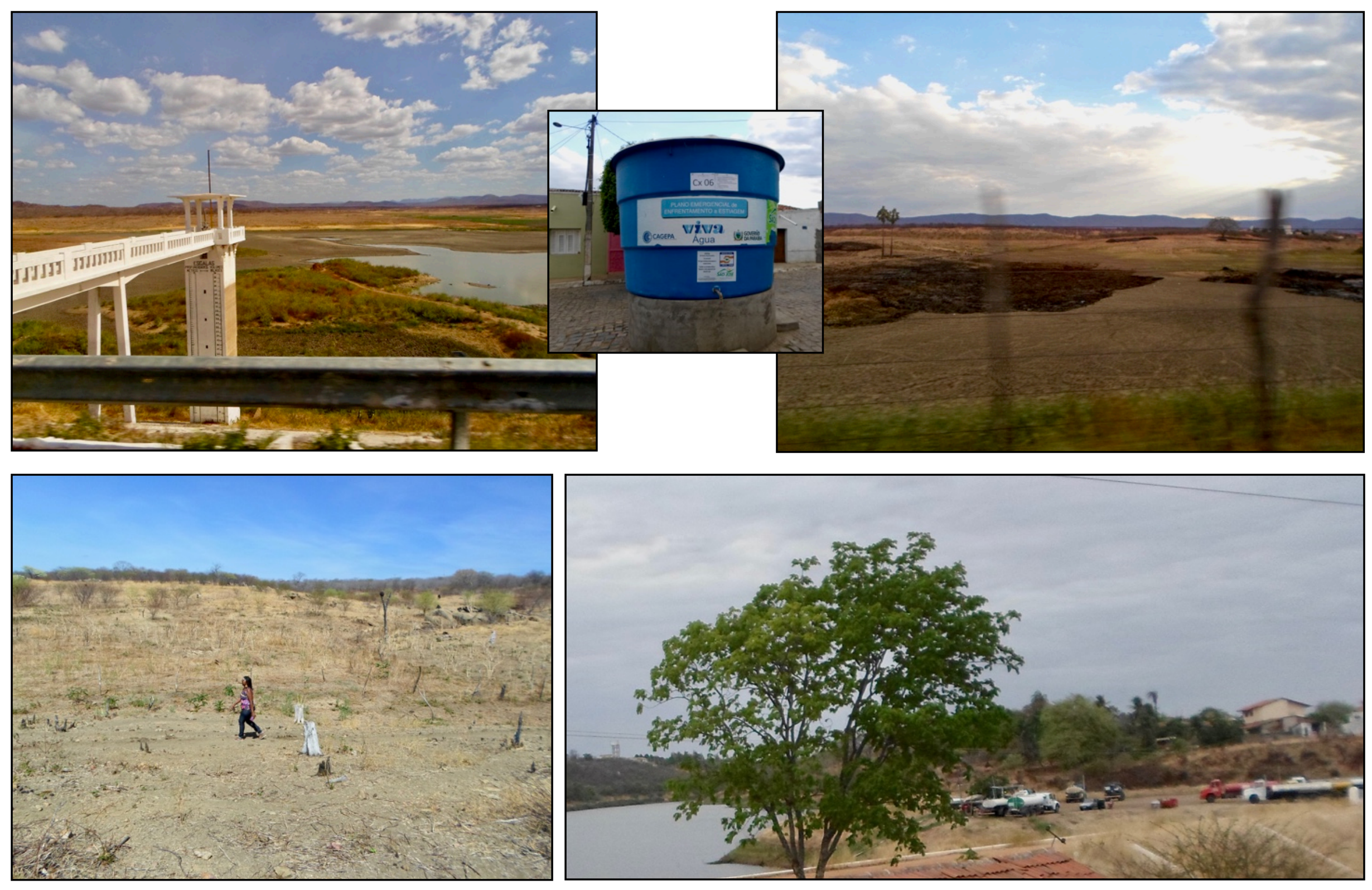
A Seca transforma completamente a paisagem. Durante a seca dos últimos cinco anos, os açudes Coremas, Mãe D'água, Condado e São Gonçalo, entre outros, atingiram níveis críticos.

1. Marcador de volume de água do açude Condado. Dez. 2016.

2. Ana Lucia caminha no açude Mãe D'água em Barreiras. Foi preciso andar mais de um quilômetro dentro do açude para chegar até a água. Dez. 2016.

3. Caixa D'água "emergencial" em São José da Lagoa Tapada. Dez. 2016.

4. Açudes secos nas fazendas ao longo da estrada Coremas - São José da Lagoa Tapada. Dez. 2016.

5. Carros pipa retirando água do açude São Gonçalo. Dez. 2016.

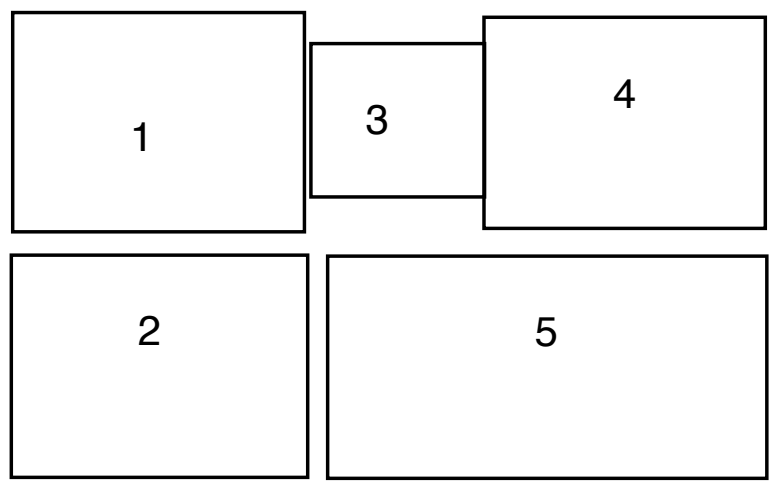



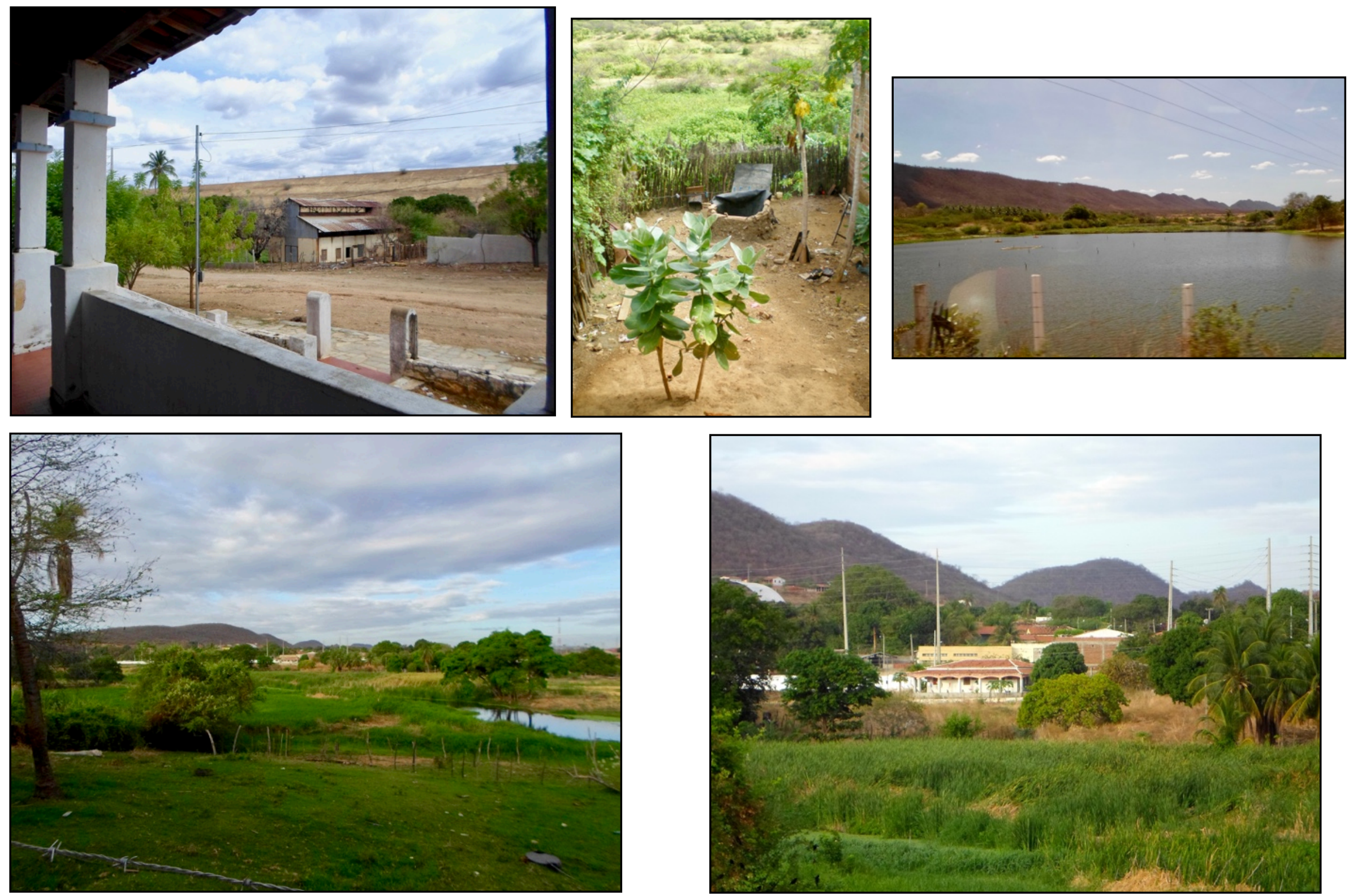
Ao contrário do que aconteceu em São Gonçalo, onde, apesar da diminuição do prestígio do Dnocs e desgaste das construções e do próprio açude, o conjunto arquitetônico inicial permanece praticamente intacto, em Coremas o antigo acampamento está totalmente descaracterizado e poucas das antigas casas continuam em pé. A venda das casas de engenheiros e funcionários deu lugar a novas construções.

1. Vista de um galpão desativado do Dnocs da varanda da sede do órgão em Coremas. Dez. 2016.

2. Vista do antigo acampamento do Dnocs do outro lado do rio Piancó. Dez. 2016.

3. Vista das terras do Dnocs do terreiro da casa de Dona Francisca na rua conhecida por "rua do trilho". Jun. 2009.

4. Fazenda ao lado do canal de Souza que manteve seus tanques de peixes apesar da proibição do Dnocs, Aesa e Ana. Como comentou seu Zé Pequeno com relação às construções irregulares, "aqui não tem democracia".

5. Uma das poucas casas dos funcionários de alto escalão que não foram derrubadas. Atualmente, o casarão abriga um projeto de ensino à distância da Ufpb. Dez. 2017.

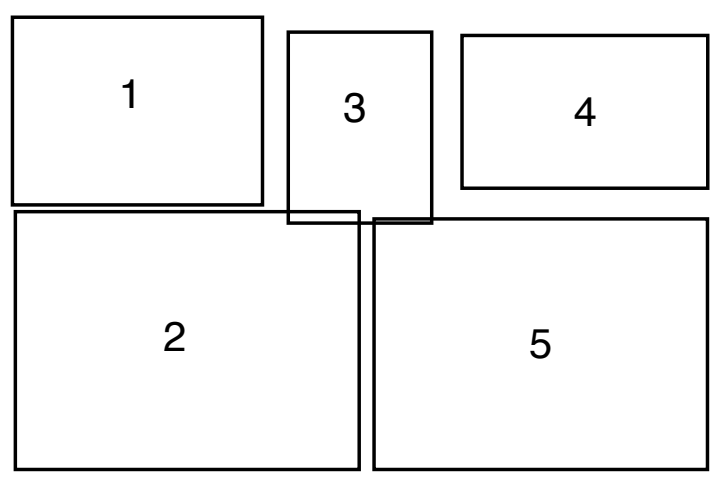




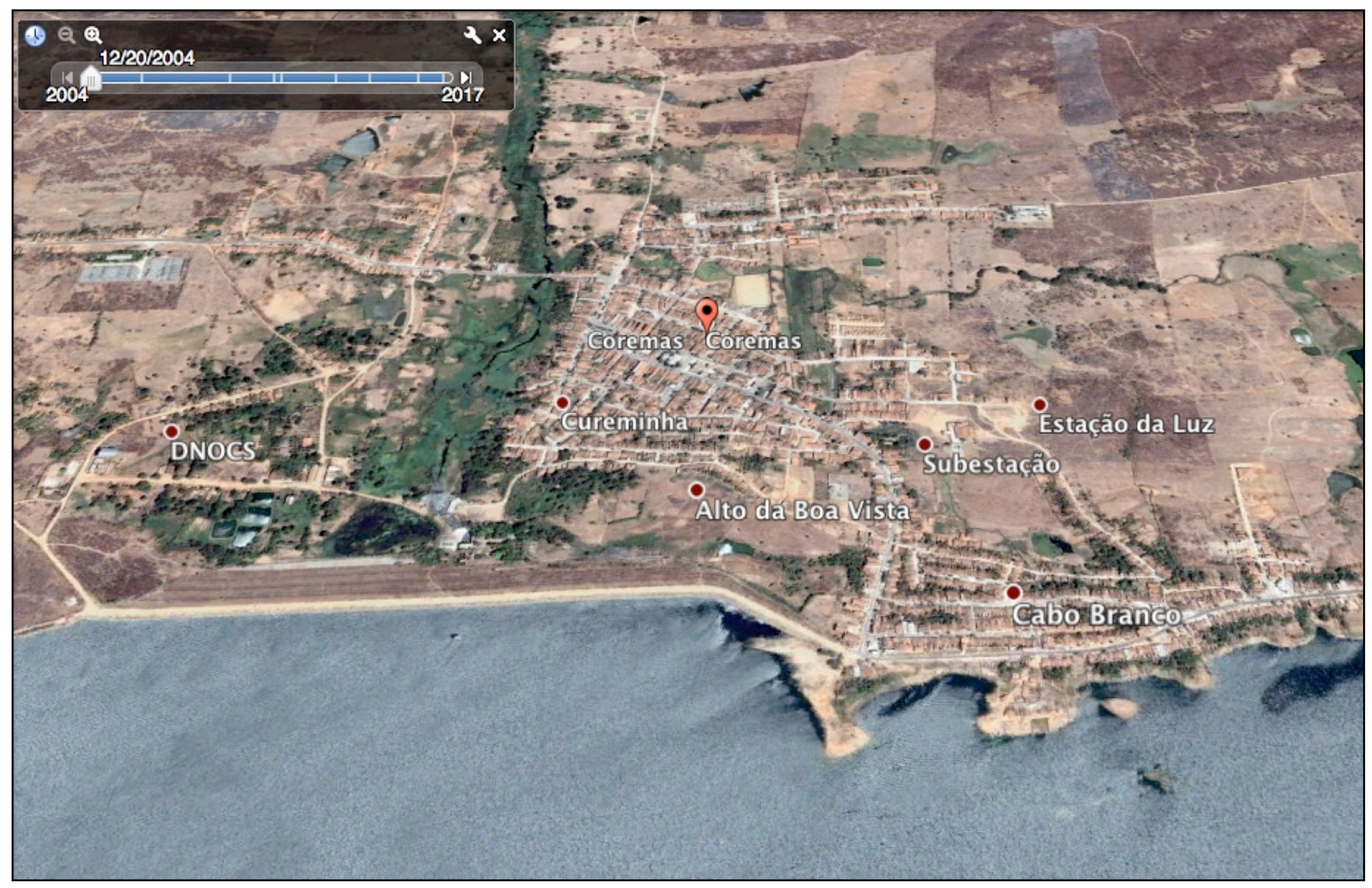


Vista da cidade de Coremas, em dezembro de 2004. Saindo da parede do açude grande (Coremas / Estevam Marinho) o rio Piancó divide a cidade de Coremas e o antigo Acampamento do Dnocs. A foto foi tirada em dezembro, no final do período seco. No ano em que foi feita a imagem o açude estava bem cheio, deixando claro a incapacidade do mesmo de garantir água para irrigar os terrenos da região em época de seca.

Apesar da alegação do Dnocs de que o órgão não poderia destinar áreas próximas ao açude à comunidade quilombola Cruz da Tereza, nem mesmo para a tradicional cultura de vazante, fica claro que existem muitas construções na beira do açude. O Dnocs foi instado a regularizar a situação não só em Coremas, como em São Gonçalo e muitos outros lugares no Ceará e Rio Grande do Norte, não tendo tomado praticamente nenhuma atitude apesar das pressões sucessivas por parte do Ministério Público Federal.

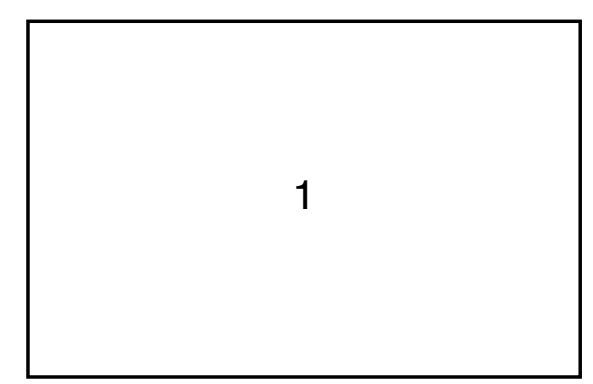




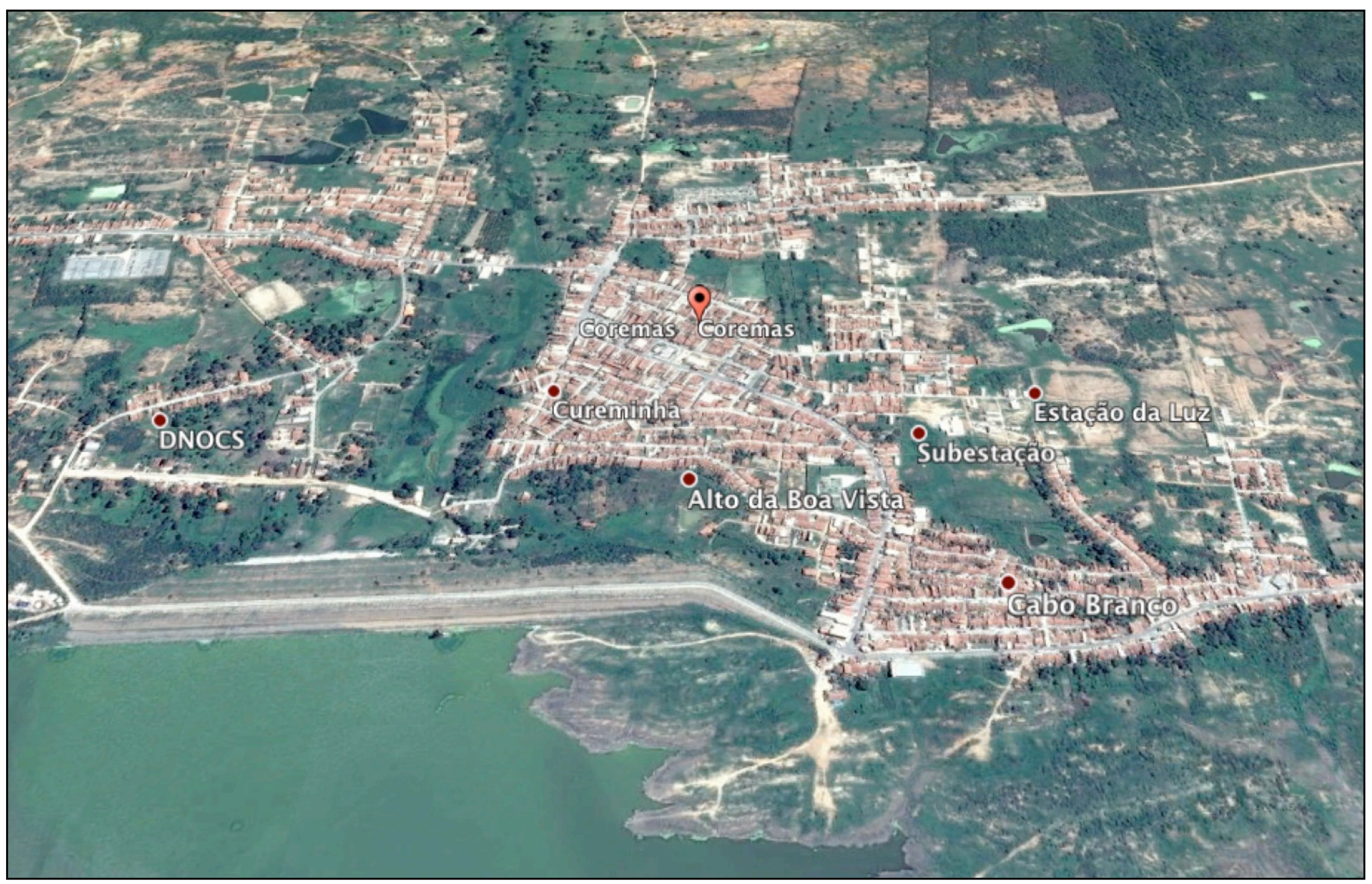


Vista da cidade de Coremas, em fevereiro de 2017. As chuvas que caíram no final de 2016 e 2017 mudaram o aspecto da vegetação do município apesar de o nível do açude permanecer crítico, reforçando a pouca utilidade do reservatório para manter as áreas de seu entorno irrigadas e propícias ao cultivo.

O crescimento da cidade se faz de maneira desordenada e sobretudo na periferia. Já há alguns anos a prefeitura negocia com o Dnocs o repasse das áreas do órgão para a expansão da cidade, e a concessão de casas de projetos habitacionais tem sido a principal moeda de garantia de votos. 


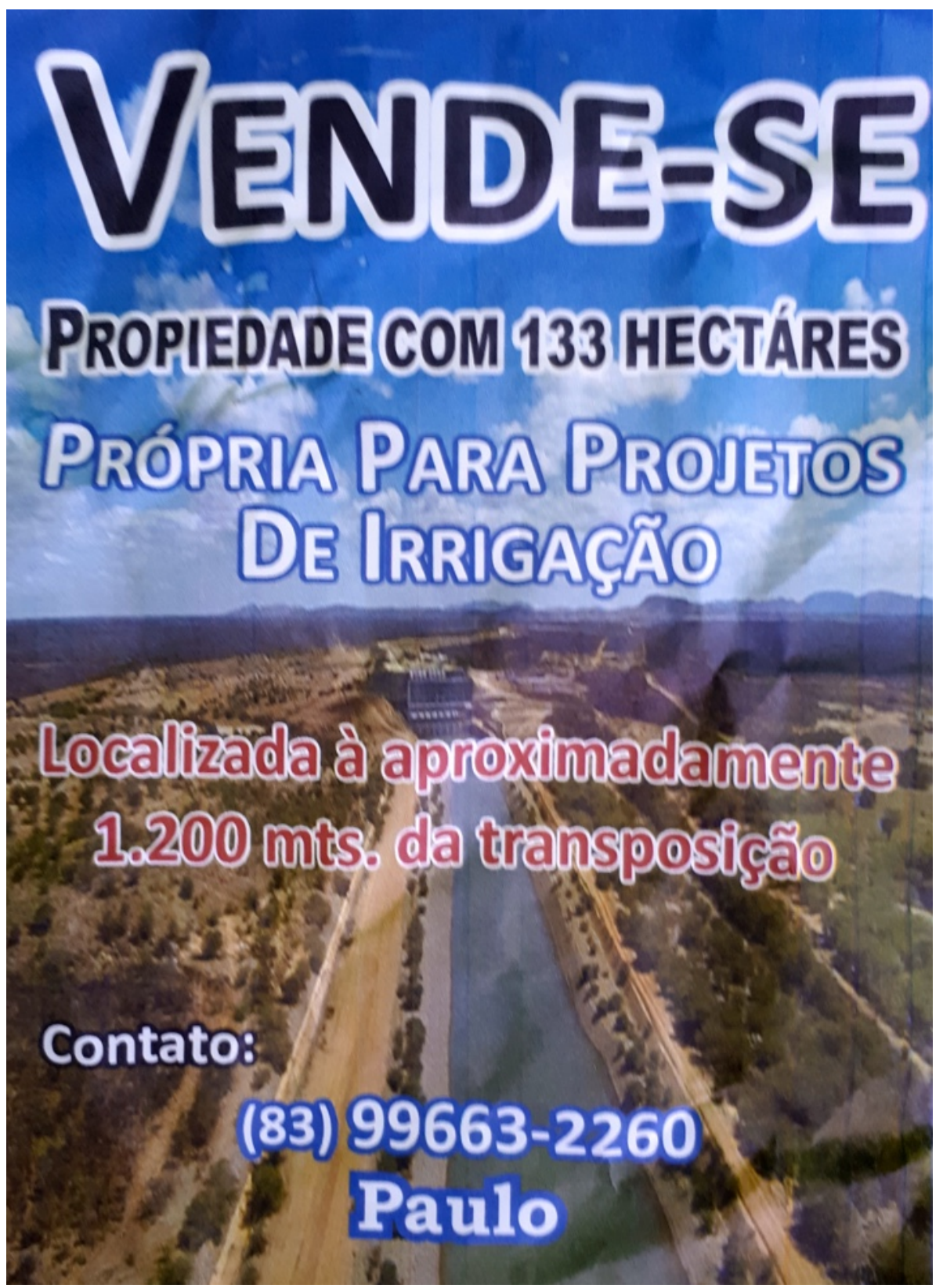


Desde o início das concessões de terrenos na bacia hidráulica dos açudes Coremas e Mãe D'água, em forma de arrendamento de lotes de tamanhos diferenciados, são comuns as vendas de lotes de propriedade do Dnocs. A valorização das áreas conforme a proximidade dos açudes e a possibilidade de projetos de melhoria, como tanques de peixe, kits de irrigação, entre outros, terminou por pressionar as famílias mais pobres para áreas piores e mais longe da água, num processo que sempre se renova. A possibilidade da chegada de um ramal das águas da transposição do rio São Francisco para o açude de Coremas tende a forçar um reordenamento das áreas ocupadas.

1. Panfleto de venda de lotes beneficiados pela transposição do Rio São Francisco distribuído em Monteiro, PB, durante a festa de comemoração da chegada das águas do São Francisco no cariri paraibano, em 19 março de 2017. O assentamento de famílias pobres permanece como a promessa nunca concluída dos projetos de irrigação.

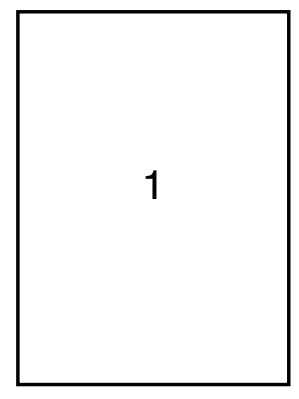



Ohen $20 \%$

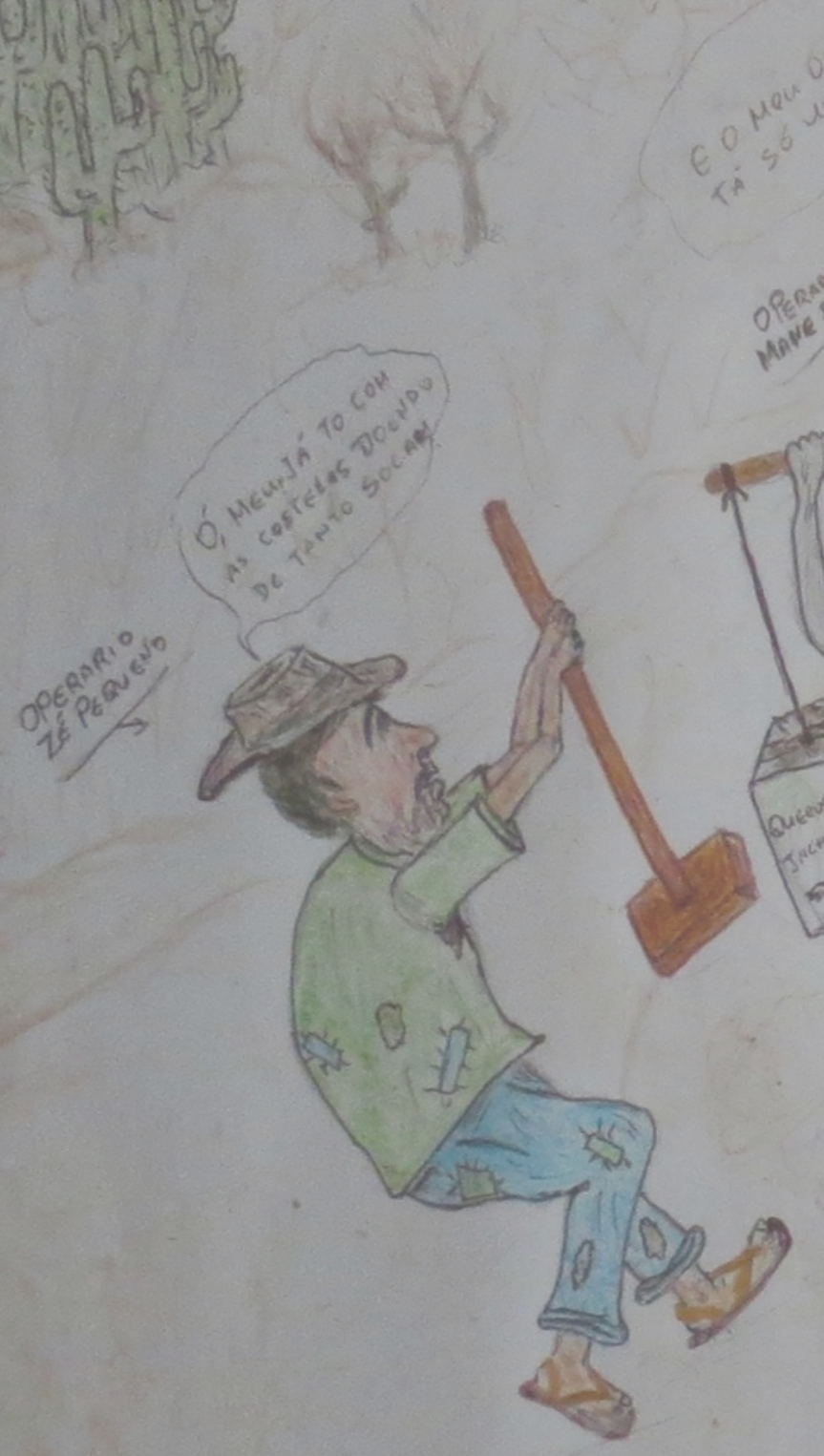<smiles>CCCCc1ccccc1OC</smiles>

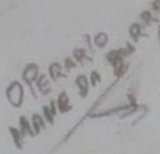
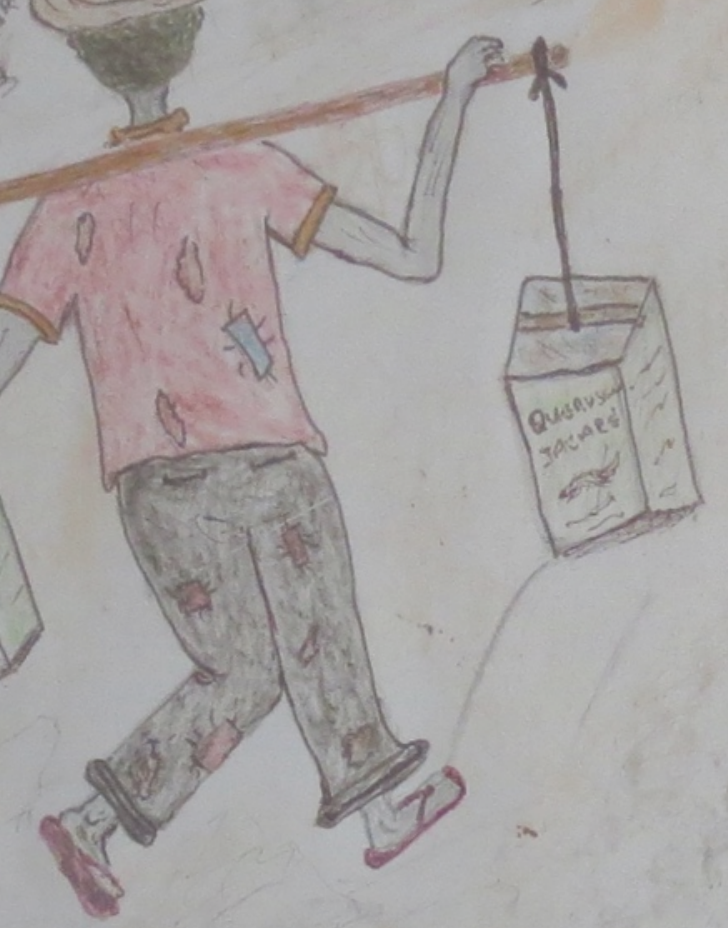